\title{
Instrumentos de Avaliação Pós-Ocupação (APO) adaptados a pré-escolares com deficiência física, auditiva e visual
}

\author{
Tese apresentada à Faculdade de Arquitetura e \\ Urbanismo da Universidade de São Paulo para \\ obtenção do título de Doutor em Arquitetura e \\ Urbanismo
}

Área de concentração: Tecnologia da Arquitetura

Orientadora: Prof ${ }^{\mathrm{a}}$. Dr ${ }^{\mathrm{a}}$. Rosaria Ono

Coorientadora: Prof ${ }^{\mathrm{a}}$. Dr ${ }^{\mathrm{a}}$. Maria Elisabete Lopes

São Paulo 
AUTORIZO A REPRODUÇÃO E DIVULGAÇÃO TOTAL OU PARCIAL DESTE TRABALHO, POR QUALQUER MEIO CONVENCIONAL OU ELETRÔNICO, PARA FINS DE ESTUDO E PESQUISA, DESDE QUE CITADA A FONTE.

Nome do autor: Tania Pietzschke Abate

Endereço eletrônico (e-mail): tania.arquiteta@usp.br

Catalogação da Publicação

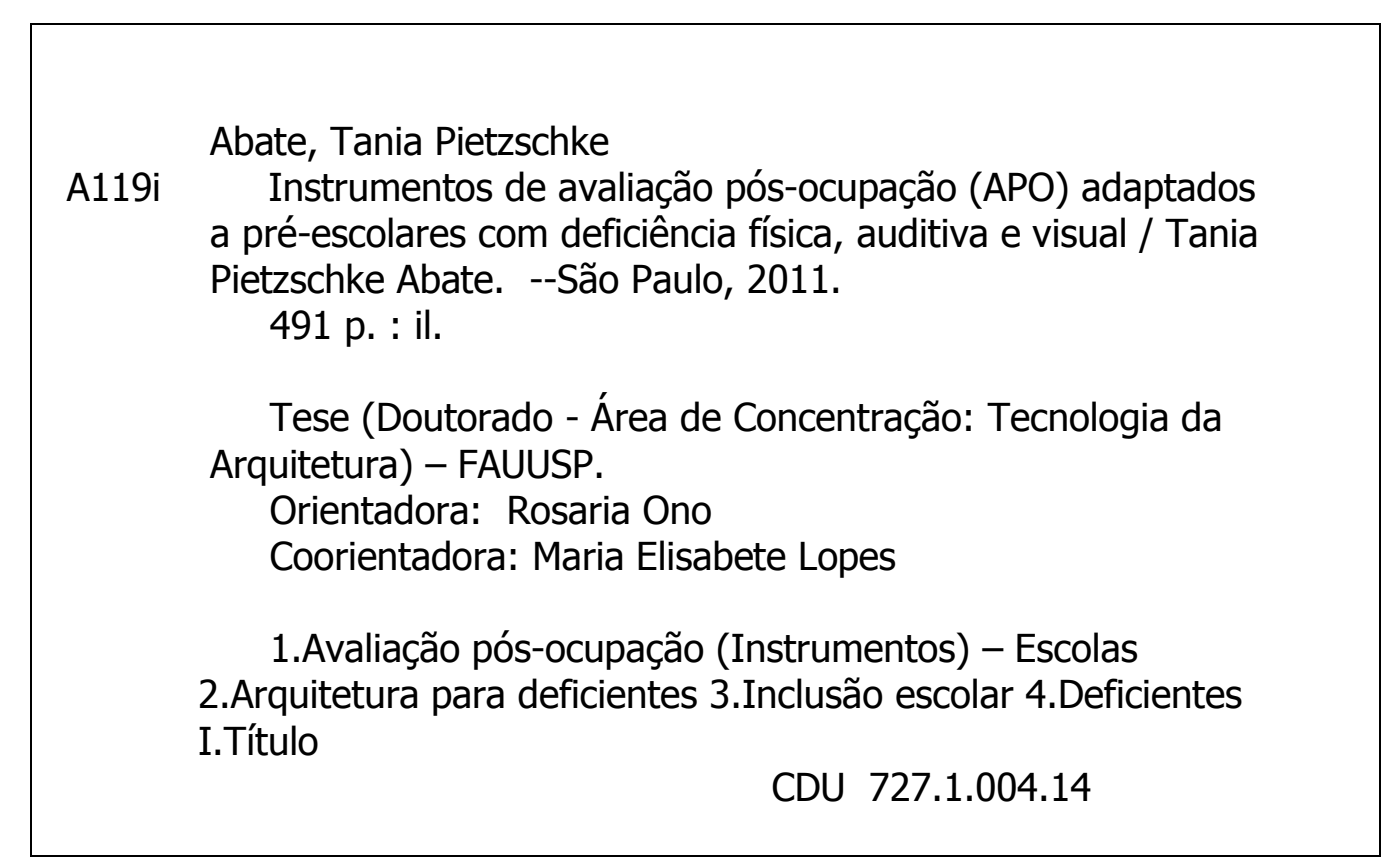


Dedico este trabalho a meu marido, Cesar, e minha filha, Bianca, indispensáveis em minha vida;

minha irmã, Aline, meus sogros, Sandra e Domênico, e minha cunhada, Mônica, pelo incentivo e apoio sempre;

meus queridos sobrinhos, Fafá e Léo, que crescerão em um mundo mais inclusivo;

meu irmão, Andreas (in memoriam), por me ensinar que o otimismo sobrepõe a deficiência;

meus pais, Gert e Ivete (in memoriam), que foram um exemplo de tudo em minha vida. 


\section{AGRADECIMENTOS}

Sobretudo a Deus, por me guiar, me dar força em todos os momentos deste intenso trabalho e por me oferecer a oportunidade de pesquisar um tema tão relevante.

Ao meu amado marido Cesar Abate, pelo apoio incondicional.

À minha amada filha Bianca Pietzschke Abate e afilhada espiritual Leticia dos Anjos Estrada, pela colaboração na elaboração dos questionários através de sua visão infantil, bem como pelo empréstimo de brinquedos para a realização das atividades lúdicas na pesquisa de campo.

À minha cunhada Monica Abate Guglielmi, pelas longas conversas e pelo imprescindível apoio na aplicação dos instrumentos destinados aos alunos cegos e com baixa visão.

Às professoras $\mathrm{Dr}^{\mathrm{a}}$. Rosaria Ono e $\mathrm{Dr}^{\mathrm{a}}$. Maria Elisabete Lopes, pela orientação valiosa, pela dedicação, pelo incentivo e presença constantes durante todo o doutorado e, acima de tudo, pela amizade sincera.

À professora Dr ${ }^{\text {a }}$. Simone Correia Tostes da Fundação Getúlio Vargas, pelos ensinamentos na disciplina de Metodologia de Pesquisa que forneceu ferramentas para lapidar o presente estudo, pela sua inesgotável dedicação à discussão das questões metodológicas e revisão de texto desta tese e, sobretudo pelo companheirismo.

À Sueli Oliveira de Vasconcelos, pela preciosa revisão do texto desta tese segundo a nova ortografia.

À professora $\mathrm{Dr}^{\mathrm{a}}$. Sheila Walbe Ornstein, pelos ensinamentos na disciplina de APO e, juntamente com a professora $\operatorname{Dr}^{\mathrm{a}}$. Cibelle Haddad, pela motivação e pelas importantes e decisivas colocações na banca de qualificação.

À professora Dra . Edna Antonia de Mattos da Faculdade de Educação da USP, que plantou em minha alma a semente da inclusão. 
Ao Dr. Pedro Cheque Bernardo, pela prótese auricular infantil utilizada no questionário de conforto acústico destinado aos alunos cegos.

À fonoaudióloga Adriana Peres, pela conversão do questionário destinado aos alunos com paralisia cerebral $^{1}(\mathrm{PC})$ na linguagem dos símbolos de comunicação pictórica (PCS) ${ }^{2}$.

À psicóloga Yone Rafaeli, pelo incentivo à pesquisadora em relação às entrevistas realizadas pela mesma junto aos alunos com deficiência.

Aos colegas de academia Selso Dal Belo, Mariângela Carvalho Dezotti, Nina Cormedi, Walter José Ferreira Galvão, Maria Beatriz Barbosa,Tarsila Miyazato, Sandra Maria Bernardi, pelo apoio nesta caminhada.

Às queridas amigas Cecil, Dan, Lúcia, Roseli e Raquel, pela amizade sincera.

Aos funcionários do departamento de tecnologia: Silvana, Viviane, Eliane e Tiago, da secretaria de pós-graduação: Ivani, Cristina, Cilda, Sara, Diná, Regina e Isa, e da biblioteca: a paciente Maria José, da Faculdade de Arquitetura e Urbanismo (FAU) da Universidade de São Paulo (USP), pela simpatia e disponibilidade sempre.

À Aparecida da Silva Machado, pelo apoio na aplicação dos instrumentos destinados aos alunos surdos, cegos e com baixa visão.

À Fundação de Amparo à Pesquisa do Estado de São Paulo (FAPESP), pela concessão da bolsa de doutorado e pelo apoio financeiro que possibilitou a minha total dedicação à temática deste trabalho.

À Secretaria Municipal da Educação de São Paulo, pela autorização desta pesquisa junto a uma das escolas municipais de educação especial (EMEE).

\footnotetext{
${ }^{1}$ Designa uma sequela de caráter não progressivo, que acomete o sistema nervoso central imaturo e em desenvolvimento, ocasionando déficits posturais, tônicos e motores. (MANCINI et al., 2004).

2 Picture Communication Symbols (PCS), traduzido como Símbolos de Comunicação Pictórica, formam um sistema de comunicação completo utilizado por pessoas sem fala funcional (ver item 2.2.1.1).
} 
Às diretoras, às coordenadoras, aos docentes das escolas de educação especial, pelas autorizações de pesquisa, pelo acolhimento durante as atividades e pelas valiosas entrevistas concedidas.

À equipe de voluntários da escola especial destinada aos alunos com deficiência física, pelo apoio durante as atividades na pesquisa.

Aos alunos com deficiência e aos seus pais, pelo exemplo de superação e força de vida. 

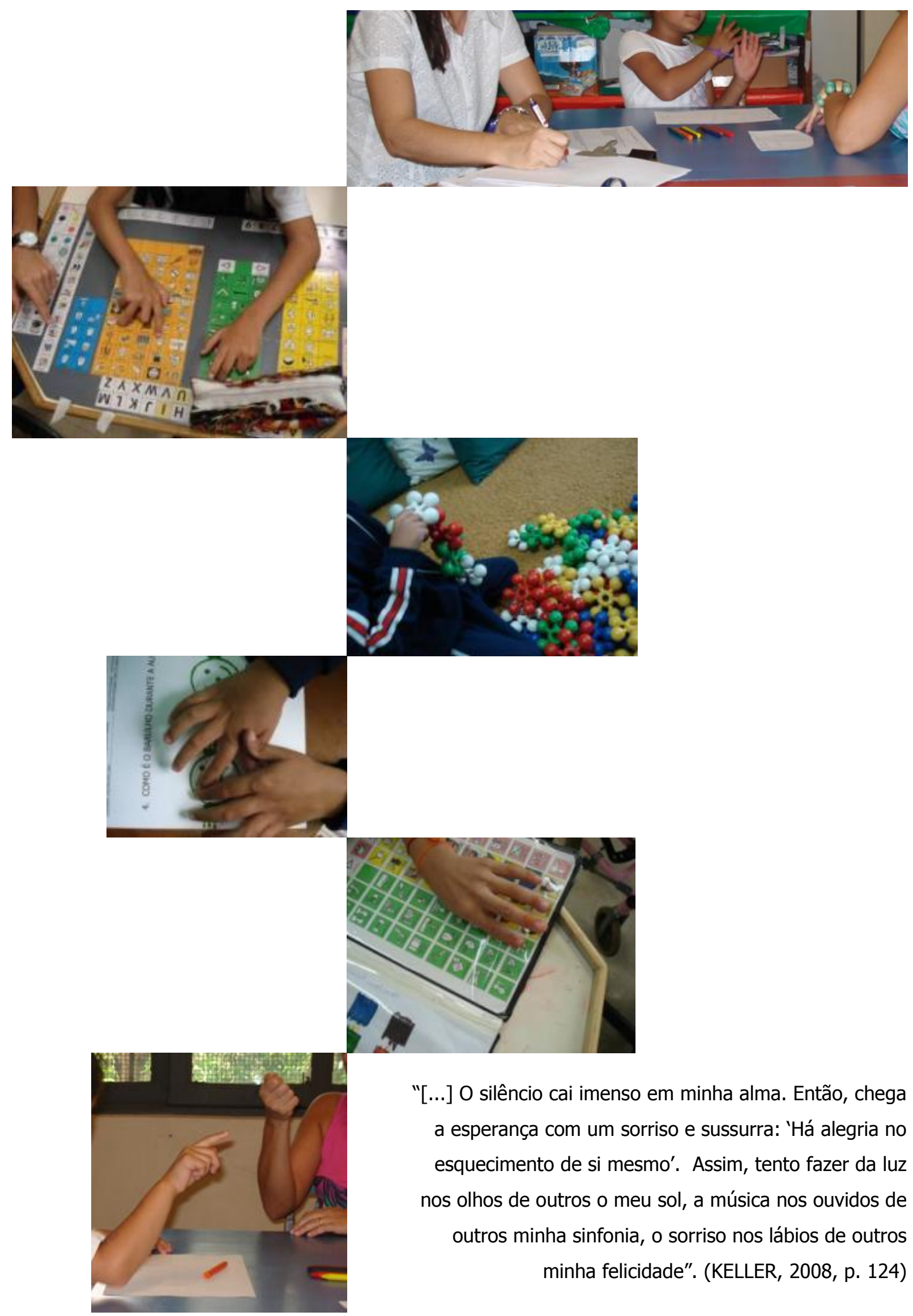

"[...] O silêncio cai imenso em minha alma. Então, chega a esperança com um sorriso e sussurra: 'Há alegria no esquecimento de si mesmo'. Assim, tento fazer da luz nos olhos de outros o meu sol, a música nos ouvidos de outros minha sinfonia, o sorriso nos lábios de outros minha felicidade". (KELLER, 2008, p. 124) 


\section{RESUMO}

ABATE, Tania Pietzschke. Instrumentos de Avaliação Pós-Ocupação (APO) adaptados a pré-escolares com deficiência física, auditiva e visual. 2011. Tese (Doutorado) Faculdade de Arquitetura e Urbanismo, Universidade de São Paulo, São Paulo, 2011.

Este estudo objetiva o desenvolvimento de instrumentos de Avaliação Pós-Ocupação (APO) destinados a alunos com deficiência física, auditiva e visual. Tem-se como meta a elaboração de referencial teórico e prático para futuros trabalhos relacionados a APO em escolas que considerem a inclusão da opinião dos alunos com deficiência e visa à melhoria qualitativa das condições de uso e o consequente favorecimento da inclusão dos mesmos. A avaliação da acessibilidade, conforto ambiental, segurança patrimonial e contra incêndios, dentre outras formas de avaliação, em ambientes escolares, tem adotado, no meio acadêmico, a APO como uma das metodologias. A APO consiste na aplicação de um conjunto de métodos e técnicas no ambiente construído e nos seus usuários e objetiva aferir o desempenho físico e a satisfação dos usuários em relação ao ambiente (ORNSTEIN; BRUNA; ROMÉRO, 1995). Alinhados com os objetivos do grupo de pesquisa Qualidade e Desempenho no Ambiente Construído, da Faculdade de Arquitetura e Urbanismo da Universidade de São Paulo (FAUUSP), se apresentam os resultados da elaboração e da aplicação dos instrumentos de coleta de dados: entrevista lúdica e questionário, adaptados aos alunos de pré-escola com deficiência física, auditiva e visual utilizando como base os resultados dos instrumentos aplicados na direção e nos docentes (entrevistas), bem como na observação dos alunos em três escolas especiais ${ }^{3}$ localizadas na cidade de São Paulo. A pesquisa de campo foi realizada em duas etapas, nos períodos entre agosto e dezembro de 2009 (pré-teste) e de 2010 (validação). A primeira etapa da pesquisa de campo teve como meta a verificação prática da metodologia proposta, incluindo a receptividade e a participação dos alunos envolvidos e a prospecção de erros visando à melhoria dos instrumentos para a nova aplicação realizada em 2010, que teve como meta a validação dos mesmos, bem como a comprovação das premissas levantadas. Adotou-se como estratégia de pesquisa o estudo de casos múltiplos incorporados (YIN, 2005), que se baseia em várias fontes de evidências e beneficia-se do desenvolvimento prévio de proposições teóricas para conduzir a coleta e a análise de dados, sendo que cada escola é o objeto de um estudo de caso individual. Este trabalho apresenta caráter qualitativo e multidisciplinar e fundamenta-se nos pressupostos teóricos da arquitetura e da APO, da educação; da pedagogia; da medicina; da sociologia e da psicologia ambiental, dentre outras áreas. Constatou-se que as limitações decorrentes de cada deficiência determinam as especificidades na adaptação e no processo de aplicação dos instrumentos para coleta de dados visando à medição da satisfação destes usuários em relação ao ambiente da pré-escola.

Palavras-chave: Avaliação pós-ocupação (instrumentos) - escolas, arquitetura para deficientes ${ }^{4}$, inclusão escolar, deficientes.

\footnotetext{
${ }^{3}$ A escola especial ou escola de educação especial oferece atendimento especializado, separado da rede regular de ensino, somente para os alunos com deficiência, sempre que, em função das condições específicas dos alunos, não for possível a sua integração nas classes comuns de ensino regular. Cada escola especial é especializada em uma deficiência específica e a sua associação com outras deficiências, limitações, condições ou disfunções.

${ }^{4} \mathrm{O}$ termo usual é pessoa com deficiência. Os termos constantes nas palavras-chave foram extraídos do Vocabulário Controlado do Sistema Integrado de Bibliotecas - SIBI (UNIVERSIDADE DE SÃO PAULO, 2006).
} 


\section{ABSTRACT}

ABATE, Tania Pietzschke. Post Occupancy Evaluation tools (POE) adapted to preschool children with physical, hearing, and visual disabilities. 2011. Thesis (Doctorate) - Faculty of Architecture and Urbanism, University of São Paulo, São Paulo, 2011.

This study aims at developing Post-Occupational Evaluation tools (POE) for students with physical, hearing, and visual disabilities. The objective consists of elaborating theoretical and practical references for future studies related to POE in schools that consider the opinion of students with disabilities and aim at qualitative conditions of use and inclusion. POE has been adopted as a method to assess accessibility, environmental comfort, asset security and fire safety, among other types of evaluation, in school environments. POE consists of applying a range of methods and techniques in the built environment in order to assess the users' satisfaction in relation to it (ORNSTEIN; BRUNA; ROMÉRO; 1995). The results of data designing and application are aligned with the aims of the Quality and Performance in the Built Environment research group, of the Faculty of Architecture and Urbanism of the University of São Paulo (FAUUSP): playful interview and questionnaire adapted to pre-school children with physical, hearing and visual disabilities based on results of tools applied in the head and teachers (interviews) as well as on the observation of students in three special schools ${ }^{5}$ located in the city of São Paulo. The field research was conducted in two phases: between August and December of 2009 (pre-testing) and of 2010 (validation). The first phase of the field research focused on the practical evaluation of the chosen method, including reception and participation of students involved and prediction of mistakes to improve tools for the new application, which occurred in 2010, in order to validate them, as well as to confirm the stated premises. The study of multiple incorporated cases has been adopted (YIN, 2005), which is based on various sources of evidence and benefits from previous development of theoretical propositions to perform data collection and analysis, being each school the object of an individual case study. This research presents qualitative and multidisciplinary approach and is based on theoretical presuppositions of architecture and POE; education; pedagogy; medicine; sociology and environmental psychology, among other areas. It has been observed that the limitations associated to each disability determine specificities in the adaptation and application of data collection instruments to assess the satisfaction of subjects in relation to pre-school environment.

Keywords: Post Occupancy Evaluation (tools) - schools, architecture for disabled people ${ }^{6}$, inclusion, disabled people.

\footnotetext{
${ }^{5}$ A special school or a school for special education offers specialized education outside the regular school system, exclusively for disabled students who, due to their specific needs, cannot be integrated in regular classes. Each special school is skilled in one type of disability and its association with other deficiencies, limitations, conditions, or disorders.

${ }^{6}$ The usual term is person with disability. The words chosen as keywords are based on the Controlled Vocabulary of the Integrated System of Libraries - SIBI (UNIVERSITY OF SÃO PAULO, 2006)
} 


\section{LISTA DE FIGURAS}

Figura 1 - Gráfico da projeção da distribuição da população brasileira com menos e mais de 18 anos em 2000 e 2020. Fonte: elaborado pela autora com dados do Censo 2000 (IBGE, 2000).

Figura 2 - Modelos de carteira escolar inclusiva: dos designers Guto Índio da Costa (a) e Érika Foureaux (b), e da FDE (c); balanço acessível ao uso de crianças com deficiência (d). Fonte: elaborada pela autora com os dados disponíveis em: <http://www.designacessivel.net> (a); <http://www.agenciaminas.mg.gov.br> (b); <http://www.fde.sp.gov.br> (c) - Acessos em: 20 jun. de 2010 e Laufer, 2001 (d).

Figura 3 - Esquema de organização das deficiências físicas e doenças. Fonte: Elaborada pela autora com base em Smith, 2008, p. 264.

Figura 4 - Símbolos de comunicação pictórica. Fonte: Disponível em: <http://www.clik.com.br>. Acesso em: 20 dez. 2009.

Figura 5 - Pasta (a) e prancha (b) de CAA sobre o tampo que se acoplada à cadeira de rodas. 75

Figura 6 - Técnica de seleção direta na prancha (a) e na pasta (b) de CAA. 76

Figura 7 - Cela Braille.

Figura 8 - Reglete em alumínio cromado fixado a uma prancha de madeira (a) e punção em madeira (b). Fonte: Disponível em: <http://intervox.nce.ufrj.br> (a); <http://www.bengalalegal.com.br> (b). Acessos em: 11 abr. 2009.

Figura 9 - Mapa tátil. Fonte: Disponível em: <http://www.arcomodular.com.br>. Acesso em: 16 abr. 2009.

Figura 10 - Engrossadores de lápis confeccionados com EVA enrolado e amarrado (a) e substituição da mesa por prancha de madeira fixada na cadeira de rodas (b).

Figura 11 - Duas vistas de manopla com ventosa fixa a mesa para apoio da mão esquerda do aluno.

Figura 12 - Mouse ocular. Fonte: Disponível em <http://www.redetec.org.br>. Acesso em: 15 jun. 2010.

Figura 13 - Órtese funcional (a) e próteses de membros inferiores (b). Fonte: Disponível em: <http://nteassistivas.blogspot.co/>. Acesso em: 15 abr. 2009.

Figura 14 - Goteira. Fonte: Disponível em: <http://ogatoderodas.blogspot.com>. Acesso em: 20 abr. 2009.

Figura 15 - Abdutor de quadril. Fonte: Disponível em: <http://ogatoderodas.blogspot.com>. Acesso em: 20 abr. 2009.

Figura 16 - Classificação das cadeiras de rodas. Fonte: Elaborada pela autora com base em Bertoncello e Gomes, 2002, p. 2.

Figura 17 - Cadeiras de rodas (a, b, c) mecanomanuais e carrinho (d) infantis. Fonte: Elaborado pela autora com dados disponíveis em: <http://www.baxmannjaguaribe.com.br>. Acesso em: 20 abr. 2009.

Figura 18 - Método de estudo de caso. Fonte: YIN, 2005, p. 72. 


\section{LISTA DE FIGURAS (continuação)}

Figura 19 - A família fundadora da escola para surdos. Fonte: Disponível em:

<http://www.educarede.org.br>. Acesso em: 26 dez. 2009.

Figura 20 - Entrevista com a coordenadora da unidade-caso 1.

Figura 21 - Entrevista semiestruturada com a coordenadora da unidade-caso 3.

Figura 22 - Entrevista semiestruturada com a docente da unidade-caso 1.

Figura 23 - Jogos de encaixe $(a, b)$ da pré-escola da unidade-caso 1.

Figura 24 - Máquina de escrever no sistema Braille da unidade-caso 1.

Figura 25 - Grupo focal das docentes de pré-escola da unidade-caso 3.

Figura 26 - Vaso sanitário no banheiro da unidade-caso 3.

Figura 27 - Apresentação da pesquisadora à classe da unidade-caso 1.

Figura 28 - Alunos chegaram à unidade-caso 2.

Figura 29 - Brinquedo de montar eleito para dar suporte à entrevista. 283

Figura 30 - Início da aplicação da entrevista lúdica com brinquedo destinada ao aluno D., de 5 anos, cego.

Figura 31 - Início da fase de aquecimento da entrevista lúdica com brinquedo destinada ao aluno D., de 5 anos, cego.

Figura 32 - Fase de aquecimento da entrevista lúdica com brinquedo destinada ao aluno D., de 5 anos, cego.

Figura 33 - Início da confecção do desenho pelos alunos com baixa visão.

Figura 34 - Postura inadequada do aluno V., de 5 anos, com baixa visão, durante a confecção do desenho temático.

Figura 35 - Repetição das perguntas da entrevista lúdica com desenho temático destinado ao aluno T., de 5 anos, à esquerda, com baixa visão.

Figura 36 - Anotação das respostas do aluno T., de 5 anos, à esquerda, com baixa visão pela pesquisadora.

Figura 37 - Apoio de outra docente durante a entrevista lúdica com desenho temático destinada aos alunos surdos.

Figura $38-1^{\text {a }}$ entrevista lúdica com desenho temático destinada ao aluno I., de 7 anos, surdo. 298

Figura 39 - $2^{\mathrm{a}}$ entrevista lúdica com desenho temático destinada ao aluno F., de 7 anos, surdo. 298

Figura 40 - $3^{a}$ entrevista lúdica com desenho temático destinada à aluna T., de 7 anos, surda. 299

Figura 41 - 4a entrevista lúdica com desenho temático destinada à aluna M., de 7 anos, surda. 299

Figura 42 - Apoio da voluntária para a confecção do desenho pela aluna com PC. 304

Figura 43 - Entrevista lúdica com desenho temático destinada ao aluno L. S., de 8 anos, com PC. 


\section{LISTA DE FIGURAS (continuação)}

Figura 44 - Entrevista lúdica com desenho temático destinada ao aluno M., de 7 anos, com PC. 306

Figura 45 - Entrevista lúdica com desenho temático destinada à aluna V., de 9 anos, com PC. 307

Figura 46 - Entrevista lúdica com desenho temático destinada à aluna P., de 7 anos, com distúrbio da medula espinhal. $\quad 308$

Figura 47 - Entrevista lúdica com desenho temático destinada à aluna I., de 7 anos, com PC. $\quad 308$

Figura 48 - Diretora apresentou o mapa tátil à pesquisadora. 315

Figura 49 - Mapa tátil da unidade-caso 1 eleito para dar suporte à entrevista. 322

Figura 50 - Mapa tátil das ruas do entorno da unidade-caso 1.

Figura 51 - Aluna I., de 6 anos, cega, utilizou o banheiro antes da entrevista lúdica com mapa tátil na $2^{\mathrm{a}}$ etapa da pesquisa.

Figura 52 - Condução da aluna I., de 6 anos, cega, para a entrevista lúdica com mapa tátil na $2^{\mathrm{a}}$ etapa da pesquisa.

Figura 53 - Entrevista lúdica com mapa tátil destinada à aluna I., de 6 anos, cega, na $2^{\mathrm{a}}$ etapa da pesquisa.

Figura 54 - Entrevista lúdica com mapa tátil destinada à aluna I., de 6 anos, cega, na $2^{\mathrm{a}}$ etapa da pesquisa.

Figura 55 - Alcance frontal de alunos cegos (a-c) e aluno cego no colo da pesquisadora e auxiliar durante a entrevista lúdica (d).

Figura 56 - Início da entrevista lúdica com desenho temático destinada à aluna V., de 8 anos, à frente, e ao aluno N., de 9 anos, ao fundo (esquerda), ambos com baixa visão.

Figura 57 - Confecção do desenho pela aluna V., de 8 anos, com baixa visão.

Figura 58 - Confecção do desenho pelo aluno N., de 9 anos, com baixa visão.

Figura 59 - Início da entrevista com a aluna V., de 8 anos (a), e com o aluno N., de 9 anos (b), ambos com baixa visão.

Figura 60 - Confecção do desenho pelo aluno T., de 6 anos, com baixa visão.

Figura 61 - Alunos cegos e com baixa visão assistidos pela auxiliar da pesquisadora.

Figura 62 - Entrevista lúdica com o aluno T., de 6 anos, com baixa visão.

Figura 63 - Confecção do desenho pela aluna E., de 8 anos, com baixa visão (a) pesquisadora realizou anotações durante a confecção do desenho (b).

Figura 64 - Entrevista lúdica com aluna E., de 8 anos, com baixa visão (a) e questionamento dos símbolos desenhados pela aluna realizados ao final.

Figura 65 - Configuração espacial da entrevista lúdica (a) e apoio de auxiliar da pesquisadora (b), na entrevista lúdica destinada aos alunos surdos em 09/09/2010.

Figura 66 - Configuração da entrevista lúdica (a) e apoio da docente ao fundo na sala de vídeo (b) durante a entrevista lúdica destinada aos alunos surdos em 04/10/2010. 


\section{LISTA DE FIGURAS (continuação)}

Figura 67 - Alunos surdos: K. dos R., de 6 anos (a); S., de 5 anos (b); P., de 6 anos (c) e G., de 6 anos (d), na escolha do tema antes da confecção do desenho.

Figura 68 - Alunos surdos: M., de 6 anos (a); T., de 6 anos, à esquerda (b), K. dos R., de 6 anos (c); S., de 5 anos (d); P., de 6 anos (e); e G., de 6 anos, à esquerda (f), confeccionavam o desenho.

Figura 69 - Docente solicitou que a aluna K., de 6 anos, surda, realizasse o desenho (a, b, c) e convidou outra aluna, à esquerda, para desenhar em conjunto (d).

Figura 70 - Docente e aluna M., de 6 anos, surda, se comunicavam em LIBRAS na entrevista lúdica, e a pesquisadora anotou a verbalização da docente.

Figura 71 - A docente fixou o papel à mesa (a) e apontou para as canetas, uma a uma, para que a aluna A., de 10 anos, com PC (b) elegesse uma cor.

Figura 72 - Docente posicionou a mão da aluna A., de 10 anos, com PC, para pega da caneta para o início do desenho temático.

Figura 73 - A docente auxiliou a aluna A., de 10 anos, com PC, na confecção do desenho temático (ac) e a pesquisadora iniciou a mesma tarefa de forma conjunta (d).

Figura 74 - Pesquisadora auxiliou a aluna A., de 10 anos, com PC, na confecção do desenho temático.

Figura 75 - Entrevista lúdica com aluna A., de 10 anos, com PC.

Figura 76 - Aluno M., de 8 anos, com PC, segurou a caneta sozinho e realizou os traços do desenho (a), a voluntária permaneceu ao seu lado para auxiliar na troca das canetas e posicionamento da mão do aluno (b).

Figura 77 - A docente realizou verbalmente as perguntas da entrevista (a, c), o aluno M., de 8 anos, com PC, indicou com a mão a alternativa eleita nos Quadro 41 e 43, respectivamente (b, d). 368

Figura 78 - 0 aluno M., de 8 anos, com PC, indicou o símbolo desenhado após verbalização do mesmo pela docente (a) e a pesquisadora anotou o número no símbolo e relacionou seu significado em sua planilha de anotações (b).

Figura 79 - Dois alunos, com PC, desenharam com independência $(a, c)$ e responderam a entrevista verbalmente, com diferentes graus de dificuldade $(b, d)$.

Figura 80 - Acabamento da ilustração do questionário em tinta plástica para relevo (a) e em barbante colado com detalhe (olho) em tinta plástica para relevo (b), destinados aos alunos cegos. $\quad 390$

Figura 81 - Início da aplicação do questionário ilustrado tátil destinado ao aluno D., de 5 anos, cego.

Figura 82 - Pesquisadora auxilia o aluno D., de 5 anos, cego, no posicionamento das mãos.

Figura 83 - Reconhecimento tátil da ilustração do questionário pelo aluno D., de 5 anos, cego. 393

Figura 84 - Docente direcionou as duas mãos da aluna $(a, b)$, alternou com o direcionamento de uma das mãos (c, d), durante a aplicação do questionário ilustrado tátil destinado a aluna cega.

Figura 85 - Início da aplicação do questionário ilustrado ampliado destinado ao aluno V., de 5 anos, com baixa visão. 


\section{LISTA DE FIGURAS (continuação)}

Figura 86 - Aplicação coletiva do questionário ilustrado em alunos surdos(a) e explicação do questionário em LIBRAS pela docente (b).

Figura 87 - Início da aplicação do questionário ilustrado destinado aos alunos surdos na $1^{\text {a }}$ etapa da pesquisa.

Figura 88 - $O$ aluno F., de 7 anos, surdo, respondeu o questionário com facilidade (a) e a aluna T., de 7 anos, surda, não entendeu as questões (b).

Figura 89 - Início da aplicação do questionário ilustrado em alunos com deficiência física.

Figura 90 - Técnica de seleção direta (a) e auxílio na marcação da alternativa eleita (b) no questionário ilustrado destinado aos alunos com deficiência física.

Figura 91 - Técnica de varredura no questionário ilustrado destinado aos alunos com deficiência física.

Figura 92 - Execução do questionário ilustrado em PCS pela aluna V., de 9 anos, com PC.

Figura 93 - Execução do questionário ilustrado em PCS pelo aluno M., de 8 anos, com PC.

Figura 94 - Realização com independência do questionário ilustrado destinado aos alunos com deficiência física.

Figura 95 - Fonoaudióloga (a) pesquisou os símbolos em PCS no software (b), ilustrações em PCS do manual (impresso) do usuário do Boardmaker (c) e sua respectiva capa (d).

Figura 96 - Símbolos em PCS.

Figura 97 - Opções de ilustrações descartadas relativas à questão de conforto lumínico.

Figura 98 - Dados antropométricos da criança de 6 anos. Fonte: DREYFUSS, 1959.

Figura 99 - Maquete tátil sonora destinada aos alunos cegos na $2^{\mathrm{a}}$ etapa da pesquisa.

Figura 100 - Etiqueta afixada na maquete tátil sonora.

Figura 101 - Alternativas impressas para visualização do aplicador.

Figura 102 - Maquete tátil térmica destinada aos alunos cegos na $2^{\mathrm{a}}$ etapa da pesquisa $(\mathrm{a}, \mathrm{b})$ aparelho de luz infravermelha (c) e o mesmo no interior da maquete citada (d).

Figura 103 - Etiqueta de identificação afixada na maquete tátil térmica.

Figura 104 - Três alternativas móveis da maquete tátil relativas ao corredor (a), à escada (b) e ao banheiro (c) - destinada aos alunos cegos na $2^{\mathrm{a}}$ etapa da pesquisa - e troca da alternativa pela pesquisadora (d).

Figura 105 - Etiqueta de identificação afixada na maquete tátil.

Figura 106 - Fase de aquecimento da questão relativa a conforto acústico pelo aluno R., de 13 anos, cego, na $2^{\mathrm{a}}$ etapa da pesquisa.

Figura 107 - Reconhecimento das alternativas da questão relativa a conforto acústico pelo aluno R., de 13 anos, cego, na $2^{a}$ etapa da pesquisa. 


\section{LISTA DE FIGURAS (continuação)}

Figura 108 - Processo de escolha da alternativa referente a conforto acústico pelo aluno R., de 13 anos, cego, na $2^{\mathrm{a}}$ etapa da pesquisa.

Figura 109 - Reconhecimento das alternativas da questão relativa a conforto térmico pelo aluno R., de 13 anos, cego, na $2^{\mathrm{a}}$ etapa da pesquisa.

Figura 110 - Processo de eleição de uma das alternativas da questão relativa a conforto térmico pelo aluno R., de 13 anos, cego, na $2^{\mathrm{a}}$ etapa da pesquisa.

Figura 111 - As alternativas correspondentes ao corredor (a) e à escada (b) da questão de acessibilidade foram reconhecidas pelo aluno R., de 13 anos, cego, na $2^{\mathrm{a}}$ etapa da pesquisa.

Figura 112 - A alternativa da questão de acessibilidade referente ao banheiro é tateada pelo aluno R., de 13 anos, cego, na $2^{\mathrm{a}}$ etapa da pesquisa.

Figura 113 - Realização do questionário ampliado pela aluna E., de 8 anos, com baixa visão (a, b c,d)

Figura 114 - Aluno N., de 9 anos, com baixa visão severa não conseguiu enxergar as alternativas do questionário ilustrado ampliado.

Figura 115 - As alternativas relativas à questão sobre conforto térmico $(a, b)$ são explicadas em LIBRAS à aluna M., de 6 anos, surda; a aluna responde o questionário ilustrado.

Figura 116 - A aluna V., de 10 anos, com PC indicou as alternativas $(a, c)$ e a docente as assinalou (b, d). 


\section{LISTA DE QUADROS}

Quadro 1 - Panorama geral da CIF. Fonte: CIF, 2003, p. 22.

Quadro 2 - Interações entre os componentes da CIF. Fonte: CIF, 2003, p. 30.

Quadro 3 - Áreas do corpo afetadas pela paralisia cerebral. Fonte: Elaborada pela autora com base em Smith (2008).

Quadro 4 - Categorias de tecnologia assistiva segundo a ADA. Fonte: Elaborado pela autora com dados disponíveis em: <http://www.assistiva.com.br/>. Acesso em: 20 mai. 2009; (SEESP/SEED/MEC, 2007, p. 58).

Quadro 5 - Definições relativas à deficiência. Fonte: Elaborada pela autora com base nos documentos citados no quadro.

Quadro 6 - Dados da unidade-caso 1.

Quadro 7 - Dados da unidade-caso 2.

Quadro 8 - Dados da unidade-caso 3.

Quadro 9 - Dados da eventual unidade-caso 4.

Quadro 10 - Técnicas baseadas no método centrado na pessoa. Fonte: Elaborado pela autora com base em Ornstein e Moreira (2008); Günther, Elali, Pinheiro (2008); Günther, H. (2008); Günther, I. (2008); Pinheiro, Elali, Fernandes (2008); Rheingantz et al. (2008); Sbarra (2007); Zeisel (2005); Elali (2002b); Higuchi (1999); Aiello-Vaisber, (1995, 1997, 1999), Ornstein, Bruna e Roméro (1995); Ornstein e Roméro (1992); Sanoff (1991, 1994), Trinca (1976), dentre outros.

Quadro 11 - Técnicas baseadas no método centrado no lugar. Fonte: Elaborado pela autora com base em Ornstein e Moreira (2008); Bomfim (2008); Günther, Elali, Pinheiro (2008); Günther, H. (2008); Günther, I. (2008); Pinheiro, Elali, Fernandes (2008); Rheingantz et al. (2008); Sbarra (2007); Zeisel (2005); Elali (2002b); Higuchi (1999); Ornstein, Bruna e Roméro (1995); Ornstein e Roméro (1992); Sanoff (1991, 1994); Lynch (1980), dentre outros.

Quadro 12 - Modalidades de entrevista adotadas na $1^{\mathrm{a}}$ e $2^{\mathrm{a}}$ etapas da pesquisa por unidade-caso.

Quadro 13 - Roteiro da entrevista semiestruturada destinada à direção das unidades-caso.

Quadro 14 - Entrevistas semiestruturadas destinadas aos docentes das unidades-caso na $1^{\text {a }}$ etapa da pesquisa.

Quadro 15 - Vantagens e desvantagens da técnica de coleta de dados observação.

Quadro 16 - Observações destinadas aos alunos das unidades-caso 1, 2 e 3.

Quadro 17 - $1^{\text {a }}$ observação não estruturada dos alunos com deficiência visual da unidade-caso 1.

Quadro 18 - 2a observação não estruturada dos alunos com deficiência visual da unidade-caso 1.

Quadro 19 - $1^{\text {a }}$ observação não estruturada de parte dos alunos com deficiência auditiva das 4 classes de pré-escola da unidade-caso 2 (a).

Quadro 20 - $1^{\text {a }}$ observação não estruturada de alguns dos alunos com deficiência auditiva das 4 classes de pré-escola da unidade-caso 2 (b). 


\section{LISTA DE QUADROS (continuação)}

Quadro 21 - $2^{\mathrm{a}}$ observação não estruturada dos alunos com deficiência auditiva da classe de préescola apta a participar da pesquisa da unidade-caso 2 .

Quadro 22 - 3a observação não estruturada dos alunos com deficiência auditiva de duas classes de pré-escola da unidade-caso 2.

Quadro 23 - $1^{\text {a }}$ observação não estruturada dos alunos com deficiência física da uma das classes de pré-escola da unidade-caso 3 (a).

Quadro 24 - $1^{\text {a }}$ observação não estruturada dos alunos com deficiência física da uma das classes de pré-escola da unidade-caso 3 (b).

Quadro 25 - $2^{\mathrm{a}}$ observação não estruturada da aluna de pré-escola da unidade-caso 3.

Quadro 26 - Roteiro da entrevista lúdica com brinquedo destinada aos alunos cegos na $1^{\text {a }}$ etapa da pesquisa (pré-teste).

Quadro 27 - Alguns dos procedimentos para a aplicação adotados na entrevista com desenho temático na $1^{\text {a }}$ etapa da pesquisa (pré-teste), por deficiência.

Quadro 28 - Roteiro da entrevista lúdica com desenho temático na $1^{a}$ etapa da pesquisa (pré-teste), por deficiência.

Quadro 29 - Síntese da entrevista lúdica com desenho temático destinada ao aluno V., de 5 anos, com baixa visão, da unidade-caso 1 na $1^{\text {a }}$ etapa da pesquisa.

Quadro 30 - Síntese da entrevista lúdica com desenho temático destinada ao aluno T., de 5 anos, com baixa visão, da unidade-caso 1 na $1^{\text {a }}$ etapa da pesquisa.

Quadro 31 - Síntese da entrevista lúdica com desenho temático destinada ao aluno I., de 7 anos, surdo, da unidade-caso 2 na $1^{\text {a }}$ etapa da pesquisa.

Quadro 32 - Síntese da entrevista lúdica com desenho temático destinada à aluna M., de 7 anos, surda, da unidade-caso 2 na $1^{\text {a }}$ etapa da pesquisa.

Quadro 33 - Síntese da entrevista lúdica com desenho temático destinada ao aluno E., de 7 anos, com $\mathrm{PC}$, da unidade-caso 3 na $1^{\mathrm{a}}$ etapa da pesquisa.

Quadro 34 - Síntese da entrevista lúdica com desenho temático destinada à aluna I., de 7 anos, com $\mathrm{PC}$, da unidade-caso 3 na $1^{\mathrm{a}}$ etapa da pesquisa.

Quadro 35 - Síntese da entrevista lúdica com desenho temático destinada à aluna P., de 7 anos, com distúrbio da medula espinhal, da unidade-caso 3 na $1^{\text {a }}$ etapa da pesquisa.

Quadro 36 - Síntese da entrevista lúdica com desenho temático destinada ao aluno M., de 7 anos, com PC, da unidade-caso 3 na $1^{\text {a }}$ etapa da pesquisa.

Quadro 37 - Alguns dos procedimentos de aplicação adotados na entrevista com desenho temático na $2^{\mathrm{a}}$ etapa da pesquisa, por deficiência.

Quadro 38 - Roteiro da entrevista lúdica com desenho temático na $2^{\mathrm{a}}$ etapa da pesquisa.

Quadro 39 - Painel com alternativas ilustradas de respostas (Questões 1 e 3) da entrevista lúdica destinada aos alunos com baixa visão na $2^{\mathrm{a}}$ etapa da pesquisa.

Quadro 40 - Painel com alternativas ilustradas de respostas (Questões 1 e 3) da entrevista lúdica destinada aos alunos com surdez na $2^{\mathrm{a}}$ etapa estapa da pesquisa. 


\section{LISTA DE QUADROS (continuação)}

Quadro 41 - Painel com alternativas ilustradas de respostas (Questões 1 e 3) da entrevista lúdica destinada aos alunos com PC na $2^{\mathrm{a}}$ etapa etapa da pesquisa.

Quadro 42 - Alternativas ilustradas de resposta (Questão 5) da entrevista lúdica destinada aos alunos com surdez na $2^{\mathrm{a}}$ etapa etapa da pesquisa.

Quadro 43 - Alternativas ilustradas de resposta (Questão 5) da entrevista lúdica destinada aos alunos com PC na $2^{\mathrm{a}}$ etapa etapa da pesquisa.

Quadro 44 - Síntese da entrevista lúdica com desenho temático destinada à aluna V., de 8 anos, com baixa visão da unidade-caso 1 na $2^{\mathrm{a}}$ etapa da pesquisa.

Quadro 45 - Síntese da entrevista lúdica com desenho temático destinada ao aluno N., de 9 anos, com baixa visão da unidade-caso 1 na $2^{\mathrm{a}}$ etapa da pesquisa.

Quadro 46 - Síntese da entrevista lúdica com desenho temático destinada ao aluno T., de 6 anos, com baixa visão da unidade-caso 1 na $2^{\mathrm{a}}$ etapa da pesquisa.

Quadro 47 - Síntese da entrevista lúdica com desenho temático destinada a aluna E., de 8 anos, com baixa visão da unidade-caso 1 na $2^{a}$ etapa da pesquisa.

Quadro 48 - Síntese da entrevista lúdica com desenho temático destinada a aluna M., de 6 anos, surda, da unidade-caso 2 na $2^{\mathrm{a}}$ etapa da pesquisa.

Quadro 49 - Síntese da entrevista lúdica com desenho temático destinada à aluna K., de 6 anos, surda, da unidade-caso 2 na $2^{\text {a }}$ etapa da pesquisa.

Quadro 50 - Síntese da entrevista lúdica com desenho temático destinada a aluna A., de 10 anos, com PC, da unidade-caso 3 na $2^{\mathrm{a}}$ etapa da pesquisa.

Quadro 51 - Síntese da entrevista lúdica com desenho temático destinada ao aluno M. de 8 anos com

PC da unidade-caso 3 na $2^{\text {a }}$ etapa da pesquisa.

Quadro 52 - Síntese da entrevista lúdica com desenho temático destinada ao aluno E., de 8 anos, com PC, da unidade-caso 3 na $2^{\text {a }}$ etapa da pesquisa.

Quadro 53 - Síntese da entrevista lúdica com desenho temático destinada a aluna P., de 8 anos, com distúrbio da medula espinhal, da unidade-caso 3 na $2^{\mathrm{a}}$ etapa da pesquisa.

Quadro 54 - Alguns dos procedimentos de elaboração e aplicação do questionário adotados na $1^{a}$ etapa da pesquisa (pré-teste), por deficiência.

Quadro 55 - Ilustrações da questão de conforto térmico destinada aos alunos com deficiência visual (cegueira e baixa visão), auditiva e física na $1^{\text {a }}$ etapa da pesquisa.

Quadro 56 - Ilustrações da questão de conforto lumínico destinada aos alunos com deficiência visual (baixa visão), auditiva e física na $1^{\text {a }}$ etapa da pesquisa.

Quadro 57 - Ilustrações da questão de conforto acústico destinada aos alunos com deficiência visual (cegueira e baixa visão) e física na $1^{\mathrm{a}}$ etapa da pesquisa.

Quadro 58 - Ilustrações da questão de acessibilidade destinada aos alunos com deficiência visual (cegueira e baixa visão), auditiva e física na $1^{\text {a }}$ etapa da pesquisa.

Quadro 59 - Ilustrações em PCS da questão de conforto térmico destinada aos pré-escolares com deficiência visual (baixa visão), auditiva e física na $2^{\mathrm{a}}$ etapa da pesquisa. 


\section{LISTA DE QUADROS (continuação)}

Quadro 60 - Ilustrações em PCS da questão de conforto acústico destinada aos pré-escolares com deficiência visual (baixa visão) e física na $2^{\mathrm{a}}$ etapa da pesquisa.

Quadro 61 - Ilustrações da questão de conforto lumínico destinada aos alunos com deficiência visual (baixa visão), auditiva e física na $2^{\mathrm{a}}$ etapa da pesquisa.

Quadro 62 - Ilustrações da questão de acessibilidade física destinada aos alunos com deficiência visual, auditiva e física na $2^{\mathrm{a}}$ etapa da pesquisa.

Quadro 63 - Dados da maquete tátil sonora destinada aos alunos, cegos, na $2^{\mathrm{a}}$ etapa da pesquisa.

Quadro 64 - Dados da maquete tátil térmica destinada aos alunos cegos na $2^{\mathrm{a}}$ etapa da pesquisa.

Quadro 65 - Dados da maquete tátil destinada aos alunos cegos na 2a etapa da pesquisa. 


\section{LISTA DE TABELAS}

Tabela 1 - Proporção da população residente, portadora de pelo menos uma das deficiências investigadas, por grandes grupos de idade (\%), segundo as grandes regiões do Brasil.

Tabela 2 - Distribuição da população residente, portadora de pelo menos uma das deficiências investigadas, por grupos de idade de 0 a 17 anos.

Tabela 3 - Levantamento do número de alunos matriculados nas pré-escolas das EMEEs existentes no município de São Paulo em 2009 e 2010.

Tabela 4 - Distribuição dos docentes e dos alunos nos anos letivos de 2009 e de 2010 por classe de pré-escola e por tipo de deficiência visual na unidade-caso 1 .

Tabela 5 - Distribuição dos alunos com deficiência auditiva matriculados nos anos letivos de 2009 e de 2010 por classe de pré-escola na unidade-caso 2.

Tabela 6 - Distribuição dos alunos com deficiência física matriculados nos anos letivos de 2009 e de 2010 por classe de pré-escola e período na unidade-caso 3.

Tabela 7 - Distribuição dos alunos na $1^{a}$ etapa da pesquisa (ano letivo de 2009) por classe de préescola e por tipo de deficiência nas unidades-caso.

Tabela 8 - Distribuição dos alunos na $2^{\mathrm{a}}$ etapa da pesquisa (ano letivo de 2010) por classe de préescola e por tipo de deficiência nas unidades-caso. 


\section{LISTA DE SIGLAS}

AAMD Associação Americana de Deficiência Mental

AASI Aparelho de Amplificação Sonora

ABNT Associação Brasileira de Normas Técnicas

ADA American with Disabilities Act

ADG Associação de Designers Gráficos

AHIMSA Associação Educacional para Múltipla Deficiência

APAE Associação de Pais e Amigos dos Excepcionais

APO Avaliação Pós-Ocupação

ASHA American Speech-Language-Hearing Association

AVD Atividades da Vida Diária

BIREME Centro Latino-Americano e do Caribe de Informação em Ciências da Saúde

BO Boletim de Ocorrência Policial

CAA Comunicação Aumentativa e Alternativa

CAT Comunicação de Acidentes do Trabalho

CEFAI Centro de Formação e Acompanhamento à Inclusão

CEI Centro Educacional Integrado

CELE Centre for Effective Learning Environments

CID Classificação Internacional de Doenças

CIEJA Centro Integrado de Educação de Jovens e Adultos

CIF Classificação Internacional de Funcionalidade, Incapacidade e Saúde

CORDE Coordenadoria Nacional para Integração da Pessoa Portadora de

Deficiência

DENATRAN Departamento Nacional de Trânsito

DORT Doenças Osteomusculares

DRE Diretorias Regionais de Educação

EI Educação Infantil

EJA Educação de Jovens e Adultos

EMEE Escola Municipal de Educação Especial 


\section{LISTA DE SIGLAS (continuação)}

EMEF Escola Municipal de Ensino Fundamental

EMEFM Escola Municipal de Ensino Fundamental e Médio

EMEI Escola Municipal de Educação Infantil

EUA Estados Unidos da América

EVA Etil, Vinil e Acetato

FAPESP Fundação de Amparo à Pesquisa do Estado de São Paulo

FAUUFR] Faculdade de Arquitetura e Urbanismo da Universidade Federal do Rio de Janeiro

FAUUSP Faculdade de Arquitetura e Urbanismo da Universidade de São Paulo

FCC Fundação Carlos Chagas

FDE Fundação para o Desenvolvimento Escolar

GAE Grupo Ambiente-Educação

GMFCS Gross Motor Function Classification System

IBGE Instituto Brasileiro de Geografia e Estatística

INEP Instituto Nacional de Estudos Pedagógicos

INES Instituto Nacional da Educação dos Surdos

LDBEN Lei de Diretrizes e Bases da Educação Nacional

LIBRAS Língua Brasileira de Sinais

MACS Manual Abilities Classification System

MEC Ministério da Educação e Cultura

NEE Necessidades Educacionais Especiais

OECD Organisation for Economic Co-operation and Development

OG Organizações Governamentais

OMS Organização Mundial da Saúde

ONG Organizações Não Governamentais

ONU Organização das Nações Unidas

PAAI Professor de Apoio e Acompanhamento à Inclusão

PAED Programa de Complementação ao Atendimento Educacional Especializado às Pessoas Portadoras de Deficiência 


\section{LISTA DE SIGLAS (continuação)}

PC

Paralisia Cerebral

PCS

Picture Communication Symbols

PIC

Pictogram Ideogram Communication Symbols

PUCSP Pontifícia Universidade Católica de São Paulo

QI Quociente de Inteligência

SAAI Salas de Apoio e Acompanhamento à Inclusão

SDH/PR Secretaria de Direitos Humanos da Presidência da República

SEED Secretaria de Estado da Educação

SEESP Secretaria de Educação do Estado de São Paulo

SIBI/USP Sistema Integrado de Bibliotecas da Universidade de São Paulo

SIH/SUS Sistema de Informações Hospitalares do Sistema Único de Saúde

SIM/MS Sistema de Informação de Mortalidade do Ministério da Saúde

SINITOX Sistema Nacional de Informações Tóxico-Farmacológicas

SMESP Secretaria Municipal da Educação de São Paulo

SNPD Subsecretaria Nacional de Promoção dos Direitos da Pessoa com

Deficiência

3D Três dimensões

TTY Telefones com Teclado-Teletipo

UCPA United Cerebral Palsy Association

UNESCO Organização das Nações Unidas para a Educação, a Ciência e a Cultura

UNESP Universidade Estadual Paulista

UNIFESP Universidade Federal de São Paulo 


\section{SUMÁRIO}

Resumo

ix

Abstract

Lista de figuras

xi

Lista de quadros

xiii

Lista de tabelas

xix

Lista de siglas

xxiii

1 INTRODUÇÃO

1.1 Apresentação

1.2 Problemática e justificativa

1.3 Relevância e originalidade

1.4 Objetivos

1.4.1 Objetivo geral

1.4.2 Objetivo específico

1.5 Caráter e premissas da pesquisa

1.6 Estrutura e descrição dos capítulos

2 PRESSUPOSTOS TEÓRICOS RELATIVOS À DEFICIÊNCIA

51

2.1 A deficiência

2.1.1 A Classificação Internacional de Funcionalidade, Incapacidade e Saúde (CIF)

2.2 Os tipos de deficiências

2.2.1 A deficiência física

2.2.1.1 A comunicação aumentativa e alternativa (CAA)

2.2.2 A deficiência auditiva

2.2.2.1 A Língua Brasileira de Sinais (LIBRAS)

2.2.3 A deficiência visual

2.2.3.1 O Sistema Braille

2.2.4 A deficiência intelectual

2.2.5 A deficiência múltipla

2.2.5.1 Os recursos de comunicação

2.3 A doença crônica orgânica

2.4.1 Transtornos da linguagem

2.4.2 Transtornos de aprendizagem

$\begin{array}{ll}2.5 \text { Indicadores estatísticos relativos à deficiência } & 107 \\ 2.6 \text { A tecnologia assistiva } & 113\end{array}$

2.7 Considerações do capítulo $2 \quad 124$

3 PRESSUPOSTOS TEÓRICOS RELATIVOS À INCLUSÃO ESCOLAR DOS ALUNOS COM NECESSIDADES EDUCACIONAIS ESPECIAIS (NEE)

$\begin{array}{ll}\text { 3.2.1.1 Boas práticas de educação inclusiva no cenário internacional } & 137 \\ \text { A escola especial e a educação especial } & 140\end{array}$

3.2.2 A escola especial e a educação especial
3.2.2.1 Serviços de educação especial oferecidos na rede municipal de ensino de São Paulo 
3.2.3 Críticas à educação inclusiva e especial

3.2.3.1 A questão da faixa etária na pré-escola 150

3.3 Legislação relevante ao aluno com NEE 153

3.3.1 Legislação Internacional 153

3.3.2 Legislação Federal (Brasil) 155

3.3.3 Legislação no Estado de São Paulo 159

3.3.4 Legislação no Município de São Paulo 159

3.4 Vertentes pedagógicas da educação infantil 161

3.5 Considerações do capítulo $3 \quad 169$

4 FUNDAMENTOS METODOLÓGICOS DA PESQUISA DE CAMPO 173

4.1 Estratégia de pesquisa: estudos de casos múltiplos incorporados 173

4.2 Abordagem $\quad 176$

4.3 Critérios de seleção 177

4.3.1 Modalidade escola de educação especial 177

4.3.2 Unidades-caso ou escolas especiais 177

4.3.2.1 Unidade-caso 1: especializada no aluno com deficiência visual 178

4.3.2.2 Unidade-caso 2: especializada no aluno com deficiência auditiva 180

4.3.2.3 Unidade-caso 3: especializada no aluno com deficiência física 182

4.3.3 Justificativa da não inclusão de alunos com deficiência múltipla no estudo 183

4.4 Etapas dos estudos de casos $\quad 185$

$\begin{array}{lll}\text { 4.4.1 } & 1^{\text {a }} \text { etapa: pré-teste } & 185\end{array}$

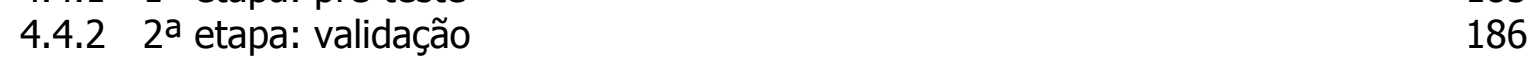

4.5 Delimitação dos sujeitos da pesquisa 186

4.5.1 Unidade-caso 1: especializada no aluno com deficiência visual 187

4.5.2 Unidade-caso 2: especializada no aluno com deficiência auditiva 189

4.5.3 Unidade-caso 3: especializada no aluno com deficiência física 191

4.6 Panorama das técnicas de coleta de dados em situações educativas 193

$\begin{array}{ll}\text { 4.6.1 Técnicas de coleta de dados adotadas } & 197\end{array}$

4.7 Considerações do capítulo $4 \quad 198$

5 A TÉCNICA DA ENTREVISTA DESTINADA AOS ADULTOS 201

5.1 Referencial teórico $\quad 201$

$\begin{array}{lll}5.1 .1 & \text { Modalidades } & 204\end{array}$

$\begin{array}{ll}5.1 .2 & \text { Os protagonistas da entrevista } \\ & 206\end{array}$

$\begin{array}{lll}5.1 .3 & \text { Fase preparatória da entrevista } & 208\end{array}$

$\begin{array}{ll}\text { 5.1.4 Desenvolvimento da entrevista } & 210\end{array}$

$\begin{array}{ll}\text { 5.1.5 Análise da entrevista } & 210\end{array}$

5.1.6 A entrevista em grupo 212

$5.21^{\text {a }}$ etapa da pesquisa $\quad 214$

5.2.1 Entrevistas não estruturadas individuais com diretoras ou coordenadoras $\quad 215$

$\begin{array}{ll}\text { 5.2.1.1 Unidade-caso 1: resultados } & 216\end{array}$

$\begin{array}{ll}\text { 5.2.1.2 Unidade-caso 2: resultados } & 217\end{array}$

$\begin{array}{ll}\text { 5.2.1.3 Unidade-caso 3: resultados } & 218\end{array}$

5.2.2 Entrevistas semiestruturadas individuais com diretoras ou coordenadoras $\quad 219$

5.2.2.1 Unidade-caso 1: resultados 221

5.2.2.2 Unidade-caso 2: resultados 223

5.2.2.3 Unidade-caso 3: resultados 224

5.2.3 Entrevistas semiestruturadas com docentes 227

5.2.3.1 Unidade-caso 1: resultados - individual 229

5.2.3.2 Unidade-caso 2: resultados - individual 233 
5.2.3.3 Unidade-caso 3: resultados - grupo focal 234

$5.32^{\mathrm{a}}$ etapa da pesquisa 236

5.3.1 Entrevistas não estruturadas individuais com diretoras ou coordenadoras 236

$\begin{array}{ll}\text { 5.3.1.1 Unidade-caso 1: resultados } & 237\end{array}$

$\begin{array}{ll}\text { 5.3.1.2 Unidade-caso 2: resultados } & 238\end{array}$

5.3.1.3 Unidade-caso 3: resultados 238

5.3.2 Entrevistas não estruturadas com docentes 239

5.3.2.1 Unidade-caso 1: resultados - grupo focal 240

5.3.2.2 Unidade-caso 2: resultados - individual 242

5.3.2.3 Unidade-caso 3: resultados - grupo focal 243

5.4 Análise dos resultados nas duas etapas da pesquisa 245

6 A TÉCNICA DA OBSERVAÇÃO DESTINADA ÀS CRIANÇAS 249

6.1 Referencial teórico $\quad 249$

6.1.1 Modalidades 251

6.1.2 Fase preparatória da observação $\quad 254$

$\begin{array}{ll}\text { 6.1.3 Desenvolvimento da observação } & 255\end{array}$

6.1.4 Análise da observação $\quad 256$

$6.21^{\text {a }}$ etapa da pesquisa $\quad 256$

6.2.1 Observações não estruturadas 258

6.2.1.1 Alunos cegos e com baixa visão: resultados da unidade-caso $1 \quad 258$

6.2.1.2 Alunos surdos: resultados da unidade-caso 2

6.2.1.3 Alunos com PC: resultados da unidade-caso 3

$\begin{array}{ll}\text { 6.2.1.4 Análise dos resultados } & 269\end{array}$

7 A TÉCNICA DA ENTREVISTA LÚDICA DESTINADA ÀS CRIANÇAS 271

$\begin{array}{ll}7.1 \text { Referencial teórico } & 271\end{array}$

$\begin{array}{lll}7.1 .1 & \text { Modalidades } & 272\end{array}$

$7.21^{\text {a }}$ etapa da pesquisa $\quad 282$

7.2.1 Entrevista lúdica com brinquedo $\quad 282$

7.2.1.1 Alunos cegos: resultados da unidade-caso 1

7.2.2 Entrevista lúdica com desenho temático 287

7.2.2.1 Alunos com baixa visão: resultados da unidade-caso 1

7.2.2.2 Alunos surdos: resultados da unidade-caso $2 \quad 296$

7.2.2.3 Alunos com PC: resultados da unidade-caso $3 \quad 303$

7.2.3 Análise dos resultados e modificações para a próxima etapa 313

$7.32^{\mathrm{a}}$ etapa da pesquisa $\quad 321$

7.3.1 Entrevista lúdica com mapa tátil 321

7.3.1.1 Alunos cegos: resultados da unidade-caso 1

7.3.2 Entrevista lúdica com desenho temático 330

7.3.2.1 Alunos com baixa visão: resultados da unidade-caso 1

7.3.2.2 Alunos surdos: resultados da unidade-caso $2 \quad 351$

7.3.2.3 Alunos com PC: resultados da unidade-caso $3 \quad 359$

$\begin{array}{lll}\text { 7.3.3 Análise dos resultados } & 374\end{array}$

8 A TÉCNICA DO QUESTIONÁRIO DESTINADA ÀS CRIANÇAS 379

8.1 Referencial teórico $\quad 379$

$8.21^{\text {a }}$ etapa da pesquisa 385

8.2.1 Questionário ilustrado 385

8.2.1.1 Alunos cegos: resultados da unidade-caso 1 
8.2.1.2 Alunos com baixa visão: resultados da unidade-caso 1

8.2.1.3 Alunos surdos: resultados da unidade-caso 2

8.2.1.4 Alunos com PC: resultados da unidade-caso $3 \quad 397$

8.2.1.5 Análise dos resultados e modificações para a próxima etapa 404

$8.32^{\mathrm{a}}$ etapa da pesquisa

8.3.1 Questionário 3D - com o uso de maquetes táteis 413

8.3.1.1 Alunos cegos: resultados na unidade-caso 1

8.3.2 Questionário ilustrado

8.3.2.1 Alunos com baixa visão: resultados na unidade-caso 1

8.3.2.2 Alunos surdos: resultados da unidade-caso $2 \quad 431$

8.3.2.3 Alunos com PC: resultados da unidade-caso 3

8.3.3 Análise dos resultados 436

9 CONSIDERAÇÕES FINAIS $\quad 439$

9.1 Considerações gerais $\quad 439$

9.2 Premissas da pesquisa $\quad 442$

9.3 Recomendações para trabalhos futuros 444

REFERÊNCIAS $\quad 449$

BIBLIOGRAFIA 


\section{INTRODUÇÃO}

\subsection{Apresentação}

A temática deste estudo encontra-se imersa na questão da inclusão escolar das crianças com deficiência. Em geral excluídas da escola, essas crianças acabam ficando à margem da sociedade, sendo estigmatizadas por questões de racismo; pelo preconceito contra a deficiência; pela sua ligação com pais presidiários ou até pela situação de miséria em que se encontram, que acarreta a falta de cuidados básicos como a higiene e a alimentação, dentre outros problemas.

Segundo Araújo (2007, p. 12), "no Brasil se verifica uma forte exclusão da criança com origem na pobreza, na falta de educação básica e no estabelecimento do preconceito." A sociedade deveria se apresentar responsável por todos os seus membros, proporcionando suporte e acolhimento (SASSAKI, 1997), porém na sociedade atual em que vivemos

[...] os valores mais cultuados são as capacidades de se ajustar a um mundo competitivo e individualizado. Todos devemos ser independentes e produtivos. Os ideais de felicidade não combinam com incapacidade e com formas diferentes daquelas que são ditadas como modelo de se comportar e de viver em sociedade. (CORRER, 2003, p. 18)

Infelizmente, verifica-se que "[...] a exclusão não é um lugar, ou um estado, mas representa um processo no qual o preconceito é a principal barreira a ser enfrentada para que a mudança de atitude possa ocorrer." (SEKKEL, 2004, p. 178). Para que esta realidade seja alterada e propicie a inclusão social de pessoas com deficiência, se faz necessário o ajuste da comunidade, dos espaços, das leis, enfim de toda a 
coletividade nessa direção. A sociedade deve se mobilizar para, num futuro próximo, se adaptar ao convívio com as diferenças, "[...] sendo importante entender os mecanismos da exclusão e propor o seu desmonte em termos individuais e coletivos, por meio de ações capazes de romper com o medo, com a superstição, com os preconceitos e com as ignorâncias." (ROCHA, 2006, p. 7).

Faz-se necessário aprender a ver a deficiência como diferença, e não como forma de se acentuar a desigualdade, sendo a infância o melhor momento para se promover esse aprendizado. "A multiplicidade de deficiências e suas origens causou uma dificuldade de implementação de uma ação conjunta de proteção ao grupo, pois são problemas de ordem estrutural." (ARAÚJO, 2007, p. 12). Segundo Amaral (1995, p. 112):

A deficiência jamais passa em "brancas nuvens", muito pelo contrário: ameaça, desorganiza, mobiliza. Representa aquilo que foge ao esperado, ao simétrico, ao belo, ao eficiente, ao perfeito [...] e, assim como quase tudo que se refere à diferença, provoca a hegemonia emocional.

\subsection{Problemática e justificativa}

Segundo o Instituto Brasileiro de Geografia e Estatística (IBGE, 2000), no ano de 2000 o Brasil apresentava cerca de 64 milhões de pessoas com menos de 18 anos, ou seja, 38\% da população, e para o ano de 2020 a estimativa é de aproximadamente $31 \%$ da população, ou seja, cerca de 65 milhões de pessoas (Figura 1). 


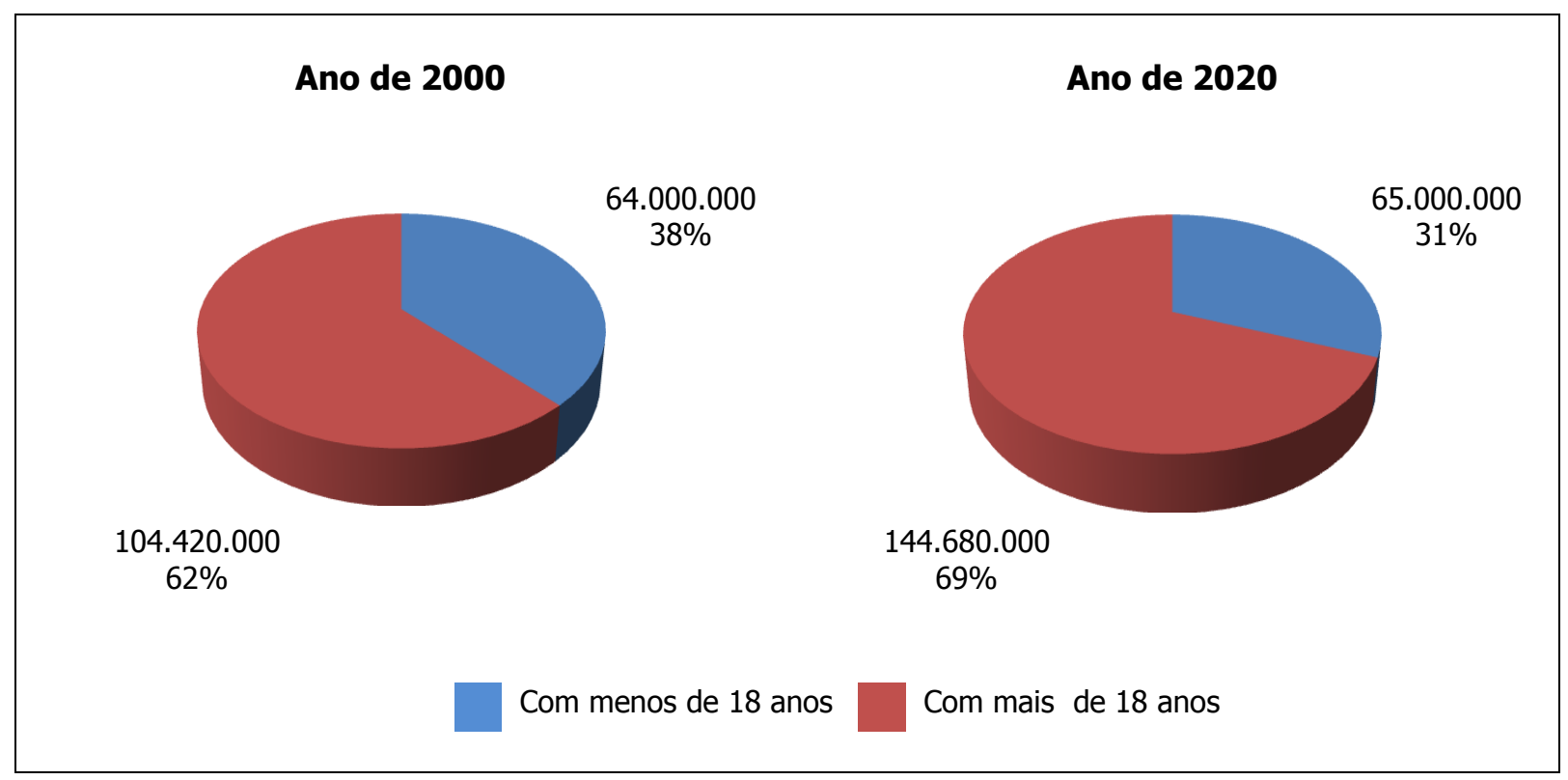

Figura 1 - Gráfico da projeção da distribuição da população brasileira com menos e mais de 18 anos em 2000 e 2020. Fonte: elaborado pela autora com dados do Censo 2000 (IBGE, 2000).

Mesmo caminhando para um processo aparentemente irreversível de envelhecimento populacional, as crianças constituem uma parcela significativa da população brasileira. Assim, tendo por base a intensa demanda social para o ensino na préescola, nas grandes e médias cidades brasileiras, tem surgido um grande número de estabelecimentos destinados à educação infantil7, porém desprovidos de acessibilidade física (ELALI, 2002b).

Atuar no sentido de minimizar tal problema, "oferecendo melhor qualidade de vida à infância, é uma das responsabilidades sociais não só dos educadores, mas também dos arquitetos" (ELALI, 2002b, p. 2) enquanto profissionais projetistas do ambiente construído, que buscam criar espaços apropriados e estimuladores. Neste sentido, confirma-se a necessidade da atuação multidisciplinar "que vislumbre a melhoria da

\footnotetext{
${ }^{7}$ A educação infantil, primeira etapa da educação básica, é composta por: creches ou entidades equivalentes para crianças de até três anos de idade e pré-escolas para as crianças de quatro a seis anos de idade (ver 3.2.3.1).
} 
qualidade de ensino de forma geral, o que significa incluir a participação do profissional de arquitetura, responsável pelas definições das características físicas do ambiente escolar." (KOWALTOWSKI; DELIBERADOR, p. 1, 2010).

Uma série de acontecimentos que envolve a economia e os meios de comunicação mundial vem ocorrendo nos últimos anos. Cita-se como exemplo, a globalização da economia e a internet, além das mudanças no conceito de produção, qualidade e outros, que criam uma situação altamente dinâmica, impondo novas exigências para os mais variados setores da atividade humana.

A qualidade de vida de um indivíduo jovem "é significativamente afetada pela qualidade do ambiente escolar que frequenta" (ELALI, 2002b, p. 1), no qual passa entre quatro e oito horas diárias. No entanto, pouco se sabe sobre a influência desse espaço escolar construído no desenvolvimento humano, sobretudo no início deste processo, fase na qual somos extremamente suscetíveis às influências do meio (BEE, 1996).

Em relação à aplicabilidade deste estudo, como ainda não existe no Brasil uma norma técnica destinada ao dimensionamento do ambiente escolar que contemple crianças com e sem deficiência, busca-se a elaboração de material referencial para os arquitetos, que encontram dificuldade no dimensionamento do espaço escolar, dentre outros, específico para o uso pelas crianças. Uma das barreiras para a elaboração desse documento técnico (norma) é a obtenção de dados antropométricos mais completos de crianças brasileiras. A escassez desses dados se 
deve ao custo requerido para a realização desses levantamentos, tanto pelo material a ser utilizado para medição, pela elevada quantidade de pessoas e variáveis a serem medidas em cada indivíduo, como pelas dimensões territoriais do país (QUARESMA, 2001).

Abate (2004) relacionou os levantamentos antropométricos nacionais de préescolares, como o de Casarotto (1993) no município de São Paulo, o de Paschoarelli (1997) no município de Bauru e os estudos sobre antropometria nutricional que utiliza somente duas variáveis (altura e peso), relativos aos levantamentos desenvolvidos por Marcondes (1978) e Souza Freitas (1975). Em um país tão carente como o Brasil "é importante atentar para quaisquer meios que venham a baratear e agilizar o processo de obtenção de dados para análises de projetos adaptados a toda a nossa população." (GUIMARÃES; BIASOLLI, 2002, p. 2). Além da amostra reduzida e da grande variação de medidas para as diferentes faixas etárias, encontramos outro desafio: o de que a população brasileira, formada ao longo de quase cinco séculos, é resultado da mistura de raças. Esta miscigenação de brancos, negros e índios associada às condições ambientais e socioeconômicas faz com que a distribuição da frequência de cada medida antropométrica adquira um caráter singular para o povo brasileiro (CASAROTTO, 1993).

Segundo Lopes, M. E. (2007, p. 319), "no começo dos anos 1990 com a promulgação de leis mais completas surgiu a necessidade de adequação dos espaços de uso coletivo à pessoa com deficiência acarretando na elaboração de normas técnicas", como, a NBR 9050 publicada em 1985, 1994 e 2004 (revisão em 
elaboração) pela Associação Brasileira de Normas Técnicas (ABNT, 2004) que estabelece padrões para utilização e circulação de pessoas adultas com deficiência nas edificações e espaços. A definição de parâmetros específicos de acessibilidade em escolas para crianças com deficiência integra a outra norma técnica, cujas pesquisas tiveram início em 2006.

Como referência no Brasil, pode-se citar alguns trabalhos que tratam de arquitetura escolar e design inclusivos (Figura 2) como os de Abate, Ono e Lopes (2010c); Moreira e Ornstein (2010); Carvalho (2008); Luz et al. (2007); Brandão et al. (2006); Dischinger et al. (2004, 2006); Araújo (2004); Laufer (2001), dentre outros.

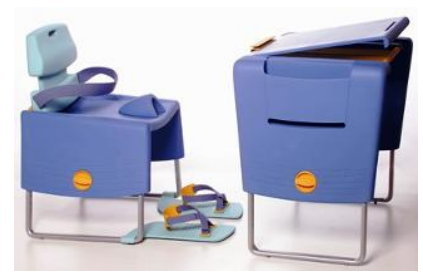

(a)

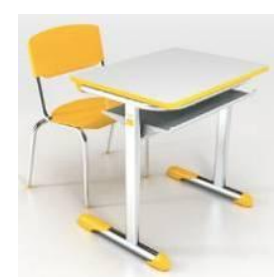

(c)

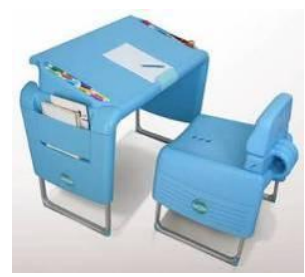

(b)

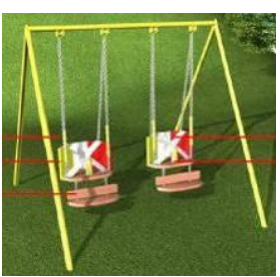

(d)

Figura 2 - Modelos de carteira escolar inclusiva: dos designers Guto Índio da Costa (a) e Érika Foureaux (b), e da FDE (c); balanço acessível ao uso de crianças com deficiência (d). Fonte: elaborada pela autora com os dados disponíveis em: <http://www.designacessivel.net> (a); <http://www.agenciaminas.mg.gov.br> (b); <http://www.fde.sp.gov.br> (c) - Acessos em: 20 jun. de 2010 e Laufer, 2001 (d).

A justificativa para a existência de poucos estudos relacionados à criança com deficiência e ao ambiente escolar é a de que a inclusão destas crianças nas escolas 
no Brasil é uma prática recente e em fase de implantação. No plano legal, o Brasil acompanhou os preceitos internacionais quanto à inclusão de alunos com deficiências nas classes do ensino regular, proclamados na Declaração Mundial sobre Educação para Todos em Jomtien, na Tailândia (BRASIL, 1990), e na Declaração de Salamanca (BRASIL, 1994). Consequentemente, foram promulgadas no Brasil a Lei de Diretrizes e Bases da Educação Nacional (LDBEN) (BRASIL, 1996) e a Resolução CNE/CEB n² 2 (CONSELHO NACIONAL DE EDUCAÇÃO, 2001). Esta última institui as Diretrizes Nacionais para a Educação Especial na Educação Básica e determina em seu artigo 70 que 0 atendimento aos alunos com necessidades educacionais especiais deve ser realizado em classes comuns do ensino regular, em qualquer etapa ou modalidade da Educação Básica.

Somente a partir de 2004 as edificações de uso público (incluindo-se nestas as escolas) foram obrigadas a incorporar a acessibilidade em seus edifícios, através do Decreto Federal $n^{0} 5.296$ (BRASIL, 2004) que estabelece normas gerais e critérios básicos para a promoção da acessibilidade das pessoas com deficiência ou com mobilidade reduzida.

Segundo o Estatuto da Criança e do Adolescente, artigo n 17 - "o direito ao respeito consiste na inviolabilidade da integridade física, psíquica e moral da criança e do adolescente, abrangendo a preservação da imagem, da identidade, da autonomia, dos valores, ideias e crenças, dos espaços e objetos pessoais." (BRASIL, 1990). Do ponto de vista social, a pesquisa aqui proposta pode auxiliar na compreensão da 
criança com deficiência no contexto pré-escolar, ensejando uma identidade social fortalecedora do equilíbrio humano.

\subsection{Relevância e originalidade}

A avaliação sobre as condições de acessibilidade, de conforto ambiental, de segurança patrimonial e contra incêndio, dentre outras, em ambientes escolares tem no meio acadêmico utilizado a metodologia da Avaliação Pós-Ocupação (APO), que consiste na aplicação de um conjunto de métodos e técnicas aos ambientes construídos e aos seus usuários, cujo objetivo principal é aferir o desempenho físico e a satisfação dos usuários (ORNSTEIN; BRUNA; ROMÉRO, 1995). Da APO em edifícios destinados ao ensino, destaca-se a série de estudos em escolas de ensino fundamental e médio, não incluída nestes a pré-escola, que vêm sendo realizada no Estado de São Paulo por meio de uma parceria entre a Faculdade de Arquitetura e Urbanismo da Universidade de São Paulo (FAUUSP), a Fundação para o Desenvolvimento Escolar (FDE), a Secretaria de Educação do Estado de São Paulo (SEESP) e a Organisation for Economic Co-operation and Development (OECD) por meio do Centre for Effective Learning Environments (CELE), organização internacional composta por 31 países e responsável mundial pela iniciativa. Destacase também a atuação do Grupo Ambiente-Educação ${ }^{8}$ (GAE) e do Núcleo de Pesquisa, Ensino e Projeto Sobre Acessibilidade e Desenho UniversaP (PRÓ-ACESSO), ambos

\footnotetext{
${ }^{8}$ Que tem como foco principal a reflexão sobre os ambientes destinados à educação infantil.

${ }^{9}$ Específico sobre Acessibilidade e Desenho Universal.
} 
da Faculdade de Arquitetura e Urbanismo da Universidade Federal do Rio de Janeiro (FAUUFRJ), bem como a atuação da Universidade Estadual de Campinas (UNICAMP) e da Universidade Federal do Rio Grande do Norte (UFRN), que desenvolvem pesquisas relevantes na área de arquitetura escolar.

Quanto às contribuições metodológicas da APO aplicadas a ambientes escolares, no que diz respeito aos aspectos comportamentais e à satisfação dos usuários, destacam-se no Brasil pesquisas realizadas por Kowaltowski (2011); Kowaltowski e Deliberador (2010); Ornstein e Ono (2010); Abate, Ono e Lopes (2010a, b); Ornstein et al. (2009); Barbosa et al. (2009); Sousa (2009); Ornstein e Moreira (2008); Kowaltowski e Moreira (2008); Issa, Poltronieri e Ornstein (2008); Pinheiro e Günther (2008); Blower (2008); Carvalho (2008); Moreira (2005); Elali (2002a, b); Sousa e Rheingantz (2001); Kowaltowski e Pina (2001); Kowaltowski et al. (2000); Bernardi (2001); Faccin (1995, 2001); Ornstein, Bruna e Roméro (1995); Ornstein e Roméro (1992); Kowaltowski (1980), dentre outros. No campo internacional, podem ser citados os trabalhos elaborados por Zeisel (2005); Preiser e Ostroff (2001); Baker e Mednick (1990), Sanoff (1992, 2001); Bishop, Adams e Kean (1992); Sheat e Beer (1989); Bechtel, Marans e Michelson (1987); Sebba e Churchman (1986); Groning (1986), dentre outros. 
Após a revisão da bibliografia citada verificou-se a inexistência de técnicas de coleta de dados relacionadas a APO baseadas no método de estudos centrados na pessoa ${ }^{10}$, destinadas às crianças com deficiência ${ }^{11}$.

Verificou-se a importância da presente pesquisa em função da falta de instrumentos de APO para a medição do nível de satisfação dos alunos com deficiência em relação ao ambiente escolar, que no caso do Brasil é justificado pelo fato da inclusão destes alunos nas escolas regulares ser uma prática recente e em fase de implantação.

\subsection{Objetivos}

\subsubsection{Objetivo geral}

O objetivo geral é a elaboração e a aplicação de instrumentos de coleta de dados em APOs destinados a alunos com deficiência física, auditiva e visual, tendo como meta a construção de referencial teórico e prático para futuros trabalhos relacionados a APO em pré-escolas que considerem a opinião dos alunos com deficiência visando a melhoria dos edifícios destinados a escola regular.

\footnotetext{
${ }^{10}$ Günther, Elali e Pinheiro (2008, p. 377) resumiram os métodos de pesquisa, adotando como base as categorias propostas por Proshansky et al. (1970), em: métodos centrados nas pessoas e métodos centrados no ambiente (item 4.6).

${ }^{11}$ Foram aplicados instrumentos de APO destinados a alunos com necessidades especiais, porém não foram especificadas as deficiências, sendo apenas utilizado o termo genérico sem limitações cognitivas e syndrome de Down (CARVALHO, 2008, p. 155).
} 


\subsubsection{Objetivo específico}

O objetivo específico é apresentar os resultados da elaboração e do processo de aplicação dos instrumentos coleta de dados relacionados a APO: entrevista lúdica e questionário, adaptados aos alunos com deficiência visual (baixa visão ${ }^{12}$ e cegueira), deficiência auditiva (surdez) e deficiência física (PC). Para tal, foram utilizados como base os resultados dos instrumentos aplicados na direção e docentes (entrevistas) e nos alunos (observação) em três pré-escolas gratuitas de educação especial localizadas na cidade de São Paulo. A pesquisa de campo foi realizada em duas etapas, nos períodos entre agosto e novembro de 2009 (pré-teste) e de 2010 (validação dos instrumentos aplicados). A primeira etapa da pesquisa teve como meta a verificação prática da metodologia proposta, incluindo a receptividade e a participação dos alunos envolvidos e a prospecção de erros, já visando à melhoria dos instrumentos para a nova aplicação realizada em 2010, que teve como meta a validação dos mesmos, bem como a comprovação das premissas levantadas no item 1.5.

\subsection{Caráter e premissas da pesquisa}

A presente tese constitui um trabalho original de pesquisa, pois representa avanço na disciplina à qual se dedica (ECO, 2008), no caso a Avaliação Pós-Ocupação (APO).

${ }^{12}$ A baixa visão ou visão subnormal ou visão reduzida é uma visão considerada inferior à visão normal, representada por padrões aceitos de acuidade, campo visual ou motilidade. A baixa visão geralmente se refere a transtornos visuais causados por doenças que não podem ser corrigidas por refração. BIREME (s/d). 
Destaca-se a relevância científica e social do presente estudo, inserido num quadro teórico, com evidente contribuição ao conhecimento disponível da APO e opção por temática engajada na prática social, "critérios de uma pesquisa científica que prima pela qualidade." (ANDRÉ, 2001, p. 20). Esta pesquisa apresenta caráter qualitativo, pois

a pesquisa qualitativa considera que há uma relação dinâmica entre o mundo real e o sujeito, isto é, um vínculo indissociável entre o mundo objetivo e a subjetividade do sujeito que não pode ser traduzido em números. A interpretação dos fenômenos e a atribuição de significados são básicas no processo de pesquisa qualitativa. Não requer o uso de métodos e técnicas estatísticas. O ambiente natural é a fonte direta para coleta de dados e o pesquisador é o instrumento-chave. É descritiva. Os pesquisadores tendem a analisar seus dados indutivamente. O processo e seu significado são os focos principais de abordagem. (SILVA; MENEZES, 2001, p. 20)

Segundo Gatti (2000, p.7), "a busca da pergunta adequada, da questão que não tem resposta evidente é que constitui o ponto de origem de uma investigação científica." O presente estudo seguiu à risca as recomendações da banca de qualificação em relação à elaboração de premissas e não a de hipóteses no presente estudo, dentre outras recomendações, em função do seu caráter qualitativo. Geralmente verifica-se que

Os manuais de metodologia de pesquisa enfatizam como ponto de partida para investigação uma hipótese de pesquisa. Esta se baseia na afirmação (hipotética, justamente) que seria investigada a fim de confirmarmos, ou não, se efetivamente corresponde aos fatos. Consideramos que, nas pesquisas qualitativas, essa insistência pode levar a equívocos. A pretendida necessidade da hipótese de pesquisa leva a um esforço do pesquisador para apresentar alguma coisa que seja aceita como tal. Como nós sempre temos ideias, impressões e propostas referentes aos temas que nos interessam (e que nos motivam a pesquisar), é fácil decidir que uma dessas proposições é nossa hipótese. Tipicamente, entretanto, se trata de premissas ou de sacações (no dicionário Houaiss: "ideia, invenção, lampejo". Refere-se ao habitual anglicismo insight). Os lampejos correspondem àquelas ideias explicativas ou interpretativas que acabamos descobrindo de modo espontâneo por nos envolvermos continuadamente com um tema, por experiência prática ou por leituras. (BRAGA, 2005, p. 1, grifo do autor)

Parte-se da premissa principal de que é possível aplicar os instrumentos de coleta de dados baseados na APO e no método de estudos centrados na pessoa, destinados 
aos alunos com deficiência física, auditiva e visual para a medição da satisfação destes usuários em relação ao ambiente escolar e consequente validação dos instrumentos aplicados. Apresentam-se as seguintes premissas secundárias:

- as limitações decorrentes de cada deficiência determinam as especificidades na adaptação e no processo de aplicação dos instrumentos de coleta de dados visando à medição da satisfação desses usuários em relação ao ambiente pré-escolar;

- independentemente do método pedagógico (ver item 3.4) adotado pelas préescolas consideradas no presente estudo, seus ambientes devem oferecer condições de acessibilidade e de conforto ambiental, dentre outras, para a inclusão dos alunos com deficiência física, auditiva e visual.

Após a revisão bibliográfica citada no item 1.3, não foram encontrados instrumentos de coleta de dados destinados à APO para a medição do nível de satisfação dos alunos com deficiência física, auditiva e visual em relação ao ambiente escolar. Os edifícios escolares não são foco deste estudo, pois os métodos adotados na pesquisa de campo são os para estudos centrados nas pessoas.

É importante salientar que este estudo atendeu a política de pesquisa de cada entidade envolvida e contou com a colaboração de pesquisadores com experiência, sendo realizada com o respaldo das equipes multidisciplinares existentes nas respectivas instituições onde se encontram as pré-escolas de educação especial conhecedoras das capacidades de cada aluno, composta por educadores, voluntários, fisioterapeutas, fonoaudiólogos e psicólogos (em momentos-chave). 
Em função de questões éticas, inerentes às pesquisas que envolvam seres humanos, os nomes das três escolas de educação especial, bem como os dos sujeitos envolvidos na pesquisa (direção, docentes e alunos) não foram citados, visando à preservação da identidade dos mesmos. Foram elaboradas: cartas de solicitação de autorização da pesquisa destinadas a direção, bem como cartas de consentimento livre e esclarecido ${ }^{13}$ destinadas aos responsáveis dos alunos envolvidos na pesquisa das três escolas de educação especial do presente estudo. As entrevistas concedidas pela direção e pelos docentes envolvidos na pesquisa foram transcritas e enviadas aos mesmos para aprovação ${ }^{14}$. O referencial teórico e prático resultante da presente tese fundamentará a aplicação dos instrumentos de coleta de dados desenvolvidos em futuras APOs em pré-escolas que incluam os alunos com deficiência física, auditiva e visual, bem como trabalhos relacionados a avaliação e desenvolvimento de novos instrumentos às crianças com deficiência.

\subsection{Estrutura e descrição dos capítulos}

Este estudo encontra-se desenvolvido em nove capítulos. O capítulo 1, relativo à introdução, expõe a problemática e a justificativa, a relevância e a originalidade, os objetivos, o caráter, as premissas e a estrutura da tese.

\footnotetext{
${ }^{13}$ Solicitação de autorização para a utilização das imagens dos alunos envolvidos durante a pesquisa, bem como dos resultados dos instrumentos aplicados (desenhos, entrevistas, questionários), sendo coletadas as assinaturas dos responsáveis.

${ }^{14}$ Foram realizadas, posteriormente, reuniões para a discussão das alterações. Todas as solicitações de alteração foram atendidas.
} 
O capítulo 2 descreve os pressupostos teóricos relativos à deficiência com o intuito de servirem como base para o entendimento das necessidades e especificidades das deficências recorrentes nos alunos com deficiência, sujeitos da pesquisa, visando contribuir para a elaboração de instrumentos de coleta de dados relacionados à APO destinados aos mesmos. Apresenta ainda os conceitos relativos à deficiência; à Classificação Internacional de Funcionalidade, a Incapacidade e Saúde (CIF); às definições das deficiências física, auditiva, visual, intelectual e múltipla e suas respectivas especificidades relativas às formas de comunicação; às definições da doença crônica orgânica e dos transtornos da comunicação que abrangem os transtornos de linguagem e de aprendizagem ${ }^{15}$. Por fim, descreve os indicadores estatísticos relativos à deficiência e aborda a tecnologia assistiva.

O capítulo 3 expõe os pressupostos teóricos relativos à inclusão escolar dos alunos com necessidades educacionais especiais (NEE) ${ }^{16}$ e abrange os preceitos antagônicos da exclusão e da inclusão social da pessoa com deficiência, bem como os da inclusão escolar. Descreve a prática da educação em escolas inclusivas da rede regular de ensino, bem como as práticas da educação inclusiva ${ }^{17}$ no cenário internacional. Aborda a escola especial onde é praticada a educação especial oferecida aos alunos com deficiência que não conseguem se inserir na escola inclusiva da rede regular de

${ }^{15}$ As deficiências intelectual e múltipla, a doença crônica orgânica e os transtornos da comunicação são descritos visando o entendimento geral dos pressupostos teóricos relativos à deficiência, além de serem base para a compreensão e a seleção dos sujeitos da pesquisa (alunos com deficiência física, auditiva e visual).

${ }^{16}$ As necessidades educacionais especiais são decorrentes de condições atípicas como, por exemplo: deficiências, insuficiências orgânicas, transtornos mentais, altas habilidades, experiências de vida marcantes etc. (SASSAKI, 2008, p. 83).

17 A educação inclusiva é um processo onde se amplia a participação de todos os alunos nos estabelecimentos de ensino regular e que pretende estar atento à diversidade inerente à espécie humana e atender as necessidades educativas de todas as crianças em um sistema regular de ensino único. 
ensino, bem como faz considerações sobre os serviços de educação especial oferecidos na rede municipal de ensino da cidade de São Paulo. Apresenta reflexões sobre a legislação relevantes ao aluno com NEE - Internacional, Federal (Brasil), Estadual (São Paulo) e Municipal (São Paulo). Por último, apresenta as principais vertentes pedagógicas da educação infantil.

O capítulo 4 apresenta os fundamentos metodológicos da pesquisa de campo relativos ao método estudo de caso adotado como estratégia de pesquisa, a abordagem e os critérios de seleção da modalidade educação especial e das três escolas de educação especial ou unidades-caso. Justifica a não inclusão da deficiência múltipla severa na pesquisa de campo. Descreve as etapas do estudo de casos e os sujeitos da pesquisa, vinculados e matriculados, respectivamente, nos anos letivos de 2009 e 2010. Apresenta o panorama das técnicas de coleta de dados em situações educativas, bem como as técnicas de coleta de dados adotadas no presente estudo.

O capítulo 5 discorre sobre o referencial teórico da técnica da entrevista destinada aos adultos (direção e docentes) na pesquisa de campo, bem como sobre os resultados de sua aplicação nas duas etapas da pesquisa de campo.

O capítulo 6 apresenta o referencial teórico da técnica da observação destinada às crianças, os resultados da sua aplicação na primeira etapa da pesquisa de campo, bem como a análise dos resultados. 
O capítulo 7 expõe o referencial teórico da técnica da entrevista lúdica destinada às crianças, os resultados do seu processo de aplicação na primeira etapa, bem como a análise desses resultados e modificações para a próxima etapa da pesquisa de campo. Expõe os resultados do processo de aplicação da técnica da entrevista lúdica na segunda etapa da pesquisa de campo.

O capítulo 8 traz o referencial teórico da técnica do questionário destinada às crianças, os resultados do seu processo de aplicação na primeira etapa, bem como a análise desses resultados e modificações para a próxima etapa da pesquisa de campo. Apresenta os resultados do processo de aplicação da técnica do questionário na segunda etapa da pesquisa de campo.

Os resultados de cada processo de aplicação de instrumentos de APO não foram reunidos para todas as unidades caso. Em vez disso, os resultados fazem parte das descobertas para cada unidade caso separada, sendo os dados qualitativos. No decorrer deste trabalho e a cada fechamento de capítulo foram realizadas considerações (Capítulos 2 ao 4) e análises dos resultados dos processos de aplicação (Capítulos 5 ao 8).

O capítulo 9 expõe as considerações e reflexões finais sobre os principais conceitos abordados. 


\section{PRESSUPOSTOS TEÓRICOS RELATIVOS À DEFICIÊNCIA}

\subsection{A deficiência}

Há algumas décadas tem se questionado o uso correto do termo para designar a pessoa com deficiência, sendo utilizados os termos: portador de deficiência, pessoa portadora de deficiência, portador de necessidades especiais, dentre outros. Segundo Sassaki (2005a), jamais houve ou haverá um único termo correto, válido definitivamente em todos os tempos e espaços. A razão disto reside no fato de que a cada época são utilizados termos cujo significado seja compatível com os valores vigentes em determinada sociedade enquanto esta evolui em seu relacionamento com as pessoas que possuem alguma deficiência. No Brasil, tornou-se bastante popular, acentuadamente entre 1986 e 1996, o uso do termo portador de deficiência, inclusive na legislação brasileira.

Segundo Araújo (2007, p. 15), o Decreto Federal nº 914 (BRASIL, 1993), ao regulamentar a Lei $\mathrm{n}^{0} 7.853$ (BRASIL, 1989), definiu o termo pessoa portadora de deficiência para designar a pessoa com deficiência, porém o critério adotado foi vago e dificultou a divulgação do conceito, pois não houve a definição de deficiência, e segundo o seu artigo 10:

Ficam estabelecidas normas gerais que asseguram o pleno exercício dos direitos individuais e sociais das pessoas portadoras de deficiências, e sua efetiva integração social, nos termos desta Lei.

No Decreto Federal $n^{0} 3.298$ (BRASIL, 1999) se manteve o uso do termo pessoa portadora de deficiência, porém com a inclusão das definições das deficiências. No 
Decreto Federal $\mathrm{n}^{\circ} 5.296$ (BRASIL, 2004), que regulamenta as Leis Federais $\mathrm{n}^{\circ}$ 10.048 (BRASIL, 2000a), e n 10.098 (BRASIL, 2000b), o termo pessoa portadora de deficiência ainda se manteve, incluindo a este, as pessoas com mobilidade reduzida, sendo alteradas as definições das deficiências.

A Lei Federal $\mathrm{n}^{0} 10.098$ (BRASIL, 2000b), utiliza o termo pessoa portadora de deficiência e estabelece normas gerais e critérios básicos para a promoção de acessibilidade das pessoas com deficiência ou mobilidade reduzida e normas específicas para a Língua Brasileira de Sinais (LIBRAS), representando um avanço significativo no ponto de vista legislativo para as pessoas com deficiência. Entretanto, percebeu-se que a condição de ter uma deficiência faz parte da pessoa e esta pessoa não porta sua deficiência. Atualmente, adota-se mundialmente o termo pessoa com deficiência, que faz parte do texto da Convenção Internacional para Proteção e Promoção dos Direitos e Dignidade das Pessoas com Deficiência, aprovada em 2006 pela Assembléia Geral da Organização das Nações Unidas (ONU) em Nova Iorque.

O Decreto Federal n. 3.956 (BRASIL, 2001) que reconhece o texto da Convenção Interamericana para a Eliminação de Todas as Formas de Discriminação contra as Pessoas Portadoras de Deficiência (1999) também conhecida como Convenção da Guatemala ${ }^{18}$, utiliza o termo pessoas portadoras de deficiência e cita:

[...] O termo deficiência significa uma restrição física, mental ou sensorial, de natureza permanente ou transitória, que limita a capacidade de exercer uma ou mais atividades essenciais da vida diária, causada ou agravada pelo ambiente econômico e social.

${ }^{18}$ Disponível em: <http://www.cedipod.org.br/cedipod.htm>. Acesso em: 12 nov. 2010. 
A Classificação Internacional de Funcionalidade, Incapacidade e Saúde (CIF) elaborada em 2001 (ver item 2.1.1) apresenta uma evolução da abordagem deste tema e traz definições sobre as mudanças em termos conceituais, filosóficos, políticos e metodológicos, na medida em que a sua concepção de deficiência leva em conta "a capacidade de pessoas com deficiência, não a incapacidade ou a questão da doença ou a situação que causou a sequela, mas outros fatores, como a capacidade do indivíduo em se relacionar com o seu ambiente de vida." (BRASIL/MINISTÉRIO DA SAÚDE, 2008, p. 10). Segundo a $\mathrm{CIF}^{19}$, a incapacidade é caracterizada como

o resultado de uma relação complexa entre o estado ou condição de saúde do indivíduo e fatores pessoais com os fatores externos que representam as circunstâncias nas quais o indivíduo vive. Assim, diferentes ambientes podem ter um impacto distinto sobre o mesmo indivíduo com uma determinada condição de saúde. (CIF, 2003, p. 29)

O Relatório sobre a prevalência de deficiências, incapacidades e desvantagens (BRASIL/CORDE, 2004, p. 20) define a deficiência como a perda ou anormalidade de uma estrutura ou função psicológica, fisiológica ou anatômica. A norma brasileira NBR 9050 (ABNT, 2004) Acessibilidade a edificações, mobiliário, espaços e equipamentos urbanos define a deficiência como

redução, limitação ou inexistência das condições de percepção das características do ambiente ou de mobilidade e de utilização de edificações, espaço, mobiliário, equipamento urbano e elementos, em caráter temporário ou permanente.

A Política Nacional de Saúde da Pessoa Portadora de Deficiência (BRASIL/MINISTÉRIO DA SAÚDE, 2008), instrumento que orienta as ações do setor

\footnotetext{
${ }^{19}$ [...] As deficiências podem ser temporárias, ou permanentes, progressivas, regressivas ou estáveis, intermitentes ou contínuas. O desvio em relação ao modelo baseado na população pode ser leve ou grave e pode flutuar ao longo do tempo. Essas características são consideradas nas descrições adicionais, principalmente nos códigos ${ }^{19}$, aos quais são acrescentados qualificadores - separados dos códigos por um ponto. As deficiências podem ser parte ou uma expressão de uma condição de saúde, mas não indicam necessariamente a presença de uma doença ou que o indivíduo deva ser considerado doente. (CIF, 2003, p. 23)
} 
Saúde voltadas a esse segmento populacional, adota o conceito fixado pelo Decreto Federal n. ${ }^{\circ} 3.298$ (BRASIL, 1999), que considera

deficiência- toda perda ou anormalidade de uma estrutura ou função psicológica, fisiológica ou anatômica que gere incapacidade para o desempenho de atividade, dentro do padrão considerado normal para o ser humano; deficiência permanente - aquela que ocorreu ou se estabilizou durante um período de tempo suficiente para não permitir recuperação ou ter probabilidade de que se altere apesar de novos tratamentos.

Em 2009, a então Coordenadoria Nacional para Integração da Pessoa Portadora de Deficiência (CORDE) foi elevada a Subsecretaria Nacional de Promoção dos Direitos da Pessoa com Deficiência (SNPD), através do Decreto Federal $n^{0} 6.980$ (BRASIL, 2009a) e da Lei Federal $n^{\circ} 11.958$ (BRASIL, 2009c), sendo a Subsecretaria o órgão da Secretaria de Direitos Humanos da Presidência da República (SDH/PR) responsável pela articulação e coordenação das políticas públicas voltadas para as pessoas com deficiência. A nova Subsecretaria ganhou mais importância no momento em que o Brasil ratificou a Convenção sobre os Direitos da Pessoa com Deficiência e seu Protocolo Facultativo, assinados na sede da ONU, em Nova Iorque, em 2007. O referido instrumento ganhou status de Emenda Constitucional, quando foi aprovada pelo Congresso Nacional por meio do Decreto Legislativo $\mathrm{n}^{\circ} 186$ (BRASIL, 2008b) e pelo Decreto Federal no 6.949 (BRASIL, 2009b) conforme o procedimento do $\S^{\circ}$ do art. $5^{\circ}$ da Constituição (BRASIL, 1988). Atualmente, a Convenção juntamente com leis específicas dão suporte à política nacional para a inclusão da pessoa com deficiência. A Convenção sobre os Direitos das Pessoas com Deficiência (BRASIL, 2007), não define os tipos de deficiências, mas cita no preâmbulo que

[...] a deficiência é um conceito em evolução e que a deficiência resulta da interação entre pessoas com deficiência e as barreiras devidas às atitudes e ao ambiente que impedem a plena 
e efetiva participação dessas pessoas na sociedade em igualdade de oportunidades com as demais pessoas.

O conceito relativo a essa população tem evoluído com o passar dos tempos, acompanhando, de uma forma ou de outra, as mudanças ocorridas na sociedade e as próprias conquistas alcançadas pelas pessoas com deficiência (BRASIL, 2008a). Em alguns países, como os Estados Unidos e o Canadá, são consideradas pessoas com incapacidades todas aquelas que têm alguma desvantagem e ou dificuldade de desempenho funcional, o que engloba a população de idosos e com doenças crônicas potencialmente incapacitantes. No Brasil, a cultura vigente e a definição legal consideram pessoas com deficiência aquelas pertencentes aos segmentos com déficit mental (intelectual), motor, sensorial e múltiplo.

Em contrapartida à busca de definições para a deficiência, devemos pensar a mesma de uma forma mais humanizada, e não somente em termos científicos. Sendo assim, a deficiência pode ser vista como "a diversidade da natureza e da condição humana, em lugar da noção de desvio e de patologia." (AMARAL, 1995, p. 37).

\subsubsection{A Classificação Internacional de Funcionalidade, Incapacidade e Saúde (CIF)}

Em 1980, a Organização Mundial da Saúde (OMS) divulgou sugestões e padronizações universais de termos e conceitos relativos à deficiência. Atualmente, a OMS apresenta duas classificações de referência para a descrição dos estados de 
saúde: a Classificação Estatística Internacional de Doenças e Problemas Relacionados

à Saúde, que corresponde à décima revisão da Classificação Internacional de Doenças (CID-10) ${ }^{20}$ e a Classificação Internacional de Funcionalidade, Incapacidade e Saúde (CIF), aprovada em 2001; sendo que ambas se complementam, havendo a necessidade de aplicação conjunta. A efetiva utilização da CIF no Brasil vem sendo aguardada com grande expectativa pelas organizações de pessoas com deficiências e instituições relacionadas (DI NUBILA; BUCHALLA, 2008).

O Centro Colaborador da OMS para a Família de Classificações Internacionais em Português realizou, em 2007, na Faculdade de Saúde Pública da Universidade de São Paulo, a $1^{\text {a }}$ Reunião Nacional sobre a CIF. O objetivo do encontro foi divulgar a CIF e suas aplicações, assim como propiciar o contato e a troca de experiências entre pesquisadores com interesse na classificação ${ }^{21}$. 0 objetivo geral dessa nova classificação ${ }^{22}$ foi proporcionar uma linguagem unificada e padronizada de uma estrutura que descreva a saúde e os estados relacionados à saúde. Os domínios da classificação da CIF são descritos com base na perspectiva do corpo, do indivíduo e da sociedade em duas listas básicas: as funções e estruturas do corpo e as atividades e participação (ROCHA, 2006, p. 23). Os objetivos específicos da CIF são:

- Proporcionar uma base científica para a compreensão e o estudo da saúde e das condições relacionadas à saúde, de seus determinantes e efeitos;

\footnotetext{
${ }^{20}$ A CID-10 fornece um diagnóstico de doenças, distúrbios ou outras condições de saúde e essas informações são complementadas pelos dados adicionais fornecidos pela CIF sobre funcionalidade. Em conjunto estas informações fornecem uma imagem mais ampla e significativa da saúde da população, havendo possibilidade de comparações das mesmas em contexto internacional, referentes às causas de mortalidade e morbidade (CIF, 2003).

21 A autora participou deste encontro.

${ }^{22}$ A CIF em sua versão de 1980 fornecia a classificação de consequências da doença (impacto das doenças na saúde das pessoas), tranformando-se em sua nova versão de 2001 em uma classificação dos componentes da saúde (o que constitui a saúde) (CIF, 2003).
} 
- Estabelecer uma linguagem comum para a descrição da saúde e dos estados relacionados à saúde para melhorar a comunicação entre diferentes usuários, como profissionais de saúde, pesquisadores, elaboradores das políticas públicas e o público, inclusive pessoas com incapacidades;

- Permitir comparação de dados entre países, entre disciplinas relacionadas à saúde, entre os serviços e em diferentes momentos ao longo do tempo;

- Fornecer um esquema de codificação para sistemas de informações de saúde. (CIF, 2003, p. 16)

Os objetivos estão inter-relacionados, dado que a necessidade e a utilização da CIF requerem a construção de um sistema prático e útil para ser aplicado em diferentes usos, na política de saúde, na garantia de qualidade e na avaliação de resultados em diferentes culturas (CIF, 2003). Desde a sua publicação como uma versão experimental, em 1980, tem sido utilizada para vários fins, como uma ferramenta:

- estatística: na coleta e registro de dados (em estudos populacionais e pesquisas ou em sistemas de gerenciamento de informações);

- de pesquisa: para medir resultados, qualidade de vida ou fatores ambientais;

- clínica: na avaliação de necessidades, na compatibilidade dos tratamentos com condições específicas, avaliação vocacional, reabilitação e avaliação de resultados;

- de política social: no planejamento dos sistemas de previdência social, sistemas de compensação e projeto e implementação de políticas públicas;

- pedagógica: na elaboração de programas educativos, para aumentar a conscientização e realizar ações sociais.

A CIF contribui com o aperfeiçoamento da avaliação de potenciais, inserindo dados no contexto da gestão da saúde pública e em associação com a CID, que considera as condições de saúde relacionadas às doenças, aos transtornos ou às lesões, fornecendo um modelo baseado na etiologia, na anatomia e nas causas externas das 
lesões. Dessa forma, constitui-se em um instrumento útil para as estatísticas de saúde, "tornando possível monitorar as diferentes causas de morbidade e de mortalidade em indivíduos e populações, tornando-se uma ferramenta gerencial capaz de aproximar a realidade das informações dos gestores governamentais." (BRASIL, 2008a, p. 11).

Como a CIF é uma classificação de saúde e dos aspectos relacionados à saúde,

ela também é utilizada por setores como o de seguros, previdência social, trabalho, educação, economia, política social, desenvolvimento geral de legislação e modificação ambiental. Ela foi aceita como uma das classificações sociais das Nações Unidas, sendo incorporadas pelas Regras Uniformes para a Igualdade de Oportunidades para Pessoas com Incapacidade. Assim, a CIF constitui um instrumento apropriado para o desenvolvimento da legislação internacional sobre os direitos humanos bem como de legislação nacional. (CIF, 2003, p. 17)

A CIF se encontra dividida em duas partes, sendo a primeira parte relativa à Funcionalidade e Incapacidade; sendo a mesma subdividida em:

- Funções do corpo ${ }^{23}$ e estruturas do corpo, e

- Atividades e participação.

A segunda parte da CIF é relativa aos Fatores Contextuais, sendo a mesma subdividida em:

- Fatores ambientais e

- Fatores pessoais.

${ }^{23}$ Dentre os vários capítulos de classificações das funções do corpo encontradas na CIF, são descritos no seu capítulo 1- funções mentais / no capítulo 2- funções sensoriais: visão, funções auditivas e vestibulares; funções gustativa, olfativa, proprioceptiva, tátil, relacionadas à temperatura e no capítulo 3 - funções da voz e da fala (CIF, 2003, p. 45). 
A Classificação Internacional faz referência à participação, definida como a interação que se estabelece entre a pessoa com deficiência, a limitação da atividade e os fatores do contexto socioambiental. Tal conceito significa uma mudança fundamental, que altera profundamente o perfil do tratamento dado pelos governos de todo o mundo às questões que envolvem as pessoas com deficiência, "constituindo-se em um guia de orientação que organiza e padroniza as informações sobre a funcionalidade daçs pessoas com deficiência, segundo uma nova abordagem, a da sua capacidade efetiva." (BRASIL, 2008a, p. 10). O Quadro 1 a seguir, apresenta um panorama geral da CIF.

\begin{tabular}{|c|c|c|c|c|}
\hline \multirow[b]{2}{*}{ Componentes } & \multicolumn{2}{|c|}{$\begin{array}{c}\text { Parte 1: } \\
\text { Funcionalidade e Incapacidade }\end{array}$} & \multicolumn{2}{|c|}{$\begin{array}{l}\text { Parte 2: } \\
\text { Fatores Contextuais }\end{array}$} \\
\hline & $\begin{array}{l}\text { Funções e } \\
\text { estruturas do } \\
\text { corpo }\end{array}$ & $\begin{array}{l}\text { Atividades e } \\
\text { participação }\end{array}$ & $\begin{array}{c}\text { Fatores } \\
\text { ambientais }\end{array}$ & $\begin{array}{l}\text { Fatores } \\
\text { pessoais }\end{array}$ \\
\hline Domínios & $\begin{array}{l}\text { Funções do } \\
\text { corpo } \\
\text { estruturas do } \\
\text { corpo } \\
\end{array}$ & $\begin{array}{l}\text { Áreas da vida } \\
\text { (tarefas, ações) }\end{array}$ & $\begin{array}{c}\text { Influências } \\
\text { externas sobre a } \\
\text { funcionalidade e } \\
\text { a incapacidade }\end{array}$ & $\begin{array}{c}\text { Influências } \\
\text { internas sobre a } \\
\text { funcionalidade e } \\
\text { a incapacidade }\end{array}$ \\
\hline Construtos & $\begin{array}{l}\text { Mudanças nas } \\
\text { funções do corpo } \\
\text { (fisiológicas) } \\
\text { Mudanças nas } \\
\text { estruturas } \\
\text { corporais } \\
\text { (anatômicas) }\end{array}$ & $\begin{array}{c}\text { Capacidade: } \\
\text { execução de tarefas } \\
\text { em um ambiente } \\
\text { padrão } \\
\text { Desempenho: } \\
\text { execução de tarefas } \\
\text { no ambiente } \\
\text { habitual }\end{array}$ & $\begin{array}{c}\text { Impacto } \\
\text { facilitador ou } \\
\text { limitador das } \\
\text { características do } \\
\text { mundo físico, } \\
\text { social e de } \\
\text { atitude }\end{array}$ & $\begin{array}{c}\text { Impacto dos } \\
\text { atributos de uma } \\
\text { pessoa }\end{array}$ \\
\hline \multirow[t]{2}{*}{$\begin{array}{l}\text { Aspecto } \\
\text { Positivo }\end{array}$} & $\begin{array}{l}\text { Integridade } \\
\text { funcional e } \\
\text { estrutural }\end{array}$ & $\begin{array}{l}\text { Atividades e } \\
\text { participação }\end{array}$ & \multirow[t]{2}{*}{ Facilitadores } & \multirow[t]{2}{*}{ Não aplicável } \\
\hline & \multicolumn{2}{|c|}{ Funcionalidade } & & \\
\hline \multirow[t]{2}{*}{$\begin{array}{l}\text { Aspecto } \\
\text { Negativo }\end{array}$} & Deficiência & $\begin{array}{l}\text { Limitação da } \\
\text { atividade e restrição } \\
\text { de participação }\end{array}$ & \multirow[t]{2}{*}{$\begin{array}{l}\text { Barreiras / } \\
\text { obstáculos }\end{array}$} & \multirow[t]{2}{*}{ Não aplicável } \\
\hline & Inca & acidade & & \\
\hline
\end{tabular}

Quadro 1 - Panorama geral da CIF. Fonte: CIF, 2003, p. 22.

Funcionalidade é um termo que abrange todas as funções do corpo, atividades e participação; e incapacidade é um termo que abrange deficiências, limitações de 
atividades ou restrições na participação. A CIF também relaciona os fatores ambientais, permitindo ao usuário registrar perfis úteis da funcionalidade, incapacidade e saúde dos indivíduos. A CIF apresenta três principais termos que envolvem a pessoa com deficiência, apostos na classificação: deficiência, incapacidade e desvantagem (LOPES, M. E., 2007, p. 59). A deficiência passou a ser compreendida como parte ou expressão de uma condição de saúde, "mas não indica necessariamente a presença de uma doença ou que o indivíduo deva ser considerado doente." (BRASIL, 2008a, p. 10).

As observações importantes encontradas na análise da CIF são que no detalhamento referente às funções da percepção encontramos as seguintes classificações: percepção auditiva, percepção visual, percepção olfativa, percepção gustativa, percepção tátil e percepção visioespacial ${ }^{24}$. Os fatores ambientais constituem o ambiente físico, social e de atitudes nas quais as pessoas vivem e conduzem sua vida. Esses fatores são externos aos indivíduos e podem ter uma influência positiva ou negativa sobre seu desempenho enquanto membro da sociedade, sobre a capacidade do indivíduo de executar ações ou tarefas, ou sobre a função ou estrutura do corpo do indivíduo. Os fatores ambientais são organizados na classificação tendo em vista dois níveis distintos:

Individual - no ambiente imediato do indivíduo, inclusive em espaços como o domicílio, o local de trabalho e a escola. Esse nível inclui as características físicas e materiais do ambiente em que $\mathrm{o}$ indivíduo se encontra $[. .$.

Social - estruturas sociais formais e informais, regras de conduta ou sistemas predominantes na comunidade ou sociedade que têm um impacto sobre os indivíduos. (CIF, 2003, p. 28)

\footnotetext{
${ }^{24}$ Funções mentais envolvidas na distinção, por meio da visão da posição relativa dos objetos no ambiente ou em relação a si próprio. (CIF, 2003)
} 
As categorias de verificação são adotadas por cerca de 200 países, o que representa uma nova forma de avaliação. Além de representar um excepcional avanço na compreensão deste complexo universo, "a nova metodologia fornece diretrizes mais precisas para as futuras políticas públicas dos países que a adotarem, permitindo, assim, ações mais específicas e detalhadas no atendimento das necessidades da população." (BRASIL, 2008a, p. 10). A seguir, são apresentadas as interações entre os componentes da CIF (Quadro 2) que mostram que a funcionalidade de um indivíduo em um domínio específico é uma interação ou relação complexa entre estado ou condição de saúde e fatores contextuais (fatores ambientais e pessoais).

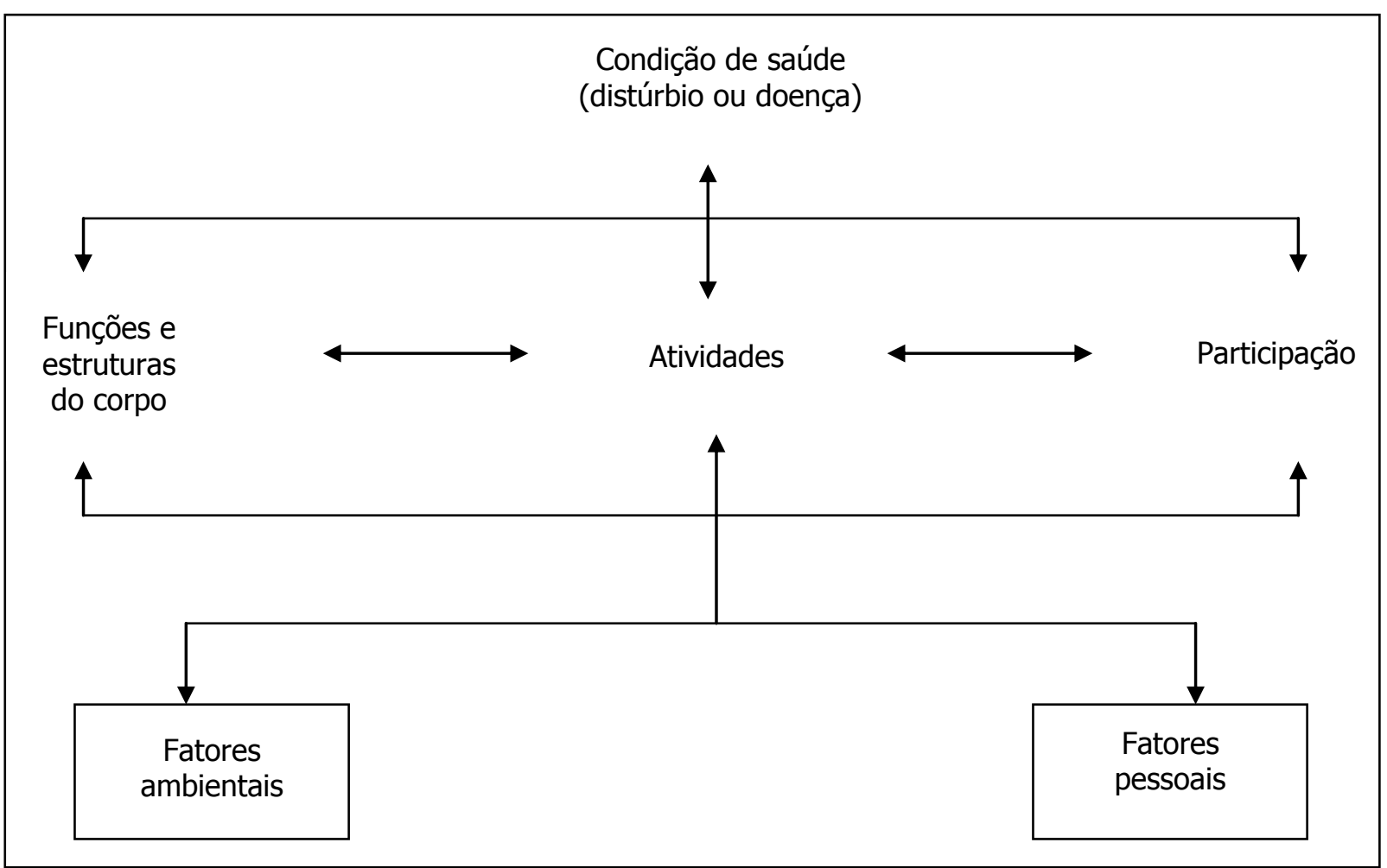

Quadro 2 - Interações entre os componentes da CIF. Fonte: CIF, 2003, p. 30.

A CIF analisa a saúde dos indivíduos a partir das categorias: funcionalidade, estrutura morfológica, participação na sociedade, atividades da vida diária e o ambiente social de cada indivíduo. Tal percepção traz maior clareza sobre "a 
qualidade do funcionamento das ações específicas e dos efeitos sobre a inserção das pessoas com deficiência, permitindo descrever situações relacionadas com a funcionalidade do ser humano e suas restrições." (BRASIL, 2008a, p. 10).

\subsection{Os tipos de deficiências}

No Brasil, ainda não existe um consenso em relação à definição dos tipos de deficiência existentes nos documentos pesquisados. O conceito ampliado utilizado no Censo de 2000 do Instituto Brasileiro de Geografia e Estatística (IBGE, 2000) para caracterizar as pessoas com deficiência, que inclui diversos graus de severidade na capacidade de enxergar, ouvir e locomover-se, sendo descrito como "compatível com a Classificação Internacional de Funcionalidade, Incapacidade e Saúde (CIF), divulgada em 2001 pela Organização Mundial de Saúde (OMS)." (BRASIL/CORDE, 2004, p. 11). No referido censo são descritos cinco tipos de deficiência: mental, física (tetraplegia, paraplegia, hemiplegia, falta de membro ou parte dele), visual, motora e auditiva. A bibliografia encontrada referente à CIF somente contempla a sua definição, os seus objetivos e as suas aplicações, e descreve o conceito de incapacidade ${ }^{25}$.

O Relatório sobre a prevalência de deficiências, incapacidades e desvantagens (BRASIL/CORDE, 2004) define os cinco tipos de deficiência: mental, visual, motora, auditiva, e múltipla. A norma brasileira NBR 9050 (ABNT, 2004) Acessibilidade a

\footnotetext{
${ }^{25}$ Não descreve os tipos de deficiência.
} 
edificações, mobiliário, espaços e equipamentos urbanos não define os tipos de deficiência. O Decreto Federal $n^{\circ} 5.296$ (BRASIL, 2004) define os quatro tipos de deficiência: física, auditiva, visual, mental e múltipla; sendo o mesmo adotado, em parte $^{26}$, no presente estudo. A Convenção sobre os Direitos das Pessoas com Deficiência (BRASIL, 2007), não define os tipos de deficiências, e somente define o termo deficiência (item 2.1).

\subsubsection{A deficiência física}

Segundo o artigo 5 (§ $1^{\circ}$ ) do Decreto Federal nº 5.296 (BRASIL, 2004), a deficiência física é definida como:

alteração completa ou parcial de um ou mais segmentos do corpo humano, acarretando o comprometimento da função física, apresentando-se sob a forma de paraplegia, paraparesia, monoplegia, monoparesia, tetraplegia, tetraparesia, triplegia, triparesia, hemiplegia, hemiparesia, ostomia, amputação ou ausência de membro, paralisia cerebral, nanismo, membros com deformidade congênita ou adquirida, exceto as deformidades estéticas e as que não produzam dificuldades para o desempenho de funções.

A complexa definição de deficiência física citada não descreve os termos médicos, sendo de incompreensão, exceto pelos especialistas. Para o melhor entendimento, seguem algumas definições práticas ${ }^{27}$ encontradas no Ministério do Trabalho e Emprego ${ }^{28}$, relativas a Lei de Cotas.

- Amputação: perda total ou parcial de um determinado membro ou segmento de membro;

- Paraplegia: perda total das funções motoras dos membros inferiores;

- Paraparesia: perda parcial das funções motoras dos membros inferiores;

- Monoplegia: perda total das funções motoras de um só membro (inferior ou superior);

${ }^{26} \mathrm{O}$ termo deficiência intelectual foi o adotado neste estudo (ver item 2.2.4).

${ }^{27}$ Muitos dos termos citados foram levantados junto a BIREME (s/d), porém não foram incluídos no presente estudo, pois alguns não foram encontrados e outros são de difícil entendimento.

${ }_{28}$ Disponível em: <http://www.mte.gov.br/fisca_trab/inclusao/lei_cotas_2.asp>. Acesso em: 22 jul. 2010. 
- Monoparesia: perda parcial das funções motoras de um só membro (inferior ou superior);

- Tetraplegia: perda total das funções motoras dos membros inferiores e superiores;

- Tetraparesia: perda parcial das funções motoras dos membros inferiores e superiores;

- Triplegia: perda total das funções motoras em três membros;

- Triparesia: perda parcial das funções motoras em três membros;

- Hemiplegia: perda total das funções motoras de um hemisfério do corpo (direito ou esquerdo);

- Hemiparesia: perda parcial das funções motoras de um hemisfério do corpo (direito ou esquerdo);

- Ostomia: intervenção cirúrgica que cria um ostoma (abertura, ostio) na parede abdominal para adaptação de bolsa de fezes e/ou urina; processo cirúrgico que visa à construção de um caminho alternativo e novo na eliminação de fezes e urina para o exterior do corpo humano (colostomia: ostoma intestinal; urostomia: desvio urinário);

- Paralisia cerebral: lesão de uma ou mais áreas do sistema nervoso central, tendo como consequência alterações psicomotoras, podendo ou não causar deficiência mental;

- Nanismo: deficiência acentuada no crescimento [...]

A definição da deficiência física é complexa em função da variedade de tipos que apresenta não havendo um consenso entre os órgãos brasileiros sobre sua classificação. Segundo o MEC (2004), outros tipos de deficiência física (diferentes dos citados no Decreto Federal $n^{0} 5.296$ de 2004) podem ser encontrados, como os relacionados a seguir:

- Lesão cerebral (paralisia cerebral, hemiplegias);

- Lesão medular (tetraplegias, paraplegias);

- Miopatias (distrofias musculares);

- Patologias degenerativas do sistema nervoso central (esclerose múltipla, esclerose);

- Lesões nervosas periféricas;

- Amputações;

- Sequelas de politraumatismos;

- Malformações congênitas;

- Distúrbios posturais de coluna;

- Sequelas de patologias da coluna;

- Distúrbios dolorosos da coluna vertebral e das articulações dos membros;

- Artropatias;

- Reumatismo inflamatório da coluna e das articulações;

- Doenças osteomusculares (DORT); e

- Sequelas de queimaduras. (MEC, 2004, p. 11)

Algumas das causas da deficiência física se encontram descritas a seguir:

- Paralisia cerebral: por prematuridade, anóxia perinatal, desnutrição materna, rubéola, toxoplasmose, trauma de parto e subnutrição;

- Hemiplegias: por acidente vascular cerebral, aneurisma cerebral, tumor cerebral;

- Lesão medular: por ferimento por arma de fogo, ferimento por arma branca, acidentes de trânsito, mergulho em águas rasas, traumatismos diretos, quedas, processos infecciosos e processos degenerativos; 
- Malformações congênitas: por exposição à radiação, uso de drogas, causas desconhecidas; e - Artropatias: por processos inflamatórios, processos degenerativos, alterações biomecânicas, hemofilia, distúrbios metabólicos e outros. (MEC, 2004, p. 11)

Após os levantamentos realizados junto à direção e às docentes da pré-escola de educação especializada em deficiência física envolvida nesta pesquisa, em 2009 e em 2010, verificou-se que a deficiência física do tipo paralisia cerebral (PC) era recorrente na grande maioria dos seus alunos matriculados ${ }^{29}$. Para a compreensão da deficiência física presente nos sujeitos da pesquisa da pré-escola citada se fez necessário um maior entendimento acerca da PC.

A definição de PC propõe que as desordens do desenvolvimento motor, advindas da lesão cerebral primária, são de caráter permanente, ocasionando alterações músculo-esqueléticas secundárias e limitações nas atividades (ROSENBAUM et al., 2006). O termo PC designa uma sequela de caráter não-progressivo, que acomete o sistema nervoso central imaturo e em desenvolvimento, ocasionando déficits posturais, tônicos e na execução dos movimentos (MANCINI et al., 2004). A paralisia cerebral é "um resultado de danos, normalmente decorrentes de uma insuficiência de oxigênio no cérebro, que ocorreu antes (pré-natal), durante (perinatal) ou imediatamente depois (pós-natal) do nascimento da criança." (SMITH, 2008, p. 265).

Na categorização das deficiências físicas e doenças (Figura 3), conseguimos compreender de forma objetiva o universo das deficiências físicas decorrentes dos

\footnotetext{
${ }^{29}$ Segundo informações obtidas da entrevista realizada com a direção da pré-escola envolvida, são recebidos alunos com vários tipos de deficiência física, e não somente com os com PC.
} 
danos neuromotores e das condições ósseas e musculares, possibilitando entender onde se enquadram os alunos com PC do presente estudo.

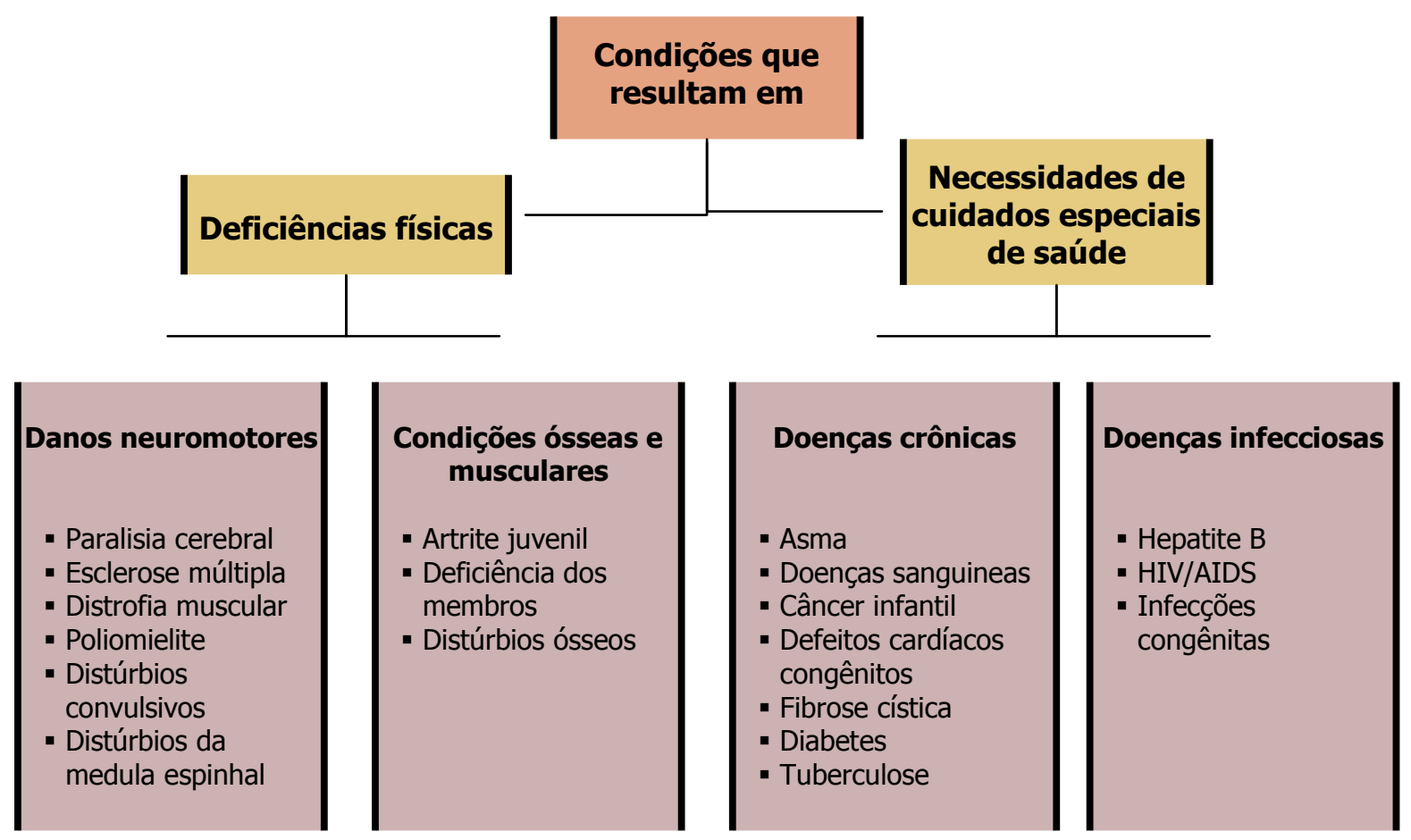

Figura 3 - Esquema de organização das deficiências físicas e doenças. Fonte: Elaborada pela autora com base em Smith, 2008, p. 264.

Existem várias classificações para a PC, que se distinguem de acordo com características específicas, incluindo tipo de tônus, distribuição do acometimento no corpo, e nível de independência. Entre as alterações tônicas, a mais comum é a espasticidade ${ }^{30}$, sendo que $75 \%$ das crianças com PC apresentam tônus elevado, exacerbação dos reflexos tendíneos e da resistência à movimentação passiva rápida (KIM; STEINBOK; WICKENHEISER, 2006).

\footnotetext{
${ }^{30}$ A espasticidade é um dos distúrbios motores mais frequentes e incapacitantes observados nos indivíduos com lesão do sistema nervoso central, comprometendo o neurônio motor superior. Este distúrbio aparece em diferentes doenças, onde destacamos por sua maior frequência a paralisia cerebral, a lesão medular e a lesão encefálica, adquiridas por diferentes causas: traumáticas, tumorais, vasculares, infecciosas e degenerativas. Disponível em:

<http://www.wgate.com.br/conteudo/medicinaesaude/fisioterapia/neuro/espasticidade_carlos.htm>. Acesso em: 4 mai. 2009.
} 
Atualmente, a literatura tem demonstrado a preferência em classificar as crianças com PC de acordo com sua independência funcional nas funções motoras grossas e finas. Existem dois sistemas de classificação funcionais que atendem a esta tendência. O Gross Motor Function Classification System (GMFCS) e o Manual Abilities Classification System (MACS) foram desenvolvidos para categorizar, respectivamente, a mobilidade e a função manual de crianças com PC. A classificação pelo GMFCS é feita de acordo com a idade da criança, e os estudos sustentam a ideia de que a classificação de uma criança por este sistema possui um bom grau de estabilidade ao longo dos anos, ou seja, uma criança, geralmente, permanece no mesmo nível de classificação (CHAGAS, 2008).

A classificação para a PC relativa a distribuição do acometimento no corpo se encontra descrita no Quadro 3 a seguir.

\begin{tabular}{|c|c|c|c|}
\hline Um dos braços & Uma das pernas & Um braço e uma perna \\
\hline Monoplegia & Paraplegia & Hemiplegia & Quadriplegia \\
\hline
\end{tabular}

Quadro 3 - Áreas do corpo afetadas pela paralisia cerebral. Fonte: Elaborada pela autora com base em Smith (2008).

Outra forma de classificação da PC baseia-se no modo como o movimento do indivíduo é afetado, existindo quatro subtipos principais: o tipo espástico, onde os movimentos são muito rígidos; o tipo atetóide, onde os movimentos involuntários são despropositados ou descontrolados, enquanto os movimentos propositais são 
destorcidos; o tipo atáxico, onde os movimentos como a caminhada são interrompidos pela falta de equilíbrio e de percepção de profundidade e a paralisia cerebral mista,

sendo a forma espástica a mais comum. $\mathrm{O}$ transtorno motor pode variar desde dificuldades no controle motor fino à espasticidade severa em todos os membros. A diplegia espástica (doença de Little) é o subtipo mais comum, e é caracterizado por espasticidade mais proeminente nas pernas que nos braços. (BIREME, s/d)

A deficiência física pode apresentar comprometimentos diversos das funções motoras do organismo físico que variam em número e grau, de indivíduo para indivíduo dependendo das causas e da abrangência. Segumdo o MEC (2004, p. 13), esses comprometimentos relativos à deficiência física podem apresentar-se como:

- leve cambalear no andar;

- necessidade do uso de muletas ou andador adequados para auxiliarem a execução da marcha;

- uso de cadeira de rodas que pode ser manobrada pelo aluno;

- uso de cadeira de rodas manobrada por terceiros devido a impossibilidade do aluno e

- uso de cadeira de rodas motorizada que poderá ser acionada por qualquer parte do corpo onde predomine alguma função voluntária.

No ambiente escolar, esses problemas poderão estar associados ou não a:

- dificuldades de linguagem (disartria, anartia,...);

- dificuldades visuais (estrabismo, nistagmo, visão sub-normal,...);

- dificuldades auditivas com possibilidade de compensação com uso de aparelho específico;

- semi-dependência para atividades da vida diária (AVD): higiene; alimentação; uso do banheiro; escrita; desenho; atividades que necessitem coordenação motora fina.

- problemas do desenvolvimento cognitivo: dificuldades para o "fazer"; o "compreender o que está sendo visto"; dificuldades para compreender a linguagem. (MEC, 2004, p. 13)

A deficiência neuromotora pode acarretar dificuldades relacionadas à fala, à locomoção, à visão, ao controle dos movimentos das mãos ou de outras partes do corpo. Crianças com deficiência neuromotora podem ser capazes de sentar sem 
suporte ou auxílio, enquanto outras podem necessitar de auxílio para a maioria das tarefas da vida diária, por toda a sua vida. ${ }^{31}$

A criança com PC não tem obrigatoriamente a deficiência intelectual associada, apresentando um comprometimento de função da fala, por exemplo. Ao contrário do que o termo sugere paralisia cerebral, não significa que o cérebro ficou paralisado, mas que não comanda corretamente os movimentos do corpo (MEC, 2004). Segundo Smith (2008, p. 266),

Embora algum grau de retardo mental esteja sempre presente em metade das crianças com paralisia cerebral, outras são intelectualmente dotadas. É um grande engano acreditar que a paralisia cerebral e retardo mental sempre ocorrem em combinação.

Lima e Fonseca (2004) relatam que em mais da metade dos casos de PC podem ocorrer déficits cognitivos, e nestes a deficiência visual é rara. As crianças com PC destacam-se em função da gravidade do comprometimento global que podem apresentar, sendo que "os distúrbios da comunicação agravam-se na presença conjunta de alterações motoras, pois limitam a utilização dos recursos próprios do indivíduo, tais como gestos, olhar e apontar com as mãos na substituição à fala." (SOUZA, 2000, p. 14).

Os alunos com PC do presente estudo, em sua grande maioria, apresentam um ótimo desenvolvimento cognitivo e intelectual e muitos se encontram alfabetizados, e cerca de $30 \%$ (Tabela 6) utilizam a comunicação aumentativa e alternativa (CAA) descrita a seguir.

\footnotetext{
${ }^{31}$ Disponível em: <http://www.tele-centros.org>. Acesso em: 3 set. 2008.
} 


\subsubsection{A comunicação aumentativa e alternativa (CAA)}

Inicialmente se faz necessário descrever os termos comunicação e língua. A Convenção Internacional para Proteção e Promoção dos Direitos e Dignidade das Pessoas com Deficiência, aprovada em 2006 pela Assembléia Geral da ONU em Nova Iorque, descreve em seu o artigo $2^{\circ}$

"Comunicação" inclui comunicação oral, comunicação usando linguagem de sinais, Braille e comunicação tátil, publicações para baixa visão, áudio, multimídia acessível, leitura humana e outros modos alternativos ou aumentativos de comunicação, incluindo informação acessível e tecnologia de comunicação.

"Língua" inclui comunicação oral e linguagem de sinais e outras formas de linguagem não falada. ${ }^{32}$

A comunicação alternativa se encontra citada por vários autores em diferentes termos, tais como: comunicação alternativa e suplementar (GONÇALVES, 2008), comunicação alternativa e ampliada (BEULKMAN; MIRENDA, 1992; SOUZA, 2000; PAULA; ENUMO, 2007) e comunicação aumentativa e alternativa (SEESP/SEED/MEC, 2007), sendo o último termo o adotado neste estudo. A comunicação aumentativa e alternativa

é uma das áreas da tecnologia assistiva ${ }^{33}$ que atende pessoas sem fala ou escrita funcional ou em defasagem entre sua necessidade comunicativa e sua habilidade em falar e/ou escrever. Busca, então, através da valorização de todas as formas expressivas do sujeito e da construção de recursos próprios desta metodologia, construir e ampliar sua via de expressão e compreensão. (SEESP/SEED/MEC, 2007, p. 58)

No sentido de ampliar as possibilidades de comunicação, vários métodos de recepção e transmissão de mensagens têm sido usados ao longo dos anos com indivíduos não

\footnotetext{
32 Disponível em: <www.mp.pe.gov.br/uploads/85f5u0tVH>. Acesso em: 12 abr. 2009.

${ }^{33}$ Tecnologia assistiva é uma expressão utilizada para identificar todo o arsenal de recursos e serviços que contribuem para proporcionar ou ampliar habilidades funcionais de pessoas com deficiência e, consequentemente, promover vida independente e inclusão (SEESP/SEED/MEC, 2007, p. 31). Este tema é aprofundado no item 2.6.
} 
vocais ou não vocais e ouvintes, e vocais ou não vocais surdos ${ }^{34}$, dentre outros, como a Língua Brasileira de Sinais (LIBRAS) empregada por pessoas com deficiência auditiva no Brasil. Porém, segundo Gonçalves (2008), o termo CAA está tradicionalmente associado à comunicação utilizada pelas pessoas com paralisia cerebral. A CAA destina-se a sujeitos de todas as idades, que não possuem fala ${ }^{35}$ e/ou escrita funcional devido a disfunções variadas como, "paralisia cerebral, deficiência mental, autismo, acidente vascular cerebral, traumatismo cranioencefálico, traumatismo raquiomedular, doenças neuromotoras (como, por exemplo, a esclerose lateral amiotrófica), apraxia oral e outros." (TETZCHNER; MARTINSEN, 1992, p. 23).

Segundo a definição da American Speech-Language-Hearing Association (ASHA), a CAA é uma área da prática clínica que se esforça para "compensar, temporária ou permanentemente, padrões de impedimentos e incapacidades com desordens severas da comunicação expressiva, impedimentos severos da linguagem oral e escrita." (BEULKMAN; MIRENDA, 1992, p. 3). O termo alternativa se refere aos recursos que "substituem a fala ou a escrita para os indivíduos que não desenvolveram a fala ou estão impedidos temporariamente de falar bem como escrever $[\ldots]^{\prime \prime}($ SOUZA, 2000, p. 18). O desenvolvimento de alternativas à fala e à escrita, para crianças com deficiência física grave, envolve

\footnotetext{
34 Mesmo que a linguagem verbal não seja a única modalidade de comunicação, quando o repertório verbal é inadequado e onde a fala não se manifesta, é ininteligível ou limitada, utiliza-se a CAA (PAULA; ENUMO, 2007).

35 Pessoas são consideradas não-falantes em duas situações: quando apresentam um comprometimento severo na fala por problemas físicos, neuromusculares, cognitivos ou déficits emocionais e não possuem prejuízos na audição; quando, no presente tempo usam fala independente como primeira forma de comunicação, porém não são compreendidos por outras pessoas que não são de convívio muito próximo. (SEESP/SEED/MEC, 2007, p. 57).
} 
a abordagem de diversas áreas do conhecimento. A disponibilidade de material pedagógico adaptado, a aplicação de meios de expressão substitutivos ou complementares à fala e à escrita, e uso de adaptações funcionais para facilitar a escrita compõem as ações necessárias ao atendimento da demanda desta parcela da população escolar. A Terapia Ocupacional como área de conhecimento e prática de saúde, voltada para a análise e aplicação terapêutica de atividades e adaptação do ambiente, pode e tem contribuído para facilitar o desempenho dos alunos com dificuldades motoras e comunicativas na escola. (SOUZA, 2000, p. 14)

Na comunicação de uma mensagem, o indivíduo faz uso dos recursos que dispõe e que não necessitam de auxílio externo: gestos, vocalização, choro, sinais manuais, atitude corporal, expressão facial (como sorrir), apontar com os olhos, mãos ou outra parte do corpo. Estes não dependem de dispositivos adicionais, pois sendo parte do próprio corpo, estão sempre disponíveis. Outros recursos podem se associar às possibilidades que o próprio corpo oferece tais como o auxílio externo, podendo ser usados objetos (reais e miniaturas), fotografias, desenhos coloridos ou em preto e branco, símbolos gráficos, letras, palavras, frases, ou combinações de todos estes, dispostos em recursos de baixa e alta tecnologia. Estes adicionais à comunicação podem ser colocados em dispositivos, como a prancha de comunicação e, desta forma, a possibilidade de oferecer determinado vocabulário é disponibilizada, para que o indivíduo possa se expressar (SOUZA, 2000; SEESP/SEED/MEC, 2007). A seguir são descritos alguns dos recursos de baixa tecnologia

Objetos reais: o aluno poderá fazer escolhas "apontando" para objetos reais, como a roupa que deseja vestir, o material escolar que deseja utilizar, o alimento que escolherá ou o produto que deseja comprar na prateleira do supermercado.

Miniaturas: são utilizadas com alunos que apresentam dificuldade de reconhecer e significar símbolos gráficos e também com alunos cegos ou com baixa visão, onde os relevos das miniaturas os auxiliam a reconhecer o objeto e assim confirmar a mensagem que desejam expressar. As miniaturas podem ser apresentadas uma a uma ou em grupos organizados em pranchas de comunicação.

Objetos parciais: utilizados em situações onde os objetos a serem representados são muito grandes. Nestes casos, a utilização de parte do objeto pode ser muito apropriada. Por exemplo, usar um mouse ou um CD para representar o computador ou um controle remoto para dizer que quer assistir à televisão.

Fotografias: podem ser utilizadas para representar objetos, pessoas, ações, lugares, sentimentos ou atividades.

Símbolos gráficos: há uma série de bibliotecas de símbolos gráficos que foram desenvolvidos para facilitar a comunicação e que com eles são construídas as pranchas e cartões de 
comunicação. Os tipos de símbolos podem ser: Pictográficos - desenhos que parecem com aquilo que desejam simbolizar; Arbitrários - desenhos que não têm relação pictográfica entre a forma e aquilo que desejam simbolizar; Ideográficos - desenhos que simbolizam a ideia de uma coisa, criam uma associação gráfica entre o símbolo e o conceito que ele representa e Compostos - grupos de símbolos agrupados para representar objetos ou ideias. (SEESP/SEED/MEC, 2007, p. 61)

Em relação aos recursos de alta tecnologia, sofisticados sistemas computadorizados podem ser empregados de forma substitutiva ou suplementar de apoio à fala, ajudando a desenvolver, quando possível, a linguagem oral. Para crianças que apresentam comprometimento motor mais grave, o acesso aos símbolos pode ser possibilitado ou facilitado quando estes estão dispostos em equipamentos eletrônicos, como comunicadores e computadores. "O computador é uma importante via de acesso aos símbolos, com ou sem uso de adaptações, como protetor de teclado (keyboard), teclado expandido, mouse adaptado e acoplado a acionadores." (SOUZA, 2000, p. 21).

A CAA abrange o uso integrado dos recursos de baixa e alta tecnologia, anteriormente citados, utilizados a partir da necessidade de cada indivíduo e dos recursos disponíveis, com o objetivo de proporcionar o melhor emprego "do esforço do indivíduo em se comunicar e potencializar seu desenvolvimento intelectual e social." (SOUZA, 2000, p. 19). Ressalta-se que

\begin{abstract}
uma pessoa pode utilizar vários recursos alternativos do mesmo modo que as pessoas que falam utilizam gestos, expressões faciais e outros recursos associados à verbalização. Enfatizase que a intervenção na área da CAA deve ser multimodal por natureza, significando que todas as habilidades comunicativas do indivíduo são aproveitadas e utilizadas em conjunto com os meios de comunicação alternativa. (BEULKMAN; MIRENDA, 1992)
\end{abstract}

Existem vários sistemas de símbolos gráficos que são conhecidos internacionalmente e utilizados para a confecção de pranchas, pastas e cartões de comunicação, entre 
eles "o Blissymbolics, o Pictogram Ideogram Communication Symbols (PIC) e o Picture Communication Symbols (PCS)."(SEESP/SEED/MEC, 2007, p. 61). O sistema simbólico mais utilizado no Brasil é o PCS traduzido como Símbolos de Comunicação Pictórica (Figura 4). Este sistema de símbolos gráficos foi originalmente desenhado para criar, rápida e economicamente, recursos de comunicação consistentes. O PCS compõe atualmente o conjunto de símbolos mais difundido em todo o mundo e foi criado no início dos anos 1980 pela fonoaudióloga americana Roxanna Mayer Johnson. ${ }^{36}$

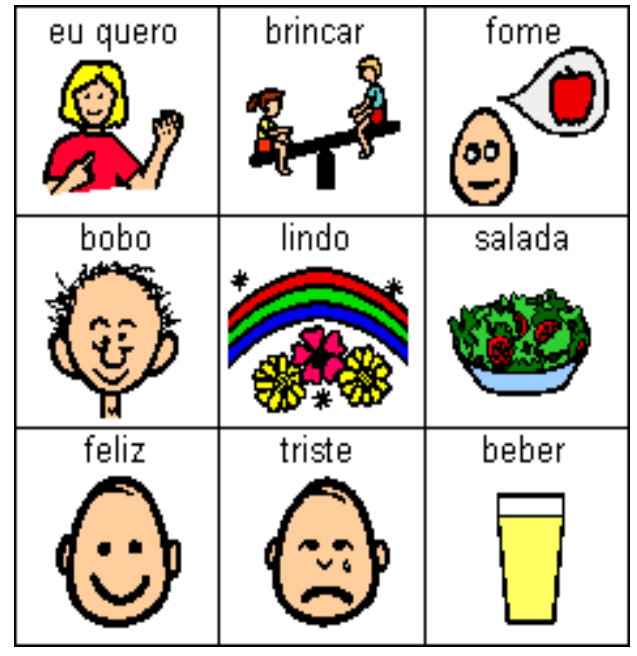

Figura 4 - Símbolos de comunicação pictórica. Fonte: Disponível em: <http://www.clik.com.br>. Acesso em: $20 \mathrm{dez} .2009$.
As características da simbologia PCS são: apresentam desenhos simples e de fácil reconhecimento; combináveis com outros sistemas de símbolos, figuras e fotos para a criação de recursos de comunicação individualizados. Os símbolos estão divididos em seis categorias ${ }^{37}$ e o PCS se encontra disponível no Brasil através dos softwares Boardmaker ${ }^{38} \mathrm{e}$ Escrevendo com Símbolos.

Na prancha, pasta ou cartão de comunicação são colocados os símbolos gráficos que representam mensagens, letras, sílabas, palavras, frases ou números, escolhidos de

\footnotetext{
${ }^{36}$ Disponível em: <http://www.clik.com.br/clik_01.html\#TClk>. Acesso em: 18 dez. 2009.

37 As seis categorias podem ser usadas no seguinte sistema de codificação de cores: pessoas contorno ou fundo amarelo; verbos - contorno ou fundo verde; substantivos - contorno ou fundo laranja; descritivos - contorno ou fundo azul; miscelânea - contorno ou fundo branco; social contorno ou fundo rosa. (JOHNSON, 1998, p. 5).

${ }^{38}$ Boardmaker é um programa de computador que contém um banco de dados gráfico contendo os mais de 4.500 símbolos em PCS no Português, característicos e próprios da história e cultura do Brasil. Disponível em: <http://www.clik.com.br/clik_01.html\#TClk>. Acesso em: 18 dez. 2009.
} 
acordo com as necessidades comunicativas e as possibilidades cognitivas, visuais e motoras de seu usuário. As pranchas são personalizadas e são elaboradas de acordo com o vocabulário do cotidiano do indivíduo. Existe uma variedade de opções para a organização e disposição dos símbolos, fotos ou figuras, como a pasta e a prancha (Figura 5), podendo ser usados:

um suporte resistente, como álbuns, fichários, blocos de madeira, pedaços de madeira ou outro tipo de material rígido para a fixação dos recursos adicionais e confecção das pranchas de comunicação [...] Para aumentar a durabilidade, os símbolos são protegidos por capa plástica, contact ou placa de acrílico. (SOUZA, 2000, p. 21)

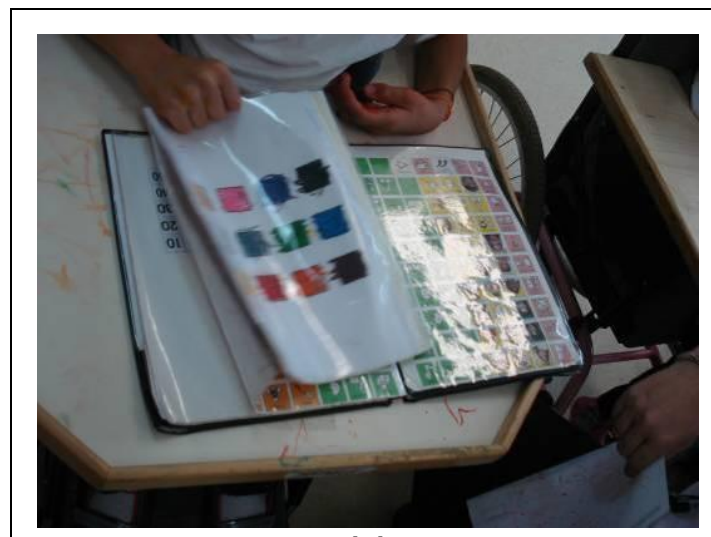

(a)

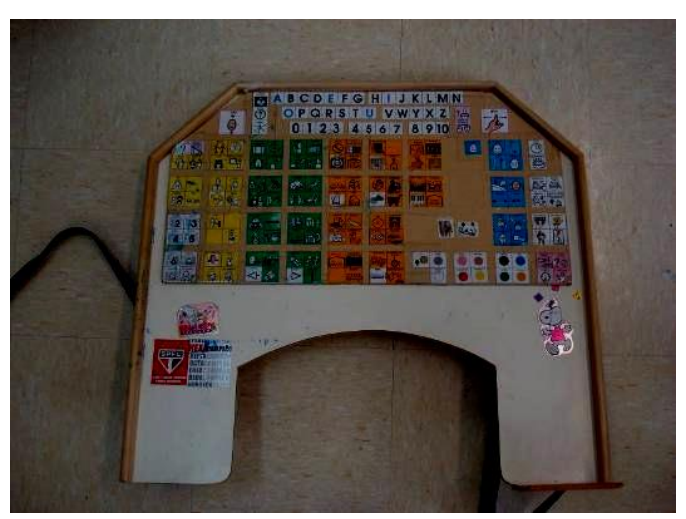

(b)

Figura 5 - Pasta (a) e prancha (b) de CAA sobre o tampo que se acoplada à cadeira de rodas.

As pranchas de comunicação têm a vantagem de serem de fácil transporte, dependendo das condições de locomoção do usuário e do tamanho da prancha, porém apresentam a desvantagem de "limitar o número de símbolos em função do tamanho dos próprios símbolos e da prancha ou dispositivo semelhante." (SOUZA, 2000, p. 21). A pasta de CAA pode conter um maior número de símbolos.

O método utilizado pelo indivíduo para indicar os símbolos é determinado por um terapeuta ocupacional, pois depende do seu nível de comprometimento. Para 
algumas pessoas com grandes dificuldades físicas, o simples fato de apontar o dedo

\author{
sobre um símbolo para indicar uma mensagem, pode não ser possível ou prático.
}

Técnicas de seleção e pranchas de símbolos com formatos alternativos foram então criadas para dar a essas pessoas outras opções. É importante determinar a técnica de seleção mais eficiente para cada indivíduo. Um terapeuta ocupacional é geralmente um membro importante da equipe na avaliação. Deve ser determinado o posicionamento ideal da prancha e do usuário. A precisão, o quanto o sujeito fadiga e a velocidade são fatores a serem considerados. (JOHNSON, 1998, p. 14)

As técnicas de seleção podem ser divididas em: técnica de seleção direta, técnica de olhar (eye-gaze), técnica da varredura e técnica da codificação. A técnica de seleção direta (Figura 6)

é o método preferível, quando possível. Geralmente consome menos tempo e requer menos do ouvinte. As técnicas mais comuns requerem que os indivíduos apontem ou toquem diretamente o símbolo. Pode-se apontar com o dedo ou com uma ponteira de cabeça ou luz fixada na cabeça. Diferentes partes do corpo, tais como o dedo do pé, punho ou cotovelo, também podem ser utilizados para a seleção direta". (JOHNSON, 1998, p. 79)

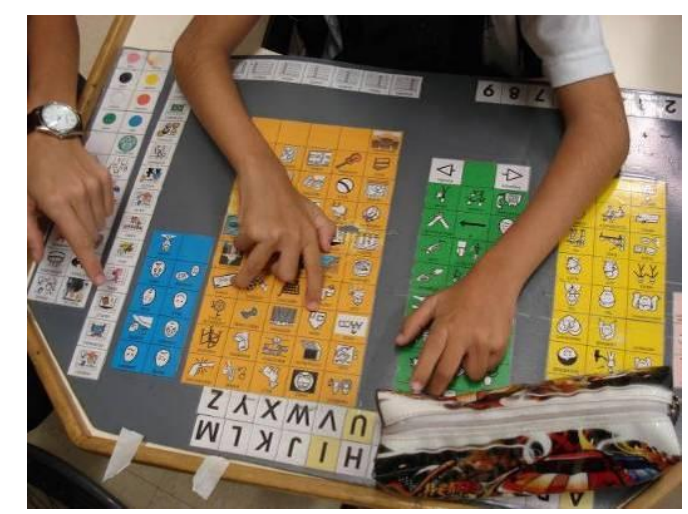

(a)

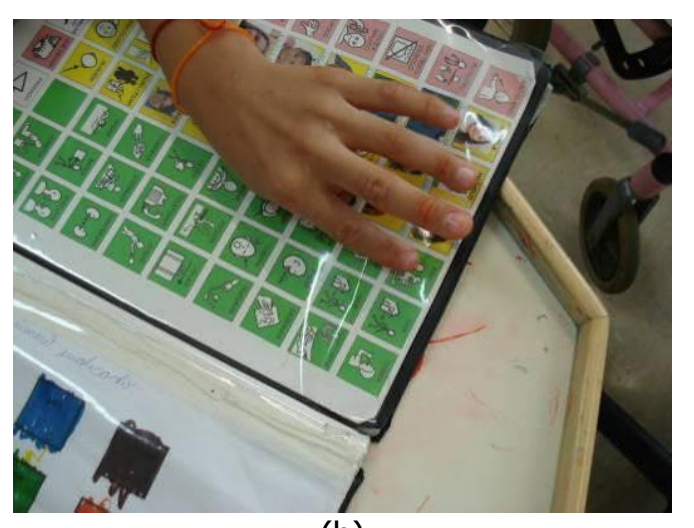

(b)

Figura 6 - Técnica de seleção direta na prancha (a) e na pasta (b) de CAA.

\title{
A técnica de olhar (eye-gaze)
}

é geralmente um bom método para indivíduos com graves problemas físicos. Confeccionamos uma prancha no formato de moldura, vazada ao centro, onde os símbolos são colocados nas pontas. $\mathrm{O}$ parceiro de comunicação se posiciona na frente do usuário, apresenta-lhe a prancha diante dos olhos. O usuário deverá então direcionar o olhar para o símbolo que corresponde à mensagem que deseja expressar. Como o parceiro está posicionado a sua frente, pode acompanhar o movimento e a fixação de seus olhos, através da área vazada da prancha de olhar. No caso de pranchas de olhar, devemos ter o cuidado de separar suficientemente os símbolos para que tenhamos certeza qual símbolo foi selecionado. (JOHNSON, 1998, p. 80) 
A técnica da varredura

exige somente que a pessoa tenha uma resposta controlável consistente, como sacudir a cabeça, bater um pé ou piscar os olhos. Os recursos de baixa tecnologia necessitam de um facilitador para apontar para os símbolos de maneira sistemática, enquanto o usuário sinalizará quando o símbolo desejado for apontado. Alguns recursos de alta tecnologia apresentam varredura automática. ${ }^{39}$ (JOHNSON, 1998, p. 81)

Segundo Johnson (1998, p. 82), a técnica da codificação "permite a ampliação de significados a partir de um número limitado de símbolos e o aumento da velocidade. É uma técnica bastante eficiente para usuários com dificuldades motoras graves, mas exige um maior grau de abstração". A codificação pode ser usada pelo indivíduo usando seleção direta ou varredura.

\subsubsection{A deficiência auditiva}

Segundo o artigo 5 (§ $1^{\circ}$ ) do Decreto Federal $n^{0} 5.296$ (BRASIL, 2004), a deficiência auditiva é definida como "perda bilateral, parcial ou total, de quarenta e um decibéis (dB) ou mais, aferida por audiograma nas frequências de $500 \mathrm{~Hz}, 1.000 \mathrm{~Hz}, 2.000 \mathrm{~Hz}$ e $3.000 \mathrm{~Hz}$.

Cada sujeito surdo é único e sua identidade se constituirá, conforme as experiências socioculturais que vivenciou ao longo de sua vida, "há surdos que têm consciência de sua diferença e necessitam de recursos essencialmente visuais nas suas interações, e

\footnotetext{
${ }^{39}$ Ainda nesta técnica o indivíduo pode ter outras respostas voluntárias consistentes como sorrir ou emitir um som para que possa sinalizar sua resposta.
} 
surdos que nasceram ouvintes e, portanto, conheceram a experiência auditiva." (MARTINS, S. L., 2008, p. 20).

Quando a perda auditiva é maior, ela impede o indivíduo de ouvir a voz humana e, portanto, de adquirir, espontaneamente, a capacidade de aprender a modalidade oral da língua, mesmo com o uso de prótese auditiva. A deficiência auditiva é diagnosticada através de exames, como a audiometria e o audiograma, e pode ser adquirida quando existe uma predisposição genética (por exemplo, a otosclerose) após o nascimento, ou devido à meningite, a ingestão de remédios ototóxicos (que causam danos aos nervos relacionados à audição), a exposição a sons impactantes, e a viroses. Durante a gestação pode ocorrer a perda auditiva da criança devido a contaminação da gestante por doenças como rubéola, sarampo, sífilis, citomegalovírus e a toxoplasmose, além da ingestão de medicamentos que lesam o nervo auditivo. ${ }^{40}$

Os aparelhos auditivos podem auxiliar crianças com perdas profundas pré-linguais ${ }^{41}$ em seu desenvolvimento auditivo e de linguagem oral, permitindo que recebam pistas auditivas como a presença e a ausência de som, duração e intensidade, o reconhecimento de traços segmentares e supra-segmentares. Porém, segundo Boothroyd (1984), essas crianças ainda não recebem uma estimulação auditiva suficiente que possa levá-la a ter acesso efetivo ao código auditivo para usar a audição no desenvolvimento da linguagem.

\footnotetext{
${ }^{40}$ Disponível em: <http://www.tele-centros.org>. Acesso em: 3 set. 2008.

${ }^{41}$ Crianças que nascem surdas ou adquirem a surdez em tenra idade, antes da aquisição de uma língua.
} 
No caso de crianças surdas totais ou profundas, uma opção é o implante coclear multicanal, onde a prótese auditiva (interna) é colocada na cabeça da criança através de uma operação cirúrgica, com indicação para tal, que requer alguns dias de hospitalização. Esta prótese emite sinais elétricos destinados a ativar o nervo coclear e gera sensações sobre as quais a criança surda congênita pode construir percepções e discriminações auditivas. Para as crianças surdas pré-linguais, os implantes permitem o desenvolvimento de uma percepção auditiva que poderá ser também utilizada na construção da linguagem oral. O processo do implante coclear implica numa modificação das relações da criança surda com o mundo externo e com seu próprio corpo (VIROLE, 2003). Este processo também implica numa modificação profunda das relações familiares assim como em transformações das representações mentais e nas expectativas imaginárias.

O implante não é unicamente a colocação de uma prótese interna. Quando bem preparado, psicologicamente, também é um ato simbólico benéfico de reparação para os pais. Pela reação ao barulho e a construção do ambiente sonoro, o implante leva geralmente a uma melhora importante da naturalidade das interações familiares e contribui assim ao bom desenvolvimento psicológico da criança surda e de seus irmãos. (VIROLE, 2003, p. 115)

Com relação ao atendimento hospitalar em saúde auditiva, a Portaria MS/GM no 1.278 de 1999 estabelece normas e critérios para a realização da cirurgia de implante coclear. "A Portaria n. ${ }^{0}$ 584, de 21 de outubro de 1999, inclui as próteses para implante coclear na Tabela de Órteses, Próteses e Materiais Especiais e na Tabela de Compatibilidade do Sistema de Informações Hospitalares do Sistema Único de Saúde (SIH/SUS)." (BRASIL, 2008a, p. 18).

A criança surda congênita pode apresentar problemas relativos à memória, atenção e dedução, entre outros. Para dominar a expressão escrita, as crianças surdas 
profundas congênitas devem desenvolver reais competências linguísticas e adquirir a língua e seu uso. Estas crianças são confrontadas a uma língua oral da qual elas só compreendem partes sem perceberem a forma completa (ROMAND, 2003a).

\subsubsection{A Língua Brasileira de Sinais (LIBRAS)}

A Língua Brasileira de Sinais (LIBRAS) foi desenvolvida a partir da língua de sinais francesa, e é a língua natural dos surdos de uso abrangente. As línguas de sinais não são universais, cada país possui a sua, apresentando dialetos até mesmo dentro de uma mesma cidade ou bairro. A LIBRAS possui estrutura gramatical própria, sendo uma língua visuo-gestual que necessita de um intérprete para a comunicação com outra pessoa que desconheça a LIBRAS e o seu uso "dificulta a aquisição do Português." (LÚCIO, 2003, p. 32).

Língua de sinais se refere a sinais gestuais que podem expressar letras, palavras ou frases inteiras e nos quais se deve considerar como parâmetros a localização, forma, orientação e movimentos da mão, bem como o da expressão facial ${ }^{42}$. A linguagem é um sistema organizado, um instrumento codificado que pode adotar diferentes materialidades: a palavra, a escrita e os gestos através da LIBRAS.

A surdez é uma experiência visual que traz ao "sujeito surdo a possibilidade de constituir sua subjetividade por meio de experiências cognitivo-linguísticas diversas,

${ }^{42}$ Disponível em: <http://www.dicionariolibras.com.br/website/>. Acesso em: 14 dez. 2009. 
mediadas por formas de comunicação simbólica alternativas, que encontram na língua de sinais seu principal meio de concretização." (MARTINS, S. L., 2008, p. 20).

A LIBRAS contribui para o desenvolvimento das competências comunicacionais e linguísticas, "mas apresenta um problema: esta língua funciona de acordo com uma estrutura e uma sintaxe totalmente independentes da língua oral e ela não se escreve." (ROMAND, 2003b, p. 14). Cerca de 95\% dos pais de crianças surdas no Brasil são ouvintes, sendo que a maioria desses pais só se exprime na língua do Português falado, são raros os que praticam fluentemente a LIBRAS, e muitas crianças surdas no Brasil crescem neste ambiente, acarretando uma difícil comunicação entre os pais e os filhos.

A criança surda profunda de nascimento está confrontada a uma língua oral a qual ela não percebe a forma concluída. Os indícios que a atingem permanecem incompletos e lacunares, muitos elementos Ihe escapam. A linguagem é apreendida sob uma forma truncada, com zonas de confusão o que não oferece nenhuma segurança à criança. (ROMAND, 2003b, p. 16)

A criança com deficiência auditiva muitas vezes não fala porque não ouve, mas pode emitir sons. Embora existam próteses cada vez mais sofisticadas, um surdo profundo ou severo não consegue percepcionar, somente pela audição, a língua falada diariamente. Ela precisa recorrer à leitura labial e, contrariamente ao que muitos podem pensar, é um trabalho impreciso, difícil e muito cansativo. Existe a ilusão de se pensar que se lê nos lábios como se lê num livro, pois alguns surdos parecem ler perfeitamente nos lábios. Entretanto, diferentemente da leitura de palavras escritas num livro, o movimento dos lábios traz informações confusas e truncadas para a pessoa surda que utiliza unicamente este canal perceptivo. Segundo Lúcio (2003), o Cued Speech ou a linguagem falada complementada foi então criado para suprimir 
essas confusões e essa imprecisão própria à leitura labial. O Cued Speech é um recurso utilizado em outros países, como a França, pela criança com surdez profunda e severa. É um sistema que complementa a leitura labial levando as informações que faltam, através da percepção visual. O Cued Speech corresponde a um código manual realizado perto da face que vai ajudar a criança surda a suprimir todas as ambiguidades da leitura labial, pois dissipa os sósias labiais graças às chaves, complementos manuais $^{43}$ que se sincronizam com a palavra (ROMAND, 2003b; LÚCIO, 2003).

De modo confortável e preciso, essa criança terá acesso direto à Língua Portuguesa. Em muitos países do mundo, estudos têm mostrado que crianças surdas habituadas ao Cued Speech têm um nível de língua oral equivalente ao de ouvintes. Se o Cued Speech está sendo conhecido e reconhecido mundialmente, é importante investir também no nosso país onde a formação é muito escassa. (LUCIO, 2003b, p. 25)

Como as línguas de sinais utilizadas pelos surdos não tem uma forma de escrita aceita universalmente foi criado o sistema sign writing (SUTTON, 2000) que expressa os movimentos, as formas das mãos, as marcas não manuais e os pontos de articulação. Criado pela americana Valerie Sutton ${ }^{44}$ em 1974 na Dinamarca, sendo similar a uma pictografia, permite registrar graficamente qualquer movimento seja de humanos ou de qualquer outro animal. Fazendo-se uma analogia, existem: as "escritas sonoras como a escrita da nossa língua, a escrita tátil relativa ao Braille e a escrita visual relativa ao sign writing." (SUTTON, 2000, p. 6).

\footnotetext{
${ }^{43}$ A utilização do sinal não deve fazer desaparecer os elementos vocais e a linguagem oral.

${ }^{44}$ Valerie Sutton, do Center for Sutton Movement Writing, é uma especialista em sistema de escrita de movimentos. Os dois principais sistemas de representação de movimentos que ela desenvolveu são o Dance Writing (um sistema para representação de coreografias, aplicado ao ballet e à dança em geral) e o Sign Writing (um sistema para representação de gestos, aplicado às línguas de sinais) (SUTTON, 2000).
} 


\subsubsection{A deficiência visual}

Segundo o artigo $5\left(\S 1^{\circ}\right)$ do Decreto Federal $n^{0} 5.296$ (BRASIL, 2004), a deficiência

visual é definida como:

cegueira, na qual a acuidade ${ }^{45}$ visual é igual ou menor que 0,05 no melhor olho, com a melhor correção óptica; a baixa visão, que significa acuidade visual entre 0,3 e 0,05 no melhor olho, com a melhor correção óptica; os casos nos quais a somatória da medida do campo visual em ambos os olhos for igual ou menor que $60^{\circ}$; ou a ocorrência simultânea de quaisquer das condições anteriores.

A deficiência visual compreende uma "situação irreversível da função visual, mesmo após tratamentos clínicos e ou cirúrgicos pertinentes e uso de óculos convencionais." (BRASIL, 2008a, p. 15). A seguir são apresentadas algumas definições pertinentes a deficiência visual encontradas em BIREME (s/d, grifo nosso):

Cegueira: é definida como a incapacidade de enxergar ou perda (ausência) da percepção dos estímulos visuais. Condição esta, que pode ser o resultado de doenças oculares, doenças do nervo óptico, doenças do quiasma óptico ou doenças cerebrais que afetam as vias visuais ${ }^{46}$ ou lobo occipital ${ }^{47}$.

Doenças do nervo óptico: são definidas como condições que produzem lesão ou disfunção do segundo nervo craniano ou nervo óptico, que geralmente é considerado um componente do sistema nervoso central. Danos às fibras do nervo óptico podem ocorrer na retina ${ }^{48}$ ou próximo a sua origem, no disco óptico ou no nervo, quiasma óptico, trato óptico ou núcleos geniculados laterais. As manifestações clínicas podem incluir diminuição da acuidade visual e sensibilidade a contraste, visão de cores prejudicada e defeito pupilar aferente. São classificadas em: Transtornos do Nervo Óptico, Doenças do II Nervo Craniano, Doenças do II Par Craniano, Síndrome de Foster-Kennedy, Transtornos do Disco Óptico, Neuropatia Óptica e Doenças do Segundo Nervo Craniano.

Baixa visão ou visão subnormal ou visão reduzida: é uma visão considerada inferior à visão normal, representada por padrões aceitos de acuidade, campo visual ou motilidade. A baixa visão geralmente se refere a transtornos visuais causados por doenças que não podem ser corrigidas por refração (ex., degeneração macular; retinite pigmentosa; retinopatia diabética, etc.).

Glaucoma: é uma doença ocular, ocorrendo em várias formas, tendo como principais características um aumento prolongado ou instável da pressão intraocular, na qual o olho não pode permanecer sem danos à sua estrutura ou prejuízo de suas funções. As consequências da

\footnotetext{
${ }^{45}$ Acuidade ou nitidez da visão: especialmente da visão das formas, que depende principalmente da nitidez do foco da retina.

${ }^{46}$ Grupo de corpos celulares e fibras nervosas que conduzem impulsos dos olhos para o córtex cerebral.

${ }^{47}$ Parte posterior do hemisfério cerebral.

${ }^{48}$ Membrana de tecido nervoso (composta por dez camadas e encontrada no olho) que se continua no nervo óptico. Recebe imagens de objetos externos e transmite essas informações ao cérebro em forma de impulsos visuais nervosos.
} 
pressão elevada podem se manifestar com uma variedade de sintomas, dependendo do tipo e severidade, como excavação do disco óptico, endurecimento do globo ocular, anestesia corneana, acuidade visual reduzida, visão de halos coloridos ao redor da luz, adaptação ao escuro prejudicada, defeitos do campo visual e cefaléias.

Catarata ou pseudoafaquia ou opacidade do cristalino: é uma opacidade, parcial ou completa, de um ou ambos os olhos, sobre ou dentro do cristalino ou sua cápsula, especialmente uma opacidade que prejudica a visão ou causa cegueira. Os muitos tipos de catarata são classificados pela sua morfologia (tamanho, forma, localização) ou etiologia (causa e época de ocorrência).

Como causadores da deficiência visual no período gestacional (transplacentárias) encontram-se as anomalias de desenvolvimento, infecções e doenças como rubéola, toxoplasmose e sífilis, além do uso de substâncias tóxicas pela gestante, e tumores. A deficiência visual pode ocorrer no nascimento devido a prematuridade, erros inatos do metabolismo, distrofias e traumas. Após o nascimento a deficiência visual pode ocorrer devido a ferimentos, traumatismos, perfurações ou vazamentos nos olhos. Segundo Santos (2004, p. 20),

a cegueira denota a incapacidade dos seres vivos de captar visualmente as imagens projetadas dos objetos circundantes. Em sentido literal, ela é signo de incapacidade visual, mas de um ponto de vista ontológico e humano, ela pode constituir-se como sinal distintivo da capacidade que certas criaturas cegas têm de interagir com o mundo de forma diferente, admirável e talvez mais criativa que aqueles possuidores de visão.

Considera-se que $80 \%$ das informações perceptivas das pessoas ocorrem através da visão (OMS, 1982). Segundo Lopes (2005, p. 85), a "visão é o sentido que fornece informações mais completas do mundo ao redor, sendo responsável por nossa percepção do espaço." Como a pessoa com deficiência visual não tem acesso a visão e consequentemente a comunicação não verbal, tão significativa para a comunicação interpessoal, se faz necessária a exploração dos sentidos remanescentes, ou seja, o tato, o paladar, o olfato e a audição, para melhorar a qualidade da comunicação (STEFANELLI, 1993). 
Ocahita e Rosa (1995) consideram de grande importância a percepção tátil para a pessoa com deficiência visual, pois possibilita o contato e o conhecimento dos objetos, sendo que permite a leitura através do sistema Braille (item 2.2.3.1 a seguir). Para a orientação e mobilidade, a audição é um dos sentidos mais importantes, pois possibilita estabelecer as relações espaciais. Outro sentido importante para a pessoa com deficiência visual, é o vestibular ou labiríntico, pois fornece informações sobre a posição vertical do corpo e dos componentes rotatórios e lineares dos movimentos. O olfato é um sentido que pode fornecer indícios para a orientação e localização de ambientes, como a cozinha, os banheiros e outros locais. A cinestesia é a sensibilidade para perceber os movimentos musculares ou das articulações. Esta percepção nos torna consciente da posição e do movimento do corpo, quando se eleva o braço, por exemplo; ou quando se sobe ou se desce um plano inclinado. A memória muscular (repetição de movimentos em uma sequencia fixa) "é uma das funções do sentido cinestésico, sendo utilizada para subir ou descer degraus ou para trajetos curtos, sem a necessidade de contar os passos." (MEC/SEESP, 2003, p. 62).

Batista (2005) descreve a importância dos processos cognitivos, especialmente linguagem e pensamento, na elaboração e integração das informações provenientes dos sentidos, tanto no ensino de conceitos para alunos com deficiência visual, como para alunos videntes. A especificidade fica por conta da elaboração de recursos auxiliares na compreensão de diferentes conceitos e sistemas de conceitos, sendo o tato, muito importante, embora não como substituto direto da visão, e a utilização da representação, como base para o planejamento de recursos didáticos. 
Ocahita e Rosa (1995) apresentam o sistema háptico ou tato ativo como o sistema sensorial mais importante para o conhecimento do mundo pela pessoa com deficiência visual, sendo necessário diferenciar o tato passivo (forma não intencional) do tato ativo, aonde a informação é buscada de forma intencional pelo indivíduo que toca. No tato ativo encontram-se envolvidos não somente os receptores da pele e os tecidos subjacentes (como ocorre no tato passivo), mas também a excitação correspondente aos receptores dos músculos e dos tendões, de maneira que o sistema perceptivo háptico capta a informação articulatória, motora e de equilíbrio. 0 sentido do tato não se encontra em uma região específica, pois

todas as regiões do organismo possuem mecanorreceptores responsáveis pela percepção do toque, termoceptores responsáveis pela percepção do frio e do calor e terminações nervosas livres responsáveis pela percepção da dor que muda apenas de intensidade. Os termoceptores reagem de acordo com a temperatura externa, ou seja, os receptores para o frio são estimulados quando a temperatura externa é fria e os receptores para o calor são estimulados quando a temperatura externa é quente. Disponível em:

<http://www.brasilescola.com/oscincosentidos/tato.htm>. Acesso em: 16 abr. 2009.

A construção da linguagem e o desenvolvimento global ocorrem na relação socioafetiva, por isso a criança necessita relacionar-se com outras de sua idade, videntes ou não, de modo a poder identificar-se, construir sua imagem corporal e testar suas hipóteses perceptivas, simbólicas e pré-lógicas. Desse modo, o convívio com outras crianças de sua faixa etária vai contribuir para a aquisição de conceitos e a construção da linguagem (BRUNO, 1993; OLIVEIRA; KARA-JOSÉ; ARIETA, 2001). Existem elementos importantes para o desenvolvimento e a construção da noção de espaço da criança com deficiência visual,

como o vínculo materno, a noção de objeto permanente (percepção de que os objetos existem), noção de casualidade (percepção de que suas ações tem consequências, como o choro aproxima sua mãe), movimento corporal intencional (noção para onde vai), desenvolvimento pessoal e autonomia. (SENA, 2007, p. 64) 
A importância da visão é tamanha que "não raramente, é solicitada pelo cérebro para reforçar ou até substituir sensações que seriam normalmente originadas em outros sentidos [...]" (LOPES, 2005, p. 85). A criança com deficiência visual vivencia o mundo por meio dos sentidos remanescentes e não contando com a percepção visual de seu ambiente e orientação no espaço, ela deve ser encorajada pelo toque, pela voz de pessoas e por brinquedos móveis e sonoros que the permitam apoio, segurança e organização postural. O contato direto com os objetos, para explorá-los tatilmente, percebendo suas formas, tamanhos, texturas e outras qualidades, favorece a percepção global, condição necessária para inclusão educacional da criança (RODRIGUES, 2002).

\subsubsection{O Sistema Braille}

O Braille é um sistema de leitura tátil e escrita para pessoa com deficiência visual, que consta da combinação de 6 pontos em relevo, dispostos em duas colunas de 3 pontos. O espaço ocupado pelos 6 pontos forma o que se convencionou chamar cela Braille (Figura 7).

Para facilitar a sua identificação, os pontos são numerados da seguinte forma: do alto para baixo, coluna da esquerda: pontos 1, 2, 3; do alto para baixo, coluna da direita: pontos 4, 5, 6. As diferentes combinações desses 6 pontos permitem a formação de 63 símbolos Braille.

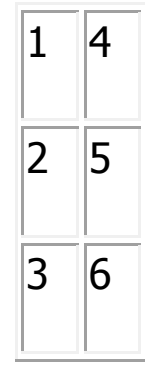

Figura 7 - Cela Braille. 
No ocidente, são utilizados 26 sinais para o alfabeto e 10 para os sinais internacionais de pontuação. Outros 27 sinais são ainda destinados às necessidades específicas de cada língua (letras acentuadas, por exemplo) e para abreviaturas. ${ }^{49} \mathrm{O}$ sistema Braille é de extraordinária universalidade, pois pode exprimir as diferentes línguas e escritas mundiais. Sua principal vantagem reside no fato das pessoas com deficiência visual e coordenação motora nos membros superiores poderem facilmente escrever por esse sistema, com o auxílio da reglete ${ }^{50}$ e do punção (Fig. 8).

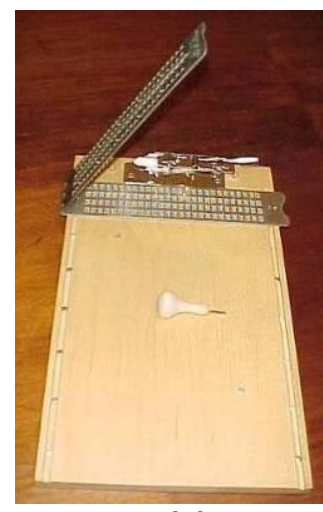

(a)

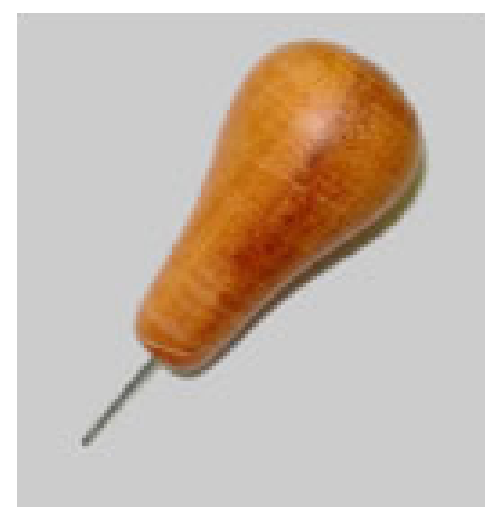

(b)

Exceto pela fadiga, a escrita Braille pode tornar-se tão automática para o cego quanto a escrita com lápis para a pessoa de visão normal. ${ }^{51}$

Figura 8 - Reglete em alumínio cromado fixado a uma prancha de madeira (a) e punção em madeira (b). Fonte: Disponível em: <http://intervox.nce.ufrj.br> (a); <http://www.bengalalegal.com.br> (b). Acessos em: 11 abr. 2009.

Atualmente, existem máquinas de escrever adaptadas para a confecção de textos em Braille e computadores que conseguem transformar um simples comando de voz em um texto adaptado a esse mesmo código (recursos de tecnologia assistiva). "O sistema Braille abriu um campo de possibilidades que rompe as limitações impostas

${ }^{49}$ Disponível em: <http://www.braille.com.br/obraille.htm>. Acesso em: 11 abr. 2009.

${ }^{50}$ As regletes, modelos de mesa ou de bolso, consistem essencialmente de duas placas de metal ou plástico, fixas de um lado com dobradiças, de modo a permitir a introdução do papel. A placa superior funciona como a primitiva régua e possui as janelas correspondentes às celas Braille. Diretamente sob cada janela, a placa inferior possui, em baixo relevo, a configuração de cela Braille. Ponto por ponto, as pessoas cegas, com o punção, formam o símbolo Braille correspondente às letras, números ou abreviaturas desejadas. Disponível em: <http://www.sac.org.br/APR_BR2.htm>. Acesso em: 11 abr. 2009.

51 Porém, no caso de crianças este processo não é tão fácil e automático. Disponível em: <http://www.bengalalegal.com/sbraille.php>. Acesso em: 11 abr. 2009. 
pelo corpo. Mesmo sem a visão do mundo material, os cegos podem produzir conhecimento e realizar projetos. ${ }^{\prime 52}$

O mapa tátil (Figura 9) é um dispositivo que permite à pessoa com deficiência visual a percepção tátil de informações relevantes de ambientes, processos e organogramas entre outras aplicações, pois as mãos e os dedos humanos ${ }^{53}$ se diferenciam por suas características neuromnemônicas (relativas à memória). Quando uma pessoa explora um mapa tátil, conexões cerebrais são ativadas, formando uma informação concreta na memória. ${ }^{54}$

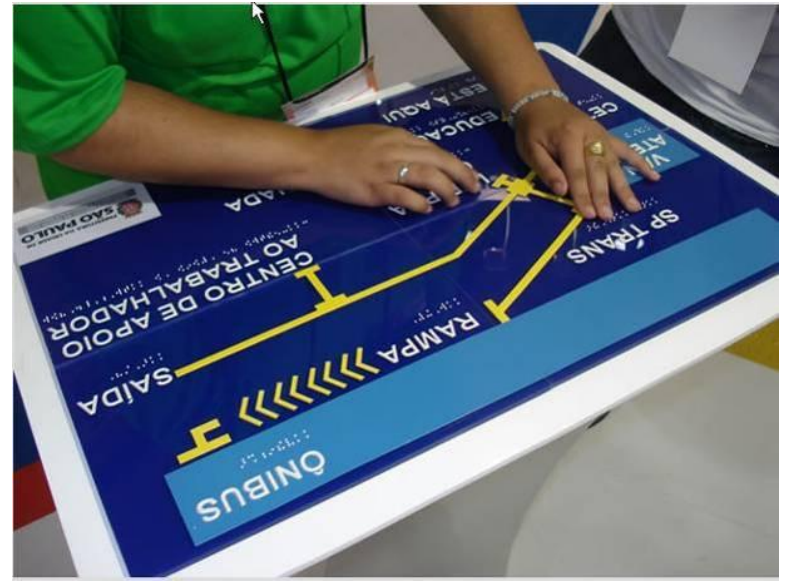

Figura 9 - Mapa tátil. Fonte: Disponível em: $<$ http://www.arcomodular.com.br>. Acesso em: 16 abr. 2009.
A cartografia tátil pode se apropriar das variáveis visuais adaptando toda a imagem para que seja percebida pelo tato, aonde a cor é a única variável que não é percebida sendo substituída por diferentes texturas (SENA, 2007).

52 Disponível em: <http://www.brasilescola.com/portugues/braile.htm>. Acesso em: 16 abr. 2009.

${ }^{53}$ A pele é nosso maior órgão sensorial. Ela recebe, a todo instante, diversos tipos de estímulos que são enviados ao encéfalo. Há uma grande área do córtex cerebral responsável pela coordenação das funções sensoriais da pele, em particular das mãos e dos lábios. Muitos dos receptores sensoriais da pele são terminações nervosas livres. Algumas delas detectam dor, outras detectam frio e outras, calor. Disponível em: <http://www.webciencia.com/11_32sensor.htm>. Acesso em: 26 abr. 2009.

${ }^{54}$ Disponível em: <http://www.arcomodular.com.br/portugues/acessibilidade-braille-piso-mapa-tatil>. Acesso em: 16 abr. 2009. 


\subsubsection{A deficiência intelectual}

Ainda não há um consenso entre os órgãos brasileiros na utilização dos termos deficiência intelectual e deficiência mental (ver item 2.2). Segundo Sassaki (2005b), a expressão deficiência intelectual foi oficialmente utilizada em 1995, quando a ONU (juntamente com The National Institute of Child Health and Human Development, The Joseph P. Kennedy, Jr. Foundation, e The 1995 Special Olympics World Games) realizou em Nova Iorque o simpósio chamado Intellectual Disability: Programs, Policies, and Planning for the Future (Deficiência Intelectual: Programas, Políticas e Planejamento para o Futuro). Segundo a Associação de Pais e Amigos dos Excepcionais (APAE), a alteração do termo deficiência mental por deficiência intelectual ocorreu no sentido de diferenciar mais claramente a deficiência mental da doença mental (quadros psiquiátricos não necessariamente associados a déficit intelectual). A Organização Pan-Americana da Saúde e a Organização Mundial da Saúde realizaram um evento em Montreal, Canadá, em 2004, que aprovou o documento Declaração de Montreal sobre Deficiência Intelectual. Porém, no artigo 5 $\left(\S 1^{\circ}\right)$ do Decreto Federal $n^{0} 5.296$ (BRASIL, 2004) a deficiência intelectual é chamada de mental, sendo definida como:

funcionamento intelectual significativamente inferior à média, com manifestação antes dos dezoito anos e limitações associadas a duas ou mais áreas de habilidades adaptativas, tais como:

1. comunicação;

2. cuidado pessoal;

3. habilidades sociais;

4. utilização dos recursos da comunidade;

5. saúde e segurança;

6. habilidades acadêmicas;

7. lazer; e

8. trabalho. 
De acordo com a Associação Americana de Deficiência Mental (AAMD), na deficiência intelectual observa-se uma substancial limitação da capacidade de aprendizagem do indivíduo e de suas habilidades para a vida diária. A pessoa com esta deficiência "caracteriza-se por apresentar um déficit na inteligência conceitual, prática e social." (BRASIL, 2008a, p. 19).

A deficiência intelectual pode ser caracterizada por um quociente de inteligência (QI) inferior a 70, média apresentada pela população, conforme padronizado em testes psicométricos ou por uma defasagem cognitiva em relação às respostas esperadas para a idade e realidade sociocultural, segundo provas, roteiros e escalas, baseados nas teorias psicogenéticas. ${ }^{55}$ Apesar dos avanços da medicina, muitas vezes não é possível estabelecer com clareza a causa desta deficiência, mas três tipos de fatores podem ser apontados: os pré-natais, os perinatais (que agem do início do trabalho de parto até o $30^{\circ}$ dia de vida do bebê) e os pós-natais. São exemplos de fatores pré-natais (que incidem desde a concepção do bebê até o início do trabalho de parto) a desnutrição materna, a má assistência médica à gestante, a presença de doenças infecciosas como sífilis, rubéola e toxoplasmose na mãe, efeitos colaterais de medicamentos teratogênicos (ou seja, que afetam a estrutura e o desenvolvimento da anatomia do bebê), alterações cromossômicas, como a síndrome de Martin Bell e a síndrome de Down, e as alterações no metabolismo. Entre os fatores perinatais (que agem do início do trabalho de parto até o $30^{\circ}$ dia de vida do bebê) da deficiência mental estão os traumas de parto, a oxigenação cerebral insuficiente, a prematuridade e a incompatibilidade sanguínea entre mãe e filho

${ }^{55}$ Disponível em: <http://www.acadef.com.br/saudexdeficiencia.html>. Acesso em: 10 jul. 2010. 
devido à presença do fator RH em apenas um dos dois. Entre os fatores pós-natais da deficiência intelectual estão a desnutrição, a desidratação grave, a carência de estimulação global e as infecções como as meningoencefalites e o sarampo, bem como o envenenamento por produtos químicos como chumbo e mercúrio, e a neurocisticircose (quando a larva da taenia solium, popularmente chamada de solitária, aloja-se no cérebro $)^{56}$.

O autismo não é considerado uma deficiência intelectual, e sim um transtorno de desenvolvimento. Os sintomas do autismo variam muito, dependendo do caso, o que fez com que os especialistas concordassem em usar certos critérios de comportamento para fazer o diagnóstico. Estes critérios foram descritos em trabalhos de referência como o Manual de Diagnóstico e Estatística (DSM-IV) da Associação Americana de Psiquiatria e a Classificação Internacional de Doenças (CID-10) publicado pela OMS. As pessoas com autismo apresentam problemas na interação social, dificuldade em desenvolver relações de companheirismo apropriadas para sua idade e pouco uso de comportamentos não verbais, como contato ocular, expressão facial, postura corporal e gestos que facilitam a comunicação.

A pessoa com deficiência intelectual não tem alterada a percepção de si mesma e da realidade e é, portanto, capaz de decidir o que é melhor para ela. Quando a percepção encontra-se alterada, a condição é denominada doença mental, que corresponde a um quadro diferente.

${ }^{56}$ Disponível em: <http://www.tele-centros.org>. Acesso em: 03 set. 2008. 


\subsubsection{A deficiência múltipla}

Segundo o artigo $5\left(\S 1^{\circ}\right)$ do Decreto Federal $n^{0} 5.296$ (BRASIL, 2004), a deficiência múltipla é definida como a associação de duas ou mais deficiências.

A deficiência múltipla "é a associação, no mesmo indivíduo, de duas ou mais deficiências primárias mental, visual, auditiva e motora, com comprometimentos que acarretam atrasos no desenvolvimento global e na capacidade adaptativa." (BRASIL, 2008a, p. 19). Crianças com deficiência múltipla geralmente devem ter acompanhamento multidisciplinar de longa duração. A deficiência múltipla tem importância crescente na população infantil cega ou com baixa visão e é mais prevalente nos países em desenvolvimento (WORLD HEALTH ORGANIZATION, 1992).

A múltipla deficiência é uma situação grave e, sua presença na população geral é menor, em termos numéricos. A deficiência múltipla apresenta possibilidades bastante amplas de combinações, como as pessoas que têm deficiência intelectual e física, ou a surdocegueira. Desde o nascimento de uma criança com deficiência múltipla é importante que a família seja orientada a manter contato com a criança por meio dos sentidos que não foram lesados, para estimular o resíduo auditivo e, principalmente, o resíduo visual, se houver. ${ }^{57}$

\footnotetext{
${ }^{57}$ Disponível em: <http://www.tele-centros.org>. Acesso em: 03 set. 2008.
} 
Nascimento (2006, p. 3) considera uma criança com múltipla deficiência sensorial

aquela que apresenta a deficiência visual e auditiva associadas a outras condições de comportamento e comprometimentos, sejam eles na área física, intelectual ou emocional, e dificuldades de aprendizagem. Quase sempre, os canais de visão e audição não são os únicos afetados, mas também outros sistemas, como os sistemas tátil (toque), vestibular (equilíbrio), proprioceptivo (posição corporal), olfativo (aromas e odores) ou gustativo (sabor)

Crianças que apresentam graves comprometimentos múltiplos e condições médicas frágeis:

1. apresentam mais dificuldades no entendimento das rotinas diárias, gestos ou outras habilidades de comunicação;

2. demonstram dificuldades acentuadas no reconhecimento das pessoas significativas no seu ambiente;

3. realizam movimentos corporais sem propósito;

4. apresentam resposta mínima a barulho, movimento, toque, odores e/ou outros estímulos. (NASCIMENTO, 2006, p. 3)

Segundo a Associação Educacional para Múltipla Deficiência (AHIMSA, 2002), a terminologia surdocegueira está sendo usada no lugar da palavra surdocego em defesa de que a condição imposta pela surdocegueira não é simplesmente a somatória de duas deficiências e sim uma dificuldade com características únicas que deve ser tratada, de modo especial, pelas dificuldades que estas pessoas apresentam para contatar o mundo e conseguir se inserir na sociedade.

A pessoa com surdocegueira não pode ser comparada com um surdo ou com um cego, que utilizam seus sentidos de forma complementar, pois a pessoa com deficiência visual utiliza mais a sua audição e a pessoa surda a sua visão. No caso da surdocegueira, esta complementação não acontece, é outra deficiência. É por esta razão que esta deficiência é escrita com uma só palavra, surdocegueira. ${ }^{58}$

${ }^{58}$ Disponível em: <http://www.tele-centros.org>. Acesso em: 03 set. 2008. 
Segundo Martins, S. L. (2008, p. 20), a surdocegueira

consiste no comprometimento, em diferentes graus, da audição e da visão, sentidos considerados pela literatura como receptores das informações à distância. Os efeitos da deficiência auditiva e visual no desenvolvimento infantil estão relacionados ao grau e ao período de surgimento de cada um dos comprometimentos. É uma combinação de deficiência visual e auditiva, reconhecida como uma única condição de incapacidade e de limite.

A falta das percepções limita a criança surdocega na antecipação do que vai ocorrer a sua volta.

A entrada da mãe no quarto do bebê, por exemplo, pode não significar tranquilidade, comida ou carinho, mas pode promover instabilidade e insegurança. Sua dificuldade na antecipação dos fatos faz com que cada experiência possa parecer nova e assustadora, como ser transportada de um lugar para o outro, sentir na boca a introdução de um alimento novo ou ser tocado repentinamente. (NASCIMENTO, 2006, p. 3)

A surdocegueira é uma deficiência única, com grave perda visual e auditiva combinadas e não há necessariamente uma perda total dos sentidos da visão e da audição. Essa condição leva a pessoa com surdocegueira a ter necessidade de formas específicas de comunicação, para ter acesso a educação, lazer, trabalho e vida social. Os tipos de surdocegueira são:

- Cegueira congênita e surdez adquirida;

- Surdez congênita e cegueira adquirida;

- Cegueira e surdez congênita;

- Cegueira e surdez adquirida;

- Baixa visão com surdez congênita e

- Baixa visão com surdez adquirida (AHIMSA, 2002).

As implicações das limitações visuais e auditivas nas interações podem ser minimizadas com a introdução do toque, porém muitas crianças podem não gostar de serem tocadas por não conseguirem identificar a origem e o significado do toque. 
Nesses casos, a utilização de objetos e/ou toques familiares à criança poderão ser usados. $^{59}$ As crianças surdocegas podem apresentar perfis distintos, em função de vários aspectos:

- características da interação que mantém com o meio, decorrentes do comprometimento dos sentidos de distância (audição e visão) e da disponibilidade do meio para interagir com elas utilizando formas adaptadas às suas necessidades;

- grau de perda auditiva;

- grau de perda visual;

- outros comprometimentos associados, entre eles o motor e o neurológico;

- período de aquisição da surdocegueira. (NASCIMENTO, 2006, p. 4)

Em relação à deficiência múltipla, "existem poucos estudos no Brasil que apresentam um perfil mais abrangente dos agentes etiológicos envolvidos na sua determinação." (BRASIL, 2008a, p. 19). As causas da surdocegueira podem ser: acidentes graves; síndrome de Usher (as manifestações clínicas desta síndrome de origem genética incluem a surdez, que se manifesta logo no início da vida e a perda visual que ocorre, geralmente, mais tarde); surdocegueira congênita, resultante de doenças como a rubéola ou de nascimentos prematuros, dentre outros. ${ }^{60}$

Os registros sobre a educação da criança surdocega relatam nomes de pessoas que conseguiram aprender a ler e a escrever, o mais conhecido deles é o de Helen Keller (1880-1968) surdocega desde os 18 meses e educada a partir dos sete anos pela sua professora particular Anne Mansfield Sullivan (1866-1936), que na infância estudou numa instituição para cegos, pois a sua visão foi afetada por

\footnotetext{
${ }^{59} \mathrm{Na}$ ausência desses cuidados, a criança surdocega poderá apresentar comportamentos inadequados indesejáveis socialmente como movimentar aleatoriamente as mãos e/ou corpo, emitir sons, direcionar o olhar compulsivamente para luz, provocar sons em locais com vibrações mais intensas e tatilmente perceptíveis, balançar, bater os pés, apertar os olhos, agredir-se, entre outros. Estes comportamentos reativos são geralmente recursos utilizados pela criança para substituir a falta dos estímulos adequados e dão aos educadores informações importantes quando interpretados numa perspectiva comunicativa. [...] O processo de aprendizagem da via de comunicação exige atendimento especializado com estimulação específica e individualizada. (NASCIMENTO, 2006).

60 Disponível em: <http://www.tele-centros.org>. Acesso em: 03 set. 2008.
} 
tracoma ${ }^{61}$, sendo parcialmente restaurada após uma série de operações nos olhos. Helen foi uma reconhecida escritora com 14 livros publicados (KELLER, 2008).

\subsubsection{Os recursos de comunicação}

Segundo Amaral (2002), a história da educação da pessoa com surdocegueira sempre esteve próxima da educação da criança surda, sendo que o método gestual, desenvolvido na França, e o oral, na Alemanha, sofreram adaptações para a sua utilização pelas pessoas com surdocegueira. Foi acrescentada a percepção tátil ou a alteração do espaço de sinalização segundo o campo visual da pessoa, possibilitando a recepção ou expressão da informação.

Os recursos de comunicação usados pelas crianças surdocegas são vários, e entre esses o tato constitui a via mais promissora no estabelecimento das interações com o ambiente. Os recursos de comunicação receptiva mais usados pelas pessoas com surdocegueira são: a língua de sinais, seguida dos gestos e insinuações táteis e depois o alfabeto digitado na mão. Em relação aos recursos de comunicação expressiva, a língua de sinais é a mais utilizada, seguida dos gestos naturais e depois a linguagem oral com combinação de outro método. Alguns surdocegos não possuem sistema de comunicação expressiva, sendo que "a língua de sinais constitui

${ }^{61}$ Também chamada de conjuntivite granular ou granulosa ou tracomatosa; e de oftalmia egípcia. Infecção crônica da conjuntiva e da córnea causada por chlamydia trachomatis (BIREME s/d). 
o recurso de comunicação mais promissor para as pessoas surdocegas." (NASCIMENTO, 2006, p. 6).

Segundo Nascimento (2006), o surdocego pode ser classificado em:

- Surdocego pré-linguístico: crianças que nascem surdacegas ou adquirem a surdocegueira em tenra idade, antes da aquisição de uma língua. A criança surdacega pré-linguística apresenta graves perdas visuais e auditivas, não adquire uma imagem real do mundo em que vive; provavelmente não sabe o que tem ao seu redor, o que se passa e nem se quer sabe que faz parte do mundo. Sua vida pode ser um caos, se não houver intervenção ${ }^{62}$. Os recursos de comunicação do surdocego pré-linguístico são os objetos de referência ${ }^{63}$, as pistas ${ }^{64}$, o caderno de comunicação, os desenhos, os gestos naturais ${ }^{65}$, os gestos indicativos, os sinais adaptados, os movimentos corporais, os gestos contextuais e a expressão facial.

- Surdocego pós-linguístico: crianças, jovens ou adultos que apresentam uma deficiência sensorial primária (auditiva ou visual) e adquirem a outra, após a aquisição de uma língua (Português ou língua de sinais), como também ocorre a aquisição da surdocegueira sem outros antecedentes. Os recursos de comunicação

\footnotetext{
${ }^{62}$ Faz-se necessário proporcionar a informação de forma que algo tenha sentido para a pessoa surdocega. Sem intervenção é provável que seu mundo seja seu próprio corpo, onde nada existe fora de si mesmo, não havendo razão para explorar e comunicar-se.

63 São objetos utilizados diariamente em diferentes atividades, os quais são apresentados às crianças como pistas, indicando o que vai acontecer a seguir ou o que ela irá fazer.

64 As pistas oferecidas poderão ser de imagens, as quais podem incluir os contornos de objetos, os desenhos e as fotografias.

${ }^{65}$ São expressões corporais, as quais podem incluir gestos faciais, corporais e manuais. Em geral, a utilização dos gestos naturais exige alguma visão, o que restringe seu uso por crianças cegas.
} 
do surdocegos pós-linguístico são a língua de sinais tátil ${ }^{66}$, a língua de sinais em campo reduzido $^{67}$, o alfabeto manual tátil ${ }^{68}$, o sistema Braille tátil ou manual ${ }^{69}$, a escrita na palma da mão ${ }^{70}$, as tablitas alfabéticas $^{71}$, a leitura labial ${ }^{72}$, a escrita em tinta $^{73}$, os materiais técnicos alfabéticos com retransmissão em Braille ${ }^{74}$, o sistema Malossi $^{75}$, a língua oral amplificada ${ }^{76}$ e o tadoma ${ }^{77}$.

\title{
A ênfase nas indicações táteis como uma forma de viabilizar o acesso às informações
}

\section{maximiza e otimiza os sentidos remanescentes através do movimento e das}

\begin{abstract}
${ }^{66}$ Esse sistema não-alfabético corresponde à língua de sinais tradicionalmente usada por surdos. Ao ser utilizada com pessoas surdocegas, é adaptada ao tato.

${ }^{67}$ Nesse sistema de comunicação não-alfabético, o professor interage com a pessoa surdocega por meios de sinais. A adaptação necessária será a de adequar o espaço de sinalização ao campo visual da criança (com resíduo de visão).

${ }^{68}$ Esse é um sistema de comunicação alfabético e correspondente ao alfabeto manual (dactilologia) utilizado comumente pelas pessoas surdas. A realização do alfabeto manual como via de comunicação às vezes necessita de adaptações, como a realização das letras sobre a palma da mão da pessoa surdocega para que ela perceba, por meio do tato, a realização do sinal, estabelecendo seu significado correspondente.
\end{abstract}

${ }^{69}$ Esse é um sistema de comunicação alfabético baseado no sistema Braille. Esse sistema segue as mesmas regras e convenções do Braille tradicional (os dedos indicador e médio representam a cela Braile e em cada falange dos dedos representa o espaço de marcação do ponto). Sua utilização ocorre no próprio corpo da pessoa surdocega e de seu interlocutor, em geral usando os dedos mencionados.

${ }^{70}$ Esse sistema alfabético consiste no registro de cada letra de uma palavra na palma da mão da pessoa surdocega ou em outras partes de seu corpo (braço). Para tanto, é necessário que a mensagem seja escrita, preferencialmente, com letras maiúsculas.

${ }^{71}$ Esse é um sistema alfabético em que se utiliza uma tablita (uma espécie de prancha em tamanho reduzido) que contém letras e números em relevo ou em Braille. A comunicação é viabilizada mediante o deslocamento do dedo indicador da pessoa surdocega de modo que, com a ponta de seu dedo, ela perceba pelo tato cada uma das letras que formam as palavras que compõem a mensagem.

72 É a recepção de mensagens transmitidas pelo interlocutor mediante a fala por meio da leitura labial realizada pela pessoa surdocega, com a utilização de seus resíduos visuais.

${ }^{73}$ É um sistema alfabético que consiste na escrita da mensagem em tinta, com tipos ampliados, de maneira que essa possa ser percebida pela pessoa surdocega por meio de seus resíduos visuais.

74 Esses materiais são equipamentos como computadores e máquinas de escrever portáteis, mecânicas ou eletrônicas que viabilizam o registro da mensagem no sistema alfabético e a transforma no sistema Braille.

${ }^{75}$ Este sistema de comunicação consiste na marcação das letras do alfabeto e dos algarismos de 0 a 9 nas falanges dos dedos e na palma de uma das mãos da pessoa surdocega. Distribui-se para cada falange uma letra do alfabeto; na medida em que o espaço destinado à letra é tocado, a pessoa vai selecionando as letras e formando as palavras que compõem a mensagem.

${ }^{76}$ É a recepção da mensagem expressa pelo interlocutor por meio da língua oral, mediante o uso, por parte da pessoa surdocega, de aparelho de amplificação sonora (AASI).

${ }^{77}$ Este método de comunicação consiste na percepção tátil da língua oral emitida, mediante uso de uma ou das duas mãos da pessoa surdocega. A recepção das mensagens orais ocorre, geralmente, mediante o posicionamento suave do dedo polegar da pessoa surdocega, sobre os lábios do interlocutor. Os demais dedos se mantêm sobre a bochecha, a mandíbula e a garganta do interlocutor. 
sensações realizados em parceria. Proporcionam-se, assim, novas condições da relação entre as influências recíprocas dos fatores biológicos (habilidades e recursos que a criança dispõe) e socioculturais, na aprendizagem de novos repertórios dos comportamentos (VYGOTSKY, 1988).

\subsection{A doença crônica orgânica}

Segundo a BIREME (s/d), a doença crônica é definida como

doenças que têm uma ou mais das seguintes características: são permanentes, deixam incapacidade residual, são causadas por alteração patológica não reversível, requerem treinamento especial do paciente para reabilitação, pode-se esperar requerer um longo período de supervisão, observação ou cuidado.

A doença crônica é definida como perturbações de saúde que persistem por longos períodos de tempo, podendo se estender ao longo de toda vida (PICCININI, 2003). As doenças crônicas podem ser manejadas ou controladas no intuito de diminuir o sofrimento e melhorar a qualidade de vida dos doentes, porém na maioria dos casos não são completamente curadas. As hospitalizações extensivas, mesmo no período de diagnóstico, também são frequentes (GARRALDA, 1994).

São consideradas doenças crônicas a fibrose cística, a disfunção renal crônica, as doenças cardíacas, o câncer, a artrite reumatóide, a diabetes, a atresia de vias biliares (um tipo de doença hepática congênita) e a talassemia ${ }^{78}$, dentre outras. A

${ }^{78}$ A talassemia é o nome que se dá a uma doença caracterizada por baixo número de glóbulos vermelhos no sangue. Geralmente as pessoas com talassemia se tornam muito anêmicas e pálidas, não crescendo até a estatura que atingiriam se fossem saudáveis. Outro sinal frequente é a existência 
doença crônica também pode se manifestar como deficiências físicas (deformidades e falta de algum membro do corpo), dificuldades de aprendizagem e enfermidades neurológicas (déficit de atenção e epilepsia), doenças psicossomáticas (asma e obesidade), doenças mentais e o autismo.

A maneira como a criança responde à presença de uma doença crônica dependerá de fatores relacionados à própria doença (limitações físicas e sociais, diagnóstico precoce ou tardio, prognóstico, gravidade, visibilidade e origem genética), relacionados à criança (idade, gênero, temperamento e personalidade) e relacionados à família (estrutura familiar, habilidades de comunicação e solução de problemas). As implicações de longo prazo da doença crônica orgânica sobre o desenvolvimento cognitivo, social e emocional também diferem consideravelmente dependendo da interação dos vários fatores citados (QUERY; REICHELT; CHRISTOFERSON, 1990; WASSERMAN, 1992).

\subsection{Os transtornos da comunicação}

Os transtornos da comunicação verbal e não-verbal são causados por transtornos da linguagem receptivos ou expressivos, disfunção cognitiva (como o retardo mental), condições psiquiátricas e transtornos da audição. Neste trabalho são abordados os transtornos de comunicação segundo a BIREME (s/d), descritos a seguir.

de um aumento no baço. A talassemia é uma característica do sangue transmitida de pais para filhos. Disponível em: <http://www.tele-centros.org>. Acesso em: 03 set. 2008. 


\subsubsection{Transtornos da linguagem}

Condições caracterizadas por deficiências da compreensão ou expressão das formas de linguagem escrita e falada. Incluem transtornos adquiridos e desenvolvidos.

\section{a) Agrafia ou disgrafia}

Perda ou deficiência da capacidade em escrever (cartas, sílabas, palavras ou frases) devido a uma lesão em uma área cerebral específica ou ocasionalmente devido a fatores emocionais. Esta condição raramente ocorre isolada e geralmente é acompanhada de afasia.

\section{b) Anomia ou afasia nominal}

Disfunção de linguagem caracterizada pela incapacidade em nomear pessoas e objetos que são corretamente percebidos. O indíviduo é capaz de descrever o objeto em questão, mas não pode dizer o nome. Esta condição está associada com lesões do hemisfério dominante envolvendo as áreas de linguagem.

\section{c) Dislexia ou transtorno da leitura}

Transtorno cognitivo caracterizado pela capacidade deficiente em compreender palavras ou frases escritas e impressas, apesar da visão estar intacta. Esta condição pode ser decorrente do desenvolvimento ou, adquirida. A dislexia do desenvolvimento é marcada por realização de leitura que decai substancialmente abaixo do esperado, dada a idade cronológica do indivíduo, medida de inteligência e educação apropriada à idade. O distúrbio da leitura interfere significantemente com 
as realizações acadêmicas ou com atividades da vida diária que necessitam habilidades de leitura.

\section{d) Transtornos do desenvolvimento da linguagem ou atraso da fala}

Condições caracterizadas por capacidades de linguagem (compreensão e expressão de fala e escrita) que estão abaixo do nível esperado para uma determinada idade, geralmente na ausência de uma deficiência intelectual. Estas condições podem estar associadas com surdez, doenças cerebrais, transtornos mentais ou fatores ambientais.

\section{e) Distúrbios da fala ou aprosodia}

Condições adquiridas ou desenvolvidas, caracterizadas por habilidade deficiente em compreender ou gerar formas da linguagem falada.

\section{$>$ Afasia}

Transtorno cognitivo caracterizado pela habilidade deficiente em compreender ou expressar a linguagem nas suas formas escrita ou falada. Esta condição é causada por doenças que afetam as áreas de linguagem do hemisfério dominante. Os sinais clínicos são usados para classificar os vários subtipos desta condição.

\section{$>$ Transtornos da articulação da fala}

Transtornos na qualidade da fala caracterizados pela substituição, omissão, distorção e adição de fonemas. 


\section{- Disartria}

Transtornos da articulação da fala causados por coordenação imperfeita da faringe, laringe, língua ou músculos faciais. Podem resultar de doenças dos nervos cranianos, doenças neuromusculares, doenças cerebelares, doenças dos gânglios da base, doenças do tronco encefálicol ou doenças dos tratos corticobulbares. Os centros de linguagem corticais estão intactos nesta condição.

\section{- Ecolalia}

Repetição sem sentido, involuntária (como papagaio) de uma canção, frase ou palavra recém escutada. Esta condição pode estar associada com afasia transcortical, esquizofrenia ou outros transtornos.

\section{- Mutismo}

Incapacidade em gerar expressão oral-verbal apesar da compreensão da fala estar normal. Pode estar associada com doenças cerebrais ou transtornos mentais. O mutismo orgânico pode estar associado com danos no lobo frontal, tronco encefálico, tálamo e cerebelo. O mutismo seletivo é uma condição psicológica que normalmente afeta crianças e é caracterizado por recusa contínua em falar em situações sociais por uma criança que é capaz e deseja falar com pessoas selecionadas. 


\section{- Gagueira}

Distúrbio dos padrões normais de tempo e fluência da fala sendo inapropriado para a idade do indivíduo. Este distúrbio é caracterizado por repetições frequentes ou prolongações de sons ou sílabas. Vários outros tipos de disfluências de fala podem também estar envolvidos incluindo interjeições, palavras quebradas, bloqueio silencioso ou audível, palavras produzidas com excesso de tensão física e repetições monossilábicas da palavra toda. A gagueira pode ocorrer como condição do desenvolvimento da infância ou como transtorno adquirido que pode estar associado a infartos cerebrais e outras doenças cerebrais.

\subsubsection{Transtornos de aprendizagem}

Condições caracterizadas por uma discrepância significante entre nível intelectual percebido de um indivíduo e sua capacidade em adquirir novas habilidades de linguagem e outras cognitivas. Estes transtornos podem resultar de condições psicológicas ou orgânicas. Os subtipos relativamente comuns incluem dislexia, discalculia e disgrafia ${ }^{79}$.

A discalculia é um dos transtornos de aprendizagem que causa a dificuldade na matemática, que decorre em erros diversos na solução de problemas verbais, nas

\footnotetext{
${ }^{79}$ Ver item 2.4.1 Transtornos da linguagem.
} 
habilidades de contagem, nas habilidades computacionais, na compreensão dos números (SAMPAIO, 2004).

A definição do que se considera como distúrbio, transtorno, dificuldade e/ou problema de aprendizagem é divergente para aqueles que atuam no diagnóstico, prevenção e reabilitação do processo de aprendizagem, pois envolve uma vasta literatura fundamentada em concepções divergentes (NUTTI, 2002). A diferenciação entre o distúrbio e a dificuldade de aprendizagem se apresenta da seguinte maneira:

aparentemente os defensores da abordagem comportamental preferem a utilização do termo distúrbio, enquanto os construtivistas parecem ser adeptos do termo dificuldade. [...] 0 termo "dificuldade" está mais relacionado a problemas de ordem psicopedagógica e/ou socioculturais, ou seja, o problema não está centrado apenas no aluno, sendo que essa visão é mais frequentemente utilizada em uma perspectiva preventiva; por outro lado, o termo "distúrbio" está mais vinculado ao aluno, na medida em que sugere a existência de comprometimento neurológico em funções corticais específicas, sendo mais utilizado pela perspectiva clínica ou remediativa. (FRANÇA, 1996, p. 20)

Segundo a Classificação de Transtornos Mentais e de Comportamento da

Classificação Internacional de Doenças - CID 10, elaborado pela OMS:

O termo "transtorno" é usado por toda a classificação, de forma a evitar problemas ainda maiores inerentes ao uso de termos tais como "doença" ou "enfermidade". "Transtorno" não é um termo exato, porém é usado para indicar a existência de um conjunto de sintomas ou comportamentos clinicamente reconhecível, associado, na maioria dos casos, a sofrimento e interferência com funções pessoais.

Moojen (1999, p. 20) afirma que,

ao lado do pequeno grupo de crianças que apresenta Transtornos de Aprendizagem decorrente de imaturidade do desenvolvimento e/ou disfunção psiconeurológica, existe um grupo muito maior de crianças que apresenta baixo rendimento escolar em decorrência de fatores isolados ou em interação. As alterações apresentadas por esse contingente maior de alunos poderiam ser designadas como "dificuldades de aprendizagem". Participariam dessa conceituação os atrasos no desempenho escolar por falta de interesse, perturbação emocional, inadequação metodológica ou mudança no padrão de exigência da escola, ou seja, alterações evolutivas normais que foram consideradas no passado como alterações patológicas. 


\subsection{Indicadores estatísticos relativos à deficiência ${ }^{80}$}

Segundo a Carta para o Terceiro Milênio aprovada em 1999, em Londres, pela Assembléia Governativa da Rehabilitation International, estatisticamente, pelo menos $10 \%$ de qualquer sociedade nasce com ou adquire uma deficiência; e aproximadamente uma em cada quatro famílias possui uma pessoa com alguma deficiência. A Lei Federal n.0 7.853 (BRASIL, 1989), faz referência à obrigatoriedade da inclusão de questões específicas sobre a população com deficiências nos censos nacionais como condição essencial para o conhecimento da realidade brasileira e indispensável para sustentar a definição de políticas específicas. Atendendo ao que preconiza a lei, o Censo Demográfico de 1991, pela primeira vez, incluiu questões referentes a essa população (BRASIL, 2008a).

Os resultados do Censo Demográfico de 2000 (IBGE, 2000), mostram que, aproximadamente, 24,6 milhões de pessoas, ou $14,5 \%$ da população total, apresentaram algum tipo de incapacidade ou deficiência (Tabela 1). São pessoas com ao menos alguma dificuldade de enxergar, ouvir, locomover-se ou alguma deficiência física ou mental. O conceito ampliado utilizado neste censo para caracterizar as pessoas com deficiência, que inclui diversos graus de severidade na

80 O Censo realizado pelo IBGE em final de 2010 ainda não disponibilizou os resultados totais em tempo hábil para a introdução dos mesmos no presente estudo. Os dados parciais conseguidos do Censo 2010 indicam 190.732.694 pessoas para a população brasileira em 10 de agosto, data de referência. Em comparação com o Censo 2000, ocorreu um aumento de 20.933 .524 pessoas. Esse número demonstra que o crescimento da população brasileira no período foi de $12,3 \%$, inferior ao observado na década anterior $(15,6 \%$ entre 1991 e 2000). Disponível em: <http://www.ibge.gov.br/home/presidencia/noticias/noticia_visualiza.php?id_noticia=1766\&id_pagina $=1>$. Acesso em: 20 jan. 2011. 
capacidade de enxergar, ouvir e locomover-se, é compatível com a CIF (item 2.1.1), divulgada em 2001 pela OMS. Este conceito inclui a percepção que as pessoas pesquisadas têm sobre as alterações provocadas pela deficiência na capacidade de realização, no comportamento e na participação social, ou seja, privilegia as incapacidades como ponto de partida para a identificação das deficiências e do grau de comprometimento das condições físicas e mentais dessas pessoas. O Censo Demográfico de 2000 avançou no sentido de superar as dificuldades conceituais com relação às deficiências, o que provocou um impacto positivo no sentido de aproximação com a realidade e com os dados internacionais (BRASIL, 2008a).

Tabela 1 - Proporção da população residente, portadora de pelo menos uma das deficiências investigadas, por grandes grupos de idade (\%), segundo as grandes regiões do Brasil.

\begin{tabular}{|c|c|c|c|c|}
\hline \multirow{2}{*}{$\begin{array}{l}\text { Grandes } \\
\text { Regiões }\end{array}$} & \multicolumn{4}{|c|}{$\begin{array}{l}\text { Proporção da população residente, portadora de pelo menos uma das } \\
\text { deficiências investigadas, por grandes grupos de idade (\%) }\end{array}$} \\
\hline & Total & 0 a 14 anos & 15 a 64 anos & 65 anos ou mais \\
\hline Brasil & 14,5 & 4,3 & 15,6 & 54,0 \\
\hline Norte & 14,7 & 4,6 & 18,1 & 63,2 \\
\hline Nordeste & 16,8 & 5,2 & 18,7 & 62,3 \\
\hline Sudeste & 13,1 & 3,7 & 13,5 & 48,0 \\
\hline Sul & 14,3 & 3,7 & 15,1 & 53,5 \\
\hline Centro-Oeste & 13,9 & 4,4 & 15,5 & 56,2 \\
\hline
\end{tabular}

Fonte: Elaborada pela autora com base no Censo IBGE, 2000.

Os resultados do Censo 2000 (IBGE, 2000) ainda indicam que entre os 16,6 milhões de pessoas com algum grau de deficiência visual, quase 150 mil se declararam cegos; 3,3\% da população declararam ter algum problema auditivo, sendo que pelo menos $1 \%$ dessas declarações foram de pessoas que disseram sentir grande dificuldade ou relataram ser incapazes de ouvir. Entre os 5,7 milhões de brasileiros 
com algum grau de deficiência auditiva, cerca de 170 mil se declararam surdos. Na literatura internacional, a presbiacusia (perda auditiva devido à idade) é apontada como a principal causa de deficiência auditiva nos idosos, com uma incidência de cerca de $30 \%$ na população com mais de 65 anos de idade. O ruído, principalmente no ambiente de trabalho, é apontado como a segunda principal causa de perda auditiva neurossensorial entre os adultos. É importante destacar que a proporção de pessoas com deficiência aumenta com a idade, passando de 4,3\% nas crianças até 14 anos, para 54\% do total das pessoas com idade superior a 65 anos. Os dados do Censo 2000 mostram, também, que os homens predominam no caso de deficiência mental, física (especialmente no caso de falta de membro ou parte dele) e auditiva. O resultado é compatível com o tipo de atividade desenvolvida pelos homens e com o risco de acidentes de diversas causas. Já a predominância das mulheres com dificuldades motoras (incapacidade de caminhar ou subir escadas) ou visuais é coerente com a composição por sexo da população idosa, com o predomínio de mulheres a partir dos 60 anos. O alto índice de deficiências visuais pode ser explicado pela combinação de dois fatores: o envelhecimento populacional ocorrido a partir da década de 1990 e a própria ampliação do conceito de deficiência, que não se restringe apenas à cegueira, inclui também grande ou alguma dificuldade permanente de enxergar, desde que não corrigida pelo uso de órtese. Esse dado reflete também a dificuldade de acesso da população ao sistema de saúde, principalmente no que diz respeito aos serviços ambulatoriais especializados ou mesmo à aquisição de óculos. O aumento da expectativa de vida da população brasileira nas últimas décadas tem possibilitado que as causas das deficiências estejam cada vez mais relacionadas a males crônico-degenerativos, como a 
hipertensão arterial, a diabetes, o infarto, os acidentes vásculo-encefálicos, a doença de Alzheimer, o câncer, a osteoporose e outros (BRASIL, 2008a).

A deficiência motora assume maior relevância a partir dos 25 anos de idade, refletindo a importância dos acidentes, da violência urbana e de certas doenças na gênese desta deficiência. As pessoas com deficiência motora ressentem-se de uma variedade de condições neurossensoriais que as afetam em termos de mobilidade, de coordenação motora geral ou da fala, como decorrência de lesões nervosas, neuromusculares e osteoarticulares ou, ainda, de má-formação congênita ou adquirida. As principais causas das deficiências são: (1) os transtornos congênitos e perinatais, decorrentes da falta de assistência ou da assistência inadequada às mulheres na fase reprodutiva; (2) as doenças transmissíveis e crônicas nãotransmissíveis; (3) as perturbações psiquiátricas; (4) o abuso de álcool e de drogas; (5) a desnutrição; e (6) os traumas e as lesões, principalmente nos centros urbanos mais desenvolvidos, onde são crescentes os índices de violências e de acidentes de trânsito. A crescente urbanização e industrialização, sem os devidos cuidados com a preservação da vida e do meio ambiente, geram o aumento de incapacidades. Há indícios de correlação entre o aumento de incapacidades e a incidência de neuroses, doenças psicossomáticas, alcoolismo, vício de drogas, acidentes de trânsito e violência urbana (BRASIL, 2008a).

Em relação às causas de deficiência decorrentes dos acidentes e da violência urbana, os mesmos resultam de ações ou omissões humanas e de condicionantes técnicos e sociais. Ao considerar que se trata de fenômeno de conceituação complexa e 
controversa, descreve-se como violência o evento representado por ações realizadas por indivíduos, grupos, classes, nações, que ocasionam danos físicos, emocionais, morais e ou espirituais a si próprio ou a outros (MINAYO; SOUZA, 1998). Os acidentes e as violências configuram, assim, um conjunto de agravos à saúde, que pode ou não levar a óbito, no qual se incluem as causas ditas acidentais - devidas ao trânsito (acidentes de automóvel ou de moto, atropelamentos), trabalho, quedas, envenenamentos, afogamentos, mergulhos em águas rasas, disparo acidental de armas de fogo, e outros tipos de acidentes - e as causas intencionais (agressões e lesões autoprovocadas). No conjunto das causas externas, os acidentes de trânsito se destacam em termos de magnitude, tanto de mortes, quanto de feridos (centenas de milhares de sequelados definitivos) ${ }^{81}$.

As principais fontes oficiais de informação para o estudo dos acidentes e das violências, nas diferentes fases do evento até a morte, são o Boletim de Ocorrência Policial (BO); o Boletim de Registro de Acidentes de Trânsito do Departamento Nacional de Trânsito (DENATRAN); a Comunicação de Acidentes do Trabalho (CAT); o Sistema de informações Hospitalares do Sistema Único de Saúde (SIH/SUS); o Sistema de Informação de Mortalidade do Ministério da Saúde (SIM/MS); e o Sistema Nacional de Informações Tóxico-Farmacológicas (SINITOX). Em função do crescimento dos acidentes e das violências, da relativa inconsistência dos dados e da ausência de registros e conhecimento sobre certos agravos, somente nos últimos anos é que têm sido desencadeadas algumas tentativas pontuais de estruturação de

\footnotetext{
${ }^{81}$ Disponível em: <http://www.cbc.org.br/upload/pdf/comissoes_trauma_projetotrauma.pdf>. Acesso em: 15 jul. 2010.
} 
sistemas de informação mais integrados objetivando a vigilância epidemiológica destes eventos. $^{82}$

Os resultados do Censo 2000 (IBGE, 2000), ainda indicam cerca de 2,1 milhões de crianças (0 a 14 anos) com deficiências (Tabela 2). Segundo Franciozi (2008), os acidentes no trânsito e as quedas de altura são, em geral, responsáveis pelos comprometimentos mais sérios em crianças.

Tabela 2 - Distribuição da população residente, portadora de pelo menos uma das deficiências investigadas, por grupos de idade de 0 a 17 anos.

\begin{tabular}{|c|c|c|c|c|}
\hline \multirow{2}{*}{$\begin{array}{l}\text { Brasil } \\
\text { Total } \\
\end{array}$} & \multicolumn{4}{|c|}{$\begin{array}{c}\text { População residente, portadora de pelo menos uma das deficiências } \\
\text { investigadas, por grupos de idade }\end{array}$} \\
\hline & 0 a 4 anos & 5 a 9 anos & $\begin{array}{c}10 \text { a } 14 \text { anos ou } \\
\text { mais }\end{array}$ & $\begin{array}{l}15 \text { a } 17 \text { anos ou } \\
\text { mais }\end{array}$ \\
\hline 2.850 .604 & 370.530 & 707.763 & 1.083 .039 & 689.272 \\
\hline
\end{tabular}

Fonte: Elaborada pela autora com base nos dados do Censo IBGE, 2000.

Dentre as causas de queda de altura pelas crianças se destacam, principalmente na periferia, a queda da laje de cobertura das casas, em função da falta de cuidado dos próprios donos dos terrenos, que aos poucos vão construindo suas casas e sobrepondo um andar ao outro, sem a proteção devida. Esse comportamento social que tem se desenvolvido nos últimos anos facilita a ocorrência de quedas e de lesões medulares.

Segundo o grupo de estudo e pesquisa de segurança da criança e do adolescente da Universidade Federal de São Paulo (UNIFESP), acredita-se que a existência da norma

${ }^{82}$ Disponível em: <http://portal.saude.gov.br/portal/arquivos/pdf/portaria737.pdf>. Acesso em: 15 jul. 2010. 
NBR 14.350 (ABNT, 1999), sobre segurança de brinquedos de Playground, em nosso país, seja um ponto importante a ser destacado, enquanto diretriz que tem a possibilidade de conduzir a sociedade para a escolha correta destes equipamentos visando à diminuição dos acidentes envolvendo crianças.

\subsection{A tecnologia assistiva}

No âmbito europeu, o conceito de tecnologia assistiva é também traduzido pelas expressões ajudas técnicas ou tecnologia de apoio. A terminologia adotada pela OMS na Classificação Internacional de Funcionalidade (CIF, 2003, p. 20) é a de ajudas técnicas, definida como

qualquer produto, instrumento, estratégia, serviço e prática, utilizado por pessoas com deficiências e pessoas idosas, especialmente produzido ou geralmente disponível para prevenir, compensar, aliviar ou neutralizar uma deficiência, incapacidade ou desvantagem e melhorar a autonomia e a qualidade de vida dos indivíduos.

A tecnologia assistiva é um termo utilizado para identificar todo o arsenal de recursos (são todo e qualquer item, equipamento ou parte dele, produto ou sistema fabricado em série ou sob medida utilizado para aumentar, manter ou melhorar as capacidades funcionais das pessoas com deficiência) e serviços (são definidos como aqueles que auxiliam diretamente uma pessoa com deficiência a selecionar, a comprar ou a usar os recursos referidos) que contribuem para proporcionar ou ampliar habilidades funcionais de pessoas com deficiência e consequentemente promover vida independente e inclusão. ${ }^{83}$ A tecnologia assistiva é também definida como "uma

${ }^{83}$ Disponível em: <http://assistiva.com.br>. Acesso em: 14 ab. 2009. 
ampla gama de equipamentos, serviços, estratégias e práticas concebidas e aplicadas para minorar os problemas encontrados pelos indivíduos com deficiências" (COOK; HUSSEY, 1995, p. 20).

A 4a edição da Norma Internacional ISO 9999 publicada em 2007, altera a terminologia utilizada, trocando a expressão ajudas técnicas, utilizada até a versão de 2002, por produtos assistivos. No Brasil o Comitê de Ajudas Técnicas aprovou por unanimidade, em sua Reunião VII, de dezembro de 2007, a adoção da seguinte formulação para o conceito de tecnologia assistiva, adotado no presente estudo:

Tecnologia Assistiva é uma área do conhecimento, de característica interdisciplinar, que engloba produtos, recursos, metodologias, estratégias, práticas e serviços que objetivam promover a funcionalidade, relacionada à atividade e participação de pessoas com deficiência, incapacidades ou mobilidade reduzida, visando sua autonomia, independência, qualidade de vida e inclusão social. (CAT, 2007)

No Brasil, o processo de apropriação e sistematização do conceito e classificação de tecnologia assistiva,

é ainda mais incipiente e recente. A expressão "Tecnologia Assistiva" com frequência é utilizada na língua portuguesa ao lado das expressões "Ajudas Técnicas" e "Tecnologia de Apoio", na maioria das vezes como sinônimos, em outras, apontando diferenças no sentido de cada uma delas. (GALVÃO FILHO, 2009, p. 14)

O termo Assistive Technology, traduzido no Brasil como tecnologia assistiva, foi criado em 1988 como importante elemento jurídico dentro da legislação norteamericana conhecida como Public Law 100-407 e que foi renovada em 1998 como Assistive Technology Act , compondo com outras leis, o American with Disabilities Act $(A D A)$, que regula os direitos dos cidadãos com deficiência nos Estados Unidos, além de prover a base legal dos fundos públicos para compra dos recursos que estes 
categorias da tecnologia assistiva segundo a ADA.

\begin{tabular}{|c|c|}
\hline Categoria & Definição \\
\hline $\begin{array}{l}\text { Auxílios para a } \\
\text { vida diária }\end{array}$ & $\begin{array}{l}\text { Materiais e produtos para auxílio em tarefas rotineiras tais como comer, } \\
\text { cozinhar, vestir-se, tomar banho e executar necessidades pessoais, } \\
\text { manutenção da casa etc. }\end{array}$ \\
\hline $\begin{array}{l}\text { Comunicação } \\
\text { aumentativa e } \\
\text { alternativa (CAA) }\end{array}$ & $\begin{array}{l}\text { Atende pessoas sem fala ou escrita funcional ou em defasagem entre sua } \\
\text { necessidade comunicativa e sua habilidade em falar e/ou escrever. Busca, } \\
\text { através da valorização de todas as formas expressivas do sujeito e da } \\
\text { construção de recursos próprios desta metodologia, construir e ampliar sua via } \\
\text { de expressão e compreensão (SEESP/SEED/MEC, 2007, p. 58). Ver item } \\
\text { 2.2.1.1. }\end{array}$ \\
\hline $\begin{array}{l}\text { Recursos de } \\
\text { acessibilidade ao } \\
\text { computador }\end{array}$ & $\begin{array}{l}\text { Equipamentos de entrada e saída (síntese de voz, Braille), auxílios alternativos } \\
\text { de acesso (ponteiras de cabeça, de luz), teclados modificados ou alternativos, } \\
\text { acionadores, softwares especiais (como os de reconhecimento de voz), que } \\
\text { permitem o uso do computador. }\end{array}$ \\
\hline $\begin{array}{l}\text { Sistemas de } \\
\text { controle } \\
\text { de ambiente }\end{array}$ & $\begin{array}{l}\text { Sistemas eletrônicos que permitem às pessoas com limitações moto- } \\
\text { locomotoras, controlar remotamente aparelhos eletro-eletrônicos, sistemas de } \\
\text { segurança, entre outros, localizados em seu quarto, sala, escritório, casa e } \\
\text { arredores. }\end{array}$ \\
\hline $\begin{array}{l}\text { Projetos } \\
\text { arquitetônicos } \\
\text { para } \\
\text { acessibilidade }\end{array}$ & $\begin{array}{l}\text { Adaptações estruturais e reformas na casa e/ou ambiente de trabalho } \\
\text { (rampas, elevadores, adaptações em banheiros entre outras) que retiram ou } \\
\text { reduzem as barreiras físicas, facilitando a locomoção. }\end{array}$ \\
\hline $\begin{array}{l}\text { Órteses e } \\
\text { próteses }\end{array}$ & $\begin{array}{l}\text { As próteses são peças artificiais que substituem partes ausentes do corpo. As } \\
\text { órteses são externas e colocadas junto a um segmento do corpo, garantindo- } \\
\text { lhe um melhor posicionamento, estabilização e/ou função. Incluem os } \\
\text { protéticos para auxiliar nos déficits ou limitações cognitivas, como os } \\
\text { gravadores de fita magnética ou digital que funcionam como lembretes } \\
\text { instantâneos. }\end{array}$ \\
\hline $\begin{array}{l}\text { Adequação } \\
\text { postural }\end{array}$ & $\begin{array}{l}\text { Adaptações para cadeira de rodas ou outro sistema de sentar visando o o } \\
\text { conforto e distribuição adequada da pressão na superfície da pele (almofadas } \\
\text { especiais, assentos e encostos anatômicos), bem como posicionadores e } \\
\text { contentores que propiciam maior estabilidade e postura adequada do corpo } \\
\text { através do suporte e posicionamento de tronco, cabeça e membros. }\end{array}$ \\
\hline $\begin{array}{l}\text { Auxílios } \\
\text { de mobilidade }\end{array}$ & $\begin{array}{l}\text { Cadeiras de rodas manuais e motorizadas, bases móveis, andadores, scooters } \\
\text { de três rodas e qualquer outro veículo utilizado na melhoria da mobilidade } \\
\text { pessoal. }\end{array}$ \\
\hline $\begin{array}{l}\text { Auxílios para } \\
\text { cegos ou com } \\
\text { visão sub-normal }\end{array}$ & $\begin{array}{l}\text { Auxílios para grupos específicos que incluem lupas e lentes, Braille para } \\
\text { equipamentos com síntese de voz, grandes telas de impressão, sistema de TV } \\
\text { com aumento para leitura de documentos, publicações etc. }\end{array}$ \\
\hline $\begin{array}{l}\text { Auxílios para } \\
\text { surdos ou com } \\
\text { déficit auditivo }\end{array}$ & $\begin{array}{l}\text { Auxílios que incluem vários equipamentos (infravermelho), aparelhos para } \\
\text { surdez, telefones com teclado-teletipo (TTY), sistemas com alerta tátil-visual, } \\
\text { entre outros. }\end{array}$ \\
\hline $\begin{array}{l}\text { Adaptações em } \\
\text { veículos }\end{array}$ & $\begin{array}{l}\text { Acessórios e adaptações que possibilitam a condução do veículo, elevadores } \\
\text { para cadeiras de rodas, caminhonetes modificadas e outros veículos } \\
\text { automotores usados no transporte pessoal. }\end{array}$ \\
\hline
\end{tabular}

Quadro 4 - Categorias de tecnologia assistiva segundo a ADA. Fonte: Elaborado pela autora com dados disponíveis em: <http://www.assistiva.com.br/>. Acesso em: 20 mai. 2009; (SEESP/SEED/MEC, 2007, p. 58). 


\section{Segundo Galvão Filho (2009, p. 2),}

Existe um número incontável de possibilidades, de recursos simples e de baixo custo, que podem e devem ser disponibilizados nas salas de aula inclusivas, conforme as necessidades específicas de cada aluno com necessidades educacionais especiais presente nessas salas, tais como: suportes para visualização de textos ou livros; fixação do papel ou caderno na mesa com fitas adesivas; engrossadores de lápis ou caneta confeccionados com esponjas enroladas e amarradas, ou com punho de bicicleta ou tubos de PVC "recheados" com epóxi; substituição da mesa por pranchas de madeira ou acrílico fixadas na cadeira de rodas; órteses diversas, e inúmeras outras possibilidades.

\section{As Figuras 10 e 11 ilustram alguns exemplos dos recursos simples e de baixo custo}

\section{os quais podem e devem ser disponibilizados nas salas de aula inclusivas.}

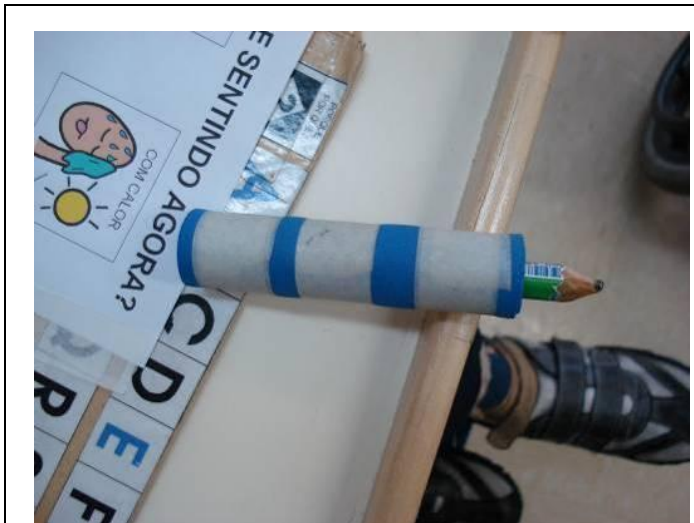

(a)

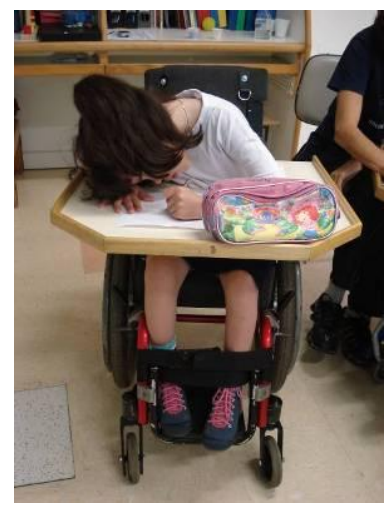

(b)

Figura 10 - Engrossadores de lápis confeccionados com EVA enrolado e amarrado (a) e substituição da mesa por prancha de madeira fixada na cadeira de rodas (b).

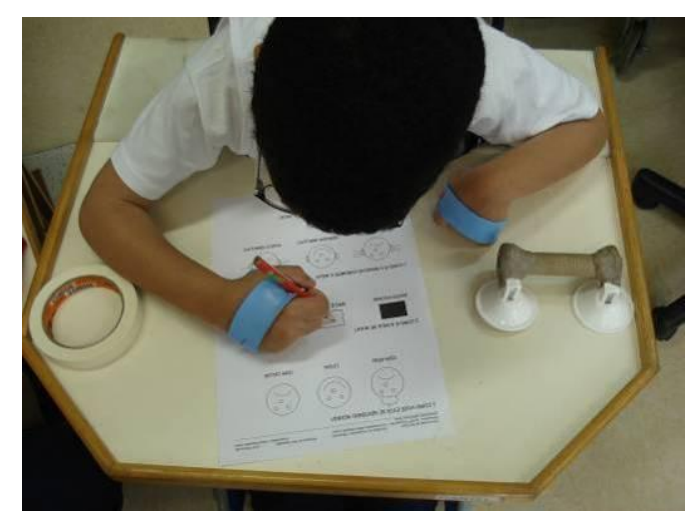

(a)

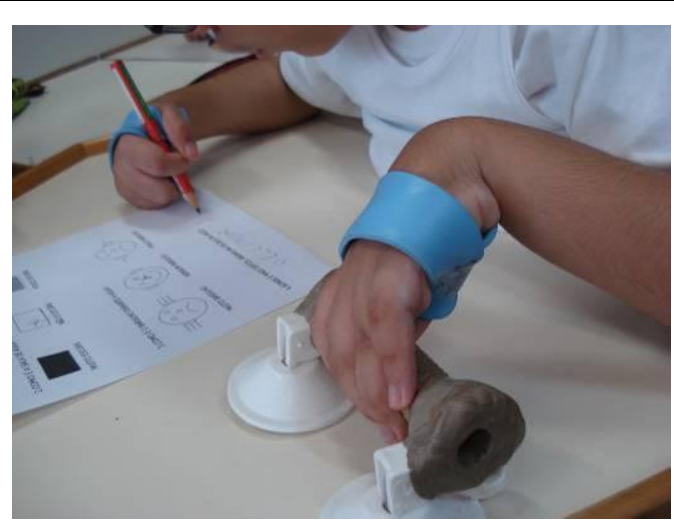

(b)

Figura 11 - Duas vistas de manopla com ventosa fixa a mesa para apoio da mão esquerda do aluno. 
A seguir serão apresentados alguns exemplos de recursos pertencentes às categorias de tecnologia assistiva segundo a ADA.

\section{a) Mouse ocular}

O mouse ocular é um dos recursos pertencentes à categoria da tecnologia assistiva denominada recursos de acessibilidade ao computador. O mouse ocular é um aparelho que possibilita o controle do cursor do computador através da movimentação dos olhos de uma pessoa com deficiência física. Quando os olhos são movimentados, os músculos da face geram pequenos sinais elétricos (Figura 12). Estes sinais são capturados pelo mouse ocular através de eletrodos, posicionados na face do usuário.

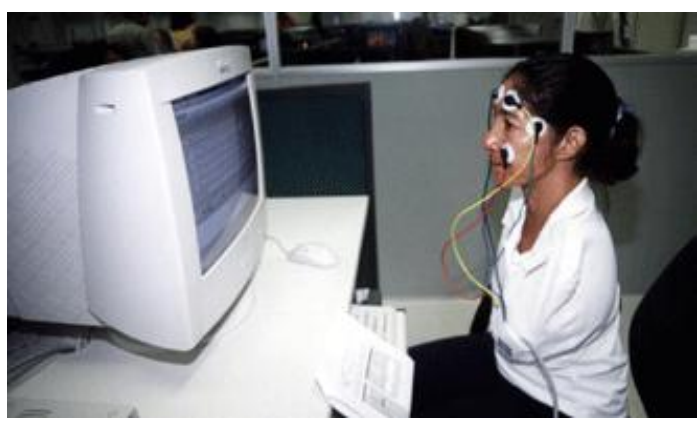

Figura 12 - Mouse ocular. Fonte: Disponível em <http://www.redetec.org.br>. Acesso em: 15 jun. 2010.
Os rastreadores eletrônicos capturam e codificam digitalmente os movimentos do globo ocular, convertendo-os em sinais elétricos que são enviados ao computador por um software para executar cada função de forma específica.

O equipamento analisa os sinais recebidos pelos eletrodos e os transforma em comandos de movimentação do cursor do mouse na tela do computador, de acordo com o movimento realizado pelo usuário. O clique do mouse é realizado através de piscados feitos de modo diferenciado. Através deste controle do cursor, a pessoa com deficiência pode utilizar plenamente o computador para a digitação de textos, 
para a navegação na internet, para o envio e recebimento de e-mail, ou seja, para a realização de qualquer atividade que possa ser realizada através do computador.

\section{b) Próteses e órteses}

As próteses e órteses correspondem a uma das categorias da tecnologia assistiva. A prótese é definida como "[...] substituição de um órgão ou parte do corpo por uma peça artificial. Órgão ou parte do corpo artificiais, tais como um olho, uma perna, a dentadura" ${ }^{84}$. As órteses servem no auxílio de mobilidade, de funções manuais (escrita, digitação, utilização de talheres, manejo de objetos para higiene pessoal), correção postural, dentre outros. A Figura 13 a seguir exemplifica o uso da órtese e da prótese.

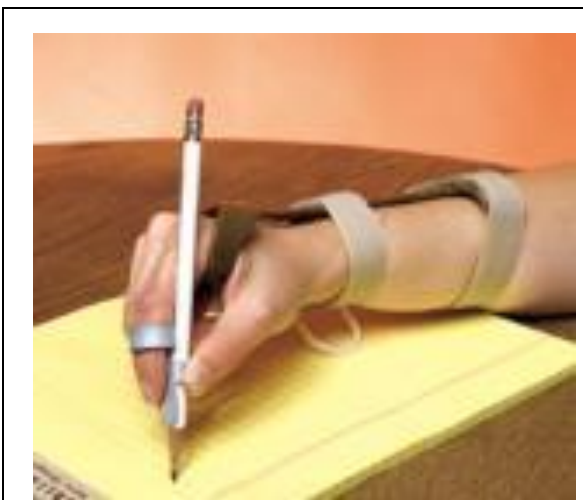

(a)

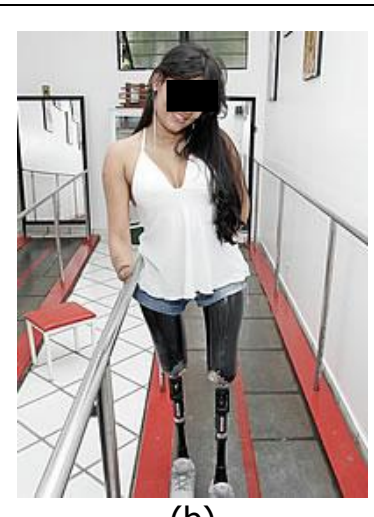

(b)

Figura 13 - Órtese funcional (a) e próteses de membros inferiores (b). Fonte: Disponível em:

<http://nteassistivas.blogspot.co/>. Acesso em: 15 abr. 2009.

No caso das crianças com paralisia cerebral a órtese é utilizada para dar suporte aos músculos paralisados, visando à promoção de movimentos específicos, prevenção ou correção de deformidades musculoesqueléticas. Caso ocorra a presença de

84 Disponível em: <http://michaelis.uol.com.br/moderno/portugues/index.php?lingua=portuguesportugues\&palavra=prótese $>$. Acesso em: 14 nov. 2010. 
deformidades, as órteses são recomendadas apenas após as cirurgias de correções, com o objetivo de manter o resultado obtido. São equipamentos terapêuticos de auxílio funcional, utilizadas em membros superiores, inferiores e tronco. O objetivo de se utilizar a órtese em membros inferiores é de estabilizar as articulações e obter um marchar mais adequado, pois o tipo de órtese depende do nível de função motora da criança. As órteses destinadas a promover a posição em pé devem ser prescritas o mais precocemente possível, em geral, entre os 10 e 12 meses de idade, época em que a criança começa normalmente a se sustentar sobre os membros inferiores e já possui controle adequado da cabeça. Este processo pode ser realizado com o uso do parapódio que proporciona total contato e suporte nos tornozelos, joelhos, quadris e tronco da criança. A posição em pé é capaz de promover a postura em extensão, favorecendo o desenvolvimento visual e motor da criança, ao estimular o uso dos membros superiores, e facilitar a fisiologia intestinal e urinária (FERNANDES, s/d).

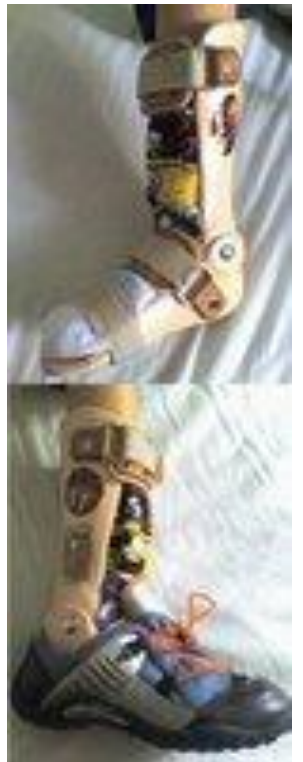

A goteira (Figura 14) é uma órtese que funciona como um tipo de tala confeccionada em polipropileno e revestida em espuma ou com a borracha não tóxica originada da mistura de etil, vinil e acetato (EVA). O calçado é usado por cima da goteira, que é presa ao tornozelo e à canela com velcros. Ela serve para previnir o encurtamento do tendão de Aquiles, e ajuda a criança a aprender o correto posicionamento do seu pé.

Figura 14 - Goteira. Fonte: Disponível em: <http://ogatoderodas.blogspot.com>. Acesso em: 20 abr. 2009. 
O quadril pode apresentar deformidade nas crianças com PC, sendo que a articulação do quadril é feita através do encaixe da cabeça do fêmur na cavidade do osso pélvico. Nos primeiros meses da infância, essa cavidade é mais rasa e só se torna um encaixe à medida que a criança coloca peso sobre a articulação, ficando em pé. Para uma criança que por qualquer motivo não tenha condição de ficar em pé sozinha, essa cavidade não se formará como deveria e permanecerá rasa. Isso predispõe essa criança a um deslocamento parcial (subluxação) ou até mesmo total (luxação) do quadril, sendo necessária uma intervenção cirúrgica. O Scottish-Rite, ou abdutor de quadril (Figura 15) busca evitar esse deslocamento.

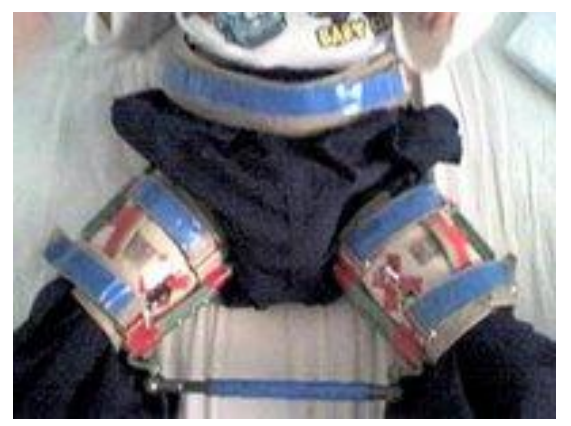

O Scottish-Rite ou abdutor de quadril é confeccionado em duralumínio, aço, couro sintético e velcro, e mantém a cabeça femural encaixada permitindo movimentos das articulações do quadril.

Figura 15 - Abdutor de quadril. Fonte: Disponível em:

<http://ogatoderodas.blogspot.com>. Acesso em: 20 abr. 2009.

\section{c) Cadeiras de rodas}

Segundo a ADA, a cadeira de rodas é um dos recursos pertencentes à categoria da tecnologia assistiva denominada auxílios de mobilidade (não é considerada uma órtese). As cadeiras de rodas podem ser didaticamente classificadas em manual, motorizada, especializada e esportiva ou recreacional, sendo que a indicação deverá avaliar as condições médicas (ortopédicas e fisiológicas), funcionais, aspectos 
pessoais e sociais (COOPER, 1998). Segundo Lianza (1994), as cadeiras de rodas podem ser classificadas em quatro grandes grupos:

- cadeiras de rodas de armação rígida: para uso somente em ambientes internos e em casos excepcionais (atualmente são pouco usadas);

- cadeiras de rodas dobráveis: para uso em ambientes internos e externos e com propulsão manual;

- cadeiras de rodas motorizadas: para uso de tetraplégicos com ampla paralisia dos membros superiores;

- cadeiras de rodas para uso em esportes: feitas com material ultraleve e submetidas a desenho aerodinâmico.

Segundo Bertoncello e Gomes (2002), as cadeiras de rodas podem ser ainda classificadas em relação ao grau de tecnologia envolvido na sua fabricação (Figura 16). As cadeiras de rodas de alto grau de complexidade tecnológica foram denominadas de eletroeletrônicas, as de média complexidade tecnológica, de eletromecânicas e as de baixa complexidade tecnológica, de mecanomanuais. No grupo das eletroeletrônicas, estão incluídas as cadeiras que possuem dispositivos elétricos e/ou eletrônicos, que podem utilizar princípios computacionais, como a cadeira de rodas conduzida pela voz do usuário, sendo as mais modernas e úteis em casos de pessoas com deficiência física com perda funcional e motora ampla e grave. As cadeiras de rodas eletromecânicas, conhecidas como motorizadas, são utilizadas principalmente quando a distância a ser percorrida é extensa, ou se houver impossibilidade da condução manual independente, sendo incluídos os veículos pessoais elétricos, ou triciclos elétricos que proporcionam autonomia na locomoção 
em lugares externos e podem ser dirigidos com uma das mãos apenas. As cadeiras de rodas mecanomanuais são as conduzidas pelo trabalho muscular do próprio usuário ou por uma segunda pessoa e não possuem mecanismos complexos de funcionamento. Esse grupo pode ser subdividido em: incrementadas, especiais $e$ padrão (Figura 16).

A cadeira de rodas incrementada é mais desenvolvida e tem maior tecnologia projetual aplicada, as principais características desse grupo são o conforto, a leveza e a praticidade (desmontagem, transporte e facilidade nas transferências) e destina-se principalmente para uso em ambiente externo, já que o requisito desse grupo é a roda pneumática, que diminui o impacto e gera efeito de amortecedor.

As cadeiras de rodas especiais formam um grupo à parte, pois há grande tecnologia envolvida, embora apresentem características manuais, como por exemplo, as cadeiras de rodas esportivas.

As cadeiras de rodas padrão ${ }^{85}$ são as que possuem rodas de borracha maciça que diminuem o atrito com o solo, facilitando a locomoção em ambientes internos e se apresentam em fixas e dobráveis.

${ }^{85}$ As cadeiras de rodas de banho estão incluídas no grupo das cadeiras de rodas padrão fixas. 


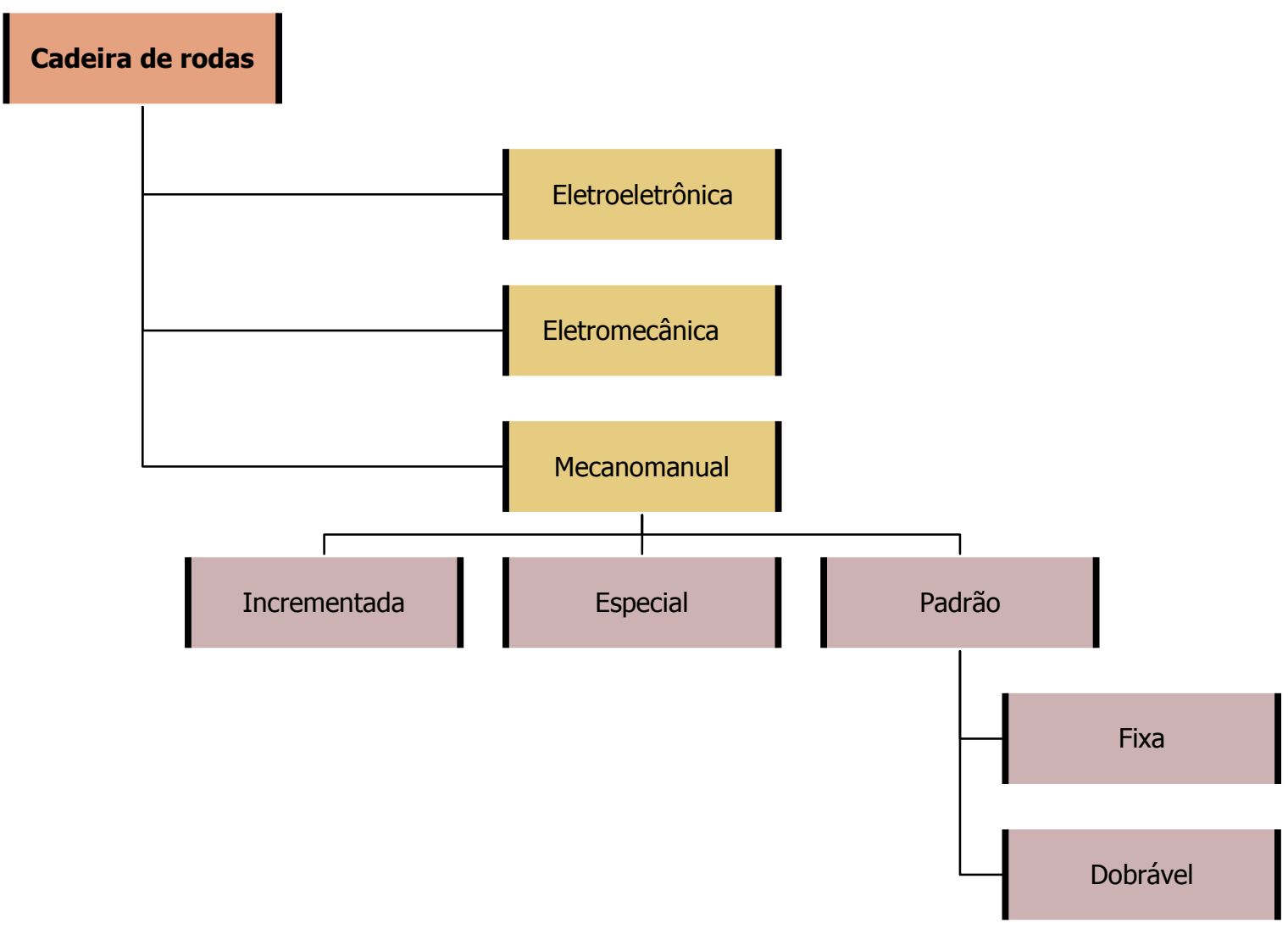

Figura 16 - Classificação das cadeiras de rodas. Fonte: Elaborada pela autora com base em Bertoncello e Gomes, 2002, p. 2.

A Figura 17 apresenta alguns exemplos de cadeiras de rodas e carrinho infantis do tipo mecanomanuais disponíveis no mercado e indicados para usuários de até $50 \mathrm{~kg}$.

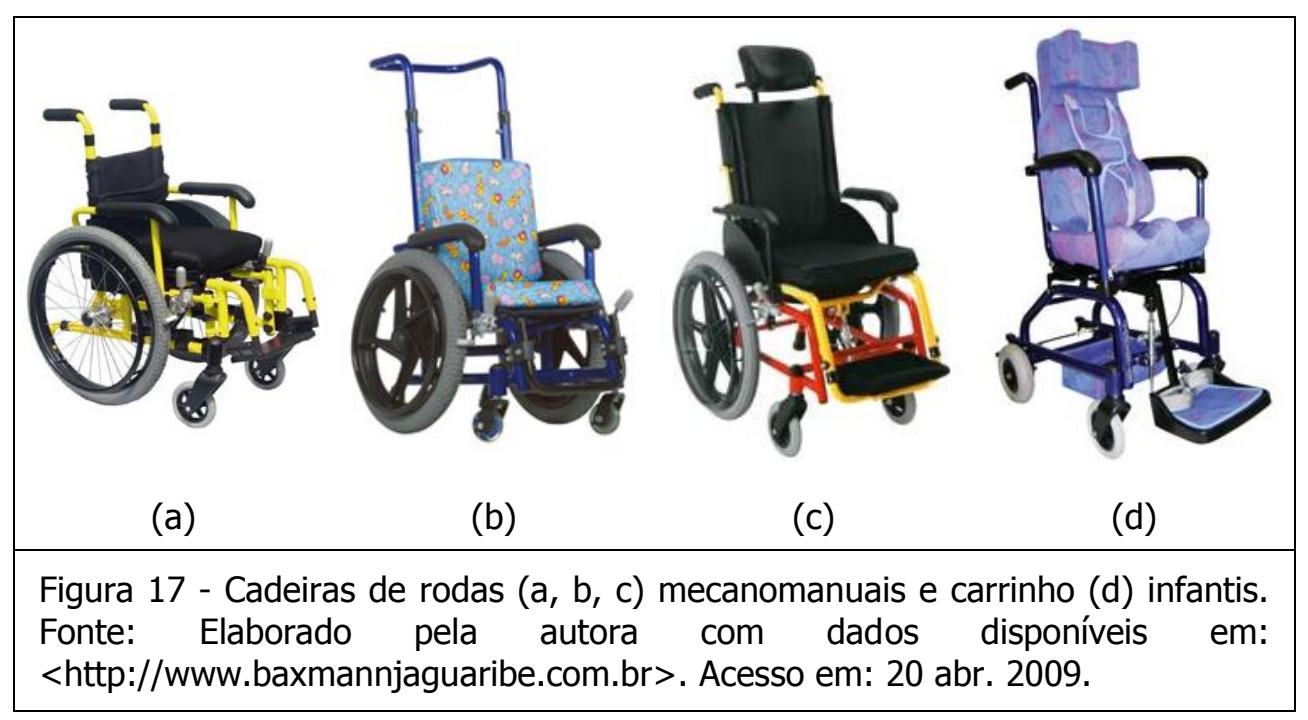


Os serviços de tecnologia assistiva são normalmente transdisciplinares envolvendo profissionais de diversas áreas, tais como: fisioterapia, terapia ocupacional, fonoaudiologia, pedagogia, psicologia, enfermagem, medicina, engenharia, arquitetura e design, dentre outros.

A cooperação técnica e financeira internacional constante na Convenção sobre Direitos das Pessoas com Deficiência Comentada (BRASIL, 2008a) responde por um conjunto de investimentos, e não apenas do aporte de recursos, como também pela transferência de novos conhecimentos, experiências, tecnologias e equipamentos, sendo fundamental para o avanço e a disseminação da tecnologia assistiva em termos mundias.

O desenvolvimento e a popularização das tecnologias assistivas, peças de equipamentos ou sistemas de produtos, usadas para aumentar, manter ou melhorar habilidades de pessoas com limitações funcionais, sejam físicas ou sensoriais, que ao auxiliar no desempenho funcional de atividades, reduz incapacidades para a realização de atividades da vida diária e da vida prática, deverão ser um dos aspectos fundamentais da Cooperação Internacional. (VITAL, 2008, p. 105)

\subsection{Considerações do capítulo 2}

Os pressupostos teóricos apresentados neste capítulo serviram de base para o entendimento das definições de deficiência (Quadro 5) e de sua tipologia que abrange as deficiências física, auditiva, visual, intelectual e múltipla, bem como as suas respectivas formas de comunicação. 


\section{Definições relativas à deficiência}

[...] restrição física, mental ou sensorial, de natureza permanente ou transitória, que limita a capacidade de exercer uma ou mais atividades essenciais da vida diária, causada ou agravada pelo ambiente econômico e social. Decreto Federal nº 3956 (BRASIL, 2001)

[...] podem ser temporárias, ou permanentes, progressivas, regressivas ou estáveis, intermitentes ou contínuas. O desvio em relação ao modelo baseado na população pode ser leve ou grave e pode flutuar ao longo do tempo [...] (CIF, 2003)

[...] perda ou anormalidade de uma estrutura ou função psicológica, fisiológica ou anatômica. (BRASIL/CORDE, 2004)

[...] redução, limitação ou inexistência das condições de percepção das características do ambiente ou de mobilidade e de utilização de edificações, espaço, mobiliário, equipamento urbano e elementos, em caráter temporário ou permanente. (ABNT, 2004)

[...] perda ou anormalidade de uma estrutura e/ou função psicológica, fisiológica ou anatômica que gere incapacidade para o desempenho de atividade, dentro do padrão considerado normal para o ser humano; deficiência permanente - aquela que ocorreu ou se estabilizou durante um período de tempo suficiente para não permitir recuperação ou ter probabilidade de que se altere apesar de novos tratamentos. Decreto Federal $n^{\circ} 10.890$ (BRASIL, 2004)

Pessoas com deficiência são aquelas que têm impedimentos de longo prazo de natureza física, mental, intelectual ou sensorial, os quais, em interação com diversas barreiras, podem obstruir sua participação plena e efetiva na sociedade em igualdades de condições com as demais pessoas. Decreto Federal $n^{\circ} 6.949$ (BRASIL, 2009b)

Quadro 5 - Definições relativas à deficiência. Fonte: Elaborada pela autora com base nos documentos citados no quadro.

Em relação aos indicadores estatísticos relativos à deficiência no Brasil verificou-se que o dimensionamento da problemática da deficiência, tanto em termos qualitativos quanto quantitativos, é muito difícil em razão da inexistência quase total de dados e informações de abrangência nacional, produzidos sistematicamente, que retratem de forma atualizada a realidade do Brasil nesta área. Constatou-se que cada pessoa com deficiência apresenta diferentes níveis de dificuldades para a realização de uma mesma tarefa, e que os produtos e equipamentos oriundos da tecnologia assistiva possibilitam a estas pessoas executar as suas atividades com autonomia e independência relativas. A tecnologia assistiva é um dos fatores que possibilita a inclusão de crianças com deficiência na escola e na sociedade como um todo. 0 capítulo 2 forneceu os pressupostos teóricos relativos à deficiência que serviram de base para o desenvolvimento do capítulo 3 a seguir, relativo à inclusão da criança com deficiência no contexto social e escolar. 


\section{PRESSUPOSTOS TEÓRICOS RELATIVOS À INCLUSÃO ESCOLAR DOS ALUNOS COM NECESSIDADES EDUCATIVAS ESPECIAIS (NEE)}

\subsection{A exclusão social}

Castel (1997), busca chamar a atenção para o uso da expressão exclusão, que amarra os diferentes tipos de desigualdades, misérias do mundo e diferenças, sem que se interrogue sobre as dinâmicas sociais globais que são responsáveis pelo desequilíbrio e pelos estados de desfiliação e rupturas.

Em muitas sociedades a segregação social das pessoas com deficiência ainda é presente e esta se deve, dentre outros, a temores e crenças fortemente arraigadas, originadas de convicções culturais e religiosas, o que demonstra haver exclusão social. Dentre estas crenças, destaca-se a de que o homem deve ter a imagem e a semelhança de Deus e ser perfeito, deixando as pessoas com deficiência à margem da condição humana (PACHECO; COSTAS, 2005).

Goffman (1988) em seu estudo sobre a manipulação de identidades deterioradas investigou os diversos fatores ligados ao estigma do valor negativo atribuído a uma condição existencial, e destacou a visibilidade, o encobertamento e a identidade pessoal. As marcas da deficiência podem ser vistas não somente na pessoa com deficiência, mas em seu entorno, principalmente na família através das atitudes e comportamentos. Verifica-se que a discriminação social da pessoa com deficiência 
é um problema da sociedade que a estigmatiza e a separa, mas é igualmente um problema seu enquanto indivíduo/sociedade - produto e produtor de história. Sem esse pressuposto poderíamos correr o risco de "coisificar" e "vitimizar" o deficiente, perpetuando a ideia maniqueísta de força/fragilidade cabendo à sociedade o primeiro termo e ao deficiente 0 segundo. (AMARAL, 1995, p. XIX)

Castel (1997) discorre sobre a exclusão social que atinge um número imenso de situações diferentes, como o desempregado de longa duração que é espreitado pela depressão e talvez pelo suicídio, o jovem da periferia suscetível a delinquência, a taxonomia e talvez a AIDS, o sem domicílio fixo como o mendigo, dentre outros. "Falar em termos de exclusão é rotular com uma qualificação puramente negativa que designa a falta, sem dizer no que ela consiste e de onde provém." (CASTEL, 1997, p. 19).

O processo de diferencialismo ocorre não somente com as diferenças corporais e de comunicação, mas também no âmbito racial, sexual, etário e de classe social, sendo que "a preocupação com as diferenças tem se transformado, assim, em uma obsessão pelos diferentes." (SKLIAR, 2006, p. 24).

Antagonicamente ao termo exclusão, o termo inclusão tem sido bastante polêmico e desde a sua oficialização, em meados da década de 1990,

ora tratam-no como se fosse continuidade do processo de integração vivido por deficientes especialmente a partir da década de 70 , ora percebem-no como um conceito à parte, em si mesmo imbuído de status teórico suficiente para diferenciá-lo de qualquer outro arranjo historicamente proposto para um certo segmento da população apenas. (SANTOS, 2003, p. 64)

A sociedade inclusiva não é só um desejo social, mas um direito de todos os seus membros e atualmente há muitas lições a aprender. A força da legislação internacional relativa à proteção dos direitos humanos permite fortalecer a 
argumentação por uma sociedade mais justa, igualitária e inclusiva. Porém, é conhecida a resistência em torno da proteção constitucional à pessoa com deficiência, "que se converteu até num comportamento cultural da sociedade brasileira, sendo esperado um futuro próximo com uma sociedade menos preconceituosa e mais inclusiva." (SILVA NETO, 2007, p. 244). Para que a inclusão social de pessoas com deficiência ocorra, se faz necessário o ajuste da comunidade, dos espaços, das leis, enfim de toda a coletividade nessa direção, pois "a sociedade deve se apresentar responsável por todos os seus membros, proporcionando suporte e acolhimento." (ROCHA, 2006, p. 6).

A luta para que fossem respeitados os direitos de cidadania das pessoas com deficiência ganhou força após a Segunda Guerra Mundial. Esta mudança de comportamento e de visão social deve ser entendida dentro do conjunto de movimentos das chamadas minorias sociais que se multiplicaram pela Europa e, sobretudo nos Estados Unidos, particularmente, nos anos 1960 e 1970. (LOPES, M. E., 2007).

No Brasil, as questões referentes às pessoas com deficiência são conduzidas na esfera dos direitos humanos desde 1995, quando passou a existir a Secretaria Nacional de Cidadania do Ministério da Justiça. A política de inclusão social das pessoas com deficiência existe desde a Constituição Federal de 1988, que originou a Lei Federal $n^{\circ} 7.853$ (BRASIL, 1989), posteriormente regulamentada pelo Decreto Federal n 3.298 (BRASIL, 1999). Esses documentos nacionais, junto a outros, com destaque para as Leis Federais $n^{\circ} 10.048$ (BRASIL, 2000a) e $n^{\circ} 10.098$ (BRASIL, 
2000b) e o Decreto Federal n 5.296 (BRASIL, 2004), conhecido como o decreto da acessibilidade, nos colocam em igualdade com o ideário da Convenção da ONU (MAIOR, 2008).

No campo internacional, os movimentos sociais a favor da inclusão social favoreceram a elaboração da Convenção sobre os Direitos das Pessoas com Deficiência, resolução aprovada pela Assembléia Geral da ONU em 1975, que contribuiu significativamente para os princípios de igualdade e não-discriminação. Suas contribuições somam-se às trazidas pelas demais convenções do mesmo gênero como a

\begin{abstract}
"Convenção Concernente a Discriminação em Matéria de Emprego e Profissão" (1958), a "Convenção relativa à Luta contra a Discriminação no Campo do Ensino" (1960) e a "Convenção Internacional sobre a Eliminação de Todas as Formas de Discriminação Racial" (1965). Outras vieram depois, como a "Convenção sobre a Eliminação de Todas as Formas de Discriminação contra a Mulher" (1979), a "Declaração para a Eliminação de Todas as Formas de Intolerância e de Discriminação baseada em Religião ou Crença" (1982) e a "Convenção de Guatemala ou Convenção Interamericana para a eliminação de Todas as Formas de Discriminação contra as Pessoas Portadoras de Deficiência" (1999). (FÁVERO, 2007a, p. 84)
\end{abstract}

A ONU fixou 1981 como o Ano Internacional da Pessoa Deficiente colocando em evidência e em discussão, entre os países membros, a situação da população com deficiência no mundo e, particularmente, nos países em desenvolvimento, onde a pobreza e a injustiça social são agravantes desta situação. A principal consequência foi a aprovação na Assembléia Geral da ONU, realizada em 1982, do Programa de Ação Mundial para Pessoas com Deficiências, que ressalta o direito dessas pessoas a oportunidades idênticas às dos demais cidadãos, bem como o de usufruir, em condições de igualdade, das melhorias nas condições de vida resultantes do desenvolvimento econômico e do progresso social. Nesse programa, foram 
estabelecidas diretrizes nas diversas áreas de atenção à população com deficiência, como a de saúde, de educação, de emprego e renda, de seguridade social, de legislação, dentre outras, as quais os estados membros devem considerar na definição e na execução de suas políticas, seus planos e programas que contemplem as pessoas com deficiência. Consequentemente no Brasil foi promulgado o Decreto Federal n.0 3.956 (BRASIL, 2001) que reconhece o texto da Convenção Interamericana para a Eliminação de Todas as Formas de Discriminação contra as Pessoas Portadoras de Deficiência de 1999, também conhecida como Convenção da Guatemala $^{86}$, sendo considerado um marco na conquista pelos direitos das pessoas com deficiência, e que cita no artigo II:

[...] o termo "discriminação contra as pessoas portadoras de deficiência" significa toda diferenciação, exclusão ou restrição baseada em deficiência, antecedente de deficiência, consequência de deficiência anterior ou percepção de deficiência presente ou passada, que tenha o efeito ou propósito de impedir ou anular o reconhecimento, gozo ou exercício por parte das pessoas portadoras de deficiência de seus direitos humanos e suas liberdades fundamentais.

A Convenção Internacional para Proteção e Promoção dos Direitos e Dignidade das Pessoas com Deficiência (ONU, 2006), aprovada pela Assembléia Geral da ONU em Nova Iorque também abordou a questão da discriminação em razão da deficiência e cita no artigo $2^{\circ}$

Discriminação em razão da deficiência significa qualquer distinção, exclusão ou restrição em razão da deficiência, que tenha o propósito ou efeito de prejudicar ou anular o reconhecimento, apreciação ou exercício, com base na igualdade, de todos os direitos humanos e liberdades fundamentais na área política, econômica, social, cultural, civil ou qualquer outra área. Inclui todas as formas de discriminação, incluindo a negação de acomodações com adaptações adequadas [...]

${ }^{86}$ Disponível em: <http://www.cedipod.org.br/cedipod.htm>. Acesso em: 12 nov. 2010. 


\subsection{A inclusão escolar}

Inicialmente se faz necessário descrever o termo aluno com necessidades educacionais especiais (NEE), utilizado no contexto pedagógico, onde o termo NEE não substitui a palavra deficiência, pois a maioria das pessoas com deficiência pode apresentar necessidades especiais (na escola, no trabalho, no transporte etc.), mas nem todas as pessoas com necessidades especiais têm deficiência. As necessidades especiais são decorrentes

de condições atípicas como, por exemplo: deficiências, insuficiências orgânicas, transtornos mentais, altas habilidades, experiências de vida marcantes etc. Estas condições podem ser agravadas e/ou resultantes de situações socialmente excludentes (trabalho infantil, prostituição, pobreza ou miséria, desnutrição, saneamento básico precário, abuso sexual, falta de estímulo do ambiente e de escolaridade). Na integração escolar, os alunos com deficiência eram o foco da atenção. $\mathrm{Na}$ inclusão escolar, o foco se amplia para os alunos com necessidades especiais (dos quais alguns têm deficiência), já que a inclusão traz para dentro da escola toda a diversidade humana. (SASSAKI, 2008, p. 83)

A inclusão escolar é o processo de adequação da escola para que "todos os alunos possam receber uma educação de qualidade, cada um a partir da realidade com que chega à escola, independentemente de raça, etnia, gênero, situação socioeconômica, deficiências, dentre outros." (SASSAKI, 2008, p. 84). Historicamente, a proposta de integração escolar foi elaborada em 1972, na educação especial, por um grupo de profissionais da Escandinávia, na forma do chamado princípio de normalização. Este princípio se baseia no conceito de que todas as pessoas com deficiência têm o direito de usufruir de condições de vida o mais comum ou normal possível, na sociedade em que vivem (PACHECO; COSTAS, 2005). O movimento pela normalização e integração social "surgiu concomitantemente à depressão econômica decorrente da crise do petróleo, por volta da década de 1970, e serviu para fechar instituições e reduzir 
gastos." (MENDES, 2006, p. 400). Portanto, os determinantes econômicos exerceram influência no movimento de inclusão. O movimento pela inclusão escolar de crianças e jovens com NEE surgiu de forma mais focalizada nos Estados Unidos, e por força da penetração da cultura desse país, ganhou a mídia mundial ao longo da década de 1990, fazendo com que países europeus abandonassem a terminologia até então utilizada de integração (MENDES, 2006). Correia (1999) afirma que é favor da inclusão sempre que possível, e que a criança com deficiência tem o direito de usufruir da educação especial se necessário, quando o seu sucesso escolar não for assegurado na escola regular. A inclusão escolar defende a inserção de todos os alunos nas classes regulares com a manutenção dos serviços de educação especial.

Paralelamente à inclusão escolar, surgiu a proposta de inclusão total escolar ou full inclusion que é um movimento mais radical, originado da escola especial norteamericana, "[...] defendendo a inclusão de todas as pessoas, independentemente do tipo e grau de limitação, na classe regular, também, a eliminação dos programas especializados paralelos." (MATTOS et al., 2004, p. 56).

A proposta de inclusão total se encontra fundamentada na ética de participação e do desenvolvimento social sem a preocupação com ganhos acadêmicos, e é defendida pelos advogados dos direitos das pessoas com deficiências mais severas, enquanto a inclusão escolar tem como "população-alvo os indivíduos com limitações leves ou no máximo moderadas." (MENDES, 2006, p. 393). 
Surgem duas posições distintas, estando em um dos extremos a proposta da inclusão total onde todos os alunos devem ser incluídos na escola regular com a eliminação total do serviço de apoio de ensino especial. Do outro lado estão os adeptos da educação inclusiva que consideram que a melhor colocação dos alunos com NEE seria na classe comum, porém admitindo a possibilidade de serviços de suporte, ou mesmo ambientes diferenciados, como classes de recursos, classes especiais parciais ou autocontidas, escolas (ou instituições) especiais. Segundo Mendes (2006, p. 394), observa-se o "surgimento de um contexto histórico mundial que passou a reforçar cada vez mais a ideologia da educação inclusiva [...]"

Uma semelhança entre a inclusão escolar e a inclusão total escolar é a de que os teóricos de ambas postulam que na escola devem ocorrer mudanças estruturais e "ambas tiveram as suas origens no movimento pela integração escolar e buscavam a fusão dos sistemas de ensino regular e especial." (MENDES, 2006, p. 393).

No entanto a falta de recursos humanos e financeiros nas escolas brasileiras atuais "transforma aquilo que se chama educação inclusiva numa full inclusion forçada, isto é, a colocação de um aluno com NEE na sala regular sem nenhum atendimento especial, não por uma opção teórica que assume [...], mas por uma contingência." (MATTOS et al., 2004, p. 59).

As políticas e processos de inclusão de alunos com NEE no ensino regular tem sido "objeto de controvérsias, polêmicas e divergências, não só por parte do 
professorado, tanto da educação especial como do ensino regular, mas também por parte de especialistas, acadêmicos e pesquisadores." (SIQUEIRA, 2008, p. 310).

No Brasil, a proposta de escolarização adotada para alunos com NEE é a da inclusão escolar através da escola inclusiva e a educação inclusiva, descritas a seguir.

\subsubsection{A escola inclusiva e a educação inclusiva}

A escola inclusiva é aquela que deve ser capaz de acolher todo tipo de aluno e de lhe oferecer uma educação de qualidade com a pedagogia e o ritmo pedagógico compatíveis com as suas habilidades, necessidades e expectativas. As escolas passam a ser chamadas inclusivas no momento em que decidem aprender com os alunos o que deve ser eliminado, modificado, substituído ou acrescentado no sistema escolar para que ele se torne totalmente acessível. Isto permite que cada aluno possa aprender mediante seu ritmo e estilo de aprendizagem e com o uso de todas as suas capacidades. A escola inclusiva percebe o aluno como um ser único e ajudao a aprender como uma pessoa por inteiro (SASSAKI, 2008). As escolas e as classes inclusivas não deveriam estar interessadas em incluir nas escolas regulares uma categoria particular de alunos, como os com deficiência ou NEE, sendo que o interesse deveria se encontrar "em como operar as turmas e as escolas como comunidades que proporcionam apoio aos seus membros e que incluam e satisfaçam as necessidades de todos os alunos." (STAINBACK; STAINBACK, 1999, p. 229). Na 
escola inclusiva é praticada a educação inclusiva, ambas originadas da proposta da inclusão escolar.

A educação inclusiva teve início nos Estados Unidos através da Lei Pública n ${ }^{\circ}$ 94.142, de 1975 , e ainda em processo de estabelecimento de seus programas e projetos. A educação inclusiva é o conjunto de princípios e procedimentos implementados pelos sistemas de ensino para adequar a realidade das escolas à realidade do alunado que, por sua vez, deve representar toda a diversidade humana (SASSAKI, 2008). "Não se trata de manter todos os alunos fisicamente juntos, durante o maior período educacional possível, senão de conciliar dois princípios tão antagônicos [...] como a igualdade e a diversidade." (COLL; PALACIOS; MARCHESI, 1995, p. 324). Quando se pensa em educação inclusiva, surge a questão de quem se pretende incluir.

"Educação" e "Inclusão" já são por excelência impactantes, cada uma carrega em si um valor positivo. Diante do impacto desta fórmula "Educação Inclusiva", emerge, na maioria das vezes, um sentimento primário de que devemos incluir pessoas e grupos que não participam da educação. (SILVA FILHO; FOGLI, 2007, p. 2)

Segundo a Secretaria de Educação Especial $(\operatorname{SEESP} / \mathrm{MEC})^{87}$, educação inclusiva é uma questão de direitos humanos e implica a definição de políticas públicas, traduzidas nas ações institucionalmente planejadas, implementadas e avaliadas.

A concepção que orienta as principais opiniões acerca da educação inclusiva é de que a escola é um dos espaços de ação e de transformação, que conjuga a ideia de políticas educacionais e políticas sociais amplas que garantam os direitos da população. A implantação de propostas com vistas à construção de uma educação inclusiva requer mudanças nos processos de gestão, na formação de professores, nas metodologias educacionais, com ações compartilhadas e práticas colaborativas que respondam às necessidades de todos os alunos.

A promoção da educação inclusiva é fundamentada no princípio da universalização do acesso à educação e na atenção à diversidade e requer uma filosofia de educação de qualidade para todos.

87 SEESP - Secretaria de Educação Especial (MEC). Educação inclusiva. Disponível em: $<$ http://portal.mec.gov.br/seesp/index.php?option=content\&task=view\&id=106>. Acesso em: $21 \mathrm{fev}$. 2009. 
Stainback e Stainback (1999), discorrendo sobre estratégias para construção de um contexto inclusivo na escola, concluíram que o planejamento das ações deve contar com o consentimento e participação da pessoa com deficiência e sua família, usar informações concentradas na pessoa, manter a dignidade e o respeito, usar uma abordagem baseada nas potencionalidades, atentar para a redução da ênfase dos rótulos, preescrever em vez de descrever, envolver a pessoa como participante ativo, estimular perguntas e identificar fontes de suporte e de informação.

\subsubsection{Boas práticas de educação inclusiva no cenário internacional}

As duas grandes Guerras Mundiais, dentre outros fatores, impulsionaram o desenvolvimento das questões relativas às pessoas com deficiência, como a questão da inclusão das crianças com deficiência na escola. Em alguns países a educação inclusiva apresenta bons resultados, sendo objeto de estudo de orgãos internacionais. Em Israel as crianças com deficiência física, com deficiência intelectual e com dificuldades de aprendizagem são colocadas em níveis pedagógicos adequados em função da natureza da sua deficiência, para ajudá-los a alcançar maior integração na vida social e profissional da sua comunidade. Assim, algumas crianças são atendidas em configurações especiais, enquanto outras frequentam escolas regulares. A responsabilidade pela inclusão destes alunos é compartilhada por profissionais de saúde, psicólogos, assistentes sociais e profissionais da educação especial, bem como pela família e grupos de apoio comunitários. Uma comissão 
constituída por Lei e designada pelo Ministro da Educação determina a seleção de crianças com deficiência para os programas de educação especial. ${ }^{88}$

Segundo Silva (2009), têm-se elaborado leis em Portugal que asseguram as condições para que todos os alunos, mesmo os que têm problemáticas mais complexas, como é o caso da surdocegueira e do autismo, possam frequentar a escola regular. Foram criadas unidades de atendimento para estes alunos, que são originalmente, salas de recursos para toda a escola.

A Agência Européia para o Desenvolvimento (AGÊNCIA EUROPEIA PARA O DESENVOLVIMENTO EM NECESSIDADES EDUCATIVAS ESPECIAIS, 2003) realizou um projeto que pretendeu identificar, analisar, descrever e disseminar as práticas de sala de aula eficazes em contextos inclusivos relativos aos alunos de faixa etária dos 7 aos 11 anos. Nesse projeto foram selecionados, descritos e analisados exemplos de boas práticas de educação inclusiva em 15 países europeus (Noruega, Suíça, Luxemburgo, Holanda, Portugal, Bélgica, Islândia, França, Suécia, Irlanda, Áustria, Alemanha, Finlândia, Grécia e Finlândia). Como resultado dessa pesquisa, destaca-se que os problemas de comportamento, sociais e/ou emocionais, representam o maior desafio na inclusão de alunos com NEEs. A gestão da diversidade na sala de aula constitui o segundo maior desafio e, os estudos de caso realizados e as discussões com os especialistas sugerem que, o que é bom para os alunos com NEEs é bom

${ }^{88}$ Disponível em: <http://www.israelmybeloved.com/channel/israel_today/article/96>. Acesso em: 6 jul. 2010. 
para todos os alunos. Finalmente, abordagens como o ensino cooperativo ${ }^{89}$, a

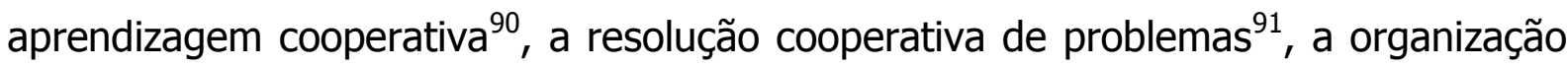
de grupos heterogêneos ${ }^{92}$ e 0 ensino efetivo ${ }^{93}$ parecem contribuir para a implementação de salas de aula inclusivas. A seguir, são apresentadas práticas escolares realizadas por alguns dos países participantes da pesquisa realizada pela Agência Européia para o Desenvolvimento.

Na Finlândia se adota como prática inclusiva a divisão dos alunos em grupos menores e heterogêneos. Sempre que possível alguns grupos podem juntar-se para constituir um grupo de ensino maior. O tamanho dos grupos é determinado em função do tema da aula a ser abordado, por exemplo, nas disciplinas de música, de ciências e de artes, os grupos são maiores, enquanto nas de matemática e língua materna os grupos são menores.

$\mathrm{Na}$ Noruega revela-se que as equipes educativas que se ocupam de uma classe apresentam um trabalho altamente coordenado. Os professores são distribuídos em equipes educativas para cada nível de ensino, de forma que os alunos não tenham

${ }^{89}$ Os professores precisam de apoio e colaborar com os colegas da escola e com profissionais exteriores à escola.

90 A tutoria entre pares ou a aprendizagem cooperativa é eficaz para a aprendizagem e para o desenvolvimento cognitivo e afetivo (socioemocional) dos alunos.

${ }^{91}$ Especialmente para os professores que precisam de ajuda para a inclusão de alunos com problemas sociais e comportamentais, uma abordagem sistemática dos comportamentos indesejáveis na sala de aula, constitui um meio para diminuir a quantidade e a intensidade dos distúrbios durante as aulas.

${ }^{92} \mathrm{~A}$ formação de grupos heterogêneos e uma abordagem diferenciada são necessárias e eficazes para a gestão da diversidade na sala de aula. Os objetivos a atingir, as diferentes formas de aprendizagem, o ensino flexível e a constituição de pequenos grupos incrementam a educação inclusiva.

93 Todos os alunos e, consequentemente, também aqueles que apresentam NEE, fazem progressos caso o seu trabalho seja sistematicamente planejado, controlado e avaliado. O currículo pode ser adaptado às necessidades individuais e pode ser adequadamente, introduzido um apoio adicional através de programas educativos 
que se relacionar com um grande número de adultos. A equipe cobre todos os conteúdos curriculares de cada nível. Trata-se de uma medida concebida para criar um enquadramento que se traduz na segurança dos alunos. Os professores com formação adicional em educação especial fazem parte integrante das equipes. Na Suíça, o docente de apoio prepara materiais que o docente da turma pode utilizar, se necessário. Além disso, há encontros e reuniões com os pais, com o diretor da escola especial e com o professor de turma. A boa relação entre todos constitui um prérequisito para o sucesso do projeto integrativo.

A Áustria não adota o critério de faixa etária para a divisão das salas (como ocorre no Brasil), e sim o do nível pedagógico. Uma classe com alunos de diferentes idades reflete em uma educação conjunta de crianças com capacidades heterogêneas, desde o jardim de infância até ao quarto ano de escolaridade, numa única classe. 0 objetivo é o de respeitar os diferentes ritmos de aprendizagem durante toda a escolaridade primária.

\subsubsection{A escola especial e a educação especial}

No Brasil, a atenção às pessoas com deficiência surgiu com o caráter de atendimento elementar, nas áreas de educação e de saúde, desenvolvidas em instituições filantrópicas, evoluindo depois para o atendimento de reabilitação, sem assumir, contudo, uma abordagem integradora desse processo e preservando, na maioria dos casos, uma postura assistencialista (BRASIL, 2008a). O atendimento a pessoas com 
deficiências começa, ainda à época do Império, com a fundação de duas instituições:

o Imperial Instituto dos Meninos Cegos (atual Instituto Benjamin Constant), em 1854, e o Instituto dos Surdos-Mudos, (atual Instituto Nacional da Educação dos Surdos - INES), em 1856 ambos no Rio de Janeiro (KASSAR, 1999, p. 18).

A escola especial ou escola de educação especial oferece atendimento especializado, separado da rede regular de ensino, somente para os alunos com deficiência, sempre que, em função das condições específicas dos alunos, não for possível ${ }^{94}$ a sua integração nas classes comuns de ensino regular. A escola especial seria uma mediação (não um complemento) $)^{95}$ para o ensino comum, sendo somente obrigatória a sua oferta no ensino fundamental. Cada escola especial é especializada em somente uma deficiência principal e a sua associação com outras deficiências, limitações, condições ou disfunções. A educação especial é oferecida também na rede regular, pois segundo o Decreto Federal $\mathrm{n}^{0} 6.253$ (BRASIL, 2007), o atendimento educacional especializado poderá ser oferecido pelos sistemas públicos de ensino ou pelas instituições conveniadas (ver item 3.2.2.1).

Segundo a Lei Federal no 9.394 (BRASIL, 1996), que estabelece as diretrizes e bases da educação nacional (LDBEN) descreve no Capítulo V a educação especial,

Art. 58. Entende-se por educação especial, para os efeitos desta Lei, a modalidade de educação escolar, oferecida preferencialmente na rede regular de ensino, para educandos portadores de necessidades especiais.

${ }^{94}$ Segundo Carneiro (2008), as crianças com severos comprometimentos de saúde e deficiências graves, devem permanecer em escolas especiais, pois necessitam de cuidados de saúde que as impedem, ao menos temporariamente, de ingressarem na escola regular. Caso ocorra uma melhora dessa condição de saúde, essas crianças terão o direito de frequentar escolas comuns da rede regular, caso estas realmente ofereçam as condições necessárias para tal.

${ }^{95} \mathrm{O}$ aluno cursa a escola especial ou a escola regular. 
$\S 10$ Haverá, quando necessário, serviços de apoio especializado, na escola regular, para atender às peculiaridades da clientela de educação especial.

$\S 200$ atendimento educacional será feito em classes, escolas ou serviços especializados, sempre que, em função das condições específicas dos alunos, não for possível a sua integração nas classes comuns de ensino regular.

$\S 3^{\circ} \mathrm{A}$ oferta de educação especial, dever constitucional do Estado, tem início na faixa etária de zero a seis anos, durante a educação infantil [...]

Art. 60. Os órgãos normativos dos sistemas de ensino estabelecerão critérios de caracterização das instituições privadas sem fins lucrativos, especializadas e com atuação exclusiva em educação especial, para fins de apoio técnico e financeiro pelo Poder Público.

Parágrafo único. O Poder Público adotará, como alternativa preferencial, a ampliação do atendimento aos educandos com necessidades especiais na própria rede pública regular de ensino, independentemente do apoio às instituições previstas neste artigo. ${ }^{96}$

Segundo o Decreto Federal no 6.571 (BRASIL, 2008c), que dispõe sobre o atendimento educacional especializado e complementa a Lei Federal no 9.394 (BRASIL, 1996), e o Decreto Federal no 6.253 (BRASIL, 2007), considera-se atendimento educacional especializado o conjunto de recursos de acessibilidade e de atividades pedagógicas organizados institucionalmente, prestados de forma complementar ou suplementar à formação dos alunos no ensino regular. Descreve-se o atendimento educacional especializado como sendo destinado aos alunos com deficiência, transtornos globais do desenvolvimento e altas habilidades ou superdotação, sendo que o referido Decreto determina:

Art. 3ํำ 0 Ministério da Educação prestará apoio técnico e financeiro às seguintes ações voltadas à oferta do atendimento educacional especializado, entre outras que atendam aos objetivos previstos neste Decreto:

I - implantação de salas de recursos multifuncionais;

II - formação continuada de professores para o atendimento educacional especializado;

III - formação de gestores, educadores ${ }^{97}$ e demais profissionais da escola para a educação inclusiva;

IV - adequação arquitetônica de prédios escolares para acessibilidade;

$V$ - elaboração, produção e distribuição de recursos educacionais para a acessibilidade; e

VI - estruturação de núcleos de acessibilidade nas instituições federais de educação superior.

\footnotetext{
${ }^{96}$ Disponível em: <http://www.planalto.gov.br/ccivil_03/Leis/L9394.htm>. Acesso em: 15 nov. 2010.

${ }^{97}$ Verifica-se que a inclusão de alunos com deficiência nas classes comuns de ensino envolve tanto os professores do ensino regular quanto professores especializados, sendo "este fato um entrave à inclusão devido à falta de qualidade na formação dos professores." (OLIVEIRA, 2008, p. 169).
} 


\subsubsection{Serviços de educação especial oferecidos na rede municipal de ensino de São Paulo}

Os serviços de educação especial previstos para aos alunos com NNEs abrangem a educação infantil (onde se insere a pré-escola), o ensino fundamental e o ensino médio ${ }^{98}$ e são oferecidos na Rede Municipal de Ensino de São Paulo aos alunos:

com deficiência intelectual, visual, física, auditiva e múltipla, surdocegos, alunos com condutas típicas de quadros neurológicos, psiquiátricos e psicológicos, com altas habilidades e superdotação que, no contexto escolar, evidenciam necessidades educacionais especiais e demandam atendimento educacional especializado. A escola, para o atendimento da diversidade dos alunos deve se organizar para, em conjunto com os professores, funcionários, pais e alunos, elaborar o seu projeto pedagógico, planejando ações que favoreçam o processo de desenvolvimento e aprendizagem dos alunos levando-se em conta as mobilizações indispensáveis ao atendimento das necessidades educacionais especiais de cada um. (Disponível em: <http://educacao.prefeitura.sp.gov.br>. Acesso em: 20 jul. 2010)

O Decreto Municipal no 45.652 (SÃO PAULO/MUNICÍPIO, 2004b) busca viabilizar e dar sustentação ao desenvolvimento do trabalho pedagógico junto aos alunos com NEEs através dos serviços oferecicos pela Secretaria Municipal de Educação de São Paulo (SMESP) descritos a seguir ${ }^{99}$ :

\section{a) Centro de Formação e Acompanhamento à Inclusão (CEFAI)}

Em funcionamento nas 13 Diretorias Regionais de Educação (DRE) do município de São Paulo, tem como atribuições, o acompanhamento aos alunos com deficiência por meio de visitas sistemáticas às escolas, avaliação pedagógica, reuniões com professores e coordenadores pedagógicos, atendimentos a pais, mapeamento dos atendimentos da região. $\mathrm{O}$ atendimento ao aluno com NEE é dividido em duas

\footnotetext{
${ }^{98}$ Ver item 3.2.3.1.

${ }_{99}$ Disponível em: <http://portalsme.prefeitura.sp.gov.br/Anonimo/EdEsp/escolas.aspx>. Acesso em: 22 jul. 2010.
} 
etapas: o primeiro ocorre na sede do CEFAI com a triagem das famílias, onde é feito cadastro e anamnese (histórico de vida), e o segundo é o encaminhamento das mesmas para matrícula no Ensino Municipal e na Sala de Apoio e Acompanhamento à Inclusão (SAAI).

\section{b) Atuação do Professor de Apoio e Acompanhamento à Inclusão (PAAI)}

O CEFAI é composto por Professores de Apoio e Acompanhamento à Inclusão que devem ter especialização comprovada ou habilitação nas áreas das deficiências física, intelectual, visual e auditiva, e desenvolvem ações que podem abranger alunos, professores, pais e funcionários. Os PAAIs são encarregados em fazer um trabalho de acompanhamento dos alunos com NEEs incluídos nas Unidades Educacionais, que abrangem: Centro Educacional Integrado (CEI), Escola Municipal de Educação Infantil (EMEI), Escola Municipal de Ensino Fundamental (EMEF), Escola Municipal de Ensino Fundamental e Médio (EMEFM) e Centro Integrado de Educação de Jovens e Adultos (CIEJA), orientando a equipe técnica e professores do ensino regular, quanto às adequações curriculares para a inclusão destes alunos, oferecendo materiais adaptados que facilitam o aprendizado do educando.

\section{c) Salas de Apoio e Acompanhamento à Inclusão (SAAI)}

As Salas de Apoio e Acompanhamento à Inclusão, instaladas nas unidades educacionais da rede municipal de ensino, são destinadas ao atendimento educacional em caráter complementar, suplementar ou exclusivo aos alunos que 
apresentam algum tipo de deficiência. Após verificação da listagem da SME ${ }^{100}$ constatou-se que existem apenas oito Escolas Municipais de Educação Infantil (EMEI) com este tipo de serviço.

\section{d) Escolas Municipais de Educação Especial (EMEE)}

As EMEEs são escolas de educação especial e destinam-se àqueles alunos que não conseguem acompanhar classes regulares por falta de um trabalho de estimulação ${ }^{101}$ da fala e da audição ${ }^{102}$ e de oportunidade de desenvolvimento de linguagem (PFEIFER, 1999). "As EMEE destinam-se às crianças, adolescentes, jovens e adultos com deficiência auditiva (surdez), surdocego ou com outras deficiências, limitações, condições ou disfunções associadas à deficiência auditiva"103. No município de São Paulo existem seis EMEE (ver item 4.3.2.2).

\section{e) Instituições conveniadas}

Os convênios de educação especial firmados entre a SMESP e as 40 instituições (ver item 4.3.2.3.) visam os seguintes atendimentos: escolar, educacional (apoio), terapêutico, avaliação e oficinas profissionalizantes. Esses atendimentos são oferecidos em caráter transitório, na perspectiva de se garantir a permanência ou o retorno à classe comum. Porém, estas instituições, muitas vezes

são apresentadas como um momento necessário de segregação, para uma posterior integração mais eficiente, como se precisássemos (ou pudéssemos) estar abstraindo a pessoa de seu

${ }^{100}$ Disponível em: <http://www.portalsme.prefeitura.sp.gov.br/documentos/edesp/saai.pdf>. Acesso em: 21 jul. 2010.

101 As crianças chegam à escola sem uma forma de comunicação, pois os pais desconhecem a LIBRAS.

${ }^{102}$ Para os alunos com deficiência auditiva que apresentam algum resíduo de audição.

${ }^{103}$ Disponível em:

<http://portalsme.prefeitura.sp.gov.br/Anonimo/EdEsp/escolas.aspx?MenuID=166\&MenuIDAberto>. Acesso em: 22 jul. 2010. 
contexto social, a fim de "consertá-la" ou torná-la "menos diferente", e depois devolvê-la a este contexto, de forma que não haveria ou haveria menos motivo para estigmatizá-la e marginalizála nos inúmeros espaços sociais. (FERREIRA, 1994, p. 7)

Verificou-se no decorrer da pesquisa que apenas algumas das instituições conveniadas oferecem o atendimento educacional para alunos com deficiência na forma de escolas especiais e/ou de apoio pedagógico especializado (que ocorre em alguns dias da semana). Para frequentar o apoio pedagógico especializado o aluno deve estar obrigatoriamente matriculado em uma escola regular ou em uma escola de educação especial. ${ }^{104}$

\subsubsection{Críticas à educação inclusiva e especial}

A Declaração de Salamanca (BRASIL, 1994) propõe o atendimento de todos em escolas comuns inclusivas, e considera a manutenção e/ou ampliação de recursos educacionais especiais, tal como pode ser constatado em suas orientações: nas escolas comuns inclusivas, as crianças com NEEs devem receber todo apoio adicional necessário para garantir uma educação eficaz. As escolas especiais públicas ${ }^{105} \mathrm{e}$ privadas estão inseridas no sistema educacional como prestadoras do atendimento educacional especializado. A educação especial seria uma mediação para o ensino comum, só permanecendo nela as crianças com problemas que não permitam a participação das mesmas no ensino comum [...] (JANNUZZI, 1992, p. 61).

\footnotetext{
${ }^{104}$ Informações fornecidas pelas diretoras das escolas especiais nas entrevistas realizadas.

${ }^{105}$ São oferecidas pelos municípios através de escolas municipais ou instituições credenciadas.
} 
Aranha (1979, p. 24) com base em seus estudos, apresentou uma série de críticas às instituições criadas exclusivamente para a educação da criança com deficiência, tais como: isolamento social, construções precárias e inadequadas, intensa estimulação para comportamentos adaptativos ao ambiente institucional; desenvolvimento de comportamentos que dificultam a vida na sociedade mais ampla; situações que extinguem comportamentos que são requisitados e desejáveis na sociedade. Em seu estudo em inúmeras instituições educacionais especializadas no atendimento de pessoas com deficiência mental, Kassar (1999) percebeu que a questão integração nem sempre era tratada de forma adequada, pois:

De um lado, ouvíamos o discurso sobre integração presente como lema em vários momentos da prática educativa. Por outro lado, notávamos uma resistência, por parte das pessoas com deficiências e de suas famílias, em relação ao processo de inserção dos educandos em novas instituições sociais: seja no momento de encaminhamento para a escola regular, seja no "fim" do processo de escolaridade, aos 18 anos.

[...] Parece-nos que a organização da educação especial em nosso país vem promovendo uma caracterização específica do atendimento de modo que, sob a administração particular, tem sido atendido os considerados mais lesados e, sob a administração pública, os chamados "educáveis".

[...] As "instituições assistenciais" ganham o estatuto de "Organismos (ou organizações) Não Governamentais" (as "ONGS") e a "ambiguidade" entre os setores públicos e privados é apresentada como uma necessária e fundamental "parceria" para o desenvolvimento do país. (KASSAR, 1999, p. 35)

Em contrapartida, autores como Batista e Enumo (2004), Pacheco e Costas (2005) e Bourdieu (2003) defendem que a inclusão de alunos com NEEs nas escolas e classes comuns da rede regular de ensino traz efeitos negativos do isolamento social dessas crianças, em especial no caso da deficiência intelectual. Segundo pesquisa realizada por Batista e Enumo (2004), os alunos com deficiência intelectual são rejeitados nas classes comuns da rede regular de ensino, passando a maior parte do tempo de recreio sozinhos; e demonstrando dificuldades para iniciar, manter e finalizar os contatos sociais com os colegas. 
Um outro aspecto que pode explicar essa dificuldade de relacionamento com os colegas está no fator tempo de exposição desses alunos a situações sociais mais amplas, cuja baixa frequência acaba por levá-las a agir estereotipadamente, reforçando as diferenças existentes entre eles. Com essa análise, percebe-se que esses alunos encontram-se incluídos fisicamente, mas não social e emocionalmente [...] (BATISTA; ENUMO, 2004, p. 20)

Na medida em que a área cognitiva do desenvolvimento de crianças classificadas com deficiência intelectual é considerada crítica, se faz relevante o conhecimento das relações existentes entre o desenvolvimento cognitivo e o processo de interação social. Deduz-se, a partir desses estudos, que o processo de inclusão de crianças com deficiência no ensino regular lhes possibilita interagir espontaneamente em situações diferenciadas, enquanto adquirem conhecimento e se desenvolvem. Porém, para que esta integração ocorra, não bastam resoluções de cunho legal ou teórico, uma vez que variáveis relacionadas a processos grupais e reações de preconceito podem influenciar neste processo (PACHECO; COSTAS, 2005).

Autores como Carneiro (2008), Aranha (1979) e Kassar (1999) são a favor da inclusão de alunos com NEEs nas escolas e classes comuns da rede regular de ensino, pois a mesma evitaria os efeitos negativos do isolamento social dessas crianças, criando oportunidades para a interação entre todas as crianças, inclusive como forma de diminuir o preconceito.

A consciência da educação escolar em relação às crianças com deficiência ainda é vista como uma opção. Muitos pais diante de um ambiente educacional comum, sem preparo e hostil, preferem optar por manterem seus filhos com deficiência em ambientes especializados ou em casa. Segundo a legislação internacional, 
A escolarização comum inclusiva é um meio mais eficaz para fomentar a solidariedade entre as crianças com necessidades especiais e seus colegas. A escolarização de crianças em escolas especiais - ou classes especiais na escola de caráter permanente - deveria ser uma exceção, só recomendável naqueles casos, pouco frequentes, nos quais se demonstre que a educação nas classes comuns não pode satisfazer às necessidades educativas ou sociais da criança, ou quando é necessário para o bem-estar da criança ou de outras crianças. ${ }^{106}$

Para as crianças pertencentes às classes economicamente mais favorecidas, estão à

disposição centros de reabilitação sofisticados e clínicas particulares.

De certo modo, na história da educação especial, o atendimento à população mais comprometida revela-se, apenas, quando enfocamos as "margens" da educação, através das "parcerias" do atendimento entre os setores públicos e privado. Não há previsão direta de atendimento a alunos com deficiências severas pelo serviço público, especialmente no setor educacional. Portanto a história da educação das pessoas com deficiências graves, à primeira vista, não poderia ser explicada pela historia da legislação educacional (KASSAR, 1999, p.41).

Segundo Bourdieu (2003), a escola, em nome da igualdade de oportunidades, na

verdade, contribui para a perpetuação das desigualdades sociais.

[...] no que se relaciona ao aluno com deficiência mental, observamos que a exclusão escolar não se limita à questão de origem social, mas parece se basear, principalmente, na condição de incapaz vinculada à imagem da pessoa com deficiência. A partir do momento em que essa imagem é quebrada, parece que as chances de progressão escolar se tornam mais palpáveis, muito embora os mecanismos de seleção e eliminação não desapareçam. Logo, se esse rótulo da deficiência mental não é quebrado, ele acompanha o aluno mesmo depois de ter saído da classe especial, o que consequentemente, o leva a vivenciar experiências de fracasso escolar. (SANTOS, 2008, p. 461).

[...]a baixa escolaridade alcançada, o isolamento social a que foram submetidos, tanto no âmbito familiar como escolar, as poucas chances de serem aceitos em outros grupos sociais e a imobilização pessoal gerada em decorrência dos inúmeros fracassos sofridos ao longo da trajetória, os deixam sem muita perspectiva de vida escolar e/ou social, ou de trabalho. (SANTOS, 2008, p. 463).

As crianças deveriam ser coautoras do processo de inclusão, pois segundo Sekkel (2004, p. 180), "se tornam importantes parceiras neste contexto, pois o professor não participa de todas as atividades durante todo o tempo no período escolar".

${ }^{106}$ Disponível em: <http://portal.mec.gov.br/seesp/arquivos/pdf/salamanca.pdf>. Acesso em: ab. 2009. 
Constata-se que faltam estudos mais abrangentes relativos à avaliação e a trajetória dos alunos com NEEs nas escolas e classes comuns da rede regular de ensino, em relação ao seu aprendizado, a forma de avaliação e as interações sociais que ocorrem naturalmente entre alunos com deficiência e os demais, focalizando o papel do outro como mediador de sua interação com a sociedade, buscando uma avaliação da educação inclusiva no Brasil.

Segundo Gugel et al. (2007, p. 150), para que a inclusão escolar ocorra são necessárias "a revisão no sistema de avaliação, com a introdução de um relatório de progresso, a quebra de barreiras arquitetônicas, a disponibilização de intérprete e o ensino da língua de sinais (LIBRAS), material didático e ensino em Braille, dentre outras."

\subsubsection{A questão da faixa etária na pré-escola}

É inegável que as práticas de ensino devem acolher as peculiaridades de cada aluno, independentemente de terem ou não deficiência. Entretanto, não é isso o que as escolas no Brasil têm feito e este é um dos condicionantes para que a educação escolar das pessoas com deficiência possa acontecer, de modo satisfatório, nas classes comuns de ensino regular.

A Declaração de Salamanca (BRASIL, 1994) define que as escolas inclusivas devem reconhecer e responder às necessidades diversas dos alunos, acomodando ambos os 
estilos e ritmos de aprendizagem e assegurando uma educação de qualidade a todos através da revisão e da melhoria do currículo, dos arranjos organizacionais, das estratégias de ensino, do uso de recursos e da parceria com as comunidades, pois

as tradicionais rotulações e divisões de alunos em turmas aparentemente homogêneas não são garantias de aprendizado. Ainda que nessas turmas os conteúdos escolares pareçam ser aprendidos mais facilmente, o entendimento efetivo desses conteúdos não é o mesmo para todos os alunos. Os alunos com deficiência mental, especialmente os casos mais severos, são os que forçam a escola a reconhecer a inadequação de suas práticas para atender às diferenças dos educandos. De fato, as práticas escolares convencionais não dão conta de atender à deficiência mental, em todas as suas manifestações, assim como não são adequadas às diferentes maneiras de os alunos, sem qualquer deficiência, abordarem e entenderem um conhecimento de acordo com suas capacidades. Essas práticas precisam ser urgentemente revistas [...] (CARNEIRO, 2008, p. 144)

Com a promulgação da Lei Federal n 11.114 (BRASIL, 2005) e da Indicação CEE 52, (SÃO PAULO/ESTADO, 2005), houve alterações nos artigos da Lei no 9.394 (BRASIL, 1996) em relação a faixa etária e a duração do ensino fundamental. O objetivo desta nova lei é ampliar a escolaridade e antecipar o ingresso das crianças no ensino fundamental, que passa a ter a duração de nove anos. Segundo a nova legislação, a educação escolar compõe-se de educação básica formada pela educação infantil, ensino fundamental e ensino médio; e educação superior. A educação infantil, primeira etapa da educação básica, tem como finalidade o desenvolvimento integral da criança até 6 anos de idade e é oferecida em:

- creches, ou entidades equivalentes, para crianças de até 3 anos de idade;

- pré-escolas, para as crianças de 4 a 6 anos de idade.

Em relação à faixa etária dos alunos com NEEs, geralmente a escola regular de educação inclusiva adota a faixa etária descrita acima para a divisão dos níveis da educação infantil, ao invés do nível pedagógico, como ocorre em alguns países como a Áustria (ver item 3.2.1.1). Em algumas das escolas especias participantes da 
pesquisa os alunos eram divididos segundo o nível pedagógico, havendo alunos de 4 a 15 anos na pré-escola.

Verificou-se na pesquisa de campo a existência de alunos com deficiência múltipla severa com mais de 10 anos sem qualquer forma de comunicação desenvolvida. Esses foram obrigados a se matricular na escola regular de ensino fundamental segundo o critério etário para poder adquirir o direito de frequentar o apoio especializado em instituição conveniada com a Prefeitura de São Paulo. Entretanto, estes alunos deveriam frequentar a educação infantil da escola regular, em função do nível pedagógico e da falta de comunicação ${ }^{107}$. Neste sentido, verifica-se que "as ações e políticas do MEC têm prejudicado o processo de inclusão escolar na realidade brasileira [...]" (MENDES, 2006, p. 400), onde se ressalta a falta de integração entre o poder público e a sociedade civil, a imposição de uma concepção única de política de inclusão não consensual que gera incompreensão e consequente resistência à mesma, centralização do debate educacional no aluno com NEE ao invés da melhoria da educação como um todo, dentre outros. No Brasil, todos os alunos, e em particular os com deficiência, deveriam ser avaliados pelos progressos que alcançaram nas diferentes áreas do conhecimento e a partir de seus talentos e potencialidades, habilidades naturais e construção de todo tipo de conhecimento escolar, havendo um reconhecimento e uma valorização por parte da escola das diferenças presentes entre eles.

107 Informações cedidas em conversa informal com assistente social de uma instituição que presta o apoio pedagógico especializado aos alunos com deficiência múltipla severa. 


\subsection{Legislação relevante ao aluno com NEE}

\subsubsection{Legislação Internacional}

Dentre as diretrizes e recomendações internacionais, tem sido referência importante para a constituição da legislação brasileira relativa à educação inclusiva, a partir da década de 1990, aquelas emanadas da Conferência Mundial de Educação para Todos, realizada em Jomtien, na Tailândia, em 1990 (citada no item 1.2). O documento síntese dessa conferência, intitulado Declaração Mundial sobre Educação para Todos e o Plano de Ação para Satisfazer as Necessidades Básicas de Aprendizagem (BRASIL, 1990), além de representar um consenso mundial sobre uma visão abrangente de educação básica, contém recomendações e diretrizes gerais com vistas a impulsionar os países a assumirem o compromisso político de garantir educação para todos. Em decorrência das deliberações da referida declaração, realizou-se em Salamanca, na Espanha, a Conferência Mundial sobre Necessidades Educativas Especiais: acesso e qualidade, em 1994, que aprovou o documento Declaração de Salamanca e Linha de Ação sobre Necessidades Educativas Especiais (BRASIL, 1994). Nesse documento são encontradas recomendações e orientações para que Organizações Governamentais (OG) e Organizações Não Governamentais (ONG) possam garantir educação para todos, considerando como princípio norteador que esta educação deva se dar através da escola comum. Ainda que na Declaração de Salamanca (BRASIL, 1994) seja proposto o atendimento de todos em escolas comuns inclusivas, não se desconsidera a manutenção e/ou ampliação de recursos educacionais especiais. 
A Carta para o Terceiro Milênio (REHABILITATION INTERNATIONAL, 1999) foi aprovada em 1999, em Londres, Grã-Bretanha, pela Assembléia Governativa da Rehabilitation International ${ }^{108}$. Esta Carta apela aos Países-Membros para que apoiem a promulgação de uma Convenção das Nações Unidas sobre os direitos das pessoas com deficiência.

A Convenção da Guatemala ou Convenção Interamericana para a Eliminação de Todas as Formas de Discriminação contra as Pessoas Portadoras de Deficiência, promulgada no Brasil pelo Decreto Federal no 3.956 (BRASIL, 2001) tem por objetivo prevenir e eliminar todas as formas de discriminação contra as pessoas com deficiência e propiciar a sua plena integração à sociedade.

A Convenção Internacional sobre os direitos das pessoas com deficiência foi uma Resolução aprovada pela Assembléia Geral da ONU em Nova York, em 30 de março de 2007. Esta Convenção adota a total inclusão educacional, bem como garante o direito aos apoios e instrumentos específicos para aqueles que necessitam de adaptações. Para esta Convenção não há acesso à educação fora de um sistema educacional inclusivo em todos os níveis.

${ }^{108}$ A tradução foi feita do original em inglês pelo consultor de inclusão Romeu Kazumi Sassaki. 


\subsubsection{Legislação Federal (Brasil)}

A legislação relacionada aos alunos com NEEs no Brasil é relativamente recente e passível de constante análise crítica, pois ocorrem contradições entre o conteúdo que se encontra na legislação e a sua aplicação prática. A falta de conhecimento acerca das deficiências e das necessidades que elas acarretam é um fator que muitas vezes torna o processo de inclusão por demais idealista e pouco prático, em função das condições em que se encontram as escolas da rede regular de ensino. Essas escolas se tornaram inclusivas por uma imposição da lei. A legislação específica à educação especial também se apresenta contraditória ao longo de sua trajetória, pois ora apoia, ora não apoia as instituições que prestam o serviço especializado de educação especial.

As leis importantes que favorecem a inclusão de alunos com NEEs no Brasil foram, muitas vezes, reflexo de ações internacionais (item 3.3.1). Destaca-se a Lei Federal $n^{0} 7.853$ (BRASIL, 1989) que fixa as diretrizes de garantias nas áreas da educação, saúde e criminalização do preconceito, porém esta Lei reflete certa distorção em relação ao que se extrai da Constituição Federal (BRASIL, 1988) e da Convenção da Guatemala (BRASIL, 2001), pois:

Os termos constantes ao garantir as pessoas com deficiência o direito de acesso ao ensino regular "sempre que possível", "desde que capazes de se adaptar", refletem uma época histórica em que a integração esteve bastante forte, principalmente no Brasil. Na ótica da integração, é a pessoa com deficiência que tem de se adaptar a sociedade, e não necessariamente a sociedade é que deve criar condições para evitar a exclusão. A integração é, portanto, a contraposição do atual movimento mundial de inclusão. Neste existe um esforço bilateral, mas é principalmente a sociedade que deve impedir que a exclusão ocorra. (CARNEIRO, 2008, p. 140) 
O direito à educação pela criança e pelo adolescente com deficiência é assegurado pela Lei Federal no 8.069 (BRASIL, 1990) referente ao Estatuto da Criança e do Adolescente - Educação Especial, que em seu Capítulo IV - Do Direito à Educação, à Cultura, ao Esporte e ao Lazer, determina:

Art. 53. A criança e o adolescente têm direito à educação, visando o pleno desenvolvimento de sua pessoa, preparo para o exercício da cidadania e qualificação para o trabalho assegurandoIhes:

I - igualdade de condições para o acesso e permanência na escola;

III - atendimento educacional especializado aos portadores de deficiência, preferencialmente na rede regular de ensino.

O Decreto Federal n. 03.956 (BRASIL, 2001) que reconhece o texto da Convenção Interamericana para a Eliminação de Todas as Formas de Discriminação contra as Pessoas Portadoras de Deficiência de 1999, também conhecida como Convenção da Guatemala- considerado um marco na conquista pelos direitos das pessoas com deficiência, determina no artigo II:

[...] o termo "discriminação contra as pessoas portadoras de deficiência" significa toda diferenciação, exclusão ou restrição baseada em deficiência, antecedente de deficiência, consequência de deficiência anterior ou percepção de deficiência presente ou passada, que tenha o efeito ou propósito de impedir ou anular o reconhecimento, gozo ou exercício por parte das pessoas portadoras de deficiência de seus direitos humanos e suas liberdades fundamentais.

Porém, o referido Decreto trata de forma genérica e sem escopo específico a definição de quem é a pessoa com deficiência; mantendo-se então "o uso em conjunto da Convenção da Guatemala e o do Decreto Federal n 5.296 de 2004" (ARAÚJO, 2007, p. 17), que regulamenta a Lei Federal $n^{\circ} 10.048$ (BRASIL, 2000a) (que dá prioridade de atendimento às pessoas que especifica) e a Lei Federal $\mathrm{n}^{0}$ 10.098 (BRASIL, 2000b) (que estabelece as normas gerais e os critérios básicos para a promoção da acessibilidade das pessoas com deficiência ou mobilidade reduzida). Após a Convenção de Guatemala é exigida uma reinterpretação da Lei de Diretrizes e 
Bases da Educação Nacional (BRASIL, 1996), e a educação especial ${ }^{109}$ "é vista como um modelo de tratamento desigual aos alunos desrespeitando as disposições desta Convenção" (CARNEIRO, 2008, p. 131).

A Lei Federal $n^{0} 10.172$ (BRASIL, 2001) aprova o Plano Nacional de Educação e reconhece a educação especial mesmo com a tendência da inclusão do aluno com NEEs no sistema regular de ensino. No que diz respeito às políticas públicas de educação especial ${ }^{110}$, destaca-se a Política Nacional de Integração da Pessoa Portadora de Deficiência, definida pela Coordenadoria Nacional para Integração da Pessoa Portadora de Deficiência (CORDE), em 1992; o Relatório das Diretrizes Nacionais para a Educação Especial na Educação Básica, de 2001 e o Programa de Complementação ao Atendimento Educacional Especializado às Pessoas Portadoras de Deficiência (PAED), criado em 2004 e que tem por finalidade garantir, supletivamente, recursos financeiros para as escolas de educação especial (PACHECO; COSTAS, 2005).

A Lei Federal $n^{0} 10.845$ (BRASIL, 2004) que institui o Programa de Complementação ao Atendimento Educacional Especializado às Pessoas Portadoras de Deficiência, determina em seu art. $3^{\circ}$ que é facultado aos Estados, ao Distrito Federal e aos Municípios prestar apoio técnico e financeiro às entidades privadas sem fins lucrativos que oferecem educação especial ${ }^{111}$.

\footnotetext{
${ }^{109}$ Neste caso a educação especial se refere àquela dada exclusivamente aos alunos com deficiência. 110 Educação especial refere-se à educação para crianças com necessidades especiais; também chamada de educação inclusiva.

${ }^{111} \mathrm{Na}$ forma de:
} 


\section{A Convenção sobre os Direitos das Pessoas com Deficiência (BRASIL, 2007)} reconhece o direito das pessoas com deficiência à educação ${ }^{112}$. O Decreto Federal no 6.571 (BRASIL, 2008c) dispõe sobre o atendimento educacional especializado, dentre outros, e determina a adequação arquitetônica de prédios escolares para acessibilidade através dos núcleos de acessibilidade ${ }^{113}$.

Verifica-se que existe a necessidade de que as leis federais promulgadas sejam complementadas e principalmente cumpridas, buscando evitar a falta de acesso ao ambiente urbano, a dificuldade de implantação da educação inclusiva, pela dificuldade de inclusão social, dentre outros.

I - cessão de professores e profissionais especializados da rede pública de ensino, bem como de material didático e pedagógico apropriado;

II - repasse de recursos para construções, reformas, ampliações e aquisição de equipamentos;

III - oferta de transporte escolar aos educandos portadores de deficiência matriculados nessas entidades[...] Disponível em: <http://www.planalto.gov.br>. Acesso em: 5 dez. 2010.

112 Esta convenção determina no artigo 24, relativo à EDUCAÇÃO:

[...] 2. Para a realização desse direito, os Estados Partes assegurarão que:

a. As pessoas com deficiência não sejam excluídas do sistema educacional geral sob alegação de deficiência e que as crianças com deficiência não sejam excluídas do ensino primário gratuito e compulsório ou do ensino secundário, sob alegação de deficiência;b. As pessoas com deficiência possam ter acesso ao ensino primário inclusivo, de qualidade e gratuito, e ao ensino secundário, em igualdade de condições com as demais pessoas na comunidade em que vivem [...]

Disponível em: <http://www.planalto.gov.br>. Acesso em: 5 dez. 2010.

113 Determina que:

$\S 1^{\mathrm{a}}$ Considera-se atendimento educacional especializado o conjunto de atividades, recursos de acessibilidade e pedagógicos organizados institucionalmente, prestado de forma complementar ou suplementar à formação dos alunos no ensino regular [...]

Art. $2^{\circ}$ São objetivos do atendimento educacional especializado:

Art. $3^{\circ} \mathrm{O}$ Ministério da Educação prestará apoio técnico e financeiro às seguintes ações voltadas à oferta do atendimento educacional especializado, entre outras que atendam aos objetivos previstos neste Decreto:

I - implantação de salas de recursos multifuncionais;

II - formação continuada de professores para o atendimento educacional especializado;

III - formação de gestores, educadores e demais profissionais da escola para a educação inclusiva;

IV - adequação arquitetônica de prédios escolares para acessibilidade;

$V$ - elaboração, produção e distribuição de recursos educacionais para a acessibilidade; e

VI - estruturação de núcleos de acessibilidade nas instituições federais de educação superior.

$\S 1^{\circ}$ As salas de recursos multifuncionais são ambientes dotados de equipamentos, mobiliários e materiais didáticos e pedagógicos para a oferta do atendimento educacional especializado $s[. .$.

$\S 3^{\circ}$ Os núcleos de acessibilidade nas instituições federais de educação superior visam eliminar barreiras físicas, de comunicação e de informação que restringem a participação e o desenvolvimento acadêmico e social de alunos com deficiência [...] (BRASIL, 2008c). 


\subsubsection{Legislação no Estado de São Paulo}

A legislação relacionada aos alunos com NEEs no Estado de São Paulo é mais voltada para questões práticas, na tentativa de cumprir a legislação federal existente. Destaca-se a Lei Estadual $n^{0} 9.167$ (SÃO PAULO/ESTADO, 1995), que cria o Programa Estadual de Educação Especial, que visa o atendimento das crianças com deficiências física, mental ou sensorial, dentro de escolas comuns. Esta Lei promove a inclusão de disciplinas relativas à educação especial nos cursos de magistério, cursos de preparação de pessoal especializado na educação relacionada às deficiências, censos escolares periódicos, dentre outros. Entretanto, somente em 2001, é promulgada a Lei Estadual $n^{0} 10.958$ (SÃO PAULO/ESTADO, 2001) que torna oficial a LIBRAS, incentivando o ensino da mesma nas escolas especiais e inclusivas para as crianças com deficiência auditiva.Destaca-se ainda o Decreto Estadual $\mathrm{n}^{0}$ 48.060 (SÃO PAULO/ESTADO, 2003) que autoriza a Secretaria da Educação a celebrar convênios (ver item 3.2.2.1) com instituições sem fins lucrativos com atuação em educação especial, para promover o atendimento de alunos com NEEs. Este decreto fortaleceu e incentivou a educação especial, reconhecendo o seu valor e o seu relevante papel em nossa sociedade.

\subsubsection{Legislação no Município de São Paulo}

A legislação relacionada aos alunos com NEEs no município de São Paulo seguiu de perto a trajetória internacional. 
A Portaria Municipal n 5.718 (SÃO PAULO/MUNICÍPIO, 2004c) dispõe sobre a regulamentação do Decreto Municipal n 45.415 (SÃO PAULO/MUNICÍPIO, 2004a) e estabelece diretrizes para a Política de Atendimento a Crianças, Adolescentes, Jovens e Adultos com Necessidades Educacionais Especiais no Sistema Municipal de Ensino, determinando em seu art. $1^{0}$ que os serviços de Educação Especial (ver item 3.2.2.1), serão oferecidos na rede municipal de ensino através:

1 - do Centro de Formação e Acompanhamento à Inclusão (CEFAI);

2 - da atuação dos Professores de Apoio e Acompanhamento à Inclusão (PAAI);

3 - das Salas de Apoio e Acompanhamento à Inclusão (SAAI)

4 - das Escolas Municipais de Educação Especial (EMEE)

5 - das Entidades Conveniadas

O Decreto Municipal no 45.415 (SÃO PAULO/MUNICÍPIO, 2004a) foi complementado pelo Decreto Municipal no 45.652 (SÃO PAULO/MUNICÍPIO, 2004b) e busca viabilizar e dar sustentação ao desenvolvimento do trabalho pedagógico junto aos alunos com NEEs. Este decreto define a demanda para atendimento educacional especializado ${ }^{114}$.

\footnotetext{
${ }^{114}$ Os identificados no parágrafo primeiro do artigo $4^{\circ}$ :

Entende-se por crianças, adolescentes, jovens e adultos com necessidades educacionais especiais aqueles cujas necessidades educacionais se relacionem com diferenças determinadas, ou não, por deficiências, limitações, condições e/ou disfunções no processo de desenvolvimento e altas habilidades/superdotação. Mais especificamente, os serviços de educação especial têm como responsabilidade o atendimento das crianças, adolescentes, jovens e adultos, matriculados na RMESP, com deficiência (intelectual, visual, física, auditiva, múltipla e surdocegueira), com transtornos globais do desenvolvimento, com altas habilidades/superdotação, que, num dado contexto escolar, tais necessidades educacionais especiais demandem atendimento educacional especializado [...] (SÃO PAULO/MUNICÍPIO, 2004a)
} 


\subsection{Vertentes pedagógicas da educação infantil}

Na Europa e na América do Norte, a expansão das instituições de educação infantil no século XIX foi associada ao trabalho materno fora do lar, a partir da Revolução Industrial. Os pensadores como Comenius, Rousseau, Pestalozzi, Froebel e Montessori, influenciaram os primórdios da educação infantil no Brasil (BRUSCATO, 2008).

O educador tcheco Jan Amos Komenský (em Português Comenius ou Comênio), nasceu em 1592 e foi o criador da didática moderna e um dos maiores educadores do século XVII. Comenius concebeu uma teoria humanista e espiritualista da formação do homem que resultou em propostas pedagógicas hoje consagradas ou tidas como muito avançadas. Entre essas ideias estavam: o respeito ao estágio de desenvolvimento da criança no processo de aprendizagem, a construção do conhecimento através da experiência, da observação e da ação e uma educação sem punição, mas com diálogo, exemplo e ambiente adequado. Comenius pregava ainda a necessidade da interdisciplinaridade, da afetividade do educador e de um ambiente escolar arejado, bonito, com espaço livre e ecológico. ${ }^{115}$

O pensador Jean-Jacques Rousseau nasceu na Suiça em 1712 e combateu as ideias de que a teoria e a prática educacional junto à criança deviam focalizar os interesses dos adultos e da vida adulta e afirmava que a educação é a expressão livre da

\footnotetext{
${ }^{115}$ Disponível em: <http://www.centrorefeducacional.com.br/comenius.htm>. Acesso em: 2 mar. 2009.
} 
criança no seu contato com a natureza, criticando a severidade da instrução e do uso excessivo da memória (SEESP/SEED/MEC, 2004).

Para a mentalidade contemporânea, amor talvez não seja a primeira palavra que venha à cabeça quando se fala em ciência, método ou teoria. Mas o afeto teve papel central na obra de pensadores que lançaram os fundamentos da pedagogia moderna. Nenhum deles deu mais importância ao amor, em particular ao amor materno, do que o educador suíço Johann Heinrich Pestalozzi, nascido em 1746. A escola idealizada por Pestalozzi deveria ser não só uma extensão do lar, como inspirar-se no ambiente familiar, para oferecer uma atmosfera de segurança e afeto (FERRARI, 2004).

O educador Friedrich Froebel nascido em 1782, foi o fundador na Alemanha em 1840 do Jardim de Infância, ou Kindergarten, relativo a uma instituição pré-escolar tipicamente educativa (KISHIMOTO, 1988). Os jardins de infância froebelianos penetraram nas instituições particulares brasileiras no início do século $X X$, como inovação pedagógica, destinadas à elite da época, como exemplo de modernidade. Froebel chegou a escrever sobre a educação para a mais tenra idade, como no seu livro para as mães com sugestões de cantigas, brincadeiras e cuidados com os bebês, porém o jardim de infância não foi pensado para esta faixa etária (KUHLMANN JR.; BARBOSA, 1998). Segundo Andrade (1996), Froebel teve a oportunidade de ter contato direto com a prática pedagógica de Pestalozzi, associada à influência de Rousseau e aos seus conhecimentos científicos e filosóficos, prática que serviu de base para as suas ideias e práticas educacionais. 
A educadora Maria Montessori nasceu na Itália (1870-1952), formou-se em medicina, iniciando um trabalho com crianças com deficiência na clínica de uma universidade. A pedagogia Montessoriana relaciona-se à normatização, que consiste em harmonizar a interação de forças corporais e espirituais, corpo, inteligência e vontade. As escolas do Sistema Montessoriano são difundidas pelo mundo todo e o método Montessoriano tem por objetivo a educação da vontade e da atenção, com o qual a criança tem liberdade de escolher o material a ser utilizado, além de proporcionar a cooperação. Os princípios fundamentais do Sistema Montessoriano são: a atividade, a individualidade e a liberdade, enfatizando os aspectos biológicos. Os estímulos externos formariam o espírito da criança, precisando, portanto serem determinados. Assim, na sala de aula, a criança era livre para agir sobre os objetos sujeitos à sua ação, mas estes já estavam preestabelecidos, como os conjuntos de jogos e outros materiais que a própria educadora Montessori desenvolveu. A pedagogia de Montessori insere-se no movimento das Escolas Novas, como uma oposição aos métodos tradicionais que não respeitavam as necessidades e os mecanismos evolutivos do desenvolvimento da criança e ocupou um papel de destaque devido às novas técnicas que apresentou para os jardins de infância e para as primeiras séries do ensino fundamental. ${ }^{116}$

No cenário dos anos 1920 e 1930 no Brasil, uma parcela expressiva da intelectualidade brasileira envolveu-se em importantes e acirrados debates sobre temas educacionais, pois os mesmos eram vistos como instrumento de superação de um quadro de atraso, bem como meio de afirmação de uma realidade nacional em

${ }^{116}$ Centro de Referência Educacional. Disponível em: <http://www.centrorefeducacional.com.br/montesso.html>. Acesso em: 4 de mar. de 2009. 
bases modernas (GONDRA, 2002). O movimento chamado Escola Nova esboçou-se, na década de 1920, no Brasil. O mundo vivia, à época, um momento de crescimento industrial e de expansão urbana e, nesse contexto, um grupo de intelectuais brasileiros sentiu necessidade de preparar o país para acompanhar esse desenvolvimento. A educação era por eles percebida como o elemento-chave para promover a remodelação requerida. Inspirados nas ideias político-filosóficas de igualdade entre os homens e do direito de todos à educação, esses intelectuais viam num sistema estatal de ensino público, livre e aberto, o único meio efetivo de combate às desigualdades sociais da nação. O movimento ganhou impulso na década de 1930, após a divulgação do Manifesto dos Pioneiros da Educação Nova (1932) que defendia a universalização da escola pública, laica e gratuita. ${ }^{117}$ Este documento consolidava a visão de um segmento da elite intelectual que, embora com diferentes posições ideológicas, vislumbrava a possibilidade de interferir na organização da sociedade brasileira do ponto de vista da educação. A escola integral e única proposta pelo manifesto era definida em oposição à escola existente, chamada de tradicional. A principal crítica a respeito da educação brasileira daquele momento é de que se compunha de um ensino fragmentado, sem articulação entre os diversos ensinamentos e deles com o mundo. Redigido por Fernando de Azevedo, o texto foi assinado por 26 intelectuais, entre os quais Anísio Teixeira e Cecília Meireles (BOMENY, 2007). Outros pontos tocados pelo Manifesto de 1932 referem-se à questão da unidade versus uniformidade da educação nacional. A exigência de um sistema de organização educacional deveria gerar a unidade, porém não a uniformidade educativa (BARROS, 2007).

${ }^{117}$ Disponível em: <http://pt.wikipedia.org/wiki/Escola_Nova>. Acesso em: dez. 2008. 
As teorias cognitivo-construtivistas da aprendizagem imprimem um caráter determinante às concepções prévias dos alunos, em função da ênfase do aluno como construtor do seu próprio conhecimento e sujeito responsável pelas suas aprendizagens. As concepções construtivistas tiveram forte impacto no ensino das ciências, pois se preocupava com o aprender a pensar e o aprender a aprender, e não com a obtenção de comportamentos observáveis, mas de responsabilizar o aluno pelo seu percurso pessoal de aprendizagem e ajudá-lo neste processo. Essa teoria dá pouca atenção à aprendizagem por descoberta, com exceção dos níveis etários baixos. A formação de conceitos é um tipo de aprendizagem por descoberta envolvendo formulação e testagem de hipóteses. Os modelos pedagógicos construtivistas dão especial realce às construções prévias que orientam os alunos na compreensão da nova informação apresentada pelos professores ou pelos manuais e dificilmente se aprende sem integrar as redes de conhecimento anterior à nova informação (VASCONCELOS; PRAIA; ALMEIDA, 2003).

É interessante notar que tanto no construtivismo como na Escola Nova, "assumiram um acento de valor claramente negativo o verbo ensinar e a expressão transmissão de conhecimentos" (DUARTE, 1998, p. 3), pois o professor é reduzido a alguém que fornece condições para que o aluno construa por si mesmo o conhecimento.

As teorias construtivistas representam um "esforço na busca de caminhos que deem conta da complexidade do processo de aprendizagem" (ARANHA, 1996, p. 202), tendo como principais representantes estudiosos de psicologia e medicina que desenvolvem uma concepção interacionista ou construtivista do conhecimento. A partir dos anos 1980, o construtivismo se disseminou pelo Brasil, baseado 
principalmente nas ideias de Jean Piaget (1896-1980), suiço formado em biologia, "que também se interessou por filosofia e psicologia." (ARANHA, 1996, p. 202). O construtivismo é apresentado como o prolongamento de uma corrente de ideias oriunda, sobretudo da obra teórica de Piaget, que se desloca da filosofia para investigar como o sujeito humano produz conhecimento, e que remonta às primeiras décadas do século XX (REVAH, 2008).

Lev Semenovich Vygotsky ${ }^{118}$ foi pedagogo e professor, e posteriormente, psicólogo. No campo da educação, Vygotsky lecionou literatura, estética, história da arte e psicologia mantendo sempre a preocupação de relacionar educação e psicologia. "Percebeu que, nas experiências realizadas com as situações escolares, o contexto socioinstitucional nunca era levado em conta [...]" (SINDER, 1997, p. 185).

Vigotsky dedicou-se ao ensino e a pesquisa e organizou o Laboratório de Psicologia para Crianças com Deficiência, e posteriormente estudou medicina. "Teve contato com a obra de Piaget e, embora a elogie em muitos aspectos, também a critica, por não ter dado a devida importância à situação social e ao meio." (SINDER, 1997, p. 207). Na perspectiva de Vigotsky, a grande tarefa do ensino reside em transmitir para a criança aquilo que ela não é capaz de aprender por si só.

Ele valora de forma altamente positiva a transmissão à criança dos conteúdos historicamente produzidos e socialmente necessários. As aprendizagens que a criança realiza sozinha não são, evidentemente, descartadas nessa concepção. Mas é preciso ficar claro que tais aprendizagens não produzem desenvolvimento, elas atuam apenas no âmbito daquilo que já se desenvolveu na criança. (DUARTE, 1998, p. 4)

${ }^{118}$ Nasceu na Rússia czarista em 1896 e morreu de tuberculose em 1934, com 37 anos. 
Vigotsky desenvolveu um grande trabalho teórico e prático, guiado pelo princípio de que cabe ao processo educativo, ou seja, ao professor dirigir o desenvolvimento psíquico do indivíduo e não caminhar a reboque de um desenvolvimento espontâneo e natural. Além das denominações socioconstrutivismo, sociointeracionismo e sociointeracionismo-construtivista, a Escola de Vigotsky foi chamada no Brasil também de construtivismo pós-piagetiano (GROSSI; BORDIN, 1993).

A obra de Vygostky influenciou as políticas e orientações educativas, propôs reformular a psicologia de sua época, "por considerá-la incapaz de explicar coerentemente os processos psicológicos do homem. Vinculado às artes, à literatura, à semiótica e à educação, ele pôde ampliar sua visão do homem psicológico" (SINDER, 1997, p. 184).

Vygotsky considerou a escola como espaço de atuação da psicologia, pois nela se realizam sistemática e intencionalmente as construções e a gênese das funções psíquicas superiores, que seriam resultado da influência cultural na aprendizagem e no desenvolvimento. Vygotsky buscou enfatizar a ligação entre as pessoas e o contexto cultural em que vivem e são educadas e desenvolveu o conceito de zona de desenvolvimento proximal, onde todo bom ensino é aquele que se direciona para as funções psicológicas emergentes, trazendo consequências educacionais. Segundo Vygotsky, a criança aprende melhor quando é confrontada com tarefas que impliquem um desafio cognitivo não muito discrepante, e o ensino deve atuar no limite da "zona de desenvolvimento proximal, estimulando os processos internos maturacionais que terminam por se efetivar, passando a constituir a base para novas 
aprendizagens." (SINDER, 1997, p. 185). Essa teoria tem implicações importantes no processo de instrução: o professor deve proporcionar aos alunos a oportunidade de aumentarem as suas competências e conhecimento, partindo daquilo que eles já sabem, levando-os a interagir com outros alunos em processos de aprendizagem cooperativa.

Em relação aos métodos pedagógicos utilizados atualmente nas escolas no Brasil sejam eles construtivistas ou tradicionais, os mesmos são reinterpretados pelo professor em função do cotidiano escolar, onde ocorre

a fragmentação do trabalho, a alienação do sujeito em prol do cumprimento de papéis idealmente constituídos (necessidade de responder às expectativas da escola por alunos disciplinados, limpos e arrumados; necessidade de se enquadrar nos critérios muitas vezes arbitrários de bom professor: o que enche a lousa de lição, o que obtém dos alunos os melhores cadernos), as intempéries do próprio sistema de ensino (mudanças repentinas das regras do jogo, do sistema de avaliação, dos conteúdos pedagógicos a serem ministrados, da metodologia de ensino empregada, mudanças das crianças de classe durante o ano letivo etc.). (SAWAYA, 2000, p. 3)

A introdução das teorias construtivistas nas escolas brasileiras nas últimas décadas tem enfrentado inúmeros problemas relativos à formação dos professores, agravados diante da exigência de reciclagem e de atualização. Muitos professores têm "dificuldade em superar o autoritarismo, o dirigismo e o empirismo tradicional." (ARANHA, p. 207, 1996).

As atividades escolares realizadas pelos professores são "atividades cotidianas em que vigora a lei do salve-se quem puder e se recorre a formas de comportamento comprometidas não com a razão objetiva, mas com a razão pragmática da vida 
cotidiana [...]" (SAWAYA, 2000, p. 3), gerando obstáculos ao processo de aprendizado dos alunos.

O estudo apresentado ${ }^{119}$ anteriormente (AGÊNCIA EUROPEIA PARA O DESENVOLVIMENTO EM NECESSIDADES EDUCATIVAS ESPECIAIS, 2003), relativo às boas práticas de educação inclusiva no cenário internacional, verificou que o papel do professor é fundamental para a promoção da inclusão dos alunos com NEEs não somente na sala de aula, mas nos outros ambientes que o aluno utiliza durante a sua permanência na escola, como um todo.

\subsection{Considerações do capítulo 3}

Os métodos pedagógicos descritos serviram como base teórica para um maior entendimento e contextualização da educação infantil, modalidade em que se insere a pré-escola. No presente estudo apresenta-se a premissa secundária (item 1.5) de que independentemente do método pedagógico adotado pela pré-escola, os seus ambientes devem oferecer condições de acessibilidade física, dentre outras, para a inclusão dos alunos com deficiência.

O tema da inclusão escolar é polêmico e gera opiniões divergentes entre diversos autores. Durante o processo de execução deste capítulo, ficaram evidentes as justificativas da inclusão dos alunos com NEEs na rede regular de ensino, relativas

${ }^{119}$ Ver item 3.2.1.1. 
aos preceitos teóricos e da legislação internacional e consequente brasileira, ligados à luta pelos direitos sociais, como o direito à educação pública, que se traduz na igualdade de oportunidades, e na igualdade da educação. Na prática, o precário sistema de ensino regular existente em nosso país ainda não oferece as condições necessárias para que a inclusão de alunos com todos os tipos de deficiência ocorra efetivamente. Muitas crianças não falantes em decorrência da deficiência física do tipo PC, da múltipla deficiência sensorial e da deficiência auditiva oriundas de camadas menos favorecidas da população, chegam à pré-escola sem ter uma forma de comunicação com as pessoas (mesmo com a sua família) e com sérios problemas cognitivos, e necessitam de atendimento especializado disponibilizado por instituições de educação especial. Os resultados de alguns estudos acadêmicos que acompanharam a trajetória de crianças com deficiência, especialmente a intelectual, na rede regular e em instituições que prestam serviços na educação especial são contraditórios, ora afirmam que na rede regular a inclusão não é satisfatória, devido ao isolamento destas crianças, a alta densidade na sala de aula e a falta de capacitação dos professores, ora afirmam que as instituições especializadas em educação especial não apresentam condições favoráveis para a inclusão. Deduz-se que tanto a rede regular como as instituições que prestam serviços na educação especial apresentam uma situação precária em relação ao atendimento aos alunos com NEEs, condizente com a situação geral de um país em desenvolvimento como o Brasil. Ferreira, E. D. de S. (2006) questiona a possibilidade de se construir uma escola inclusiva em uma sociedade excludente como a do Brasil, com uma das piores distribuições de renda no mundo e com milhões de habitantes abaixo da linha da pobreza. As atuais propostas de inclusão escolar, mesmo em tempo de globalização, 
chegam a um Brasil que não apresenta uma história bem sucedida de bem estar social e com uma população pobre e carente e, nela, pessoas com deficiência.

A diversidade e a particularidade de cada deficiência permitem afirmar que se fazem necessários maiores estudos relativos à inclusão de alunos com as várias deficiências na pré-escola pública de ensino regular objetivando a verificação do grau de inclusão dos mesmos. Acredita-se que a inclusão de alunos com NEEs deve ocorrer se a rede regular de ensino oferecer as condições necessárias para tal, como instalações apropriadas às necessidades específicas de cada deficiência, equipe pedagógica especializada, equipe de apoio aos professores, material didático, material referente à tecnologia assistiva, conscientização da comunidade visando a diminuição do preconceito, dentre outros.

Neste sentido, é evidente que este capítulo não tem a pretensão de ser uma resposta definitiva a todos os questionamentos gerados, pois o objetivo é o de oferecer um panorama da inclusão dos alunos com NEEs, subsídio para a pesquisa de campo.

Em relação à legislação brasileira relativa às pessoas com deficiência verifica-se que, apesar de o Brasil ser um dos poucos países que tem uma legislação específica, que ainda é ampla e avançada em relação às demais, estas pessoas continuam a compor "as percentagens mais elevadas das estatísticas de exclusão social." (RESENDE; VITAL, 2008, p. 18). Para corroborar esta afirmação basta proceder a análise da baixa presença de pessoas com deficiência com acesso a escola, ao trabalho, ao 
meio urbano e rural (acessibilidade física dos espaços), aos transportes e aos serviços de saúde e reabilitação. 


\section{FUNDAMENTOS METODOLÓgICOS DA PESQUISA DE CAMPO}

\subsection{Estratégia de pesquisa: estudos de casos múltiplos incorporados}

Experimentos, levantamentos, pesquisas históricas, análise de informações, estudos de caso, dentre outras, são maneiras de realizar uma pesquisa. Cada estratégia é selecionada em função do tipo de pesquisa, do controle que o pesquisador possui sobre os eventos comportamentais, e do tipo de fenômeno (histórico ou contemporâneo) (YIN, 2005). Na presente tese adotou-se a estratégia de pesquisa denominada estudo de caso, pois busca compreender fenômenos sociais complexos relativos à inclusão escolar da criança com deficiência, ou seja, o pesquisador tem pouco controle sobre os acontecimentos e direciona o foco da pesquisa para os fenômenos atuais inseridos no cotidiano escolar.

Segundo Yin (2005, p. 31), "a principal tendência em todos os tipos de estudo de caso, é que ela tenta esclarecer uma decisão ou um conjunto de decisões: o motivo pelo qual foram tomadas, como foram implementadas e com quais resultados." 0 autor classifica o estudo de caso em: estudo de caso único e estudos de casos múltiplos. Os estudos de casos múltiplos aumentaram nos últimos anos em especial em pesquisas que envolvem escolas.

Aconselha-se a escolha de projetos de casos múltiplos a projetos de caso único, caso haja possibilidade de escolha e recursos, pois 
Mesmo que você só possa fazer um estudo de caso "de dois casos", suas chances de fazer um bom estudo de caso serão melhores do que usar um projeto de caso único. Os projetos de caso único são vulneráveis no mínimo porque você terá apostado "todas as suas fichas num único número". Mais importante do que isso, os benefícios analíticos de ter dois (ou mais) casos podem ser substanciais. (YIN, 2005, p. 75)

A seguir é apresentada a Figura 18, relativa ao método de estudo de caso múltiplos.

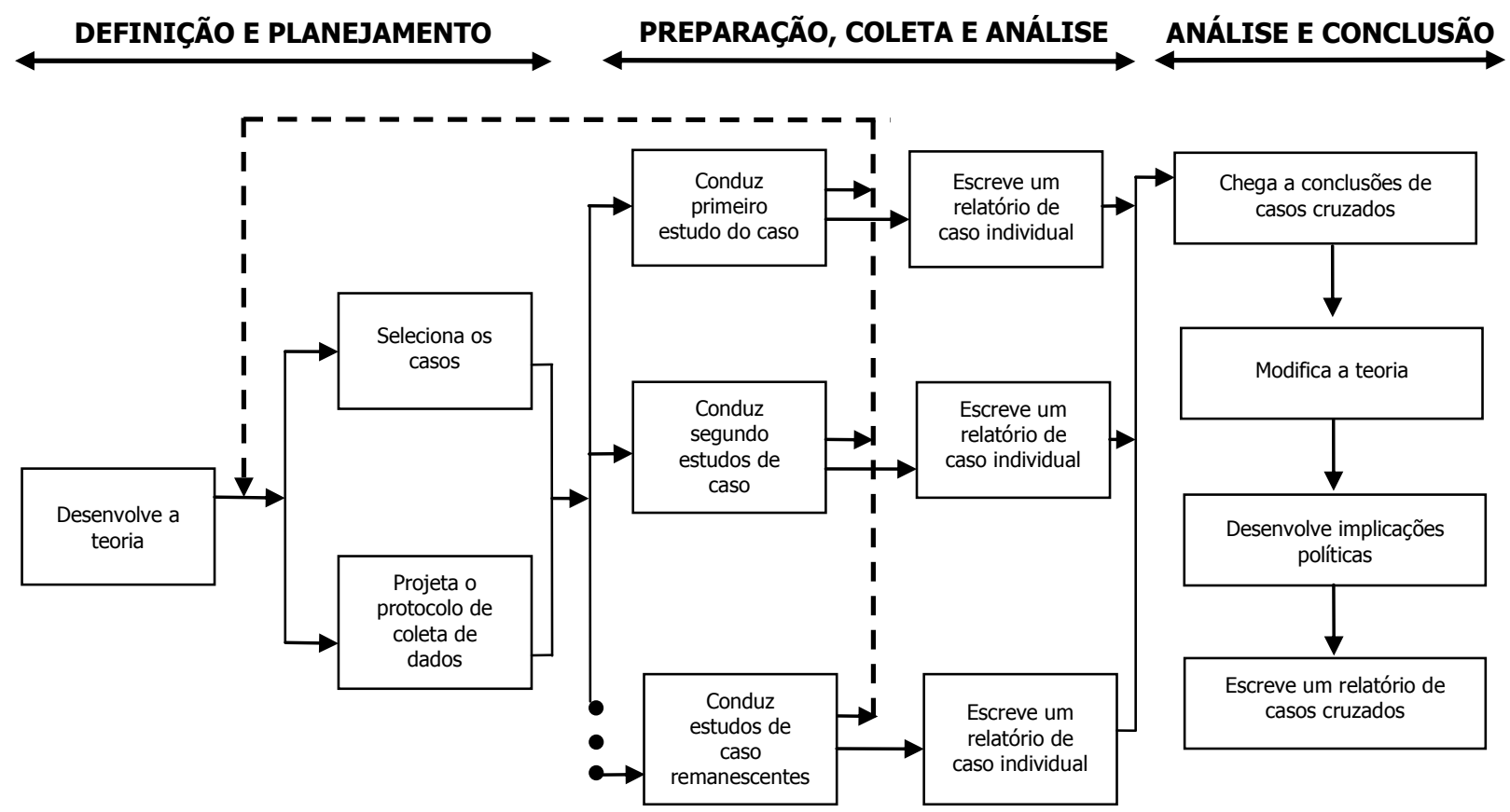

Figura 18 - Método de estudo de caso. Fonte: YIN, 2005, p. 72.

Segundo Yin (2005) os casos individuais, dentro de um projeto de estudos de casos múltiplos, podem ser tanto holísticos quanto incorporados. No presente estudo adotou-se o projeto de casos múltiplos incorporados, pois

O estudo de caso holístico deve ser aplicado quando não é possível identificar uma "subunidade lógica". O maior risco dos projetos holísticos é que eles podem levar o pesquisador a ignorar pontos importantes de um processo, por não isolá-los em unidades lógicas. (MARTINS, G. A., 2008, p. 15)

O estudo de caso incorporado é aquele no qual a situação é avaliada a partir de diferentes unidades ou níveis de análise, que podem ser analisados com critérios distintos. 
Stake (2000) descreve o estudo de caso como uma unidade específica, um sistema delimitado cujas partes são integradas. Uma escola, como estudo de caso, deve ser estudada como um sistema delimitado, embora a influência de diferentes aspectos faça parte desse sistema, como o contexto físico, sociocultural, histórico e econômico. Também o contexto da subordinação do estudo de caso à legislação e às normas de órgãos reguladores federais, estaduais e municipais deve ser levado em consideração. Diferentemente de Yin (2005), Stake (2000) distingue os seguintes tipos de estudo de caso caracterizados segundo seus objetivos:

- Estudo de caso intrínseco: não objetiva construir uma teoria, busca-se o entendimento e a compreensão de um determinado caso em si;

- Estudo de caso instrumental: o interesse no caso se deve à crença de que ele poderá facilitar a compreensão de algo mais amplo, ou para contestar uma generalização largamente aceita; e

- Estudo de caso coletivo: se estuda de forma conjunta alguns casos com o objetivo de investigar um dado fenômeno, podendo ser visto como um estudo instrumental estendido a vários casos. Os casos individuais que se incluem no conjunto estudado podem ou não apresentar uma característica comum, sendo eleitos visando uma melhor compreensão da problemática da pesquisa em questão.

Alves-Mazzotti (2006) realizou um estudo comparativo entre os autores Stake (2000) e Yin (2005) e verificou que as características de questões típicas dos estudos de caso descritas pelos dois autores são semelhantes. Estas questões típicas se referem 
a relações complexas ${ }^{120}$ situadas em um contexto, sobre as quais o pesquisador tem pouco controle. Verificou-se que há divergências entre Stake (2000) e Yin (2005) no que se refere às caracterizações descritas do estudo de caso.

Segundo Martins, G. A. (2008), a obra de Yin (2005) é referencial para a aplicação do estudo de caso em todas as áreas do conhecimento, sendo adotada na presente pesquisa. A investigação de estudo de caso

- enfrenta uma situação tecnicamente única em que haverá muito mais variáveis de interesse do que pontos de dados, e, como resultado,

- baseia-se em várias fontes de evidências, com os dados precisando convergir em um formato de triângulo, e como outro resultado,

- beneficia-se do desenvolvimento prévio de proposições teóricas para conduzir a recolha e a análise de dados. (YIN, 2005, p. 33)

\subsection{Abordagem}

Seguindo a lógica proposta por Yin (2005), em todas as escolas especiais ou unidades-caso, serão aplicados instrumentos de APO adaptados a cada deficiência atendida pela respectiva unidade-caso. Os resultados de cada aplicação de instrumentos de coleta de dados fazem parte das descobertas para cada unidade caso separada, ou para cada caso. Segundo Yin (2005, p. 75), se os dados coletados são obtidos para todos os centros, "não se está mais utilizando um projeto de estudo de casos múltiplos, e é provável que a investigação esteja usando um levantamento no lugar de um projeto de estudo de caso."

${ }^{120}$ Os estudos de caso não são fáceis de ser realizados, ao contrário, eles se revestem de grande complexidade, o que exige o recurso a técnicas variadas de coleta de dados. 


\subsection{Critérios de seleção}

\subsubsection{Modalidade escola de educação especial}

A justificativa da escolha da modalidade escola de educação especia ${ }^{\not 21}$ se baseia no fato de ocorrer, nestas escolas especiais, uma maior concentração de alunos com o mesmo tipo de deficiência na mesma sala de aula durante todos os dias letivos da semana, diferentemente do que ocorre no serviço de apoio pedagógico. A maior experiência dos docentes e da direção da escola nas formas específicas de comunicação utilizadas por cada aluno, vivenciadas no cotidiano da sala de aula, possibilita maiores subsídios para a elaboração e a aplicação dos instrumentos de coleta de dados destinados aos mesmos.

\subsubsection{Unidades-caso ou escolas especiais}

O critério de seleção das unidades-caso apresenta caráter qualitativo, onde se evitou o erro fatal que se comete ao realizar estudos de caso, o de

conceber a generalização estatística como o método de se generalizar os resultados do estudo. Isto ocorre porque os casos que você utiliza não são "unidades de amostragem" e não devem ser escolhidos por essa razã.o (YIN, 2005, p. 53)

Qualquer utilização de projetos de casos múltiplos deve seguir uma lógica de replicação, e não de amostragem, e o pesquisador deve escolher cada caso cuidadosamente. Os casos devem funcionar de uma maneira semelhante aos experimentos múltiplos, com resultados similares (replicação literal) ou contraditórios (replicação teórica) previstos explicitamente no princípio da investigação. (YIN, 2005, p. 75)

${ }^{121}$ A escola de educação especial oferece atendimento especializado com aulas todos os dias ( $2^{\mathrm{a}}$ à $\left.6^{\mathrm{a}}\right)$, somente para os alunos com deficiência, sendo que cada uma dessas escolas atende a uma deficiência específica e as deficiências múltiplas da deficiência principal atendida. 
Foram selecionadas três pré-escolas inseridas nas seguintes escolas especiais gratuitas ou unidades-caso:

> unidade-caso 1 especializada nos alunos com deficiência visual, unidade-caso 2 especializada nos alunos com deficiência auditiva e unidade-caso 3 especializada nos alunos com deficiência física.

Os critérios de seleção das três escolas especiais ou unidades-caso se encontram descritos a seguir.

\subsubsection{Unidade-caso 1: especializada no aluno com deficiência visual}

Foi eleita como unidade-caso 1 a única escola de educação especial gratuita especializada no aluno com deficiência visual (cegos e com baixa visão) no município de São Paulo ${ }^{122}$. Esta unidade-caso pertence a uma entidade sem fins lucrativos ligada à Igreja Católica não conveniada à Secretaria Municipal de Educação de São Paulo (SMESP). A instituição em questão oferece educação especial nos níveis da pré-escola e do ensino fundamental, bem como as seguintes atividades complementares: estimulação precoce, informática, datilografia comum e Braille, educação física, karate, musicografia Braille, banda, violão, teclado, piano, banda rítmica, coral infantil e infanto-juvenil; formação religiosa e atendimento odontológico, psicológico, fonoaudiológico e fisioterapêutico (Quadro 6). Ao ingressar

${ }^{122}$ Após o contato realizado com as renomadas instituições conveniadas de atendimento à deficiência visual, Associação Brasileira de Assistência ao Deficiente Visual (LARAMARA) e a Fundação Dorina Nowill, dentre outras, verificou-se que as mesmas ofereciam apenas o apoio pedagógico especializado. 
na unidade-caso 1 a criança é encaminhada para uma triagem pedagógica, onde é feita uma ficha completa da sua vida desde a gestação. Posteriormente, a criança é encaminhada para uma das classes do período preparatório ou pré-escola para que através de um intenso programa de utilização dos sentidos remanescentes possa compensar a carência de estímulos e conhecimentos puramente visuais e levar a criança até a prontidão para a alfabetização. Para tal, utiliza-se material psicopedagógico específico com a finalidade de suprir as necessidades advindas da deficiência visual e oferecer condições adequadas para o desenvolvimento de habilidades básicas, pré-requisitos para o processo ensino-prendizagem.

\begin{tabular}{|l|l|}
\hline Unidade caso 1 & Entidade filantrópica \\
\hline Natureza & $\begin{array}{l}\text { Visual, abrangendo a cegueira ou a baixa visão com ou sem outros } \\
\text { comprometimentos associados à deficiência visual }\end{array}$ \\
\hline Deficiência atendida & Diretora e coordenadora pedagógica \\
\hline Contato/cargo & 4 a 18 anos \\
\hline $\begin{array}{l}\text { Faixa etária atendida pela } \\
\text { escola especial }\end{array}$ & $\begin{array}{l}\text { Escola especial não conveniada à SMESP, gratuita e reconhecida } \\
\text { pelo MEC }\end{array}$ \\
\hline Modalidade escolar & Pré-escola e ensino fundamental \\
\hline Níveis de ensino & $\begin{array}{l}\text { Sistema Braille para os alunos com cegueira e baixa visão grave } \\
\text { (sistema convencional para os alunos com baixa visão - com } \\
\text { ampliação do material pedagógico) }\end{array}$ \\
\hline Sistema de escrita & Desenvolvimento das habilidades básicas e idade \\
\hline Critério de divisão das salas & $\begin{array}{l}\text { Odontologia, psicologia, fonoaudiologia e fisioterapia, além das } \\
\text { atividades extras descritas. Os alunos não têm direito ao transporte } \\
\text { escolar, pois a instituição não é conveniada à SMESP. }\end{array}$ \\
\hline Atendimento complementar
\end{tabular}

Quadro 6 - Dados da unidade-caso 1. 


\subsubsection{Unidade-caso 2: especializada no aluno com deficiência auditiva}

Foi eleita como unidade-caso 2 uma das seis Escolas Municipais de Educação Especial $(E M E E)^{123}$ gratuitas existentes no município de São Paulo especializadas no aluno com deficiência auditiva. As EMEEs pertencem à Secretaria Municipal de Educação de São Paulo ${ }^{124}$ e destinam-se às crianças, adolescentes, jovens e adultos com deficiência auditiva, surdocegueira ou com outras deficiências, limitações, condições ou disfunções associadas à surdez e oferecem atendimento educacional nos níveis da educação infantil e do ensino fundamental.

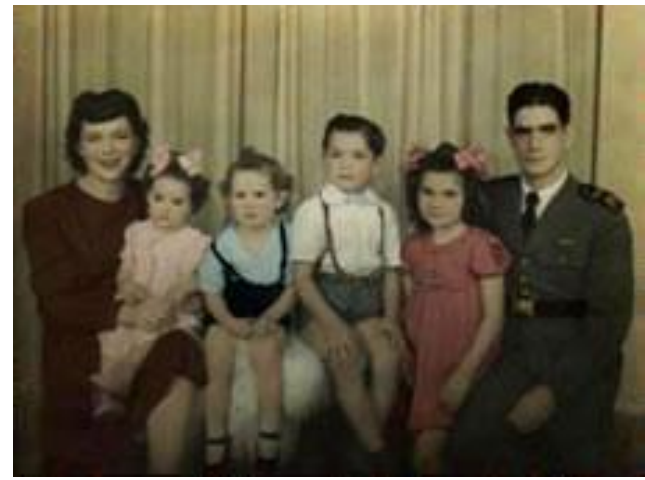

Figura 19 - A família fundadora da escola para surdos. Fonte: Disponível em: $<$ http://www.educarede.org.br>. Acesso em: 26 dez. 2009.

A primeira EMEE originou-se da escola para surdos fundada em 1952 por iniciativa o capitão de Exército Francisco Vieira Fonseca, pai de três crianças com deficiência auditiva (Figura 19). Ele propôs à Secretaria de Educação, em 1951, a criação de um Núcleo de Recuperação voltado para o atendimento especializado de crianças surdas.

O Núcleo citado foi fundado oficialmente em 13 de outubro de 1952, no bairro de Santana. Em 1956, foi transferido para o bairro da Aclimação, com o nome de

\footnotetext{
${ }^{123}$ A opção de matricular o aluno na EMEE é dos pais ou do próprio aluno, nos casos em que se demonstre que a educação nas classes comuns não pode satisfazer as necessidades educacionais especiais e sociais desses alunos na educação infantil, no ensino fundamental regular e na educação de jovens e adultos (EJA). (SÃO PAULO/MUNICÍPIO, 2007, p. 21)

124 Ver item 3.2.2.1 Serviços de educação especial oferecidos na rede municipal de ensino (São Paulo).
} 
Instituto Municipal de Surdos-Mudos. Em 1976, com a criação da Lei Municipal no 84.389, que organizava a educação de deficientes auditivos no Ensino Municipal, a escola passou a ser denominada Escola Municipal de Ensino de Deficientes Auditivos. ${ }^{125}$ Em 1998, a escola recebeu a denominação atual de Escola Municipal de Educação Especial, não sendo citado o seu nome em função de questões éticas da pesquisa visando preservar a identidade dos sujeitos envolvidos.

Após levantamento realizado junto às diretoras e coordenadoras das 6 EMEEs existentes (Tabela 3), a EMEE B foi eleita como unidade-caso 2 (Quadro 7) segundo o critério de maior número de alunos matriculados na pré-escola, tanto no ano de 2009 como em 2010 (na primeira e na segunda etapas da pesquisa de campo, respectivamente).

Tabela 3 - Levantamento do número de alunos matriculados nas pré-escolas das EMEEs existentes no município de São Paulo em 2009 e 2010.

\begin{tabular}{lcccc}
\hline \multirow{2}{*}{ EMEE } & \multicolumn{2}{c}{2009} & \multicolumn{2}{c}{$\mathbf{2 0 1 0}$} \\
\cline { 2 - 5 } & $\mathrm{N}^{\circ}$ de classes & $\begin{array}{l}\mathrm{N}^{0} \text { de alunos } \\
\text { matriculados }\end{array}$ & $\mathrm{N}^{\circ}$ de classes & $\begin{array}{c}\mathrm{N}^{\circ} \text { de alunos } \\
\text { matriculados }\end{array}$ \\
\hline $\mathrm{A}$ & 0 & 0 & 0 & 0 \\
\hline $\mathrm{B}$ & 4 & 30 & 2 & 16 \\
\hline $\mathrm{C}$ & 2 & 15 & 2 & 13 \\
\hline $\mathrm{E}$ & 2 & 15 & 1 & 10 \\
\hline $\mathrm{F}$ & 1 & 10 & 2 & 13 \\
\hline
\end{tabular}

Fonte: Elaborado pela autora, com os dados fornecidos por cada uma das EMEEs em 2009 e 2010.

${ }^{125}$ Disponível em:

$<$ http://www.educarede.org.br/educa/revista_educarede/especiais.cfm?id_especial=96>. Acesso em: 26 dez. 2009. 


\begin{tabular}{|c|c|}
\hline \multicolumn{2}{|l|}{ Unidade-caso 2} \\
\hline Natureza & Pública municipal \\
\hline Deficiências atendidas & $\begin{array}{l}\text { Auditiva, com ou sem outros comprometimentos ou } \\
\text { deficiências associados à deficiência auditiva (atendem } \\
\text { surdocegos) }\end{array}$ \\
\hline Contato/cargo & Diretora \\
\hline Faixa etária escolar atendida & 3 à 50 anos (ou mais) \\
\hline Modalidade escolar & $\begin{array}{l}\text { Escola especial pertencente à Secretaria Municipal de Educação } \\
\text { de São Paulo (SMESP) e reconhecida pelo MEC }\end{array}$ \\
\hline Níveis de ensino & $\begin{array}{l}\text { Educação Infantil, Ensino Fundamental e Educação de Jovens e } \\
\text { Adultos }\end{array}$ \\
\hline Forma de comunicação & $\begin{array}{l}\text { Aulas em LIBRAS convencional com o posterior ensino do } \\
\text { português }\end{array}$ \\
\hline Critério de divisão das salas & $\begin{array}{l}\text { Nível pedagógico em 2009, e por fixa etária a partir de } 2010 \\
\text { (determinação da SME) }\end{array}$ \\
\hline Relação alunos/sala (máxima) & Até 10 alunos/sala \\
\hline Atendimento complementar & $\begin{array}{l}\text { Não oferece serviços complementares aos alunos e o } \\
\text { atendimento fonoaudiológico }{ }^{126} \text { é realizado apenas no primeiro } \\
\text { contato do aluno com a escola. Os alunos utilizam o transporte } \\
\text { escolar oferecido pela prefeitura. }\end{array}$ \\
\hline
\end{tabular}

Quadro 7 - Dados da unidade-caso 2.

\subsubsection{Unidade-caso 3: especializada no aluno com deficiência física}

Foi eleita como unidade-caso 3 a única escola de educação especial gratuita existente no município de São Paulo especializada no aluno com deficiência física. A unidade-caso 3 é uma entidade sem fins lucrativos, conveniada à Secretaria Municipal de Educação de São Paulo que oferece atendimento educacional aos alunos com deficiência física e com boas condições cognitivas, nos níveis de préescola e do ensino fundamental. Após contato realizado com cada uma das 40 instituições conveniadas à SMESP existentes, verificou-se que as mesmas ofereciam apenas o apoio pedagógico especializado ${ }^{127}$.

\footnotetext{
${ }^{126}$ A fonoaudióloga do posto de saúde próximo realiza os exames de triagem quando o aluno chega à EMEE em função da existência de aparelhos apropriados.

127 Específico para alunos com deficiência, em alguns dias da semana.
} 
A unidade-caso 3 (Quadro 8) conta com a parceria das Secretarias de Educação do Estado e do Município para que neste esforço conjunto, o aluno com deficiência física possa ser incluído em uma escola comum o mais breve possível. A Secretaria Municipal de Educação cede professores em regime de afastamento para prestarem serviços docentes na unidade-caso $3^{128}$. Os serviços complementares aos alunos oferecidos na unidade-caso 3 são o odontológico, o psicológico, o fonoaudiológico e o fisioterapêutico.

\begin{tabular}{|l|l|}
\hline Unidade-caso 3 & Entidade privada \\
\hline Natureza & $\begin{array}{l}\text { Física sem outros comprometimentos ou deficiências associados } \\
\text { à deficiência física }\end{array}$ \\
\hline Deficiência atendida & Coordenadora \\
\hline Contato/cargo & 4 a 11 anos \\
\hline Faixa etária escolar atendida & $\begin{array}{l}\text { Escola especial conveniada à SMESP, gratuita e reconhecida } \\
\text { pelo MEC }\end{array}$ \\
\hline Modalidade escolar & Pré-escola e ensino fundamental \\
\hline Níveis de ensino & CAA destinada aos alunos com PC sem fala ou escrita funcional \\
\hline Forma de comunicação & Nível pedagógico \\
\hline Critério de divisão das salas & Até 8 alunos/sala \\
\hline Relação alunos/sala (máxima) & $\begin{array}{l}\text { Fisioterapia, terapia ocupacional, fonoaudiologia, psicologia, } \\
\text { fisioterapia aquática, reabilitação esportiva, musicoterapia, arte } \\
\text { terapia e pedagogia }\end{array}$ \\
\hline Atendimento complementar
\end{tabular}

Quadro 8 - Dados da unidade-caso 3.

\subsubsection{Justificativa da não inclusão de alunos com deficiência múltipla no estudo}

No início da pesquisa de campo havia sido eleita uma quarta unidade caso (Quadro 9) que oferece apoio pedagógico especializado (não é escola especial) ao aluno com deficiência múltipla visual e auditiva (surdocegueira) com outros comprometimentos

${ }^{128}$ Este número tem diminuído em função do deslocamento destas professoras para a rede regular em função da inclusão das crianças com deficiência. Este dado foi fornecido pela coordenadora da unidade-caso 3 em 2009 na entrevista inicial exploratória. 
e/ou deficiências associadas. Esta instituição oferece serviços de forma gratuita, é conveniada à SMESP, para alunos matriculados na rede regular de ensino ${ }^{129}$ ou em escolas especiais.

\begin{tabular}{|l|l|}
\hline Unidade-caso 4 & Entidade filantrópica \\
\hline Natureza & $\begin{array}{l}\text { Múltipla de auditiva e visual associada ou não a outros } \\
\text { comprometimentos e/ou deficiências }\end{array}$ \\
\hline Deficiência atendida & Diretora \\
\hline Contato/cargo & 0 a 18 anos \\
\hline Faixa etária escolar atendida & $\begin{array}{l}\text { Instituição conveniada à SMESP que oferece o atendimento } \\
\text { educacional especializado através do apoio pedagógico em } \\
\text { alguns dias da semana, gratuita }\end{array}$ \\
\hline Modalidade escolar & Sem definição em função da severidade das deficiências \\
\hline Níveis de ensino & CAA \\
\hline Forma de comunicação & Desenvolvimento cognitivo \\
\hline Critério de divisão das salas & Até 4 alunos/sala \\
\hline Relação alunos/sala (máxima) & Variável de duas a três vezes por semana \\
\hline Frequência pelos alunos & Fisioterapia, terapia ocupacional e fonoaudiologia \\
\hline Atendimento complementar & O aluno deve estar matriculado na escola da rede regular ou \\
\hline EMEE pertencente à rede da prefeitura de São Paulo
\end{tabular}

Quadro 9 - Dados da eventual unidade-caso 4.

Em setembro de 2009 foram aplicados os seguintes instrumentos de coleta de dados destinados aos usuários adultos: entrevista exploratória inicial com a diretora (09/09/2009), grupo focal composto por duas professoras (09/09/2009) e grupo focal composto pela coordenadora e uma professora (30/09/2009), bem como observações não estruturadas destinadas aos alunos com deficiência múltipla nas atividades em sala de aula (09/09/2009 e 30/09/2009), durante a alimentação no refeitório (09/09/2009) e na locomoção pelos ambientes da instituição (30/09/2009). A aplicação desses instrumentos de coleta de dados destinados aos usuários adultos teve como objetivo extrair informações preliminares sobre os alunos, suas capacidades, dificuldades, formas de comunicação e sua rotina, visando a obtenção

\footnotetext{
${ }^{129}$ Verificou-se junto a assistente social em conversa informal que para obter o direito de frequentar o apoio pedagógico especializado na instituição em questão, os alunos devem estar obrigatoriamente matriculados na rede regular de ensino sob o critério da faixa etária e não do nível pedagógico.
} 
de subsídios para a escolha dos métodos de pesquisa a serem utilizados junto a esses alunos. Entretanto, após a aplicação dos instrumentos descritos, verificou-se a impossibilidade da realização do estudo por não haver uma forma de comunicação consistente com nenhum dos alunos matriculados (total de 57 alunos na faixa etária dos 4 aos 17 anos) em decorrência da severidade da deficiência múltipla constatada.

\subsection{Etapas dos estudos de casos}

\subsection{1 $1^{\mathrm{a}}$ etapa: pré-teste}

O objetivo da primeira etapa da pesquisa de campo, realizada no período entre agosto e dezembro de 2009, foi a aplicação do pré-teste dos instrumentos de APO destinados aos alunos com deficiência física, auditiva e visual ${ }^{130}$. Utilizou-se como base os resultados dos instrumentos preliminares aplicados na direção e nos docentes (entrevistas) e nos alunos (observação) das três escolas especiais gratuitas ou unidades-caso. A meta desta etapa foi a verificação prática da metodologia proposta, incluindo a receptividade e a participação dos alunos envolvidos e a prospecção de erros visando a melhoria da metodologia para a nova aplicação na segunda etapa em 2010.

130 Matriculados no ano letivo de 2009. 


\subsection{2 $2^{\mathrm{a}}$ etapa: validação}

A segunda etapa da pesquisa de campo foi realizada no período entre agosto e dezembro de 2010 nas mesmas três escolas de educação especial ou unidades-caso da etapa anterior. $\mathrm{O}$ objetivo da segunda etapa da pesquisa de campo foi a aplicação dos instrumentos de coleta de dados revisados e aperfeiçoados (bem como o processo de aplicação), tendo como meta sua validação, bem como a comprovação das premissas levantadas no item 1.5.

\subsection{Delimitação dos sujeitos da pesquisa}

Os indivíduos das unidades-caso ou sujeitos da pesquisa considerados na primeira e segunda etapas do estudo em 2009 e 2010 foram as diretoras e/ou as coordenadoras e as docentes vinculadas às três escolas especiais ou unidades-caso nos anos letivos de 2009 e 2010, bem como os alunos matriculados na pré-escola no mesmo período. A seguir, serão apresentadas as características dos sujeitos, por unidade-caso. 


\subsubsection{Unidade caso 1: especializada no aluno com deficiência visual}

Na primeira etapa da pesquisa, em 2009, a unidade-caso 1 apresentou apenas uma classe de pré-escola ${ }^{131}$ (Tabela 4), totalizando 15 alunos com deficiência visual na faixa etária dos 4 aos 10 anos $^{132}$, sendo 6 meninas e 9 meninos. Destes 15 alunos, 5 não se encontravam aptos a participar da pesquisa (não apresentavam capacidade cognitiva preservada). Dos 10 alunos aptos a participar da pesquisa em 2009, todos ouviam bem e falavam com facilidade, nenhum apresentava deficiência física associada. Todos apresentavam boa coordenação nos membros superiores e iniciaram o aprendizado em Braille, inclusive os que tinham baixa visão. A densidade dos alunos desta única classe de pré-escola em 2009 foi a maior ${ }^{133}$ entre os estudos de caso, em função da presença de aluno com comprometimentos mentais, sendo a relação professor/aluno de 7,5 (duas professoras). Segundo a Resolução SE-72 (SÃO PAULO/ESTADO, 2009 $)^{134}$ que estabelece orientações e procedimentos para a celebração de convênios com instituições sem fins lucrativos atuantes em educação especial e dá providências correlatas, esta sala deveria ter no máximo 4 alunos.

\footnotetext{
${ }^{131}$ No período da manhã (não havia outras classes nos outros períodos).

${ }^{132}$ Esta instituição adota o nível pedagógico para a divisão das classes e não a faixa etária.

${ }^{133}$ Este fato dificultou a aplicação dos instrumentos de coleta de dados.

${ }^{134}$ Segundo o artigo $3^{\circ}$, a Instituição, ao cadastrar os alunos, deverá organizar as turmas conforme as necessidades específicas de cada um, obedecendo aos seguintes parâmetros:

I - mínimo de dez alunos, admitindo-se seis para a formação da última classe, nos casos de alunos com necessidades especiais;

II - mínimo de quatro alunos, nos casos de classes com alunos com necessidades múltiplas; e III - até quatro alunos, por classe, nos casos de alunos com necessidades especiais que apresentem condutas típicas de síndromes, quadros psiquiátricos e neurológicos, com comprometimentos severos. 72 (SÃO PAULO/ESTADO, 2009). A instituição em questão não é conveniada a SME, sendo que a citação serve somente como comparativo.
} 
Na segunda etapa da pesquisa, em 2010, a unidade-caso 1 apresentou duas classes de pré-escola ${ }^{135}$ (Tabela 4), totalizando 20 alunos com deficiência visual na faixa etária dos 4 aos 13 anos, sendo 10 meninas e 10 meninos. Desses 20 alunos, 9 não se encontravam aptos a participar da pesquisa (5 deles não apresentavam capacidade cognitiva preservada, dois deles se encontravam matriculados a menos de 6 meses na escola e não dominavam o espaço físico e outros 2 deles faltavam muito). Dos 11 alunos aptos a participar da pesquisa em 2010, apenas uma aluna cega não ouvia bem e falava com dificuldade (classe B), nenhum apresentava deficiência física associada (exceto um aluno com baixa visão da classe B que apresentava o andar comprometido e falta de equilíbrio). Todos apresentavam boa coordenação nos membros superiores e iniciaram o aprendizado em Braille, inclusive os com baixa visão (com exceção de um aluno cego de 4 anos da classe C).

Tabela 4 - Distribuição dos docentes e dos alunos nos anos letivos de 2009 e de 2010 por classe de pré-escola e por tipo de deficiência visual na unidade-caso 1.

\begin{tabular}{|c|c|c|c|c|c|c|}
\hline \multirow[b]{2}{*}{$\begin{array}{l}\text { Ano } \\
\text { letivo }\end{array}$} & \multirow[b]{2}{*}{$\begin{array}{c}\mathbf{N}^{\circ} \text { de classes } \\
\text { de pré-escola } \\
\text { (nomenclatura) }\end{array}$} & \multirow[b]{2}{*}{$\begin{array}{c}N^{0} \text { de } \\
\text { docentes } \\
\text { por } \\
\text { classe }\end{array}$} & \multirow[b]{2}{*}{$\begin{array}{c}\text { Tipo de } \\
\text { deficiência } \\
\text { visual }\end{array}$} & \multicolumn{3}{|c|}{$\mathbf{N}^{\circ}$ de alunos matriculados } \\
\hline & & & & $\begin{array}{c}\text { Aptos a } \\
\text { participar da } \\
\text { pesquisa (1) }\end{array}$ & $\begin{array}{l}\text { Não aptos a } \\
\text { participar da } \\
\text { pesquisa } \\
(2)\end{array}$ & $\begin{array}{r}\text { Total } \\
(1+2)\end{array}$ \\
\hline \multirow{2}{*}{2009} & \multirow{2}{*}{$\begin{array}{c}1 \\
(\mathrm{~A})\end{array}$} & \multirow{2}{*}{2} & Baixa visão & 3 & 0 & 3 \\
\hline & & & Cegueira & 7 & 5 & 12 \\
\hline \multirow{4}{*}{2010} & \multirow{2}{*}{$\begin{array}{c}1 \\
\text { (B) }\end{array}$} & \multirow{2}{*}{1} & Baixa visão & 4 & 3 & 7 \\
\hline & & & Cegueira & 5 & 1 & 6 \\
\hline & \multirow{2}{*}{$\begin{array}{l}1 \\
(\mathrm{C})\end{array}$} & \multirow{2}{*}{1} & Baixa visão & 0 & 0 & 0 \\
\hline & & & Cegueira & 2 & 5 & 7 \\
\hline $\begin{array}{l}\text { Total em } \\
2009 \text { e } \\
2010\end{array}$ & 3 & 4 & $\begin{array}{l}\text { Baixa visão } \\
\text { e cegueira }\end{array}$ & 21 & 14 & 35 \\
\hline
\end{tabular}

${ }^{135}$ No período da manhã (não havia outras classes nos outros períodos). 
Verificou-se que dos 15 alunos com deficiência visual que se encontravam matriculados em 2009, 9 deles permaneceram na pré-escola em 2010 (5 na sala B e 4 na sala C). A diretora e a coordenadora permaneceram as mesmas durante os anos letivos de 2009 e 2010. Em relação aos docentes das classes de pré-escola de alunos aptos a participarem da pesquisa em 2009, duas docentes eram responsáveis pela única classe de pré-escola e em 2010 cada uma dessas docentes ficou responsável por uma classe (Tabela 4).

\subsubsection{Unidade-caso 2: especializada no aluno com deficiência auditiva}

Na primeira etapa da pesquisa em 2009, a unidade-caso 2 apresentou 4 classes de pré-escola, todas no período da tarde, organizadas pelo nível pedagógico (não pela faixa etária) em 3 estágios ${ }^{136}$ (Tabela 5), totalizando 24 alunos com deficiência auditiva, na faixa etária dos 4 aos 8 anos. Entretanto, somente 7 alunos da classe do $3^{0}$ estágio se encontravam $\operatorname{aptos}^{137}$ a participar da pesquisa (apresentavam a capacidade cognitiva preservada e alguma comunicação em LIBRAS). Destes, nenhum apresentava deficiência física ou visual ou intelectual associada(s) à auditiva e todos apresentavam boa coordenação nos membros superiores.

Na segunda etapa da pesquisa em 2010, a unidade-caso 2 apresentou duas classes de pré-escola no período da tarde organizados pela faixa etária em apenas 2 dos 3

136 De acordo com a SME.

137 Alunos apresentavam a deficiência múltipla auditiva associada ainda a outras deficiências: visual (cegueira ou baixa visão), e/ou física, e/ou intelectual. 
estágios existentes (Tabela 5), totalizando 16 alunos com deficiência auditiva na faixa etária dos 4 aos 6 anos. E somente 2 alunos da classe do $2^{\circ}$ estágio e outros 5 alunos da classe do $3^{0}$ estágio se encontravam aptos ${ }^{138}$ a participar da pesquisa. Destes apenas uma aluna apresentava deficiência física ${ }^{139}$ associada à auditiva.

Tabela 5 - Distribuição dos alunos com deficiência auditiva matriculados nos anos letivos de 2009 e de 2010 por classe de pré-escola na unidade-caso 2.

\begin{tabular}{|c|c|c|c|c|}
\hline \multirow[b]{2}{*}{ Ano letivo } & \multirow[b]{2}{*}{$\begin{array}{l}N^{0} \text { de classes } \\
\text { de pré-escola } \\
\text { (nomenclatura) }\end{array}$} & \multicolumn{3}{|c|}{$\mathrm{N}^{0}$ de alunos matriculados } \\
\hline & & $\begin{array}{c}\text { Aptos a } \\
\text { participar da } \\
\text { pesquisa } \\
\text { (1) } \\
\end{array}$ & $\begin{array}{c}\text { Não aptos a } \\
\text { participar da } \\
\text { pesquisa } \\
\text { (2) }\end{array}$ & $\begin{array}{l}\text { Total } \\
(1+2)\end{array}$ \\
\hline \multirow{4}{*}{2009} & $\begin{array}{l}1 \text { (10 estágio) } \\
\text { (D) }\end{array}$ & 0 & 6 & 6 \\
\hline & $\begin{array}{c}1 \text { (10 estágio) } \\
(\mathrm{E})\end{array}$ & 0 & 5 & 5 \\
\hline & $\begin{array}{c}1 \text { (20 estágio) } \\
(\mathrm{F})\end{array}$ & 0 & 6 & 6 \\
\hline & $\begin{array}{c}1 \text { (30 estágio) } \\
(\mathrm{G})\end{array}$ & 7 & 1 & 7 \\
\hline \multirow{2}{*}{2010} & $\begin{array}{c}1 \text { (20 estágio) } \\
(\mathrm{H})\end{array}$ & 2 & 7 & 9 \\
\hline & $\begin{array}{c}1 \text { (30 estágio) } \\
\text { (I) }\end{array}$ & 5 & 3 & 8 \\
\hline $\begin{array}{l}\text { Total } \\
(2009+2010)\end{array}$ & 6 & 14 & 21 & $33^{*}$ \\
\hline
\end{tabular}

*O $\mathrm{n}^{\circ}$ de alunos em relação ao levantamento realizado em fevereiro de 2009 se reduziu em função de desistências e transferências.

Verificou-se que os alunos com deficiência auditiva que participaram da segunda etapa da pesquisa de campo realizada em 2010 não foram os mesmos que participaram da primeira etapa realizada em $2009^{140}$.

\footnotetext{
${ }^{138}$ Após as entrevistas realizadas com as docentes em 2009 e em 2010 verificou-se que alguns alunos apresentavam déficit cognitivo e não participaram da pesquisa.

${ }^{139}$ Comprometimento motor na parte direita do corpo.

140 Justificado em parte pelo fato da EMEE ter passado a adotar a partir de 2010 o critério da faixa etária para a divisão dos níveis educacionais.
} 
A surdez apresenta consequências como dificuldades comunicativas, "com decorrentes problemas no desenvolvimento de funções mentais de abstração, de memória, de generalização, de atenção, de dedução, entre outras." (LEIBOVICI, 2003, p. 72). Foram observadas as dificuldades citadas na maioria dos alunos aptos a participar da primeira e segunda etapas da pesquisa na unidade-caso 2 , sendo que a maioria dos alunos era composta por surdos profundos ${ }^{141}$ e se encontravam na fase inicial de aprendizado de LIBRAS.

Na unidade-caso 2 verificou-se que a mesma diretora permaneceu durante os anos letivos de 2009 e 2010, enquanto a docente da única classe de pré-escola com alunos aptos a participarem da pesquisa em 2009, esteve ausente durante 4 meses em 2010, em licença médica, coincidentemente no período em que a pesquisa era realizada, sendo substituída por uma experiente docente do ensino fundamental da própria unidade-caso 2.

\subsubsection{Unidade-caso 3: especializada no aluno com deficiência física}

Na primeira e segunda etapas da pesquisa todos os alunos matriculados na préescola da unidade-caso 3 apresentavam a deficiência física do tipo paralisia cerebral $(P C)^{142}$, se encontravam pré-alfabetizados, com ótimo desenvolvimento cognitivo e

\footnotetext{
${ }^{141}$ Apenas alguns alunos apresentam resíduo de audição, segundo uma das docentes.

${ }^{142}$ Exceto uma aluna apresentou deficiência física do tipo distúrbio da medula espinhal (ver 2.2.1 e Figura 3), sendo usuária de cadeira de rodas e com ótima fala e movimentação nos membros superiores. Os laudos médicos dos alunos não foram disponibilizados à pesquisadora (imposição da direção da unidade caso 3).
} 
foram considerados aptos a participar da pesquisa ${ }^{143}$ (esta era uma das exigências para se matricularem na unidade caso-3, segundo o critério do nível pedagógico e não o da faixa etária).

Na primeira etapa da pesquisa em 2009, a unidade-caso 3 apresentou 3 classes de pré-escola (Tabela 6) totalizando 25 alunos com deficiência física na faixa etária dos 7 aos 17 anos, sendo 14 meninas e 11 meninos. Destes 25 alunos, 7 eram usuários do $\mathrm{PCS}^{144}, 22$ eram usuários de cadeira de rodas, 2 eram usuários de andador e 1 deambulava sem auxílio do andador ou da muleta.

Tabela 6 - Distribuição dos alunos com deficiência física matriculados nos anos letivos de 2009 e de 2010 por classe de pré-escola e período na unidade-caso 3.

\begin{tabular}{lccccc}
\hline \multirow{2}{*}{ Ano letivo } & $\begin{array}{c}\text { No de classes } \\
\text { de pré-escola } \\
\text { (nomenclatura) }\end{array}$ & Período & & \multicolumn{3}{c}{$\mathbf{N}^{\mathbf{0}}$ de alunos matriculados } \\
\cline { 5 - 7 } & $\begin{array}{c}\text { Não usuários } \\
\text { do PCS } \\
(1)\end{array}$ & $\begin{array}{c}\text { Usuários do } \\
\text { PCS } \\
(2)\end{array}$ & $\begin{array}{c}\text { Total } \\
(1+2)\end{array}$ \\
\cline { 2 - 6 } 2009 & $\begin{array}{c}1 \\
(\mathrm{~K})\end{array}$ & manhã & 7 & 2 & 9 \\
\cline { 2 - 6 } & $\begin{array}{c}1 \\
(\mathrm{~L})\end{array}$ & manhã & 6 & 2 & 8 \\
\hline $\begin{array}{c}1 \\
(\mathrm{M})\end{array}$ & $\begin{array}{c}1 \\
(\mathrm{~N})\end{array}$ & manhã & 3 & 3 & 8 \\
\hline $\begin{array}{l}\text { Total } \\
(2009+2010)\end{array}$ & 5 & manhã & 6 & 3 & 9 \\
\hline
\end{tabular}

*Dois alunos se encontravam afastados em função de cirurgia e, portanto não foram computados na Tabela 6.

143 Exceto uma aluna da classe J que se encontrava em licença médica em 2009.

144 Picture Communication Symbols (PCS) traduzido como Símbolos de Comunicação Pictórica (ver 2.2.1.1) 
Na segunda etapa da pesquisa em 2010, a unidade caso 3 apresentou duas classes de pré-escola (Tabela 6) totalizando 17 alunos com deficiência física na faixa etária dos 8 aos 11 anos, sendo 6 meninas e 11 meninos. Destes 17 pré-escolares, 8 eram usuários do PCS, 13 eram usuários de cadeira de rodas, 1 era usuário de muleta e 3 deambulavam sem o auxílio do andador ou da muleta. Verificou-se que dos 25 alunos com deficiência física que se encontravam matriculados no ano de 2009, 10 deles permaneceram na pré-escola em 2010. A mesma coordenadora permaneceu durante os anos letivos de 2009 e 2010 na unidade caso 3. Em relação às 3 docentes de cada uma das classes de pré-escola em 2009, somente duas delas permaneceram em 2010, em função da existência de apenas duas classes ${ }^{145}$.

\subsection{Panorama das técnicas de coleta de dados em situações educativas}

Günther, Elali e Pinheiro (2008, p. 377) resumiram os métodos de pesquisa nos estudos pessoa-ambiente, adotando como base as categorias propostas por Proshansky et al. (1970), em métodos centrados nas pessoas e métodos centrados no ambiente. A distinção entre ambos os métodos se dá em função do tipo da relação entre os usuários do ambiente (pessoas) e o ambiente em um determinado estudo, sendo que:

- métodos centrados nas pessoas: remetem aos atributos das pessoas em função do ambiente, e

\footnotetext{
145 Para o ano de 2011 apenas uma classe de pré-escola se formou e uma das duas docentes foi transferida para uma escola regular.
} 
- métodos centrados no ambiente: remetem às características do ambiente em função das pessoas.

A APO é uma vertente metodológica interdisciplinar utilizada para avaliar o desempenho do ambiente construído em uso segundo a ótica de seus usuários (através dos métodos centrados nos ambientes), avaliando também os atributos das pessoas em função do ambiente (através dos métodos centrados nas pessoas), bem como avaliando o ambiente construído diretamente através das vistorias e medições realizadas pelo especialista.

No método centrado na pessoa destacam-se as seguintes técnicas de coleta de dados: observação, mapa comportamental centrado na pessoa, entrevista, autorrelatos, diário pessoal, atividades lúdicas e artísticas (incluindo-se nestes as atividades que envolvem o desenho), poema dos desejos ou wish poem, modelagem topografia/topológica, mapeamento visual, seleção visual ou visual cues ou photo questionnaires e o questionário (Quadro 10).

Dentre as técnicas de coleta de dados do método centrado no lugar destacam-se o walkthrough, o mapa comportamental centrado no lugar, os vestígios ambientais, as medições de conforto ambiental, o mapa mental ou cognitivo e o mapa afetivo (Quadro 11). 


\begin{tabular}{|c|c|c|}
\hline & Técnicas & Descrição \\
\hline \multirow{2}{*}{ 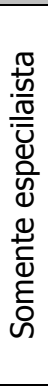 } & 1. Observação & $\begin{array}{l}\text { Pode ser estruturada ou não estruturada, naturalística ou participante, ou } \\
\text { outra forma. No caso de crianças, serve como outra fonte de evidências em } \\
\text { função da limitada qualidade do depoimento verbal. Permite ao pesquisador } \\
\text { inferir usos do espaço e equipamentos, bem como comportamentos dos } \\
\text { usuários. }\end{array}$ \\
\hline & $\begin{array}{l}\text { 2. Mapa comportamental } \\
\text { centrado na pessoa }\end{array}$ & $\begin{array}{l}\text { Baseia-se na observação naturalística, o foco do estudo está nas pessoas, } \\
\text { seus percursos e modo de utilização do espaço. Corresponde ao } \\
\text { acompanhamento de um indivíduo durante o tempo em que permanece no } \\
\text { espaço em estudo, os dados são transferidos para uma planta ou mapa } \\
\text { visando a representação gráfica. }\end{array}$ \\
\hline \multirow{11}{*}{ 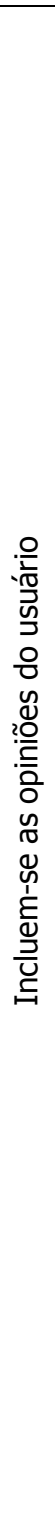 } & 3. Entrevista & $\begin{array}{l}\text { Tradicional na pesquisa em ciências sociais. É bastante adequada para a } \\
\text { obtenção de informações sobre o que as pessoas sabem, creem, esperam, } \\
\text { sentem ou desejam, pretendem fazer, fazem ou fizeram, bem como acerca de } \\
\text { suas explicações a respeito de temas específicos. Pode ser aplicada de forma } \\
\text { coletiva nos alunos em ambientes escolares. }\end{array}$ \\
\hline & 4. Autorrelatos & $\begin{array}{l}\text { Textos escritos ou gravação de voz ou vídeo, narrados em primeira pessoa e } \\
\text { relativos à vivência pessoal do autor ou a sua percepção sobre a experiência } \\
\text { do grupo. }\end{array}$ \\
\hline & 5. Diário pessoal & $\begin{array}{l}\text { O participante estrutura o seu relato segundo a sua própria percepção, e em } \\
\text { função da ocorrência de fatos de interesse da pesquisa em questão. }\end{array}$ \\
\hline & $\begin{array}{l}\text { 6. Atividades lúdicas e } \\
\text { artísticas }\end{array}$ & $\begin{array}{l}\text { Com o uso de brinquedos, modelagem em argila, colagens, oficinas de } \\
\text { material reciclável e mosaico, dentre outras. Indicadas para ambientes } \\
\text { educativos e aplicadas durante a aula visam a expressão do grupo (ou } \\
\text { individual) de uma narrativa sobre um tema determinado. }\end{array}$ \\
\hline & $\begin{array}{l}\text { 6.1 Desenhos-Estórias } \\
\text { (TRINCA, 1976) }\end{array}$ & $\begin{array}{l}\text { Utilizado na psicologia, consiste na solicitação ao pesquisado de cinco } \\
\text { desenhos, sem a introdução de qualquer tema. Após a realização de cada } \\
\text { desenho, o pesquisado é convidado a contar uma estória a partir do que } \\
\text { desenhou, bem como a atribuir-lhe um título. }\end{array}$ \\
\hline & $\begin{array}{l}\text { 6.2 Desenho-Estória com } \\
\text { Tema } \\
\text { (AIELLO-VAISBER, 1995; } \\
\text { 1997; 1999) }\end{array}$ & $\begin{array}{l}\text { Idealizado a partir do "Procedimento de Desenhos-Estórias" (TRINCA, 1976) } \\
\text { consiste na solicitação ao(s) pesquisado(s) de um desenho especificado em } \\
\text { termos temáticos. Em seguida, pede-se ao pesquisado que vire a página e, } \\
\text { em seu verso, invente uma história sobre o que desenhou. }\end{array}$ \\
\hline & $\begin{array}{l}\text { 7. Poema dos Desejos ou } \\
\text { Wish Poem } \\
\text { (SANOFF, 1991) }\end{array}$ & $\begin{array}{l}\text { Tem como ponto de partida o questionamento previamente proposto "Eu } \\
\text { gostaria que o edifício/ambiente...." onde os usuários de um determinado } \\
\text { ambiente declaram, por meio de um conjunto de sentenças escritas ou de } \\
\text { desenhos, suas necessidades, sentimentos e desejos demonstrando a sua } \\
\text { expectativa em relação ao edifício ou ambiente em questão. }\end{array}$ \\
\hline & $\begin{array}{l}\text { 8. Modelagem } \\
\text { topográfica/topológica } \\
\text { (HIGUCHI,1999) }\end{array}$ & $\begin{array}{l}\text { Processa-se através do uso de maquetes tridimensionais que representam } \\
\text { áreas geofísicas, naturais e construídas frente a qual o pesquisado é } \\
\text { questionado sobre as formas de uso do espaço. }\end{array}$ \\
\hline & 9. Mapeamento visual & $\begin{array}{l}\text { Possibilita identificar a percepção dos usuários em relação a um determinado } \\
\text { ambiente e o registro de pontos positivos e negativos pelo usuário em plantas } \\
\text { baixas de fácil identificação. É uma abordagem mais lúdica e dispensa a } \\
\text { formalização verbal, possibilitando uma maior liberdade nas respostas visuais. }\end{array}$ \\
\hline & $\begin{array}{l}\text { 10. Seleção visual ou } \\
\text { Visual Cues } \\
\text { (SANOFF, 1991) ou }\end{array}$ & $\begin{array}{l}\text { Ou Photo Questionnaires (SANOFF, 1994). Objetiva, a partir de um conjunto } \\
\text { de imagens referenciais pré-selecionadas, identificar os valores e os } \\
\text { significados agregados aos ambientes analisados, se possível, relacionando-os } \\
\text { com os ambientes que são vivenciados pelos respondentes. }\end{array}$ \\
\hline & 11. Questionário & $\begin{array}{l}\text { Conjunto de perguntas sobre um determinado tema, utilizado no survey } \\
\text { (levantamento de dados). }\end{array}$ \\
\hline
\end{tabular}

Quadro 10 - Técnicas baseadas no método centrado na pessoa. Fonte: Elaborado pela autora com base em Ornstein e Moreira (2008); Günther, Elali, Pinheiro (2008); Günther, H. (2008); Günther, I. (2008); Pinheiro, Elali, Fernandes (2008); Rheingantz et al. (2008); Sbarra (2007); Zeisel (2005); Elali (2002b); Higuchi (1999); Aiello-Vaisber, (1995, 1997, 1999), Ornstein, Bruna e Roméro (1995); Ornstein e Roméro (1992); Sanoff (1991, 1994), Trinca (1976), dentre outros.

\section{LEGENDA}

Métodos contextualizados em situações educativas. 


\begin{tabular}{|c|c|c|}
\hline & Técnicas & Descrição \\
\hline \multirow{4}{*}{ 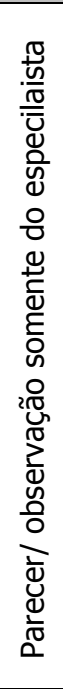 } & $\begin{array}{l}\text { 1. Walkthrough } \\
\text { (PREISER, 1988) }\end{array}$ & $\begin{array}{l}\text { Método de análise que combina simultaneamente a observação a } \\
\text { entrevista com uma pessoa-chave do edifício em questão. Possibilita a } \\
\text { identificação descritiva dos aspectos físicos negativos e positivos dos } \\
\text { ambientes analisados. O percurso dialogado abrange todos os ambientes, } \\
\text { sendo complementado por fotografias, croquis gerais e gravação de áudio } \\
\text { e de vídeo e possibilita que os observadores se familiarizem com a } \\
\text { edificação, com sua construção, com seu estado de conservação e com } \\
\text { seus usos. }\end{array}$ \\
\hline & $\begin{array}{l}\text { 2. Mapa comportamental* } \\
\text { centrado no lugar }\end{array}$ & $\begin{array}{l}\text { Baseia-se na observação naturalística onde o estudo é focado no } \\
\text { ambiente. Os dados coletados são traduzidos em representações gráficas } \\
\text { nas quais os diversos tipos de comportamento dos usuários são } \\
\text { relacionados a seções específicas do espaço em períodos de tempo } \\
\text { determinados. }\end{array}$ \\
\hline & $\begin{array}{l}\text { 3. Vestígios ambientais de } \\
\text { comportamento ou da ação } \\
\text { humana }\end{array}$ & $\begin{array}{l}\text { Análise de sinais resultantes da ocupação de um local encontrados após o } \\
\text { término das atividades, mesmo na ausência de seus usuários onde as suas } \\
\text { atividades podem ou não ter sido presenciada(s) pelo(s) pesquisador(es). }\end{array}$ \\
\hline & $\begin{array}{l}\text { 4. Medições de conforto } \\
\text { ambiental }\end{array}$ & Medição do conforto térmico, acústico e lumínico. \\
\hline 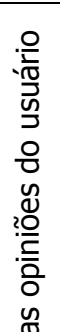 & 5. Mapa mental ou cognitivo & $\begin{array}{l}\text { Baseado na elaboração de desenhos ou relatos de memória } \\
\text { representativas das idéias ou da imaginabilidade que uma pessoa ou um } \\
\text { grupo de pessoas tem de um determinado ambiente. Caracteriza-se por } \\
\text { imagens que combinam os espaços urbanos (vias, ruas, praças) a outros } \\
\text { aspectos e elementos físicos relacionados em um espaço de ação } \\
\text { detalhado. Lynch (1980) foi o responsável pela sua disseminação no } \\
\text { campo das relações homem-ambiente. }\end{array}$ \\
\hline 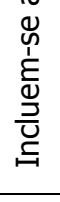 & 6. Mapa afetivo & $\begin{array}{l}\text { Baseia-se no mapa mental ou cognitivo. Definido como imagens ou } \\
\text { representações do espaço elaborados a partir de desenhos, fotos e/ou } \\
\text { objetos de arte, pode ser gerado a partir do mapa cognitivo, porém o seu } \\
\text { objetivo não é a localização geográfica, pois foca-se na teoria do apego e } \\
\text { na síntese do afeto. Acessam os sentimentos do usuário de um espaço. }\end{array}$ \\
\hline
\end{tabular}

Quadro 11 - Técnicas baseadas no método centrado no lugar. Fonte: Elaborado pela autora com base em Ornstein e Moreira (2008); Bomfim (2008); Günther, Elali, Pinheiro (2008); Günther, H. (2008); Günther, I. (2008); Pinheiro, Elali, Fernandes (2008); Rheingantz et al. (2008); Sbarra (2007); Zeisel (2005); Elali (2002b); Higuchi (1999); Ornstein, Bruna e Roméro (1995); Ornstein e Roméro (1992); Sanoff (1991, 1994); Lynch (1980), dentre outros.

*O mapa comportamental visa o registro das observações sobre as localizações e o comportamento dos usuários em um determinado ambiente, através de uma representação gráfica relativa à ocupação humana em uma área. Esta técnica possibilita a análise crítica das atividades e a sua comparação com aquelas que estavam planejadas para o local. O mapa comportamental pode ser centrado na pessoa (Quadro 11) ou centrado no lugar (Quadro 12), sendo que ambos podem ser usados em paralelo em um mesmo estudo (PINHEIRO; GÜNTHER, 2008; PINHEIRO; ELALI; FERNANDES, 2008).

\section{LEGENDA}

Métodos contextualizados em situações educativas. 


\subsubsection{Técnicas de coleta de dados adotadas}

Günther, Elali e Pinheiro (2008) enfatizam que no planejamento de qualquer pesquisa o direcionamento das ações passa, necessariamente, pela definição das técnicas para a coleta de dados, sendo essenciais alguns critérios como o conhecimento prévio da temática, a quantificação do tempo ${ }^{146}$ e dos recursos disponíveis (financeiros, materiais e humanos) e o domínio dos instrumentos a serem utilizados $^{147}$. A elaboração de instrumentos de coleta de dados para crianças, em geral é uma tarefa desafiadora, pois contempla questões pertinentes ao universo infantil: as questões éticas relativas às autorizações dos responsáveis, habilidades cognitivas e motoras inerentes a cada faixa etária, nível de alfabetização e a habilidade do pesquisador em lidar com crianças. Tornou-se necessária a busca de técnicas de coleta de dados que contemplassem os aspectos descritos anteriormente, viessem a otimizar o tempo de permanência ${ }^{148}$ nas três unidades-caso e pudessem ser adaptadas às crianças com deficiência. Para tal, inicialmente foram realizadas, nas três unidades-caso, entrevistas com a direção e docentes de cada uma destas unidades, além de observações não estruturadas dos alunos com deficiência visando à obtenção de informações preliminares sobre eles, contribuindo assim, na escolha das técnicas de coletas de dados destinados aos mesmos.

\footnotetext{
${ }^{146}$ Métodos qualitativos fornecem dados muito significativos e densos, mas, também, muito difíceis de se analisarem. Sempre se lê isso em textos sobre metodologias de pesquisa em ciências sociais, entretanto só se tem ideia da dimensão dessa afirmação quando se está diante de seu próprio material de pesquisa e se sabe que é preciso dar conta dele (DUARTE, 2002, p. 151).

${ }^{147}$ A elaboração dos mesmos partiu da experiência adquirida no estudo anterior realizado pelo grupo de arquitetas e psicóloga (BARBOSA, BERNARDI, ABATE, MIYASATO, ONO, ORNSTEIN, 2009), destinados a alunos sem deficiência.

${ }^{148}$ Visando não interferir na rotina da escola.
} 
Após a realização desta fase preliminar (Capítulos 5 e 6) foram adotadas a entrevista lúdica (Capítulo 7) e o questionário (Capítulo 8), adaptados e aplicados de forma específica às necessidades e formas de comunicação presentes nos alunos com as deficiências física, auditiva ou visual, sendo que a última abrange os alunos cegos ou com baixa visão.

\subsection{Considerações do capítulo 4}

Os fundamentos apresentados neste capítulo serviram de base metodológica para a pesquisa de campo realizada nos anos letivos de 2009 (pré-teste) e 2010 (validação). O método estudo de casos múltiplos incorporados, adotado como estratégia de pesquisa, permitiu o planejamento e a coordenação dos três estudos de caso concomitantemente.

As pesquisas em geral utilizam várias técnicas de coleta de dados ao mesmo tempo (técnicas de natureza qualitativa e quantitativa) com o intuito de complementar e equilibrar as eventuais fraquezas de cada abordagem. Segundo Creswell (2003), os principais objetivos do uso de mais de um método de pesquisa em um fenômeno de interesse são:

- a triangulação: relativa à corroboração dos dados coletados;

- a complementaridade: focaliza as diferentes facetas do fenômeno fornecendo uma maior perspectiva;

- o desenvolvimento: combina ou usa os resultados de outros estudos; 
- a iniciação: envolve a análise intencional de novas perspectivas para estudar um fenômeno de interesse e

- a expansão: relativa ao aumento geral do escopo, amplitude ou alcance de um estudo.

Para que a pesquisa em estudo de usuários alcance resultados mais concretos e relevantes

é necessário que se conheça a variedade de métodos existentes e que se saiba utilizar o método mais adequado ao problema. Somente assim é que será possível obter conclusões e dados que contribuirão para a construção da tão almejada teoria sobre o uso da informação científica e tecnológica. (CUNHA, 1982, p. 18)

Em função da existência de três estudos de caso diferentes, cada um especializado em uma deficiência específica, bem como a aplicação de instrumentos de coleta de dados adaptados a cada uma das deficiências, optou-se, após uma extensa reflexão, agrupar os resultados da pesquisa de campo por instrumento de coleta de dados em capítulos distintos visando maior clareza e objetividade na redação do texto do presente trabalho. 


\section{A TÉCNICA DA ENTREVISTA DESTINADA AOS ADULTOS}

\subsection{Referencial teórico}

A entrevista é, após o questionário, o método mais utilizado para a coleta de dados no estudo de usuários (CUNHA, 1982). A entrevista pode ser definida como uma conversação séria, cujas finalidades são: recolher dados, informar e motivar seus participantes.

A entrevista é uma técnica tradicionalmente utilizada na coleta de dados das ciências sociais que "tem passado por desenvolvimentos e mudado sua posição no elenco de métodos de pesquisa [...]" (MACHADO, 2002, p. 17), recebendo maior credibilidade no seu estatuto de cientificidade a partir da década de 1990, deixando de ser apenas um instrumento de apoio e ganhando espaço como instrumento independente.

Essa técnica é de grande potencialidade e tem sido empregada em pesquisas qualitativas como uma solução para o estudo de significados subjetivos e complexos demais para serem investigados por instrumentos fechados e padronizados (BANISTER et al., 1994). As entrevistas permitem condução, direcionamento e aprofundamento sobre questões e temas específicos, sendo uma das mais importantes fontes de informações para um estudo de caso.

Segundo Nogueira (1968), a situação social em que se desenvolve a entrevista é, em si mesma, uma situação de interação entre entrevistador e entrevistado, onde ambos 
se influenciam um ao outro, através das palavras que pronunciam, da inflexão da voz, dos gestos, das expressões faciais, da postura, do modo de olhar, da aparência, dentre outros. Esta técnica de coleta de dados verbais é bastante adequada para "a obtenção de informações sobre o que as pessoas sabem, crêem, esperam, sentem ou desejam, pretendem fazer, fazem ou fizeram, bem como acerca de suas explicações ou razões a respeito de questões ou temas específicos." (PINHEIRO; ELALI; FERNANDES, 2008, p. 75).

A entrevista é um encontro entre pessoas, "com diferentes histórias, experiências, expectativas e com diferentes disposiçõs afetivas [...]" (ALMEIDA; SZYMANSKI, 2010, p. 87), a fim de que "uma delas obtenha informações a respeito de determinado assunto, mediante uma conversação de natureza profissional." (LAKATOS; MARCONI, 1993, p. 195).

Segundo Maturana e Verden-Zöller (1993), o espaço relacional do conversar é a interação do linguajar com o emocionar, onde os interlocutores coordenam sua conduta de forma consensual. Durante uma conversa ocorre um contínuo ajuste de ações e emoções, que se modifica no decorrer do processo relacional.

A entrevista é "fundamentalmente uma situação de interação humana, em que estão em jogo as percepções do outro e de si, expectativas, sentimentos, preconceitos e interpretações para os protagonistas: entrevistador e entrevistado." (SZYMANSKI, 2010, p. 12). A intenção do entrevistador vai além da busca de respostas, pretende criar um vínculo de confiabilidade e credibilidade para que o entrevistado se sinta à 
vontade para colaborar e fornecer as informações relevantes e necessárias para o estudo em questão.

A concordância em ceder uma entrevista demonstra por parte do entrevistado o aceite dos interesses da pesquisa, a importância em ser ouvido e considerado detentor de informações relevantes. O entrevistado pode utilizar estratégias de ocultamento ou de distorções de informações que supostamente considere ameaçadoras ou desqualificadoras para si ou para o grupo a que pertence.

Se por um lado, para quem pesquisa a intenção clara é a de colher informações para sua investigação, para quem é entrevistado as intenções subjacentes à sua participação podem variar e serem ou não explicitadas. (ALMEIDA; SZYMANSKI, 2010, p. 87)

No seu relato sobre a história da utilização da entrevista, Machado (2002) descreve o surgimento de três grandes enfoques que se diferem, sobretudo pelo tratamento dado ao entrevistado e pelo método de análise das informações obtidas. No primeiro enfoque o que interessa ao entrevistador são respostas quantificáveis, sendo o mesmo um elemento dominador e controlador da relação através de questões préestabelecidas que buscam limitar as respostas e facilitar a tabulação dos resultados. No segundo enfoque a apreensão dos temas relevantes passa a ser o foco através de uma abordagem não diretiva e sem a preocupação da padronização de perguntas. No terceiro enfoque ${ }^{149}$ a interação entre o entrevistador e o entrevistado passa a ser o foco, sendo que as trocas linguísticas são objetos de análise e o discurso é obtido com pouca interferência (não padronizada) do entrevistador. O complexo processo interativo da entrevista apresenta caráter reflexivo "num intercâmbio contínuo entre significados e o sistema de crenças e valores, perpassados pelas emoções e

${ }^{149} \mathrm{~A}$ qualidade da entrevista está vinculada à qualidade da interação. 
sentimentos dos protagonistas." (SZYMANSKI, 2010, p. 14). A participação do entrevistador e do entrevistado é fundamental para o resultado final da entrevista, pois o significado é construído na interação entre ambos.

\subsubsection{Modalidades}

Destacam-se três modalidades de entrevista: não estruturada, estruturada e semiestruturada descritas a seguir.

Na entrevista não estruturada nenhuma pergunta é previamente elaborada, sendo que o entrevistado é incentivado a falar livremente sobre temas ou hipóteses de interesse do entrevistador, sendo utilizada em

pesquisas mais aprofundadas sobre percepção, atitudes e motivações, especialmente quando se procura descobrir quais são as questões básicas - como as pessoas conceituam os tópicos, que terminologia é utilizada pelos respondentes - e qual é o seu nível de compreensão do problema ou ambiente a ser pesquisado. (RHEINGANTZ et al., 2008, p. 73)

Na entrevista estruturada as questões são previamente elaboradas e o entrevistador segue a ordenação das mesmas que servem de roteiro da conversação e "caracterizam-se por questões fechadas, exemplificadas em formulários, inventários, questionários." (GÜNTHER, H., 2008, p. 61).

A entrevista não estruturada mascara pressupostos, agendas e expectativas sendo primordial ter claro o objetivo. Por outro lado, a entrevista estruturada "pode tender a aproximar-se mais de questionários, dificultando a investigação de significados 
subjetivos e de temas muito complexos para a investigação quantitativa." (SZYMANSKI, 2010, p. 19)

As entrevistas semiestruturadas "baseiam-se em lista com temas e questões a serem seguidas conforme certa ordem ou referencial. São, na maioria das vezes, formuladas a partir de observações ou entrevistas informais, exploratórias." (GÜNTHER, H. 2008, p. 61). De um modo geral, "pesquisas de cunho qualitativo exigem a realização de entrevistas, quase sempre longas e semiestruturadas" (DUARTE, 2002, p. 141) que buscam elucidar assuntos específicos cuja importância tenha sido identificada preliminarmente. Szymanski (2010, p. 18) adota este tipo de entrevista na pesquisa em educação "realizada no mínino em dois encontros, individuais ou coletivos", não havendo um roteiro fechado, pois se baseia na fala do entrevistado.

Uma maneira de obter dados da experiência consciente ${ }^{150}$ é através de entrevistas seguindo um roteiro flexível e aberto aos diferentes modos de reação do entrevistado (GOMES, 1997). O recurso às entrevistas semiestruturadas como material empírico privilegiado na pesquisa constitui

uma opção teórico-metodológica que está no centro de vários debates entre pesquisadores das ciências sociais. Em geral, a maior parte das discussões trata de problemas ligados à postura adotada pelo pesquisador em situações de contato, ao seu grau de familiaridade com o referencial teórico-metodológico adotado e, sobretudo, à leitura, interpretação e análise do material recolhido (construído) no trabalho de campo. (DUARTE, 2002, p. 145).

${ }^{150}$ A experiência é para Kant (1781/1978), o ponto de início e de validação do conhecimento. Assim, não é possível conhecer nada que não se ache dentro da experiência. A experiência é, para Hegel (1810/1992), um movimento dialético que conduz a consciência até si mesma, explicitando-se a si mesma como objeto próprio. O conteúdo da consciência é o real. A mais imediata consciência de tal conteúdo é a experiência. A experiência é o modo como aparece o sujeito e o objeto (GOMES, 1997, p. 2). 
No presente estudo foram adotadas as entrevistas não estruturadas e semiestruturadas. O Quadro 12 indica as modalidades de entrevista adotadas na primeira e segunda etapas da pesquisa por unidade-caso.

\begin{tabular}{|c|c|c|c|c|c|c|c|}
\hline & \multirow{3}{*}{$\begin{array}{l}\text { Modalidades } \\
\text { entrevista }\end{array}$} & \multicolumn{6}{|c|}{ Unidade-caso } \\
\hline & & \multicolumn{2}{|c|}{1} & \multicolumn{2}{|c|}{2} & \multicolumn{2}{|c|}{3} \\
\hline & & Direção & Docentes & Direção & Docentes & Direção & Docentes \\
\hline \multirow{3}{*}{ 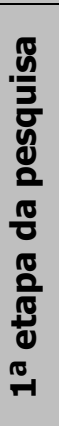 } & $\begin{array}{l}\text { Não estruturada } \\
\text { individual } \\
\text { (inicial exploratória e } \\
\text { sem gravação) }\end{array}$ & $x$ & & 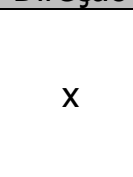 & & - & \\
\hline & $\begin{array}{l}\text { Semiestruturada } \\
\text { individual } \\
\text { (com gravação) }\end{array}$ & $x$ & $x$ & $x$ & $x$ & $x$ & \\
\hline & $\begin{array}{l}\text { Semiestruturada } \\
\text { Grupo focal } \\
\text { (com gravação) }\end{array}$ & & & & & & $x$ \\
\hline \multirow{3}{*}{ 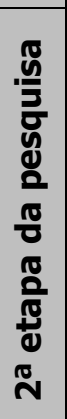 } & $\begin{array}{l}\text { Não estruturada } \\
\text { individual } \\
\text { (inicial exploratória e } \\
\text { sem gravação) }\end{array}$ & $x$ & & $x$ & & $x$ & \\
\hline & $\begin{array}{l}\text { Não estruturada } \\
\text { individual } \\
\text { (com gravação) }\end{array}$ & & & & $x$ & & \\
\hline & $\begin{array}{l}\text { Não estruturada } \\
\text { Grupo focal } \\
\text { (com gravacão) }\end{array}$ & & $x$ & & & & $x$ \\
\hline
\end{tabular}

Quadro 12 - Modalidades de entrevista adotadas na $1^{\mathrm{a}}$ e $2^{\mathrm{a}}$ etapas da pesquisa por unidade-caso.

\subsubsection{Os protagonistas da entrevista}

A definição de critérios segundo os quais serão selecionados os sujeitos que vão compor o universo de investigação é algo primordial,

pois interfere diretamente na qualidade das informações a partir das quais será possível construir a análise e chegar à compreensão mais ampla do problema delineado. A descrição e delimitação da população base, ou seja, dos sujeitos a serem entrevistados, assim como o seu grau de representatividade no grupo social em estudo, constituem um problema a ser imediatamente enfrentado, já que se trata do solo sobre o qual grande parte do trabalho de campo será assentado (DUARTE, 2002, p. 141). 
O entrevistador tem expectativas em relação ao entrevistado, pois espera que o último entenda e esteja disposto a fornecer as informações solicitadas, bem como pode desejar um parceiro no processo de construção e reconstrução do conhecimento. Para o entrevistado, a entrevista pode ser interpretada de várias formas, tais como oportunidade para expor suas ideias, ou uma avaliação, uma ameça, um aborrecimento, uma invasão. Esta interpretação por parte do entrevistado pode provocar uma determinada reação no entrevistador, como a admiração, o medo, a solidariedade, etc. A receptividade e a disponibilidade do entrevistado pode propiciar um maior tempo na entrevista e o consequente nível de aprofundamento na temática em questão. A situação onde se verifica o contato entre o entrevistador (pesquisador) e o entrevistado (sujeito da pesquisa) configura-se como

parte integrante do material de análise. Registrar o modo como são estabelecidos esses contatos, a forma como o entrevistador é recebido pelo entrevistado, o grau de disponibilidade para a concessão do depoimento, o local em que é concedido (casa, escritório, espaço público etc.), a postura adotada durante a coleta do depoimento, gestos, sinais corporais e/ou mudanças de tom de voz etc., tudo fornece elementos significativos para a leitura/interpretação posterior daquele depoimento, bem como para a compreensão do universo investigado. (DUARTE, 2002, p. 145)

A entrevista serve como veículo de comunicação, e segundo Gomes (1997, p. 5)

é organizada em torno de um roteiro direcionado para certos temas, mas aberto para ambiguidades. A entrevista explora o mundo vivido do entrevistado, definido como experiência consciente, e está a procura do sentido que este mundo vivido tem para o entrevistado. Neste processo, a consciência do entrevistador, como expressa no roteiro da entrevista, modifica-se, amplia-se, atualiza-se na interação com o entrevistado. O movimento corretivo é possível pela reversibilidade das percepções e expressões do entrevistador e do entrevistado. $O$ entrevistador deixa-se conduzir pela expressão do entrevistado e oferece suas percepções, reduzidas na expressão, para serem especificadas pelo entrevistado. Notem a mediação da linguagem (verbal e não verbal) criando momentaneamente uma mutualidade de experiência entre os dois comunicantes.

O entrevistador não deve manter-se alheio na posição de simples escuta, pois este não é um dos objetivos da entrevista científica onde o conhecimento é fruto da 
interação entre os protagonistas. Ao mesmo tempo, o entrevistador deverá ter cautela para não influenciar nas respostas do entrevistado.

No caso de escolas, é importante avaliar o clima social que prevalece, pois a personalidade da diretora exerce forte influência no comportamento de seus usuários:

[...] faz muita diferença se a diretora é uma pessoa autoritária e perseguidora ou, ao contrário, é alguém que tenha uma postura democrática e respeitadora; se o clima da escola é tenso, dado a falatórios e favoritismos, ou se o clima é de confiança e abertura. (SZYMANSKI, 2010, p. 24)

Em ambientes conflituosos ou de difícil acesso, a aproximação com os sujeitos da pesquisa deverá ocorrer de forma lenta e gradual e se possível com a mediação de pessoas ou órgãos de confiança do entrevistado. No caso de escolas poderá ser feito através das Secretarias de Educação ou instituições correlatas.

\subsubsection{Fase preparatória da entrevista}

Na fase preparatória da entrevista, a questão desencadeadora ${ }^{151}$ deverá ser cuidadosamente formulada, pois acarretará na fala inicial representativa do entrevistado e deverá oferecer amplitude suficiente para que este eleja por onde começar a responder, evitando a indução de respostas (SZYMANSKI, 2010). A questão desencadeadora tem que ser clara o suficiente e compatível com o nível intelectual do entrevistado para evitar: o pedido de esclarecimento e as formulações

${ }^{151}$ É a partir de uma discussão em torno da questão desencadeadora que surgirão os assuntos no decorrer entrevista, pertinentes a temática de interesse da pesquisa. 
que se distanciem do objetivo da investigação, bem como a irritação ou o desconforto do entrevistado. Elaborar roteiros de entrevistas exige muita cautela, pois

Em situações de coleta de depoimentos orais, posturas mais formais do tipo "respostas diretas a perguntas idem" não costumam produzir bons resultados e, quando acontecem, poucas vezes resistem às primeiras interrogações referentes a experiências de caráter pessoal [...] situações de contato exigem atenção redobrada por parte do pesquisador, pois ele corre o risco de ver a entrevista escapar-Ihe completamente das mãos e perder-se dos objetivos da pesquisa, restringindo-se a divagações ou, mesmo, resvalando para uma espécie de "troca de experiências" mútuas, que compromete bastante a qualidade do trabalho. (DUARTE, 2002, p. 146)

As questões elaboradas para a entrevista podem ser de três tipos: de esclarecimento, focalizadoras ou de aprofundamento, sendo que se faz relevante a escolha do termo interrogativo nas questões da entrevista. Iniciar a questão com a palavra como induz uma questão mais aberta comparativamente em relação ao uso da palavra por que. As respostas, mais ou menos elaboradas, referem-se aos sentidos que são expressos nas perguntas (SZYMANSKI, 2010).

O contato inicial para o agendamento da entrevista exploratória, geralmente não estruturada, pode ser realizado por telefone, onde o entrevistador fornece os seus dados e o de sua instituição de origem e o tema da pesquisa de uma maneira abreviada $^{152}$, bem como a duração da entrevista.

${ }^{152}$ Poderá haver a complementação dos objetivos da pesquisa via e-mail. 


\subsubsection{Desenvolvimento da entrevista}

No início da entrevista, se esclarece, de uma forma mais detalhada, os objetivos da pesquisa, que podem ser entregues em material impresso juntamente com os dados do pesquisador, do orientador, da instituição e o telefone para contato. Após esta fase inicial formal, poderá haver um pequeno período de aquecimento para o estabelecimento de um clima mais informal, que não deve ser considerado como perda de tempo. $\mathrm{O}$ entrevistador deve usar de bom senso para gradualmente aproximar-se de sua pergunta geradora. Nas entrevistas que envolvam docentes é interessante saber sobre a sua formação, tempo de trabalho, dentre outros dados. Podem ser feitas pausas no decorrer da entrevista, considerando o aspecto não verbal do encontro pessoal, expresso nas expressões faciais. Ao final da entrevista abre-se espaço para acréscimos ou comentários do entrevistado e solicitam-se as informações demográficas necessárias para a caracterização do grupo em estudo ou da pesquisa em questão.

\subsubsection{Análise da entrevista}

As formas de colher, transcrever e interpretar relatos orais "têm sido objeto de severas críticas por parte da sociologia, no que diz respeito à chamada garantia de confiabilidade." (DUARTE, 2002, p. 149). Entretanto, alguns estudos vêm mostrando a viabilidade de se estabelecerem critérios rigorosos para a avaliação da 
confiabilidade de conclusões que se baseiam no procedimento de investigação denominado de entrevista.

A ordenação dos itens do roteiro da entrevista é importante, pois pode facilitar e diferenciar as respostas dos entrevistados. Segundo Gomes (1997) a entrevista pode se iniciar conversando sobre o presente, aos poucos pode se deslocar para acontecimentos passados e a seguir para os projetos futuros.

A análise das informações obtidas em uma entrevista depende do tipo de pesquisa, do objeto de estudo e da técnica de coleta de dados adotada, destacando-se três procedimentos: a análise estatística com vistas à quantificação, a análise do conteúdo com vistas a um tratamento qualitativo e a complexa análise do discurso onde "o texto é analisado no interior de um sistema de valores, no qual o seu sentido vem a ser compartilhado pelos codificadores." (MACHADO, 2002, p. 67).

Minayo (1996) aponta três tendências predominantes que orientam a análise de dados qualitativos: a análise do conteúdo (BARDIN, 1977), a análise do discurso e a hermenêutica dialética ${ }^{153}$ que significa um caminho de pensamento orientador para a compreensão da comunicação contida no texto, sendo a última a adotada no presente estudo. Segundo Gomes (1997), as entrevistas são gravadas, transcritas e estudadas em uma forma sistemática, através de três passos reflexivos: descrição fenomenológica, redução fenomenológica e interpretação fenomenológica, onde

[...] na preparação da descrição haverá um cuidado rigoroso com a evidência. Frases esclarecedoras servirão de apoio a cada fase da narrativa. Palavras extraídas dos protocolos

153 "Teoria ou filosofia da interpretação do sentido." (BLEICHER, 1992, p. 13). 
servirão como metáforas que definem novos sentidos. Cada escolha estará devidamente justificada. O produto final será uma descrição consistente e factível. Permitirá o reencontro do leitor com uma situação vivida ou de apresentação a uma situação desconhecida. Todo o trabalho de tabulação qualitativa estará à disposição dos estudiosos, mas não estará anexado à tese ou ao artigo. (GOMES, 1997, p. 3)

Na redução fenomenológica ocorrem as tarefas de exploração e especificação da descrição fenomenológica. Por fim, a interpretação do pesquisador se faz presente, colocando em ação os seus poderes cognitivos, conativos e afetivos, onde

O papel dos pares, nesta tradição de pesquisa, é questionar a consistência factível da descrição, dos procedimentos redutivos de exploração e de especificação da descrição, com a pertinência da interpretação. É também o contexto no qual interpretações alternativas são sempre possíveis e desejáveis. Este é o campo de validação da pesquisa qualitativa. (GOMES, 1997, p. 4).

Em relação ao tratamento dos resultados das entrevistas realizadas no presente estudo com os adultos (direção e docentes de cada unidade-caso) as gravações foram transcritas e interpretadas pela pesquisadora gerando os resumos (itens $5.2 \mathrm{e}$ 5.3) que foram apresentados às entrevistadas para avaliação, correção (caso fosse solicitado) e autorização da divulgação do seu conteúdo ${ }^{154}$ e das imagens geradas.

\subsubsection{A entrevista em grupo}

O grupo focal permite ao pesquisador examinar os diferentes pontos de vista das pessoas em relação a um determinado tema, bem como explorar como os fatos são articulados, censurados, confrontados e alterados por meio da interação grupal e, ainda, como isto se relaciona à comunicação de pares e às normas grupais (KITZINGER; BARBOUR, 1999).

${ }^{154}$ Foram alterados os conteúdos quando solicitado. 
A formação do grupo focal é intencional e deve seguir um critério definido, como a composição dos grupos segundo o critério de compartilhamento do mesmo local de trabalho. 0 número de participantes em um grupo focal pode variar de 6 a 15 pessoas como um módulo recomendável (DEBUS, 1997), dependendo dos objetivos de cada estudo ${ }^{155}$.

O grupo focal consiste, basicamente, de discussões informais, porém semiestruturadas, sobre temas específicos de investigação e busca informações de difícil obtenção em entrevistas individuais e diretas. O grupo focal permite a obtenção de informações em consenso e com a otimização do tempo de aplicação. 0 ideal é cada grupo focal contar com um moderador e um observador. O moderador deve conduzir e apresentar os objetivos do encontro, garantindo que todos os temas sejam discutidos e que todos os participantes contribuam com sua opinião, não interferindo nas respostas e não corrigindo os participantes. O observador permanece fora do círculo de discussão. A ele cabe a função de gravar a reunião (caso haja permissão), observar e registrar reações (expressões e gestos) dos participantes, anotando seus nomes, a função de cada um e o tempo de duração. Os participantes são informados sobre a gravação e a possibilidade de, ao término deste trabalho, terem conhecimento e acesso aos resultados do grupo focal.

As informações obtidas a partir dos grupos focais e das entrevistas individuais não são generalizadas ou empregadas para provar hipóteses, mas podem oferecer pistas

155 Quando se deseja gerar um maior número de ideias (fase inicial ou exploratória da pesquisa) podem ser organizados grupos maiores. $\mathrm{E}$, quando se espera aprofundar a temática na discussão, deve-se optar por grupos menores. 
e opiniões sobre questões posteriormente comprovadas mediante o confronto com os resultados da aplicação de outros instrumentos. As informações são agrupadas de acordo com o tema tratado e inseridas na avaliação sob a forma de comentários ou citações. Inicialmente buscou-se adotar somente as entrevistas em grupo destinadas a docentes. Entretanto, apenas na unidade-caso 1 ( $2^{a}$ etapa da pesquisa) e na unidade-caso 3 ( $1^{\text {a }}$ e $2^{\mathrm{a}}$ etapas da pesquisa), foi possível realizá-las.

\section{$5.21^{\text {a }}$ etapa da pesquisa}

Na primeira etapa da pesquisa foram adotadas as seguintes modalidades de entrevista destinadas às diretoras ou coordenadoras das três unidades-caso:

D Não estruturada individual (inicial exploratória e sem gravação) e Semiestruturada individual (com gravação).

Nesta mesma etapa da pesquisa foi adotada a seguinte modalidade de entrevista destinada a docentes das três unidades caso:

Semiestruturada (com gravação), sendo individual (unidades-caso 1 e 2) e em grupo (unidade-caso 3). 


\subsubsection{Entrevistas não estruturadas individuais com diretoras ou coordenadoras}

\section{a) Objetivos}

As entrevistas não estruturadas individuais destinadas às diretoras ou coordenadoras das unidades caso 1, 2 e 3 tiveram como objetivo a apresentação das metas da primeira etapa da pesquisa, bem como a realização do pedido de autorização. Essas entrevistas iniciais tiveram caráter informal e exploratório.

\section{b) Procedimentos adotados}

A aplicação foi individual com cada uma das diretoras ou coordenadoras de cada uma das unidades-caso. No início da entrevista foram esclarecidos os objetivos da pesquisa, entregue em material impresso, juntamente com os nomes completos da pesquisadora, da orientadora e da coorientadora, da instituição e o telefone para contato, e também solicitada sua autorização. Após esta fase inicial, ocorreu um pequeno período de aquecimento (descrito no item 5.1.4) onde a pesquisadora falou um pouco sobre o andamento de seu doutorado. Solicitou-se e agendou-se a entrevista semiestruturada, bem como dados gerais da instituição.

> Condução: foram conduzidas pela pesquisadora e sem gravação.

Data e local: foram definidos em função da disponibilidade dos entrevistados.

> Duração: variou de 20 a 40 minutos.

Os resultados das entrevistas não estruturadas concedidas pelas diretoras ou coordenadoras das unidades-caso (apresentados a seguir) não apresentam 
conteúdos homogêneos em função da modalidade de entrevista adotada que não seguiu um roteiro.

\subsubsection{Unidade-caso 1: resultados}

A entrevista não estruturada foi concedida pela coordenadora da unidade-caso 1 (especializada em alunos com deficiência visual) em 25/09/2009, na sala da coordenação e teve a duração de 30 minutos (das 9h15min às 9h45min). Não houve solicitação por parte da coordenadora de carta de autorização para a realização da pesquisa. Requereu-se apenas o envio prévio por e-mail da duração e do conteúdo detalhado das atividades a serem realizadas. A entrevistada concedeu prontamente 0 pedido realizado pela pesquisadora para o uso da máquina fotográfica durante as atividades da pesquisa gerando imagens com a posterior colocação da tarja no rosto dos alunos objetivando a preservação da identidade. Segundo a entrevistada, existe apenas uma sala do ensino preparatório (equivalente a pré-escola) no período da manhã, cuja docente foi apresentada à pesquisadora durante a entrevista. Por fim, foram agendadas as entrevistas semiestruturadas com a coordenadora e outra com a docente da única sala de pré-escola, ambas para o dia 30/09/2009. 


\subsubsection{Unidade-caso 2: resultados}

A entrevista não estruturada foi concedida pela diretora da unidade-caso 2 (especializada em alunos com deficiência auditiva) em 10/09/2009, na sala da direção e teve a duração de 20 minutos (das $10 \mathrm{~h} 45 \mathrm{~min}$ às $11 \mathrm{~h} 05 \mathrm{~min}$ ). Requereu-se uma carta de solicitação para a realização da pesquisa que deveria ser encaminhada à assessoria de imprensa da Secretaria Municipal da Educação de São Paulo (SMESP). Informado sobre a existência de quatro salas de pré-escola, foi solicitado que a pesquisa não atrapalhasse a rotina das aulas, e que não fossem feitas discussões com as docentes sobre a inclusão dos alunos com deficiência na rede regular, por se encontrarem sensibilizadas em relação aos rumos da educação especial. Segundo a diretora, inicialmente a pesquisadora deveria contratar um intérprete de LIBRAS $^{156}$ para aplicação dos instrumentos destinados aos alunos surdos, em função do reduzido número de docentes (houve a realocação dos mesmos na rede regular). A entrevistada solicitou auxílio na solução de problemas de acessibilidade do mobiliário (carteira escolar) relativos ao aluno surdocego ${ }^{157}$.

\footnotetext{
${ }^{156}$ No decorrer da pesquisa de campo a diretora cedeu uma docente de apoio, sendo que a docente titular da classe aplicou os instrumentos destinados aos alunos surdos, em LIBRAS. Nenhum outro intérprete, a não ser a docente destes alunos, poderia ser o aplicador, devido à própria faixa etária em que se encontravam e em função da LIBRAS ainda não ser fluente. Esta informação foi fornecida pela presidente da Associação dos Profissionais Intérpretes e Guias-Intérpretes da LIBRAS do Estado de São Paulo, D. Elisabeth Figueira.

${ }^{157}$ Posteriormente a pesquisadora auxiliou na adaptação da carteira escolar ao aluno surdocego.
} 


\subsubsection{Unidade-caso 3: resultados}

A entrevista não estruturada foi concedida pela coordenadora da unidade-caso 3 (especializada em alunos com deficiência física) em 10/09/2009, na sala da coordenação e teve a duração de 40 minutos (das 8 h10min às 8 h50min). Nesta entrevista exploratória inicial foram apresentados os objetivos da primeira etapa da pesquisa à coordenadora que requereu uma carta de solicitação para a realização da mesma que deveria ser encaminhada à direção da unidade-caso 3. Durante o período de aquecimento a coordenadora informou que alguns alunos não foram incluídos na rede regular de ensino a pedido da família (algumas crianças que foram para a escola regular em 2009 retornaram). A unidade-caso 3 se posiciona a favor da inclusão do aluno com deficiência na rede regular de ensino e busca o fortalecimento do aluno através da atuação de uma equipe multidisciplinar composta por fonoaudiólogas, psicólogas, fisioterapeutas e terapeutas ocupacionais. Em 2007 o número de alunos na pré-escola e no $1^{\circ}$ ciclo do ensino fundamental era de 114 , em 2008 este número passou para 84, e em 2009 para 57 alunos (sobraram vagas) distribuídos em 7 salas, sendo 3 salas de pré-escola ${ }^{158}$. Muitos dos docentes cedidos pela prefeitura para lecionar na unidade-caso 3 foram realocados na rede regular.

A unidade-caso 3 dispõe de outro setor que somente presta apoio pedagógico à rede regular e à própria escola da unidade-caso 3, sendo que os alunos frequentam este setor de uma, no máximo, duas vezes por semana.

\footnotetext{
158 Esses dados se referem a somatória dos alunos de pré-escola e do ensino fundamental. Essa entrevista foi apresentada à coordenadora em 2010, e esta complementou que neste ano a unidadecaso 3 apresentou apenas 46 alunos e em 2011 a previsão é de apenas 29 alunos.
} 


\subsubsection{Entrevistas semiestruturadas individuais com diretoras ou coordenadoras}

\section{a) Objetivo}

Na primeira etapa da pesquisa as entrevistas semiestruturadas individuais com as diretoras ou coordenadoras tiveram como objetivo obter informações relevantes para o desenvolvimento da pesquisa, tais como: dados básicos, inclusão escolar, especificidades e nível pedagógico dos alunos com deficiência.

\section{b) Procedimentos adotados}

As entrevistas semiestruturadas foram realizadas individualmente com cada uma das diretoras ou coordenadoras das três unidades-caso ou escolas especiais. Foi elaborado o roteiro da entrevista (Quadro 13) possibilitando à pesquisadora conduzir o diálogo e, eventualmente, aprofundar em questões específicas. Esse roteiro da entrevista foi enviado previamente por e-mailàs entrevistadas para conhecimento.

> Condução: as entrevistas foram conduzidas pela pesquisadora e gravadas com o prévio consentimento dos entrevistados. Ao final, foi solicitada a listagem da(s) classe(s) e dos alunos de pré-escola, com respectivo(s) docente(s).

Datas: variadas, definidas em função da disponibilidade dos entrevistados.

> Duração: variável, de 20 a 50 minutos. 


\section{Perguntas}

Qual tipo de assistência é prestada aos alunos da pré-escola?

Qual a faixa etária das crianças na pré-escola?

Qual o número mínimo e máximo de alunos por sala de aula?

Qual é o critério de divisão dos alunos nas salas de aula? Por idade, por forma de linguagem, por nível pedagógico e/ou por tipo de deficiência?

Existe algum caso de inclusão total? Algum aluno com deficiência foi incluído na rede regular?

Existe algum caso de inclusão parcial? Algum aluno com deficiência frequenta a EMEI regular e a escola especial?

Os alunos com deficiência que frequentam a pré-escola especial também frequentam outra instituição para apoio pedagógico?

Permanecem na pré-escola até qual nível pedagógico e até qual idade máxima? Para qual escola são encaminhadas e em qual etapa são inseridas?

Fale sobre as principais deficiências encontradas nos alunos: necessidades (recursos de tecnologia assistiva), autonomia e forma de comunicação ou linguagem na sala de aula.

Quantos alunos ainda não desenvolveram uma forma de linguagem ou de comunicação efetiva?

Qual é o material didático adotado?

O conteúdo pedagógico é o mesmo da pré-escola regular? Qual o nível de alfabetização que os alunos atingem?

Os alunos conseguem desenhar? Os alunos conseguem ler?

Os alunos conseguem interpretar perguntas como: Você está com frio ou com calor?

Quadro 13 - Roteiro da entrevista semiestruturada destinada à direção das unidades-caso.

\section{Legenda}

Temática:

Dados básicos

Inclusão escolar

Deficiências

Nível pedagógico

Habilidades cognitivas dos alunos

A seguir serão apresentados os resultados das entrevistas semiestruturadas

individuais com diretoras ou coordenadoras por unidade-caso. 


\subsubsection{Unidade-caso 1: resultados}

A entrevista semiestruturada foi concedida pela coordenadora da unidade-caso 1 (especializada em alunos com deficiência visual) em 30/09/2009, na sala da coordenação (Figura 20) e teve a duração de 50 minutos (das 9h05min às 9h55min).

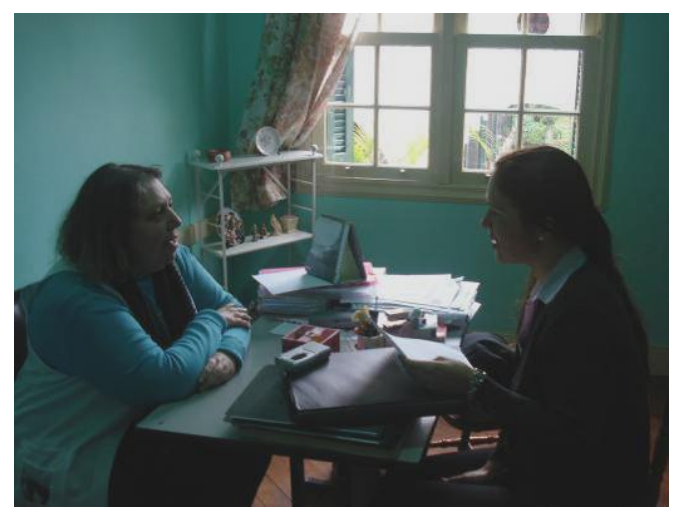

Figura 20 - Entrevista com a coordenadora da unidade-caso 1.

A unidade-caso 1 presta assistência odontológica, psicológica e fisioterapêutica aos alunos com deficiência visual da pré-escola ao ensino fundamental. Em relação à pré-escola, a faixa etária dos alunos é de 4 a 12 anos, sendo que permanecem de 2 a 4 anos neste nível escolar.

O número mínimo de alunos por sala é de 5 e o máximo de 15 alunos, sendo que em média há 12 alunos por sala. Não há um critério rígido de divisão dos alunos na préescola e existem alunos com diferentes idades e níveis pedagógicos na mesma sala. Os alunos que frequentam a pré-escola não se encontram matriculadas em outras pré-escolas da rede regular (EMEI) e apenas um aluno frequenta outra instituição que presta apoio pedagógico. Existem poucos casos de inclusão dos alunos na unidade-caso 1 em escolas da rede regular no nível do ensino fundamental. Para ingressar na unidade-caso 1 o aluno deve apresentar alguma deficiência visual (a cegueira ou a baixa visão). O familiar realiza uma entrevista com uma pessoa do setor administrativo vinculada à Igreja Católica, sendo que muitas vezes a família 
omite outros comprometimentos do aluno por receio de não conseguir a vaga. Posteriormente ao ingresso do aluno na pré-escola, a docente pode vir a detectar, em sala de aula, os comprometimentos não relatados como os relacionados à parte motora e ao nível cognitivo. A autonomia na locomoção dos alunos cegos é relativa; eles andam no espaço escolar em grupos, guiados por alunos com baixa visão, não sendo incentivado o uso da bengala dentro das dependências da escola. A autonomia do aluno com baixa visão é considerada ótima. O material didático destinado aos alunos de pré-escola com baixa visão se encontra em Português com letras ampliadas (chamado de material didático ampliado). O conteúdo pedagógico da pré-escola da unidade-caso 1 é o mesmo da rede regular, com a diferença de que aos alunos cegos é introduzido adicionalmente, noções iniciais do sistema Braille através da apresentação dos pontos, porém os alunos saem da pré-escola sem ler ou escrever neste sistema. Os alunos permanecem na pré-escola até atingir o nível pedagógico relativo à pré-alfabetização, sendo que a idade máxima permitida para a permanência nesta pré-escola é de 12 anos aproximadamente; passando então para o ensino fundamental oferecido na própria unidade-caso 1 , sendo posteriormente encaminhados para escolas da rede estadual próximos às residências, que ofereçam a sala com recursos e professores especializados no nível do ensino médio. Poucos alunos chegam ao ensino médio, sendo encaminhados em geral para a Escola Estadual Caetano de Campos próximo à EMEE Helen Keller. Ao total, cerca de 80 alunos são atendidos entre a pré-escola e o ensino fundamental. A procura por vagas não é grande, pois o transporte oferecido pela prefeitura somente atende a alunos de instituições conveniadas com a prefeitura, e este não é o caso. O familiar acompanha o aluno à unidade-caso 1 e permanece na mesma até o término da aula 
em função do gasto com a condução ou da distância até o domicílio. As mães ou familiares que aguardam o aluno até o término da aula são proibidos de permanecer na área escolar ou entrar no refeitório na hora do lanche (intervalo) com o objetivo de evitar a superproteção e não causar o constrangimento às crianças que não têm seus familiares presentes, além de incentivar a autonomia da criança. Algumas mães que permanecem na escola auxiliam no trabalho voluntário (confecção de artesanato), outras aprendem o sistema Braille, outras caminham nas redondezas. As aulas ocorrem das $7 \mathrm{~h} 30 \mathrm{~min}$ às $12 \mathrm{~h}$, sendo que o aluno pode almoçar na escola. Algumas crianças permanecem até o meio da tarde a pedido dos pais.

\subsubsection{Unidade-caso 2: resultados}

A entrevista semiestruturada foi concedida pela diretora da unidade-caso 2 (especializada em alunos com deficiência auditiva) em 08/10/2009, na sala da direção e teve a duração de 20 minutos (das 14h às 14h20min).

A unidade-caso 2 não presta os serviços complementares de psicologia, fisioterapia e fonoaudiologia. Uma fonoaudióloga de um posto de saúde próximo realiza exames de avaliação dos alunos em uma sala da unidade-caso sazonalmente. A Prefeitura oferece o transporte aos alunos. Em relação à pré-escola em 2009, a faixa etária dos alunos era de 3 a 5 anos; o número mínimo de alunos por sala é de 5 e o máximo de 8 alunos; e era oferecido somente no horário das $13 \mathrm{~h}$ às $17 \mathrm{~h}$. 0 critério de divisão dos alunos na pré-escola nas salas é por idade. Os alunos que frequentam a pré- 
escola não se encontram matriculados em outras escolas da rede regular e alguns alunos frequentam outras instituições que prestam apoio pedagógico. Existem poucos casos de inclusão dos alunos com deficiência auditiva em escolas da rede regular e alguns alunos saem da EMEE e retornam a pedido dos pais. Alguns alunos com deficiência não conseguem ser incluídos no ensino regular devido ao grau de comprometimento físico (alimentação por sonda) e na alta densidade de alunos por sala, dentre outros motivos. O material didático adotado na pré-escola para os alunos com deficiência múltipla (auditiva e baixa visão) é o ampliado. O conteúdo pedagógico da pré-escola desta Instituição não é o mesmo da pré-escola regular, pois aos alunos com deficiência auditiva é introduzido inicialmente a LIBRAS e não o ensino do Português. Os alunos precisam inicialmente aprender a LIBRAS, que segundo a entrevistada oferece suporte e visão de mundo, para então entender a língua portuguesa. Solicitou-se perguntar à docente sobre as questões mais específicas relativas aos alunos constantes no roteiro da entrevista (Quadro 13).

\subsubsection{Unidade-caso 3: resultados}

A entrevista semiestruturada foi concedida pela coordenadora da unidade-caso 3 (especializada em alunos com deficiência física) em 01/10/2009, na sala de educação física e teve a duração de 40 minutos (das $10 \mathrm{~h} 45 \mathrm{~min}$ às $11 \mathrm{~h} 25 \mathrm{~min}$ ). 0 resultado desta entrevista foi apresentado à coordenadora que solicitou alterações visando a qualidade das informações. A entrevistada autorizou o uso do conteúdo da entrevista, bem como a divulgação de sua imagem (Figura 21). 
A origem da unidade-caso 3 remete aos anos 1960. Inicialmente, a escola se encontrava no andar térreo do atual edifício, incluindo em seu programa o jardim e o playground, porém com o passar do tempo e em função da necessidade de outros segmentos, principalmente o hospitalar, a escola foi

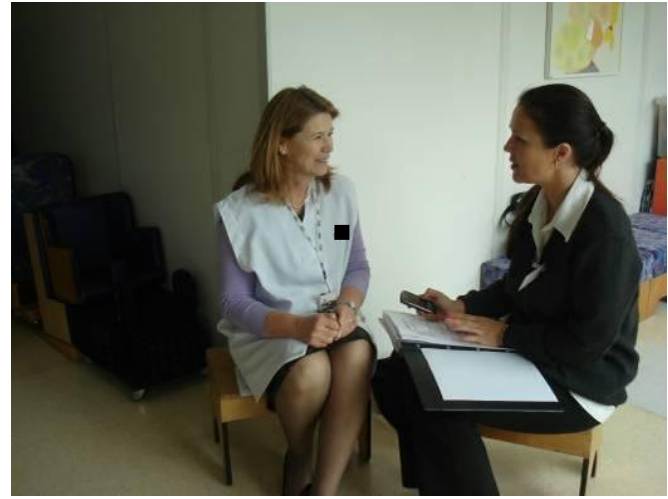

Figura 21 - Entrevista semiestruturada com a coordenadora da unidade-caso 3.

transferida para o primeiro andar do edifício

há cerca de dez anos.

Posteriormente, este espaço foi reduzido em função da necessidade da criação de salas ambulatoriais para consultas. Este fato ocorreu em paralelo com a redução da demanda de alunos com deficiência física na unidade-caso 3, devido à inclusão dos mesmos na rede regular. A procura por vagas nesta escola tem diminuído ano a ano e não há fila de espera. A unidade-caso 3 presta fundamentalmente assistência aos alunos na reabilitação, a qual abrange: fisioterapia, terapia ocupacional, fonoaudiologia, psicologia, fisioterapia aquática, reabilitação esportiva, musicoterapia, arte terapia e pedagogia. Em 2009, os alunos de pré-escola se encontravam distribuídos em 3 salas e a faixa etária deles variava entre 5 e 10 anos, sendo que a idade mínima para ingressar na pré-escola é de 5 anos com a proposta de alfabetização. Segundo a legislação relativa à educação especial, por sala de aula é permitido o número máximo de 10 alunos, e na unidade-caso 3 o número médio por sala era de 8 alunos. 0 aspecto, segundo a entrevistada, que gera maior prejuízo 
ao aprendizado do aluno sem fala funcional é a forma de comunicação ${ }^{159}$ utilizada. Em função deste problema, a unidade-caso 3 conta com o apoio de fonoaudiólogas que elaboram, junto com as docentes, algumas estratégias para que o aluno se faça entendido e não perca a linha de pensamento. A unidade-caso 3 apresenta um grande número de alunos que não fala, e que se comunica através da CAA, utilizando as pastas ou pranchas, as quais são específicas e fazem parte do material escolar do aluno. Quem elabora as pastas e pranchas não é a docente, pois se exige uma formação mais apurada e mais específica como de uma fonoaudióloga. Alguns alunos da unidade-caso 3 que tem PC apresentam impedimentos físicos para algumas ou várias ações. Existem tipos de PC como o atetóide, onde a lesão nos núcleos de base impede a ação motora desde a articulação de movimentos, com o comprometimento da parte fonoarticulatória, porém com a capacidade intelectual preservada. Outros alunos desta escola com PC apresentam uma melhor função dos membros superiores e falam. Segundo a coordenadora, a PC não é uma deficiência física evolutiva. Caso o aluno comece a apresentar outro comprometimento, é encaminhado para uma avaliação médica. Os alunos que frequentam a pré-escola da unidade-caso 3 não se encontram matriculados na rede regular. No entanto, para usufruir dos serviços do setor do atendimento educacional especializado de apoio pedagógico, outro serviço da unidade-caso 3, o aluno deve estar matriculado na rede regular. O foco da escola da unidade-caso 3 é dirigido para crianças com deficiência física, as quais podem advir de má formação congênita, distrofias neuromusculares, PC e lesão encefálica infantil, dentre outros. Os alunos com deficiência física observados na escola da unidade-caso 3 são, geralmente, usuários de cadeira de

159 CAA ver item 2.2.1.1. 
rodas, ocorrendo, em alguns casos, o processo de evolução deste quadro. Assim, alunos que entram na escola usuários de cadeira de rodas podem concluir o curso trocando passos com autonomia e quase independentes. E, o inverso disso também pode ocorrer, ou seja, alunos que entram andando com muita dificuldade podem se tornar usuários de cadeira de rodas. Os alunos com deficiência física da unidade-caso 3 têm, na sua maioria, PC. A lesão cerebral pode atingir o nervo óptico e a criança pode vir a apresentar a baixa visão (há dados que justificam que os prematuros são os que mais têm a visão comprometida), sendo que na unidade-caso 3 não se verificou nenhum caso de aluno cego ${ }^{160}$. Solicitou-se perguntar às docentes sobre as questões mais específicas relativas aos alunos constantes no roteiro da entrevista (Quadro 13).

\subsubsection{Entrevistas semiestruturadas com docentes}

\section{a) Objetivo}

Na primeira etapa da pesquisa, as entrevistas semiestruturadas com as docentes tiveram como objetivo obter informações relevantes sobre os alunos: nível pedagógico e cognitivo, fase de aprendizado, formas de comunicação, bem como apresentar os instrumentos de coleta de dados para discussão.

160 A unidade-caso 3 oferece um curso aos agentes escolares da rede regular objetivando o conhecimento das especificidades dos alunos que necessitam cuidados especiais, no que diz respeito a locomoção, higiene e alimentação para o auxílio dessas atividades desenvolvidas fora da sala de aula, dentro da unidade escolar. Disponível em:

<http://www.sinpeem.com.br/lermais_materias.php?cd_materias=3414>. Acesso em: 10 nov. 2009. 


\section{b) Procedimentos adotados}

Foi elaborado o roteiro da entrevista semiestruturada destinada às docentes (Quadro 14) contemplando os temas objeto de interesse e, eventualmente, aprofundar questões específicas identificadas pelo entrevistador.

\begin{tabular}{|c|c|}
\hline \multicolumn{2}{|c|}{ Entrevista semiestruturada } \\
\hline $\begin{array}{c}\text { Grupo focal: unidade-caso } 3 \\
\text { Temas }\end{array}$ & $\begin{array}{c}\text { Individual: unidades-caso } 1 \text { e } 2 \\
\text { Perguntas }\end{array}$ \\
\hline Fase do aprendizado dos alunos & $\begin{array}{l}\text { Em que fase do aprendizado se encontram? O que } \\
\text { estão aprendendo? }\end{array}$ \\
\hline Material pedagógico & Como é o material pedagógico? \\
\hline Formas de comunicação & $\begin{array}{l}\text { Fale sobre os alunos (sistema de linguagem ou } \\
\text { comunicação) }\end{array}$ \\
\hline Os alunos e a atividade de desenhar & Os alunos elaboram desenhos? \\
\hline $\begin{array}{c}\text { Nível pedagógico e cognitivo } \\
\text { Apresentar os instrumentos para discussão }\end{array}$ & $\begin{array}{l}\text { Fale sobre os alunos (nível cognitivo e pedagógico) } \\
\text { Apresentar os instrumentos para discussão }\end{array}$ \\
\hline
\end{tabular}

Quadro 14 - Entrevistas semiestruturadas destinadas aos docentes das unidades-caso na $1^{\text {a }}$ etapa da pesquisa.

A aplicação foi individual nas unidades-caso 1 e 2 e em forma de grupo focal ${ }^{161}$ na unidade-caso 3 (não foi possível a aplicação do grupo focal nas unidades-caso 1 e 2 em função da existência de apenas uma classe de pré-escola e falta de pessoal para o apoio nas salas de aula ${ }^{162}$, respectivamente).

No início da entrevista foram esclarecidos os objetivos da pesquisa, entregue em material impresso, juntamente com os nomes completos da pesquisadora, da orientadora e da coorientadora, da instituição e o telefone para contato.

Condução: as entrevistas foram conduzidas pela pesquisadora e gravadas com o prévio consentimento dos participantes.

${ }^{161}$ Permite a obtenção de informações em consenso e com a otimização do tempo de aplicação.

${ }^{162}$ A diretora alegou que as docentes não poderiam deixar as suas salas ao mesmo tempo devido à falta de outros funcionários para ficarem com os alunos durante a ausência das mesmas. A pesquisadora se prontificou a realizar o grupo focal em um sábado, porém esta possibilidade não foi aceita. 
> Datas: variadas, definidas em função da disponibilidade dos entrevistados sendo realizadas em cada uma das três unidades-caso.

Duração: variável, de 15 a 30 minutos.

A seguir serão apresentados os resultados das entrevistas semiestruturadas com docentes.

\subsubsection{Unidade-caso 1: resultados - individual}

A entrevista semiestruturada foi concedida pela docente da única classe de préescola existente na unidade-caso 1 (especializada em alunos com deficiência visual) em 30/09/2009, na sala da coordenadora (Figura 22) e teve a duração de 30 minutos (das $10 \mathrm{~h} 30 \mathrm{~min}$ às $11 \mathrm{~h}$ ) enquanto os alunos se encontravam em outra aula.

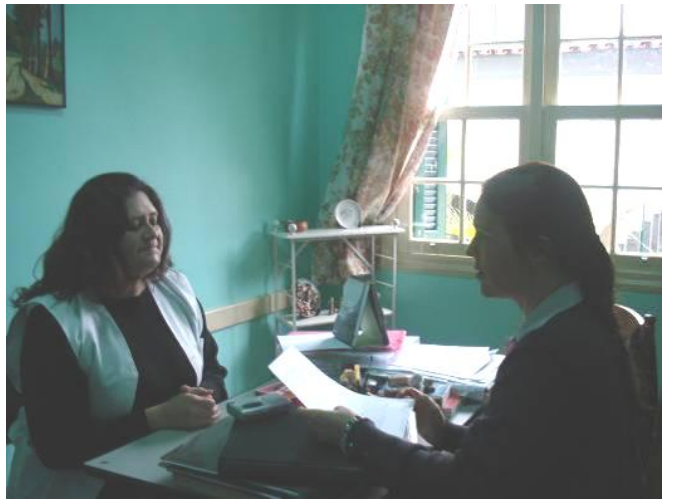

Figura 22 - Entrevista semiestruturada com a docente da unidade-caso 1.
Segundo a docente é opcional o uso de bengala pelo aluno cego para a sua locomoção dentro da unidade-caso 1. A locomoção da criança cega no ambiente escolar se faz individualmente, em duplas ou em trios ${ }^{163}$ (compostos somente por alunos cegos ou por aluno(s) cego(s) e com baixa visão).

${ }^{163}$ Grupos no máximo de três alunos para evitar a obstrução da circulação e trombadas. 
A circulação dos alunos é considerada fácil pela docente devido ao cuidado para que os percursos realizados sejam constantes. Quando o aluno cego inicia a pré-escola é realizado um trabalho de reconhecimento dos percursos e do ambiente escolar da unidade-caso 1. A posição do mobiliário na sala de aula, como carteiras e prateleiras destinadas a materiais de uso do aluno, permanece sempre a mesma devido à memorização do mesmo pelos alunos. Caso seja necessário a alteração de algum mobiliário, esta é realizada em conjunto com os alunos que desta forma circulam com facilidade na sala de aula. Os alunos cegos que se encontram no início da préescola, com cerca de quatro anos, realizam exercícios que envolvem a coordenação motora fina, como os jogos de encaixe (Figura 23) e exercícios que envolvem o tatear de objetos para a sua descrição.

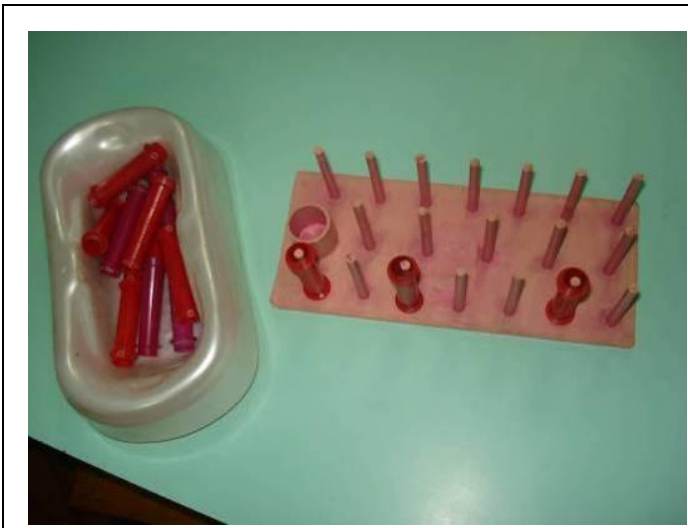

(a)

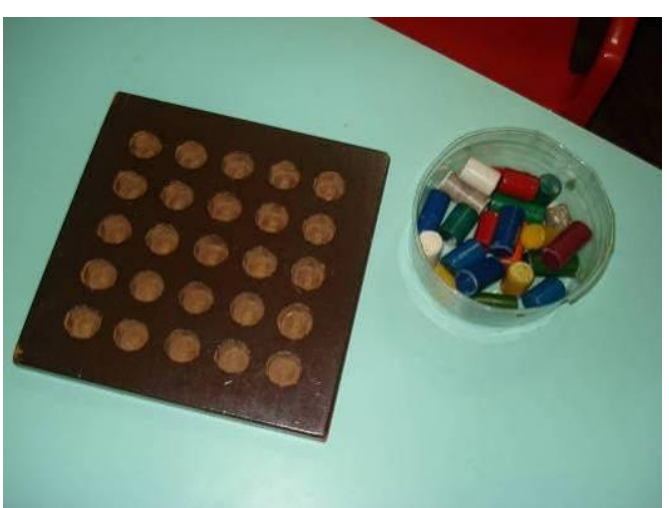

(b)

Figura 23 - Jogos de encaixe $(a, b)$ da pré-escola da unidade-caso 1.

Os alunos cegos, aos seis anos de idade, se encontram no início do aprendizado no sistema Braille por meio do uso da reglete (ver item 2.2.3). 


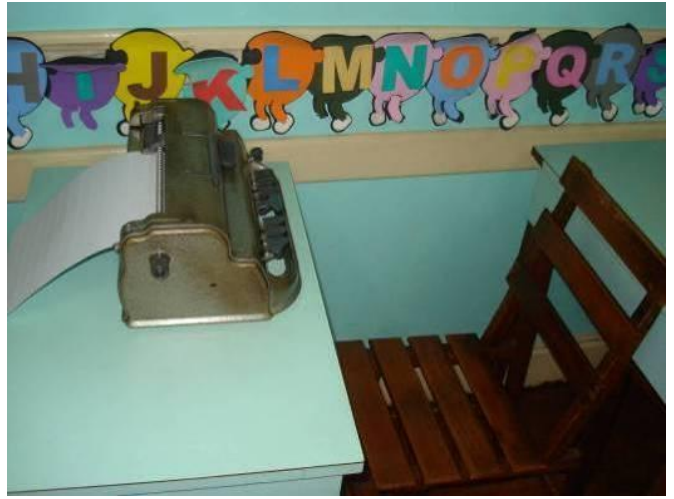

Figura 24 - Máquina de escrever no sistema Braille da unidade-caso 1.

Caso o aluno apresente dificuldade motora ou comprometimento físico mesmo com o acompanhamento da fisioterapeuta da unidade-caso 1, a máquina de escrever (Figura 24) é apresentada como alternativa para a introdução do sistema Braille por requerer menos coordenação motora fina no seu manuseio.

Segundo a entrevistada, os alunos de 5 e 6 anos com baixa visão e cegos da unidade-caso 1 se encontram no nível pedagógico equivalente ao $3^{\circ}$ estágio da préescola da rede regular municipal. Esses alunos se encontram pré-alfabetizados, pois escrevem o próprio nome, reconhecem as letras do alfabeto e a correspondência biunívoca ${ }^{164}$. O material pedagógico destinado aos alunos com baixa visão é ampliado para a fonte de tamanho 24. Todos os alunos apresentam a fala preservada e se comunicam verbalmente, não havendo a comunicação alternativa em nenhum caso.

A pesquisadora apresentou os instrumentos de coleta de dados a serem aplicados nos alunos cegos: entrevista lúdica com brinquedo ${ }^{165}$ e o questionário ilustrado tátil ${ }^{166}$, bem como os instrumentos de coleta de dados a serem aplicados nos alunos

\footnotetext{
${ }^{164}$ A correspondência biunívoca resume-se numa operação de fazer corresponder.

${ }^{165}$ Ver item 7.2.1.1.

${ }^{166}$ Ver item 8.2.1.
} 
com baixa visão: entrevista lúdica com desenho temático ${ }^{167}$ e o questionário ilustrado ampliado $^{168}$. A docente relatou que os 3 alunos com baixa visão e 7 alunos cegos (do total de 12) apresentavam boas condições para a realização das atividades propostas. Cada questão relativa ao questionário ilustrado destinado aos alunos cegos e com baixa visão foi apresentada pela pesquisadora e discutida com a docente, sendo que a mesma indicou a ampliação dos desenhos em relevo para os alunos cegos, com o objetivo de facilitar o tatear, sendo solicitada a colocação de cada questão separadamente em uma folha de papel. No caso dos alunos com baixa visão, a docente indicou o aumento da fonte para o tamanho 24. A docente achou que a linguagem do questionário estava compatível com o nível pedagógico dos alunos aptos a participarem da pesquisa (item 4.5.1), bem como as figuras, de fácil reconhecimento tátil pelos alunos cegos. Segundo a docente, a aplicação do questionário não poderia ser realizada com todos os alunos ao mesmo tempo, pois a classe é heterogênea, e com alunos que apresentam dificuldades variáveis. A docente orientou que a aplicação do questionário ilustrado tátil destinado aos alunos cegos deveria ser individual, propiciando a leitura do enunciado de cada questão pela pesquisadora, o auxílio no posicionamento dos dedos do aluno em cada figura a ser tateada, bem como o fato da marcação da alternativa escolhida ter que ser realizada pela pesquisadora. Ao final da entrevista foi entregue à docente uma planilha para preenchimento posterior dos dados relativos aos alunos (nome, ano de nascimento e dificuldades dos alunos).

\footnotetext{
${ }^{167}$ Ver item 7.2.2.1.

${ }^{168}$ Ver item 8.2.2.
} 


\subsubsection{Unidade-caso 2: resultados - individual}

A entrevista semiestruturada foi concedida pela docente da única classe de préescola apta a participar da pesquisa na unidade-caso 2 (especializada em alunos com deficiência auditiva) em 8/10/2009, no pátio coberto e teve a duração de 15 minutos (das $15 \mathrm{~h}$ às $15 \mathrm{~h} 15 \mathrm{~min}$ ) enquanto os alunos se encontravam na aula de informática.

Nenhum dos alunos com deficiência auditiva da classe da docente entrevistada apresenta outra deficiência associada, sendo que todos apresentam visão normal, bom desenvolvimento cognitivo e andam com autonomia. Nas outras três classes de pré-escola existem alguns alunos que apresentam outras deficiências associadas à auditiva, como a física (usuários de cadeira de rodas). Os alunos surdos desta classe se encontram na fase inicial do ensino de LIBRAS, são incentivados a realizar a movimentação dos lábios relativa à palavra concomitante à sua representação em LIBRAS, havendo um espelho pequeno localizado na sala de aula. A pesquisadora apresentou os instrumentos de coleta de dados a serem aplicados nos alunos surdos: entrevista lúdica com desenho temático ${ }^{169}$ e o questionário ${ }^{170}$ relativo às questões de acessibilidade e de conforto térmico, acústico e lumínico. A docente relatou que os alunos apresentavam boas condições intelectuais para a realização das atividades propostas e que costumam elaborar desenhos. A docente entrevistada se prontificou em ser a intérprete de LIBRAS. Ao final da entrevista foi entregue à docente uma

\footnotetext{
${ }^{169}$ Ver item 7.2.2.2.

${ }^{170}$ Ver item 8.2.3.
} 
planilha para preenchimento posterior dos dados relativos aos alunos (nome, ano de nascimento e dificuldades dos alunos).

\subsubsection{Unidade-caso 3: resultados - grupo focal}

A entrevista semiestruturada em grupo focal ocorreu na unidade-caso 3 (especializada em alunos com deficiência física) em 10/11/2009, na sala dos professores com a participação de 3 docentes de pré-escola e uma de educação física (Figura 25) com duração de 25 minutos

(das $9 \mathrm{~h}$ às $9 \mathrm{~h} 25 \mathrm{~min})$.

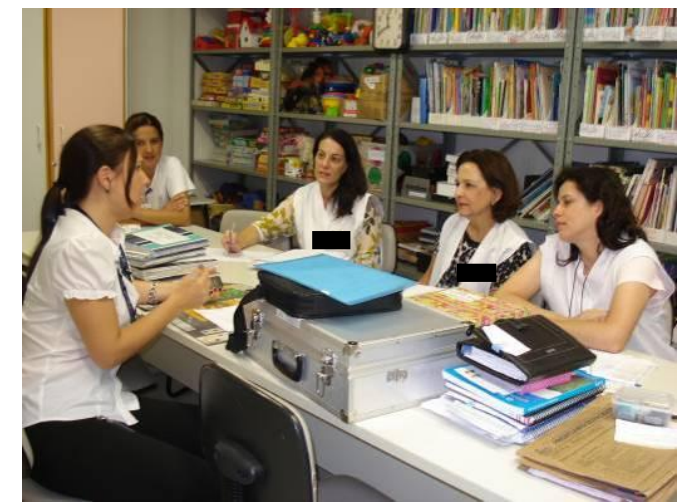

Figura 25 - Grupo focal das docentes de pré-escola da unidade-caso 3.

Os alunos de pré-escola da unidade-caso 3 se encontram em uma fase de aprendizado bem mais adiantada em relação aos da rede regular pública, pois o objetivo é a alfabetização destinada aos alunos que apresentem condições para tal. A alfabetização citada se refere à leitura e à escrita, não precisando haver fluência, porém o domínio básico.

Não é adotado material pedagógico. As docentes confeccionam o material necessário de acordo com a especificidade de cada aluno, como o tipo de caderno (com ou sem linha) e o tamanho da letra adotada, dentre outros. 
Poucos alunos apresentam boa mobilidade sendo que a maioria precisa ser conduzida na cadeira de rodas. A comunicação utilizada pelos alunos que tem a fala comprometida é a $C A A^{171}$, através da prancha ou da pasta de comunicação, que não é de difícil entendimento, mesmo em relação àqueles que além de não ter fala, não apresentam movimentação ou coordenação nos membros superiores. Esses alunos utilizam outras técnicas voluntárias para apontar o símbolo na prancha ou na pasta (como piscar, sorrir, movimentar uma parte de corpo, dentre outras).

A pesquisadora apresentou os instrumentos de coleta de dados a serem aplicados nos alunos: entrevista lúdica com desenho temático ${ }^{172}$ e questionário ilustrado ${ }^{173}$. Discutiram-se alguns procedimentos para a aplicação dos mesmos. Foi consenso a realização de uma preparação prévia junto aos alunos com o intuito de obter a fidelidade na pesquisa. Esta preparação se refere à conversação prévia das docentes com os alunos, objetivando a não ocorrência da cópia entre os mesmos. Os alunos deverão ser posicionados de forma distanciada uns dos outros antes da aplicação. Serão selecionados voluntários ${ }^{174}$ para as aplicações, objetivando obter pessoas com um bom nível de compreensão e que não tenham a prática de intervir nas respostas dos alunos. Foi esclarecido que a pesquisadora conduzirá a aplicação dos instrumentos em conjunto com a docente da classe em questão e a equipe de voluntários, sendo a pesquisadora uma referência positiva para os alunos. Segundo as docentes, a aplicação dos instrumentos não precisa ser individual, pois conta com

\footnotetext{
${ }^{171}$ Ver item 2.2.1.1.

${ }^{172}$ Ver item 7.2.2.3.

${ }^{173}$ Ver item 8.2.3.

${ }^{174}$ A unidade-caso 3 dispõe de uma equipe de voluntários para o apoio diário durante as atividades escolares. A maioria dos voluntários são senhoras que exercem o voluntariado a muitos anos.
} 
elas e com a equipe de voluntários, podendo ser rápida em função do bom desenvolvimento cognitivo dos alunos. A pesquisadora levantou a questão da dificuldade física dos alunos com comprometimento nos membros superiores para a realização dos desenhos, bem como eventual frustação dos mesmos em relação ao resultado final. Na resposta a tal indagação as docentes relataram que esses alunos costumam e gostam de confeccionar desenhos, muitos com ajuda de um adulto, e que o esforço dispendido não thes seria prejudicial. Ao final do grupo focal foi entregue a cada docente uma planilha para preenchimento posterior dos dados relativos aos alunos (nome, ano de nascimento e dificuldades dos alunos).

\section{$5.3 \quad 2^{\mathrm{a}}$ etapa da pesquisa}

\subsubsection{Entrevistas não estruturadas individuais com diretoras ou coordenadoras}

\section{a) Objetivo}

As entrevistas não estruturadas individuais tiveram como objetivo a apresentação das metas da segunda etapa da pesquisa às diretoras ou coordenadoras das unidades-caso 1, 2 e 3, bem como o pedido de autorização e informações básicas sobre a pré-escola (quantidade de classes, nome das docentes, período). Essas entrevistas iniciais tiveram caráter exploratório. 


\section{b) Procedimentos adotados}

As entrevistas não estruturadas foram aplicadas individualmente em cada uma das diretoras ou coordenadoras das três unidades-caso ou escolas especiais. Não foi elaborado um roteiro.

> Condução: as entrevistas foram conduzidas pela pesquisadora.

Datas: variadas, definidas em função da disponibilidade dos entrevistados.

Duração: variável, cerca de 15 minutos.

A seguir serão apresentados os resultados das entrevistas não estruturadas individuais com diretoras ou coordenadoras.

\subsubsection{Unidade-caso 1: resultados}

A entrevista não estruturada na segunda etapa da pesquisa foi concedida pela diretora da unidade-caso 1 (especializada em alunos com deficiência visual) (na $1^{\text {a }}$ etapa foi pela coordenadora) em 19/08/2010 e teve a duração de 15 minutos (das 11h05min às 11 h20min). Não houve solicitação de carta relativa ao pedido de autorização para a realização da pesquisa destinada à direção da unidade-caso 1.

Requereu-se apenas o envio prévio por e-mail do conteúdo detalhado das atividades a serem realizadas, bem como sua duração. A diretora informou a existência de duas classes do ensino preparatório (equivalente a pré-escola) no período da manhã. Não foi possível agendar a entrevista não estruturada com as docentes, pois a diretora 
comunicou a presença de outros pesquisadores na instituição e solicitou o retorno do contato a partir de 18/09/2010 (data de festividades na unidade-caso 1).

\subsubsection{Unidade-caso 2: resultados}

A entrevista não estruturada na segunda etapa da pesquisa foi concedida pela diretora da unidade-caso 2 (especializada em alunos com deficiência auditiva) em 20/08/2010 e teve a duração de 15 minutos (das 14 h05min às 14 h20min). Não houve necessidade de carta com pedido de autorização para a realização da pesquisa. Informou-se a existência de duas classes da pré-escola no período da tarde. A diretora solicitou que a pesquisadora entrasse em contato direto com uma das docentes para agendar e entrevista não estruturada individual.

\subsubsection{Unidade-caso 3: resultados}

A entrevista não estruturada na segunda etapa da pesquisa foi concedida pela coordenadora da unidade-caso 3 (especializada em alunos com deficiência física) em 28/09/2010 e teve a duração de 15 minutos (das 14h05min às 14 h20min). Não houve necessidade de carta de autorização para a realização da pesquisa. Informouse a existência de duas classes da pré-escola no período da tarde, bem como a relação dos alunos destas classes. A diretora solicitou que a pesquisadora entrasse 
em contato direto com as docentes para agendar a entrevista não estruturada em forma de grupo focal.

\subsubsection{Entrevistas não estruturadas com docentes}

\section{a) Objetivo}

Na segunda etapa da pesquisa, as entrevistas não estruturadas destinadas às docentes tiveram como objetivo obter dados específicos sobre os alunos com deficiência e discutir os instrumentos de coleta de dados para a posterior aplicação.

\section{b) Procedimentos adotados}

Não foi elaborado um roteiro da entrevista não estruturada destinada as docentes, e a aplicação das entrevistas foi individual na unidade-caso 2 e em grupo focal nas unidades-caso 2 e 3. No início da entrevista foram esclarecidos os objetivos da pesquisa, entregue em material impresso, juntamente com os nomes completos da pesquisadora, da orientadora e da coorientadora, da instituição e o telefone para contato.

Condução: as entrevistas foram conduzidas pela pesquisadora e gravadas com o prévio consentimento dos participantes.

> Datas: variadas, definidas em função da disponibilidade dos entrevistados sendo realizadas em cada uma das três unidades-caso.

> Duração: variável, de 33 a 50 minutos. 
A seguir serão apresentados os resultados das entrevistas não estruturadas com as docentes.

\subsubsection{Unidade-caso 1: resultados - grupo focal}

A entrevista não estruturada descrita a seguir foi realizada em grupo composto pelas duas docentes de cada uma das duas classes de pré-escola existentes na unidadecaso 1 (especializada em alunos com deficiência visual) e a pesquisadora no dia 30/09/2010, na sala de aula e teve a duração de 33 minutos (das $11 \mathrm{~h} 27$ min às $12 \mathrm{~h}$ ) enquanto os alunos se encontravam na aula de educação física.

A pesquisadora apresentou a segunda etapa da pesquisa e as docentes discorreram sobre as particularidades de cada aluno, de forma individualizada (fase de aquecimento da entrevista). Após esta fase, foram apresentados os instrumentos de coleta de dados a serem aplicados nos alunos cegos: entrevista lúdica com o mapa tátil $^{175}$ e questionário com maquetes ${ }^{176}$. Também os destinados aos alunos com baixa visão: entrevista lúdica com desenho temático ${ }^{177}$ e questionário ilustrado ampliado $^{178}$. As alternativas de cada questão foram discutidas e as docentes argumentaram que a aplicação nos alunos cegos deveria ser individual, com a explicação de cada questão e de suas respectivas alternativas acompanhada concomitantemente do tatear (mapa tátil e maquetes) do aluno dirigido pelo

\footnotetext{
175 Ver item 7.3.1.1.

${ }^{176}$ Ver item 8.3.1.

177 Ver item 7.3.2.1.

${ }^{178}$ Ver item 8.3.2.
} 
aplicador. Ficou decidido que a aplicação em alunos com baixa visão poderia ser em grupo com o devido afastamento entre os mesmos, sendo que permaneceriam na sala os alunos aptos a participar da pesquisa. Os alunos não aptos deveriam se encontrar nas aulas regulares de música, artes, informática ou educação física, ministradas por outros docentes. Realizou-se um comparativo com a dinâmica de aplicação da etapa anterior (pré-teste) buscando a melhores resultados para a nova aplicação. Após a discussão dos instrumentos bem como a sua forma de aplicação discutiu-se quais alunos estariam aptos a realizarem a pesquisa. As docentes discorreram sobre as dificuldades individuas de cada aluno.

A pesquisadora solicitou a permissão para trazer duas pessoas para apoio da aplicação, sendo o pedido concedido pelas docentes, e também que uma das docentes acompanhasse a aplicação dos instrumentos destinados aos alunos cegos (o que não ocorreu). Foi necessário o endereço eletrônico (email) das docentes para o envio de tabela síntese da entrevista para apreciação das mesmas com a relação aos dados dos alunos aptos a participarem da pesquisa, data de nascimento, condições motoras nos membros superiores e inferiores. A pesquisadora solicitou que as docentes fornecessem uma data para a aplicação da pesquisa destinada aos alunos, que não comprometesse as atividades próprias da rotina escolar, sendo somente possível em 25/10/2010, após as festividades da semana da criança. 


\subsubsection{Unidade-caso 2: resultados - individual}

A entrevista não estruturada a seguir foi concedida pela docente substituta da classe com maior número de alunos aptos a participarem da pesquisa da unidade-caso 2 (especializada em alunos com deficiência auditiva) no dia 25/08/2010, na sala da direção e teve a duração de 50 minutos (das 7h45min às 8 h30min), enquanto os alunos se encontravam na aula de artes.

A pesquisadora apresentou a segunda etapa da pesquisa, e a docente discorreu sobre as particularidades de cada aluno (fase de aquecimento da entrevista). Após esta fase, a pesquisadora apresentou os instrumentos de coleta de dados a serem aplicados nos alunos surdos: entrevista lúdica com desenho temático ${ }^{179}$ e questionário ilustrado ${ }^{180}$. As alternativas de cada questão foram discutidas e a docente participou com entusiasmo. Decidiu-se que a aplicação dos instrumentos destinados aos alunos deveria ser individual e que os alunos não aptos deveriam se encontrar nas aulas regulares de música, artes, informática ou educação física, ministradas por outros docentes. A pesquisadora mostrou as fotos da dinâmica de aplicação da etapa anterior (pré-teste) buscando a melhores resultados para a nova aplicação. Após a discussão dos instrumentos bem como sua forma de aplicação discutiu-se quais alunos estariam aptos a participar da pesquisa.

\footnotetext{
${ }^{179}$ Ver item 7.3.2.2.

180 Ver item 8.3.3.
} 
A pesquisadora solicitou a permissão para trazer uma pessoa para apoio da aplicação, sendo o pedido concedido pela docente (e posteriormente pela diretora). Decidiu-se que a docente iria realizar a aplicação dos instrumentos em função da LIBRAS na presença da pesquisadora, a qual somente registraria o processo de aplicação e auxiliaria no decorrer das aplicações. A pesquisadora também solicitou que a docente fornecesse uma data para a aplicação destinada aos alunos visando o não comprometimento das atividades regulares.

\subsubsection{Unidade-caso 3: resultados - grupo focal}

A entrevista não estruturada a seguir foi realizada em grupo composto pelas duas únicas docentes das duas classes de pré-escola existentes na unidade-caso 3 (especializada em alunos com deficiência física) e a pesquisadora no dia 01/10/2010, na sala de aula, e teve a duração de 45 minutos (das $11 \mathrm{~h}$ às $11 \mathrm{~h} 45 \mathrm{~min}$ ) enquanto os alunos ouviam histórias de uma contadora (voluntária).

Apresentada a segunda etapa da pesquisa, iniciou-se a fase de aquecimento onde se discorreu sobre algumas necessidades dos alunos em sala de aula: a lousa mais baixa propiciando a participação durante a aula dos alunos usuários de cadeiras de rodas com coordenação nos membros superiores; a necessidade da maca, ducha e biombo no banheiro para troca de fraldas e higienização com privacidade. Comentou-se sobre o descontentamento dos alunos em relação ao banheiro verificado nos resultados dos instrumentos aplicados em 2009 e justificado pelas 
docentes em função da espera, embora curta, dos alunos pelas duas cuidadoras e pela dificuldade no controle dos esfíncteres.

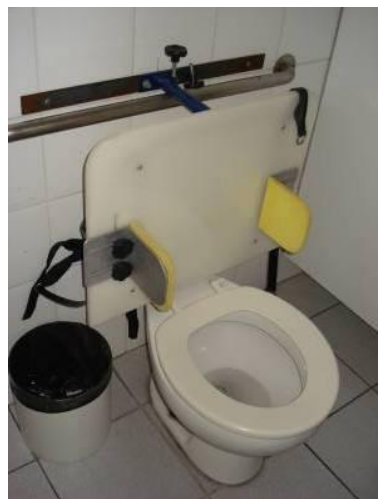

Figura 26 - Vaso sanitário no banheiro da unidade-caso 3.
O vaso sanitário (Figura 26) apresenta adaptações (contenções laterais e cintos) para o aluno com PC, sem coordenação nos membros superiores e que não utiliza fraldas, não cair para o lado. Geralmente, enquanto o aluno utiliza o vaso sanitário, a cuidadora sai do box e fecha a porta, apenas retornando após algum sinal sonoro enviado pelo aluno.

Foram apresentados e discutidos os instrumentos de coleta de dados a serem aplicados nos alunos com PC (previamente elaborados pela fonoaudióloga em conjunto com a pesquisadora): entrevista lúdica com desenho temático ${ }^{181} \mathrm{e}$ questionário ilustrado em $\mathrm{PCS}^{182}$. Realizou-se um comparativo com a dinâmica de aplicação da etapa anterior (pré-teste) buscando melhores resultados para a nova aplicação e decidiu-se que a aplicação nos alunos deveria ser individual, apesar de todos os alunos se encontrarem juntos na mesma sala de aula durante a aplicação (na primeira etapa esta aplicação foi em conjunto). Somente a explicação inicial do tema do desenho da entrevista lúdica poderia ser em grupo visando otimizar a aplicação e reduzir o seu tempo.

\footnotetext{
${ }^{181}$ Ver item 7.3.2.3.

${ }^{182}$ Ver item 8.3.4.
} 
As docentes discorreram sobre as dificuldades individuas de cada aluno e questionaram a duração das aplicações. A pesquisadora solicitou o apoio dos voluntários presentes diariamente na unidade-caso 3, e questionou a preferência de que a aplicação fosse realizada pelas docentes, na presença da pesquisadora e voluntários, ou em conjunto (pesquisadora e docente) na presença de voluntários. Houve o acordo de que as aplicações destinadas aos alunos seriam em conjunto (pesquisadora e docente) na presença de voluntários, pois a presença de uma pessoa estranha observando na sala de aula, sem interação, pode intimidar os alunos.

Solicitou-se o endereço eletrônico (email) das docentes para o envio de tabela síntese contendo os dados dos alunos coletados na entrevista, como data de nascimento, condições motoras nos membros superiores e inferiores. A pesquisadora solicitou que as docentes fornecessem uma data para a aplicação dos instrumentos visando o não comprometimento das atividades regulares dos alunos.

\subsection{Análise dos resultados}

A pesquisadora buscou ser solícita (em relação aos dias e horários determinados pelas entrevistadas); demostrar princípios de ética (através da elaboração de cartas de autorização destinadas aos responsáveis pelos alunos) e de rigor na pesquisa, através de sua pontualidade, seriedade, apresentação dos objetivos da pesquisa em material impresso, envio prévio da temática das entrevistas por e-mail, bem como o 
posterior envio dos resultados das entrevistas concedidas (impressas ou por email) às entrevistadas para a autorização da divulgação de seu conteúdo e correção (se necessária).

As entrevistas não estruturadas e semiestruturadas destinadas à direção e às docentes trouxeram informações qualitativas valiosas para o presente estudo, sendo a primeira técnica utilizada nas duas etapas da pesquisa de campo.

\section{a) $1^{\text {a }}$ etapa da pesquisa}

Na primeira etapa a pesquisadora buscou criar um vínculo com a direção de cada uma das três unidades-caso na primeira entrevista não estruturada de caráter exploratório $^{183}$ (sem gravação) que serviu de base para a elaboração da entrevista semiestruturada realizada posteriormente, de caráter formal. Nas unidades-caso 2 e 3 foram elaboradas cartas com pedido de autorização formal, à SMESP e direção, respectivamente, sendo que a pesquisa foi autorizada em todas as unidades-caso. As entrevistas semiestruturadas com as diretoras ou coordenadoras das unidades-caso 1, 2 e 3 levaram 50, 20 e 40 minutos, respectivamente, forneceram dados sobre a pré-escola, seus alunos e docentes, e foram gravadas. Percebeu-se que a inclusão dos alunos com deficiência na rede regular é um tema polêmico, e a pesquisadora se mostrou neutra em relação ao posicionamento de cada uma das unidades-caso.

\footnotetext{
${ }^{183}$ Nas unidades-caso 1 e 3 essas entrevistas excederam o tempo previsto em 20 minutos, e levaram 30 e 40 minutos, respectivamente.
} 
A pesquisadora realizou conversas informais com psicóloga, fisioterapeuta e cuidadoras (unidade-caso 1), docentes de classes não participantes da pesquisa e cuidadoras (unidade-caso 2), fonoaudióloga ${ }^{184}$ e cuidadoras (unidade-caso 3) e psicóloga com experiência em entrevista lúdica com crianças, com o intuito de obter um maior entendimento dos alunos com deficiência, base para a elaboração e aplicação dos instrumentos destinados aos mesmos. O respaldo dos profissionais citados em momentos-chave da pesquisa proporcionou um clima de confiança e tranquilidade para a atuação da pesquisadora em campo junto aos alunos com deficiência.

As entrevistas semiestruturadas ${ }^{185}$ concedidas pelas docentes forneceram informações relevantes sobre os alunos: nível pedagógico e cognitivo, fase de aprendizado, formas de comunicação, bem como apresentar os instrumentos de coleta de dados.

A vivência das docentes na aplicação dos instrumentos proporcionou maior confiabilidade em relação a pesquisa e a pesquisadora favorecendo o andamento da etapa seguinte da pesquisa.

${ }^{184}$ A fonoaudióloga elaborou o questionário ilustrado em PCS em conjunto com a pesquisadora na $1^{a}$ e $2^{a}$ etapas da pesquisa, com o uso do software Board Maker.

${ }^{185}$ Nas unidades-caso 1, 2 e 3 essas entrevistas levaram 30, 15 e 25 minutos, respectivamente. 


\section{b) $2^{\text {a }}$ etapa da pesquisa}

A direção de cada unidade-caso permaneceu a mesma na segunda etapa da pesquisa, a pesquisadora já era conhecida e sua imagem era familiar e confiável, pois a direção acompanhou o decorrer de toda a pesquisa de campo realizada em 2009. As entrevistas não estruturadas individuais com a direção (unidades-caso 1, 2 e 3) foram rápidas (não excederam 15 minutos) e sem formalismo ou burocracia, pedidos de autorização de pesquisa não foram necessários, pois a segunda etapa foi vista como a continuação da pesquisa iniciada em 2009. As entrevistas semiestruturadas com as docentes fluíram de uma forma mais descontraída em 2010, com resultados mais práticos e proveitosos; os instrumentos foram analisados pelas docentes de uma forma mais aprofundada (as entrevistas tiveram a duração de 33,50 e 45 minutos, nas unidades-caso 1, 2 e 3, respectivamente), pois as docentes já haviam aplicado os instrumentos no pré-teste (com a exceção da docente substituta da unidade-caso 2 , todas as docentes de pré-escola permaneceram as mesmas e já conheciam a pesquisadora). Verifica-se que a aplicação do pré-teste e da validação na mesma unidade-caso traz resultados mais favoráveis em relação ao instrumento entrevista, destinado à direção e aos docentes, bem como facilita o processo de autorização da pesquisa. 


\title{
6 A TÉCNICA DA OBSERVAÇÃO DESTINADA ÀS CRIANÇAS
}

\subsection{Referencial teórico}

A observação é a ação de observar, de olhar nitidamente. Nesta técnica de coleta de dados o pesquisador pode captar a realidade observada. Vários tipos de profissionais, como o médico e o psicólogo, dentre outros, fazem uso frequente da observação. A observação é largamente utilizada na psicologia infantil e está relacionada à noção de comportamento, onde o que se observa, particularmente na criança, são "condutas em resposta a estímulos dados em situações dadas." (ARFOUILLOUX, 1983, p. 15). Por meio da observação, podemos

\begin{abstract}
captar os aspectos - fatos - essenciais e acidentais de um determinado fenômeno/evento empírico. Como a simples observação não nos permite reformular, experimentar e explicar fenômenos e eventos, além de utilizar instrumentos que podem nos auxiliar nessas tarefas, no ato de observar devemos ter sagacidade, curiosidade, atenção, persistência, perseverança, para que possamos chegar à compreensão desses fenômenos e eventos. Os métodos observacionais são constituídos de procedimentos de natureza sensorial. (FUNDAÇÃO GETÚLIO VARGAS, 2010, p. 76)
\end{abstract}

Segundo Machado (2002, p. 17), o papel do observador "é central na definição dos objetos de estudo: é ele quem decide o que observar, escolhe os elementos constitutivos de seus sitemas, interfere na realidade $[\ldots] "$. Geralmente a observação é executada por um indivíduo e exige experiência do mesmo, pois o observador deverá estar atento a condutas humanas captadas através dos sentidos auditivo e visual, podendo ocorrer distorções de interpretação ou concentração em aspectos menos relevantes (CUNHA, 1982). 
O observador-pesquisador em uma pesquisa de campo é geralmente externo ao sistema observado, mas para apreender a autorreferência do sistema em questão, pode se posicionar como se fizesse parte do mesmo (MACHADO, 2002). A seguir é apresentado o Quadro 15 com as vantagens e desvantagens da técnica de coleta de dados observação.

\begin{tabular}{|c|c|c|}
\hline & Vantagens & Desvantagens \\
\hline & $\begin{array}{l}\text { - Permite captar o comportamento natural das } \\
\text { pessoas, bem como suas atitudes } \\
\text { comportamentais típicas, que dificilmente } \\
\text { poderiam ser estudados de outra forma; } \\
\text { - Possibilita por meios diretos e objetivos } \\
\text { explorarem-se temas que os participantes não } \\
\text { se sentem à vontade para responder; } \\
\text { - Enseja baixo nível de interferência ou } \\
\text { intromissão do aplicador; } \\
\text { - Pode ser realizada com pessoas não } \\
\text { alfabetizadas (não depende do grau de } \\
\text { instrução do observado), pois exige menos do } \\
\text { mesmo do que outras técnicas; } \\
\text { - Consiste em instrumento útil para o } \\
\text { levantamento de ideias iniciais e opiniões para } \\
\text { a formulação de hipóteses; } \\
\text { - Permite a evidência de dados que não } \\
\text { constam no roteiro da entrevista ou no } \\
\text { questionário; } \\
\text { - Permite o registro de acontecimentos } \\
\text { simultaneamente com sua ocorrência } \\
\text { espontânea (informação no momento e no } \\
\text { espaço onde ocorre a ação); } \\
\text { - Permite o registro de situações típicas; } \\
\text { - Possibilita o registro (filmadora e máquina } \\
\text { fotográfica) para posterior análise por outros } \\
\text { observadores. }\end{array}$ & $\begin{array}{l}\text { - Torna-se polarizada pelo observador; } \\
\text { - Limita-se ao campo de observação e ao limite } \\
\text { temporal de ocorrência dos fatos; } \\
\text { - Pode produzir efeitos do observador nas } \\
\text { pessoas observadas (a pessoa que está sendo } \\
\text { observada pode alterar seu comportamento); } \\
\text { - Gera falta de uniformidade, pois é possível } \\
\text { observarem-se coisas diferentes em momentos } \\
\text { diferentes; } \\
\text { - Possibilita deixar de lado fatores importantes, } \\
\text { devido à ocorrência de muitos fatos } \\
\text { simultaneamente, o que torna difícil a coleta } \\
\text { das informações; } \\
\text { - Há risco de interferência de fatores } \\
\text { imprevistos sobre o observador; } \\
\text { - Representa custo alto em função da aquisição } \\
\text { de equipamentos para o registro; } \\
\text { - Permite má interpretação da relação causa- } \\
\text { efeito; } \\
\text { - Não garante o anonimato dos sujeitos } \\
\text { envolvidos de forma direta186; } \\
\text { - Consiste em técnica de difícil interpretação e } \\
\text { análise dos resultados. }\end{array}$ \\
\hline
\end{tabular}

Quadro 15 - Vantagens e desvantagens da técnica de coleta de dados observação.

186 Requer o uso da tarja preta da distorção da imagem do rosto para a preservação da identidade dos sujeitos, bem como do anonimato da instituição. 


\subsubsection{Modalidades}

A técnica da observação recebe diferentes categorizações segundo Trujillo-Ferrari (1971); Silva e Menezes (2001); Yin (2005); Sbarra (2007); Rheingantz et al. (2008); Pinheiro, Elali e Fernandes (2008); Günther, Pinheiro e Elali (2008), dentre outros.

Segundo Trujillo-Ferrari (1971) as modalidades do método de observação são:

- observação espontânea não estruturada: também chamada de observação informal, de não orientada, não dirigida, não planificada, ou de observação assistemática. É aquela em que, a partir de uma observação espontânea, são extraídas conclusões através do mínimo de controle ou direcionamento por parte do observador.

- observação participante não sistemática: também chamada de observação participante não estruturada ou não controlada, é aquela em que um participante capta os acontecimentos, similarmente ao papel de um repórter, sem participar ou influir no fluxo dos acontecimentos.

- observação sistemática: o observador conta com recursos de controle da situação observada, podendo estruturar o processo de observação. Destina-se a comprovar hipóteses causais, à manipulação de variáveis experimentais, à descrição e explicação sistemática dos fenômenos e processos.

Segundo Silva e Menezes (2001, p. 33), a observação objetiva a obtenção de dados de determinados aspectos da realidade, podendo ser de várias modalidades no mesmo nível de categorização: 
- observação assistemática: não tem planejamento e controle previamente elaborados;

- observação sistemática ${ }^{187}$ : tem planejamento, realiza-se em condições controladas para responder aos propósitos pré-estabelecidos.

- observação não participante ${ }^{188}$ : o pesquisador presencia o fato, mas não participa;

- observação individual: realizada por um pesquisador;

- observação em equipe: feita por um grupo de pessoas;

- observação na vida real: registro de dados à medida que ocorrem;

- observação em laboratório: onde tudo é controlado.

Yin (2005, p. 119) utiliza o termo observações diretas que podem variar em observações de atividades formais e não formais de coleta de dados, onde

ao realizar uma visita de campo ao local escolhido para o estudo de caso, você estará criando a oportunidade de fazer observações diretas. Partindo-se do princípio de que os fenômenos de interesse não são puramente de caráter histórico, encontrar-se-ão disponíveis para observação alguns comportamentos ou condições ambientais relevantes. Essas observações servem como outra fonte de evidências em um estudo de caso.

A chamada observação incorporada é o resultado do questionamento do grupo de pesquisa Qualidade do Lugar e Paisagem (ProLUGAR) à excessiva atenção dispensada aos aspectos operacionais e instrumentais em uma pesquisa de campo, em detrimento da reflexão sobre a própria experiência vivenciada pelo pesquisador em sua observação (RHEINGANTZ, 2004). Seu principal objetivo é possibilitar que durante a observação o pesquisador redirecione suas capacidades e a sua atenção

${ }^{187}$ A "observação constitui, sem dúvida, o ponto de partida para qualquer ciência desde que seja sistemática." (GÜNTHER, PINHEIRO, ELALI, 2008, p. 379).

${ }^{188}$ Não é citada a observação participante. 
na interação com o ambiente. Baseia-se nos pressupostos de que o foco é a experiência do homem no lugar e como a presença humana dá sentido e significado a cada lugar ou ambiente; implica em aceitar que a observação pode ser conscientemente guiada, e que o foco da reflexão passa a ser o modo como o observador guia suas ações, passando a ser o ponto de referência da observação (RHEINGANTZ et al., 2008).

Na observação participante, o pesquisador (observador) torna-se parte dos eventos por estar imerso no ambiente observado por um longo período de tempo, compartilhando da vida diária das pessoas observadas, sendo que "segundo Sommer (1973), Zeisel (1981) e Sommer e Sommer (1997), para descobrir o que as pessoas fazem, é preciso observá-las; para descobrir o que elas pensam, é preciso questionálas diretamente." (SBARRA, 2007, p. 14).

Segundo Pinheiro, Elali e Fernandes (2008, p. 75), a observação naturalística "assume particular importância, como um recurso de que o pesquisador dispõe para conhecer os aspectos efetivamente manifestos do comportamento humano da vida real", pois:

A observação permite acesso do pesquisador a aspectos do comportamento humano a respeito dos quais os indivíduos não estão plenamente conscientes, uma vez que o "comportamento de uma pessoa, o que ela expressa não verbalmente através de gestos intencionais ou não, revela sobre si muito mais do que ela seria capaz de contar" [...] sendo de especial importância para situações em que é limitada a qualidade do depoimento verbal (caso de crianças pequenas, por exemplo). (CORRAZE, 1982, p. 23)

Segundo Günther, Pinheiro, Elali (2008) a observação pode se realizar em situações não estruturadas e em situações estruturadas, sendo esta a categorização adotada 
no presente estudo. O método observacional pode ser utilizado em situações não estruturadas,

fora do controle do experimentador, e implicar, de modo geral, múltiplos comportamentos e/ou múltiplos atores. Uma vantagem adicional deste método é que, na medida em que o participante da pesquisa não sabe que está sendo observado, o método torna-se não-invasivo, não provocando reação. (GÜNTHER; ELALI; PINHEIRO, 2008, p. 379)

A observação é utilizada quando se procura identificar e obter evidências a respeito de indivíduos que não possuem consciência de elementos, que de alguma forma orientam seu comportamento (LAKATOS; MARCONI, 1993).

\subsubsection{Fase preparatória da observação}

O método observacional é descrito por Ferreira e Mousquer (2004) como um processo de seleção, provocação, registro e codificação de comportamentos. Na etapa da seleção ocorre a escolha dos comportamentos, eventos ou situações a serem observados, bem como os períodos de tempo ou duração da observação. Nesta fase preparatória busca-se o conhecimento prévio do que observar, determinando que tipo de fenômeno merecerá registro. Este registro pode ser realizado de forma simples onde o observador apenas possui um bloco para anotações, sendo que o resultado está atrelado a capacidade de interpretação do observador. Geralmente são utilizados para o registro da observação meios eletrônicos ou mecânicos ${ }^{189}$ tais como:

\footnotetext{
${ }^{189}$ Disponível em: <http://www.scribd.com/doc/36856193/1-Modelos-Basicos-de-Pesquisa-e-Tiposde-Dados>. Acesso em: 15 fev. 2011.
} 
> câmera fotográfica que gera o documento filmográfico ${ }^{190}$ (gênero documental integrado por documentos que contêm imagens fixas, impressas, desenhadas ou fotografadas, como fotografias e gravuras);

Filmadora que gera o documento iconográfico (gênero documental integrado por documentos que contêm imagens em movimento, com ou sem som);

> Gravadores de som para o registro da fala do observador e/ou do(s) observado(s) e

> Cronômetros para medir o tempo de duração das observações.

A vantagem em o observador utilizar meios eletrônicos ou mecânicos de registro é a possível reprodução das cenas e a análise por mais de um observador, o que permite um consenso.

\subsubsection{Desenvolvimento da observação}

A etapa da provocação (FERREIRA; MOUSQUER, 2004) pressupõe a decisão do início da observação, verificando-se, se os comportamentos observados serão artificialmente induzidos ou observados em sua ocorrência espontânea. Tais comportamentos deverão ser registrados utilizando-se da memória do observador (por este motivo é interessante elaborar o relatório dos resultados o mais cedo possível), suas anotações escritas, recursos audiovisuais, cronômetro e outros meios.

\footnotetext{
${ }^{190}$ Disponível em:

<http://www.histedbr.fae.unicamp.br/navegando/artigos_pdf/Nailda_Marinho_da_Costa_Bonato_artig o.pdf>. Acesso em: 15 fev. 2011.
} 


\subsubsection{Análise da observação}

Por fim, os dados coletados serão sistematizados mediante um sistema de seleção dos registros audiovisuais e codificação, que consiste na etapa mais complexa do procedimento de observação. Essa etapa de reflexão e análise assemelha-se ao processo que ocorre na entrevista (item 5.1.5). Os dados levantados podem ser analisados qualitativamente ou quantitativamente - depende do enfoque dado à forma de tratamento dos dados da observação. A observação não está restrita ao sentido da visão, mas se utiliza dos demais sentidos para a obtenção de dados relevantes para a pesquisa. Ferreira e Mousquer (2004) consideram que é impossível dissociar os sentimentos e percepções do observador daquilo que é observado.

\section{$6.21^{a}$ etapa da pesquisa}

\section{a) Objetivo}

A técnica da observação nesta pesquisa teve como objeto de estudo os alunos da pré-escola com baixa visão, cegueira, surdez e PC (unidades-caso 1, 2 e 3). As modalidades adotadas, bem como seus objetivos encontram-se descritos no Quadro 16. 


\begin{tabular}{|l|l|l|}
\hline $\begin{array}{l}\text { Etapa da } \\
\text { pesquisa }\end{array}$ & \multicolumn{1}{|c|}{ Modalidade } & \multicolumn{1}{c|}{ Objetivos } \\
\hline $1^{\text {a }}$ & $\begin{array}{l}\text { Observação em } \\
\text { situações não } \\
\text { estruturadas }\end{array}$ & $\begin{array}{l}\text { Em atividades informais relativas a recreação, alimentação, } \\
\text { estudo ou locomoção, dentre outros, com o objetivo de extrair } \\
\text { informaç̃es preliminares sobre os alunos, suas dificuldades e } \\
\text { sua rotina visando a obtenção de subsídios para escolha das } \\
\text { técnicas de pesquisa a serem utilizadas junto aos mesmos }\end{array}$ \\
\hline $1^{\text {a }}$ e $2^{\mathrm{a}}$ & $\begin{array}{l}\text { Observação em } \\
\text { situações } \\
\text { estruturadas }\end{array}$ & $\begin{array}{l}\text { Sob o controle da pesquisadora, em atividades formais } \\
\text { relativas a aplicação dos instrumentos entrevista lúdica e } \\
\text { questionário com o objetivo de registrar o processo de } \\
\text { aplicação e a efetividade dos instrumentos citados. }\end{array}$ \\
\hline
\end{tabular}

Quadro 16 - Observações destinadas aos alunos das unidades-caso 1, 2 e 3.

\section{b) Procedimentos adotados}

Utilizou-se a câmera digital para o registro fotográfico durante as observações, porém de forma reduzida e discreta nas observações não estruturadas realizadas pela pesquisadora, a fim de não alterar o comportamento dos alunos e adultos envolvidos. Buscou-se fotografar os alunos de costas ou em um ângulo em que seus rostos não fossem revelados, independentemente da colocação da tarja preta no rosto dos alunos para a preservação de identidade ter sido adotada. Não foi utilizado o flash para não se tornar tão notório aos alunos videntes o uso da máquina fotográfica e em função da sensibilidade dos olhos, principalmente no caso dos alunos com baixa visão, iniciativa esta tomada pela pesquisadora. Em relação às questões éticas que envolvem o presente estudo, foi solicitada a autorização dos pais para a divulgação das imagens dos alunos, através da assinatura da carta de consentimento livre e esclarecido, adicionalmente ao uso da tarja preta no rosto e a não divulgação do nome da criança e da instituição, visando a preservação de sua integridade.

${ }^{191}$ As observações estruturadas realizadas na primeira e na segunda etapas da pesquisa nas três unidades-caso, descritas nos capítulos 7 e 8, propiciaram o registro do processo de aplicação dos instrumentos de coleta de dados destinados aos alunos com deficiência física, auditiva e visual e ocorreram sob o controle da pesquisadora. 
Condução: Na primeira etapa da pesquisa as observações não estruturadas e estruturadas $^{192}$ foram realizadas pela pesquisadora, e na segunda etapa solicitou-se o apoio de outras pessoas, conhecidas (que não faziam parte da unidade-caso) na realização das observações estruturadas.

Data, local e duração das observações: foram definidos em função das atividades dos alunos a serem observadas com duração variável. Apesar da pesquisadora permaner por um longo período observando os alunos nas observações não estruturadas, foram produzidas poucas imagens para não intimidar os alunos.

A seguir serão apresentados os resultados das observações não estruturadas realizadas nas três unidades-caso durante a primeira etapa da pesquisa de campo.

\subsubsection{Alunos cegos e com baixa visão: resultados na unidade-caso 1}

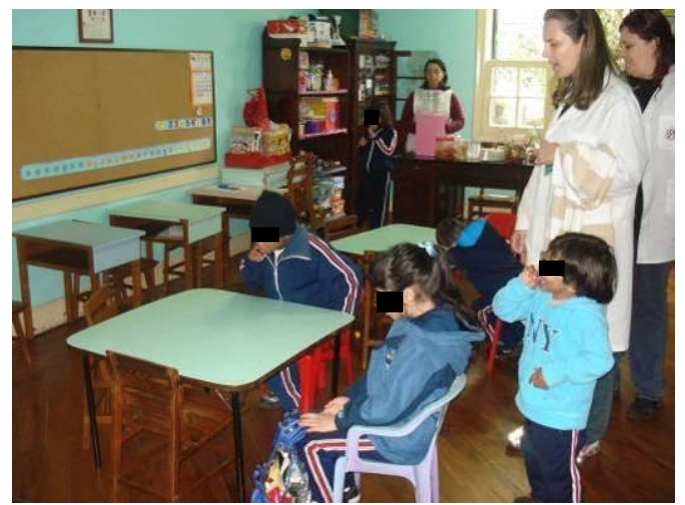

Figura 27 - Apresentação da pesquisadora à classe da unidade-caso 1 .
Inicialmente a docente apresentou a pesquisadora à classe (Figura 27) e explicou que a mesma estaria presente durante alguns dias para a realização de atividades. Alguns dos alunos cegos se encostaram junto à pesquisadora, realizando algumas perguntas relativas à profissão da mesma.

${ }^{192}$ Com exceção da unidade-caso 3 onde havia muitos voluntários. 
Na primeira etapa da pesquisa, a observação não estruturada inicial na unidade-caso

1 (Quadro 17) envolveu os alunos com deficiência visual da única classe de préescola existente na atividade de recreação (intervalo para o lanche), no dia 30/09/2009 e teve a duração de 20 minutos (das $10 \mathrm{~h}$ às $10 \mathrm{~h} 20 \mathrm{~min}$ ).

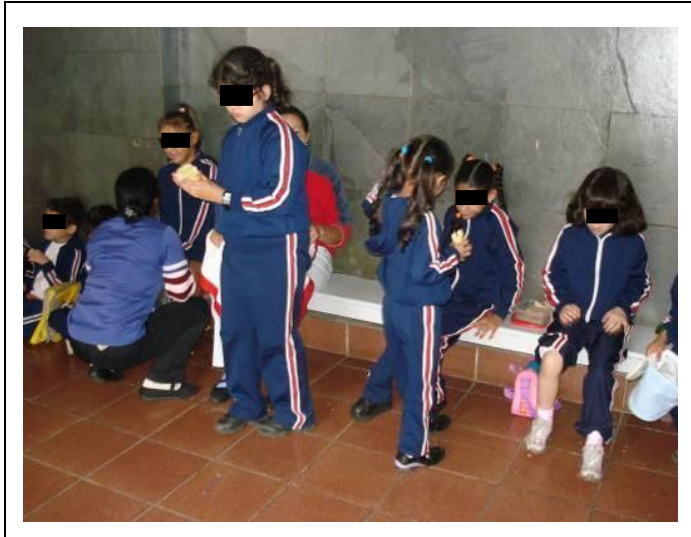

Os alunos cegos e com baixa visão da única classe de pré-escola utilizaram o pátio coberto para comer o lanche oferecido pela instituição e brincar, sem a presença de alunos de outras classes. Os 15 alunos foram assistidos por 3 cuidadoras e a diretora. 0 local se encontrava escuro sendo que o contraste das imagens foi alterado para facilitar a visualização das mesmas, pois o flash não foi utilizado em função da sensibilidade dos olhos de algumas crianças. Apenas alguns alunos cegos utilizavam óculos escuros.

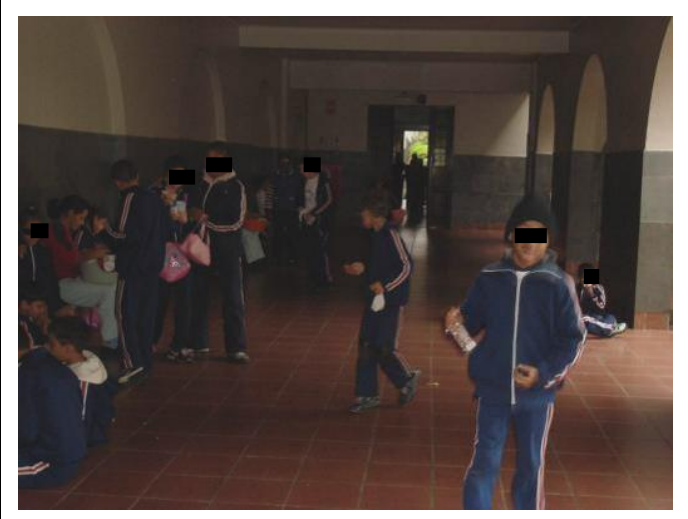

A maioria dos alunos cegos circulava livremente pelo pátio sem o posicionamento das mãos a frente do corpo, sendo que alguns arriscavam corridas e gritavam para localizarem os seus pares, esbarrandose. Outros alunos cegos preferiram permanecer sentados no banco durante todo o tempo, próximos a uma das cuidadoras. Questionadas em relação ao comportamento destes alunos, as cuidadoras relataram que os mesmos entraram tardiamente na escola, com cerca de cinco anos, e ainda não haviam desenvolvido uma maior segurança na locomoção em função, dentre outros, da proteção da família.

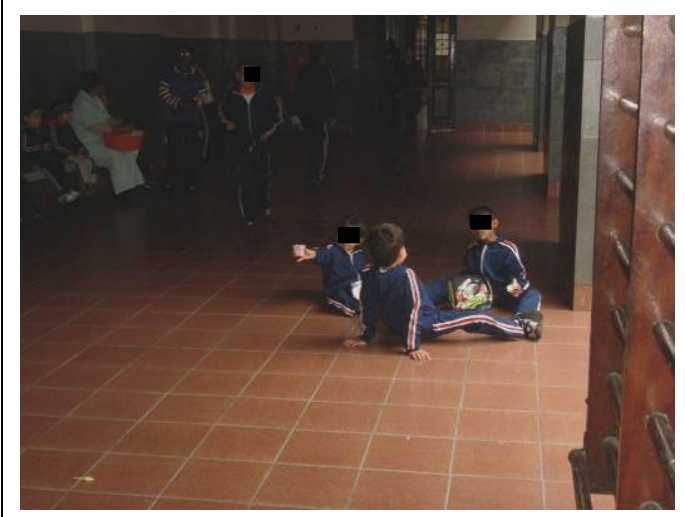

A pesquisadora apresentou dificuldade em se posicionar, mesmo o espaço sendo amplo, pois logo era descoberta por um aluno com baixa visão e consequentemente por alunos cegos, que nela se encostavam para conversar. As cuidadoras explicaram que os alunos cegos apresentam este comportamento em relação a uma pessoa estranha somente nas dependências da escola. Dois alunos com baixa visão e um cego se encontravam sentados no chão conversando em local com maior luminosidade. Um aluno com comprometimentos mentais permaneceu todo o tempo sentado no banco.

Quadro 17 - $1^{\text {a }}$ observação não estruturada dos alunos com deficiência visual da unidade-caso 1.

Na primeira etapa da pesquisa, a segunda observação não estruturada na unidadecaso 1 (Quadro 18) ocorreu logo após a primeira observação e envolveu os mesmos 
alunos com deficiência visual da única classe de pré-escola existente na atividade de locomoção (no trajeto do pátio de recreação para frente do edifício que abrigava as salas de aula, através de uma galeria com pilares), no dia 30/09/2009 e teve a duração de 15 minutos (das 10h20min às $10 \mathrm{~h} 35 \mathrm{~min}$ ).

Os alunos se encontravam saindo do pátio de
recreação em direção às salas de aula em pequenos
grupos (duplas ou trios) guiados ou não por videntes
(diretora, cuidadora ou aluno com baixa visão). A
variação de tipos de piso, o plano inclinado, o som
diferenciado desta galeria de circulação (ruído das
araras engaioladas no jardim anexo), o cheiro exalado
pelas flores podem servir como auxílio na percepça da
mudança dos ambientes para os alunos cegos

Quadro 18 - $2^{\mathrm{a}}$ observação não estruturada dos alunos com deficiência visual da unidade-caso 1.

193 Segundo informações da coordenadora e da professoras nas duas entrevistas concedidas.

194 Foi o único aluno com bengala observado pela pesquisadora na unidade-caso 1. 


\subsubsection{Alunos surdos: resultados da unidade-caso 2}

Na primeira etapa da pesquisa, a observação não estruturada inicial na unidade-caso 2 (Quadros 19 e 20) envolveu os alunos com deficiência auditiva da única classe de pré-escola apta a participar da pesquisa, bem como alguns alunos das outras três classes de pré-escola durante a atividade de alimentação (almoço antes do início da aula), ocorreu no dia 04/11/2009 e teve a duração de 30 minutos (das $13 \mathrm{~h}$ às 13h30min).

Inicialmente os alunos chegaram à EMEE com o transporte oferecido pela prefeitura, foram acompanhados por uma cuidadora até o refeitório para almoçarem antes do início da aula.

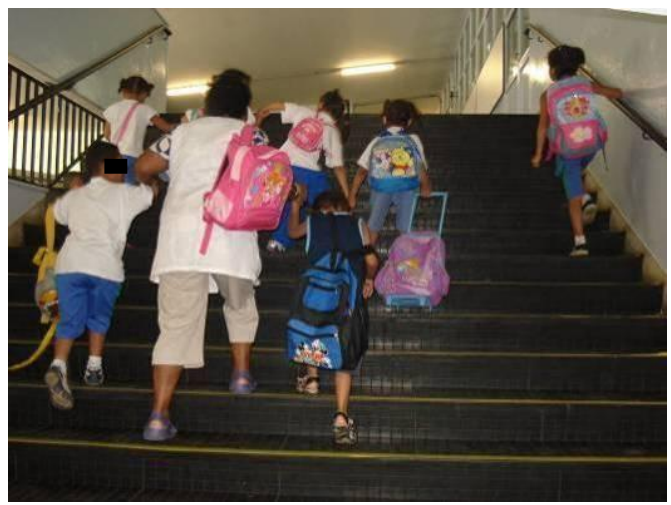

Os alunos subiram as escadas (Figura 28) sem dificuldades e apenas uma aluna utilizou o corrimão, os alunos gritavam e emitiam sons não compreensíveis.

Figura 28 - Alunos chegaram à unidadecaso 2. 


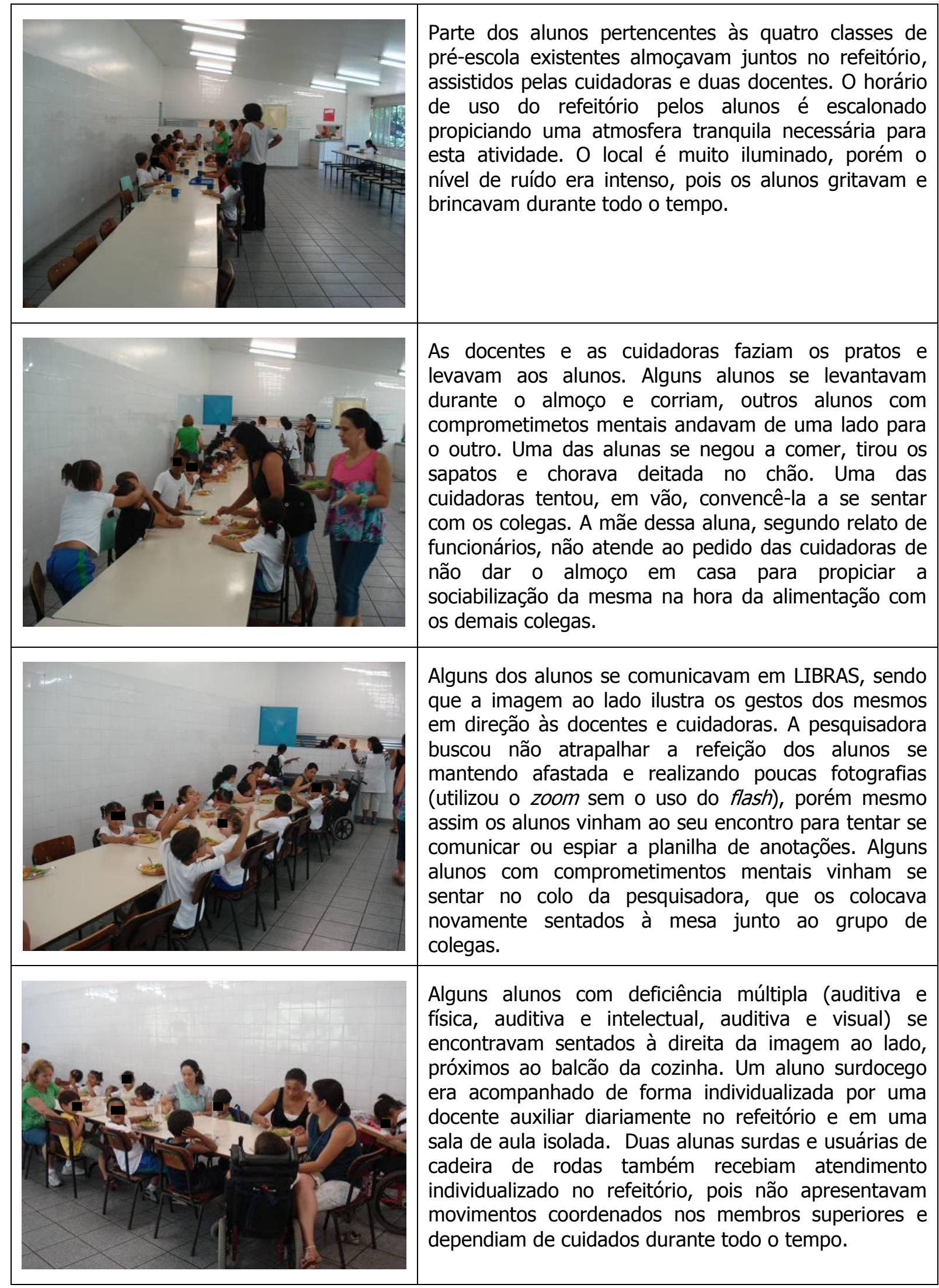

Quadro 19 - $1^{\text {a }}$ observação não estruturada de parte dos alunos com deficiência auditiva das 4 classes de pré-escola da unidade-caso 2 (a). 


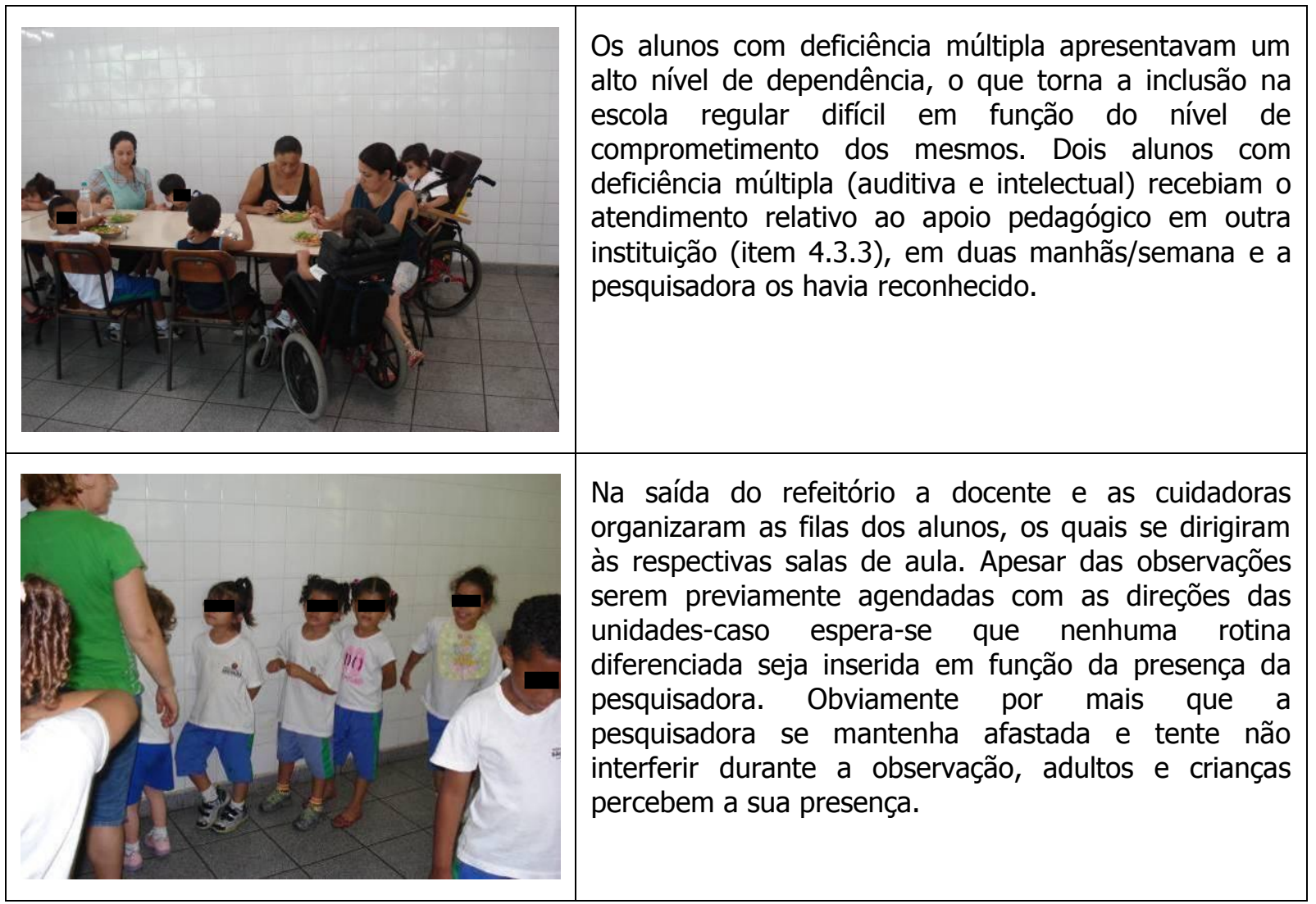

Quadro 20 - $1^{\text {a }}$ observação não estruturada de alguns dos alunos com deficiência auditiva das 4 classes de pré-escola da unidade-caso 2 (b).

Na primeira etapa da pesquisa, a segunda observação não estruturada na unidadecaso 2 (Quadro 21) ocorreu logo após a primeira observação e envolveu os mesmos alunos com deficiência auditiva durante atividades didáticas (realização de exercícios objetivando a prática da LIBRAS) na sala de aula, no dia 04/11/2009 e teve a duração de 20 minutos (das 13h40min às 14h). 

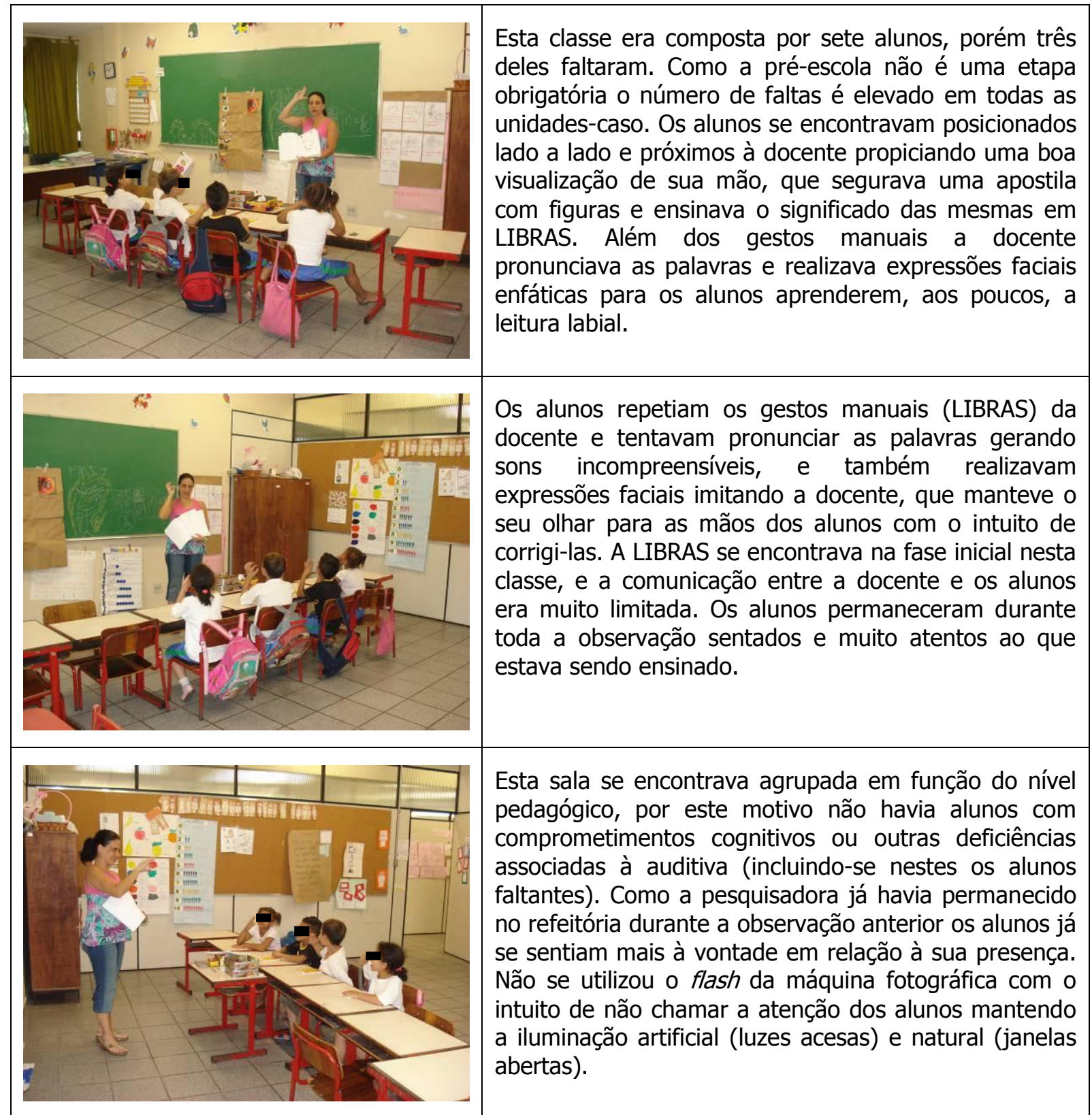

Esta sala se encontrava agrupada em função do nível pedagógico, por este motivo não havia alunos com comprometimentos cognitivos ou outras deficiências associadas à auditiva (incluindo-se nestes os alunos faltantes). Como a pesquisadora já havia permanecido no refeitória durante a observação anterior os alunos já se sentiam mais à vontade em relação à sua presença. Não se utilizou o flash da máquina fotográfica com o intuito de não chamar a atenção dos alunos mantendo a iluminação artificial (luzes acesas) e natural (janelas abertas).

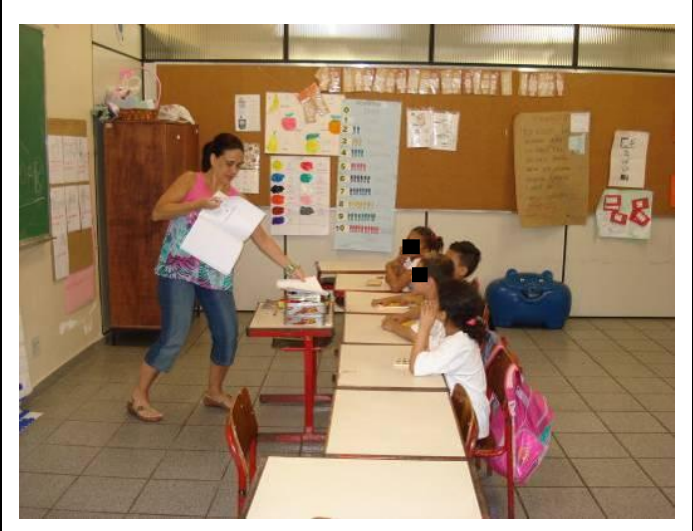

A docente utilizava uma mesa de apoio para o material didático à frente dos alunos. As paredes sem janelas foram utilizadas como murais contendo informações relevantes para a rotina dos alunos. Em nenhum momento a docente ficou de costas para os alunos. Logo após esta observação não estruturada ocorreu a aplicação dos instrumentos de coletas de dados: entrevista lúdica com desenho e questionário ilustrado, aplicados pela docente em LIBRAS.

Quadro 21 - 2a observação não estruturada dos alunos com deficiência auditiva da classe de préescola apta a participar da pesquisa da unidade-caso 2. 
Na primeira etapa da pesquisa, a terceira observação não estruturada na unidadecaso 2 (Quadro 22) envolveu os alunos com deficiência auditiva da única classe de pré-escola apta a participar da pesquisa e de outra classe de pré-escola durante a atividade de recreação no parquinho, ocorreu no dia 04/11/2009 e teve a duração de 20 minutos (das 15h25min às $15 \mathrm{~h} 45 \mathrm{~min})$. 


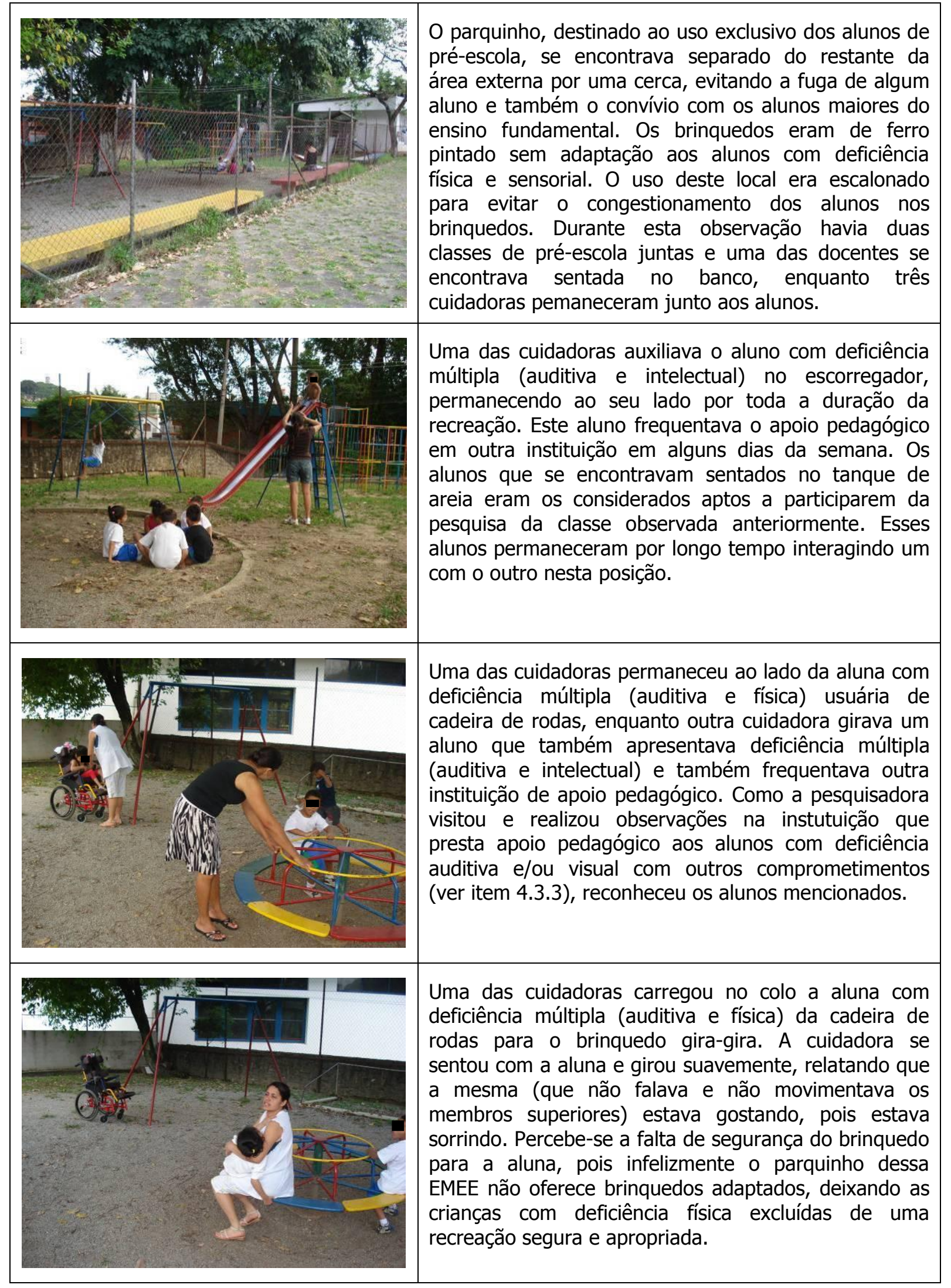

Quadro 22 - 3a observação não estruturada dos alunos com deficiência auditiva de duas classes de pré-escola da unidade-caso 2. 


\subsubsection{Alunos com PC: resultados da unidade-caso 3}

Na primeira etapa da pesquisa, a observação não estruturada inicial (Quadros 23 e 24) na unidade-caso 3, que envolveu os alunos com deficiência física de uma das três classes de pré-escola durante atividades de ensaio para a apresentação de final de ano, na sala de educação física, ocorreu no dia 17/11/2009 e teve duração de 45 minutos (das $13 \mathrm{~h} 10 \mathrm{~min}$ às $13 \mathrm{~h} 55 \mathrm{~min}$ ).
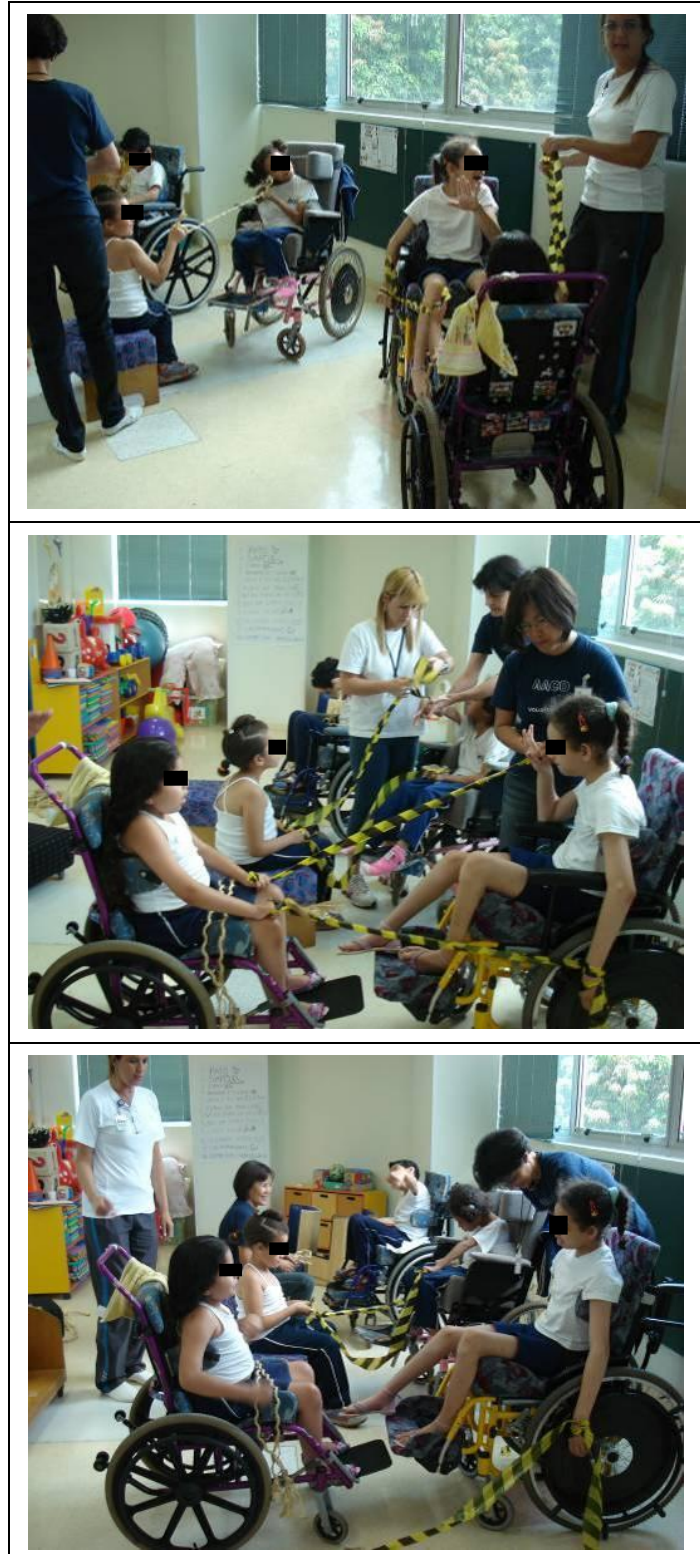

Cinco alunos de uma das três classes de pré-escola (alguns alunos faltaram) se encontravam na sala de educação físca, onde as atividades de rotina foram alteradas em função do ensaio da apresentação do final do ano. Desses alunos somente dois falavam sem dificuldade e apresentavam boa coordenação nos membros superiores (um destes andava) e três eram usuários da CAA, pois não apresentavam fala funcional, embora emitissem sons. A docente se encontra posicionada à direita nesta imagem e era auxiliada por três voluntários.

A docente e os voluntários posicionaram os alunos em duplas com um aluno em frente ao outro. As faixas plásticas utilizadas eram provisórias (foram trocadas posteriormente por fitas de tecido coloridas, pois faziam parte da coreografia) e estavam sendo amarradas nas mãos dos alunos sem coordenação nos membros superiores e consequentemente sem a pega na mão. Os alunos estavam muito alegres e alguns sacudiam o corpo em movimentos descontrolados demostrando a sua euforia.

A docente colocou uma música e os alunos começaram a agitar os braços para que as fitas realizassem movimentos. As duas alunas com coordenação motora nos membros superiores conseguiram realizar esta tarefa de modo bem mais fácil do que os outros três, sem coordenação nos membros superiores. A pesquisadora permaneceu durante os 45 minutos no ensaio, porém tirou poucas fotos a fim de não constranger os alunos e não atrapalhar, pois a sala era muito pequena.

Quadro 23 - $1^{\text {a }}$ observação não estruturada dos alunos com deficiência física da uma das classes de pré-escola da unidade-caso 3 (a). 


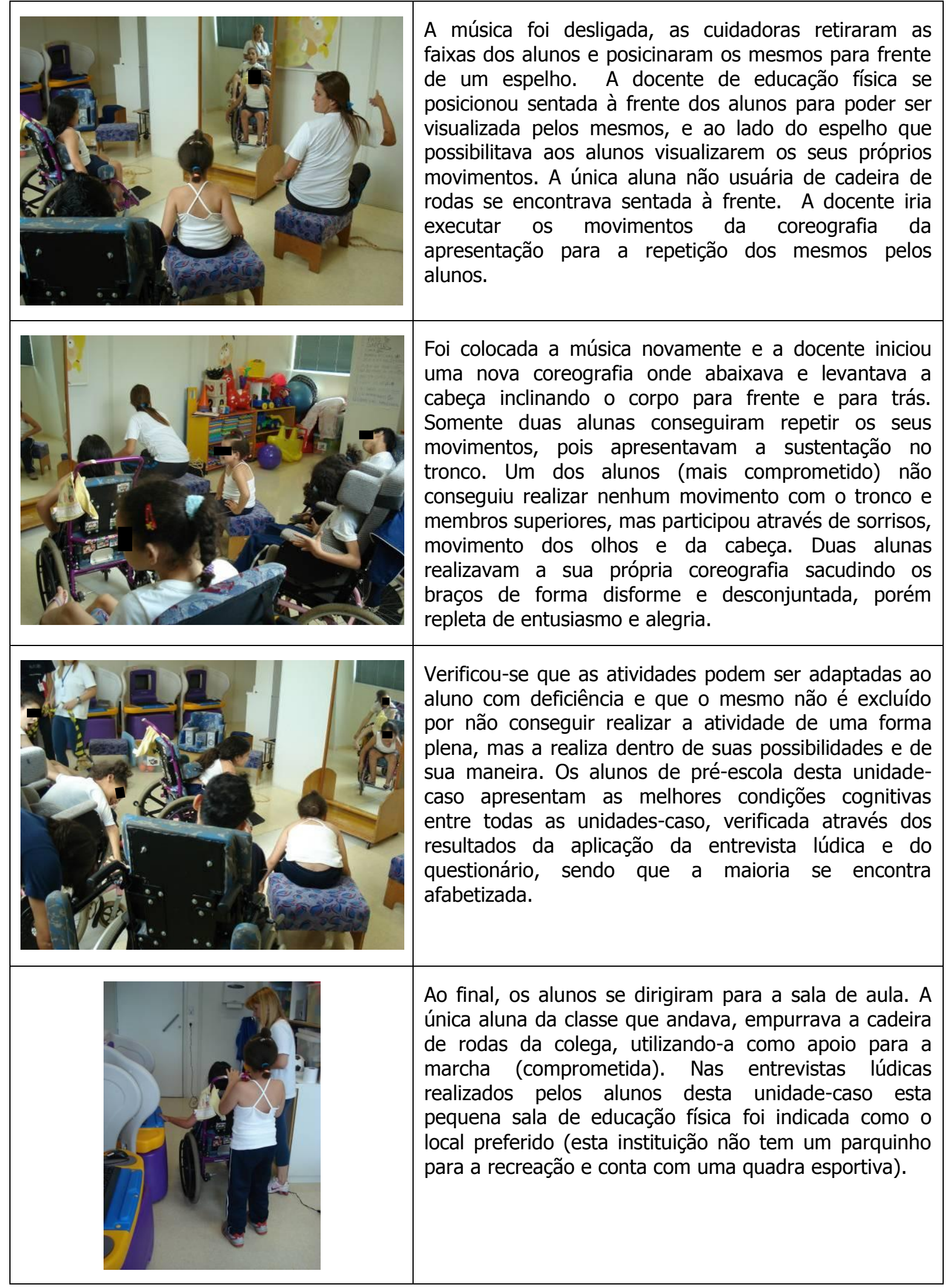

Quadro 24 - $1^{\text {a }}$ observação não estruturada dos alunos com deficiência física da uma das classes de pré-escola da unidade-caso 3 (b). 
Na primeira etapa da pesquisa, a segunda observação não estruturada (Quadro 25)

na unidade-caso 3 envolveu somente uma aluna com PC e 3 voluntários durante a atividade de transferência da aluna da cadeira convencional para a cadeira de rodas, na sala de aula, ocorreu no dia 12/11/2009 e teve a duração de 6 minutos (das $11 \mathrm{~h} 50 \mathrm{~min}$ às $11 \mathrm{~h} 56 \mathrm{~min})$.

A aluna com PC, usuária de cadeira de rodas, de uma
das classes de pré-escola, quando questionada,
preferiu por vontade própria assistir parte da aula
sentada na cadeira convencional. Após o término da
aula e a saída dos alunos essa aluna foi transferida da
cadeira comum para a sua cadeira de rodas, sendo
auxiliada pela docente e dois voluntários. A aluna não
apresentava coordenação nos membros superiores e
não podia realizar a tranferência sozinha. Uma das
voluntários segurava a cadeira de rodas enquanto a
outra voluntária e a docente carregavam-na com
cuidado.
Verificou-se que, apesar do trabalho dispendido pelos
adultos envolvidos, permite-se que a aluna opte pelo
local onde quer permanecer durante a aula (na
cadeira comum ou na de rodas). Aos alunos que não
apresentam sustentação na coluna não é oferecida
esta opção, pois o mesmo pode sofrer uma queda da
cadeira comum. Verificou-se que a maioria dos alunos
permaneceu em sua respectiva cadeira de rodas por
todo o período escolar (exceto no uso do vaso
sanitário) e utilizavam as pranchas adaptadas às
mesmas. Uma das alunas de pré-escola muito pesada
utilizava fraldas.

Quadro 25 - 2a observação não estruturada da aluna de pré-escola da unidade-caso 3.

\subsubsection{Análise dos resultados}

As observações não estruturadas realizadas na primeira etapa da pesquisa nas três unidades-caso propiciaram o primeiro contato da pesquisadora com os alunos de pré-escolas com deficiência física, auditiva e visual; ocorreram fora do controle da 
pesquisadora e permitiram a coleta de informações preliminares sobre esses alunos, as suas dificuldades e a sua rotina para a obtenção de subsídios para a escolha das técnicas de pesquisa a serem utilizados junto aos mesmos. A maior dificuldade enfrentada pela pesquisadora foi a de realizar as fotos sem que os alunos com deficiência (inclusive os cegos) e os adultos envolvidos percebessem, com o objetivo de não intimidar.

As observações realizadas mostraram que o ambiente escolar é marcado pela ação vigiada, além de apresentar limites físicos claros. A maior dificuldade enfrentada pela pesquisadora foi a de se posicionar para a realização das observações sem atrapalhar a dinâmica dos alunos, e sem que os mesmos percebessem a sua presença e o fato de estar fotografando os mesmos, com o objetivo de não provocar reação. Verificouse que o principal problema da técnica da observação é que a presença do pesquisador pode provocar alterações no comportamento dos observados, destruindo a espontaneidade dos mesmos e produzindo resultados pouco confiáveis. A observação de crianças cegas, com baixa visão, surdas e com PC serve como uma fonte complementar de evidências em um estudo de caso, em função da limitada qualidade do depoimento verbal inerente às crianças e em especial às com surdez e com PC usuárias da LIBRAS e da CAA, respectivamente.

A observação direta depende mais da habilidade do pesquisador em captar informação através dos cinco sentidos, julgá-las sem interferências e registrá-las com fidelidade [....] Uma das vantagens desta técnica é que o pesquisador não precisa se preocupar com as limitações das pessoas em responder às questões. Entretanto, é um procedimento de custo elevado e difícil de ser conduzido de forma confiável, principalmente quando se trata da obtenção de dados sobre comportamentos que envolvem alguma complexidade. Outro ponto a considerar é o problema da interferência do pesquisador (observador) no comportamento do observado. Disponível em: <http://www.sit.com.br/SeparataENS0019.htm>. Acesso em: 14 jan. 2011. 


\section{A TÉCNICA DA ENTREVISTA LÚDICA DESTINADA ÀS CRIANÇAS}

\subsection{Referencial teórico}

Segundo Carvalho et al. (2004, p. 291), a entrevista com crianças é uma técnica ainda relativamente pouco explorada na literatura, pois usualmente pensa-se a criança

como incapaz de falar sobre suas próprias preferências, concepções ou avaliações. Com um conhecimento sobre a criança cada vez mais acurado, essa suposição tem sido questionada e tem sido explorado, crescentemente, o uso de entrevista com crianças (por exemplo, Dunn, 1988). Yates e Smith (1989) propõem a entrevista ou o questionário como forma de obtenção de dados sobre fenômenos pouco suscetíveis de serem observados diretamente, ou ainda, com o objetivo de investigar percepções ou concepções da criança [...]

O uso do brinquedo e do desenho na entrevista com crianças tem como objetivo "inicialmente estabelecer um contato quando a relação verbal falha pela idade muito precoce ou por mecanismos de defesa [...]" (ARFOUILLOUX, 1983, p. 158). Por definição, estas atividades não podem substituir completamente o discurso, que continua sendo o objeto principal da entrevista.

A entrevista lúdica, que proporciona o brincar durante a entrevista, é uma técnica largamente utilizada na psicologia visando à investigação clínica da personalidade de crianças e foi introduzida inicialmente por Aberastury (1992). Segundo Brougère (1998, p. 4), "deve-se a Winnicott (1975) a reativação de um pensamento segundo o qual o espaço lúdico vai permitir ao indivíduo criar e entreter uma relação aberta e positiva $[\ldots]^{\prime \prime}$. Nesse procedimento, o comportamento da criança é observado em uma sala destinada à ludoterapia, com brinquedos e jogos (TRINCA, 1983). 
Tendo em vista que a atividade lúdica é a forma como a criança expressa suas fantasias, desejos e experiências, o emprego desses recursos tem como objetivo a instrumentalização de suas possibilidades comunicacionais [...] (FRANCO; MAZORRA; 2007, p. 3).

A entrevista lúdica é usualmente destinada às crianças e pode ser a semiestruturada ou não estruturada (ver 5.1.1) - nesta pesquisa foi adotada a semiestruturada. Em alguns casos, a criança parece bloqueada em suas possibilidades de expressão verbal em função de sua inibição ou de seu estado emocional. Segundo Arfouilloux (1983, p. 149), "o desenho, ou, se for o caso, o brinquedo, são meios muitos úteis para criar o contato, mas sua eficácia não é absolutamente constante $[\ldots]^{\prime \prime} ;$ a criança deve estar à vontade para responder quando estiver envolvida pelas atividades agradáveis que o brincar proporciona.

\subsubsection{Modalidades}

Em relação às modalidades de entrevista lúdica, destacam-se a entrevista lúdica com brinquedo e a com desenho temático, adotadas no presente estudo em função das observações dos alunos com deficiência e das entrevistas com a direção e as docentes, realizadas anteriormente.

Existem outras técnicas de coleta de dados que permitem à criança exprimir-se e comunicar-se com outrem através de uma maneira lúdica, como o uso da argila ou da massa de modelagem (indicados para a criança cega), de jogos, de colagens, dentre outros (ver Quadro 10). A simplicidade do ato de desenhar para as crianças 
videntes e com boa coordenação nos membros superiores ${ }^{195}$, bem como a possibilidade de conservar e de estudar o desenho e seu relato a qualquer momento constituem o seu interesse prático.

\section{$>$ Entrevista lúdica com brinquedo}

Os psicólogos Greenspan e Greenspan (1993, p. 79) utilizam as atividades lúdicas como uma forma indireta para a criança comunicar sua personalidade a outros, quando não se consegue realizar esta tarefa de uma forma direta através da comunicação verbal, pois os jogos infantis e o próprio ato de brincar fazem parte do cotidiano das crianças (KISHIMOTO, 2007).

As técnicas da entrevista lúdica são utilizadas em função da abordagem psicológica sobre crianças que se apoia no lúdico como mediador da relação e da possibilidade de compreensão dos aspectos subjetivos, onde o brinquedo é "um meio de comunicação, é a ponte que permite ligar o mundo externo e o interno, a realidade objetiva e a fantasia." (QUINTANA et al., 2007, p. 416).

Segundo Martins et al. (2001, p. 77), "o brinquedo é tão importante que constitui a base da psicoterapia infantil, a ludoterapia ${ }^{196}$." Na atividade lúdica com brinquedos é

195 O desenho é um tipo de atividade muito complexa que depende intimamente da maturação dos aparelhos perceptivos e motores e põe em jogo múltiplos fatores psicológicos.

${ }^{196}$ Técnica psiquiátrica usada em crianças com distúrbios emocionais, neuróticos ou psicóticos. Cada sessão pode ser conduzida por um psiquiatra, psicólogo ou enfermeiro especializado, num ambiente muito bem controlado. Sua meta é promover a compreensão da criança sobre seu próprio 
possível se observar e conhecer a criança de uma forma mais completa, por meio dos brinquedos com os quais elege e o ato do brincar. Uma das estratégias de trabalho com brinquedos é a livre expressão do falar, pensar e agir (AZEVEDO, 2004).

Diferindo do jogo, o brinquedo ${ }^{197}$ - e a consequente brincadeira estabelece uma relação íntima entre o adulto e a criança de uma forma livre, em função da ausência de um sistema de regras que organizam a utilização do brinquedo (KISHIMOTO, 1994). O brinquedo traduz o real para a realidade infantil e suaviza o impacto provocado pelo tamanho e pela força dos adultos,

diminuindo o sentimento de impotência da criança. Brincando, sua inteligência e sua sensibilidade estão sendo desenvolvidas. A qualidade de oportunidade que estão sendo oferecidas à criança através de brincadeiras e de brinquedos garante que suas potencialidades e sua afetividade se harmonizem... Brincando, a criança experimenta, descobre, inventa, aprende e confere habilidades. Além de estimular a curiosidade, a autoconfiança e a autonomia, proporcionam o desenvolvimento da linguagem, do pensamento e da concentração e da atenção. (MAURÍCIO, 2006, p. 3)

\section{Entrevista lúdica com desenho temático}

O desenho infantil tem uma grande relevância e segundo Mèredieu (1974, p. 3):

Não existe visão verdadeira, e a visão adulta não pode, de modo algum, representar a medida padrão. Portanto, não se deve reduzir os processos infantis qualificando-os de "infantis". A criança está tão "perto das coisas" quanto o adulto, o pintor chamado realista, o primitivo ou o abstrato.

comportamento e sentimento. O terapeuta deve refletir as expressões verbais e não verbais da criança, bem como interpretá-las para ela. Normalmente as sessões de ludoterapia são de uma hora e podem continuar por vários meses. (MARTINS et al., 2001, p. 77).

197 O vocábulo brinquedo não pode ser reduzido à pluralidade de sentidos do jogo, pois conota a criança e tem uma dimensão material, cultural e técnica. Enquanto objeto, é sempre suporte de brincadeira. (MAURÍCIO, 2006). 
Segundo Bronfenbrenner (1996, p. 20), o desenho pode ser considerado uma atividade molar $^{198}$, pois

uma atividade molar é um comportamento contínuo com um movimento ou tensão próprios, percebido pelo sujeito como tendo um significado ou intenção. A atividade molar é de complexidade variável, podendo invocar objetos, pessoas e acontecimentos não concretamente presentes no ambiente imediato. A invocação pode ser realizada através de conversas, de contar estórias, da representação pictórica, ou de uma variedade de outros meios. Sendo assim, deduz-se que o desenho pode ser considerado uma atividade molar, pois é caracterizado por uma intenção e significados próprios e traz em seu conteúdo fatos, pessoas e conhecimentos percebidos.

Segundo Pereira (2009, p. 5), o desenho infantil deve ser considerado "não apenas como uma modalidade de expressão ou de representação da realidade, mas também como o resultado de atividade intencional envolvendo aspectos cognitivos e emotivos no seu ajuste à realidade com a qual convive." O desenho é um importante meio de comunicação e representação da criança e apresenta-se como uma atividade fundamental, pois

a partir dele a criança expressa e reflete suas ideias, sentimentos, percepções e descobertas. Para a criança o desenho é muito importante, é seu mundo, é sua forma de transformá-lo, é seu meio de comunicação mais precioso. Nele estão muitos de seus medos, de suas vontades, de suas carências e de suas realizações. Tudo o que está ao redor interage, criando um sistema de representação muito rico e de extrema relevância para a criança. (GOLDBERG, 2005, p. 6)

O convite a desenhar apresenta uma ampla aceitação pelas crianças, pois a maioria delas mostra interesse e prazer neste ato. Ainda mais do que o brinquedo, o desenho da criança fascina, pois

a criança desmancha o seu brinquedo quando o adulto chega, mas o desenho permanece, como as coisas escritas. Ele é um traço, um testemunho. É afixado nas salas de aula, é exposto ao olhar alheio, é colocado num álbum que será folheado alguns anos mais tarde em busca do que foi, das marcas de uma história. Muitas vezes ele tem para nós a força de nossas próprias lembranças de infância. É sempre com emoção que revemos, anos depois, os desenhos que nós mesmos tínhamos feito quando crianças, ou os de nossos próprios filhos. (ARFOUILLOUX, 1983, p. 128)

\footnotetext{
${ }^{198}$ Atividade molar é o desenvolvimento de atividades por estímulo próprio, com prazer. Disponível em: <http://www.judobrasil.com.br/2000/mataruna2.htm>. Acesso em: 1 mar. 2010.
} 
O desenho é como "uma janela aberta para uma terra incógnita, um continente perdido, onde moramos há muito tempo, e que é o domínio de seres muito enigmáticos: as crianças." (ARFOUILLOUX, 1983, p. 128). O desenho infantil é muito revelador e traduz o grau de maturidade da criança, o seu equilíbrio emocional e afetivo e o seu estágio de desenvolvimento motor e cognitivo. Luquet (1969) distingue quatro estágios do desenho infantil:

1- O realismo fortuito começa por volta dos dois anos e põe fim ao período chamado de rabisco. A criança que começou a traçar signos sem desejo de representação descobre uma analogia com um objeto e passa a nomear seu desenho.

2- O realismo fracassado ocorre aproximadamente entre os três e os quatro anos, onde a criança tendo descoberto a identidade forma-objeto, procura reproduzir esta forma. Com o passar dos anos e progressivamente, a criança deixará de desenhar unicamente por prazer, pois o desenho ocupará um lugar entre as atividades dirigidas e orientadas pela escolaridade. Verifica-se o contraste entre o que a criança produz em termos de desenho durante sua passagem pela educação infantil e o que se obtém dela no início do ensino fundamental, pois

à exuberância das formas e ao abuso das cores sucedem a linearidade, a geometria, a procura da ordem e da retidão, como se houvesse também aí uma sintaxe para aprender ou uma ortografia para respeitar. No entanto, a criatividade extraordinária dos primeiros anos não desapareceu. Ela está apenas em repouso. Durante algum tempo ainda se pode interrogá-la, suscitá-la, antes que ela tenha perecido completamente, asfixiada sob o peso dos papéis sociais. (ARFOUILLOUX, 1983, p. 129).

3- $O$ realismo intelectual abrange dos 4 aos 10 ou 12 anos e caracteriza-se pelo fato de que a criança desenha do objeto não aquilo que vê, mas aquilo que sabe. Nesta fase ela mistura diversos pontos de vista (perspectivas). A premissa de que a criança desenha menos o que vê e mais o que sabe de um objeto 
é um ponto de concordância entre diferentes concepções teóricas sobre o desenvolvimento do desenho. O desenho, entre o jogo simbólico e a imagem mental, subordina-se às leis da conceituação e da percepção. A percepção do objeto corresponde à atribuição de sentido dada pela criança, constituindo-se realidade conceituada, e não material. (PEREIRA, 2009, p. 1)

4- O realismo visual ocorre geralmente por volta dos 12 anos, sendo marcado pelo uso da perspectiva. Nesta fase ocorre um empobrecimento progressivo do grafismo que tende a se aproximar das produções adultas.

Segundo Cox (2007, p. 243), desde que entram na escola até atingirem a idade de sete ou oito anos, as crianças não costumam ficar insatisfeitas com o que produzem. Este dado é importante ser considerado no presente estudo, em função do resultado da aplicação do desenho e a reação esperada por parte da criança. Durante a primeira infância até a idade aproximada de oito anos, as crianças produzem cenas e procuram desenhá-las de maneira realista, "em vez de desenhar vários objetos separados na folha de papel, elas talvez tentem colocá-los juntos, de modo a compor uma cena." (COX, 2007, p. 9).

Há poucas atividades infantis "tão diversamente descritas, tão contraditoriamente interpretadas e de modo tantas vezes redutor quanto o desenho." (ARFOUILLOUX, 1983, p. 128). Segundo Pereira (2009), Cox (2007), Aguiar (2004) e Mèredieu (1974) não devemos tirar conclusões sobre os desenhos, e sim pedir às crianças que nos falem sobre eles. A interpretação do desenho da criança depende do olhar do intérprete, "daí emerge a importância de se considerar o primeiro desses intérpretes, a própria criança, para que se possa compreender o seu significado." (FERREIRA, 2001, p. 105) 
As crianças nos falam em seus desenhos como se sentem acerca de si mesmas e em uma relação. Segundo Aguiar (2004), os desenhos devem ser considerados apenas como mais uma ferramenta no procedimento de entendimento, pois, sendo uma das formas de linguagem da criança pode trazer lacunas e o material projetivo ${ }^{199}$ não possui uma simbologia pré-definida. Segundo Romero (2001), os símbolos contam uma história cujo sentido intuímos, embora ignoremos seu significado original. É importante considerar as interpretações da própria criança na construção do seu desenho, fato que se operacionaliza durante e após a confecção do mesmo. Portanto, desenho ou imagem e palavra escrita ou verbal devem se complementar na busca de compreensão. Segundo Di Leo (1985), melhor que a fala, os desenhos podem expressar sutilezas do intelecto e afetividade, que estão além do poder ou liberdade de expressão verbal.

A mentalidade da criança é essencialmente animista e mágica, sendo difícil querer descobrir a significação de um desenho infantil nem possível atribuir significado ao desenho sem a narrativa complementar da criança, pois:

Modo de expressão próprio da criança, o desenho constitui uma língua que possui seu vocabulário e sua sintaxe, daí a tentativa de incluí-lo no quadro da semiologia, aquela ciência geral dos signos [...]. A pertinência do signo gráfico é uma noção que está longe de ser evidente no grafismo infantil. Que determinado símbolo possa designar uma árvore e não um boneco ou qualquer outro objeto, eis aí uma discriminação que não existe em determinado momento do desenho... daí o recurso ao comentário verbal [...]. (MÈREDIEU, 1974, p. 14)

A criança desenha primeiramente para si própria, como quando brinca, porém seu desenho dirige-se sempre a alguém real ou imaginário, quase sempre sua mãe, seu pai ou alguns dos que a cercam. $O$ ato de desenhar realizado pelas crianças

199 O material projetivo deve ser entendido como o desenho resultante da técnica terapêutica, no processo de interação entre a criança e o profissional - psicólogo. 
É um dom, saído de suas próprias mãos e de que ela espera alguma coisa em troca: um sinal de prazer, bem mais do que um cumprimento ou um julgamento, pois a criança desenha por seu próprio prazer e para dar prazer a alguém. (ARFOUILLOUX, 1983, p. 129)

O desenho infantil é utilizado por psicólogos como uma ferramenta para a obtenção de informações sobre a criança, e "numerosos são os analistas que se apóiam no desenho durante o tratamento." (MÈREDIEU, 1974, p. 77). O procedimento desenhos-estórias, idealizado pelo psicólogo Trinca (1976), consiste na

solicitação, ao paciente, de cinco desenhos, sem a introdução de qualquer tema por parte do terapeuta. Após a realização de cada desenho, o paciente é convidado a contar uma estória a partir do que desenhou, bem como a atribuir-Ihe um título. (TACHIBANA; AIELLO-VAISBERG; 2007, p. 25)

No diagnóstico psicológico, o desenho-estória ocupa uma posição intermediária entre os testes projetivos gráficos e temáticos e as entrevistas semi e não-estruturadas, sendo que

Na verdade, constitui-se na reunião de processos expressivos-motores (entre os quais se inclui o desenho livre) e processos aperceptivos-dinâmicos (verbalizações temáticas). Inclui, ainda, associações dirigidas do tipo "inquérito". Dessa junção, surgiu um novo e individualizado instrumento, que possui características próprias [...] Destina-se a sujeitos de ambos os sexos, que podem pertencer a quaisquer níveis mental, sócioeconômico e cultural. De início, pensavase que a aplicação deveria se circunscrever a sujeitos de 5 a 15 anos de idade. Posteriormente, verificou-se que a faixa etária poderia ser estendida a crianças de 3 e 4 anos, bem como a adultos de todas as idades.

Disponível em: <http://www.desenhos-estorias.com/indexpt.html>. Acesso em 20 dez. 2009.

O procedimento de desenhos-estórias com tema ${ }^{200}$ foi criado por Aiello-Vaisber (1995; 1997; 1999) a partir do procedimento de desenhos-estórias de Trinca (1976)

e consiste

200 Oferece as seguintes vantagens: a facilidade com que se pode treinar um pesquisador em sua aplicação; a possibilidade do material ser interpretado por outro pesquisador que não aplicou o procedimento; a particularidade, semelhante ao Desenho-Estória de Trinca (1976) que o originou, de poder ser aplicado em sujeitos de qualquer faixa etária, em diferentes condições psicopatológicas, com variados níveis intelectuais, em diferentes idiomas, inclusive diferente do pesquisador; a possibilidade de aplicação coletiva ou individual. (RIBEIRO, 2007, p. 60) 
[...] na solicitação de um desenho especificado em termos temáticos: desenhe uma pessoa gorda, um hospital, um menino de rua, uma criança-problema, uma escola, o fórum etc. Em seguida, pede-se à pessoa que vire a página e, em seu verso, invente uma história sobre o que desenhou. Crianças, adolescentes e adultos dispõem-se bastante facilmente a fazer uso deste instrumento, em aplicações individuais ou coletivas. Quando o grupo é grande, usualmente cada indivíduo cria um desenho-estória. (AIELLO-VAISBERG, 2004, p. 242-243)

Adotou-se no presente estudo o uso do desenho com tema ou temático durante a entrevista lúdica baseado no Procedimento de Desenhos-Estórias com Tema criado por Aiello-Vaisber (1995; 1997; 1999), com algumas alterações, como a execução de somente um desenho com tema, seguido de perguntas relativas ao ambiente escolar e não intrínsecas à criança. Não cabe no escopo deste trabalho uma revisão e uma reflexão mais detalhada sobre o relato verbal de questões intrínsecas à criança e suas implicações teóricas e metodológicas ligadas à psicologia (ludoterapia), uma vez que este instrumento foi escolhido para a obtenção do relato verbal de questões relativas a acessibilidades e preferências do ambiente escolar.

Quando a criança (sujeito da pesquisa) exerce 0 ato de desenhar, todos os elementos podem ser considerados pelo pesquisador nesta ação: as reações diante da folha branca, a qualidade do traço, a paginação (retrato ou paisagem), a disposição dos objetos no espaço da folha, a escolha das cores e a articulação dos temas apresentados. A criança é, em geral, "pouco capaz de fazer um longo discurso sobre si mesma. Não sabe, com a realidade que vive, manter uma distância suficiente para falar de si mesma e expor seus problemas, como o faria o adulto." (ARFOUILLOUX, 1983, p. 147). O desenho pode suprir essa falha, mas não pode substituir a linguagem da palavra. 
Na entrevista lúdica com o uso do desenho não se indica propô-lo logo no início, havendo um mínimo de entrevista antes para se travar o conhecimento com a criança, "ter uma ideia de seus gostos, aptidões, preocupações do momento, estado afetivo, e para dar-Ihe confiança, permitir-Ihe uma adaptação ao clima da entrevista e a compreensão de suas finalidades." (ARFOUILLOUX, 1983, p. 149).

A criança deseja antes de tudo desenhar algo bonito e espera ser cumprimentada por isso e caso ela "se sentir incapaz, por sua falta de jeito ou porque viu a entrevista como um deslocamento da situação escolar, isso pode bastar para paralisá-la. A recusa de desenhar muitas vezes não tem outra significação." (ARFOUILLOUX, 1983, p. 147). Como o desenho é executado pela criança na frente de um desconhecido (como um juiz), o aplicador deve mostrar interesse não pela forma, mas pelo conteúdo do desenho. Desta forma o ato de desenhar e o próprio desenho não se tornam comprometedores para a criança, sendo que não se indica a interrupção da criança até o término do desenho, quando a mesma solta o lápis ou indica verbalmente que finalizou o mesmo. Durante a confecção do desenho é necessário demonstrar que estamos presentes, que compreendemos o seu significado, e ainda estimular a criança com alguns elogios.

Desenhar junto com a criança, "como toda a dimensão lúdica que isso comporta, é uma intervenção que pode revelar-se particularmente dinamizadora durante a entrevista." (ARFOUILLOUX, 1983, p. 150). Não é necessário que a criança o peça de modo explícito - é uma questão de aptidão do entrevistador em se colocar no mesmo 
nível da criança, como no brinquedo, e em se comunicar com os mesmos meios de expressão que ela.

\section{2 $\quad 1^{\mathrm{a}}$ etapa da pequisa}

\subsubsection{Entrevista lúdica com brinquedo}

A modalidade da entrevista lúdica com brinquedo na primeira etapa da pesquisa teve como objeto de estudo os alunos cegos aptos a participarem da pesquisa (ver Tabela 4) da pré-escola da unidade-caso 1.

\section{a) Objetivo}

O objetivo da entrevista lúdica com brinquedo foi o de promover a interação entre 0 aluno e o entrevistador antes e durante a entrevista e obter informações sobre as preferências e a acessibilidade do ambiente escolar.

\section{b) Procedimentos adotados}

Os procedimentos para a aplicação adotados foram discutidos com a docente em entrevista realizada previamente ${ }^{201}$. O local da aplicação foi a sala de brinquedos ao lado da sala de aula da unidade-caso 1, eleita segundo os critérios conforto acústico e proximidade física em relação à sala de aula. A aplicação foi realizada somente pela

\footnotetext{
${ }^{201}$ Ver item 5.2.3.1.
} 
pesquisadora ${ }^{202}$ e de forma individual (o fato de o aluno não enxergar requer maior cuidado e atenção, em especial na locomoção). A forma de comunicação utilizada foi a verbal, a pesquisadora forneceu ao aluno um brinquedo de montar disponível na sala de brinquedos da unidade-caso 1 , conhecido previamente pelo aluno.

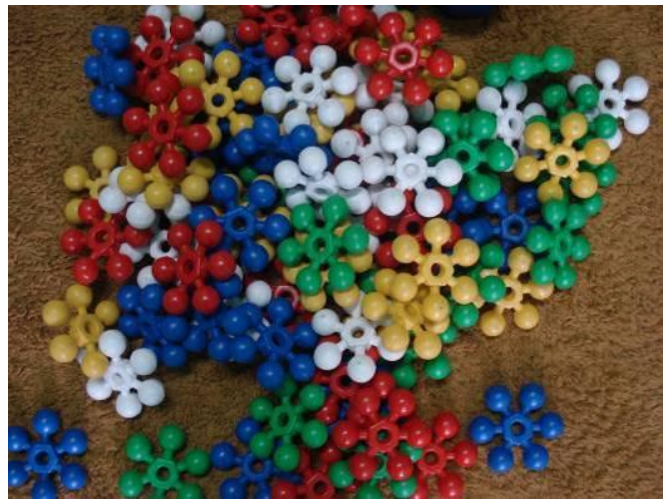

Figura 29 - Brinquedo de montar eleito para dar suporte à entrevista.
Esse brinquedo (Figura 29) é composto por peças de encaixe, não requerer raciocínio intenso para a sua montagem, liberando o aluno para responder às perguntas realizadas pela entrevistadora.

Iniciou-se o período de aquecimento (ver item 5.1.4) onde o aluno foi convidado a montar o brinquedo em conjunto com a pesquisadora durante cerca de 15 minutos, sendo que a pesquisadora somente verbalizou alguns assuntos sobre a brincadeira em andamento. Após esta fase inicial e ainda durante a montagem das peças do brinquedo pelo aluno foram realizadas, pausadamente, as perguntas ${ }^{203}$ descritas no Quadro 26.

202 A docente se encontrava com os demais alunos.

203 A elaboração das questões baseou-se na experiência da pesquisadora em estudo anterior (BARBOSA, et al 2009). 


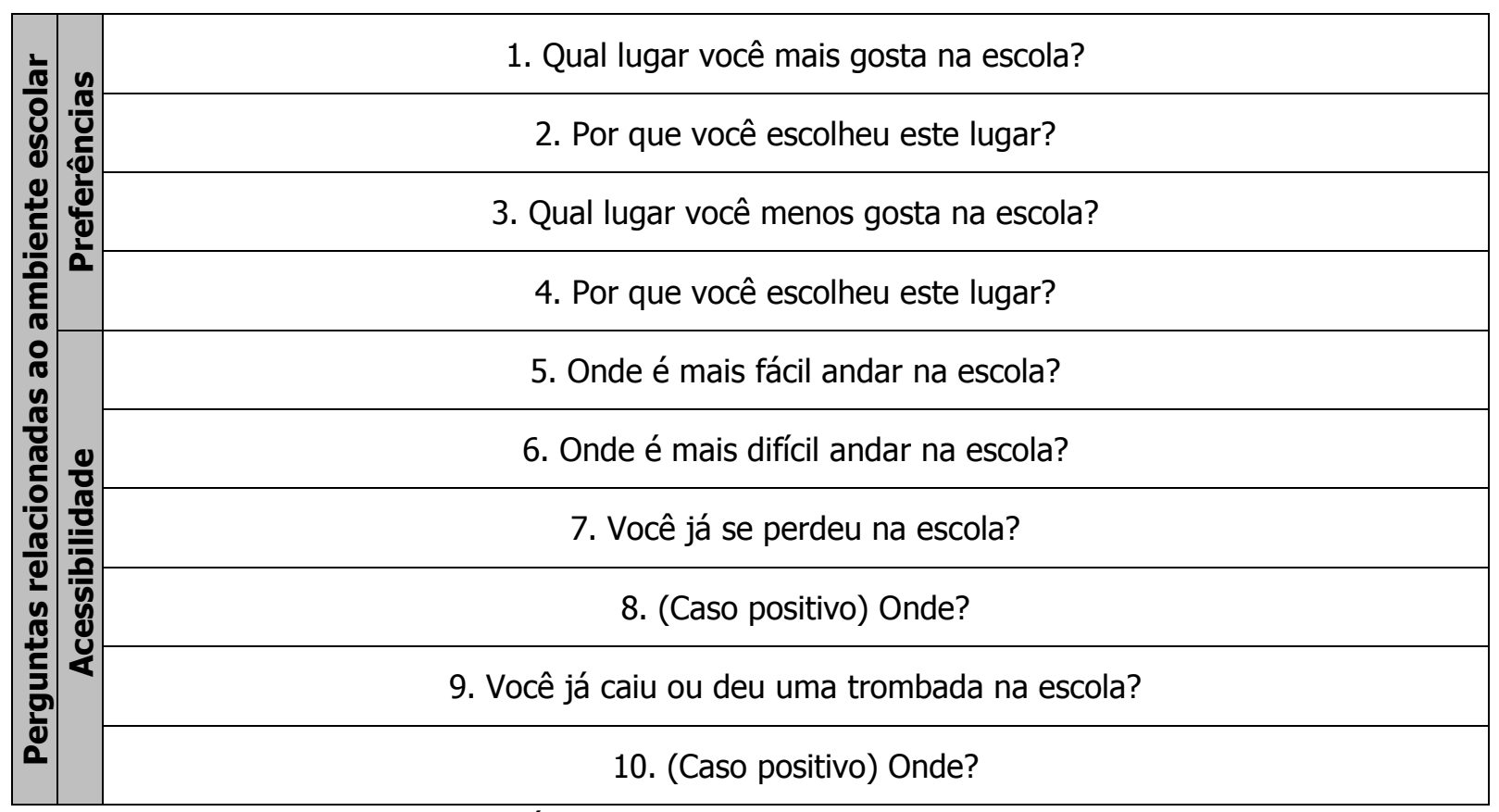

Quadro 26 - Roteiro da entrevista lúdica com brinquedo destinada aos alunos cegos na $1^{\mathrm{a}}$ etapa da pesquisa (pré-teste).

Anotou-se a informação fornecida pelo aluno.

> Condução: as entrevistas foram conduzidas pela pesquisadora com o prévio consentimento dos participantes e não foram gravadas.

Datas: variadas, definidas em função da disponibilidade dos entrevistados.

Duração: variável, de 20 a 27 minutos.

A seguir, serão apresentados os resultados da entrevista lúdica com brinquedo.

\subsubsection{Alunos cegos: resultados da unidade-caso 1}

Na primeira etapa da pesquisa, a entrevista lúdica com o brinquedo na unidade-caso

1 envolveu os 7 alunos cegos aptos a participarem da pesquisa (ver Tabela 4) da 
única classe de pré-escola existente, e ocorreu nos dias 08/10/2009 (4 alunos) e 10/10/2009 (3 alunos).

Apresentam-se o processo de aplicação e os resultados da entrevista realizada com o aluno D. de 5 anos, cego, sendo que as demais ocorreram de forma similar. Inicialmente a pesquisadora convidou o aluno a brincar, o conduziu da sala de aula até a sala ao lado (de brinquedos) e o posicionou sobre um tapete no chão, longe da janela onde a incidência de raios solares era grande, e sentou-se a sua frente.

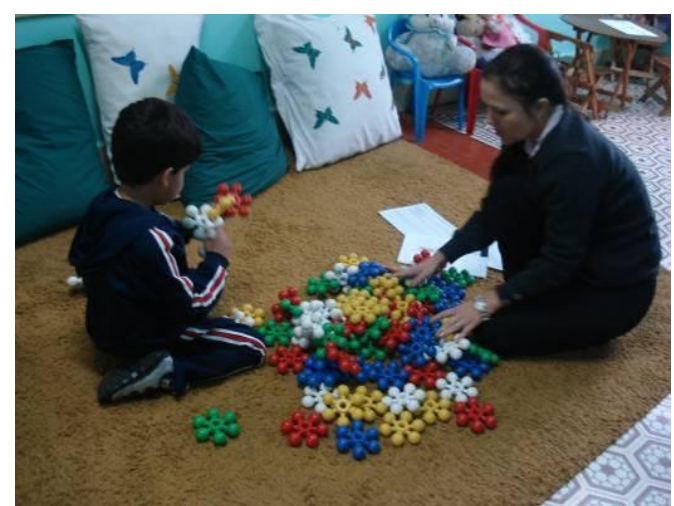

Figura 30 - Início da aplicação da entrevista lúdica com brinquedo destinada ao aluno D., de 5 anos, cego.
As peças do brinquedo de montar eleito foram espalhadas no chão, e o aluno foi convidado a tateá-las para o reconhecimento inicial de suas formas e quantidade (Figura 30). 0 aluno demonstrou interesse nesta tarefa e a realizou com facilidade, pois apresentava boa pega e coordenação motora.

Nesta fase de aquecimento, a pesquisadora convidou o aluno a fazer uma escultura com as peças do brinquedo, o aluno entendeu a proposta da brincadeira e logo começou a tatear as peças e tentar juntá-las, conforme a Figura 31. 


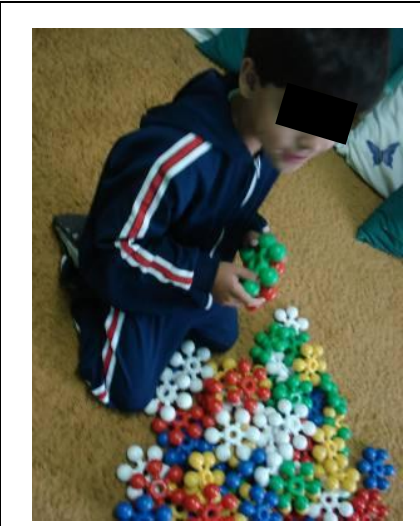

(a)

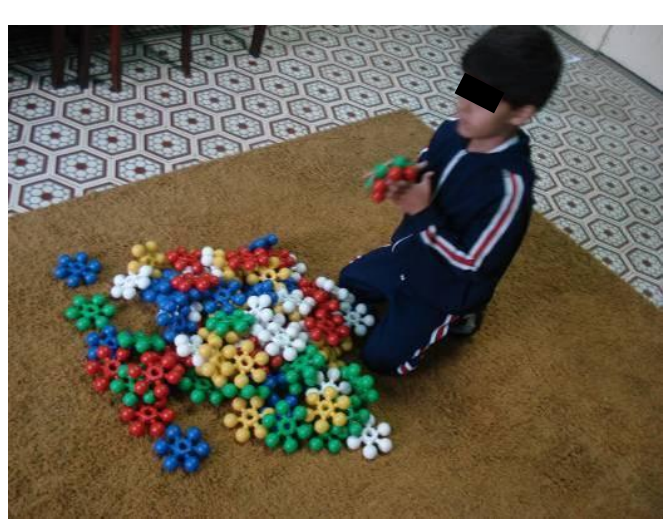

(b)

Figura 31 - Início da fase de aquecimento da entrevista lúdica com brinquedo destinada ao aluno D., de 5 anos, cego.

Durante os 15 primeiros minutos a pesquisadora brincou com o aluno, conforme a Figura 32 a seguir.

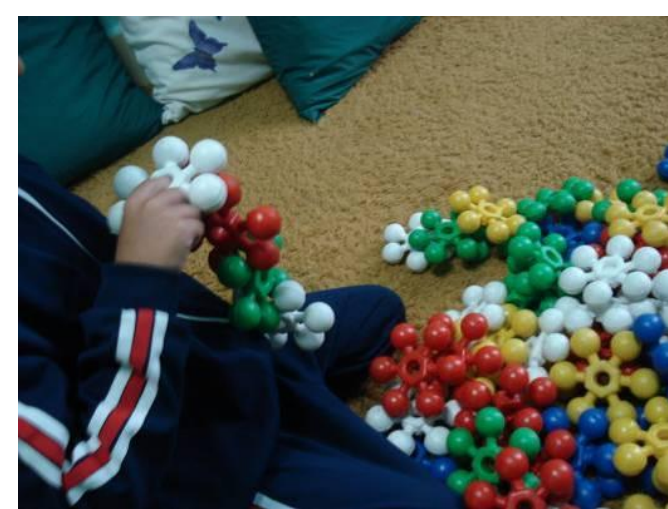

(a)

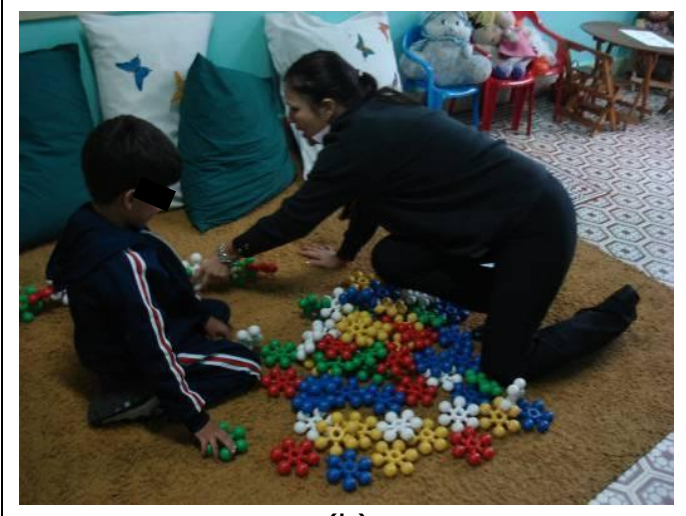

(b)

Figura 32 - Fase de aquecimento da entrevista lúdica com brinquedo destinada ao aluno D., de 5 anos, cego.

Após essa fase inicial de aquecimento e ainda durante a atividade de montagem das peças do brinquedo pelo aluno, foram realizadas, pausadamente, as perguntas descritas anteriormente ${ }^{204}$. O aluno respondeu às questões prontamente e sem dificuldade enquanto brincava. A pesquisadora anotou a verbalização das respostas do aluno, descritas a seguir:

${ }^{204}$ Ver procedimentos adotados. 
1. "Sala de brinquedo."

2. "Eu acho legal."

3. "Quadra."

4. "Não gosto de ficar sozinho na quadra."

5. "Galeria com amigo." 205

6. "Refeitório porque não dá para ir sozinho."

7. "Sim. Atrás do ginásio de esportes. Um colega me deixou lá. Fiquei sentado esperando alguém chegar e demorou." 206

8. "Não."

Ao término das questões e já passados 25 minutos do início da aplicação do instrumento entrevista lúdica, a pesquisadora informou o término da brincadeira, sendo que o aluno não se mostrou cansado, pois não havia parado de montar as peças. A pesquisadora elogiou o produto final da montagem das peças, bem como o aluno pelo seu desempenho. A aplicação deste instrumento se iniciou às $11 \mathrm{~h} 05 \mathrm{~min}$ e terminou às $11 \mathrm{~h} 30$ min do dia 08/10/2009.

\subsubsection{Entrevista lúdica com desenho temático}

A modalidade da entrevista lúdica com desenho temático teve como objeto de estudo os alunos com baixa visão, surdez e PC aptos a participarem da pesquisa (ver Tabelas 4, 5 e 6) das pré-escolas das unidades-caso 1, 2 e 3, respectivamente. A

\footnotetext{
${ }^{205}$ A galeria é de circulação onde geralmente os alunos videntes guiam os cegos, pois andam juntos (ver entrevista com docente item 5.2.3.1).

${ }^{206}$ Nesta questão o aluno externou um problema ocorrido.
} 
entrevista lúdica com desenho temático no presente estudo não foi destinada aos alunos cegos (unidade-caso 1), pois, mesmo havendo trabalhos neste tema (AMIRALIAN, 1997; DUARTE, 2004), ainda se encontram em fase de experimentação, conforme a citação a seguir

Julgamos este um campo inexplorado e muitas outras pesquisas são necessárias. Tais como: estudos sobre a evolução do grafismo de pessoas cegas, o desenho como expressão de aspectos da personalidade, o desenho como um recurso para a compreensão de suas representações mentais. Em outra linha, acreditamos sejam enriquecedores os estudos sobre a utilização da expressão gráfica pelos cegos como instrumento para o desenvolvimento de conceitos, organizações espaciais, criatividade, enfim um colaborador para a organização cognitiva. Em síntese, estudos que trouxessem maiores conhecimentos sobre o desenho de pessoas portadores de cegueira ${ }^{207}$ e das possibilidades de utilização da expressão gráfica como um recurso para o favorecimento do desenvolvimento e aprendizagem destas pessoas trariam rica contribuição para a expansão e melhoria de seus atendimentos, tanto na área de educação como na de reabilitação. (AMIRALIAN, 1997, p. 307)

\section{a) Objetivo}

Os objetivos da entrevista lúdica com desenho temático foram promover a interação entre 0 aluno e o entrevistador antes e durante a entrevista e obter informações relativas às preferências e à acessibilidade do ambiente escolar.

\section{b) Procedimentos adotados}

Os procedimentos de aplicação adotados na entrevista com desenho temático destinada aos alunos com baixa visão, surdez e PC foram discutidos com as respectivas docentes em entrevistas realizadas previamente ${ }^{208}$ e se encontram descritos, em parte, no Quadro 27 a seguir.

${ }^{207} \mathrm{O}$ termo mais usual é pessoa com deficiência visual (cegueira).

${ }^{208}$ Ver item 5.2.3. 


\begin{tabular}{|c|c|c|c|}
\hline Unidade-caso & 1 & 2 & 3 \\
\hline Deficiência & Visual (baixa visão) & Auditiva (surdez) & Física (PC) \\
\hline $\begin{array}{l}\text { Ordenação em } \\
\text { relação à } \\
\text { aplicação do } \\
\text { questionário } \\
\end{array}$ & Anterior & Anterior & Anterior \\
\hline $\begin{array}{l}\text { Local da } \\
\text { aplicação }\end{array}$ & Sala de brinquedos & Sala de aula & Sala de aula \\
\hline $\begin{array}{l}\text { Forma de } \\
\text { aplicação }\end{array}$ & $\begin{array}{l}\text { Em dupla na } \\
\text { confecção do } \\
\text { desenho e } \\
\text { individual }^{209} \text { na } \\
\text { entrevista }\end{array}$ & Individual & $\begin{array}{l}\text { Todos os alunos juntos na } \\
\text { confecção do desenho e } \\
\text { individual }\left.\right|^{210} \text { na entrevista }\end{array}$ \\
\hline Aplicador(es) & Pesquisadora & $\begin{array}{c}\text { Docente com o apoio de } \\
\text { outra docente, na } \\
\text { presença da } \\
\text { pesquisadora }\end{array}$ & $\begin{array}{c}\text { Docente e pesquisadora } \\
\text { com o apoio de } 3 \text { a } 4 \\
\text { voluntários }\end{array}$ \\
\hline $\begin{array}{l}\text { Forma de } \\
\text { comunicação } \\
\text { para a aplicação }\end{array}$ & Verbal & LIBRAS $^{211}$ & Verbal \\
\hline $\begin{array}{l}\text { Forma de } \\
\text { comunicação do } \\
\text { aluno }\end{array}$ & Verbal & LIBRAS & $\begin{array}{l}\text { Verbal: alunos com fala e } \\
\text { CAA: alunos sem fala }\end{array}$ \\
\hline $\begin{array}{l}\text { Material } \\
\text { fornecido a cada } \\
\text { aluno pela }\end{array}$ & $\begin{array}{r}\text { Giz de ce } \\
3 \text { primárias, } 3 \text { secu }\end{array}$ & $\begin{array}{l}\text { em } 8 \text { cores: } \\
\text { lárias, preto e marrom }\end{array}$ & $\begin{array}{l}\text { Material pertencente aos } \\
\text { alunos }^{212}\end{array}$ \\
\hline pesquisadora & & & \\
\hline & \multicolumn{3}{|c|}{ Uma folha de papel sulfite A4 branca com o dados do aluno no verso } \\
\hline
\end{tabular}

Quadro 27 - Alguns dos procedimentos para a aplicação adotados na entrevista com desenho temático na $1^{\text {a }}$ etapa da pesquisa (pré-teste), por deficiência.

$\mathrm{Na}$ aplicação da entrevista com desenho temático destacaram-se as quatro fases descritas a seguir:

${ }^{209}$ Com os demais alunos presentes.

${ }^{210}$ Idem anterior.

${ }^{211}$ A docente serviu como intérprete da LIBRAS dos alunos surdos. Nenhum outro intérprete, a não ser a própria professora destes alunos, poderia ser o aplicador em função da LIBRAS ainda não ser fluente entre estes alunos e da faixa etária em que se encontram.

212 Alguns dos alunos com PC e comprometimento dos membros superiores necessitavam de adaptações relativas à tecnologia assistiva, como engrossadores de lápis ou giz, além do uso de fita adesiva para fixar a folha à mesa. 
- Na fase 1, a pesquisadora explicou que os alunos não poderiam olhar o desenho dos colegas e, principalmente, que não havia certo ou errado, pois o importante era a opinião de cada um.

- Na fase 2, foi proposto o tema do desenho aos alunos a partir da questão: Qual o lugar que você mais gosta na escola? Durante os três primeiros minutos, no mínimo, o aluno não foi questionado. Esta fase teve a função de promover no aluno um desligamento ou um relaxamento, período preparatório para a fase descrita a seguir. - Na fase 3, durante a execução do desenho, foram realizadas, pausadamente, e de forma individual (mesmo nas aplicações com mais de um aluno) as seguintes perguntas (relativas a aspectos gerais da escola e a acessibilidade) descritas no Quadro 28 a seguir, por deficiência:

\begin{tabular}{|c|c|c|c|}
\hline & \multicolumn{3}{|c|}{ Deficiências } \\
\hline & Visual (baixa visão)* & Auditiva (surdez) & Física (PC) \\
\hline \multirow{11}{*}{ 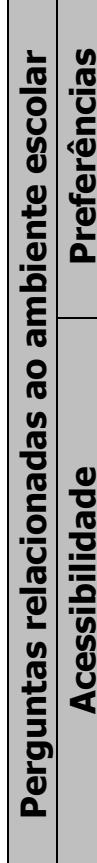 } & \multicolumn{3}{|c|}{ 1. Qual lugar você mais gosta na escola? } \\
\hline & \multicolumn{3}{|c|}{ 2. Por que você escolheu este lugar? } \\
\hline & \multicolumn{3}{|c|}{ 3. Qual lugar você menos gosta na escola? } \\
\hline & - & \multicolumn{2}{|c|}{ 4. Por que você escolheu este lugar? } \\
\hline & - & \multicolumn{2}{|c|}{ 5. O que você gostaria que tivesse na escola? } \\
\hline & $\begin{array}{l}\text { 5. Onde é mais fácil andar na } \\
\text { escola? }\end{array}$ & - & - \\
\hline & $\begin{array}{l}\text { 6. Onde é mais difícil andar } \\
\text { na escola? }\end{array}$ & \multicolumn{2}{|c|}{ 6. Onde é mais difícil andar na escola? } \\
\hline & $\begin{array}{c}\text { 7. Você já se perdeu na } \\
\text { escola? }\end{array}$ & - & - \\
\hline & 8. (Caso positivo) Onde? & - & - \\
\hline & $\begin{array}{l}\text { 9. Você já caiu ou deu uma } \\
\text { trombada na escola? }\end{array}$ & - & - \\
\hline & 10. (Caso positivo) Onde? & - & - \\
\hline
\end{tabular}

Quadro 28 - Roteiro da entrevista lúdica com desenho temático na $1^{a}$ etapa da pesquisa (pré-teste), por deficiência.

*O número de questões destinadas aos alunos com baixa visão foi superior em função da observação realizada pela pesquisadora anteriormente onde se verificou que a comunicação verbal era fluente entre os alunos aptos a participarem da pesquisa desta unidade-caso. 
Anotou-se literalmente a informação fornecida por cada aluno (verbalmentem ou em LIBRAS ou em CAA), pois a "primeira versão escrita do texto da fala do entrevistado deve ser registrada, tanto quanto possível, tal como ela se deu." (SZYMANSKI, 2010, p. 74).

- Na fase 4 da entrevista lúdica com desenho temático relativa ao término do desenho (indicado pelo aluno ${ }^{213}$ ), solicitou-se a descrição do significado dos símbolos desenhados através das formas de comunicação relativas a cada deficiência, sendo anotada esta informação pela pesquisadora. Conforme descrito no item 7.1, relativo ao referencial teórico, não devemos tirar conclusões sobre os desenhos, e sim pedir às crianças que nos falem sobre eles (PEREIRA, 2009; COX, 2007; AGUIAR, 2004; MÈREDIEU, 1974). Ao término da aplicação a pesquisadora elogiou os desenhos realizados e perguntou se poderia ficar com os mesmos como um presente. Todos os alunos concordaram e entregaram os desenhos.

Datas: variadas, definidas em função da disponibilidade dos entrevistados.

Duração: variável, de 10 a 18 minutos por aluno com baixa visão, de 9 a 15 minutos por aluno surdo e de cerca de 40 minutos por classe de alunos com PC.

A seguir serão apresentados os resultados da do processo de aplicação da entrevista lúdica com desenho temático na primeira etapa da pesquisa.

\footnotetext{
${ }^{213}$ Geralmente a pesquisadora aguardava até o aluno estar satisfeito com o seu desenho, largar o giz de cera e parar de desenhar.
} 


\subsubsection{Alunos com baixa visão: resultados da unidade-caso 1}

Na primeira etapa da pesquisa, a entrevista lúdica com desenho temático na unidade-caso 1 destinou-se a 2 alunos com baixa visão presentes (ao mesmo tempo) no dia da aplicação (do total de 3 alunos aptos a participarem da pesquisa, ver Tabela 4) da única classe de pré-escola existente. A entrevista lúdica com desenho temático ocorreu no dia 08/10/2009 e teve início às 9h30min e término às 9h40min (aluno T., de 5 anos) e 9h44min (aluno V., de 5 anos).

Inicialmente a pesquisadora conduziu os dois alunos da sala de aula até a sala ao lado, de brinquedos, e os posicionou na única mesa existente, entregando a cada um deles uma folha em branco e o giz de cera. A pesquisadora solicitou aos alunos que desenhassem o tema proposto, sendo que eles entenderam a proposta e logo iniciaram esta tarefa (Figura 33).

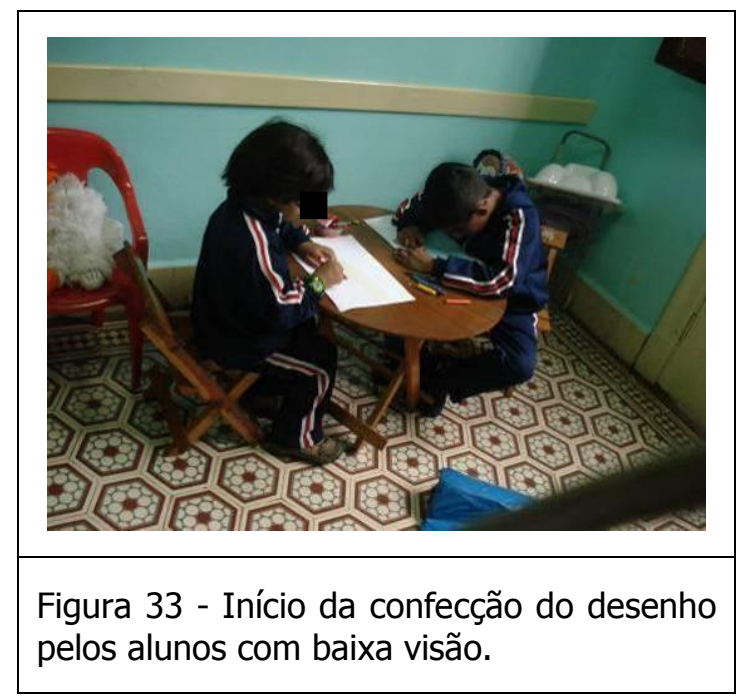


Durante a confecção do desenho, o aluno V., de 5 anos (Figura 34), apresentou postura inadequada, com a cabeça muito próxima à folha. A iluminação artificial e natura $\mathrm{l}^{214}$ se encontrava aparentemente adequada.

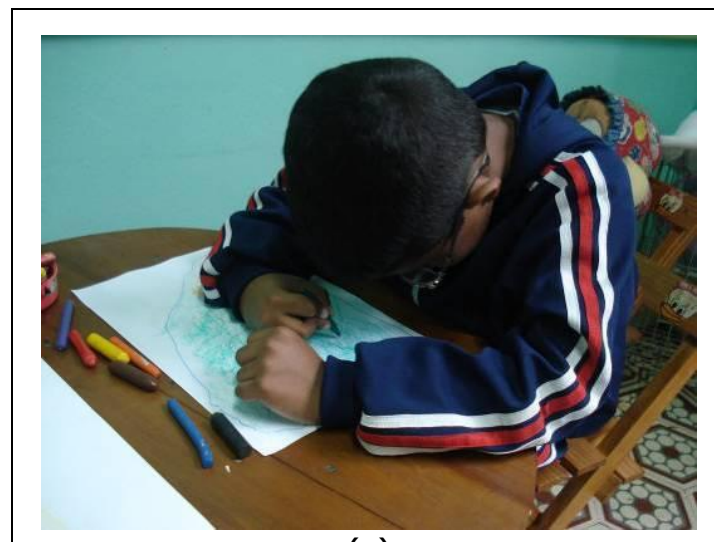

(a)

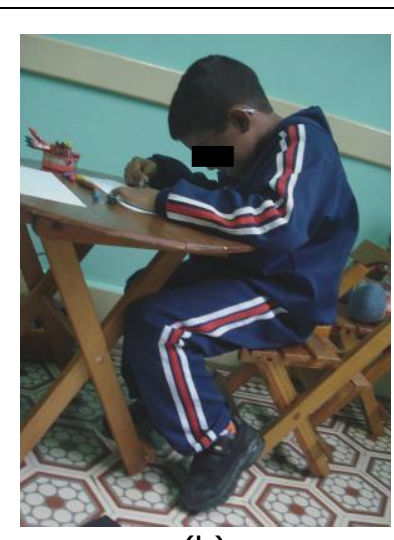

(b)

Figura 34 - Postura inadequada do aluno V., de 5 anos, com baixa visão, durante a confecção do desenho temático.

Passados cerca de 3 minutos e ainda durante a execução do desenho pelos alunos, foram realizadas, pausadamente, as perguntas relativas a aspectos gerais e à acessibilidade do ambiente escolar ${ }^{215}$ de forma individual e em tom baixo. A pesquisadora repetiu as perguntas da entrevista várias vezes ao aluno T., (Figura 35 à esquerda), que apresentou dificuldade para entender e responder, falar com fluência e se concentrar durante todo o processo, diferentemente do outro aluno, que respondeu as questões facilmente enquanto desenhava.

\footnotetext{
${ }^{214} \mathrm{~A}$ mesa se encontrava próxima à janela.

${ }^{215}$ Ver 7.2.2 b).
} 


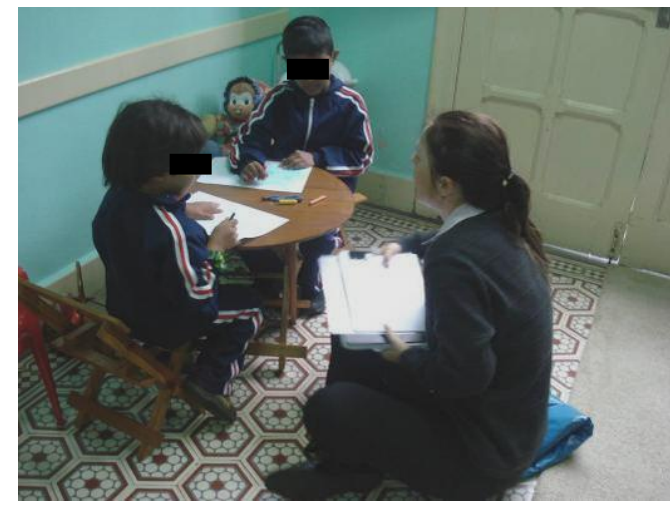

(a)

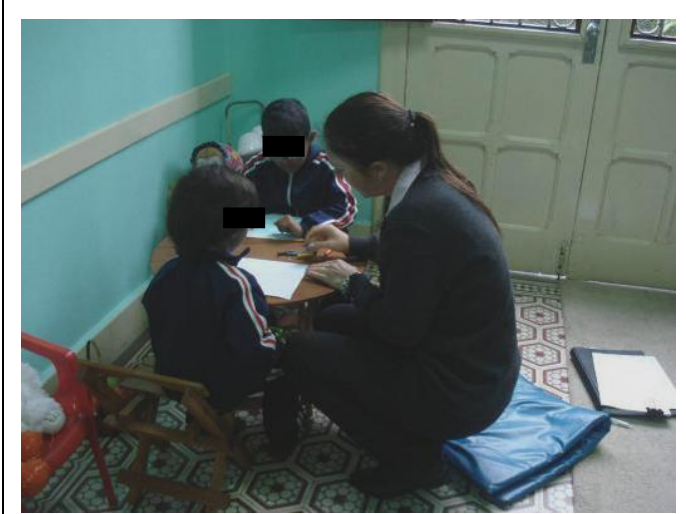

(b)

Figura 35 - Repetição das perguntas da entrevista lúdica com desenho temático destinado ao aluno T., de 5 anos, à esquerda, com baixa visão.

A pesquisadora anotou individualmente a verbalização das respostas da entrevista dos alunos, e ao término do desenho, a descrição do significado dos símbolos desenhados (Figura 36).

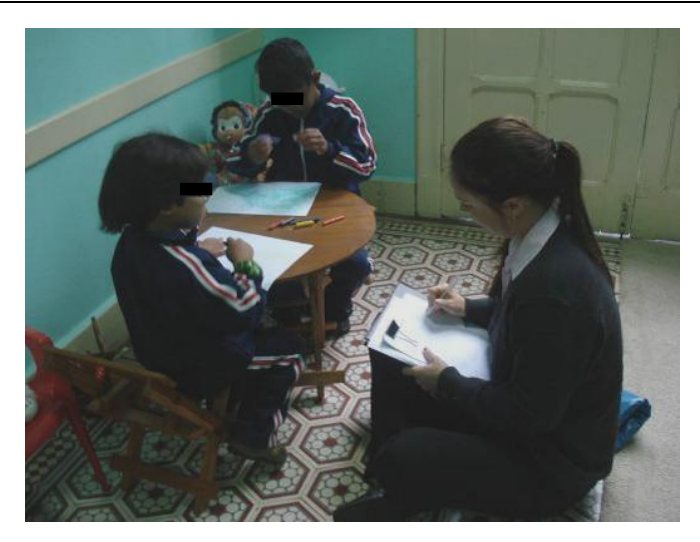

Figura 36 - Anotação das respostas do aluno $T$., de 5 anos, à esquerda, com baixa visão pela pesquisadora.

A seguir serão apresentadas sínteses de todas as entrevistas lúdicas com desenho temático da primeira etapa da pesquisa destinadas aos alunos com baixa visão (Quadros 29 e 30), contendo a imagem dos desenhos confeccionados, o significado dos símbolos desenhados, as cores utilizadas, a duração e as respostas dos alunos. 


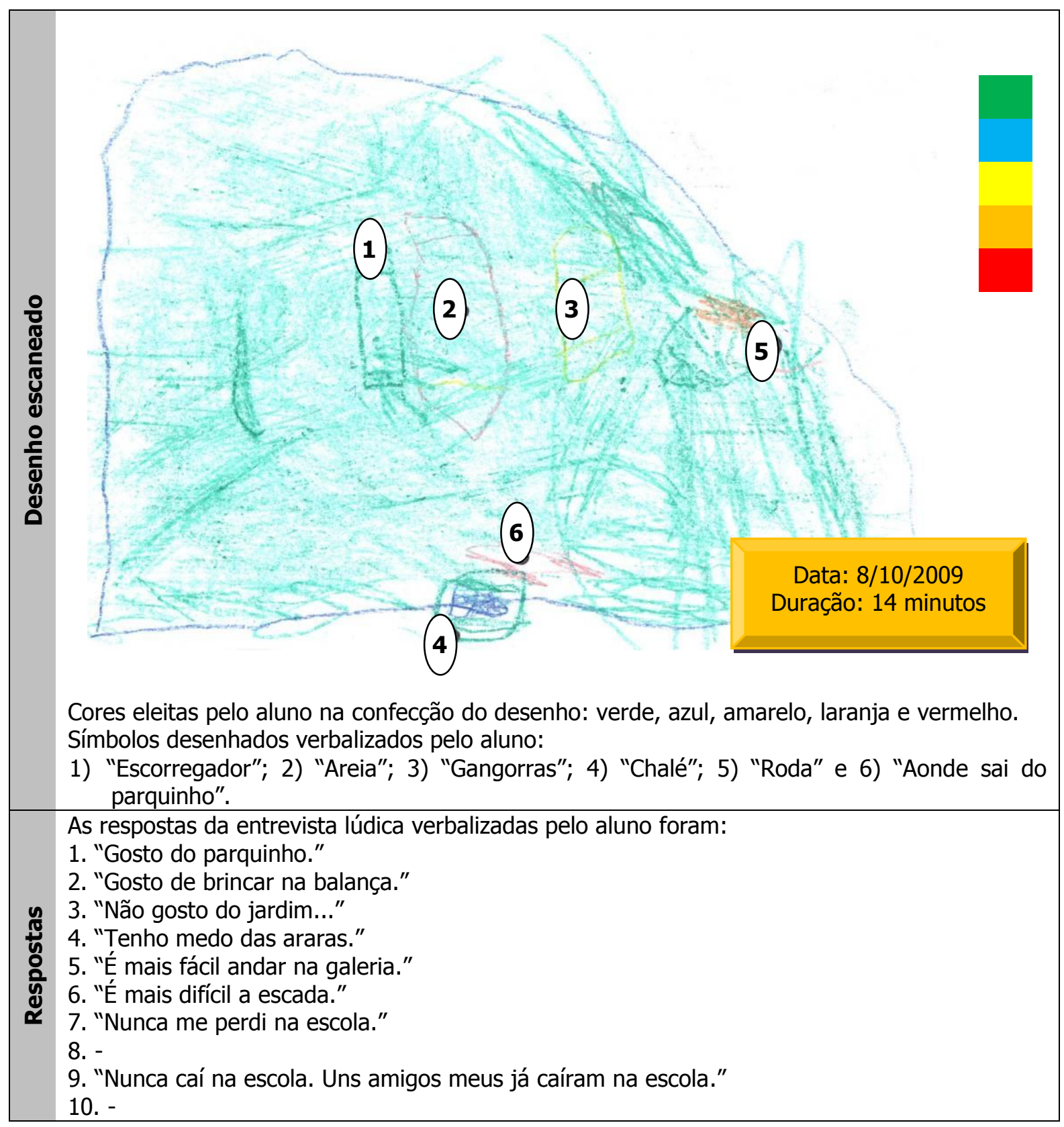

Quadro 29 - Síntese da entrevista lúdica com desenho temático destinada ao aluno V., de 5 anos, com baixa visão, da unidade-caso 1 na $1^{\text {a }}$ etapa da pesquisa. 


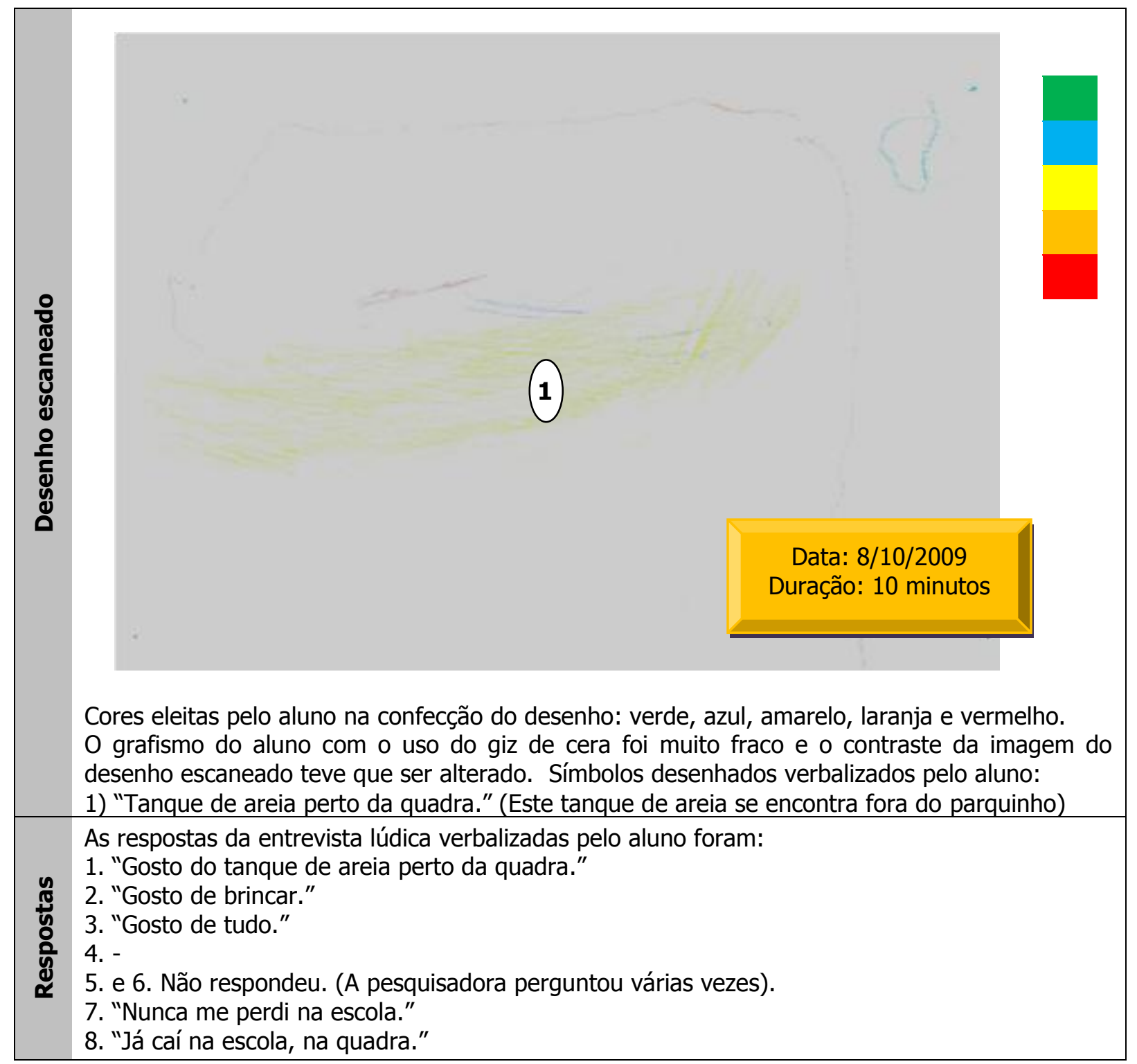

Quadro 30 - Síntese da entrevista lúdica com desenho temático destinada ao aluno T., de 5 anos, com baixa visão, da unidade-caso 1 na $1^{\text {a }}$ etapa da pesquisa.

\subsubsection{Alunos surdos: resultados da unidade-caso 2}

Na primeira etapa da pesquisa, a entrevista lúdica com desenho temático na unidade-caso 2 destinou-se a 4 alunos surdos presentes no dia da aplicação (do total de 7 alunos aptos a participarem da pesquisa, ver Tabela 5) da única classe de préescola apta a participar da pesquisa. A entrevista lúdica com desenho temático 
ocorreu no dia 04/11/2009. A aplicação desse instrumento foi realizada de forma individual e somente pela docente desses alunos (na presença da pesquisadora) em função da familiaridade e do nível de comunicação em LIBRAS de cada aluno, bem como a consequente necessidade de um intérprete.

Inicialmente, a docente e a pesquisadora posicionaram um aluno ${ }^{216}$ por vez em uma mesa existente no fundo da sala. Os demais alunos que se encontravam na sala permaneceram sentados em suas respectivas mesas realizando outras atividades propostas por uma docente de outra turma que apoiou a aplicação (Figura 37).

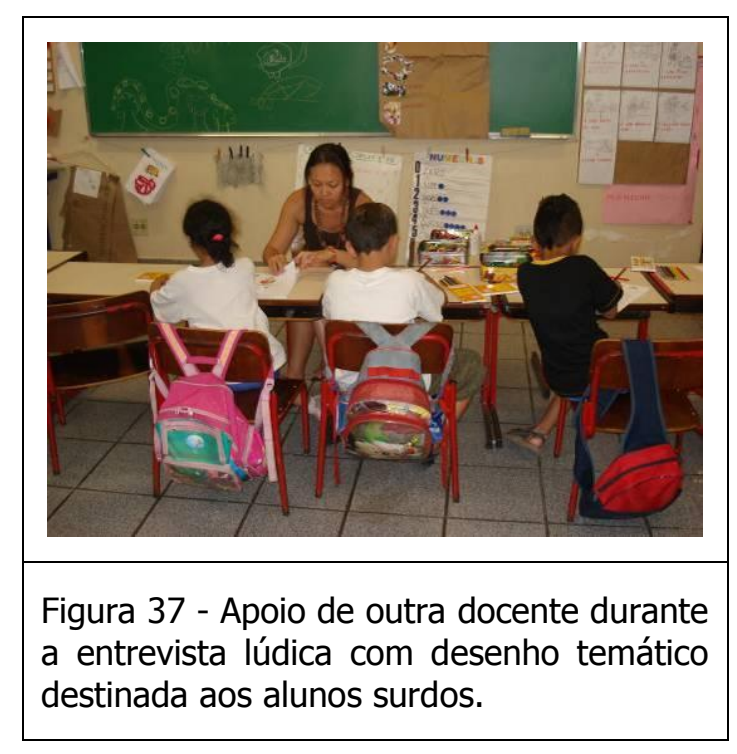

Foi solicitado ao aluno, individualmente, que realizasse um desenho temático (Figuras 38a - 41a) com giz de cera fornecido pela pesquisadora. Esta tarefa foi realizada com facilidade por todos os alunos (ótimas condições para o uso dos membros superiores). Metade dos alunos (Figuras 40 e 41) apresentou dificuldade no entendimento das seguintes questões da entrevista individual: Qual lugar você menos gosta na escola? Onde é mais difícil andar na escola? A docente teve que ${ }^{216}$ Selecionado pela docente. 
repetir várias vezes estas questões em LIBRAS em função da falta de fluência da criança e da abstração decorrente da surdez. Durante a execução do desenho os alunos foram interrompidos por várias vezes pela docente em função das perguntas em LIBRAS da entrevista, causando a perda do contato visual do aluno com o desenho por muito tempo, bem como o ato de soltar o giz de cera que estava utilizando para responder às perguntas, dificultando o recomeço do desenho (Figuras $40 b, c, d ; 41 a, b)$.

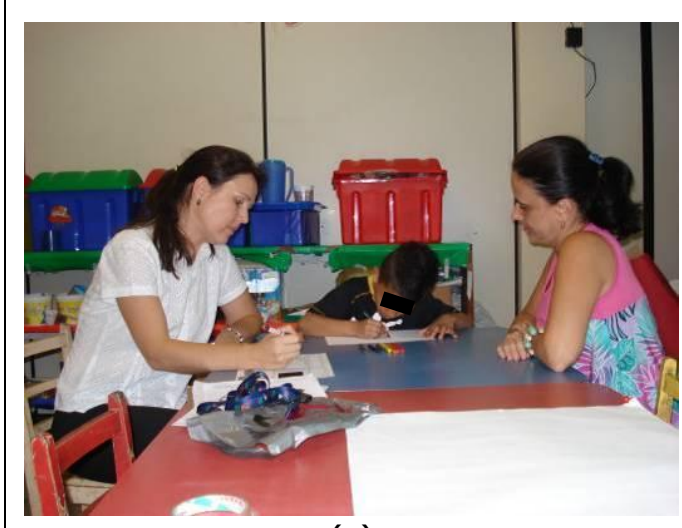

(a)

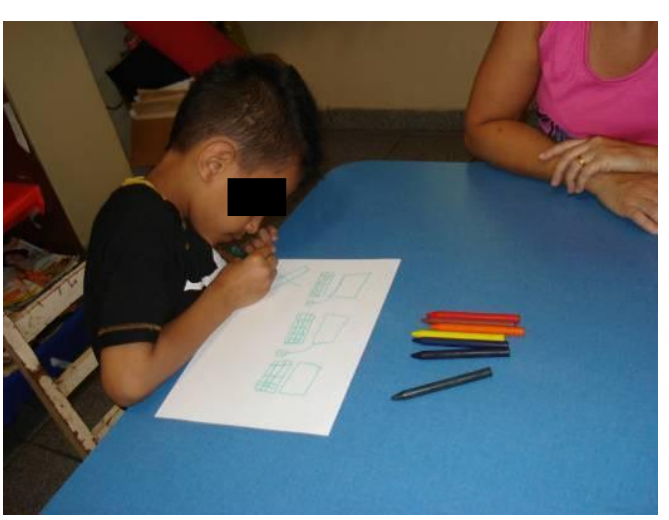

(b)

Figura 38 - $1^{\text {a }}$ entrevista lúdica com desenho temático destinada ao aluno I., de 7 anos, surdo.

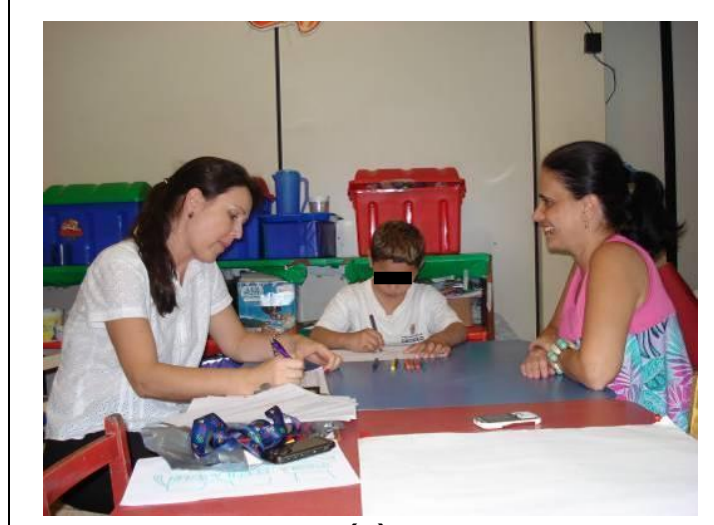

(a)

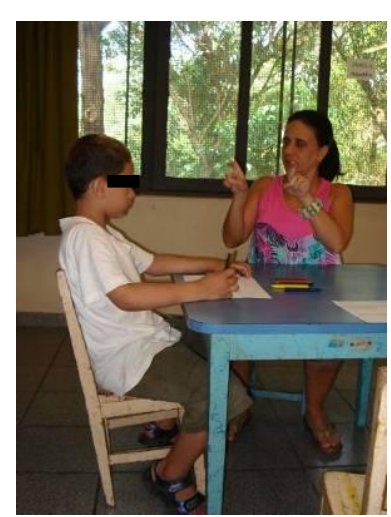

(b)

Figura $39-2^{\mathrm{a}}$ entrevista lúdica com desenho temático destinada ao aluno F., de 7 anos, surdo. 


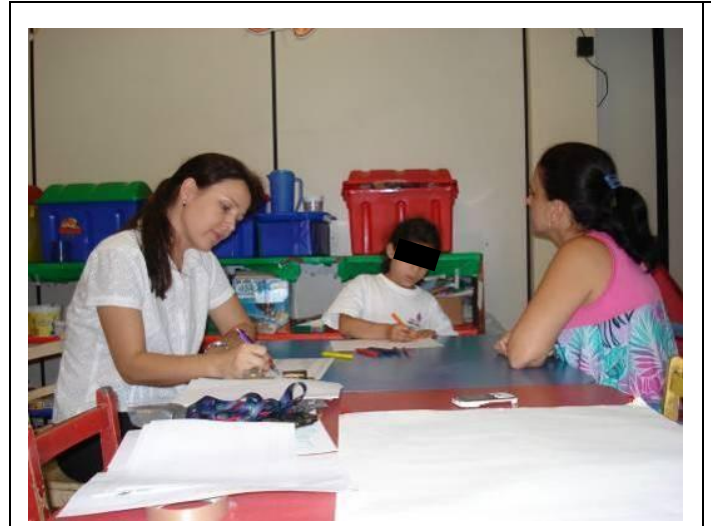

(a)

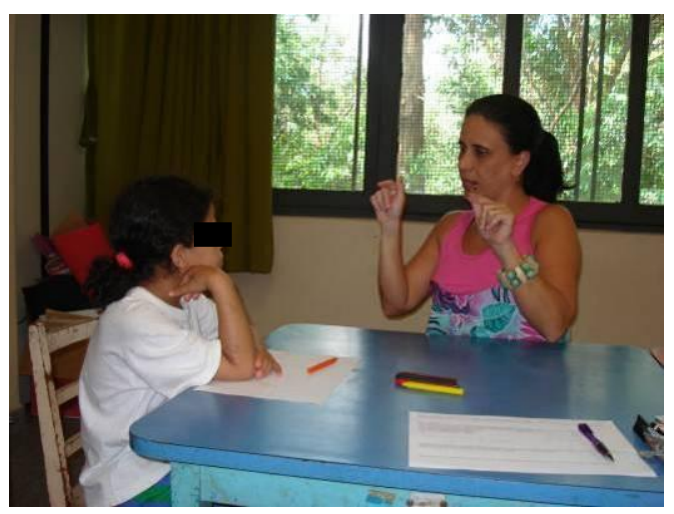

(c)

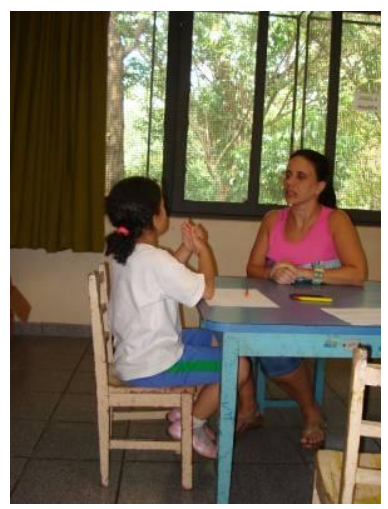

(b)

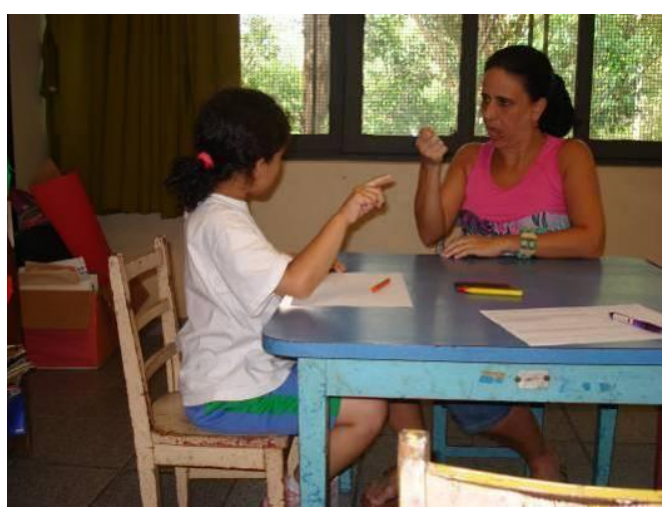

(d)

Figura 40 - $3^{a}$ entrevista lúdica com desenho temático destinada à aluna T., de 7 anos, surda.

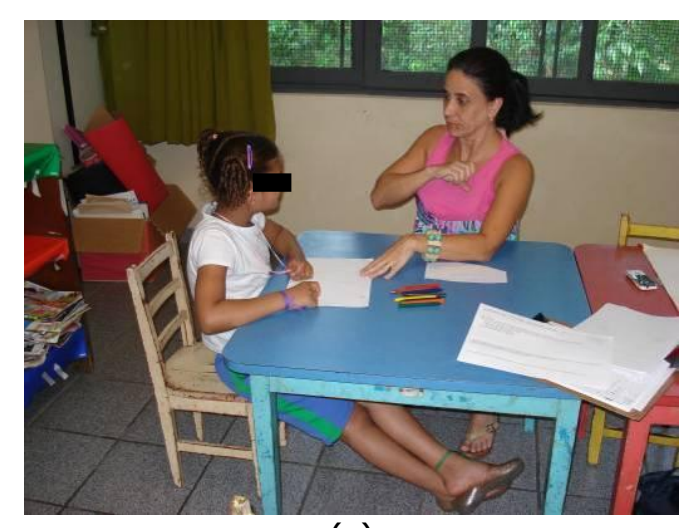

(a)

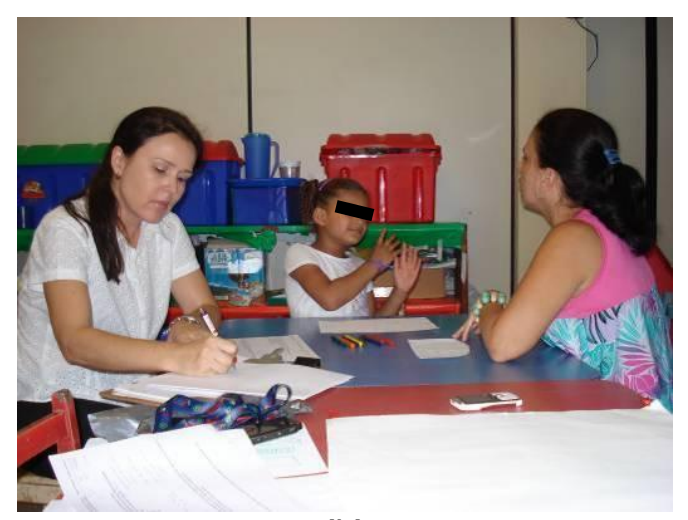

(b)

Figura 41 - $4^{a}$ entrevista lúdica com desenho temático destinada à aluna M., de 7 anos, surda.

A pesquisadora anotou a verbalização da professora que interpretou as respostas dos alunos em LIBRAS. 
Ao término do desenho, a docente solicitou aos alunos a descrição do significado dos símbolos desenhados, sendo anotadas pela pesquisadora estas informações. A docente elogiou os desenhos realizados e perguntou se a pesquisadora poderia ficar com eles como um presente. Os alunos concordaram e entregaram os desenhos.

A seguir serão apresentadas algumas sínteses de resultados da entrevista lúdica com desenho temático da primeira etapa da pesquisa destinada aos alunos surdos (Quadros 31 e 32), contendo a imagem dos desenhos confeccionados, o significado dos símbolos desenhados, as cores utilizadas, a duração e as respostas das entrevistas. 


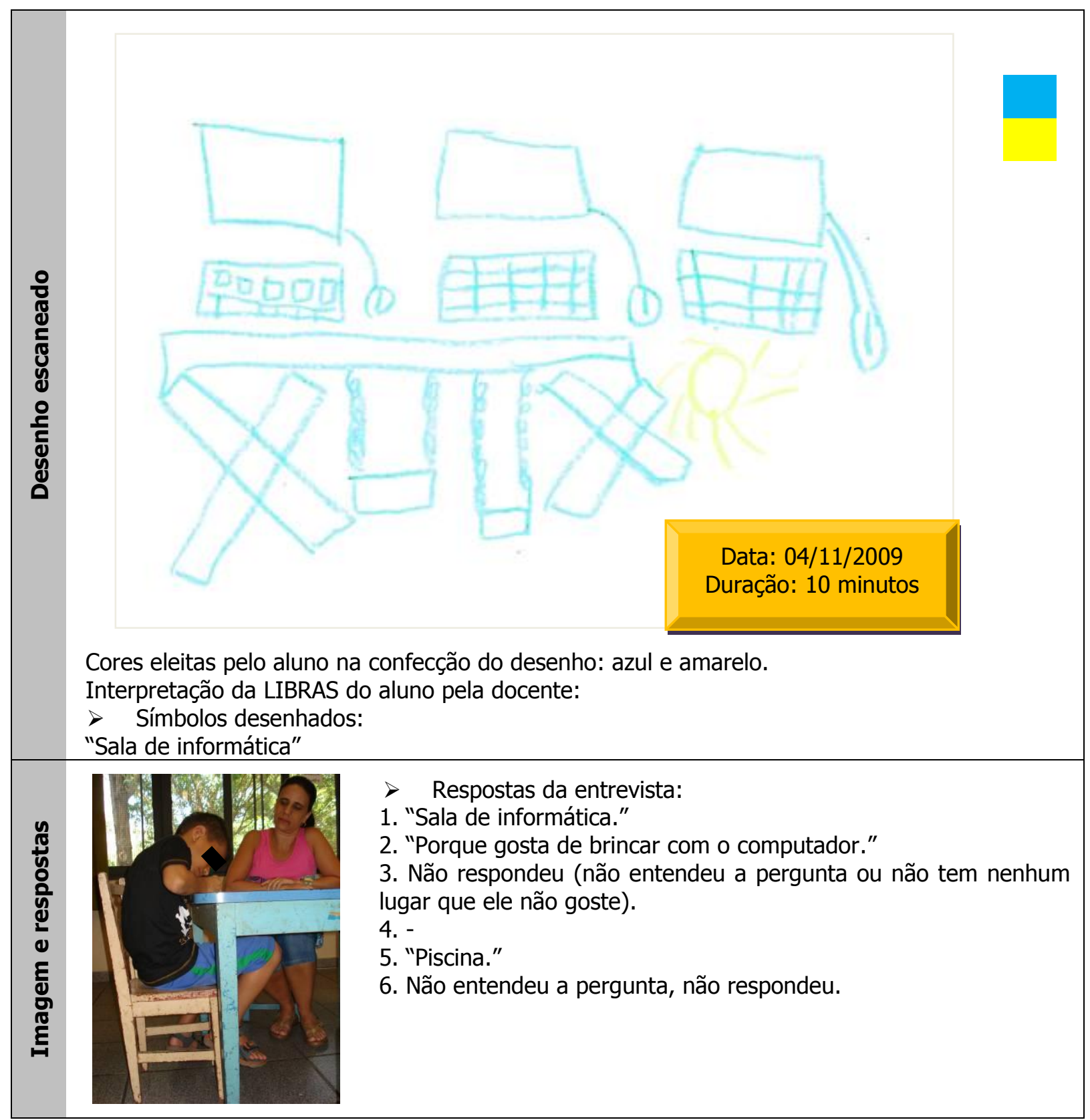

Quadro 31 - Síntese da entrevista lúdica com desenho temático destinada ao aluno I., de 7 anos, surdo, da unidade-caso 2 na $1^{\text {a }}$ etapa da pesquisa. 


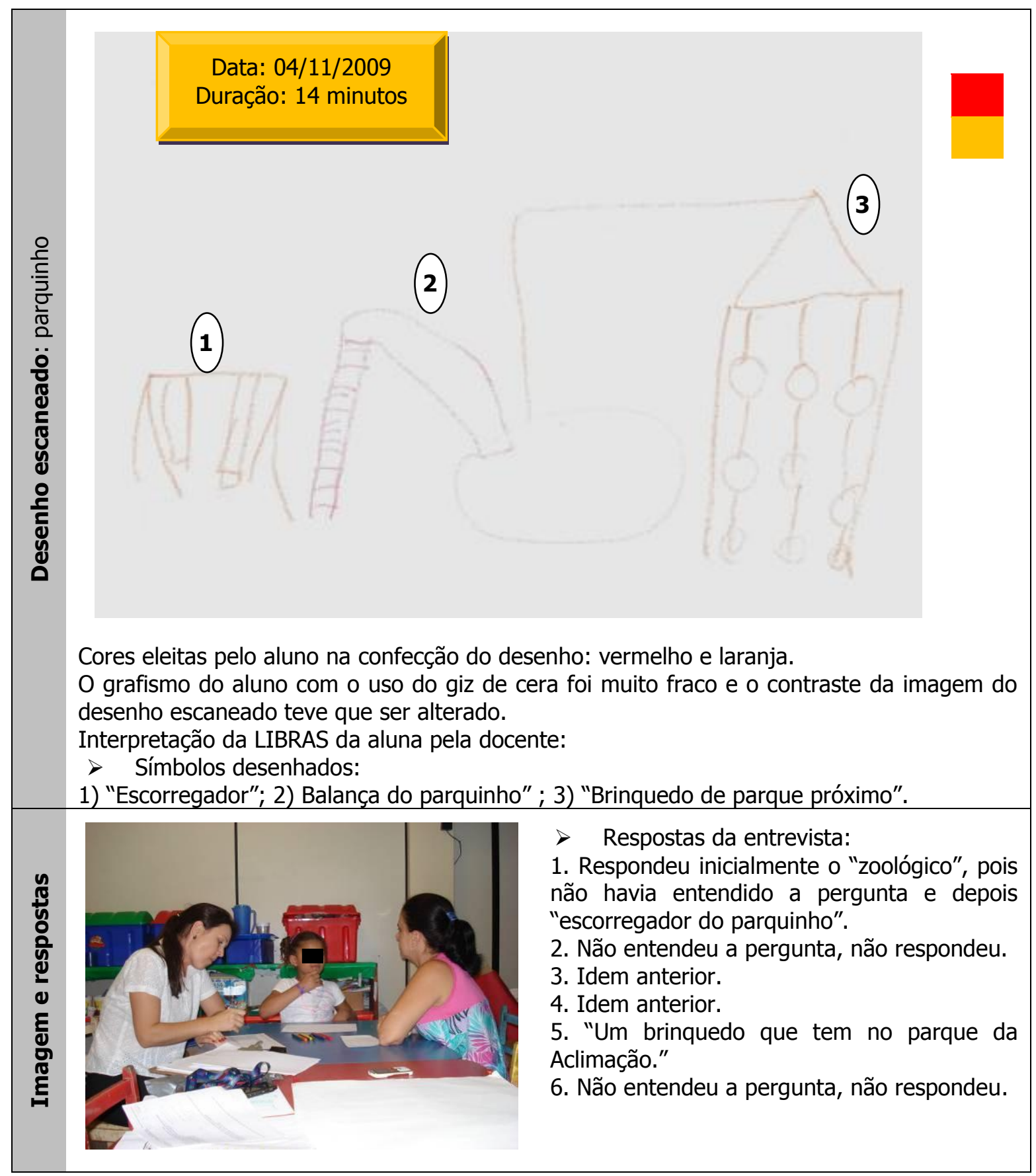

Quadro 32 - Síntese da entrevista lúdica com desenho temático destinada à aluna M., de 7 anos, surda, da unidade-caso 2 na $1^{\text {a }}$ etapa da pesquisa. 


\subsubsection{Alunos com PC: resultados da unidade-caso 3}

Na primeira etapa da pesquisa, a entrevista lúdica com desenho temático na unidade-caso 3 envolveu 19 alunos com deficiência física (18 com PC e 1 com distúrbio da medula espinhal) presentes nos dias das aplicações (do total de 25 alunos ver Tabela 6) das três classes de pré-escola existentes. A entrevista lúdica com desenho temático ocorreu nos dias 12/11/2009 (duas salas, uma de cada vez, com 6 e 8 alunos, respectivamente) e 17/11/2009 (uma sala com 5 alunos).

A entrevista lúdica com desenho temático ocorreu com todos os alunos de uma classe ao mesmo tempo, em função da equipe de apoio disponibilizada pela instituição, composta por 3 ou 4 voluntários ${ }^{217}$, pela docente e pelo apoio indireto de duas cuidadoras responsáveis pelo acompanhamento dos alunos ao banheiro. A pesquisadora orientou previamente a equipe de voluntários à não interferência na escolha do tema específico a ser eleito pelo aluno (ambiente que mais gosta na escola), bem como na escolha de cores ou formas no desenho dos alunos, auxiliando somente no caso dos alunos sem coordenação nos membros superiores, em tarefas como prender as folhas na mesa com fita crepe; ajudar na pega do giz de cera ou canetinha ${ }^{218}$; ajudar a sustentar 0 braço do aluno (deixando que o mesmo comandasse a direção do traço através de sua própria força ${ }^{219}$, e recolher os objetos $^{220}$ que caíam no chão (Figura 42).

${ }^{217}$ Cada classe contava com uma equipe de voluntários diferente.

${ }^{218}$ Alguns destes materiais eram adaptados ao aluno.

${ }^{219}$ Esta tarefa também foi realizada pela docente.

${ }^{220}$ Babadores, giz de cera ou canetinha. 


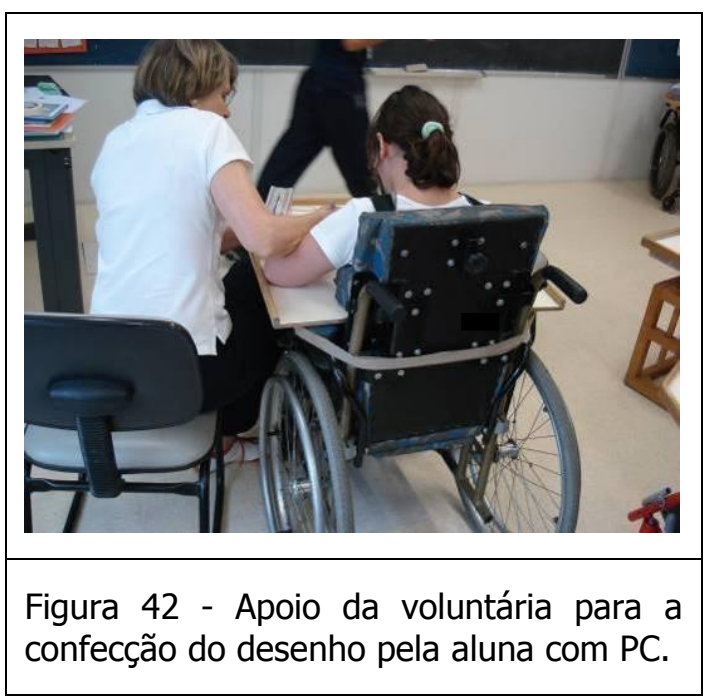

O processo de aplicação descrito a seguir ocorreu de forma similar nas três classes de pré-escola. A maioria dos alunos de uma das classes se encontrava sentada em suas respectivas cadeiras de rodas com as mesas acopladas. A pesquisadora convidou os alunos a fazerem um desenho segundo o tema proposto. A maioria dos alunos manifestou interesse em participar desta atividade através de sorrisos e gestos com as mãos.

Foi entregue a cada aluno uma folha em branco e solicitou-se que utilizassem 0 material (adaptado em alguns casos) disponível em seus estojos, para a realização do desenho temático. Os voluntários prenderam as folhas às mesas da maioria dos alunos com a fita adesiva. A pesquisadora explicou que os alunos não poderiam olhar o desenho dos colegas e, principalmente, que não havia certo ou errado, pois o importante era a opinião de cada um. Durante três a dez minutos iniciais os alunos não foram questionados e permaneceram desenhando. A seguir, a pesquisadora e a docente (em conjunto) realizaram as perguntas relativas a aspectos gerais da escola 
e a acessibilidade ${ }^{221}$, a cada aluno, individualmente, enquanto os demais permaneciam desenhando.

A pesquisadora anotou as respostas verbais dos alunos ou indicadas nas pranchas ou pastas de CAA (alunos sem fala funcional). Ao término do desenho, solicitou-se aos alunos a descrição do significado dos símbolos desenhados, sendo anotadas estas informações.

O nível de dificuldade para a confecção do desenho e para a resposta as perguntas da entrevista pelos alunos se apresentou de forma variável em função do tipo de paralisia cerebral (PC) recorrente nos mesmos. A maioria dos alunos apresentou um ótimo desenvolvimento intelectual, porém os usuários de CAA não responderam de forma satisfatória às perguntas, pois nem todas as alternativas de resposta se encontravam em suas pastas ou pranchas de CAA.

Alguns alunos com PC e menor comprometimento motor nos membros superiores conseguiram realizar o desenho com dificuldade, porém sem auxílio da docente ou dos voluntários na execução dos traços (Figuras 43a, 44a). Alguns desses alunos responderam verbalmente, e outros que não apresentavam fala funcional responderam a entrevista apontando, com o dedo, o símbolo em PCS de suas respectivas pranchas ou pastas de CAA, pela técnica de seleção direta (Figuras 43b, 44c, d). Quando a resposta do aluno não se encontrava na prancha ou pasta, a 
docente verbalizava as alternativas, e o aluno indicava através de um movimento voluntário, como um gesto com o rosto (balançar) ou um sorriso, a alternativa eleita.

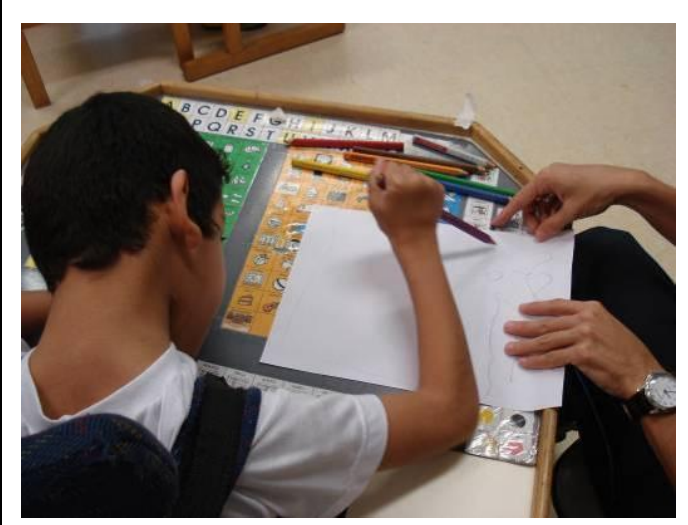

(a)

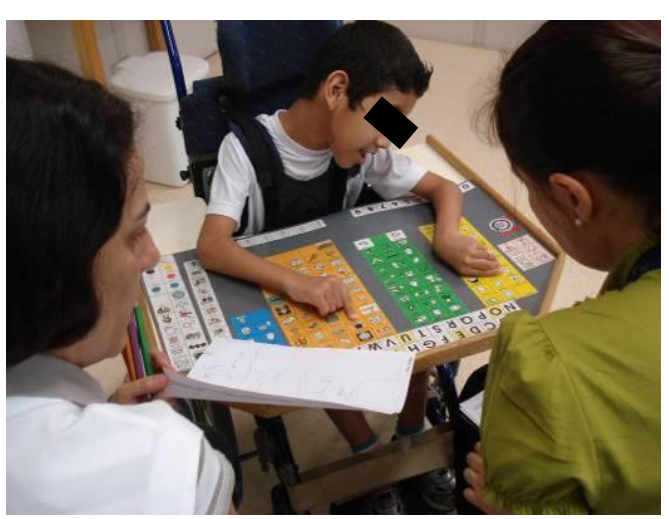

(b)

Figura 43 - Entrevista lúdica com desenho temático destinada ao aluno L. S., de 8 anos, com PC.

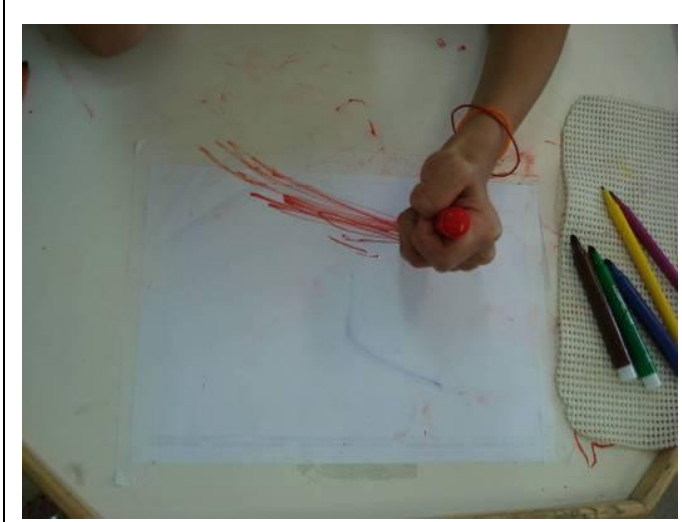

(a)

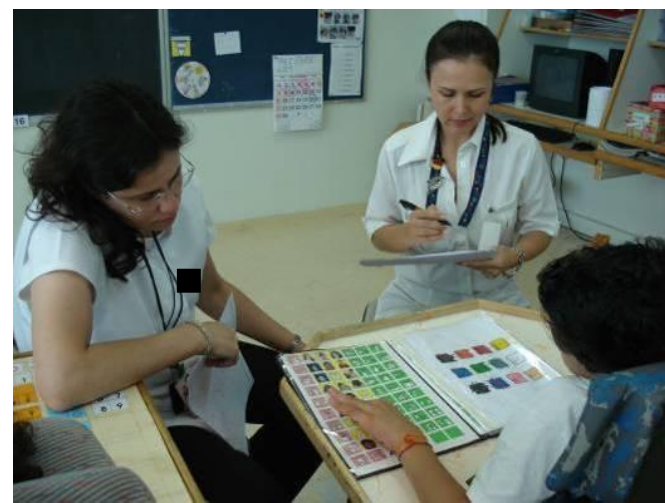

(c)

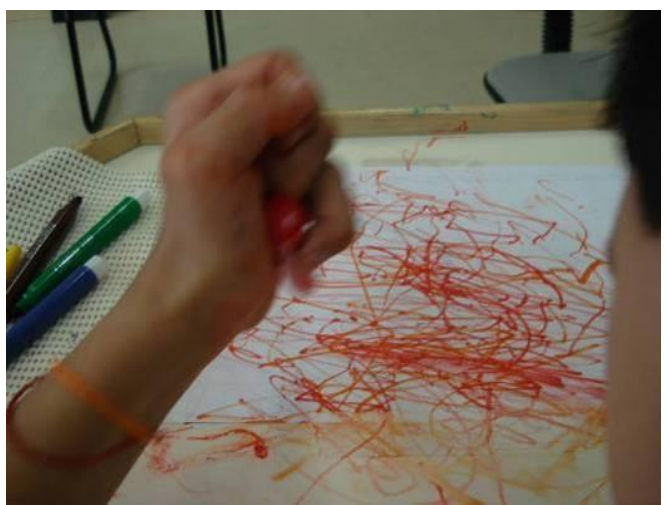

(b)

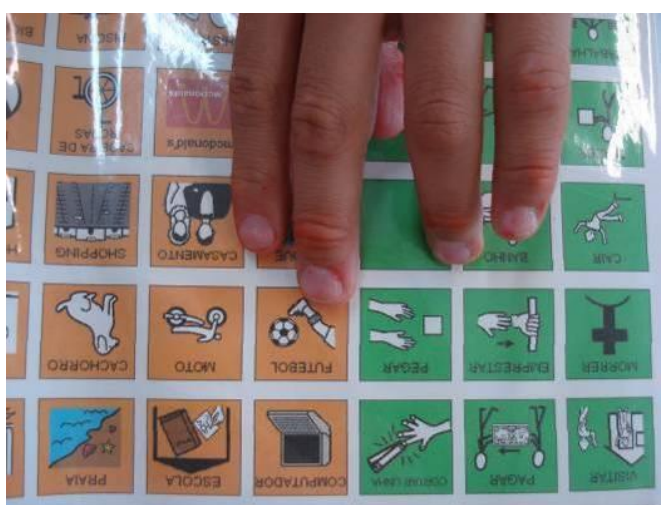

(d)

Figura 44 - Entrevista lúdica com desenho temático destinada ao aluno M., de 7 anos, com PC. 
Alguns alunos com PC e maior comprometimento motor nos membros superiores conseguiram realizar o desenho com muita dificuldade, com o auxílio da docente ou de uma voluntária na execução dos traços (Figura 45a, b). Como esses alunos não apresentavam fala funcional, responderam a entrevista apontando, com o dedo, o símbolo em PCS de suas respectivas pranchas ou pastas de CAA, por meio da técnica de seleção direta (Figura 45c, d). Alguns desses alunos que não apresentavam movimentação voluntária nos membros superiores utilizaram a técnica da varredura $^{222}$ para responder ao questionário.

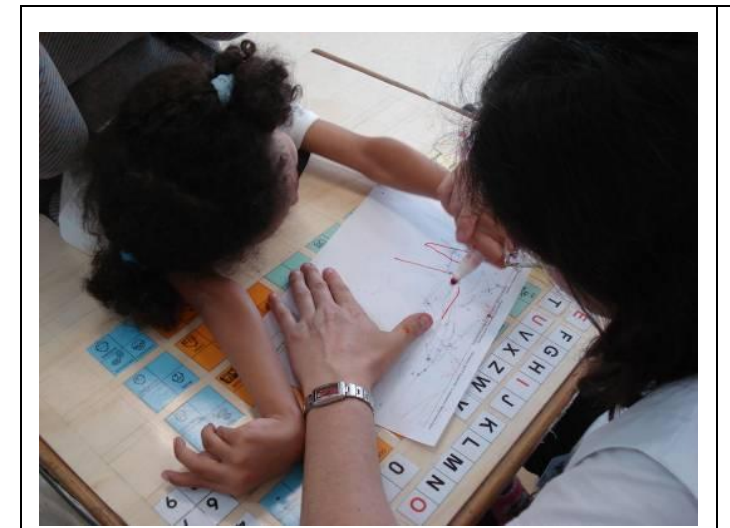

(a)

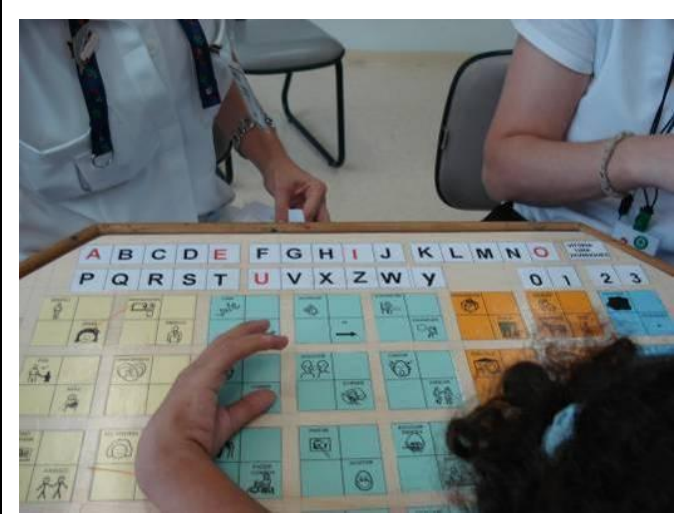

(c)

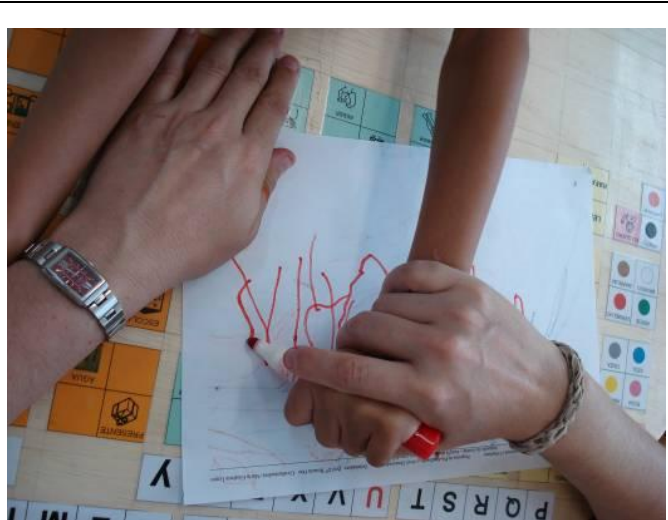

(b)

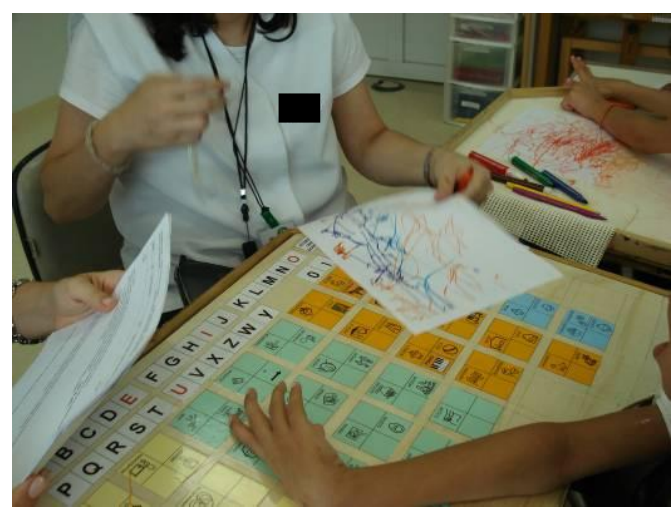

(d)

Figura 45 - Entrevista lúdica com desenho temático destinada à aluna V., de 9 anos, com PC.

${ }^{222}$ Ver item 2.2.1.1 relativo a CAA. 
Poucos alunos com deficiência física, sem (ou com leve) comprometimento na fala e motor nos membros superiores, realizaram o desenho com facilidade e sem auxílio da docente ou dos voluntários, bem como conseguiram responder verbalmente as perguntas realizadas pela pesquisadora (Figuras 46 e 47).

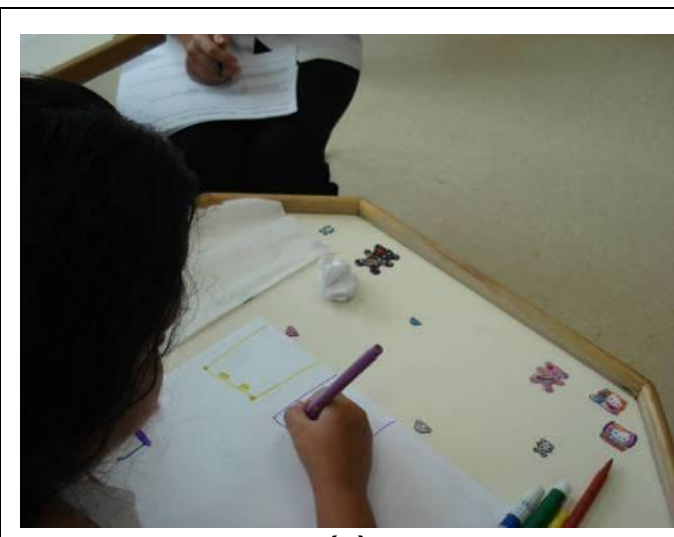

(a)

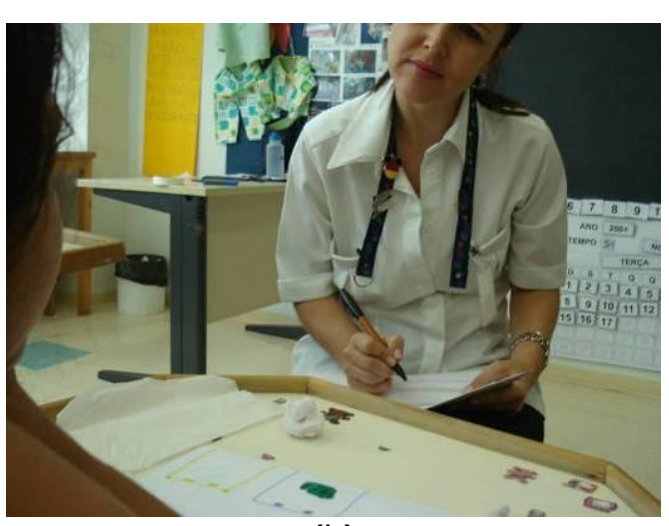

(b)

Figura 46 - Entrevista lúdica com desenho temático destinada à aluna P., de 7 anos, com distúrbio da medula espinhal.

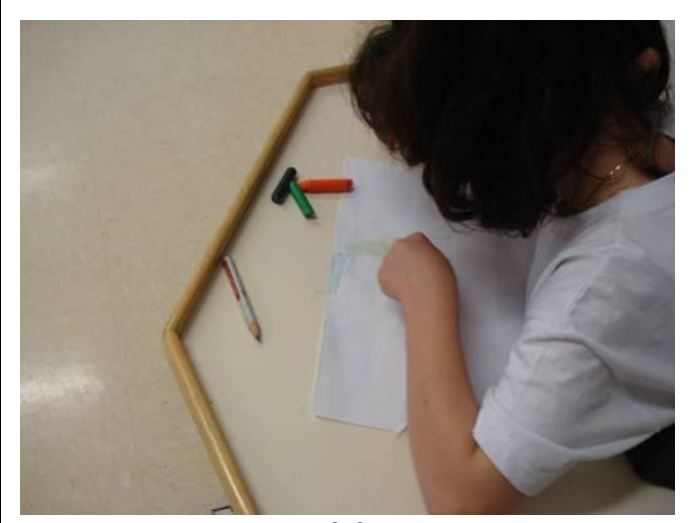

(a)

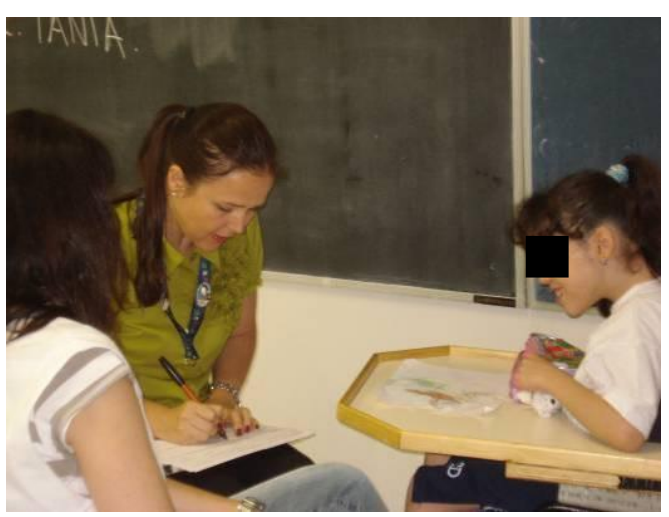

(b)

Figura 47 - Entrevista lúdica com desenho temático destinada à aluna I., de 7 anos, com PC.

A pesquisadora elogiou os desenhos realizados e solicitou-os como um presente, os alunos concordaram prontamente. A seguir serão apresentadas algumas sínteses dos resultados da entrevista lúdica com desenho temático na primeira etapa da pesquisa destinada aos alunos com deficiência física (Quadros 33 a 36). 
$\mathrm{O}$ aluno $\mathrm{E}$. , de 7 anos, com PC, apresentava dificuldade na articulação da fala e na coordenação motora dos membros superiores (apresentava movimentação involuntária), bom desenvolvimento cognitivo e era usuário de cadeira de rodas.

Realizou o desenho sem auxílio e respondeu as perguntas da pesquisadora em parte verbalmente e em parte com a indicação dos símbolos na prancha de CAA.
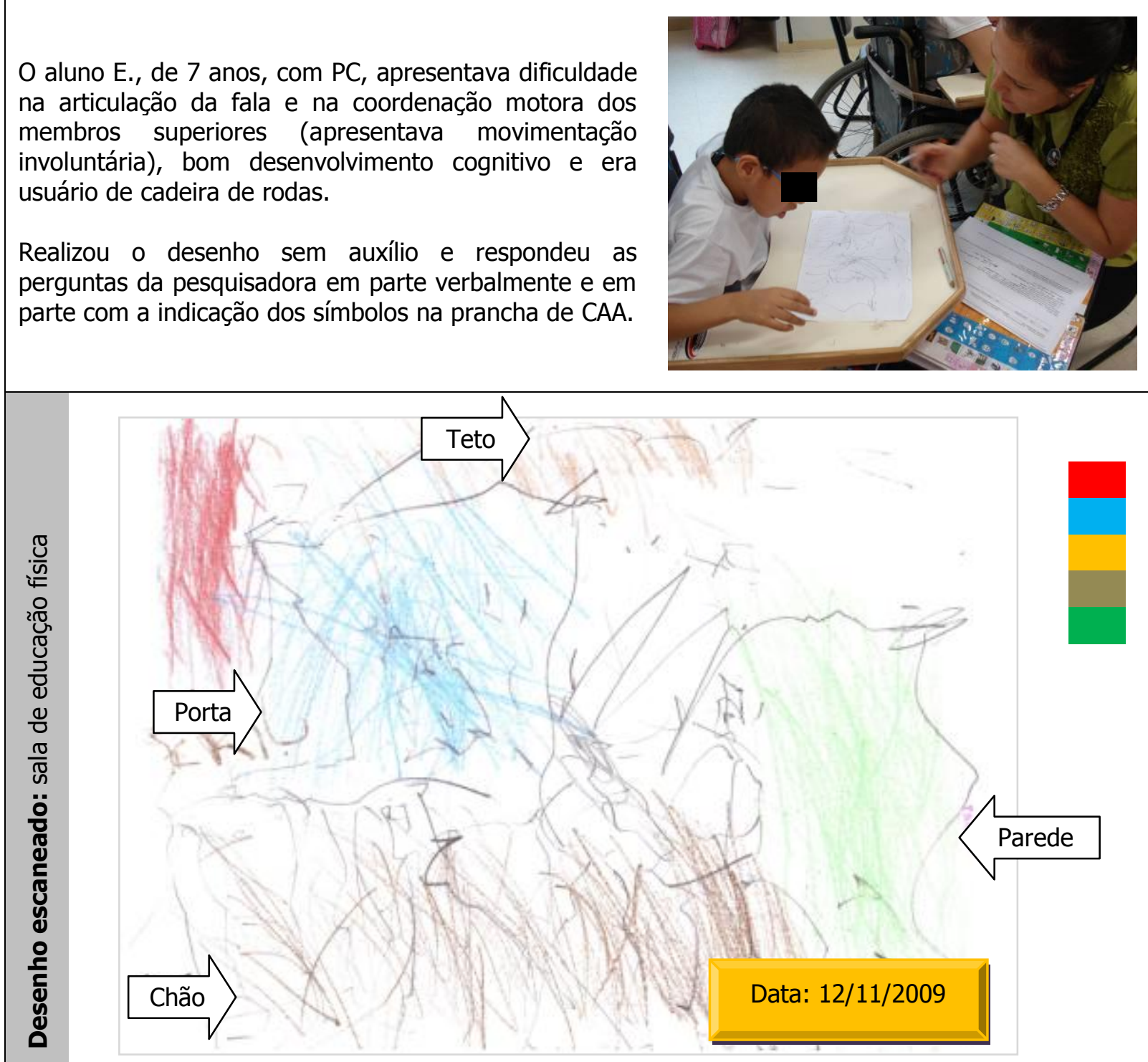

Cores eleitas pelo aluno na confecção do desenho: vermelho, azul, laranja, marrom, verde e roxo.

Os símbolos desenhados foram descritos verbalmente pelo aluno (setas).

Respostas da entrevista pelo aluno (verbal e através da pasta de CAA):

y 1. Apontou o símbolo da sala de educação física na pasta de CAA.

ڤึ 2. Não verbalizou.

3. "Não gosto do banheiro."1223

4. "Cai xixi fora."

4. Não apontou nenhum símbolo na pasta e não verbalizou.

6. "Nenhum lugar é difícil de andar na escola."

Quadro 33 - Síntese da entrevista lúdica com desenho temático destinada ao aluno E., de 7 anos, com PC, da unidade-caso 3 na $1^{\text {a }}$ etapa da pesquisa.

${ }^{223}$ Este aluno tem que usar o papagaio (urinol). 
A aluna I., de 7 anos, com PC, apresentava uma leve dificuldade na articulação da fala e na coordenação motora dos membros superiores, bom desenvolvimento cognitivo e era usuária de cadeira de rodas.

Realizou o desenho sem auxílio e respondeu as perguntas da pesquisadora verbalmente.
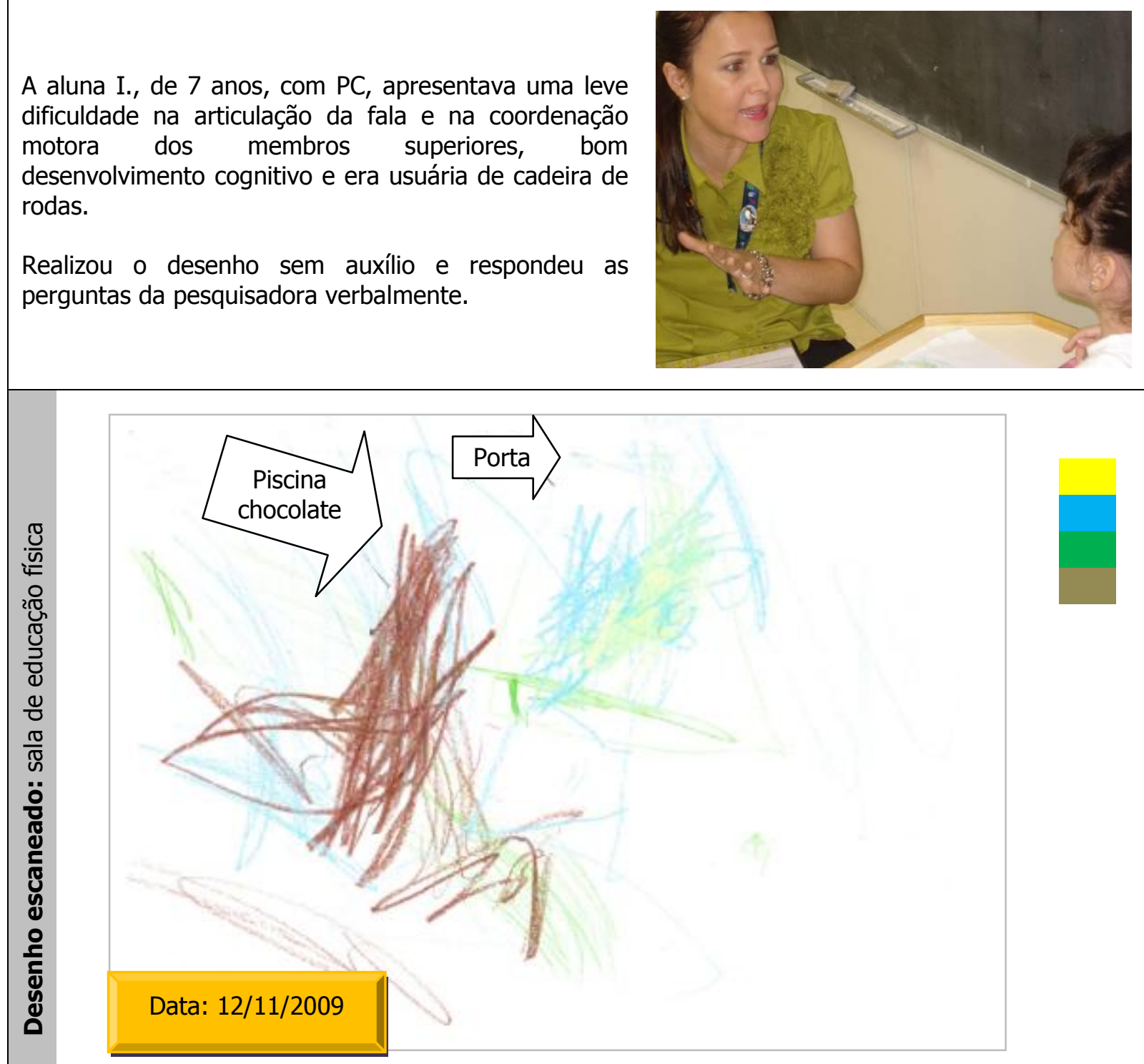

Cores eleitas pela aluna na confecção do desenho: amarelo, azul, verde e marrom. Os símbolos desenhados foram descritos verbalmente pela aluna (setas).

Respostas da entrevista pela aluna (verbal):

y 1. "Gosto da sala de educação física."

औु 2. "Gosto dos brinquedos."

3. "Gosto de tudo na escola."

4. -

5. "Gostaria de tivesse na escola um parque porque o Ibirapuera é longe."

6. "É mais difícil andar no banheiro da escola."

Quadro 34 - Síntese da entrevista lúdica com desenho temático destinada à aluna I., de 7 anos, com $\mathrm{PC}$, da unidade-caso 3 na $1^{\mathrm{a}}$ etapa da pesquisa. 
A aluna P., de 7 anos, com distúrbio da medula espinhal (única aluna que não apresentava PC da unidade-caso 3), apresentava ótima fala $e$ coordenação motora dos membros superiores, bom desenvolvimento cognitivo e era usuária de cadeira de rodas.

Realizou com habilidade e sem auxílio o desenho, e respondeu as perguntas da pesquisadora verbalmente.
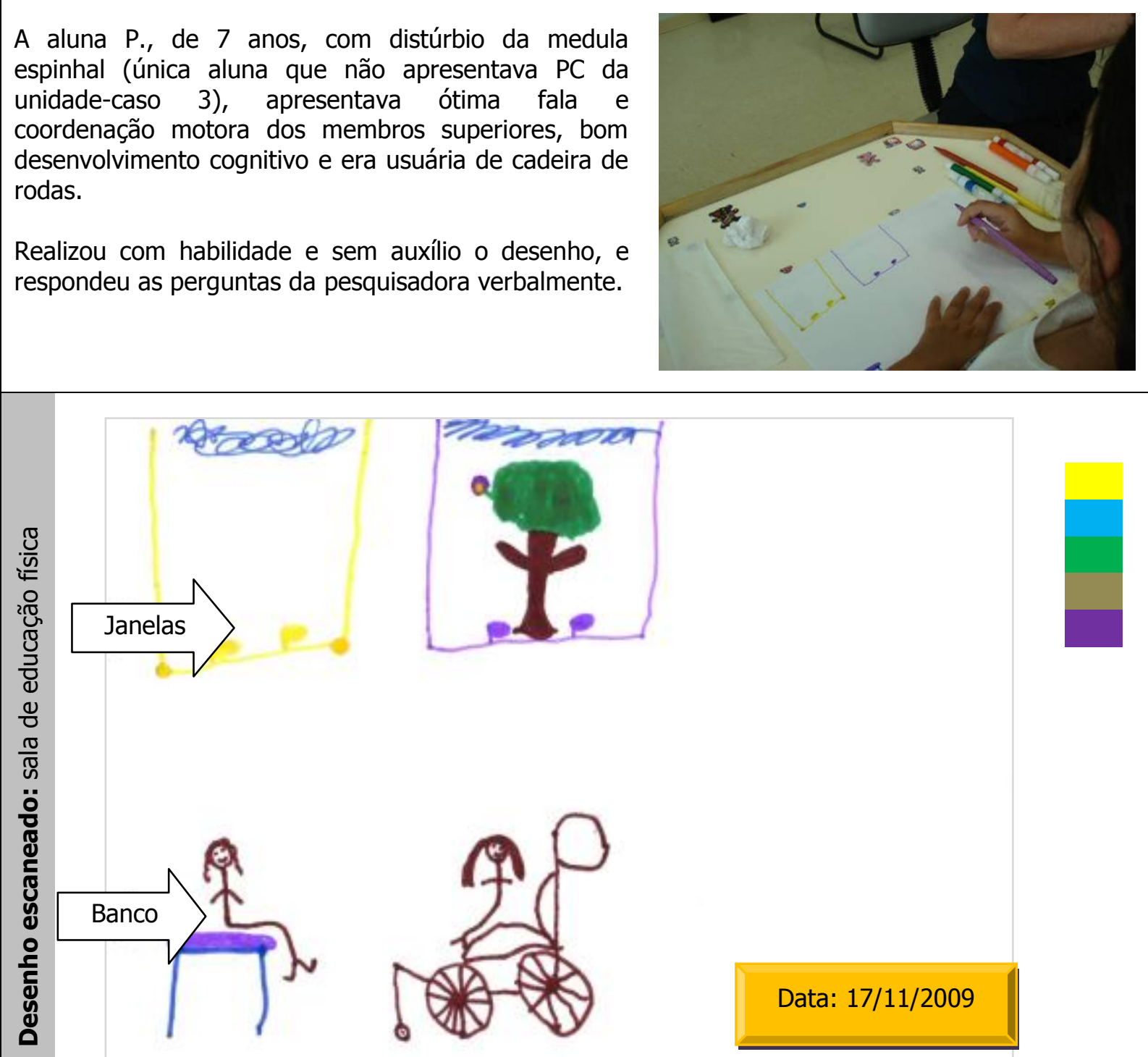

Cores eleitas pela aluna na confecção do desenho: amarelo, azul, verde, marrom e roxo.

Os símbolos desenhados foram descritos verbalmente pela aluna (setas).

Respostas da entrevista pela aluna (verbal):

y 1. "Gosto da sala de educação física."

\$ 2. "Porque é animado."

3. "Gosto de todos os lugares."

g. -

$\approx$ 5. "Eu gostaria que tivesse um parquinho."

6. "É mais difícil andar no elevador."

Quadro 35 - Síntese da entrevista lúdica com desenho temático destinada à aluna P., de 7 anos, com distúrbio da medula espinhal, da unidade-caso 3 na $1^{\text {a }}$ etapa da pesquisa. 
O aluno M., de 7 anos, com PC, não apresentava fala funcional (era usuário da pasta de CAA), apresentava dificuldade na coordenação motora dos membros superiores, bom desenvolvimento cognitivo e era usuário de cadeira de rodas.

Realizou o desenho com dificuldade, e com auxílio para a pega da caneta e troca de cores.
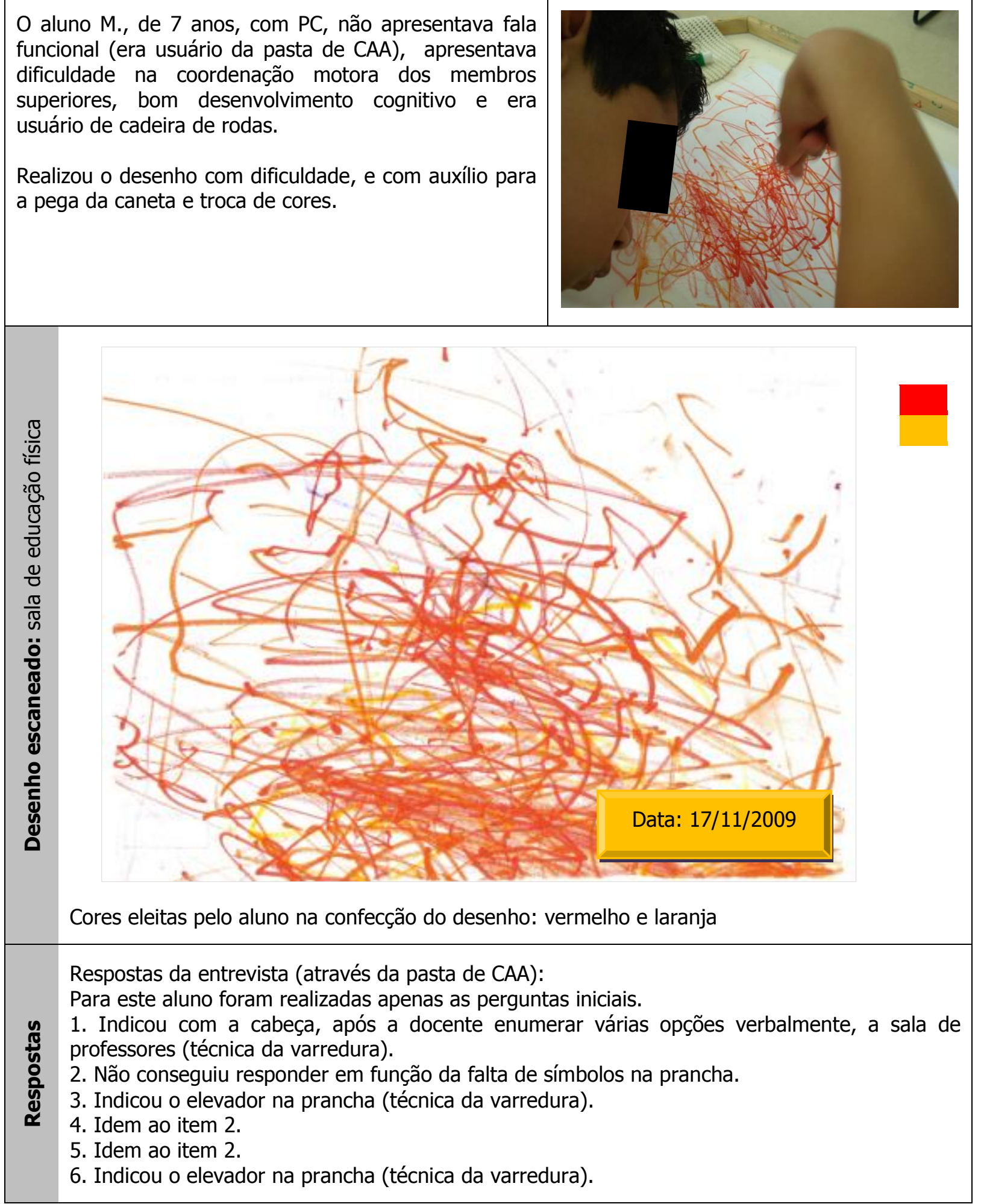

Quadro 36 - Síntese da entrevista lúdica com desenho temático destinada ao aluno M., de 7 anos, com PC, da unidade-caso 3 na $1^{\text {a }}$ etapa da pesquisa. 


\subsubsection{Análise dos resultados ${ }^{224}$ e modificações para a próxima etapa}

Na primeira etapa da pesquisa todos os alunos aptos a participarem da pesquisa (Tabela 7) conseguiram realizar a entrevista lúdica.

Tabela 7 - Distribuição dos alunos na $1^{\text {a }}$ etapa da pesquisa (ano letivo de 2009) por classe de pré-escola e por tipo de deficiência nas unidades-caso.

\begin{tabular}{ccccccc}
\hline & & & \multicolumn{3}{c}{$\mathbf{N}^{\mathbf{0}}$ de alunos matriculados } \\
\cline { 3 - 7 } $\begin{array}{c}\text { Unidade- } \\
\text { caso }\end{array}$ & $\begin{array}{c}\mathbf{N}^{\mathbf{0}} \text { de classes } \\
\text { de pré-escola }\end{array}$ & $\begin{array}{c}\text { Tipo de } \\
\text { deficiência }\end{array}$ & $\begin{array}{c}\text { Aptos a } \\
\text { participaram } \\
\text { da pesquisa } \\
(1)\end{array}$ & $\begin{array}{c}\text { Não aptos a } \\
\text { participarem } \\
\text { da pesquisa } \\
(2)\end{array}$ & $\begin{array}{c}\text { Total } \\
(1+2)\end{array}$ & $\begin{array}{c}\text { Aptos } \\
\text { presentes } \\
\text { nos dias } \\
\text { das } \\
\text { aplicações }\end{array}$ \\
\hline 1 & 1 & Baixa visão & $\mathbf{3}$ & 0 & 3 & $\mathbf{2}$ \\
\cline { 3 - 7 } & 4 & Cegueira & $\mathbf{7}$ & 5 & 12 & $\mathbf{7}$ \\
\hline 3 & 3 & surdez & $\mathbf{7}$ & 18 & 25 & $\mathbf{4}$ \\
\hline Total & 8 & PC & $\mathbf{2 5}$ & 0 & 25 & $\mathbf{1 9}$ \\
\hline
\end{tabular}

Na primeira etapa da pesquisa percebeu-se a importância do apoio de outras pessoas (docente, voluntários) no processo de aplicação da entrevista lúdica, bem como em todos os instrumentos aplicados.

\section{a) Entrevista lúdica com brinquedo}

Os alunos cegos aptos a participarem da pesquisa da única classe de pré-escola existente na unidade-caso 1 apresentaram boas condições de coordenação motora nos membros superiores (relativa à pega das peças) e inferiores (relativa à locomoção). Cerca de metade dos alunos conseguiram responder as perguntas da entrevista lúdica de forma satisfatória, apresentando bom nível de entendimento do ${ }^{224}$ Do processo de aplicação. 
enunciado e verbalização das respostas das questões, bem como no discernimento do pensamento, resultando em respostas claras. Ao contrário, a outra metade dos alunos não apresentou um bom nível de entendimento do enunciado e verbalização das respostas de todas as questões, sendo que o número de questões se mostrou muito elevado, confundindo esses alunos. Analisando as respostas dos alunos cegos verificou-se que as perguntas iniciais sobre as preferências do ambiente escolar geraram, em sua maioria, respostas relacionadas à acessibilidade (temática das questões seguintes). Portanto, decidiu-se que somente as quatro primeiras questões seriam mantidas ${ }^{225}$ na segunda etapa da pesquisa, deixando para os questionários, aplicados posteriormente as questões específicas sobre a acessibilidade, complementadas pelas relacionadas ao conforto ambiental.

A aplicação individual da entrevista lúdica com brinquedo, em ambiente tranquilo, proporcionou assistência ao aluno, em especial na locomoção, favoreceu a concentração durante o processo de aplicação (entrevistadora e entrevistado), não havendo focos para o desvio de atenção. O brinquedo de montar eleito pela pesquisadora fazia parte da brinquedoteca de uso dos alunos, pois objetivou não gerar uma maior exploração tátil do aluno e raciocínio intenso, liberando o mesmo para responder a entrevista. A pesquisadora não se sentiu à vontade nesta atividade lúdica, pelo fato de inicialmente não ser dirigida (fase de aquecimento) e de se encontrar sem apoio de outra pessoa durante a aplicação, em tarefas como anotar a verbalização do aluno e principalmente em tirar fotos. As docentes tiveram que permanecer com o restante da classe. Dentre todas as entrevistas lúdicas realizadas

${ }^{225}$ Ver Quadro 26. 
nas unidades pertencentes ao estudo, a única que a pesquisadora aplicou sozinha foi neste caso, em função de a comunicação ser a verbal. $O$ fato de haver uma triagem prévia, pela docente, dos alunos com condições de participarem da pesquisa foi fundamental, evitando situações mais difíceis.

Em relação às modificações para a próxima etapa da pesquisa de campo, decidiu-se que na entrevista lúdica destinada aos alunos cegos não se utilizaria o brinquedo, mas um mapa tátil ${ }^{226}$ relativo à planta da implantação do complexo da unidade-caso 1 (Figura 48), visando à facilidade na aplicação pela pesquisadora (com formação em arquitetura), por ser uma atividade mais focada em questões do ambiente escolar. A pesquisadora contou, nesta segunda etapa da pesquisa, com o apoio de duas pessoas externas nas aplicações ${ }^{227}$, para auxiliar na locomoção, na geração de imagens e nas anotações das repostas verbais dos alunos.

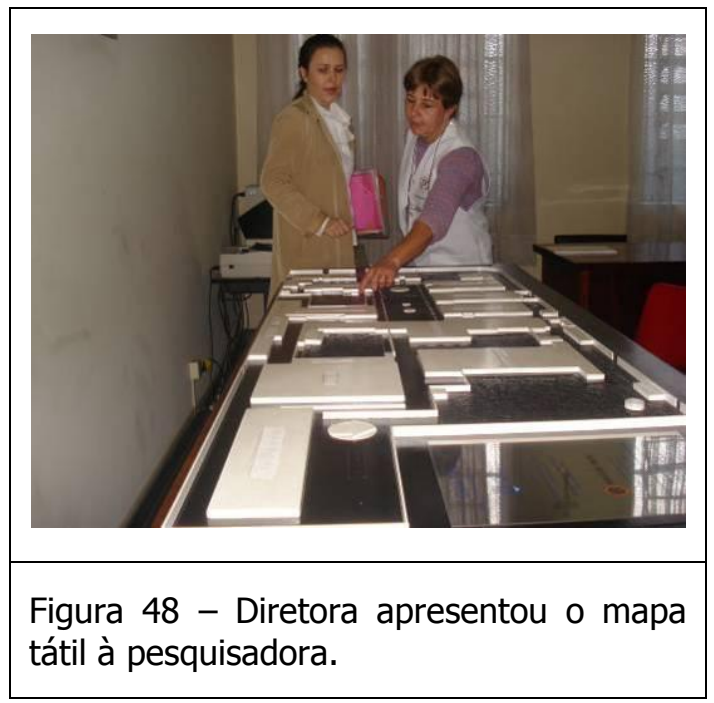

${ }^{226}$ Esse guia tátil foi confeccionado em 2005 pela Universidade São Marcos e foi cedido à unidadecaso 1.

${ }^{227}$ Trazidas pela pesquisadora. 
Reduziu-se o número de questões da entrevista lúdica, mantendo-se apenas as quatro questões iniciais relativas às preferências do ambiente escolar. Ampliaram-se os dias de aplicações desse instrumento visando a incluir a totalidade dos alunos aptos a participarem da pesquisa ${ }^{228}$. Buscou-se discutir com as docentes, nas entrevistas que antecederam a segunda etapa da pesquisa, os detalhes dos instrumentos de coleta de dados e do seu processo de aplicação.

\section{b) Entrevista lúdica com desenho temático}

\section{Apoio no processo de aplicação}

O processo de aplicação da entrevista lúdica foi mais eficaz nos alunos com PC em função do apoio da docente e dos três a quatro voluntários durante toda a aplicação por classe, resultando em uma atmosfera tranquila e propícia a pesquisa, em função do apoio aos alunos e à pesquisadora (uma enorme quantidade de imagens foi $\operatorname{gerada}^{229}$ ). $\mathrm{O}$ fato de os alunos com PC não se locomoverem sozinhos e de se encontrarem devidamente espaçados entre si em suas respectivas cadeiras de rodas não permitiu a influência entre os alunos na escolha do tema do desenho, mesmo porque a maioria era abstrata.

O processo de aplicação foi satisfatório nos alunos surdos, pois a aplicação contou com o apoio da docente destes alunos e uma docente de outra classe. Esse processo não foi satisfatório entre os alunos com baixa visão, pois a pesquisadora se

\footnotetext{
${ }^{228}$ Em função dos alunos faltantes.

${ }^{229}$ Um dos voluntários era responsável por esta tarefa, sob a supervisão da pesquisadora.
} 
encontrava sem apoio de outras pessoas, e, consequentemente quase não foram geradas imagens, pois a pesquisadora tinha que dar atenção ao aluno, bem como anotar a sua fala. A aplicação em dupla para a otimização de tempo foi proveitosa, porém os alunos deveriam ter sido posicionados mais afastados entre $\mathrm{si}^{230}$, pois, mesmo não ocorrendo influência entre os alunos na escolha do tema do desenho, as cores utilizadas foram as mesmas, bem como um dos alunos não conseguiu se concentrar durante toda a entrevista ${ }^{231}$.

\section{$>$ Confecção do desenho}

Os alunos com baixa visão e surdez das unidades-caso 1 e 2, respectivamente, conseguiram confeccionar o desenho temático com facilidade e desenvoltura, em função da ótima coordenação motora nos membros superiores (boa pega no giz de cera).

Ao contrário, a confecção do desenho foi uma tarefa muito dificultosa para $30 \%$ dos alunos com PC (usuários da CAA) e com maior comprometimento dos membros superiores. Para esses alunos o ato de desenhar exigiu um grande esforço físico, o que reafirma a solicitação de execução de apenas um desenho por aluno. Todos os alunos com PC conseguiram confeccionar o desenho temático, com ou sem o auxílio de um adulto (docente e/ou voluntários), porém com diferentes graus de dificuldade em função das limitações motoras individuais.

${ }^{230}$ Como a sala utilizada para a aplicação desse instrumento contava com apenas uma mesa, a pesquisadora deveria ter solicitado outra a direção.

${ }^{231}$ Não se pode atribuir este fato a presença do colega, pois este aluno tinha apenas quatro anos. 
A interrupção do ato de desenhar dos alunos surdos para a realização das perguntas da entrevista em LIBRAS pela docente não foi ideal, pois o aluno perdia o contato visual com o desenho para visualizar as mãos da docente, bem como soltava o giz de cera para responder em LIBRAS. Este fato acarretava um recomeço do desenho por várias vezes, pois as perguntas não eram feitas em seguida, e o aluno tinha que lembrar a cor que estava utilizando, bem como a parte do desenho onde havia parado.

\section{Perguntas e respostas da entrevista}

Analisando as respostas de todos os alunos verificou-se que as perguntas iniciais sobre as preferências do ambiente escolar geraram, em sua maioria, respostas relacionadas à acessibilidade (temática das questões seguintes). Portanto, decidiu-se que somente as cinco primeiras questões seriam mantidas ${ }^{232}$ na segunda etapa da pesquisa, deixando para os questionários, aplicados posteriormente, as questões específicas sobre a acessibilidade, complementadas pelas relacionadas ao conforto ambiental.

As respostas individuais de $30 \%$ dos alunos com PC e sem fala funcional (usuários de CAA) não foram satisfatórias, pois nem todas as alternativas de resposta se encontravam em suas pranchas ou pastas de CAA.

As respostas individuais de $50 \%$ dos alunos com baixa visão também não foram satisfatórias, pois apresentaram dificuldade no entendimento das questões. 0

232 Ver Quadro 28. 
número de questões sobrecarregou os alunos (maior em relação às outras unidadescaso, pois apresentou o dobro de questões ${ }^{233}$ ).

As respostas individuais de $50 \%$ dos alunos surdos também não foram satisfatórias, pois os mesmos apresentaram dificuldade no entendimento da LIBRAS, em estágio inicial de aprendizagem e com vocabulário restrito ${ }^{234}$. Após o término da aplicação da entrevista lúdica, a docente especialista em deficiência auditiva relatou que achava mais produtivo se as perguntas realizadas fossem ilustradas através de fotos de ambientes da escola, pois as crianças com deficiência auditiva utilizam muito o sentido da visão. Acreditou-se que os alunos com PC e baixa visão também teriam melhores resultados na entrevista com a existência de alternativas de respostas ilustradas por fotos.

Após a análise dos resultados da entrevista lúdica com desenho temático descrita anteriormente, foram elaboradas as seguintes alterações visando à nova aplicação na segunda etapa da pesquisa:

- o apoio à pesquisadora de uma pessoa externa ${ }^{235}$ nas aplicações destinadas aos alunos com baixa visão (unidade-caso 1) e surdos (unidade-caso 2), em função do auxílio na locomoção, no entretenimento dos outros alunos da classe, geração de imagens e anotações das repostas verbais dos alunos;

- a utilização da caneta hidrográfica com bitola maior (modelo Jumbo) em 12 cores na confecção do desenho em função da qualidade das imagens resultantes e a ${ }^{233}$ Ou seja, dez questões.

234 O número de questões sobrecarregou os alunos, em função da LIBRAS ainda não ser dominada com fluência e da abstração das perguntas. A docente repetiu várias vezes as perguntas.

${ }^{235}$ Trazida pela pesquisadora. 
facilidade na pega dos alunos, em especial daqueles com falta de coordenação motora nos membros superiores (PC), evitando o uso de material do aluno;

- o aumento da gramatura do papel sulfite para 180 gramas em função da danificação do papel em sua fixação à mesa;

- a observância, quando possível, de que o início das perguntas da entrevista ocorra somente após o término do desenho pelo aluno; com isso, uma das quatro fases foi eliminada, pois todas as perguntas se concentraram no final;

- a redução do número de questões da entrevista lúdica, mantendo-se apenas as cinco questões abertas iniciais relativas às preferências do ambiente escolar;

- a introdução de imagens coloridas nas alternativas de resposta da entrevista (painel impresso com fotos) destinada aos alunos surdos, com PC e com baixa visão, evitando a abstração da pergunta decorrente da surdez, possibilitando ao aluno com PC sem fala e sem movimentos nos membros superiores opções de respostas que não fazem parte de sua prancha ou pasta de CAA e auxiliando os alunos com baixa visão no entendimento das questões, respectivamente;

- a ampliação dos dias de aplicações desse instrumento visando a incluir a totalidade dos alunos aptos a participarem da pesquisa ${ }^{236} \mathrm{e}$

- a busca de discussões sobre os detalhes dos instrumentos e do seu processo de aplicação $^{237}$ nas entrevistas ${ }^{238}$ com as docentes.

\footnotetext{
${ }^{236}$ Em função dos alunos faltantes.

${ }^{237}$ Ver item 5.3.2.

${ }^{238}$ Que antecederam a segunda etapa da pesquisa.
} 


\section{3 $\quad 2^{\mathrm{a}}$ etapa da pesquisa}

\subsubsection{Entrevista lúdica com mapa tátil}

A modalidade da entrevista lúdica com mapa tátil na segunda etapa da pesquisa teve como objeto de estudo os alunos cegos aptos a participarem da pesquisa (ver Tabela

4) da pré-escola da unidade-caso 1.0 mapa tátil ${ }^{239}$ de representação da realidade é fundamental para o conhecimento espacial do indivíduo cego, tanto no ensino quanto em sua mobilidade.

É uma representação gráfica bidimensional da informação num contexto espacial e um importante instrumento de comunicação. O mapa permite identificar e localizar lugares e áreas; identificar direções; calcular distâncias; identificar, localizar e analisar a distribuição de dados territoriais, físicos, populacionais e sócioeconômicos; fazer inferências por meio de comparação com outros mapas e espacializar relações sociais. O mapa reflete o ambiente próximo e 0 distante e sua importância é inegável [...] No Brasil, o uso de mapas táteis vem ocorrendo principalmente em situações de ensino e é bastante incipiente na mobilidade, ao contrário da maioria dos países. Não podemos esquecer aqui o trabalho valioso de muitos instrutores de mobilidade que preparam plantas táteis em seu trabalho com os clientes, mas o fazem de uma forma assistemática e sem o conhecimento específico necessário. Novas pesquisas na área e trabalho conjunto entre instrutores de mobilidade e produtores de representações gráficas táteis precisam ser empreendidos. Disponível em: <http://saci.org.br/?modulo=akemi\&parametro=5413>. Acesso em: 20 mar. 2011.

\section{Os mapas táteis são representações gráficas em textura e relevo que servem para}

orientação e localização de lugares e fenômenos geográficos, para os portadores de deficiência visual. ${ }^{240}$ As representações gráficas em mapas podem ser mais facilmente elaboradas a partir do conhecimento das variáveis gráficas, da função do mapa e do público a que ele se destina [...] O exagero de informações pode dificultar a leitura do mapa pelo usuário. A experiência mostra que a quantidade de informação que você pode incluir no mapa tátil é muito limitada. (FERREIRA, 2008, p. 14).

\footnotetext{
${ }^{239}$ Ver item 2.2.3.

${ }^{240} \mathrm{O}$ termo correto é pessoa com deficiência visual.
} 
A unidade-caso 1 possuía uma sala de orientação espacial e mobilidade destinada aos alunos com deficiência visual ${ }^{241}$, com dois tipos de mapas táteis, descritos a seguir.

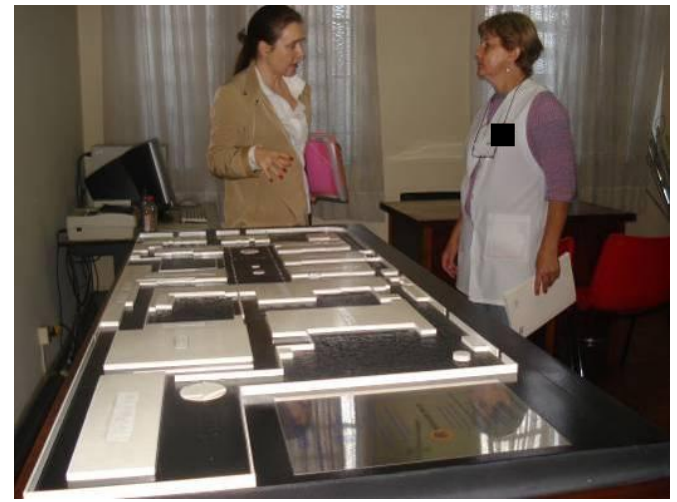

Figura 49 - Mapa tátil da unidade-caso 1 eleito para dar suporte à entrevista.

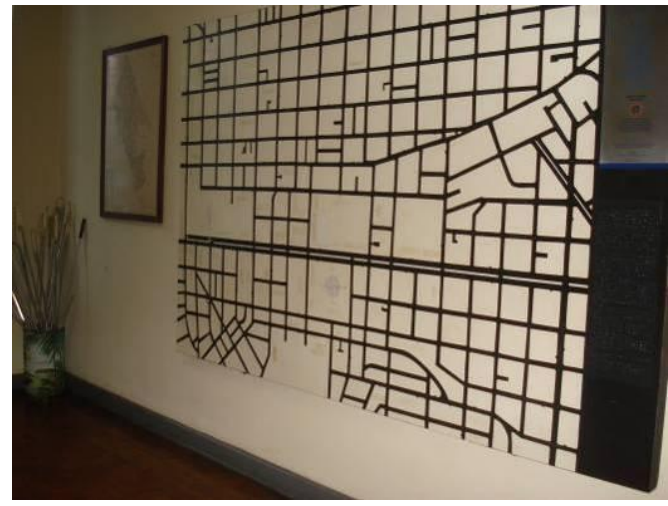

Figura 50 - Mapa tátil das ruas do entorno da unidade-caso 1.
Um dos mapas táteis era da planta da implantação do complexo da unidade-caso 1 (Figura 49) e foi confeccionado em madeira pela Faculdade de Arquitetura da Universidade São Marcos em 2005.
O segundo mapa tátil era o de guia de ruas do entorno da unidade-caso 1 (Figura 50) e se encontrava fixado na parede. Esse mapa foi confeccionado pela mesma instituição citada anteriormente, não sendo eleito em função de sua temática não ser de interesse para a pesquisa ${ }^{242}$.

\footnotetext{
${ }^{241}$ A orientação espacial dentro dos edifícios ou em áreas urbanas ocorre a partir da percepção do posicionamento que os objetos têm em relação aos outros. Como as pessoas com deficiência visual (para o caso dos cegos) não são capazes de apreender toda a situação a partir de uma imagem geral, é importante que a compreensão da organização, relacionamento, distância e organização entre objetos, edificações e arquiteturas possam ocorrer por meio de outros mecanismos. Disponível em: $<$ http://helenadegreas.wordpress.com/2011/01/10/sobre-plantas-e-maquetes-tateis-execucao-dosambodromo-diario-de-sala/>. Acesso em: 20 mar. 2011.

${ }^{242} \mathrm{O}$ primeiro mapa tátil apresentado foi o eleito, pois sua temática é pertinente à pesquisa.
} 


\section{a) Objetivo}

O objetivo da entrevista lúdica com mapa tátil foi promover a interação entre o aluno e o entrevistador antes e durante a entrevista e obter informações sobre as preferências e a acessibilidade do ambiente escolar.

\section{b) Procedimentos adotados}

Os procedimentos de aplicação adotados foram discutidos com as docentes em entrevista realizada previamente ${ }^{243}$. O local da aplicação foi a sala de orientação espacial e mobilidade localizada no bloco separado das salas de aula, na unidadecaso $1^{244}$. A aplicação foi realizada pela pesquisadora ${ }^{245}$ com o apoio de duas pessoas externas trazidas pela mesma ${ }^{246}$ e de forma individual (o fato de 0 aluno não enxergar requer maior cuidado e atenção, em especial na locomoção, principalmente em trajetos maiores, como o deste caso. A forma de comunicação utilizada foi a verbal. Enquanto os alunos se encontravam em atividades didáticas, a pesquisadora e uma das pessoas de apoio retiravam um aluno por vez da sala de aula e o acompanhavam até a sala de orientação espacial e mobilidade. Nesta sala, o aluno era posicionado em frente ao mapa tátil, sendo convidado a tatear a planta da implantação da unidade-caso 1 (suas mãos foram guiadas pela pesquisadora). 0 aluno reconhecia tatilmente os elementos que eram descritos concomitantemente pela pesquisadora. Após esta fase inicial de reconhecimento tátil pelo aluno (período

\footnotetext{
${ }^{243}$ Ver item 5.3.2.1.

${ }^{244} \mathrm{Em}$ função do tamanho e do peso da maquete do mapa tátil eleito, a mesma não pode ser deslocada para outro local mais próximo da sala de aula.

${ }^{245}$ A docente se encontrava com os demais alunos.

${ }^{246}$ Ambas mães e com experiência em lidar com crianças. Uma tirou as fotos e a segunda, estudante de pedagogia, anotou as respostas dos alunos.
} 
de aquecimento dirigido ${ }^{247}$ ) foram realizadas, pausadamente, as seguintes perguntas abertas relativas às preferências do ambiente escolar:

1. Qual lugar você mais gosta na escola?

2. Por que você escolheu este lugar?

3. Qual lugar você menos gosta na escola?

4. Por que você escolheu este lugar?

Anotou-se a informação fornecida pelo aluno.

> Condução: as entrevistas foram conduzidas pela pesquisadora com o apoio de duas pessoas externas com o prévio consentimento dos participantes e não foram gravadas.

Datas: variadas, definidas em função da disponibilidade dos entrevistados.

Duração: variável, de 6 a 11 minutos.

A seguir são apresentados os resultados do processo de aplicação da entrevista lúdica com o mapa tátil.

\subsubsection{Alunos cegos: resultados da unidade-caso 1}

Na segunda etapa, a entrevista lúdica com mapa tátil na unidade-caso 1 destinou-se a 6 alunos cegos aptos (apenas um aluno apto faltou nos dias das duas aplicações ${ }^{248}$ ) a participarem da pesquisa (ver Tabela 4) das duas classes de préescola existentes e ocorreu nos dias 25/10/2010 (5 alunos) e 5/11/2010 (1 aluno).

\footnotetext{
${ }^{247}$ Ver item 5.1.4.

${ }^{248}$ A pesquisadora retornou em $1 / 12 / 2010$, mas o aluno também havia faltado nesta data.
} 
Apresentam-se o processo de aplicação e os resultados da entrevista realizada com a aluna I., de 6 anos, cega ${ }^{249}$. Inicialmente, a pesquisadora e a estudante de pedagogia retiraram a aluna I., de 6 anos, cega, da sala de aula, que logo solicitou ir ao banheiro (Figura 51).

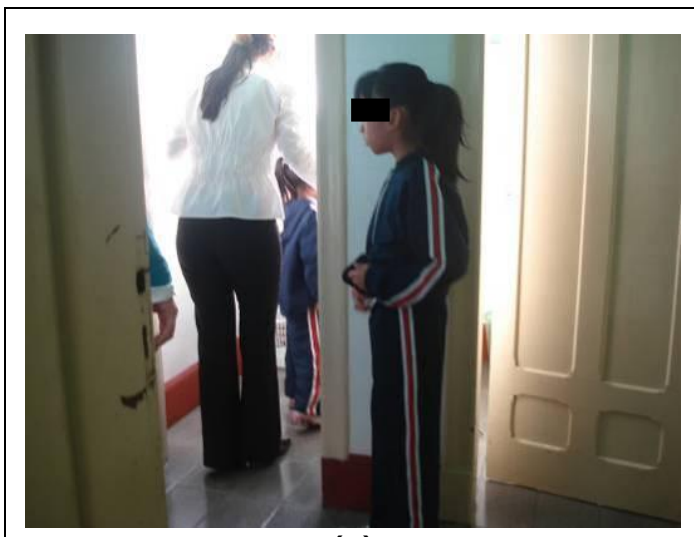

(a)

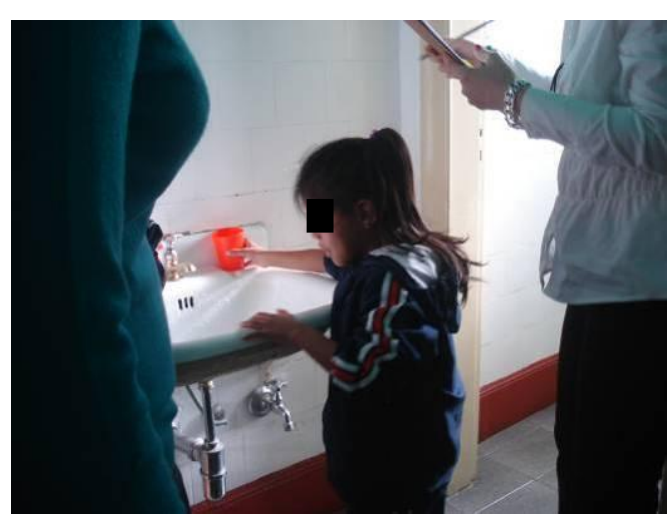

(b)

Figura 51 - Aluna I., de 6 anos, cega, utilizou o banheiro antes da entrevista lúdica com mapa tátil na $2^{\mathrm{a}}$ etapa da pesquisa.

A aluna I. foi então conduzida até a sala de orientação espacial e mobilidade. Durante o trajeto, a pesquisadora e a estudante de pedagogia procuraram conversar bastante com a aluna, para que a mesma se familiarizasse com suas vozes. A pesquisadora segurou a mão da aluna em todo o trajeto (Figura 52a, c, d), exceto na escada (Figura 52b).

${ }^{249}$ Sendo que as demais ocorreram de forma similar. 


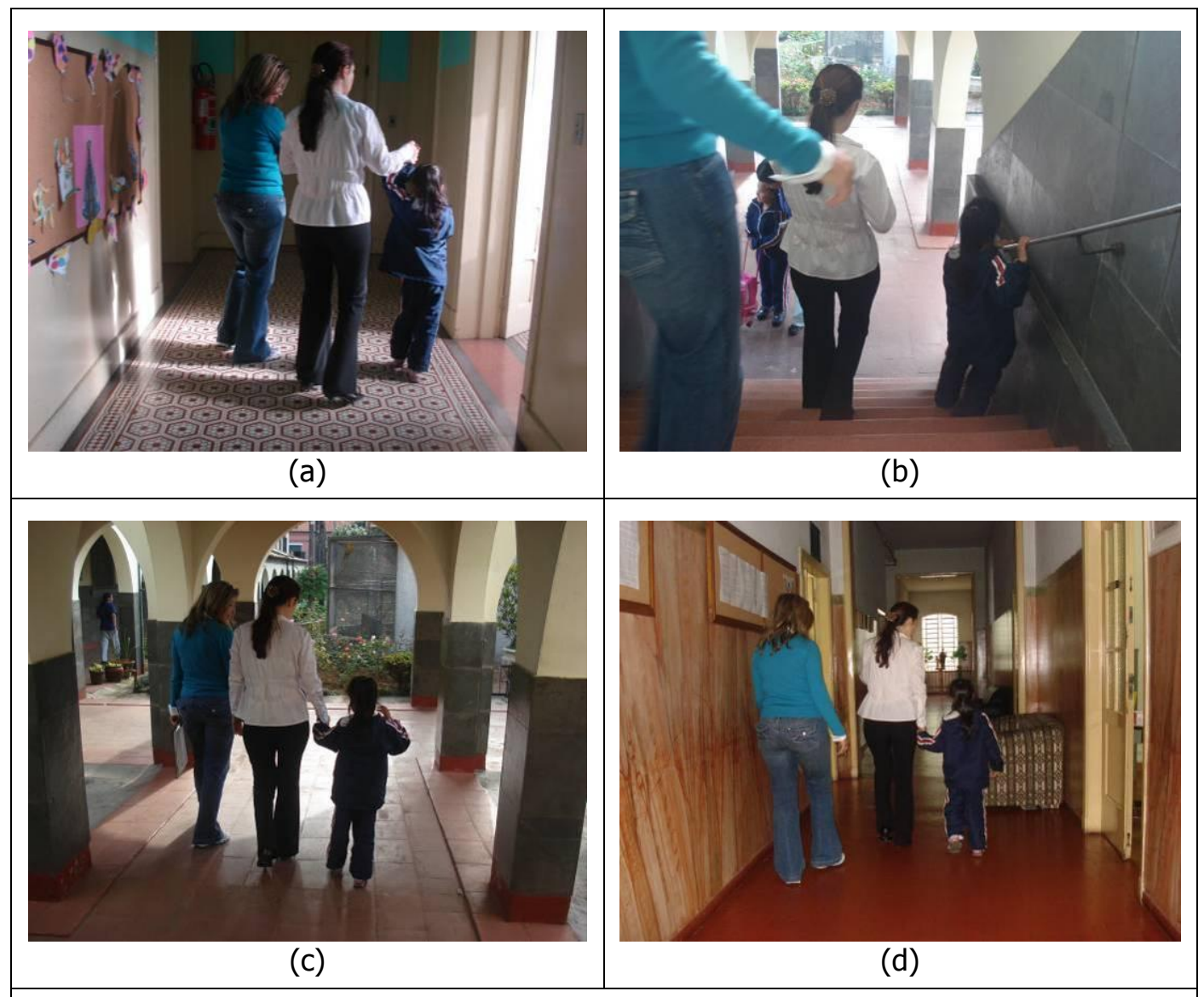

Figura 52 - Condução da aluna I., de 6 anos, cega, para a entrevista lúdica com mapa tátil na $2^{\mathrm{a}}$ etapa da pesquisa.

Na sala de orientação, a pesquisadora posicionou a aluna I. em pé na frente do mapa tátil (Figura 53a), convidou-a a tateá-lo (Figura 53b-d) para o reconhecimento inicial de suas formas enquanto as descrevia verbalmente concomitantemente. 


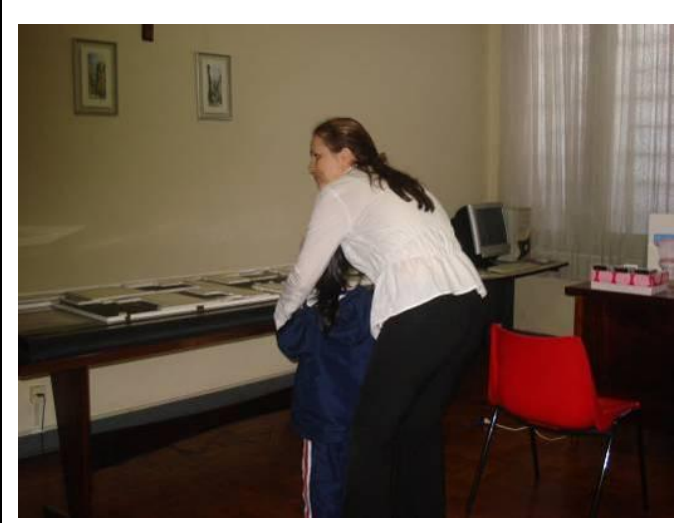

(a)

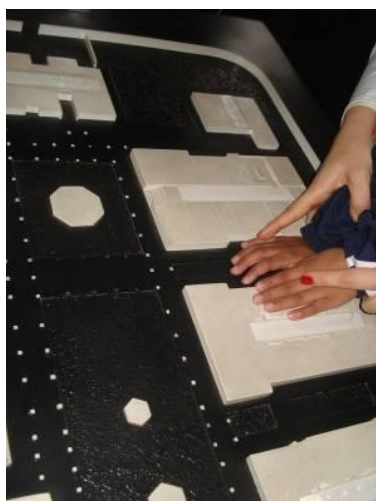

(c)

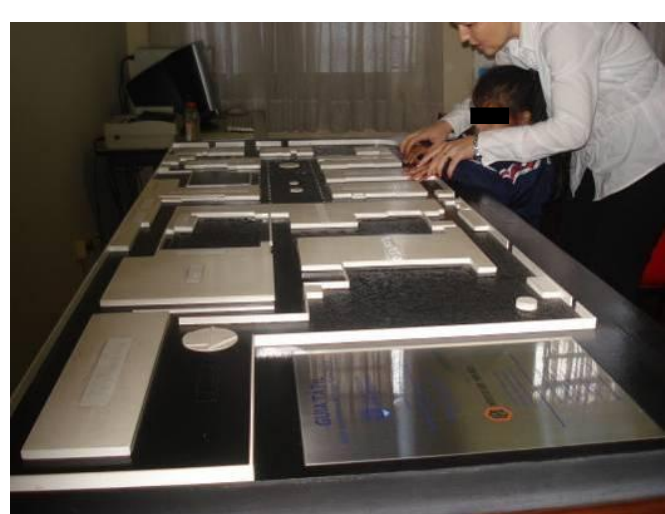

(b)

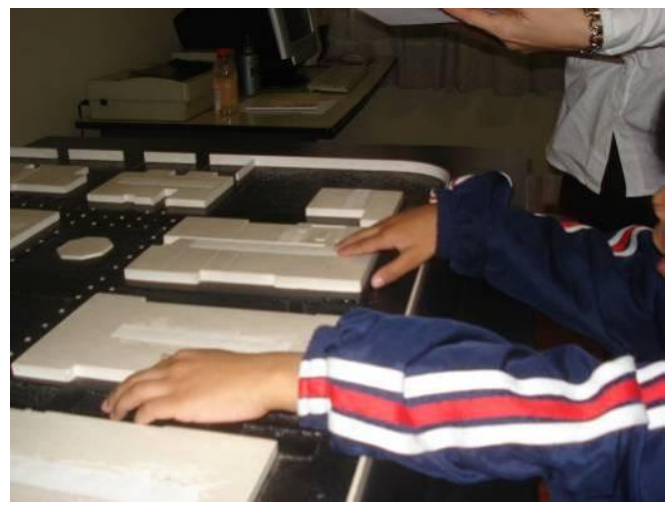

(d)

Figura 53 - Entrevista lúdica com mapa tátil destinada à aluna I., de 6 anos, cega, na $2^{\mathrm{a}}$ etapa da pesquisa.

Mesmo tendo a pesquisadora planejado todo o processo de aplicação (procedimentos) previamente, surgiu o imprevisto da aluna não apresentar o alcance frontal suficiente para tatear a parte central do mapa tátil. A pesquisadora teve que erguer a aluna (Figura 54a) e colocá-la em cima de uma cadeira (Figura 54b) $)^{250}$ para que ela conseguisse tatear a parte central do mapa tátil (Figura 54c,d).

${ }^{250}$ Este fato ocorreu com alguns dos alunos. A tarefa de erguer os alunos não foi fácil, pois os alunos, ao serem levantados do chão até o assento da cadeira, bem como o inverso, permaneciam com o corpo rígido. 


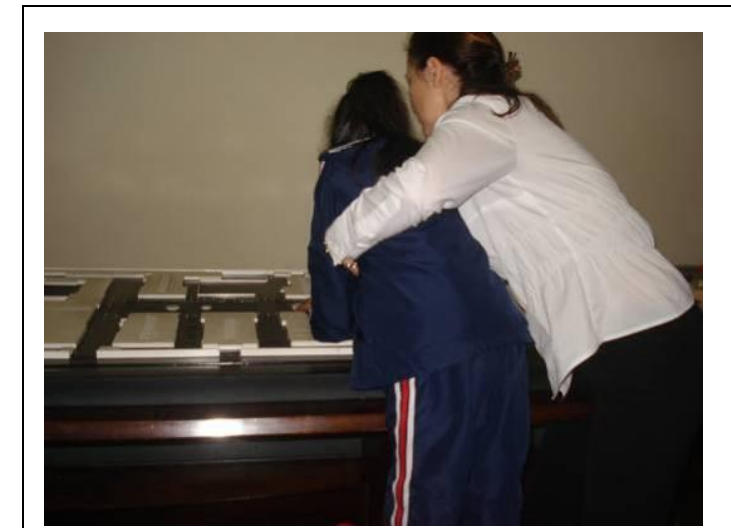

(a)

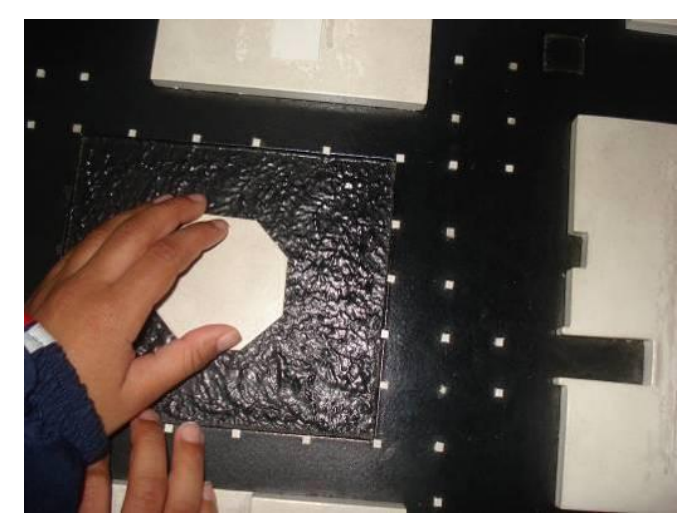

(c)

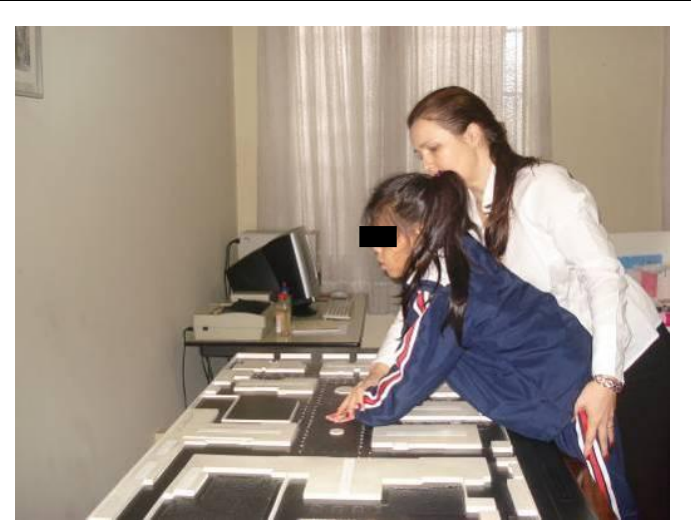

(b)

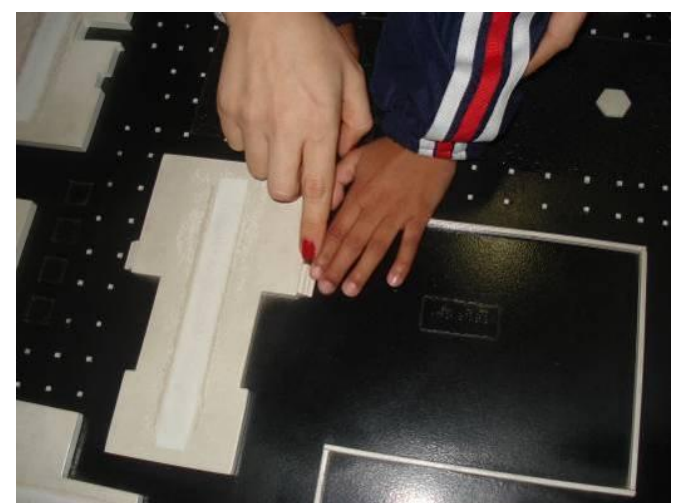

(d)

Figura 54 - Entrevista lúdica com mapa tátil destinada à aluna I., de 6 anos, cega, na 2a etapa da pesquisa.

Após essa fase inicial de aquecimento e ainda durante a atividade de tatear o mapa tátil pela aluna, foram realizadas, pausadamente, as perguntas descritas anteriormente $^{251}$. A aluna respondeu as questões prontamente e sem dificuldade. A estudante de pedagogia que apoiou a aplicação anotou a verbalização das respostas da aluna, descritas a seguir:

1. "Gosto do parquinho."

2. "Porque tem brinquedos."

\section{3. "Galeria."}

4. "Não gosto do barulho das araras."

${ }^{251}$ Ver procedimentos adotados, item 7.3.1 b). 
Essa aplicação se iniciou às 8 h10min e terminou às $8 \mathrm{~h} 21 \mathrm{~min}$ do dia $25 / 10 / 2010$. Nem todos os alunos precisaram ser suspensos e colocados na cadeira, pois alguns de 8 a 13 anos apresentaram o alcance frontal suficiente para tatear todo o mapa tátil (Figura 55a-c). Apenas uma das aplicações ocorreu de forma diferenciada, pois um dos alunos (4 anos), mais agitado, após tatear o mapa tátil resolveu explorar o restante da sala. A pesquisadora teve que segurá-lo no colo como uma forma de acalmá-lo para a realização das perguntas da entrevista (Figura 55d).

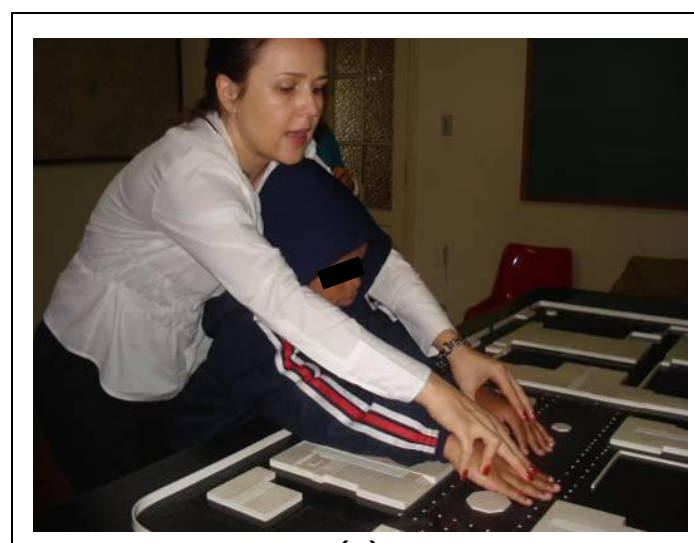

(a)

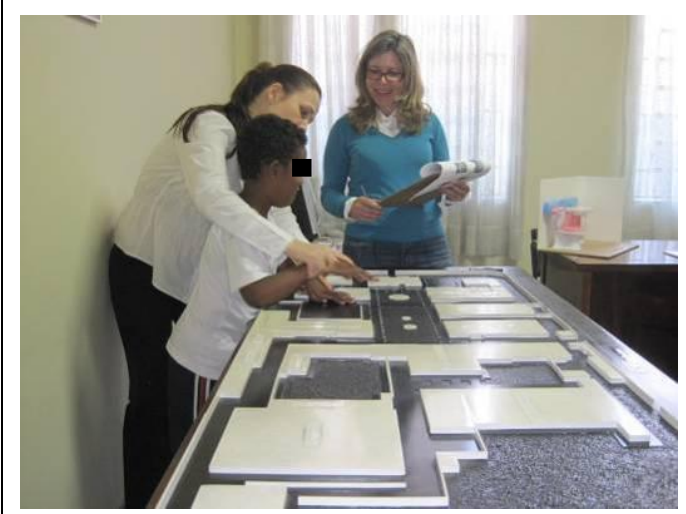

(c)

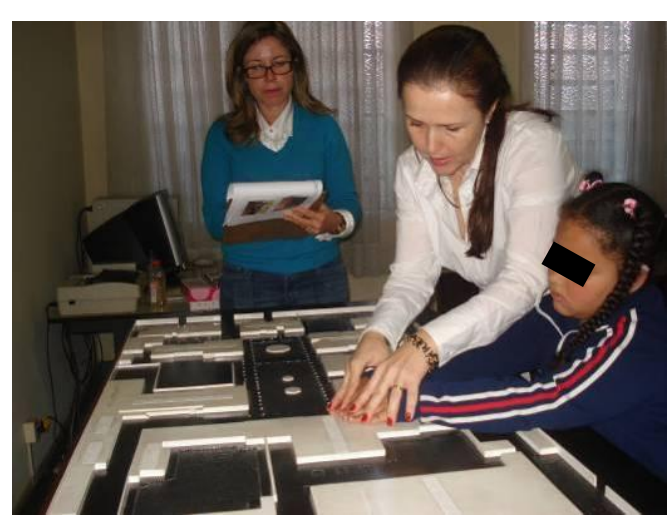

(b)

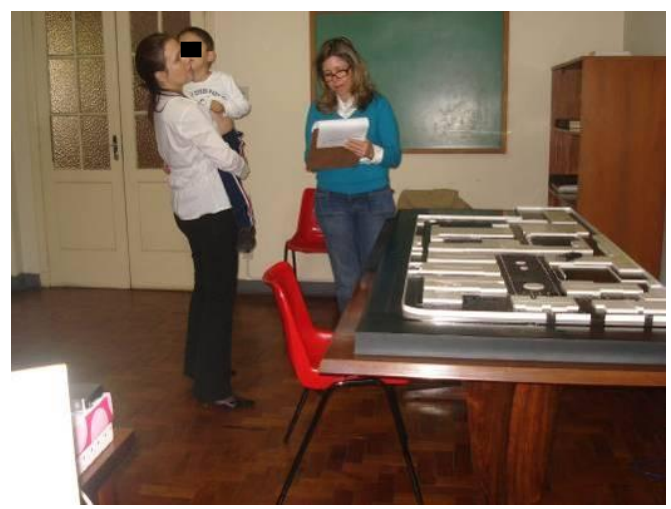

(d)

Figura 55 - Alcance frontal de alunos cegos (a-c) e aluno cego no colo da pesquisadora e auxiliar durante a entrevista lúdica (d). 


\subsubsection{Entrevista lúdica com desenho temático}

A modalidade da entrevista lúdica com desenho temático teve como objeto de estudo os alunos com baixa visão, surdez e PC aptos a participarem da pesquisa (ver Tabelas 4, 5 e 6 ) das pré-escolas das unidades-caso 1, 2 e 3, respectivamente. A entrevista lúdica com desenho temático no presente estudo não foi destinada aos alunos cegos (unidade-caso 1 ) 252 .

\section{a) Objetivo}

O objetivo da entrevista lúdica com desenho temático foi o mesmo da entrevista lúdica com brinquedo, ou seja, o de promover a interação entre o aluno e o entrevistador antes e durante a entrevista e obter informações relativas às preferências e acessibilidade do ambiente escolar.

\section{b) Procedimentos adotados}

Na segunda etapa da pesquisa de campo os procedimentos de aplicação da entrevista com desenho temático destinada aos alunos com baixa visão, surdez e PC foram melhorados (Quadro 37) e seguiram o item 7.2.3.2 b) relativo às modificações para a próxima etapa. Estas modificações levaram em consideração os resultados do pré-teste (primeira etapa), bem como as entrevistas realizadas previamente com as docentes..$^{253}$

\footnotetext{
252 Ver item 7.2.2.

253 Ver item 5.3.2.
} 


\begin{tabular}{|c|c|c|c|}
\hline Unidade-caso & 1 & 2 & 3 \\
\hline Deficiência & Visual (baixa visão) & Auditiva (surdez) & Física (PC) \\
\hline $\begin{array}{l}\text { Ordenação em } \\
\text { relação à } \\
\text { aplicação do } \\
\text { questionário }\end{array}$ & \multicolumn{3}{|c|}{ Anterior } \\
\hline $\begin{array}{l}\text { Local da } \\
\text { aplicação }\end{array}$ & \multicolumn{3}{|c|}{ Sala de aula } \\
\hline $\begin{array}{l}\text { Forma de } \\
\text { aplicação }\end{array}$ & $\begin{array}{l}\text { Todos os alunos } \\
\text { juntos na confecção } \\
\text { do desenho e } \\
\text { individual }{ }^{254} \text { na } \\
\text { entrevista }\end{array}$ & Individual e em dupla & $\begin{array}{l}\text { Todos os alunos juntos na } \\
\text { confeç̧ão do desenho e } \\
\text { individual }\left.\right|^{255} \text { na entrevista }\end{array}$ \\
\hline Aplicador(es) & $\begin{array}{c}\text { Docente e } \\
\text { pesquisadora com } \\
\text { apoio de auxiliar(es) } \\
\text { da pesquisadora }{ }^{256}\end{array}$ & $\begin{array}{l}\text { Docente com o apoio da } \\
\text { pesquisadora e da } \\
\text { auxiliar da } \\
\text { pesquisadora }\end{array}$ & $\begin{array}{c}\text { Docente e pesquisadora } \\
\text { com o apoio de } 3 \text { a } 4 \\
\text { voluntários }^{258}\end{array}$ \\
\hline $\begin{array}{l}\text { Forma de } \\
\text { comunicação } \\
\text { para a aplicação }\end{array}$ & Verbal & LIBRAS $^{259}$ & Verbal \\
\hline $\begin{array}{l}\text { Forma de } \\
\text { comunicação do } \\
\text { aluno }\end{array}$ & Verbal & LIBRAS & $\begin{array}{l}\text { Verbal: alunos com fala e } \\
\text { CAA: alunos sem fala }\end{array}$ \\
\hline \multirow[t]{2}{*}{$\begin{array}{l}\text { Material } \\
\text { fornecido a cada } \\
\text { aluno pela } \\
\text { pesquisadora }\end{array}$} & \multicolumn{3}{|c|}{$\begin{array}{c}\text { Caneta hidrográfica de modelo Jumbo (bitola grande) }{ }^{260} \text { em } 12 \text { cores: } \\
3 \text { primárias, } 3 \text { secundárias, } 4 \text { terciárias, preto e marrom }\end{array}$} \\
\hline & \multicolumn{3}{|c|}{ Uma folha de papel sulfite A4 branca $180 \mathrm{~g}$ com dados do aluno no verso } \\
\hline
\end{tabular}

Quadro 37 - Alguns dos procedimentos de aplicação adotados na entrevista com desenho temático na $2^{\mathrm{a}}$ etapa da pesquisa, por deficiência.

${ }^{254}$ Com os demais alunos presentes.

${ }^{255}$ Idem anterior.

${ }^{256}$ Uma ou duas pessoas trazidas pela pesquisadora.

${ }^{257}$ Pessoa trazida pela pesquisadora.

${ }^{258}$ Da própria unidade-caso.

${ }^{259}$ A docente serviu como intérprete da LIBRAS dos alunos surdos. Nenhum outro intérprete, a não ser a própria professora destes alunos, poderia ser o aplicador em função de a LIBRAS ainda não ser fluente entre estes alunos e da faixa etária em que se encontram.

${ }^{260}$ Evita o uso de material adaptado dos alunos com PC e comprometimento dos membros superiores; por apresentar a bitola maior, facilita a pega. 
No processo de aplicação da entrevista com desenho temático destacaram-se as três fases descritas a seguir, em vez das quatro fases na etapa anterior ${ }^{261}$ :

- Na fase 1, a pesquisadora explicou que os alunos não poderiam olhar o desenho dos colegas e, principalmente, que não havia certo ou errado, pois o importante era a opinião de cada um.

- Na fase 2, foi proposto o tema do desenho aos alunos a partir da questão: Qual o lugar que você mais gosta na escola? Durante a confecção do desenho o aluno não deveria ser questionado. Esta fase teve a função de promover no aluno um desligamento ou um relaxamento, período preparatório para a fase descrita a seguir. - Na fase 3 após o término do desenho indicado pelo aluno ${ }^{262}$, foram realizadas, pausadamente, e de forma individual (mesmo nas aplicações com mais de um aluno) as perguntas (relativas a aspectos gerais da escola) descritas no Quadro 38, bem como solicitou-se a descrição do significado dos símbolos desenhados através das formas de comunicação relativas a cada deficiência, sendo anotada esta informação pela pesquisadora.

\begin{tabular}{|c|c|c|c|}
\hline & \multicolumn{3}{|c|}{ Deficiências } \\
\hline & Visual (baixa visão) & Auditiva (surdez) & Física (PC) \\
\hline$\frac{y}{2} \div$ & \multicolumn{3}{|c|}{ 1. Qual lugar você mais gosta na escola? } \\
\hline 永 & \multicolumn{3}{|c|}{ 2. Por que você escolheu este lugar? } \\
\hline 흘 & \multicolumn{3}{|c|}{ 3. Qual lugar você menos gosta na escola? } \\
\hline 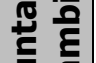 & \multicolumn{3}{|c|}{ 4. Por que você escolheu este lugar? } \\
\hline 님 윰 & \multicolumn{3}{|c|}{ 5. O que você gostaria que tivesse na escola? } \\
\hline
\end{tabular}

Quadro 38 - Roteiro da entrevista lúdica com desenho temático na $2^{\mathrm{a}}$ etapa da pesquisa.

\footnotetext{
${ }^{261}$ Ver item 7.2.3.2 b) Modificações para a próxima etapa.

${ }^{262}$ Geralmente a pesquisadora aguardava até o aluno estar satisfeito com o seu desenho, largar o giz de cera e parar de desenhar.
} 
Foi elaborado um painel com alternativas ilustradas de resposta ${ }^{263}$ para cada unidade-caso em tamanho A3, visando dar suporte à entrevista e facilitar a resposta pelos alunos ${ }^{264}$ com baixa visão (Quadro 39), surdez (Quadro 40) e PC (Quadro 41). Estes painéis foram elaborados pela pesquisadora baseados nos resultados do préteste realizado no ano anterior e em conjunto com as docentes nas entrevistas realizadas em cada uma das unidades-caso ${ }^{265}$. Nessas entrevistas discutiu-se a quantidade e a seleção das imagens, o conteúdo ${ }^{266}$ e a forma do texto escrito em baixo de cada imagem para o entendimento pelos alunos com PC (únicos alfabetizados) e leitura pelo entrevistador (docente ou pesquisadora). O texto que se encontra nos Quadros 39, 40 e 42 se encontra em letra maiúsculo-minúscula, pois apresenta maior legibilidade e facilita a leitura pelos adultos. $\mathrm{O}$ texto que se encontra nos Quadros 41 e 43 se encontra em letra maiúscula, pois facilita a leitura pelo aluno. Além das alternativas de imagens, foi oferecido ao aluno indicar outra opção não presente nos Quadros citados.

\footnotetext{
263 Questões 1 e 3.

${ }^{264}$ Principalmente em função da abstração da LIBRAS e da CAA, nos alunos com surdez e PC, respectivamente.

${ }^{265}$ Ver item 5.3.2.

${ }^{266}$ Por exemplo, o termo quadrado conhecido pelos alunos (Quadro 39) se refere ao pátio do recreio.
} 

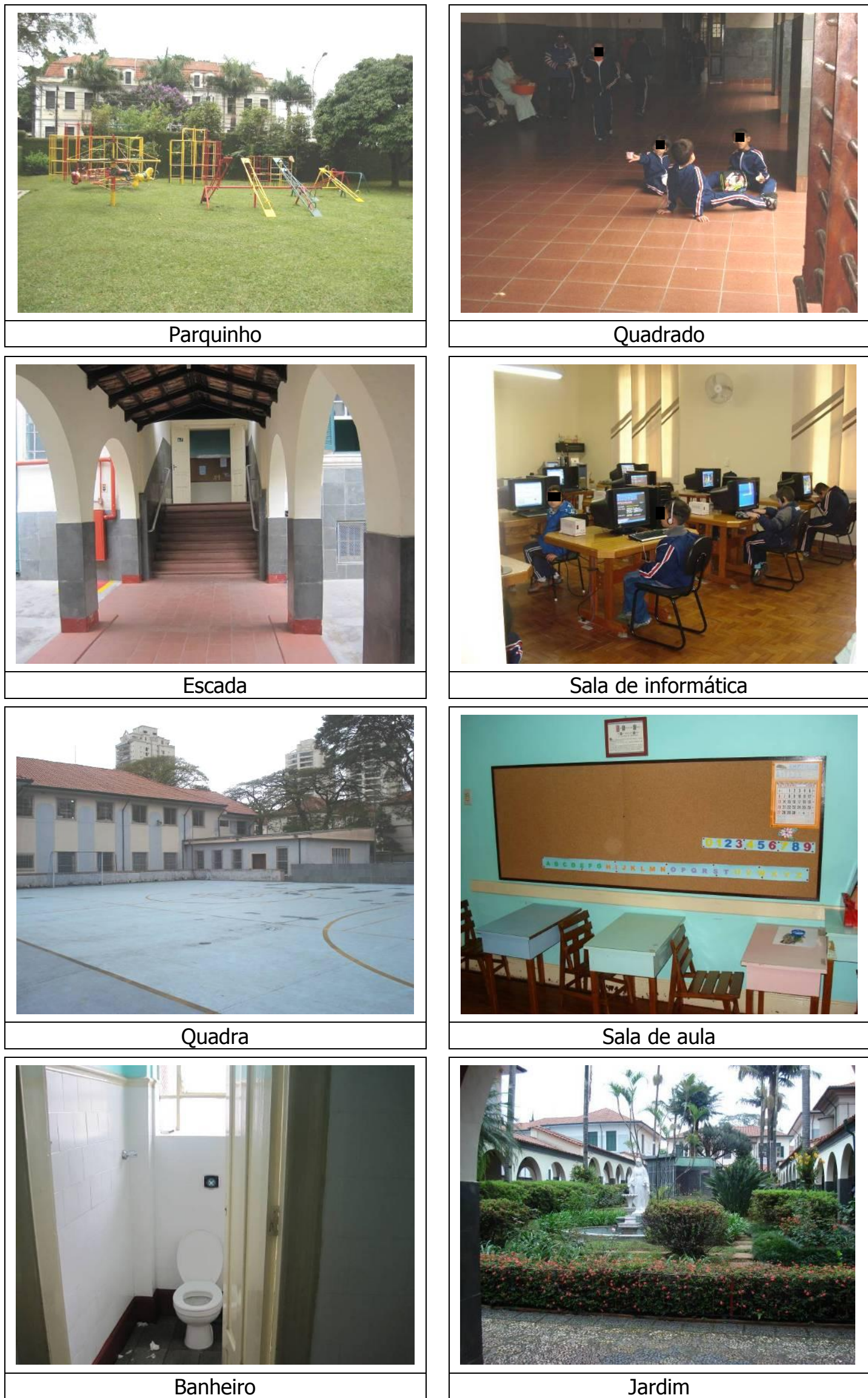

Banheiro

Jardim

Quadro 39 - Painel com alternativas ilustradas de respostas (Questões 1 e 3) da entrevista lúdica destinada aos alunos com baixa visão na $2^{\mathrm{a}}$ etapa da pesquisa. 

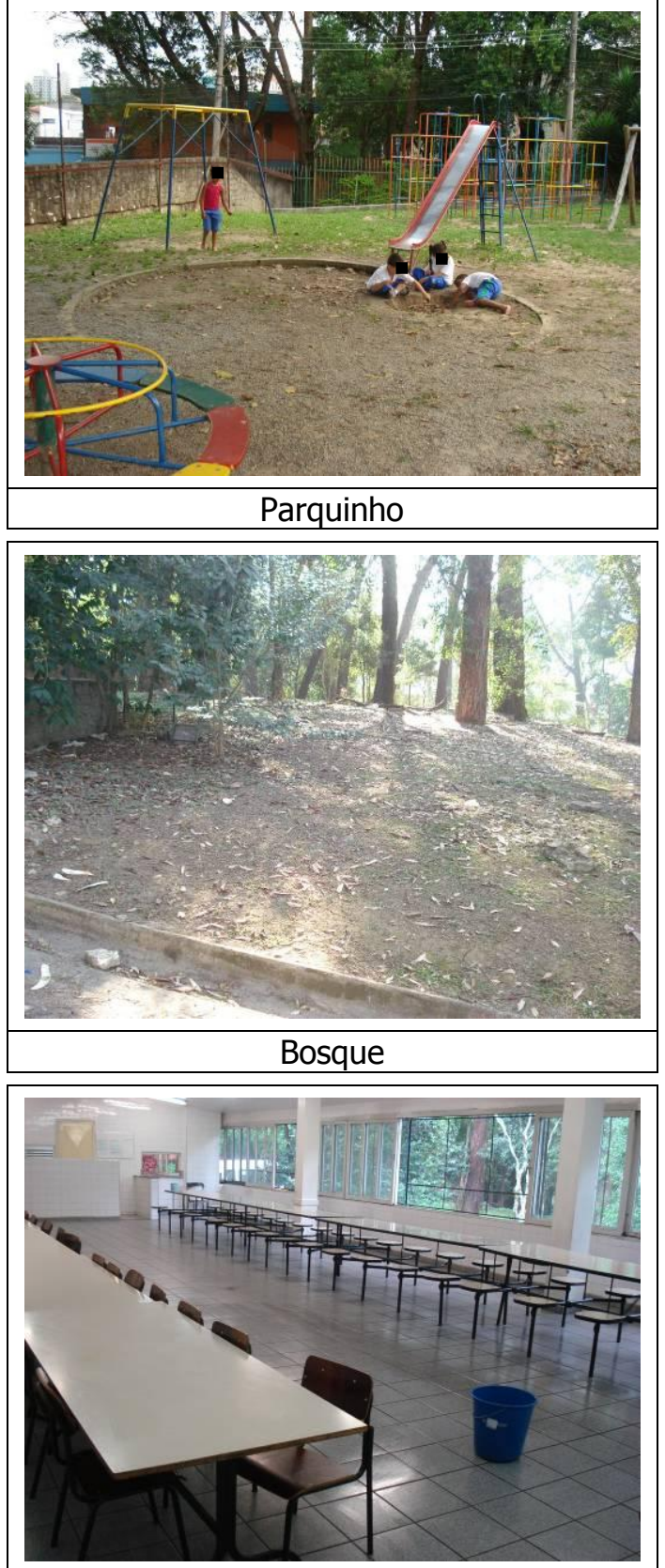

Refeitório

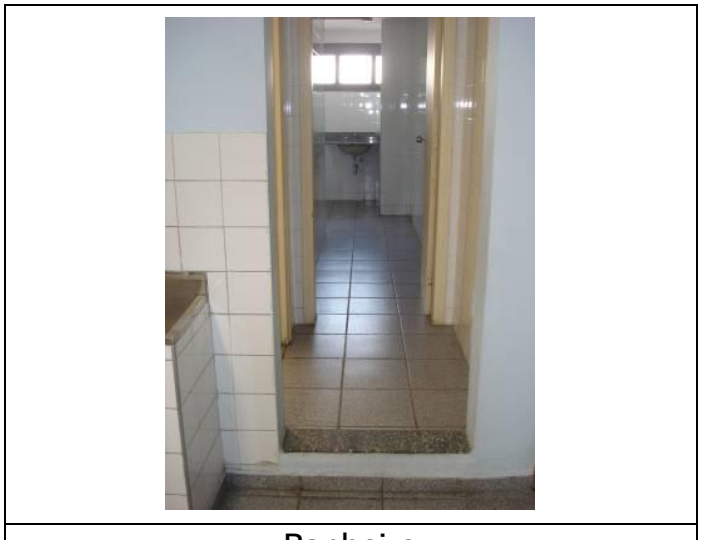

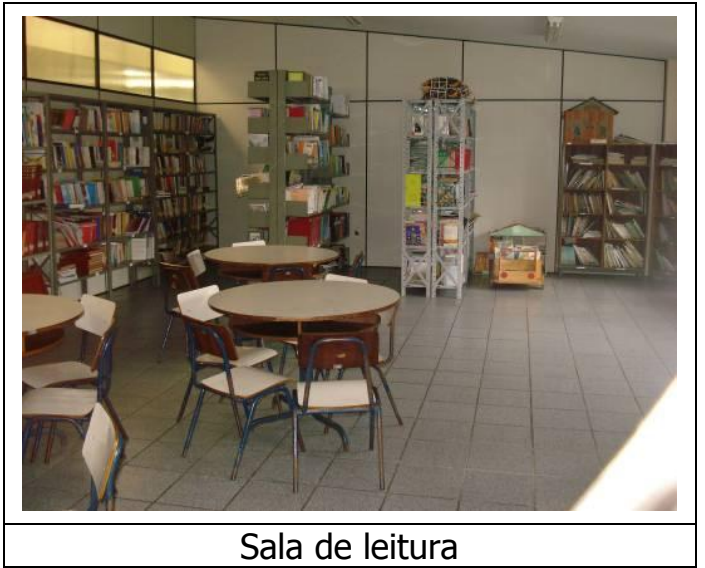

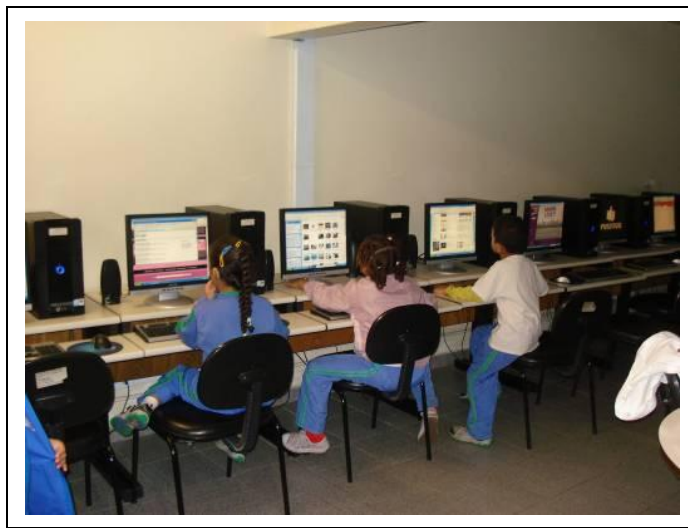

Sala de informática
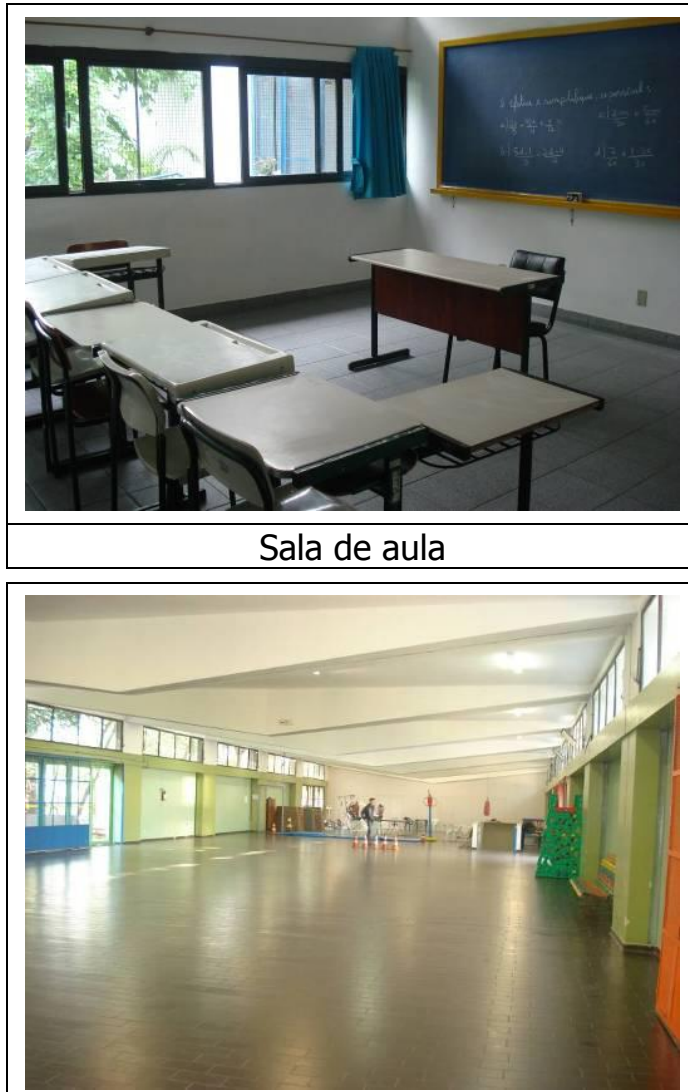

Pátio coberto

Quadro 40 - Painel com alternativas ilustradas de respostas (Questões 1 e 3) da entrevista lúdica destinada aos alunos com surdez na $2^{\mathrm{a}}$ etapa estapa da pesquisa. 

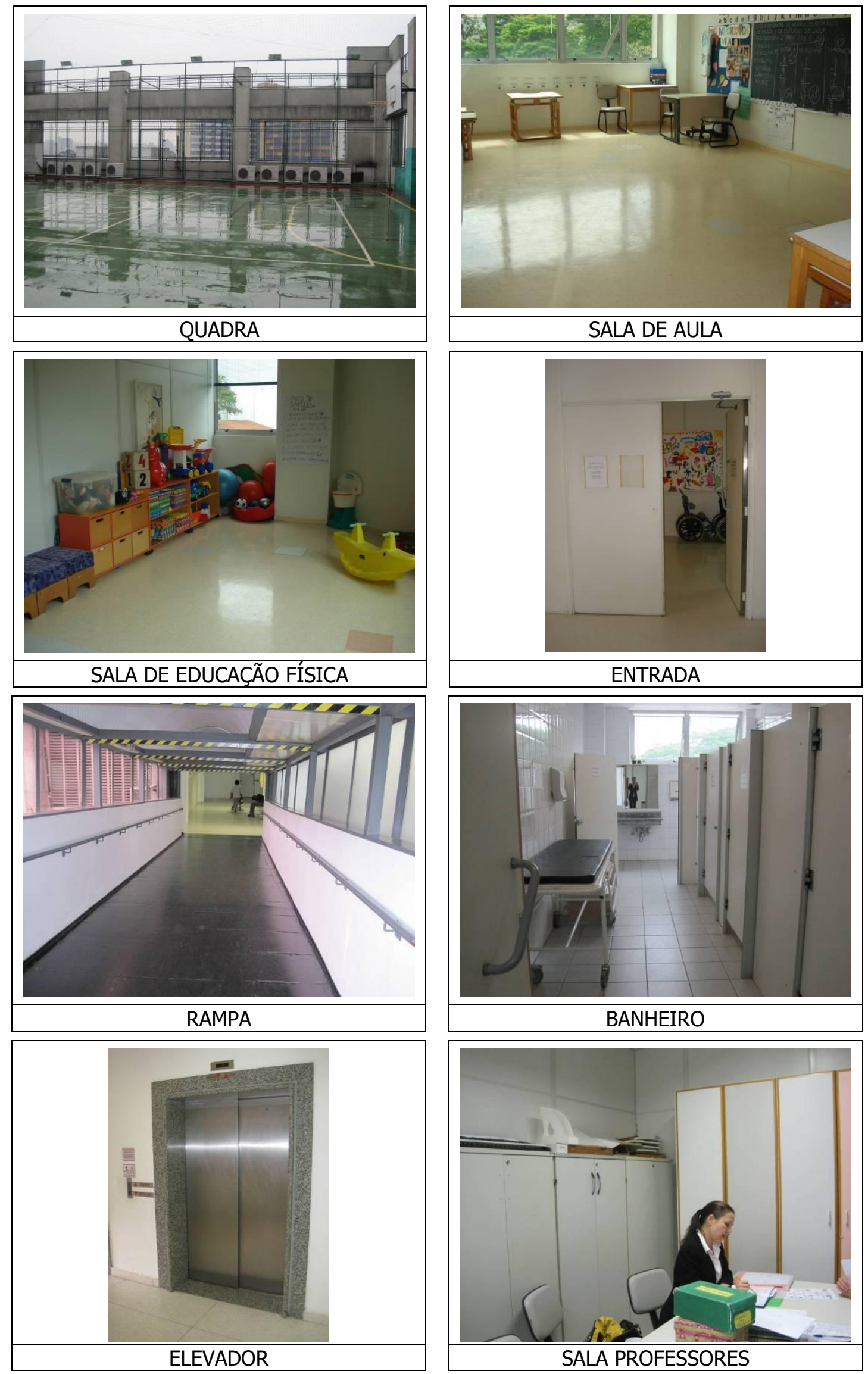

Quadro 41 - Painel com alternativas ilustradas de respostas (Questões 1 e 3) da entrevista lúdica destinada aos alunos com PC na $2^{a}$ etapa etapa da pesquisa. 
Na Questão 5 da entrevista foram elaboradas alternativas ilustradas de resposta para os alunos surdos e com PC ${ }^{267}$ (Quadros 42 e 43, respectivamente), sendo oferecida a opção de o aluno indicar outra opção não disponibilizada nas alternativas (pergunta aberta). As imagens foram selecionadas pelas respectivas docentes destes alunos.

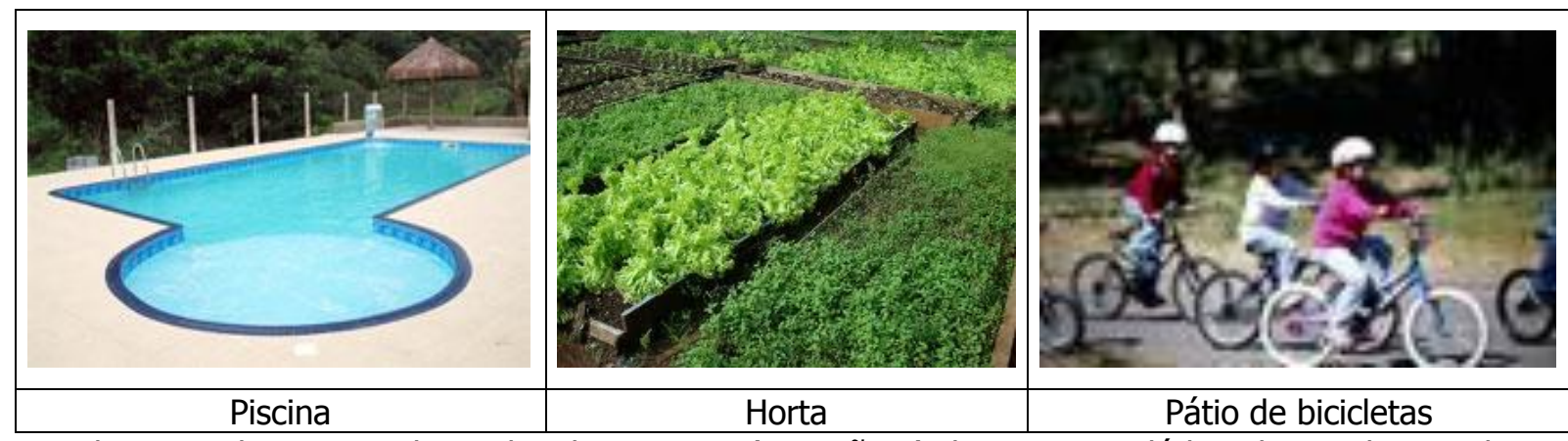

Quadro 42 - Alternativas ilustradas de resposta (Questão 5) da entrevista lúdica destinada aos alunos com surdez na $2^{\mathrm{a}}$ etapa etapa da pesquisa.

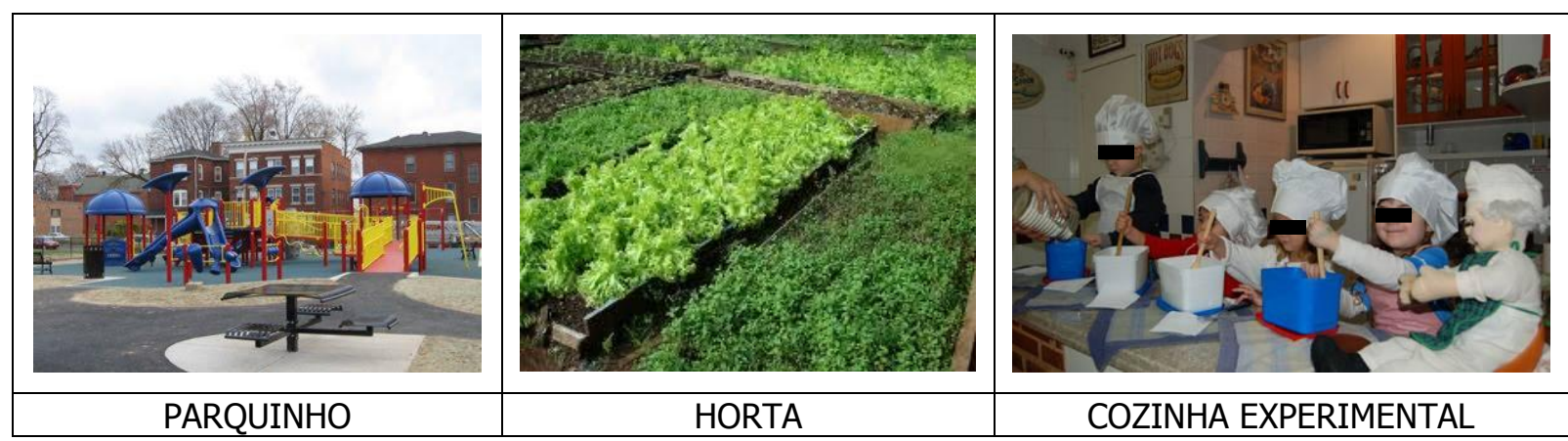

Quadro 43 - Alternativas ilustradas de resposta (Questão 5) da entrevista lúdica destinada aos alunos com PC na $2^{\mathrm{a}}$ etapa etapa da pesquisa.

A pesquisadora elogiou os desenhos realizados e solicitou os desenhos como um presente. Todos os alunos concordaram e entregaram os desenhos ${ }^{268}$.

Datas: variadas, definidas em função da disponibilidade dos entrevistados.

${ }^{267}$ Após entrevista realizada com docentes dos alunos com baixa visão na segunda etapa da pesquisa, verificou-se que a unidade-caso 1 oferecia piscina, horta, parquinho e cozinha, dentre outros. As docentes indicaram que a Questão 5 permanecesse aberta e sem alternativas ilustradas de resposta. ${ }^{268}$ Apenas uma aluna com PC não quis ceder o desenho prontamente e somente após nova solicitação concordou. 
Duração: variável, de 13 a 16 minutos por aluno com baixa visão, de 15 a 20 minutos por aluno surdo e de cerca de 45 minutos por classe de alunos com PC.

A seguir serão apresentados os resultados do processo de aplicação da entrevista lúdica com desenho temático na segunda etapa da pesquisa.

\subsubsection{Alunos com baixa visão: resultados da unidade-caso 1}

Na segunda etapa, a entrevista lúdica com desenho temático na unidade-caso 1 destinou-se a todos os alunos com baixa visão aptos a participarem da pesquisa (ver Tabela 4) e ocorreu nos dias 25/10/2010 (2 alunos) ${ }^{269}$ e 5/11/2010 (2 alunos).

No dia 25/10/2010, as entrevistas lúdicas foram aplicadas pela docente de uma das duas classes existentes e contaram com o apoio da pesquisadora e de duas pessoas trazidas pela pesquisadora. A pesquisa ocorreu na sala de aula onde somente se encontravam os alunos aptos a participarem, presentes no dia da aplicação (2 alunos do total de 4 alunos aptos). Os demais alunos ${ }^{270}$ da classe (não aptos) se encontravam na aula de educação física, com exceção de uma aluna com comprometimentos mentais que necessitava, naquele dia, da presença da docente e permaneceu na mesma sala onde se realizaram as entrevistas.

\footnotetext{
${ }^{269}$ Pois os demais aptos haviam faltado, e a pesquisadora retornou em 5/11/2010.
}

270 Não aptos a participarem da pesquisa. 
Os alunos foram posicionados afastados entre si, e a pesquisadora entregou a cada um deles uma folha em branco e o jogo de canetas hidrográficas. A docente solicitou aos alunos que desenhassem o tema proposto, sendo que eles entenderam a proposta e logo iniciaram esta tarefa (Figura 56).

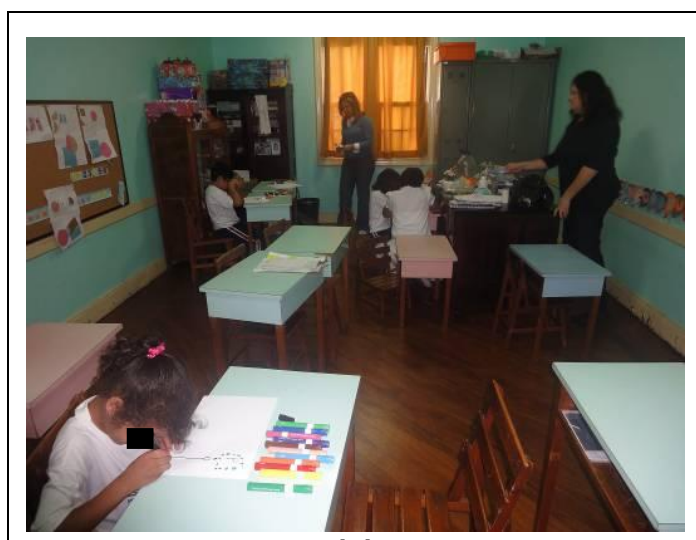

(a)

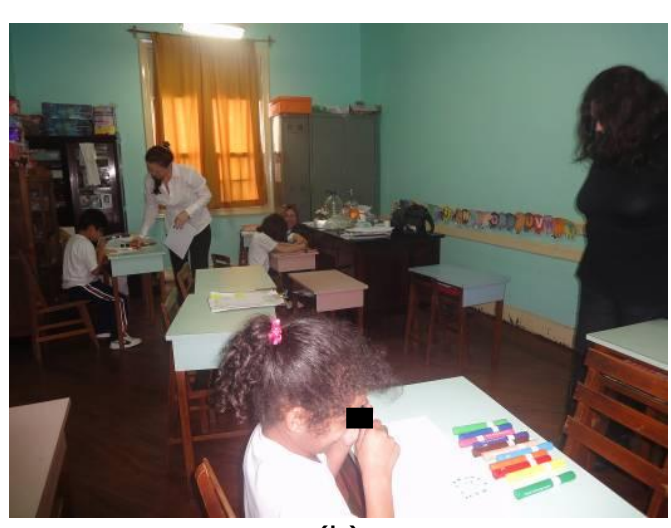

(b)

Figura 56 - Início da entrevista lúdica com desenho temático destinada à aluna V., de 8 anos, à frente, e ao aluno N., de 9 anos, ao fundo (esquerda), ambos com baixa visão.

A aluna V. realizou o desenho com desenvoltura (Figura 57), porém apresentou postura inadequada na execução dos traços do desenho, mantendo o rosto bem próximo à folha (Figura 57c). 


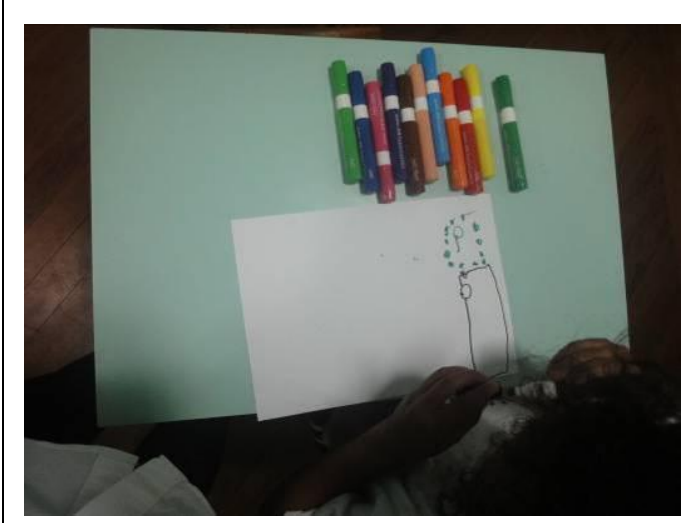

(a)

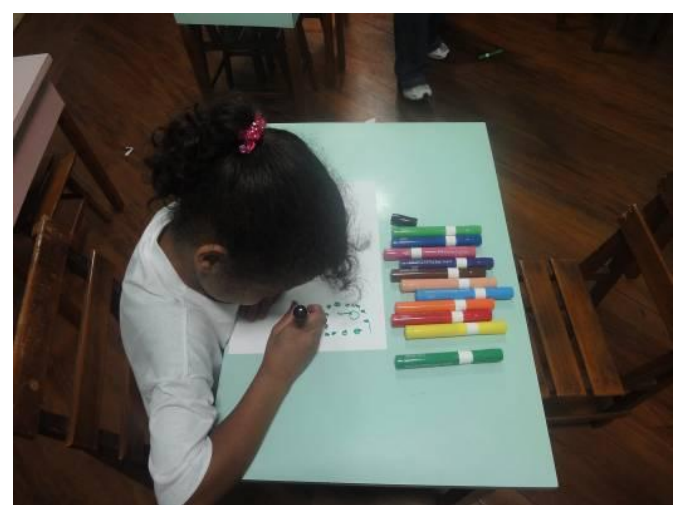

(c)

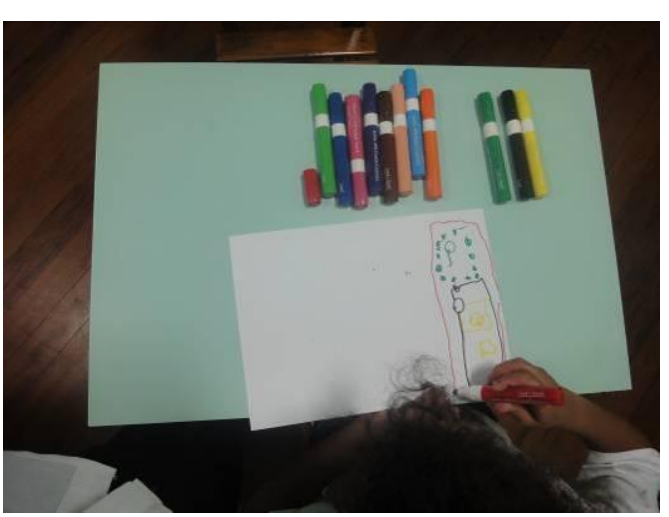

(b)

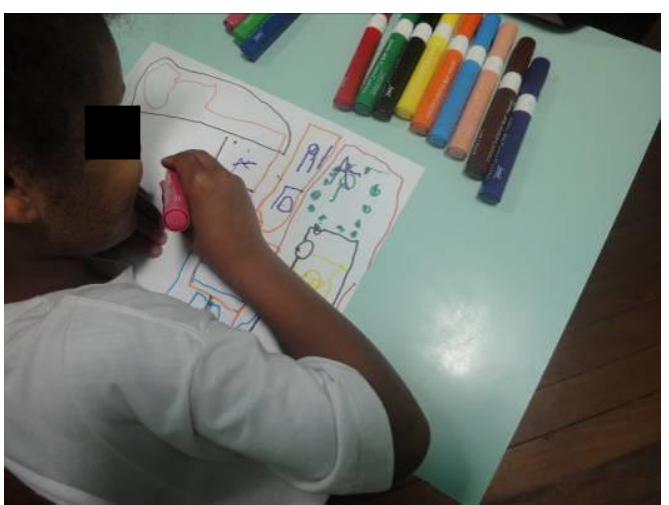

(d)

Figura 57 - Confecção do desenho pela aluna V., de 8 anos, com baixa visão.

Ao contrário, o aluno N., de 9 anos, realizou o desenho com dificuldade (Figura 58a) em decorrência de comprometimento nos movimentos dos braços e da baixa visão severa e necessitou de ajuda para abrir as tampas das canetas e identificar as cores (Figura 58b). 


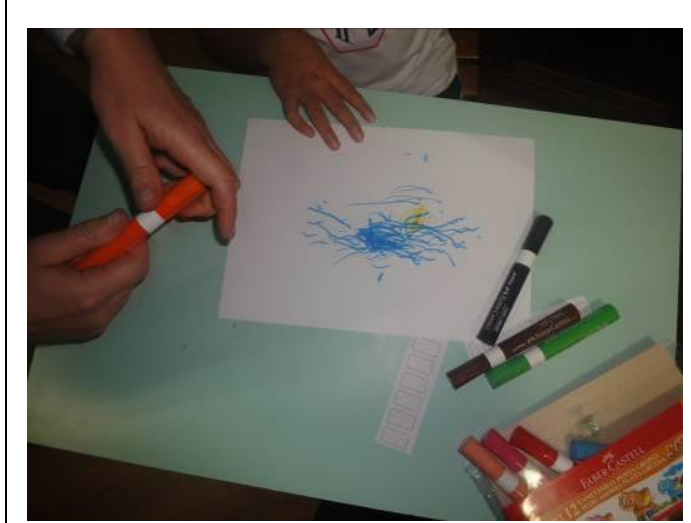

(a)

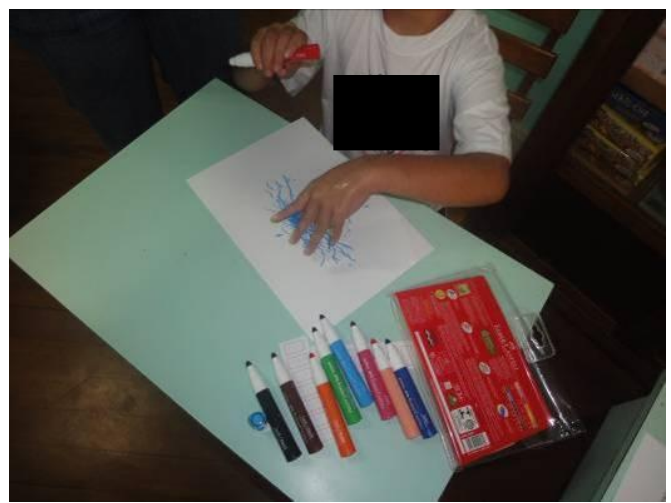

(b)

Figura 58 - Confecção do desenho pelo aluno N., de 9 anos, com baixa visão.

Após o término do desenho pelos alunos, as perguntas relativas a aspectos gerais do ambiente escolar ${ }^{271}$ foram realizadas individualmente ${ }^{272}$ pela docente (Figura 59). Os alunos não apresentaram dificuldade para entender e responder as perguntas, falaram com fluência e se concentraram durante todo o processo. $\mathrm{O}$ aluno $\mathrm{N}$. não conseguiu enxergar as imagens do painel de apoio em função da sua baixa visão severa, ao contrário da aluna V., de 8 anos. A pesquisadora anotou a verbalização das respostas e a descrição do significado dos símbolos desenhados.

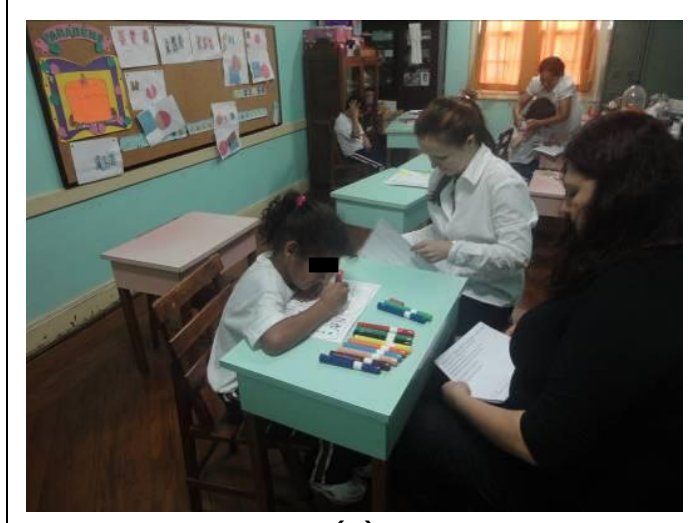

(a)

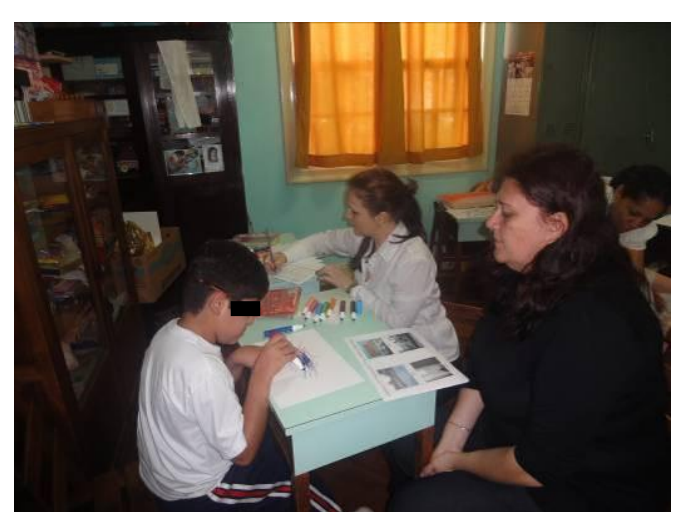

(b)

Figura 59 - Início da entrevista com a aluna V., de 8 anos (a), e com o aluno N., de 9 anos (b), ambos com baixa visão.

\footnotetext{
${ }^{271}$ Ver 7.2.2 b).

272 Pausadamente e em tom baixo de voz.
} 
No dia 5/11/2010 foi realizada a entrevista lúdica com desenho temático com dois alunos de forma individual (um aluno no início e outro no final da manhã ${ }^{273}$ ). A primeira entrevista lúdica contou com o apoio da docente e uma pessoa trazida pela pesquisadora, ocorreu na sala de aula e destinou-se ao aluno T., de 6 anos (participou da etapa anterior da pesquisa). O aluno foi posicionado próximo da pesquisadora e da docente, que the entregou uma folha em branco e um jogo de canetas hidrográficas. A docente solicitou ao aluno que desenhasse o tema proposto (o local que ele mais gosta na escola). O aluno logo entendeu a proposta e elaborou o desenho com facilidade, concentração e de forma independente (Figura 60).

${ }^{273}$ Um aluno chegou atrasado na escola. 


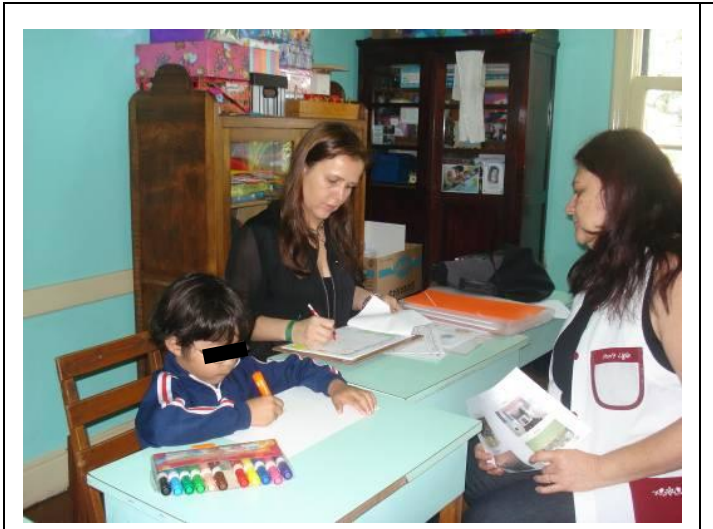

(a)

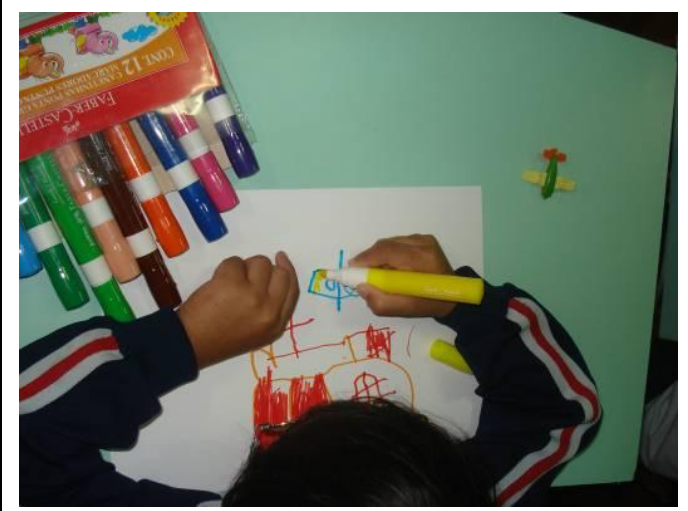

(c)

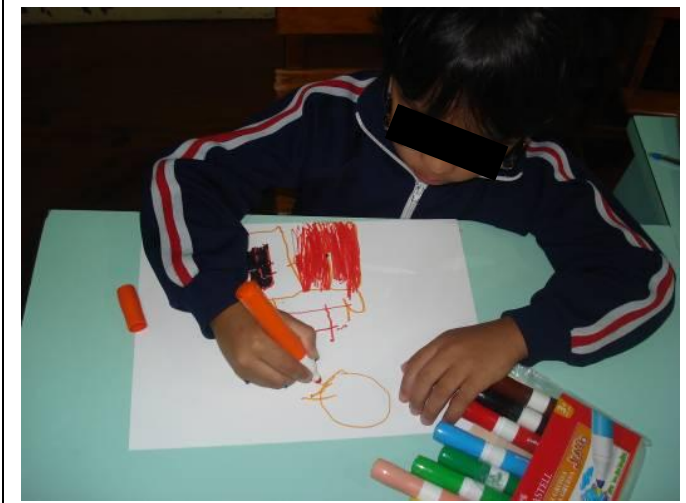

(e)

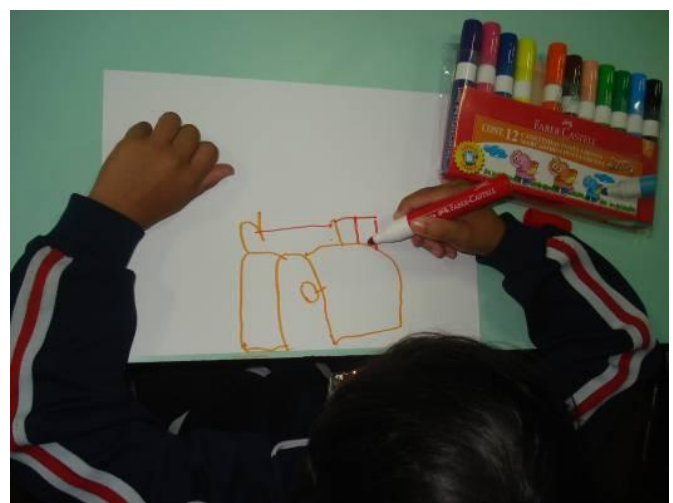

(b)

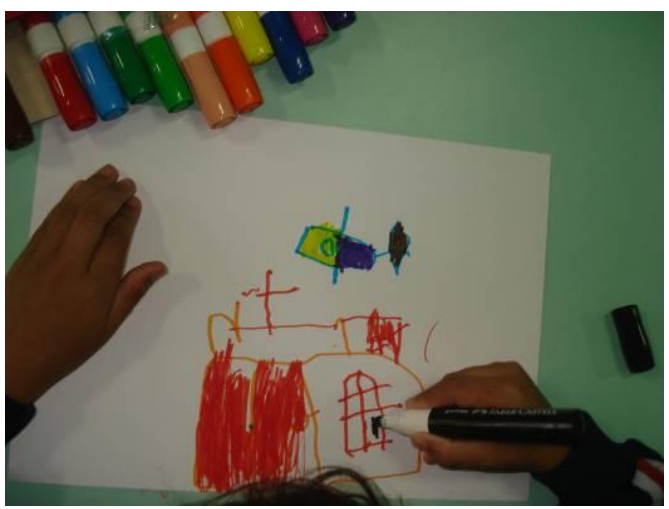

(d)

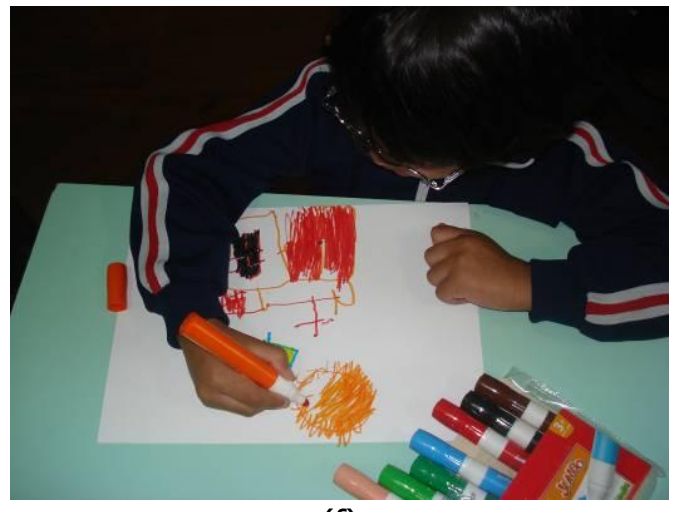

(f)

Figura 60 - Confecção do desenho pelo aluno T., de 6 anos, com baixa visão.

Entretanto, antes de o aluno T. terminar o desenho e da docente iniciar a entrevista, os demais alunos ${ }^{274}$ que se encontravam na aula de educação física entraram na sala.

${ }^{274}$ Os dois alunos aptos que já haviam participado da pesquisa e os não aptos. 
A pesquisadora e sua auxiliar distribuíram folhas e canetas para que os alunos com baixa visão se ocupassem desenhando (Figura 61). Os alunos cegos permaneceram conversando.

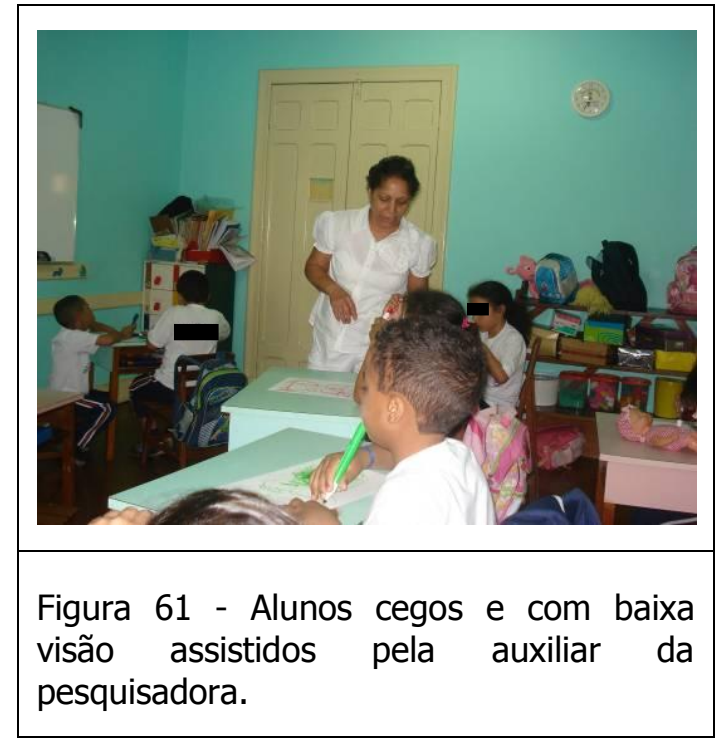

Em função da chegada dos colegas, a entrevista foi antecipada e se iniciou antes do término do desenho pelo aluno. A docente, sentada a sua frente, realizou as perguntas, e o aluno respondeu com facilidade (Figura 62).

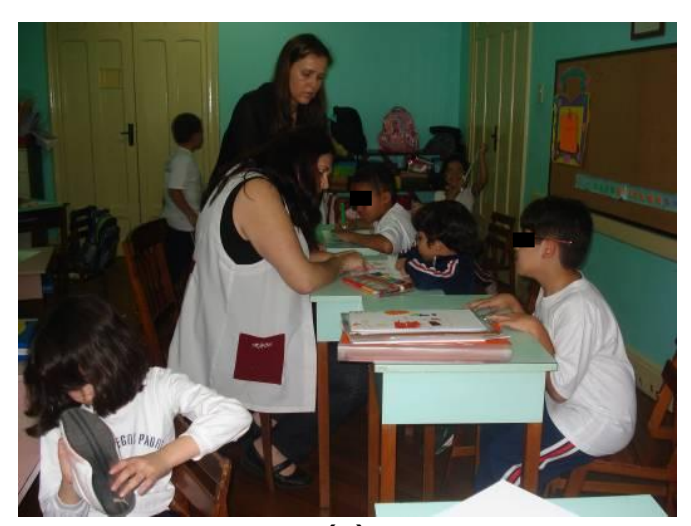

(a)

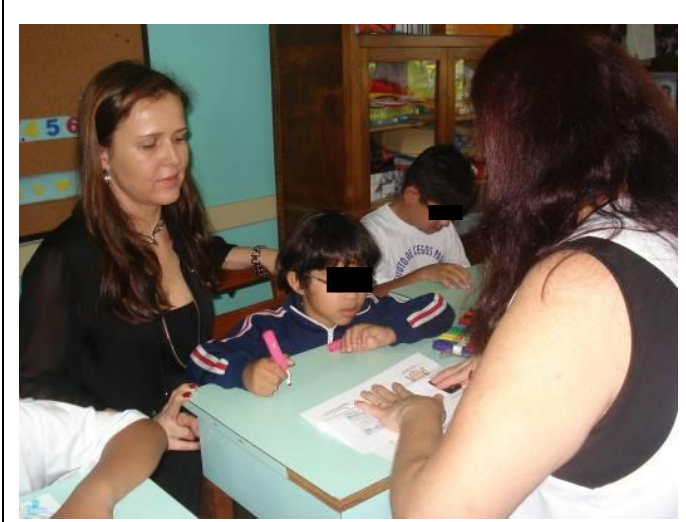

(b)

Figura 62 - Entrevista lúdica com o aluno T., de 6 anos, com baixa visão. 
Ainda no dia 5/11/2010, a segunda entrevista lúdica contou com o apoio somente da pessoa trazida pela pesquisadora ${ }^{275}$, ocorreu em uma outra sala de aula que se encontrava vazia e destinou-se somente à aluna E., de 8 anos. A aluna foi posicionada próxima à pesquisadora que lhe entregou uma folha em branco e o jogo de canetas hidrográficas e solicitou que desenhasse o tema proposto (Figura 63a). A pesquisadora permaneceu em silêncio durante a execução do desenho pela aluna, apenas anotando informações não verbais relativas à aplicação em andamento (como a postura da aluna, pega da mão e coordenação motora).

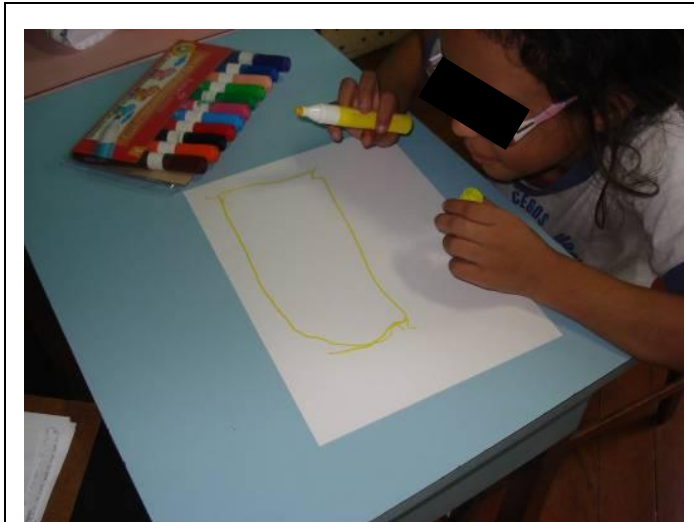

(a)

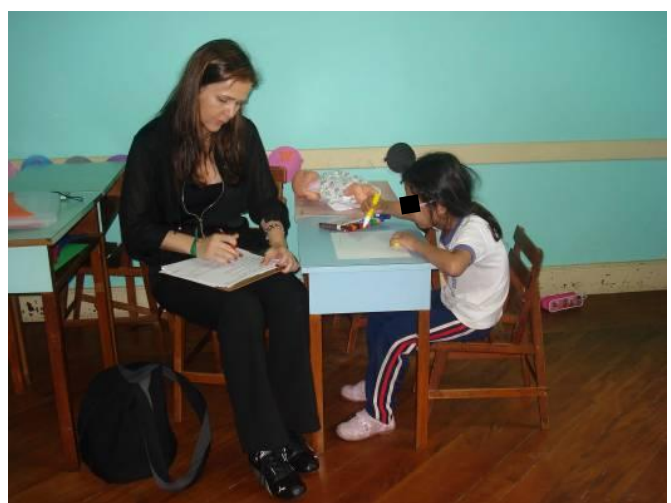

(b)

Figura 63 - Confecção do desenho pela aluna E., de 8 anos, com baixa visão (a) pesquisadora realizou anotações durante a confecção do desenho (b).

Sem que a pesquisadora perguntasse, a aluna começou a falar de sua casa e de sua mãe (externou sentimentos). A pesquisadora, que já havia conversado com psicólogas acerca deste assunto, logo mudou o rumo da conversa mantendo o foco no desenho e não em assuntos intrínsecos à criança. Quando a aluna indicou o término do desenho, foram realizadas as perguntas da entrevista (Figura 64a) e sobre os símbolos desenhados (Figura 64b). A aluna respondeu sem dificuldade.

${ }^{275}$ Que ficou responsável pelas fotos. 


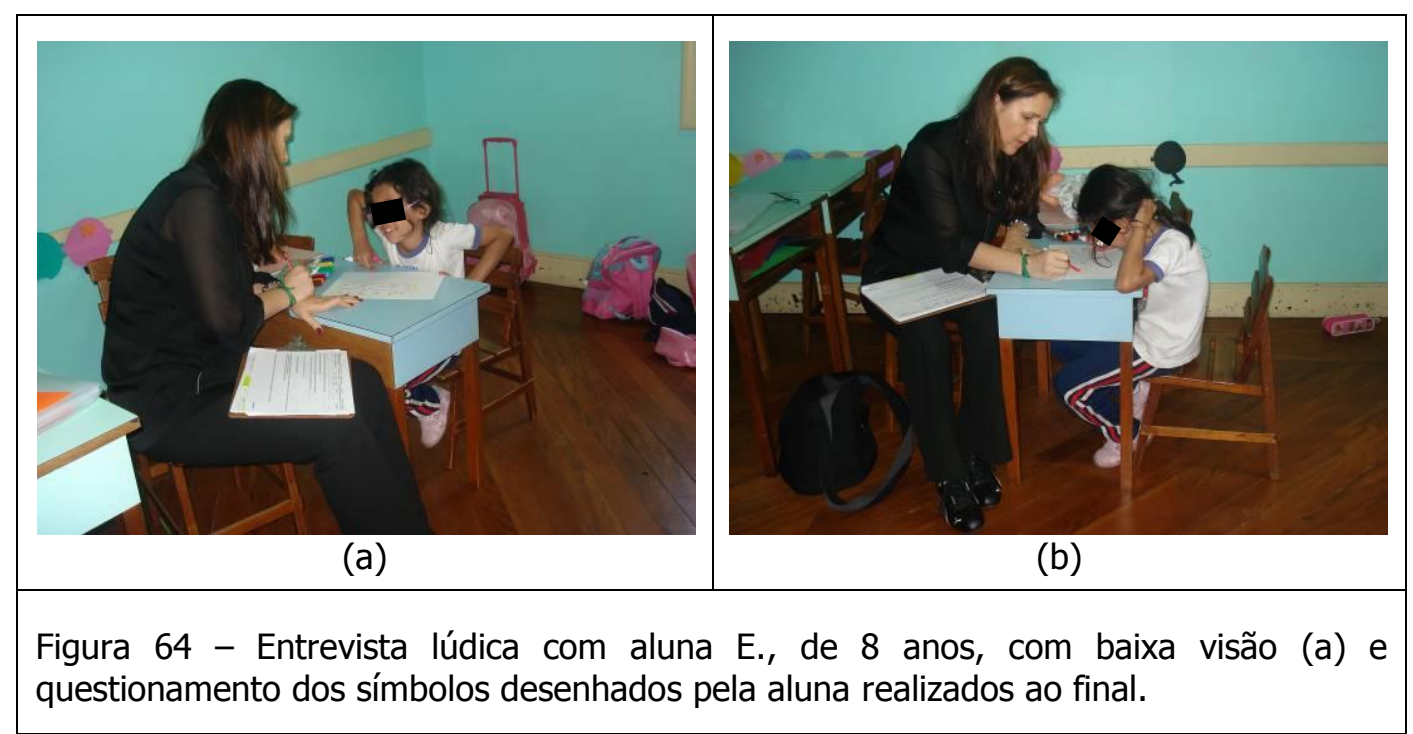

A seguir serão apresentadas as sínteses dos resultados de todas as entrevistas lúdicas com desenho temático na segunda etapa da pesquisa destinadas aos alunos com baixa visão (Quadros 44 a 47). 
O aluna V., de 8 anos, apresentava ótima fala, coordenação motora nos membros superiores e inferiores e bom desenvolvimento cognitivo. Em decorrência da baixa visão, apresentou postura inadequada durante a confecção do desenho.

Realizou o desenho com facilidade e sem auxílio para a pega da caneta e troca de cores; e respondeu as perguntas da docente verbalmente.
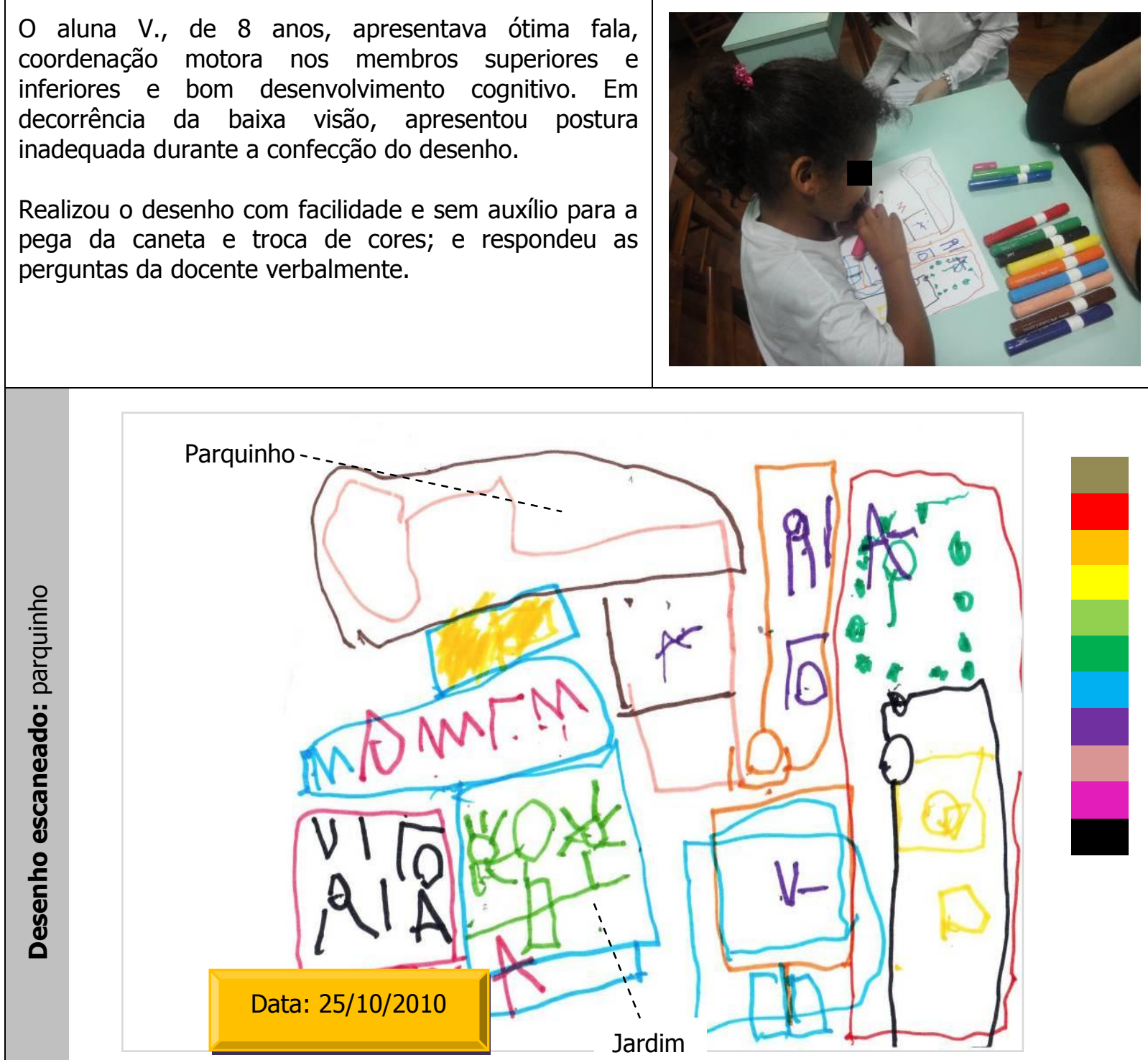

Cores utilizadas: marrom, vermelho, laranja, amarelo, verde claro, verde escuro, azul claro, roxo, rosa, lilás e preto.

Respostas da entrevista pela aluna (verbal):

1. "Parquinho."

2. "Porque tem brinquedo."

3. "Gosto de tudo."

4. -

5. Não respondeu. A pesquisadora perguntou se tinha tudo o que a aluna queria, e a mesma confirmou.

Quadro 44 - Síntese da entrevista lúdica com desenho temático destinada à aluna V., de 8 anos, com baixa visão da unidade-caso 1 na $2^{\mathrm{a}}$ etapa da pesquisa. 
O aluno N., de 9 anos, apresentava boa fala e bom desenvolvimento cognitivo, porém não apresentava boa coordenação motora nos membros superiores e inferiores (andava com dificuldade). Realizou o desenho com dificuldade e com auxílio para a abertura das tampas das canetas e seleção de cores (baixa visão severa). Apresentou postura inadequada durante a confecção do desenho e dificuldade na visualização das alternativas ilustradas da entrevista, respondeu as perguntas da docente verbalmente.
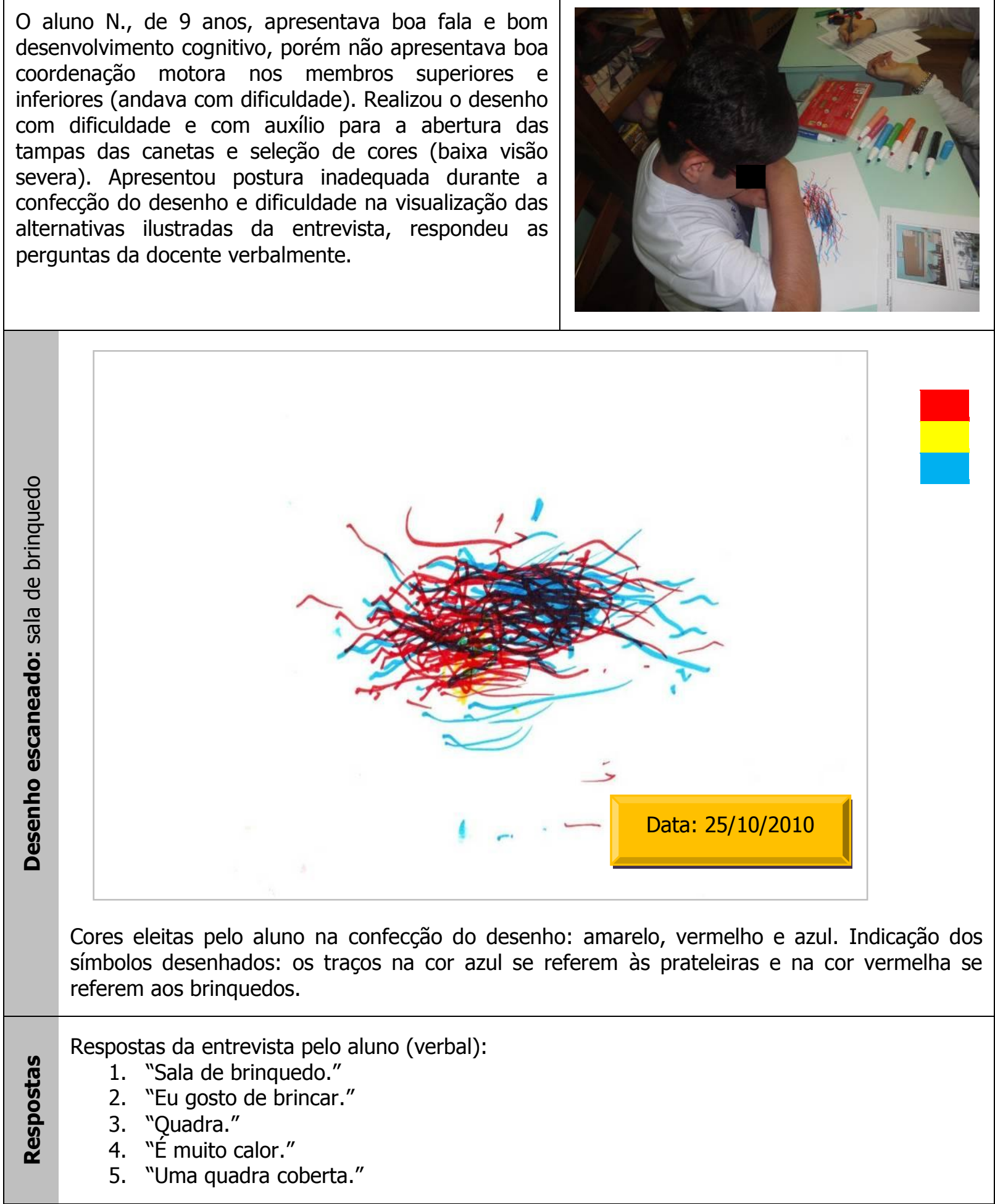

Quadro 45 - Síntese da entrevista lúdica com desenho temático destinada ao aluno N., de 9 anos, com baixa visão da unidade-caso 1 na $2^{\mathrm{a}}$ etapa da pesquisa. 
O aluno T., de 6 anos, apresentava ótima fala, coordenação motora nos membros superiores e inferiores e bom desenvolvimento cognitivo. Realizou o desenho com facilidade e sem auxílio para a pega da caneta e troca de cores; não apresentou dificuldade na visualização das alternativas ilustradas da entrevista e respondeu as perguntas da docente verbalmente.
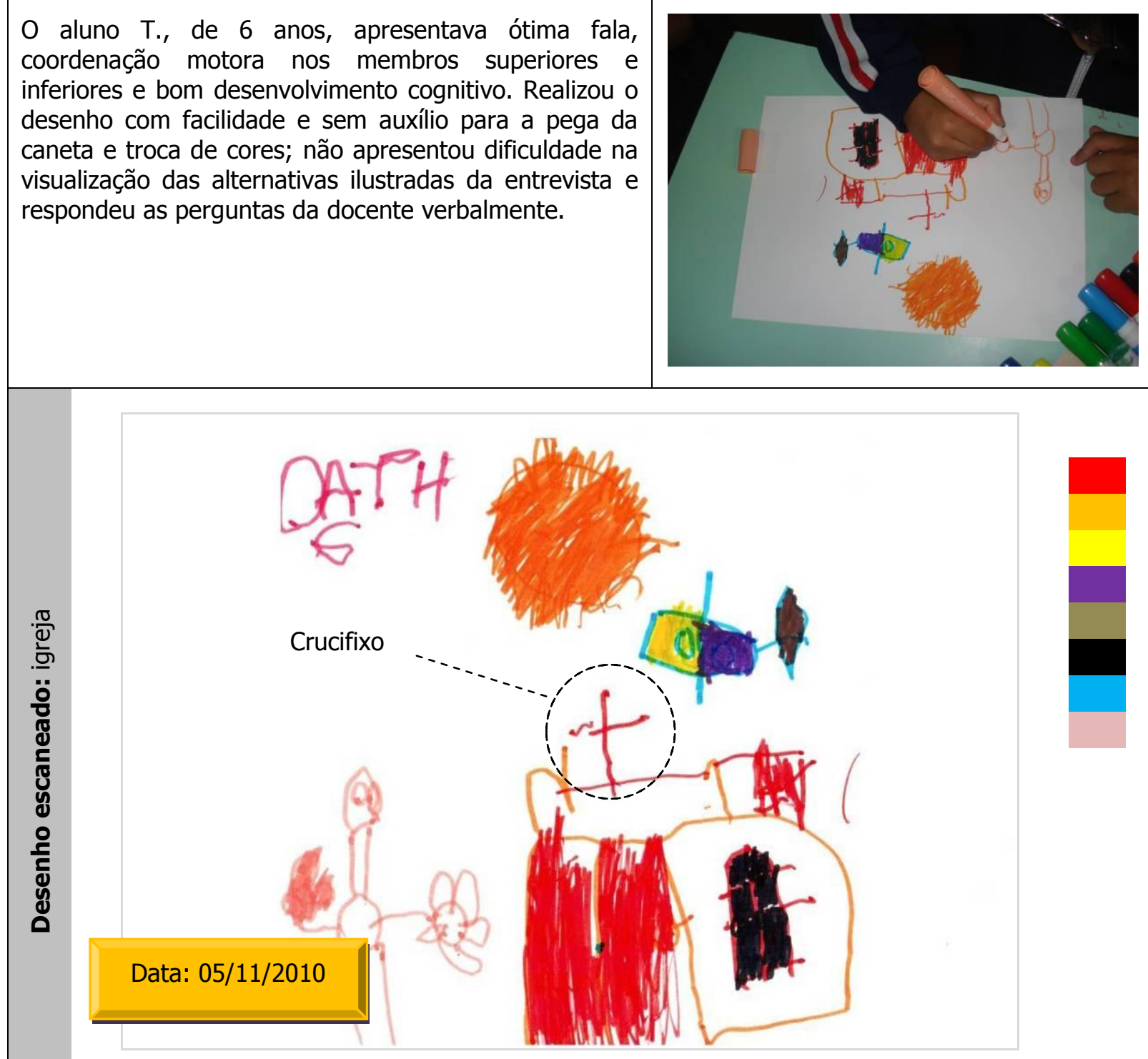

Cores eleitas pelo aluno na confecção do desenho: vermelho, laranja, amarelo, roxo, marrom, preto, azul e rosa.

Respostas da entrevista pelo aluno (verbal):

1. O aluno disse que desenhou a igreja, pois nesta unidade-caso existe uma anexa. A pesquisadora questionou se havia outro lugar de que ele gostasse, que respondeu o "parquinho."

2. "É legal."

3. Não respondeu. A pesquisadora perguntou se o aluno gostava de tudo, e o mesmo confirmou.

4. -

5. "Moto. Um lugar para andar de moto."

Quadro 46 - Síntese da entrevista lúdica com desenho temático destinada ao aluno T., de 6 anos, com baixa visão da unidade-caso 1 na $2^{\mathrm{a}}$ etapa da pesquisa. 


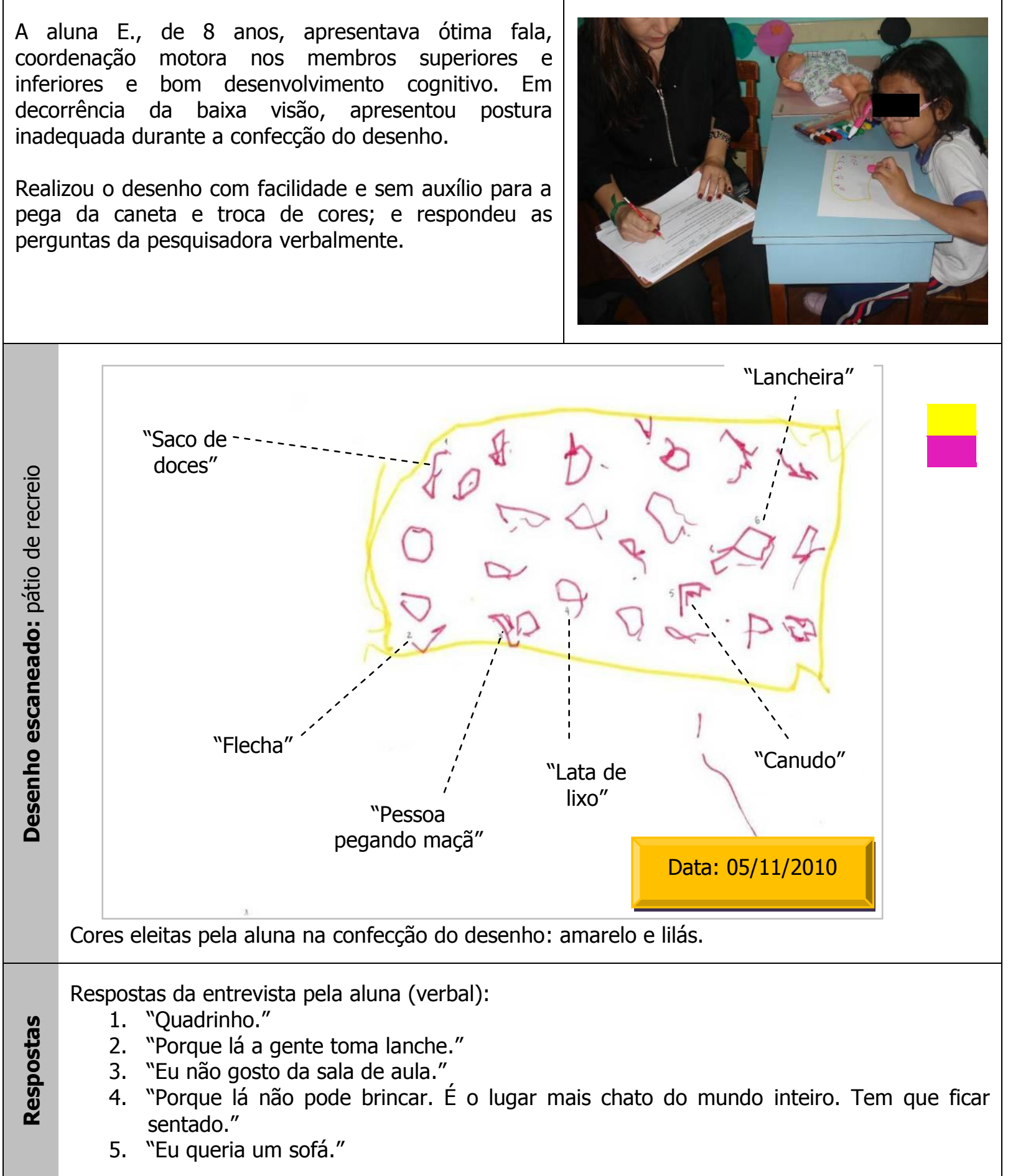

Quadro 47 - Síntese da entrevista lúdica com desenho temático destinada a aluna E., de 8 anos, com baixa visão da unidade-caso 1 na $2^{\mathrm{a}}$ etapa da pesquisa. 


\subsubsection{Alunos surdos: resultados da unidade-caso 2}

Na segunda etapa da pesquisa, a entrevista lúdica com desenho temático na unidade-caso 2 destinou-se a todos os alunos surdos aptos a participarem da pesquisa (ver Tabela 5). As entrevistas lúdicas com desenho temático foram aplicadas pela docente de uma das duas classes $^{276}$ envolvidas, em função da familiaridade e do nível de comunicação em LIBRAS de cada aluno ${ }^{277}$ e contaram com o apoio direto da pesquisadora, de uma pessoa trazida pela pesquisadora e apoio indireto da docente de outra sala de pré-escola ${ }^{278}$ da unidade-caso 2 . As entrevistas lúdicas ocorreram na sala de aula onde somente se encontravam os alunos aptos a participarem da pesquisa presentes nos dias das aplicações, 09/09/2010 (5 alunos) e 04/10/2010 (2 alunos) $)^{279}$.

No dia 09/09/2010, as entrevistas lúdicas ocorreram de forma individual: a docente e a pesquisadora posicionaram um aluno ${ }^{280}$ por vez nas mesas agrupadas na parte da frente da sala de aula (Figura 65a). Os demais alunos permaneceram sentados em algumas mesas agrupadas localizadas no fundo da sala, realizando atividades propostas pela auxiliar da pesquisadora (Figura 65b).

\footnotetext{
${ }^{276}$ Docente da sala de maior número de alunos aptos a participarem da pesquisa.

277 Mesmo sendo a docente de apenas uma das classes, a mesma conhece todos os alunos.

${ }^{278}$ Que conduziu os alunos à aula de educação em 09/09/2010 e permaneceu na sala de vídeo em 04/10/2010.

279 Os demais alunos da classe (não aptos) se encontravam na aula de educação física e na sala de vídeo, respectivamente.

${ }^{280}$ Selecionado pela docente.
} 


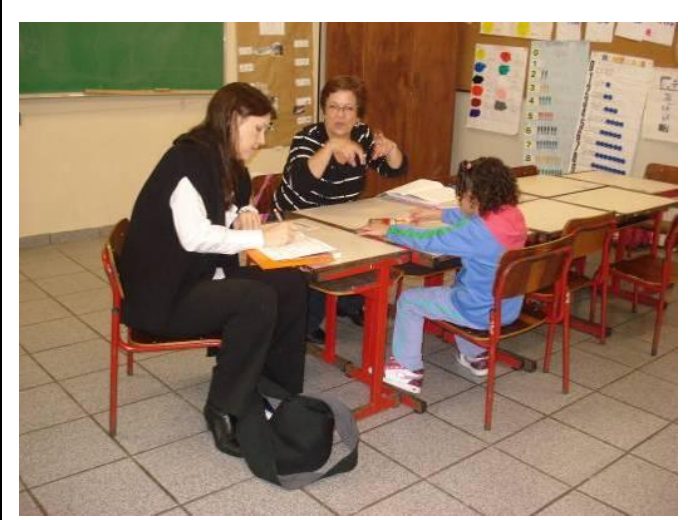

(a)

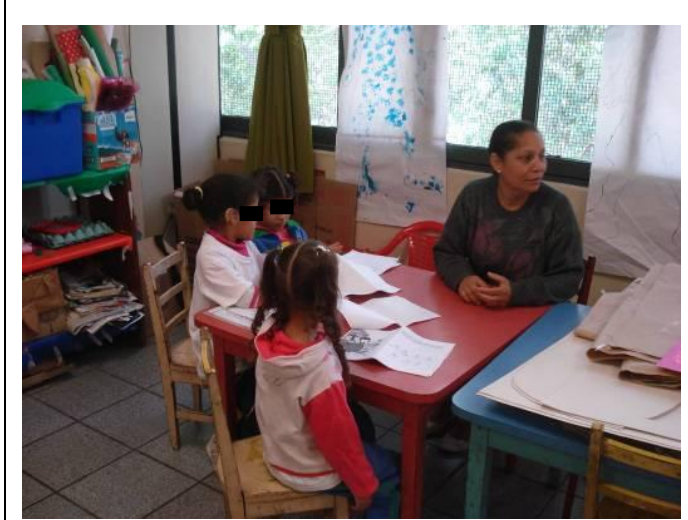

(b)

Figura 65 - Configuração espacial da entrevista lúdica (a) e apoio de auxiliar da pesquisadora (b), na entrevista lúdica destinada aos alunos surdos em 09/09/2010.

No dia 04/10/2010, a confecção do desenho ocorreu em dupla e as respectivas perguntas das entrevistas de forma individual em LIBRAS pela docente. A docente e a pesquisadora posicionaram os dois únicos alunos aptos ${ }^{281}$ (que haviam faltado no dia da aplicação anterior) nas mesas agrupadas na parte da frente da sala de aula (Figura 66a). Os demais alunos permaneceram assistindo a um vídeo em outra sala, cuidados por outra docente e uma estagiária (Figura 66b).

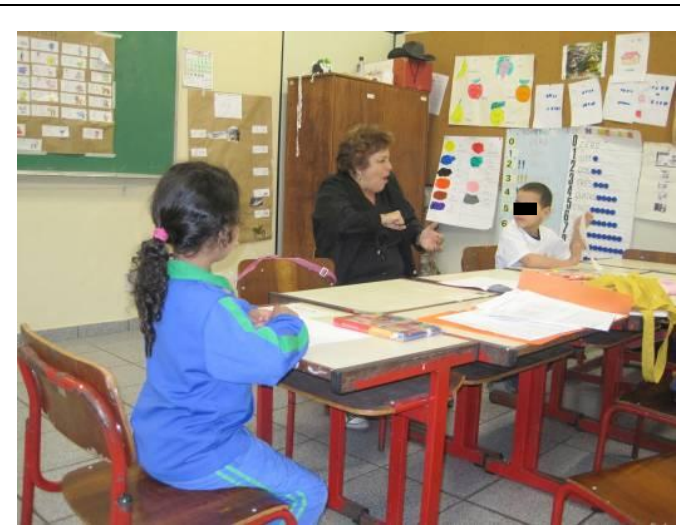

(a)

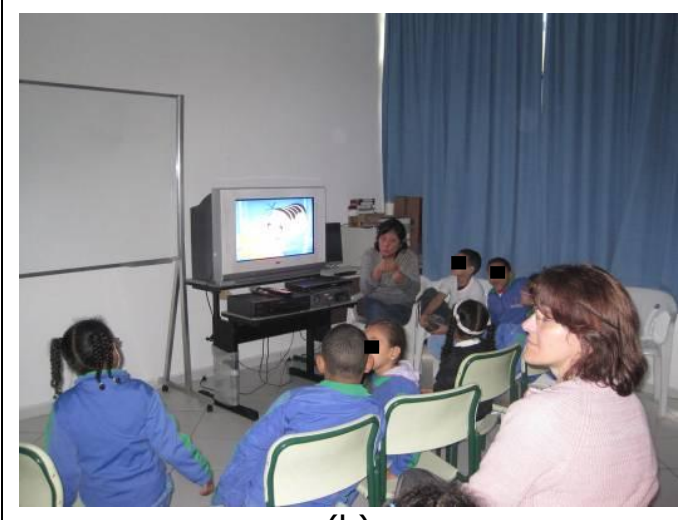

(b)

Figura 66 - Configuração da entrevista lúdica (a) e apoio da docente ao fundo na sala de vídeo (b) durante a entrevista lúdica destinada aos alunos surdos em 04/10/2010.

${ }^{281}$ Indicados pela docente. 
O processo de aplicação descrito a seguir se refere às aplicações nas duas datas citadas. Inicialmente, sem mostrar o painel ilustrado (Quadro 40), a docente solicitou ao aluno realizar um desenho segundo o tema proposto. Esta solicitação foi de fácil entendimento apenas por duas alunas, que logo iniciaram o desenho (uma delas havia participado da pesquisa no ano anterior). Em relação aos demais alunos, a docente repetiu várias vezes a proposta da atividade, que somente se esclareceu ${ }^{282}$ após a apresentação do painel com alternativas ilustradas (Figura 67) ${ }^{283}$.

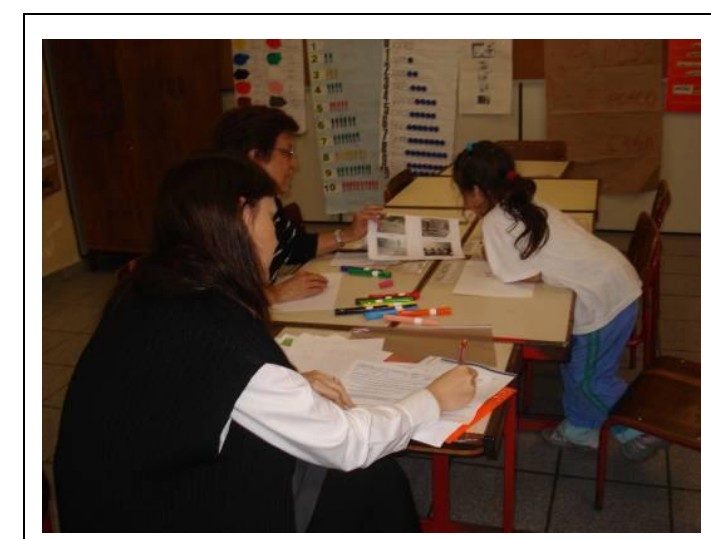

(a)

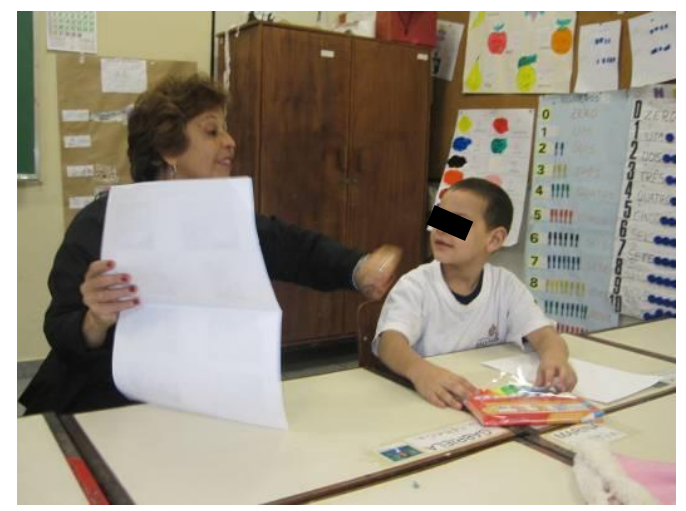

(c)

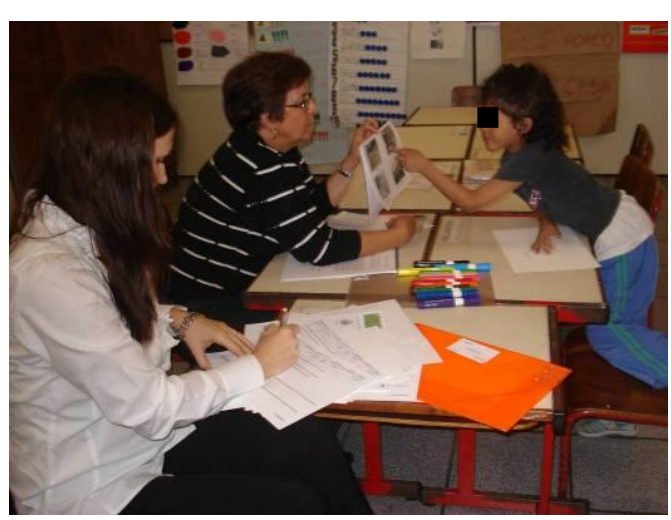

(b)

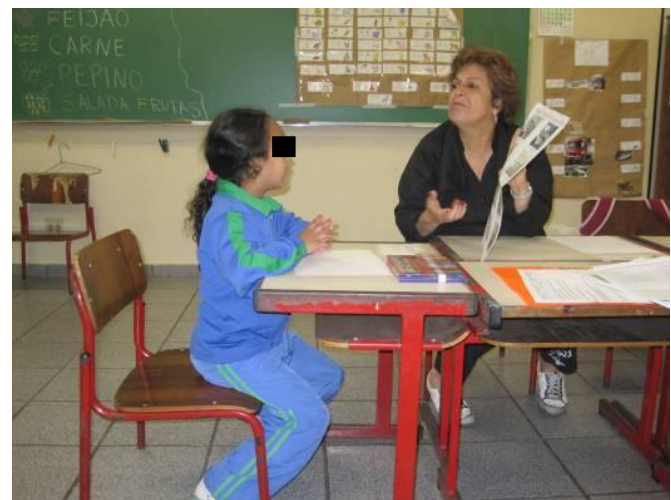

(d)

Figura 67 - Alunos surdos: K. dos R., de 6 anos (a); S., de 5 anos (b); P., de 6 anos (c) e G., de 6 anos (d), na escolha do tema antes da confecção do desenho.

282 De uma forma mais rápida.

${ }^{283}$ Quadro 40. 
A tarefa de confecção do desenho foi realizada com facilidade por todos os alunos, que apresentaram ótimas condições para o uso dos membros superiores e concentração (Figura 68).

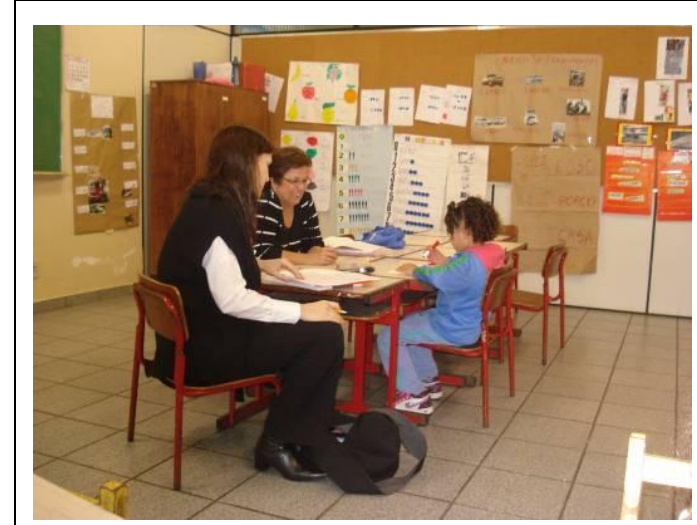

(a)

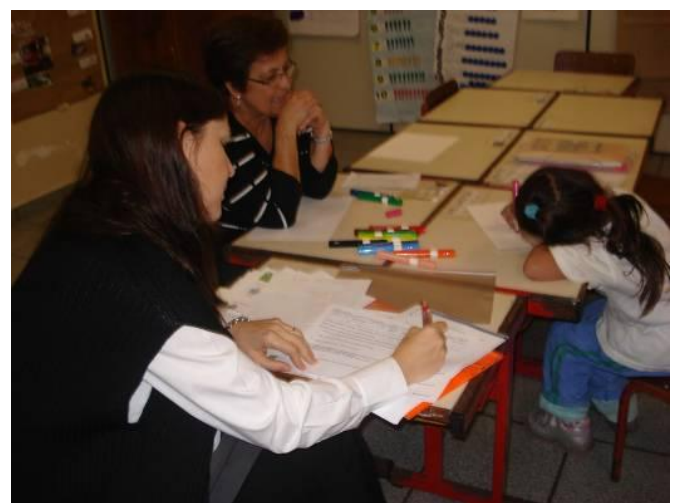

(c)

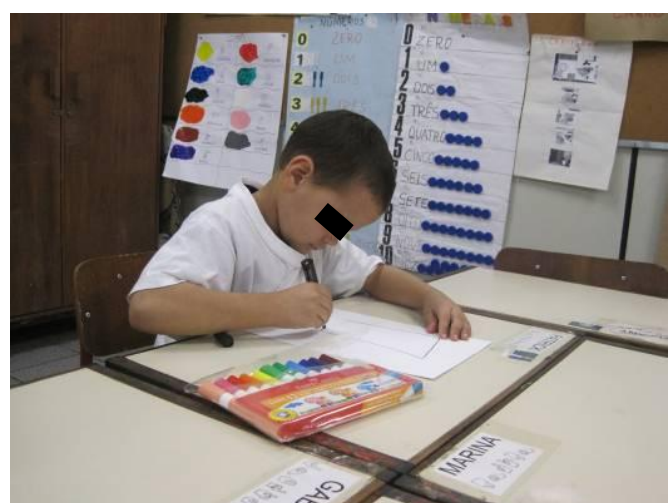

(e)

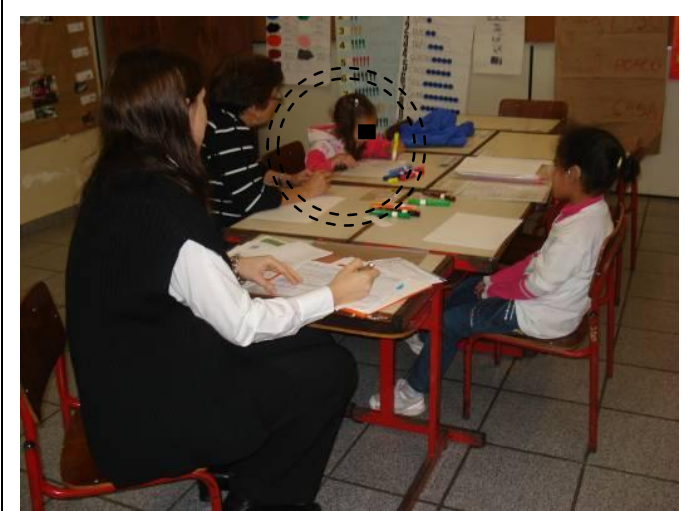

(b)

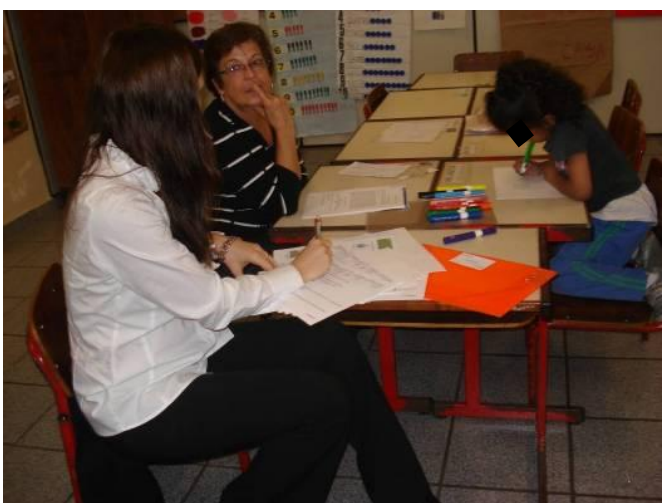

(d)

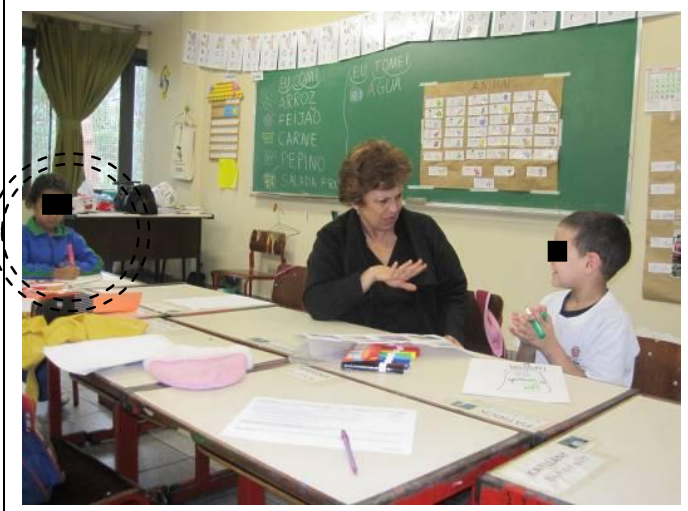

(f)

Figura 68 - Alunos surdos: M., de 6 anos (a); T., de 6 anos, à esquerda (b), K. dos R., de 6 anos (c); S., de 5 anos (d); P., de 6 anos (e); e G., de 6 anos, à esquerda (f), confeccionavam o desenho. 
Apenas um dos alunos se recusou a desenhar, segundo a docente, em função de timidez ${ }^{284}$. A docente tentou por várias vezes convencer a aluna K., de 6 anos, a realizar esta atividade (Figura 69a, b, c), porém a aluna permaneceu imóvel. A docente sentou outra aluna próxima a ela (Figura 69d) para que desenhassem juntas. Porém, a aluna permaneceu somente observando a colega desenhar.

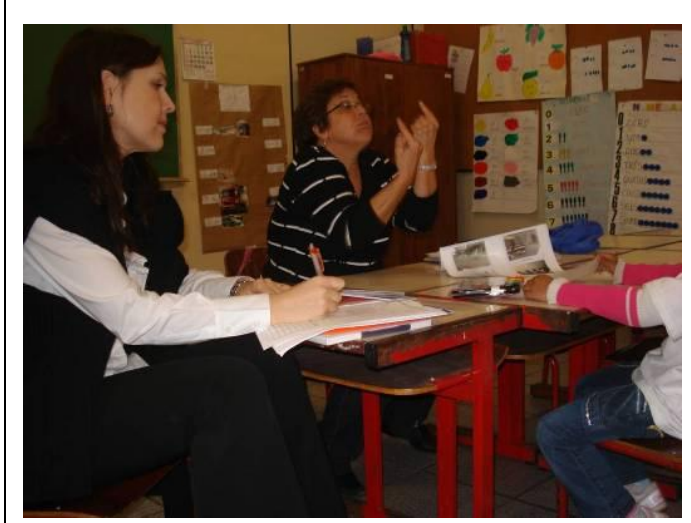

(a)

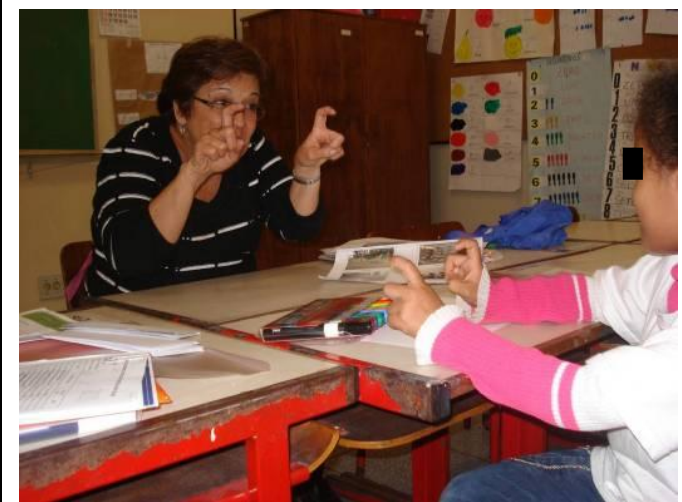

(c)

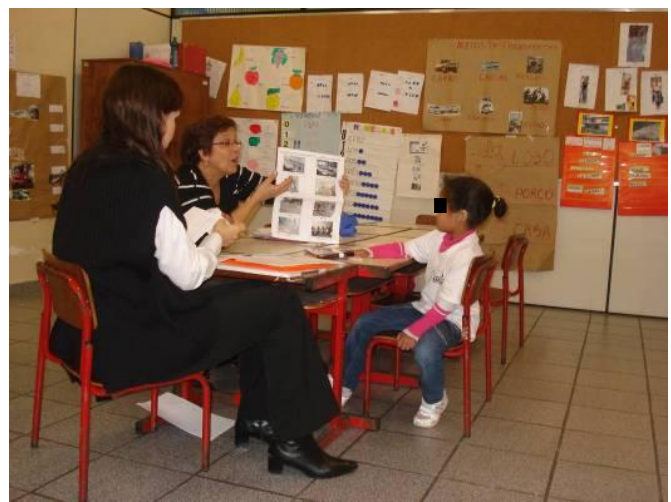

(b)

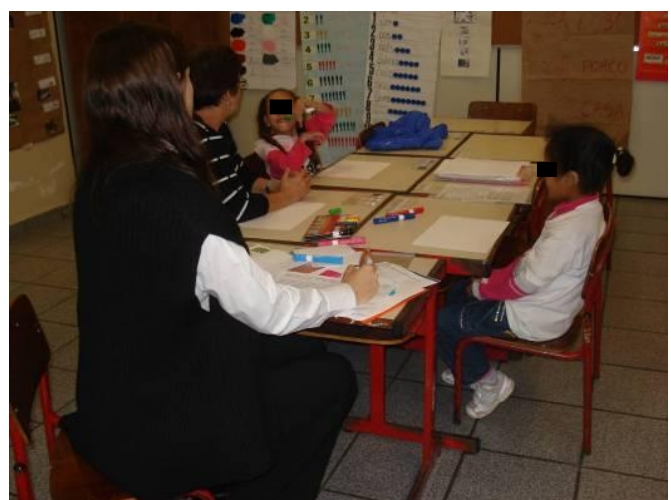

(d)

Figura 69 - Docente solicitou que a aluna K., de 6 anos, surda, realizasse o desenho (a, b, c) e convidou outra aluna, à esquerda, para desenhar em conjunto (d).

Somente após o término do desenho indicado pelo aluno foram realizadas as perguntas da entrevista individual. A maioria dos alunos apresentou dificuldade no entendimento das perguntas em LIBRAS, que a docente repetiu várias vezes. $\mathrm{O}$

\footnotetext{
${ }^{284}$ Segundo a docente, esta aluna também repete este comportamento em sala de aula. Esta aluna realizou o outro instrumento (questionário), em seguida, com facilidade.
} 
painel ilustrado (Quadro 40) auxiliou no entendimento das perguntas, pois o aluno percebia que o tema se referia à escola através das alternativas de resposta.

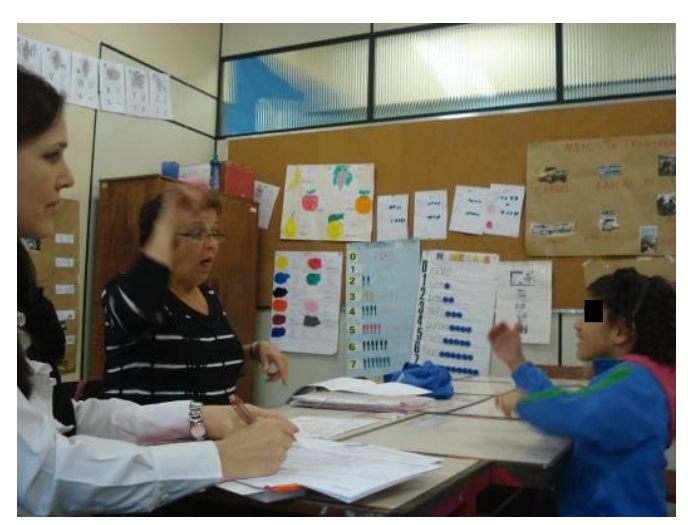

(a)

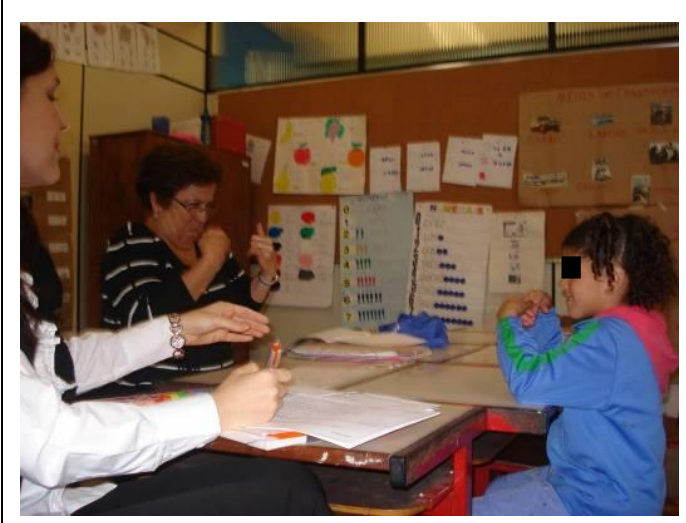

(b)

Figura 70 - Docente e aluna M., de 6 anos, surda, se comunicavam em LIBRAS na entrevista lúdica, e a pesquisadora anotou a verbalização da docente.

A pesquisadora anotou a verbalização da docente que interpretou as respostas dos alunos em LIBRAS. Ao término das perguntas da entrevista, a docente solicitou aos alunos a descrição do significado dos símbolos desenhados (a pedido da pesquisadora), sendo anotadas estas informações. A docente elogiou os desenhos realizados e perguntou se a pesquisadora poderia ficar com eles como um presente. Os alunos concordaram e entregaram os desenhos.

A seguir serão apresentados os Quadros 48 e 49 relativos a algumas sínteses dos resultados da entrevista lúdica com desenho temático destinada aos alunos surdos. 


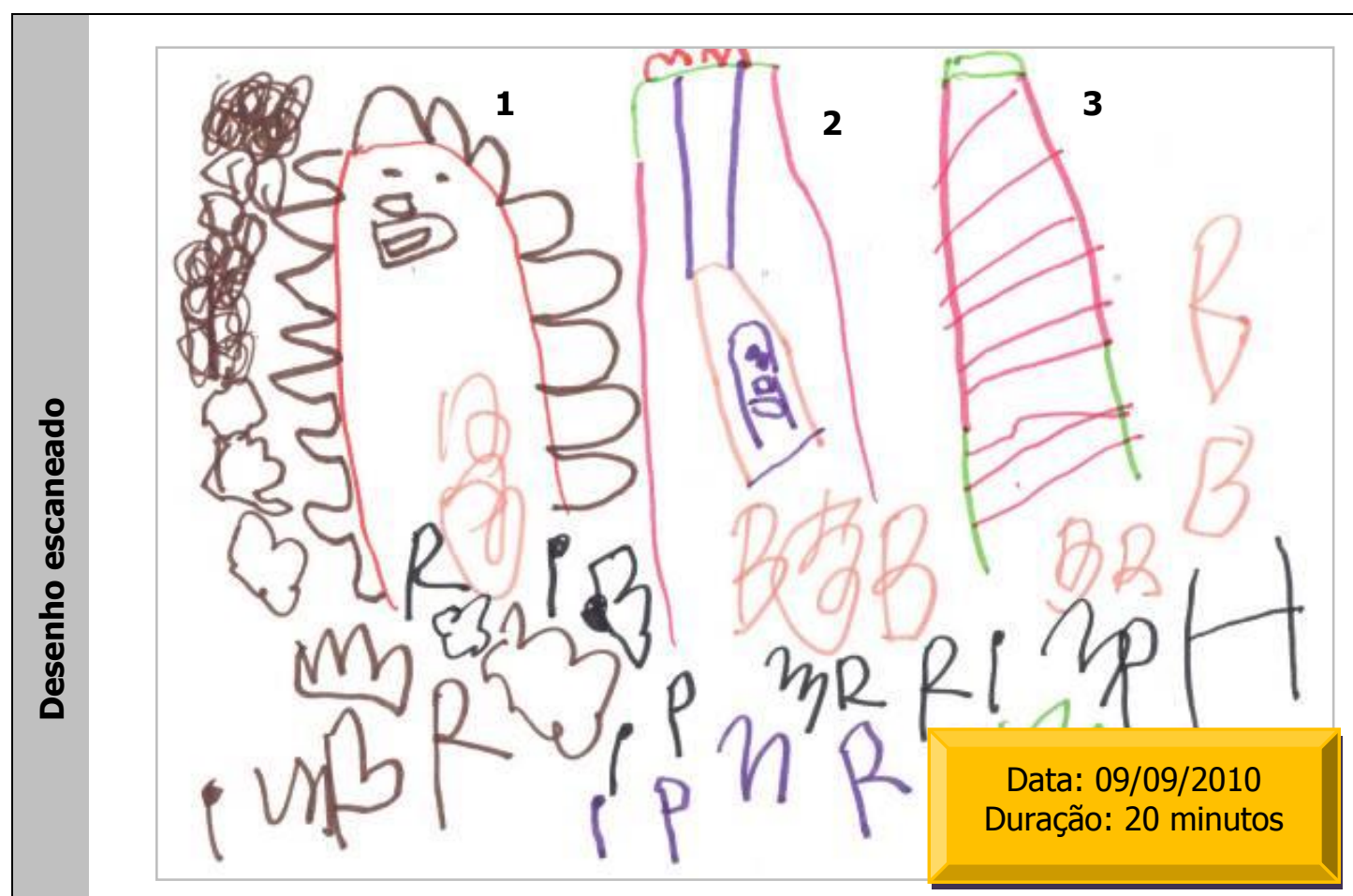

Cores eleitas pela aluna na confecção do desenho: verde claro, roxo, lilás, rosa, vermelho, preto e marrom.

Interpretação da LIBRAS da aluna ${ }^{285}$ pela docente:

> Símbolos desenhados: 1: "Tanque de areia" ; 2: "Balanço"; 3: "Escada do escorregador".

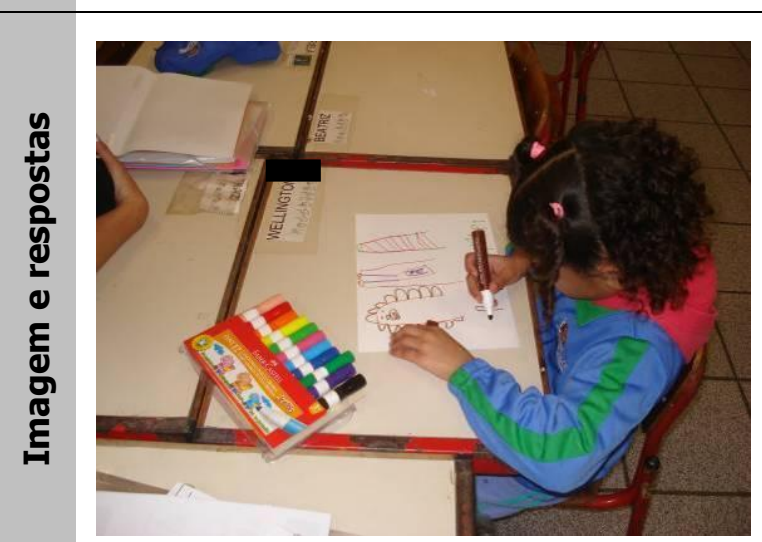

Respostas da entrevista:

1. "Parquinho."

2. "Porque ela gosta de subir, escorregar, brincar."

3. "Sala de aula."

4. Não entendeu a pergunta, não respondeu.

5. "Piscina."

Quadro 48 - Síntese da entrevista lúdica com desenho temático destinada a aluna M., de 6 anos, surda, da unidade-caso 2 na $2^{a}$ etapa da pesquisa.

${ }^{285}$ Participou da etapa anterior da pesquisa. 


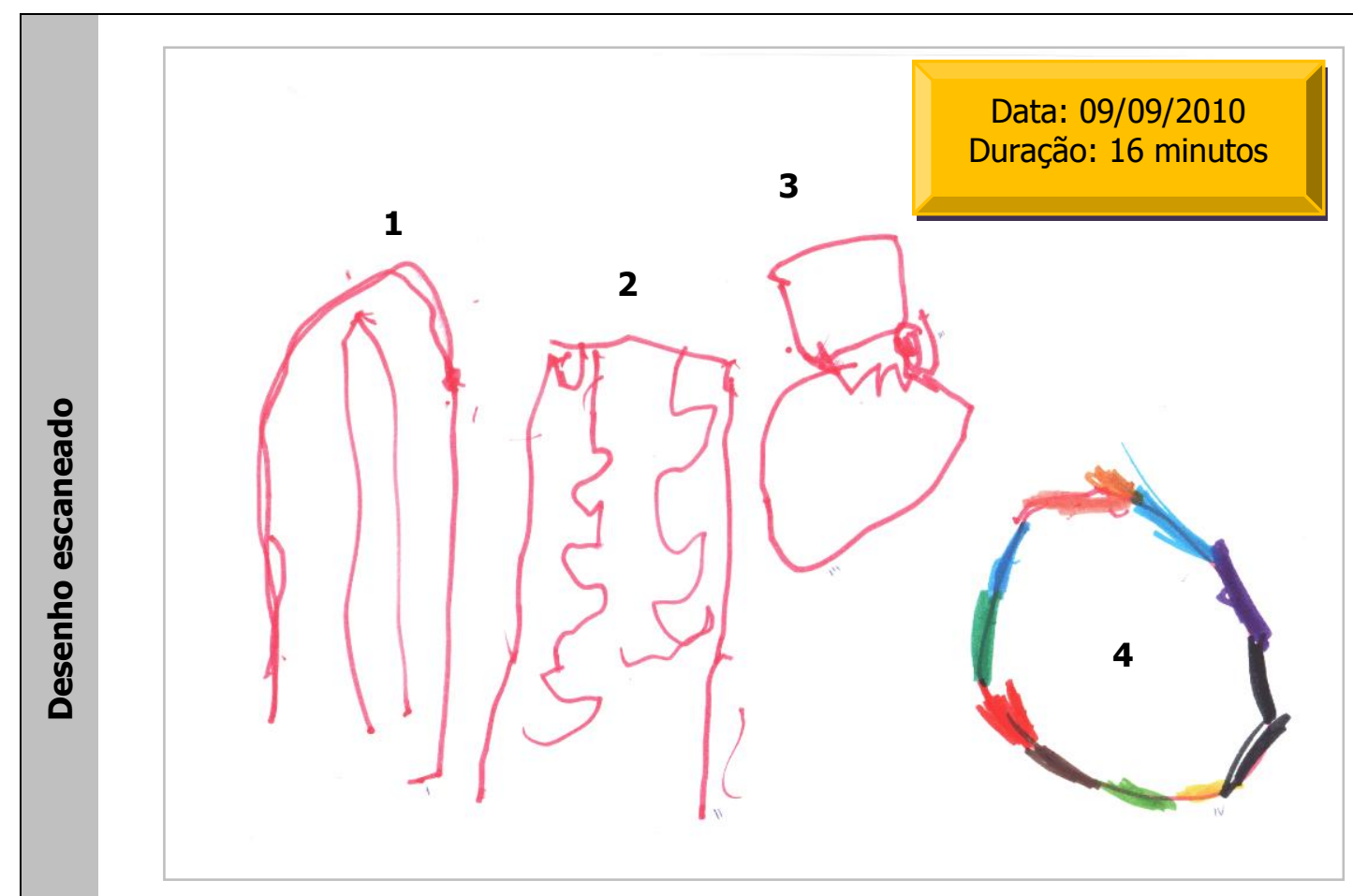

Cores eleitas pela aluna na confecção do desenho: verde claro, verde escuro, roxo, lilás, rosa, vermelho, preto, marrom, laranja e amarelo.

Interpretação da LIBRAS da aluna ${ }^{286}$ pela docente:

> Símbolos desenhados: 1: "Escorregador"; 2: "Parquinho"; 3: "Computador"; 4: "Gira-gira".

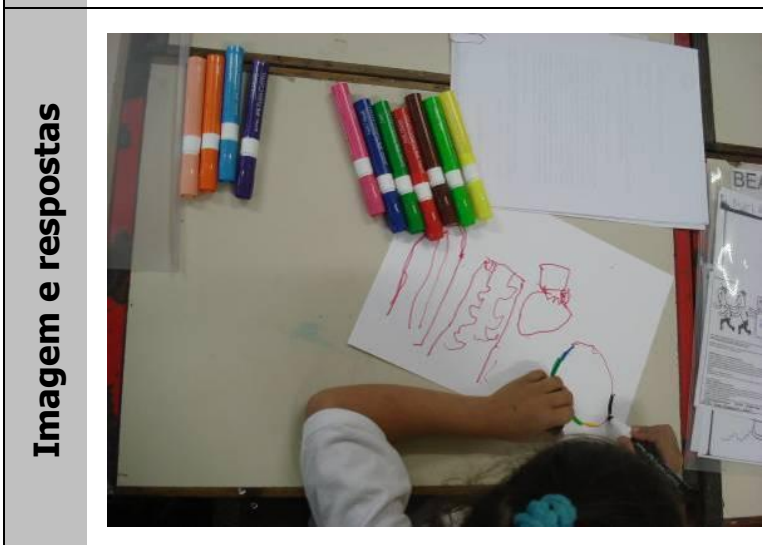

Respostas da entrevista:

1. "Sala de informática... e parquinho."

2. A aluna não conseguiu entender a pergunta (muito abstrata).

3. "Bosque."

4. Idem alternativa 2.

5. "Piscina."

Quadro 49 - Síntese da entrevista lúdica com desenho temático destinada à aluna K., de 6 anos, surda, da unidade-caso 2 na $2^{\mathrm{a}}$ etapa da pesquisa.

${ }^{286}$ Participou da etapa anterior da pesquisa.

ABATE, Tania Pietzschke 


\subsubsection{Alunos com PC: resultados da unidade-caso 3}

Na segunda etapa da pesquisa, a entrevista lúdica com desenho temático na unidade-caso 3 destinou-se a todos os alunos com deficiência física matriculados ${ }^{287}$ (15 alunos - ver Tabela 6) nas duas classes de pré-escola existentes. A entrevista lúdica com desenho temático ocorreu nos dias 3/11/2010 (uma classe com 8 alunos), 8/11/2010 (outra classe com 4 alunos) e 9/11/2010 (3 alunos faltantes nas datas de aplicação anteriores de ambas as classes).

O processo de aplicação foi similar ao da primeira etapa da pesquisa, havendo o diferencial de que as perguntas da entrevista foram realizadas somente após o término do desenho 288 no qual usou-se a caneta hidrográfica e papel mais apropriados $^{289}$. Somente na segunda etapa da pesquisa, passado um ano e com um maior vínculo de confiança com as docentes, a pesquisadora foi convidada a realizar o desenho temático de forma conjunta com aqueles alunos que apresentavam maiores comprometimentos motores nos membros superiores.

O início da entrevista lúdica com desenho temático foi aplicada em todos os alunos (ao mesmo tempo) de cada uma das três classes, em função da equipe de apoio disponibilizada pela instituição, composta por 3 ou 4 voluntários ${ }^{290}$, pela docente, além do apoio indireto de duas cuidadoras responsáveis pelo acompanhamento dos alunos ao banheiro. A pesquisadora orientou previamente a equipe de voluntários a

\footnotetext{
${ }^{287}$ Todos os alunos matriculados participaram da pesquisa, pois todos foram considerados aptos.

${ }^{288}$ Com o apoio de alternativas ilustradas em um painel (Quadros 41 e 43).

289 Ver demais modificações no item 7.2.3.2 b).

${ }^{290}$ Sendo que cada classe contava com uma equipe de voluntários diferente.
} 
não interferir na escolha do tema específico a ser eleito pelo aluno (ambiente que mais gosta na escola), bem como na escolha de cores ou formas no desenho dos alunos $^{291}$.

O processo de aplicação descrito a seguir ocorreu de forma similar nas três aplicações: a maioria dos alunos se encontrava sentada em suas respectivas cadeiras de rodas com as mesas acopladas. A pesquisadora convidou os alunos a fazerem um desenho segundo o tema proposto, entregando-lhes um jogo de canetas hidrográficas e uma folha em branco, que foi presa às mesas com a fita adesiva pelos voluntários. Em seguida explicou-lhes que não poderiam olhar o desenho dos colegas e, principalmente, que não havia certo ou errado, pois o importante era a opinião de cada um. Os alunos não foram interrompidos até que declarassem o término do desenho. Em conjunto, a pesquisadora e docente realizaram perguntas relativas aos aspectos gerais da escola ${ }^{292}$, a cada aluno, individualmente. Foram anotadas as respostas das perguntas e a descrição dos símbolos desenhados, tanto as verbalizadas como as indicadas nas pranchas, pastas de CAA (alunos sem fala funcional) ou no painel de apoio. Aos alunos sem fala funcional foram sugeridos verbalmente vários significados aos símbolos desenhados, dentro da temática do desenho, para que respondessem sim ou não por meio da técnica da varredura ou elegessem um símbolo em PCS em sua pasta ou prancha de CAA. O nível de dificuldade para confeccionar o desenho e para responder a entrevista se apresentou

\footnotetext{
291 Auxiliando somente no caso dos alunos sem coordenação nos membros superiores, em tarefas como prender as folhas na mesa com fita crepe e recolher o que caísse no chão, os ajudando a pegar o lápis ou giz de cera, além de lhes sustentar o braço deixando a eles o comando da direção do traço através de sua própria força.

292 Ver Quadro 38.
} 
de forma variável em função do nível de comprometimento global e do tipo de paralisia cerebral (PC) recorrente nos alunos.

A seguir é descrito o processo de aplicação da entrevista lúdica com desenho temático destinado a aluna A. de 10 anos, que ocorreu de forma similar em cerca de $30 \%$ dos alunos com maior comprometimento dos membros superiores (não os movimentavam de forma ordenada), todos usuários de CAA e sem fala funcional. Estes alunos realizaram, de forma dependente, os atos de desenhar e de responder a entrevista (através da CAA - técnica da varredura ${ }^{293}$ ). A docente prendeu a folha da aluna com fita crepe na mesa (Figura 71a) e apontou para as canetas hidrográficas, uma a uma, por meio da técnica da varredura (Figura 71b), até que a aluna elegesse uma delas através de um movimento voluntário (mexer a cabeça).

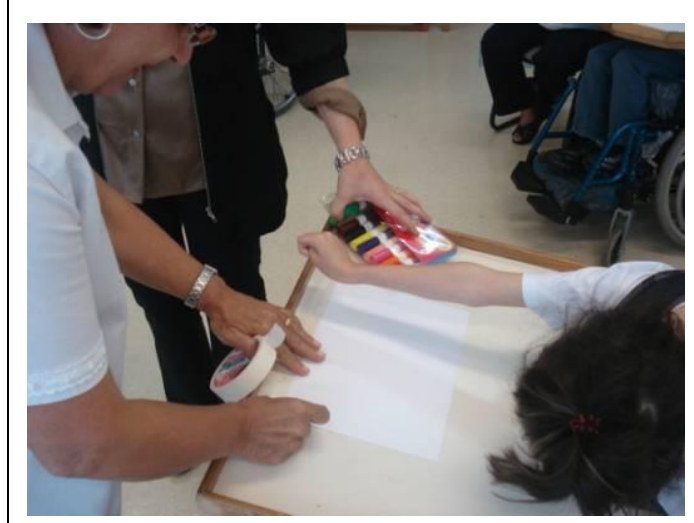

(a)

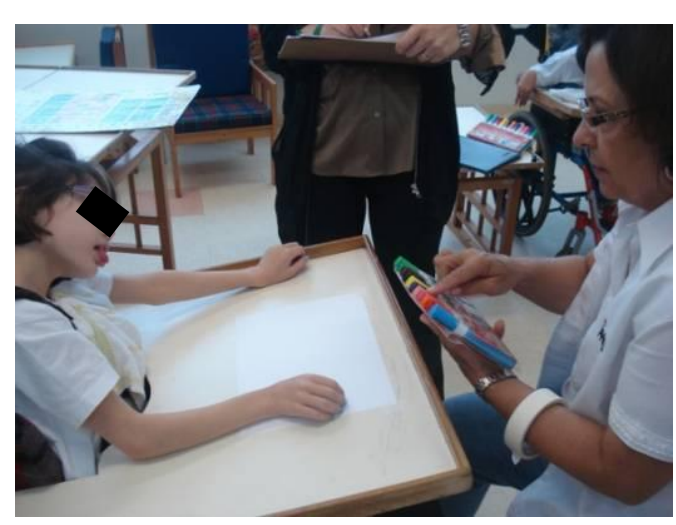

(b)

Figura 71 - A docente fixou o papel à mesa (a) e apontou para as canetas, uma a uma, para que a aluna A., de 10 anos, com PC (b) elegesse uma cor.

A docente encontrou dificuldade para posicionar a caneta na mão da aluna (Figura 72) e solicitou-lhe que relaxasse a mão. Esse processo se repetiu a cada troca de cores das canetas (cerca de 10 vezes).

${ }^{293}$ A docente apontava o símbolo ou figura e o aluno respondia através de um movimento voluntário. 


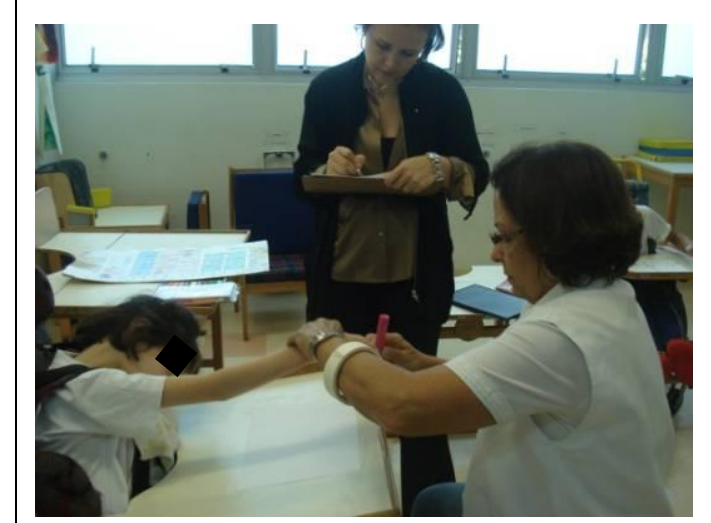

(a)

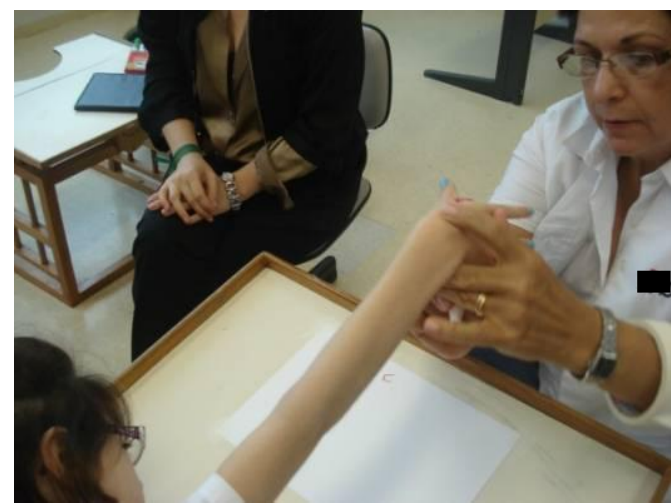

(c)

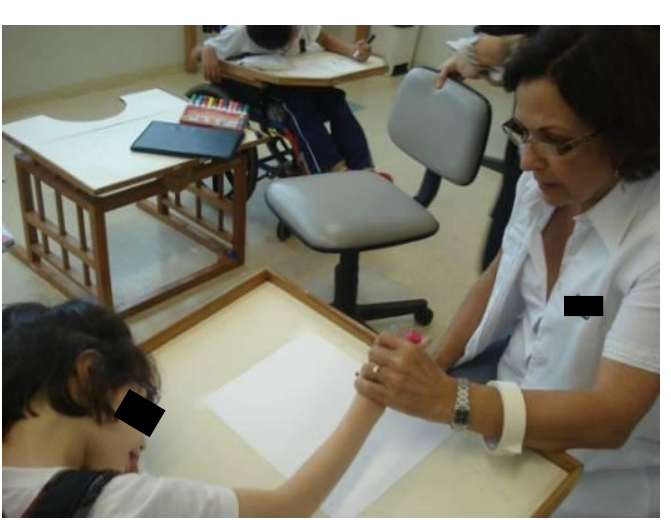

(b)

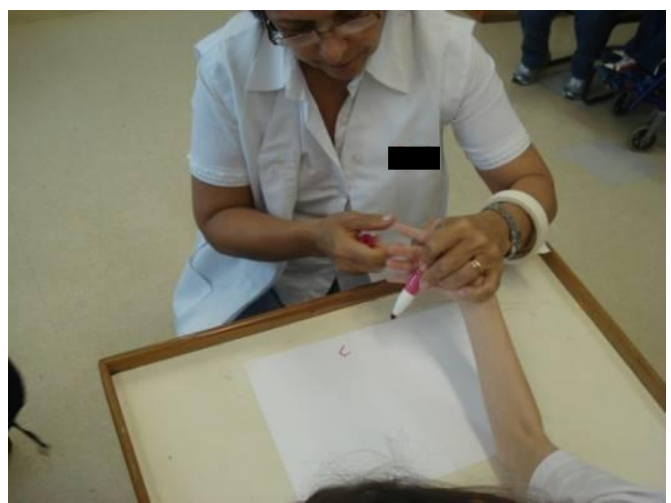

(d)

Figura 72 - Docente posicionou a mão da aluna A., de 10 anos, com PC, para pega da caneta para o início do desenho temático.

Quando a docente conseguiu finalmente posicionar a mão da aluna na caneta, se iniciou o desenho conjunto aluna-docente (Figura 73a-c). Em seguida, a docente convidou a pesquisadora a auxiliar a aluna A. na confecção do desenho (Figura 73d). 


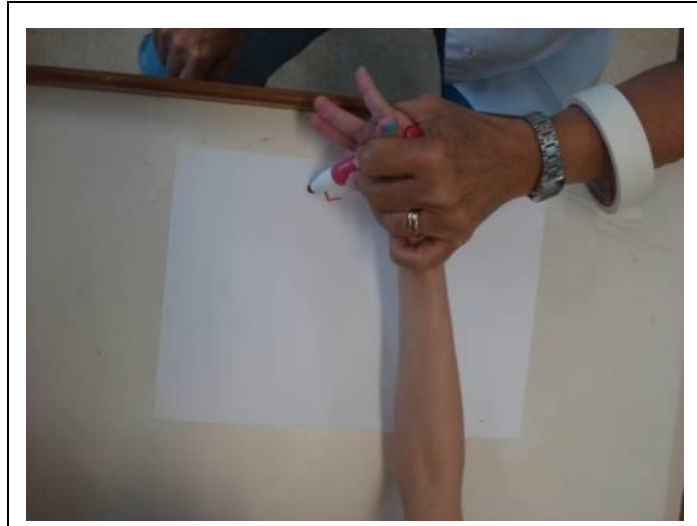

(a)

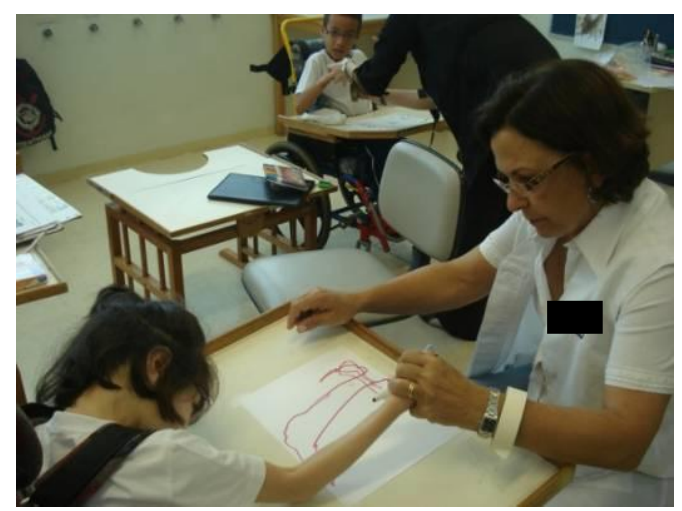

(c)

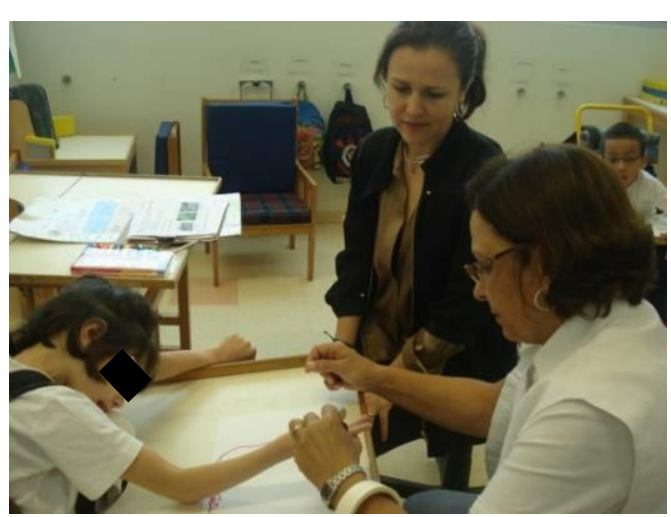

(b)

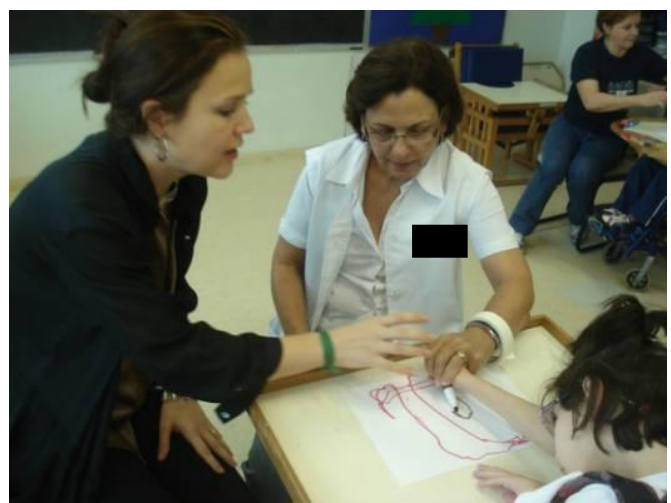

(d)

Figura 73 - A docente auxiliou a aluna A., de 10 anos, com PC, na confecção do desenho temático (a-c) e a pesquisadora iniciou a mesma tarefa de forma conjunta (d).

Durante esta atividade a pesquisadora verificou que o traço era comandado pela aluna, que exercia uma força direcionada sobre a caneta. Assim buscou apenas manter o braço da aluna suspenso, segurando delicadamente sua mão (que não apresentava pega na caneta), pressionando-a junto à caneta permitindo o contato com o papel (Figura 74). Quando a aluna deixou de exercer a força na caneta foi o indicativo de que havia terminado este trecho do desenho, e uma nova troca de cor da caneta era oferecida. 


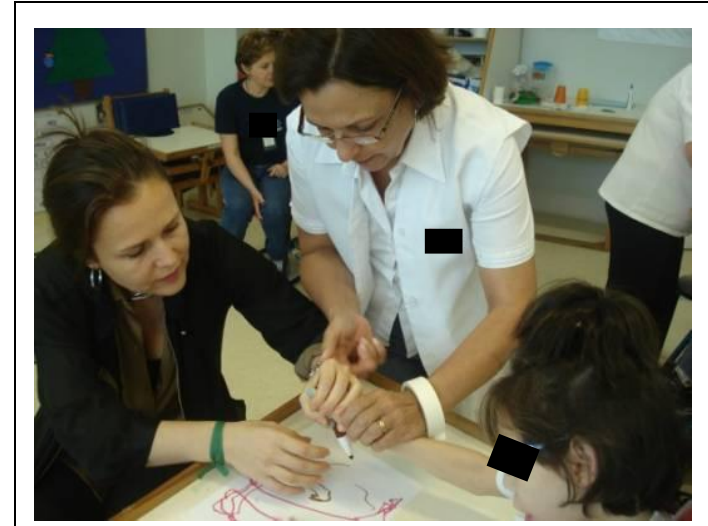

(a)

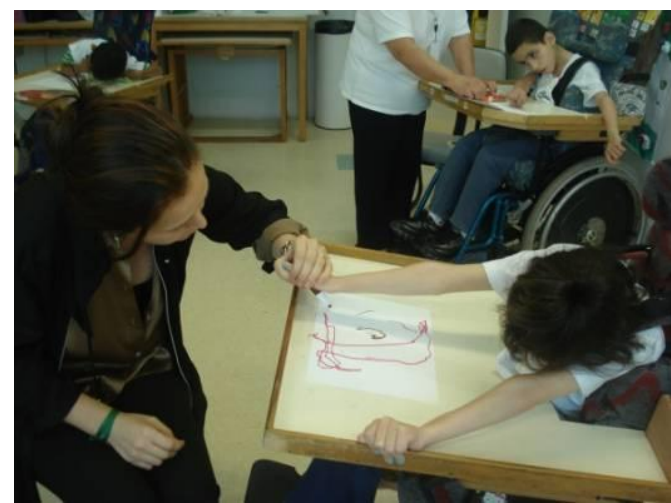

(c)

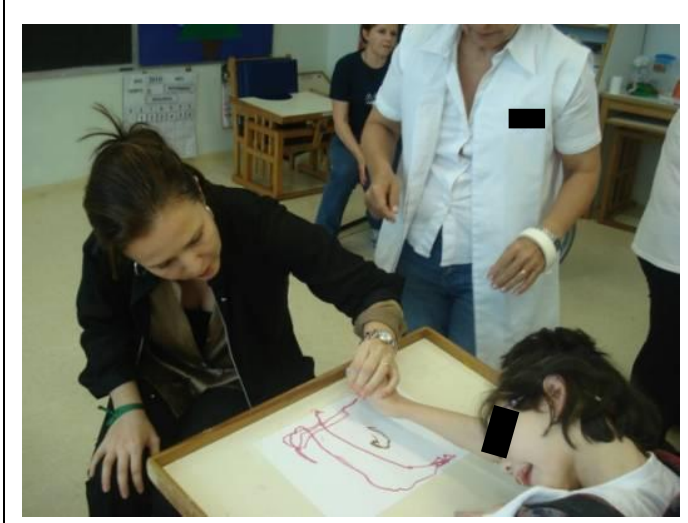

(b)

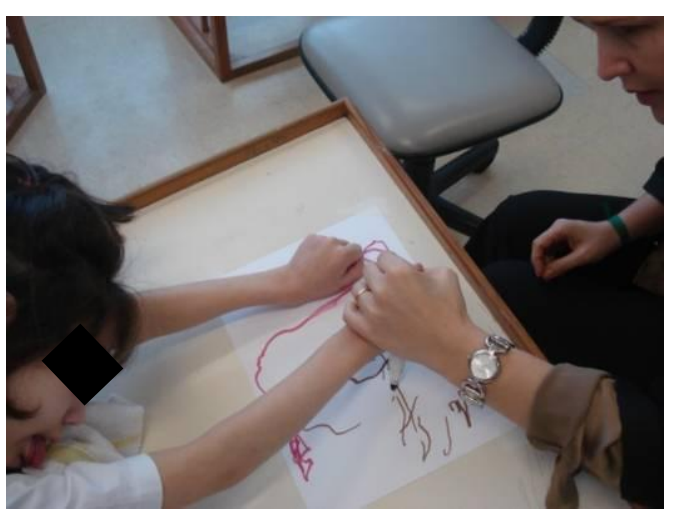

(d)

Figura 74 - Pesquisadora auxiliou a aluna A., de 10 anos, com PC, na confecção do desenho temático.

Logo a docente retomou seu posicionamento inicial junto à aluna, auxiliou-a até o término do desenho, e aplicou verbalmente as perguntas da entrevista lúdica (Figura 75a). Como a aluna não apresentava fala funcional e nem movimentava de forma coordenada os membros superiores, a docente utilizou a técnica da varredura apontando para cada alternativa do painel ilustrado ${ }^{294}$ (Figura 75b) e do Quadro 43 (Figura 75c), com o apoio da prancha de CAA de uso da aluna (Figura 75d), que indicava a alternativa eleita através do movimento consciente com a cabeça. A pesquisadora anotou as respostas indicadas verbalmente pela docente.

${ }^{294}$ Quadro 41. 


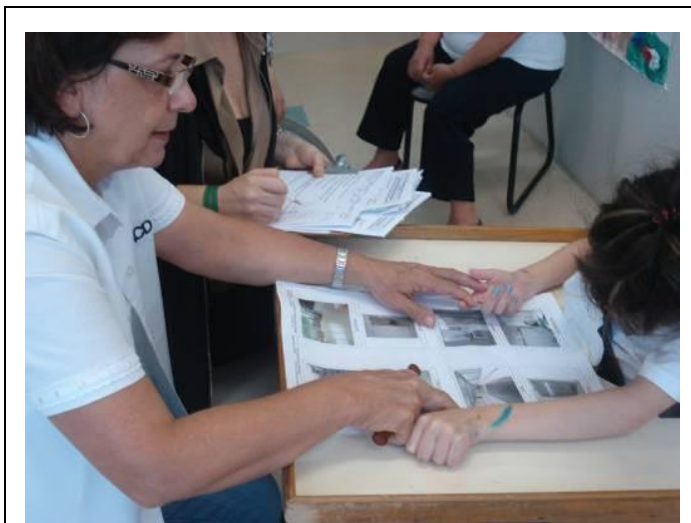

(a)

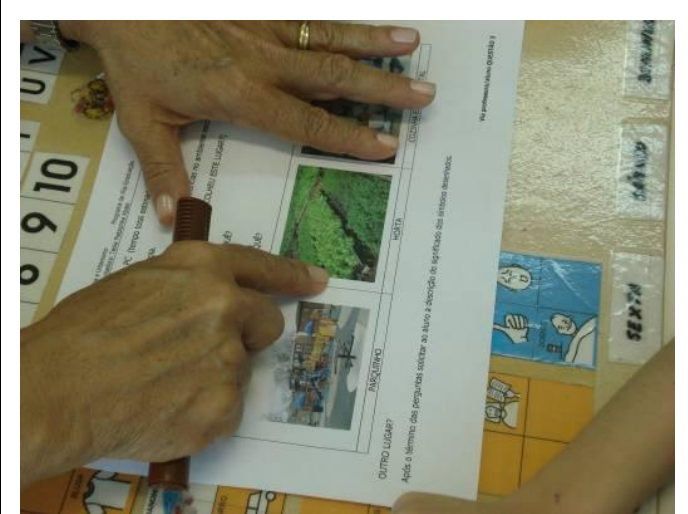

(c)

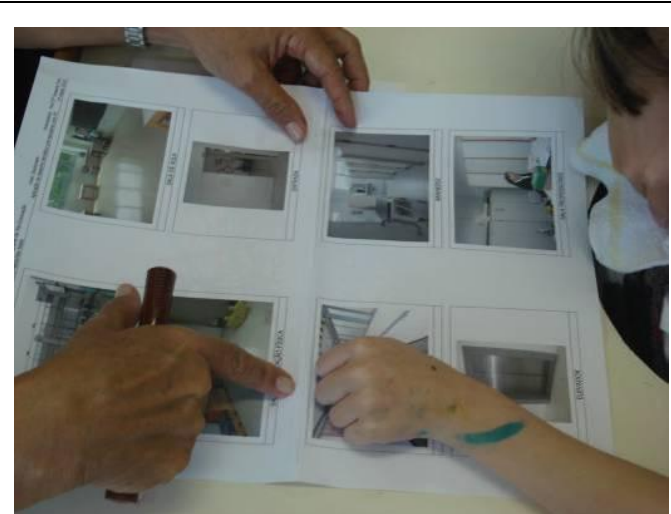

(b)

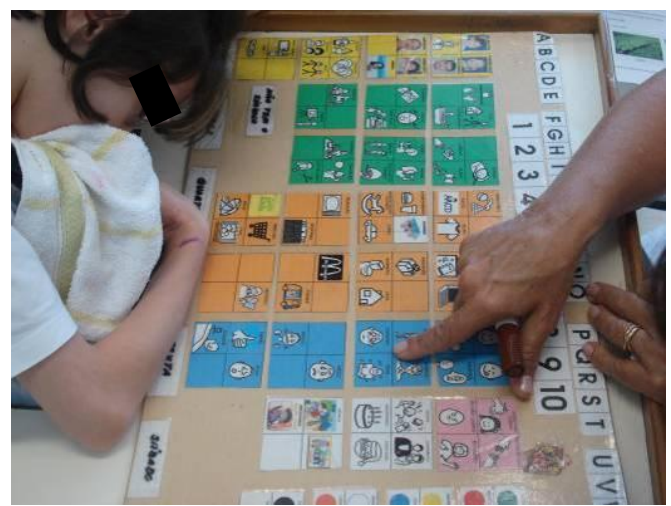

(d)

Figura 75 - Entrevista lúdica com aluna A., de 10 anos, com PC.

Em relação aos símbolos desenhados, a docente perguntou verbalmente se a trave do gol estava desenhada (o tema do desenho era a quadra), e posteriormente se própria aluna estava desenhada e, por varredura, ela indicou não em ambas as perguntas. A docente perguntou se todo o desenho representava a quadra e a aluna indicou que sim. A seguir é apresentado o Quadro 50 com o desenho escaneado e as respostas da entrevista lúdica destinada a aluna $\mathrm{A}$. 


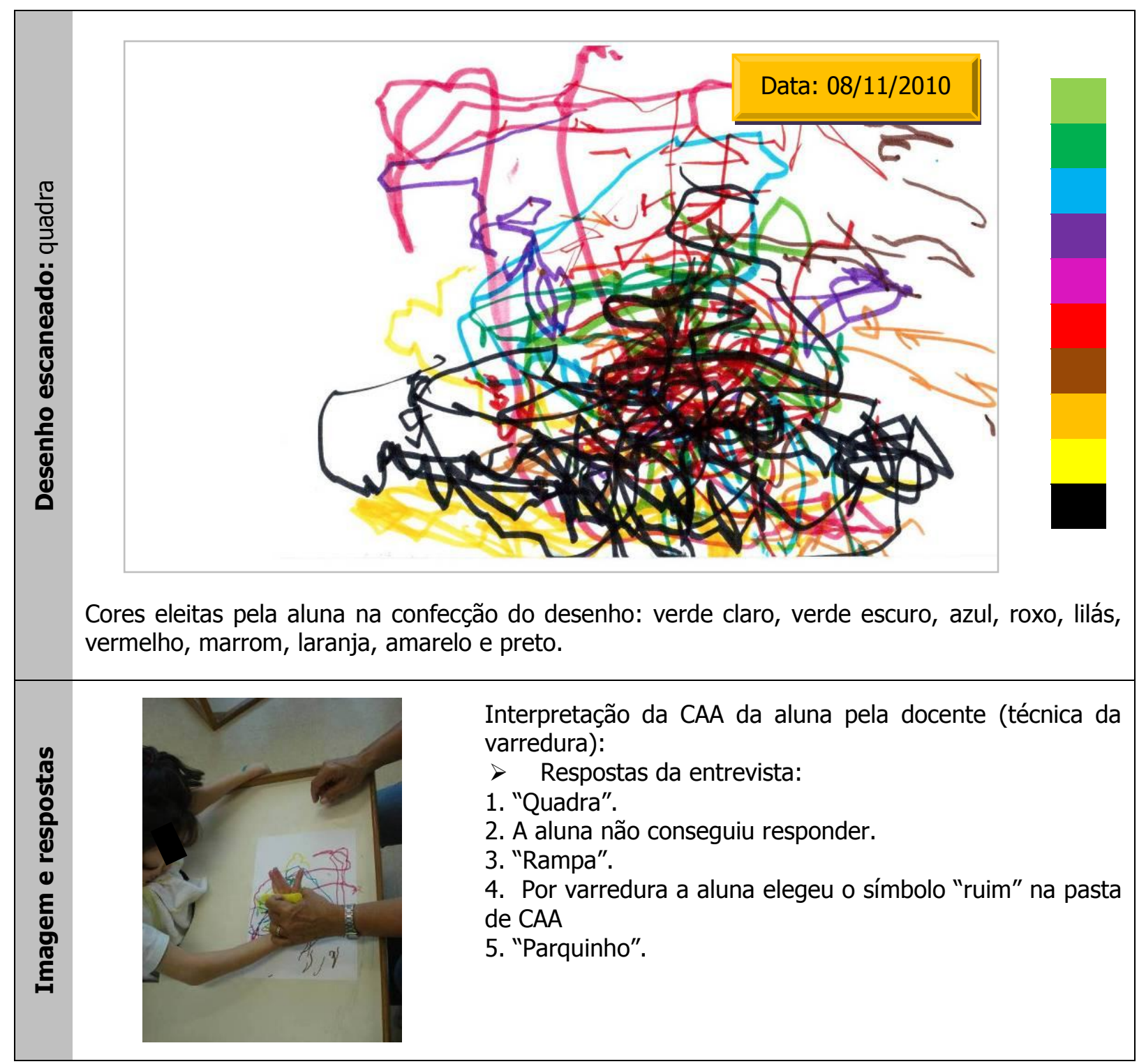

Quadro 50 - Síntese da entrevista lúdica com desenho temático destinada a aluna A., de 10 anos, com $\mathrm{PC}$, da unidade-caso 3 na $2^{\mathrm{a}}$ etapa da pesquisa.

A seguir é descrito outro processo de aplicação da entrevista lúdica com desenho temático que ocorreu de forma similar em cerca de $20 \%$ dos alunos apresentaram menor comprometimento dos membros superiores e usuários de CAA (sem fala funcional). Esses alunos desenharam de forma independente, porém com diferentes graus de dificuldade, pois conseguiam sustentar o próprio braço e desenhar sem auxílio (Figura 76). Alguns desses alunos necessitaram de ajuda somente para o posicionamento da mão após a troca da caneta. 


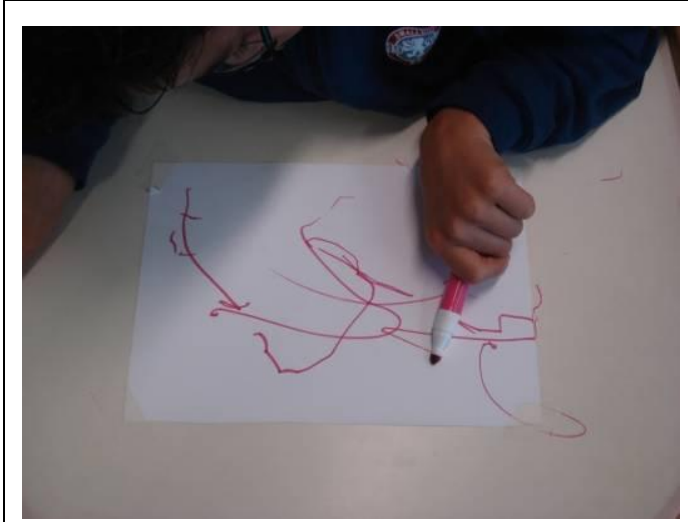

(a)

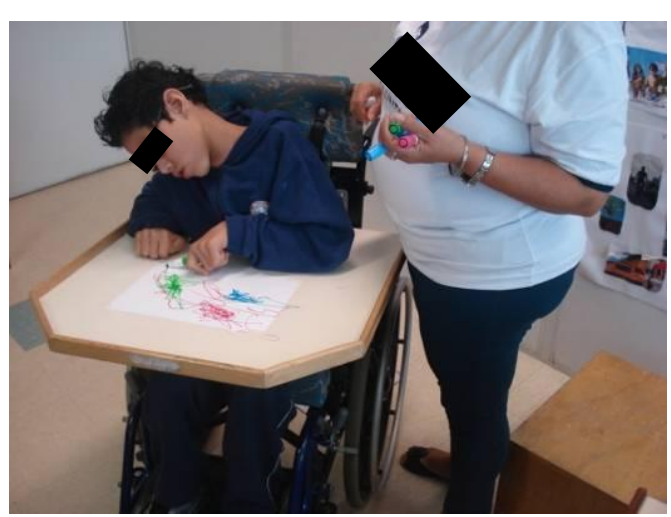

(b)

Figura 76 - Aluno M., de 8 anos, com PC, segurou a caneta sozinho e realizou os traços do desenho (a), a voluntária permaneceu ao seu lado para auxiliar na troca das canetas e posicionamento da mão do aluno (b).

Após o término do desenho indicado pelo aluno, a docente realizou verbalmente as perguntas da entrevista lúdica. Como o aluno não apresentava fala funcional e movimentava os membros superiores com dificuldade, porém de forma coordenada, utilizou-se a técnica da seleção direta - apontando a alternativa de resposta eleita no painel ilustrado 295 (Figura 77a, b) e no Quadro 43 (Figura 77c, d), não sendo necessária a utilização da prancha de CAA de uso do aluno. A pesquisadora anotou as respostas indicadas verbalmente pela docente.

295 Quadro 41. 


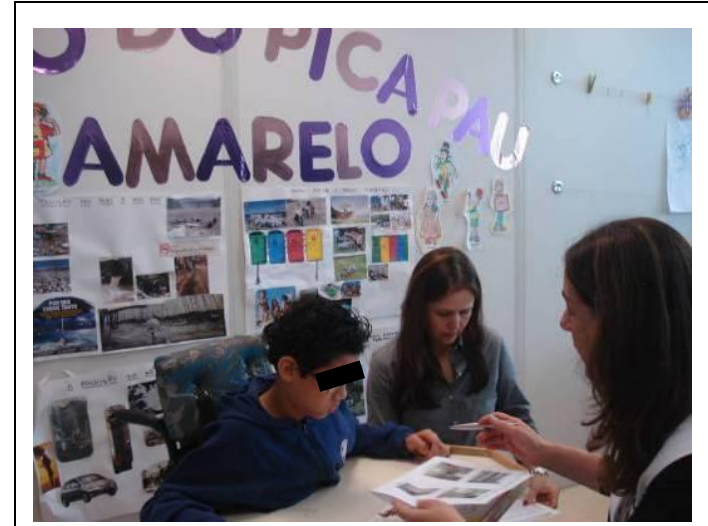

(a)

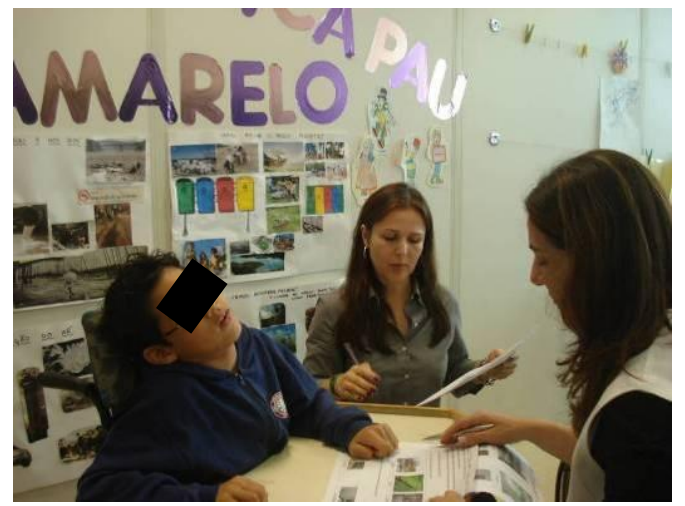

(c)

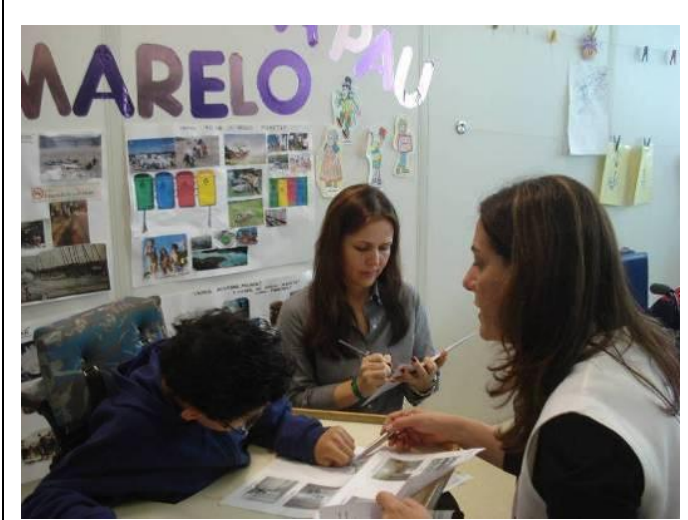

(b)

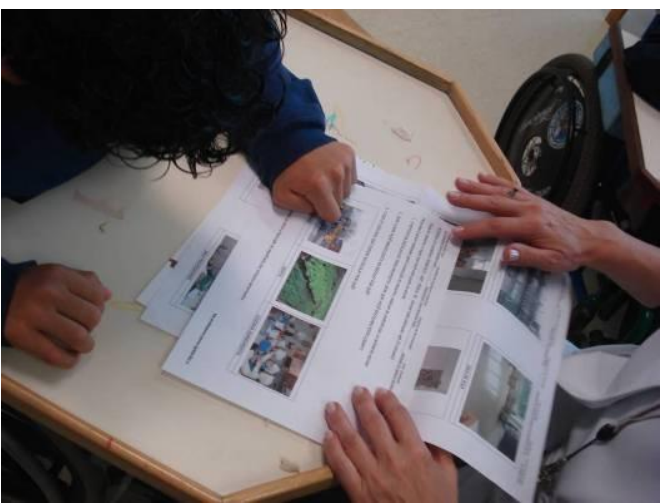

(d)

Figura 77 - A docente realizou verbalmente as perguntas da entrevista $(a, c)$, o aluno M., de 8 anos, com PC, indicou com a mão a alternativa eleita nos Quadro 41 e 43, respectivamente $(b, d)$.

Em relação aos símbolos desenhados, a docente perguntou verbalmente onde se localizavam a sala de educação física e a sala de aula (temas eleitos para o desenho pelo aluno) e, por seleção direta, o aluno as indicou (Figura 78). 


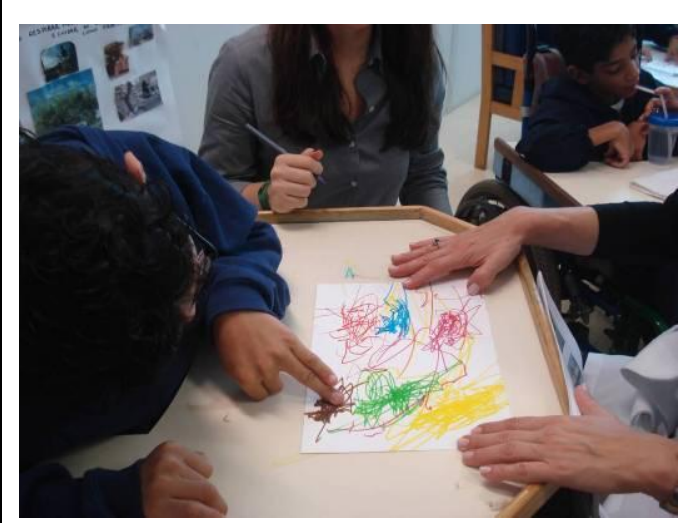

(a)

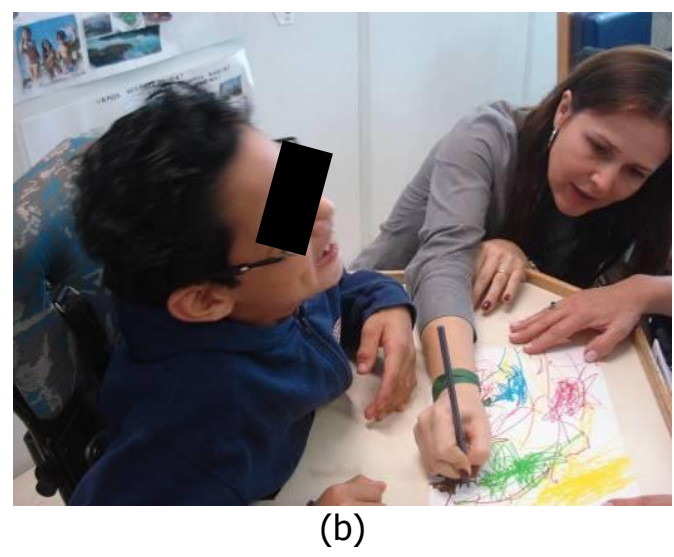

(b)

Figura 78 - $\mathrm{O}$ aluno M., de 8 anos, com PC, indicou o símbolo desenhado após verbalização do mesmo pela docente (a) e a pesquisadora anotou o número no símbolo e relacionou seu significado em sua planilha de anotações (b).

A seguir é apresentado o Quadro 51 com o desenho escaneado e as respostas da entrevista lúdica destinada ao aluno M. de 8 anos com PC. 


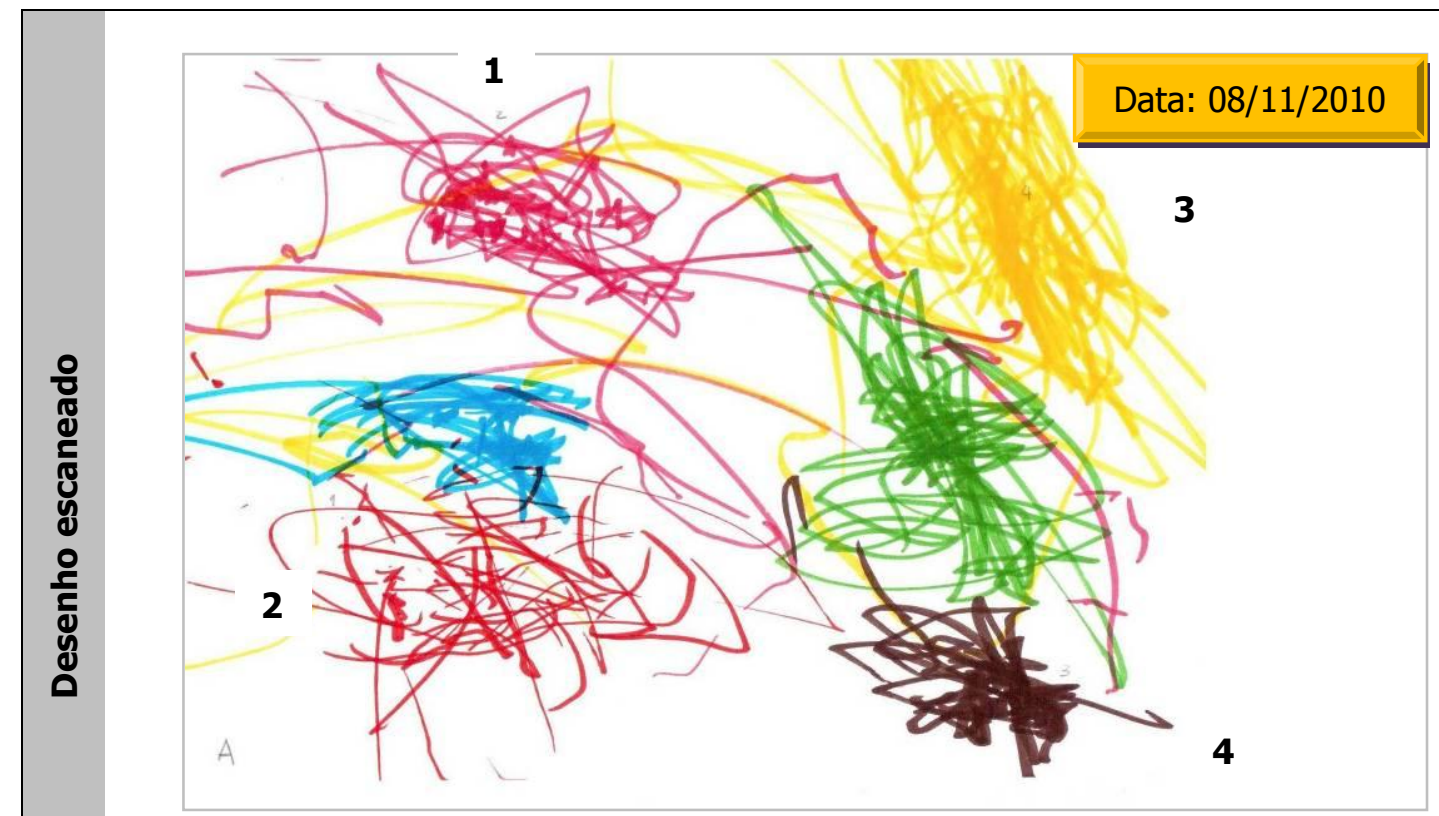

Cores eleitas pelo aluno na confecção do desenho: verde claro, azul, lilás, vermelho, marrom e amarelo. Interpretação da CAA do aluno pela docente:

$>$ Símbolos desenhados:

1: "Sala de educação física"; 2: "Sala de aula"; 3: "Quadra" e 4: "BWC".

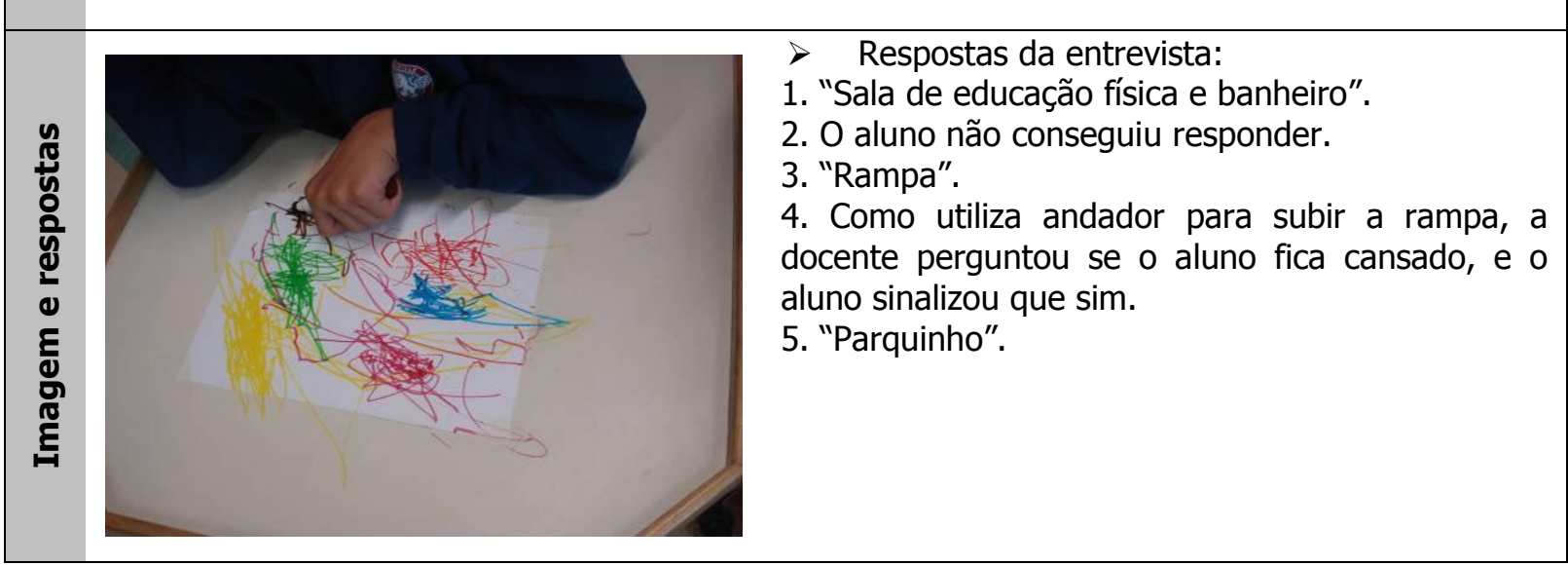

Quadro 51 - Síntese da entrevista lúdica com desenho temático destinada ao aluno M. de 8 anos com PC da unidade-caso 3 na $2^{a}$ etapa da pesquisa.

Cerca de $50 \%$ dos alunos com PC desenharam com independência e responderam a entrevista verbalmente (alguns deles exemplificados na Figura 79), com variados graus de dificuldades para ambas as tarefas, pois apresentavam fala funcional, e menor comprometimento dos membros superiores (os movimentavam de forma coordenada). 


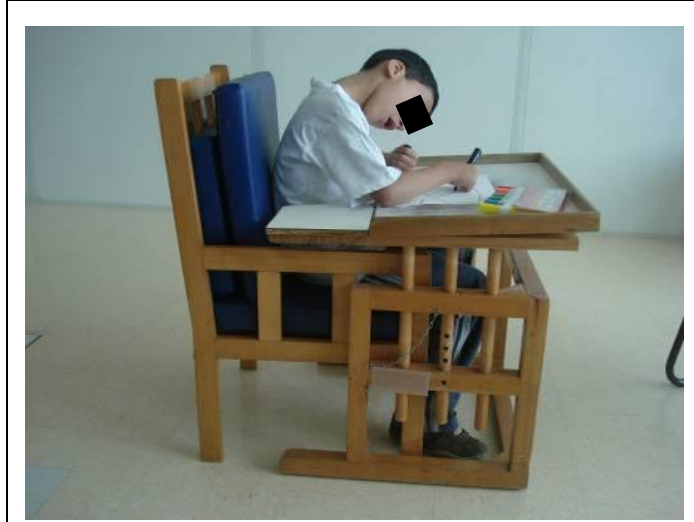

(a)

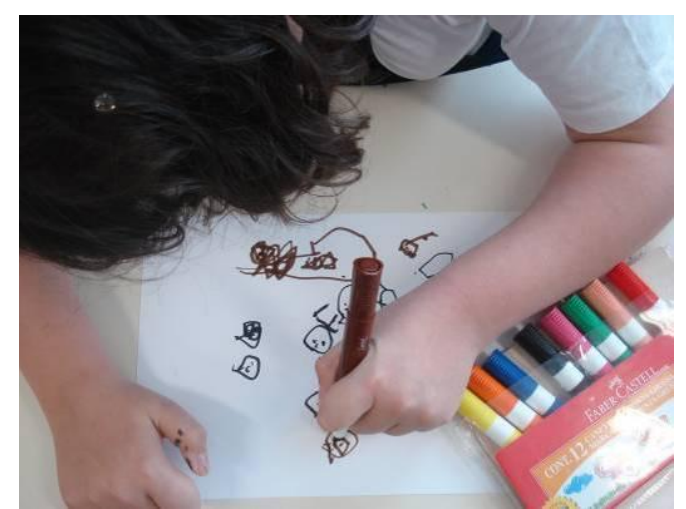

(c)

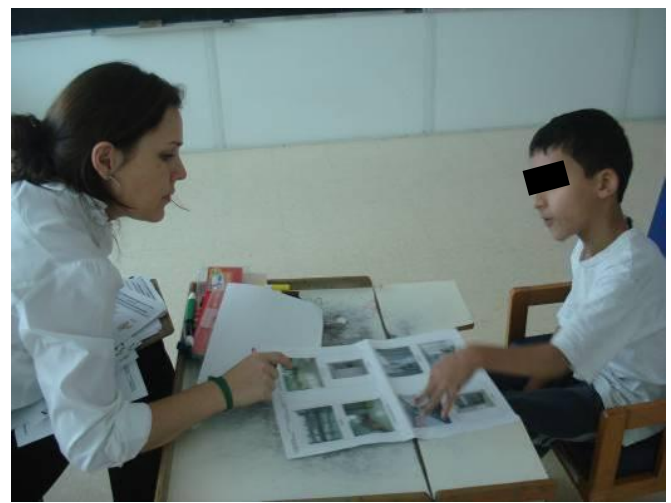

(b)

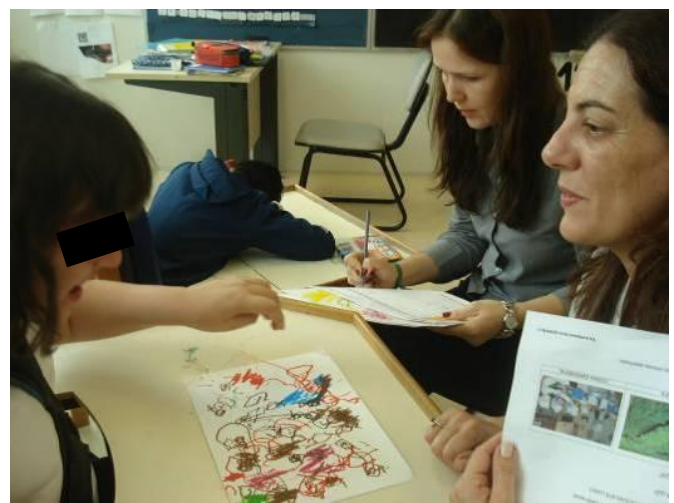

(d)

Figura 79 - Dois alunos, com PC, desenharam com independência $(a, c)$ e responderam a entrevista verbalmente, com diferentes graus de dificuldade $(b, d)$.

A seguir serão apresentadas as sínteses das entrevistas lúdicas realizadas pelos alunos E. de 8 anos com PC e P. de 8 anos com distúrbio da medula espinhal (Quadros 52 e 53, respectivamente). Ambos participaram da primeira etapa da pesquisa realizada no ano anterior. 
O aluno E. de 8 anos com PC, apresentava dificuldade na articulação da fala e na coordenação motora dos membros superiores (apresentava movimentação involuntária), bom desenvolvimento cognitivo e era usuário de cadeira de rodas.

Realizou o desenho sem auxílio e respondeu as perguntas da pesquisadora em parte verbalmente e em parte com a indicação dos símbolos na prancha de CAA.
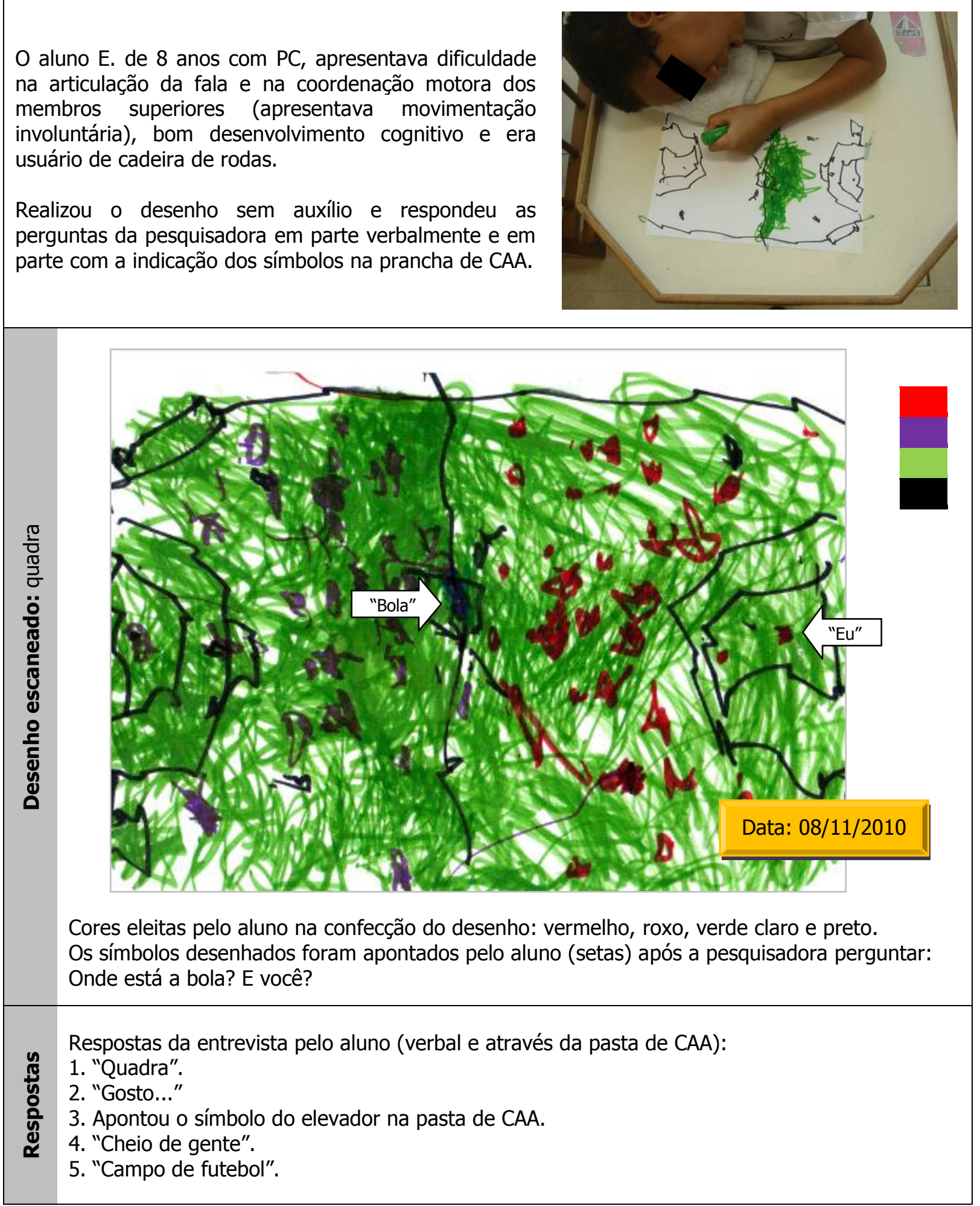

Quadro 52 - Síntese da entrevista lúdica com desenho temático destinada ao aluno E., de 8 anos, com PC, da unidade-caso 3 na $2^{\mathrm{a}}$ etapa da pesquisa. 
A aluna P., de 8 anos, com distúrbio da medula espinhal (única aluna que não tinha PC da unidadecaso 3), apresentava ótima fala e coordenação motora dos membros superiores, bom desenvolvimento cognitivo e era usuária de cadeira de rodas. Realizou com habilidade e sem auxílio o desenho, e respondeu as perguntas da pesquisadora verbalmente.
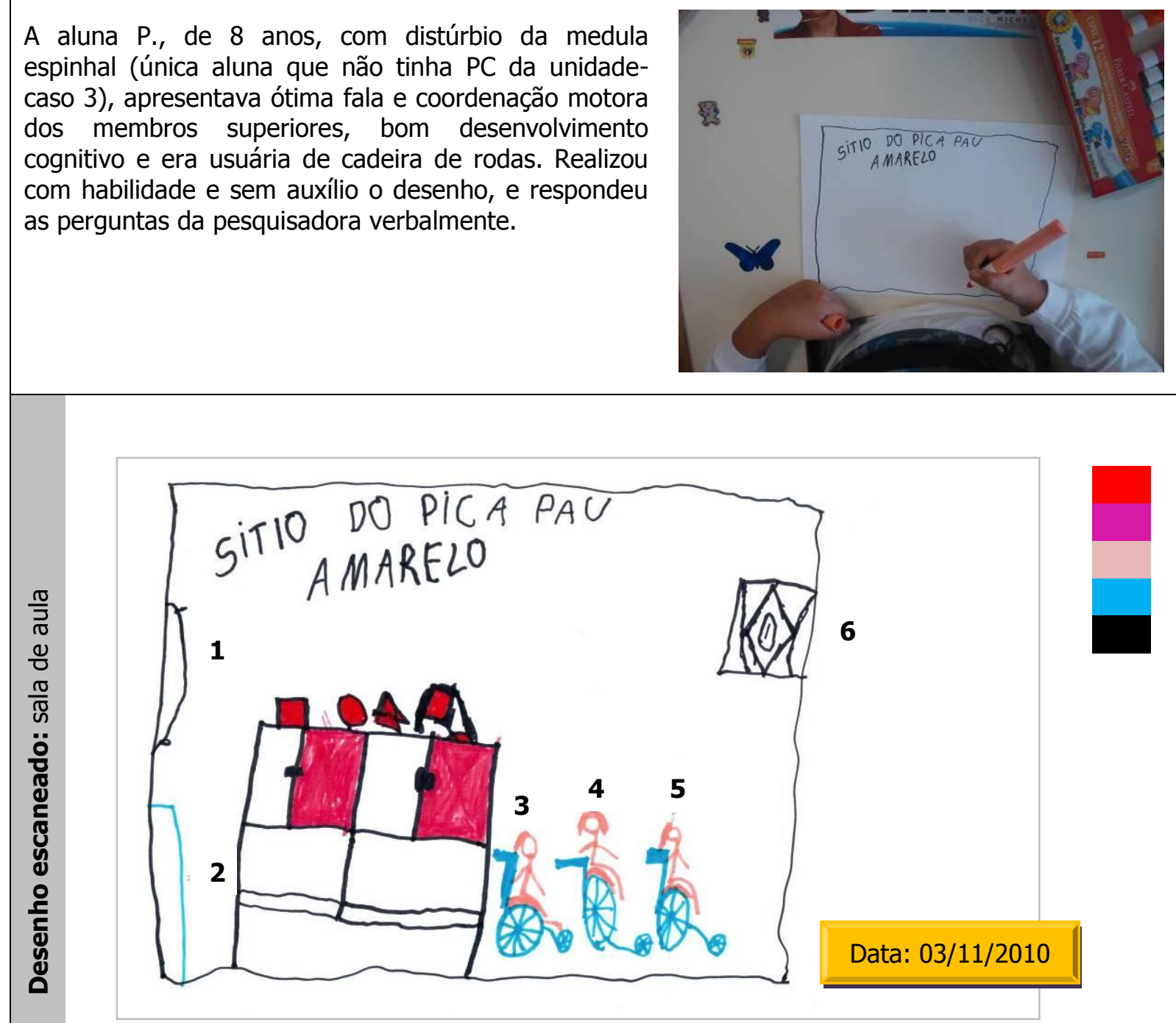

Cores eleitas pela aluna na confecção do desenho: vermelho, lilás, rosa, azul e preto.

Os símbolos desenhados foram descritos verbalmente pela aluna:

1) "Janela"; 2) "Porta"; 3) "Eu"; 4) "Luiza"; 5) "Vitório"; 6) "Bandeira do Brasil" (existente na sala)

Respostas da entrevista pela aluna (verbal):

Æ̇ 1. "Sala de aula."

ॠू. "Porque eu gosto, me sinto bem."

3. "Gosto de tudo".

4. -

5. "Horta... gosto de cuidar das flores e do... como chama? Vegetais, legumes".

Quadro 53 - Síntese da entrevista lúdica com desenho temático destinada a aluna P., de 8 anos, com distúrbio da medula espinhal, da unidade-caso 3 na $2^{\mathrm{a}}$ etapa da pesquisa. 


\subsubsection{Análise dos resultados}

Nesta segunda etapa, todos os alunos aptos a participarem da pesquisa (Tabela 8) conseguiram realizar a entrevista lúdica de forma satisfatória ${ }^{296}$.

Tabela 8 - Distribuição dos alunos na $2^{\mathrm{a}}$ etapa da pesquisa (ano letivo de 2010) por classe de pré-escola e por tipo de deficiência nas unidades-caso.

\begin{tabular}{ccccccc}
\hline \multirow{2}{*}{$\begin{array}{c}\text { Unidade- } \\
\text { caso }\end{array}$} & $\begin{array}{c}\mathbf{N}^{\mathbf{0}} \text { de classes } \\
\text { de pré-escola }\end{array}$ & $\begin{array}{c}\text { Tipo de } \\
\text { deficiência }\end{array}$ & $\begin{array}{c}\text { Aptos a } \\
\text { participar da } \\
\text { pesquisa } \\
(1)\end{array}$ & $\begin{array}{c}\text { Não aptos a } \\
\text { participar da } \\
\text { pesquisa } \\
(2)\end{array}$ & $\begin{array}{c}\text { Total } \\
(1+2)\end{array}$ & $\begin{array}{c}\text { Aptos } \\
\text { presentes } \\
\text { nos dias } \\
\text { das } \\
\text { aplicações }\end{array}$ \\
\hline 1 & 2 & Baixa visão & $\mathbf{4}$ & 3 & 7 & $\mathbf{4}$ \\
\cline { 3 - 7 } & 2 & Cegueira & $\mathbf{7}$ & 6 & 13 & $\mathbf{6}$ \\
\hline 2 & 2 & surdez & $\mathbf{7}$ & 10 & 17 & $\mathbf{7}$ \\
\hline 3 & $\begin{array}{c}\text { Distúrbio da } \\
\text { medula } \\
\text { espinhal }\end{array}$ & $\mathbf{1}$ & 0 & 14 & $\mathbf{1 4}$ \\
\hline Total & 6 & $\mathbf{1 4}$ & $\mathbf{3 3}$ & 19 & 52 & $\mathbf{3 2}$ \\
\hline
\end{tabular}

\section{a) Entrevista lúdica com mapa tátil}

Nesta segunda etapa, os alunos cegos aptos a participarem da pesquisa na préescola na unidade-caso 1 apresentaram boas condições de coordenação motora nos membros superiores e inferiores. Todos os alunos conseguiram realizar a entrevista lúdica com mapa tátil ${ }^{297}$ de forma satisfatória, apresentaram bom nível de entendimento do enunciado e verbalização das respostas das questões, bem como

\footnotetext{
296 Com exceção de uma aluna surda que não quis desenhar.

297 Relativo à planta tátil da implantação do complexo da unidade-caso 1, visando a facilidade na aplicação pela pesquisadora por ser uma atividade mais focada em questões do ambiente escolar.
} 
discernimento do pensamento resultando em respostas claras. O número de questões se mostrou coerente.

A aplicação individual da entrevista lúdica com mapa tátil, em ambiente tranquilo, favoreceu a concentração do aluno durante o processo de aplicação. 0 apoio de duas pessoas externas trazidas pela pesquisadora proporcionou assistência ao aluno (locomoção) e à pesquisadora (anotações das repostas verbais dos alunos e geração de imagens do processo de aplicação). O mapa tátil eleito pela pesquisadora pertencia à unidade-caso e era de conhecimento dos alunos, não exigindo uma maior exploração tátil e raciocínio intenso, liberando o aluno para responder à entrevista.

A pesquisadora se sentiu à vontade nesta atividade lúdica, pelo fato de ser dirigida (fase de aquecimento) e de a natureza do instrumento fazer parte da sua formação de arquiteta. Dentre todas as entrevistas lúdicas realizadas nas unidades-caso pertencentes ao estudo, a unidade-caso 1 foi a única em que a pesquisadora aplicou instrumentos de coletas de dados sem a presença de um docente, que necessitava cuidar dos alunos não aptos a participarem da pesquisa. $\mathrm{O}$ objetivo de promover a interação entre 0 aluno e o entrevistador antes e durante a entrevista e de obter informações sobre as preferências e a acessibilidade do ambiente escolar proposto pelo instrumento foi alcançado. 


\section{b) Entrevista lúdica com desenho temático}

\section{Apoio no processo de aplicação}

Na segunda etapa da pesquisa, o processo de aplicação da entrevista lúdica com desenho temático foi eficaz em todos os alunos com deficiência física, auditiva e visual (baixa visão) sendo imprescindível o apoio de outras pessoas durante 0 processo de aplicação para o seu sucesso. As entrevistas realizadas previamente com as docentes permitiram a elaboração do instrumento de forma satisfatória, bem como o planejamento do seu processo de aplicação.

\section{Confecção do desenho}

Os alunos com baixa visão ${ }^{298}$ e surdez das unidades-caso 1 e 2 , respectivamente, conseguiram confeccionar o desenho temático com facilidade e desenvoltura, devido à ótima coordenação motora nos seus membros superiores (boa pega no giz de cera). Ao contrário, a confecção do desenho foi uma tarefa dificultosa para $50 \%$ dos alunos com PC (usuários da CAA) e com maior comprometimento dos membros superiores. Para esses alunos, o ato de desenhar exigiu esforço físico (em níveis variados), o que reafirma o cuidado na limitação de execução de apenas um desenho por aluno. Todos os alunos com PC conseguiram confeccionar o desenho temático, com ou sem o auxílio de um adulto (docente e/ou voluntários), porém com diferentes graus de dificuldade em função das limitações motoras individuais.

A não interrupção do ato de desenhar dos alunos para a realização das perguntas da entrevista proporcionou melhores resultados, em especial em relação aos alunos

${ }^{298}$ Com exceção de um aluno. 
surdos, pois eles não perdiam o contato visual com o desenho, para visualizar as mãos da docente, bem como não soltavam o giz de cera para responder em LIBRAS.

\section{Perguntas e respostas da entrevista}

As respostas individuais da maioria dos alunos foram satisfatórias, pois a introdução de imagens coloridas nas alternativas de resposta das entrevistas (painel impresso com fotos) destinada aos alunos surdos, com PC e com baixa visão, evitou a abstração da pergunta decorrente da surdez; também possibilitou ao aluno com PC sem fala e sem movimentos nos membros superiores opções de respostas que não faziam parte de sua prancha ou pasta de CAA e auxiliou os alunos com baixa visão no entendimento das questões. O número de questões não sobrecarregou os alunos.

O objetivo de promover a interação entre o aluno e o entrevistador antes e durante a entrevista e de obter informações sobre as preferências e a acessibilidade do ambiente escolar proposto pelo instrumento foi alcançado. 
378

Instrumentos de Avaliação Pós-Ocupação (APO) adaptados a pré-escolares com deficiência física, auditiva e visual

ABATE, Tania Pietzschke 


\section{A TÉCNICA DO QUESTIONÁRIO DESTINADA ÀS CRIANÇAS}

\subsection{Referencial teórico}

"Se a entrevista é uma conversa com propósito, o questionário corresponde a uma variante escrita da entrevista, tipicamente autoaplicada." (GÜNTHER; ELALI, PINHEIRO, 2008, p. 379). O questionário é o método mais frequentemente utilizado em pesquisas quantitativas para a coleta de dados em estudo de usuários e "consiste numa lista de questões a serem propostas pelo pesquisador junto aos informantes para obtenção de dados, escolhidos pelos mais diversos métodos de amostragem." (CUNHA, 1982, p. 8).

O questionário é definido como "um conjunto de perguntas sobre um determinado tópico que não testa a habilidade do respondente, mas mede a sua opinião, seus interesses [...]" (GÜNTHER, 2008, p. 106), e segundo Baird (1995) é um instrumento muito útil para identificar aspectos relacionados a fatores funcionais e técnicos dos ambientes, a partir da visão do usuário. Em relação ao tipo de interação entre indivíduo e pesquisador -

se as questões forem feitas diretamente, face a face, a interação será pessoal (e se denomina entrevista estruturada); se as questões forem impressas e o informante as responder por escrito, a interação será impessoal. A interação poderá, ainda, ser mista: o pesquisador explicará os propósitos da pesquisa e, em seguida, fornecerá as questões por escrito. (HÜBNER, 1998, p. 53)

O Quadro 54 apresenta as vantagens e desvantagens dos intrumentos entrevista e questionário. 


\begin{tabular}{|c|c|c|}
\hline & Vantagens & Desvantagens \\
\hline Entrevista & $\begin{array}{l}\text { - Permite captar reações, sentimentos } \\
\text { e hábitos do entrevistado por ser um } \\
\text { instrumento qualitativo; } \\
\text { - Possibilita que o entrevistador } \\
\text { esclareça alguma pergunta ou } \\
\text { terminologia não compreendida pelo } \\
\text { entrevistado; } \\
\text { - Viabiliza a comprovação das } \\
\text { respostas; } \\
\text { - Pode ser aplicada com facilidade em } \\
\text { indivíduos não alfabetizados; } \\
\text { - Coleta dados com riqueza de } \\
\text { detalhes. }\end{array}$ & $\begin{array}{l}\text { - Demanda mais trabalho por parte do } \\
\text { aplicador, transcritor e analista dos } \\
\text { dados; } \\
\text { - Possibilita ocorrência de distorções por } \\
\text { parte do transcritor; } \\
\text { - Impossibilita generalização das } \\
\text { informaçòes obtidas; } \\
\text { - Está sujeita à polarização do } \\
\text { entrevistador; } \\
\text { - Possibilita a influência do entrevistador } \\
\text { nas respostas do entrevistado; } \\
\text { - Não garante o anonimato dos } \\
\text { entrevistados de forma direta. }\end{array}$ \\
\hline Questionário & $\begin{array}{l}\text { - Viabiliza aplicação em uma grande } \\
\text { população; } \\
\text { - Oferece mais tempo para as } \\
\text { respostas; } \\
\text { - Proporciona facilidade de tabulação } \\
\text { dos dados através de programas de } \\
\text { computador; } \\
\text { - Garante o anonimato dos } \\
\text { respondentes; } \\
\text { - Oferece maior liberdade ao } \\
\text { respondente; } \\
\text { - Possibilidade de diminuirem-se as } \\
\text { distorções. }\end{array}$ & $\begin{array}{l}\text { - Demanda difícil análise dos resultados } \\
\text { das questões abertas; } \\
\text { - Requer a sua aplicação na presença do } \\
\text { aplicador e com o uso de ilustrações nas } \\
\text { questões no caso de indivíduos não } \\
\text { alfabetizados; } \\
\text { - Dificulta o esclarecimento de } \\
\text { dúvidas em relação à compreensão das } \\
\text { perguntas; } \\
\text { - Inviabiliza a comprovação ou o } \\
\text { esclarecimento de dúvidas por ocasião da } \\
\text { tabulação e análise dos dados. }\end{array}$ \\
\hline
\end{tabular}

Quadro 54 - Vantagens e desvantagens das técnicas de coleta de dados entrevista e questionário.

O questionário é uma boa opção para coleta de dados em função do anonimato. Segundo Hübner (1998, p. 53), o número de perguntas num questionário "deve ser limitado, para evitar o cansaço do indivíduo, além de nem sempre ele estar à disposição do pesquisador por um longo período de tempo." As decisões em relação ao número de perguntas ou tipo de interação devem ser tomadas com base no problema de pesquisa e nas características dos sujeitos envolvidos. O questionário remetido pelo correio ou por qualquer outro meio como a internet é, normalmente, autoadministrável (CUNHA, 1982, p. 8) e a ausência do pesquisador requer um maior cuidado na formulação das questões. Trujillo-Ferrari (1971) destaca a demanda de colaboração por uma carta junto ao questionário, quando o aplicador não está presente. 
Segundo Gil (1991, p. 91), "a elaboração de um questionário consiste basicamente em traduzir os objetivos específicos da pesquisa em itens bem redigidos." A seguir são listadas algumas regras práticas para a elaboração de um questionário.

a) as questões devem ser preferencialmente fechadas, mas com alternativas suficientemente exaustivas para abrigar a ampla gama de respostas possíveis;

b) devem ser incluídas apenas as perguntas relacionadas ao problema proposto;

c) não devem ser incluídas perguntas cujas respostas possam ser obtidas de forma mais precisa por outros procedimentos;

d) deve-se levar em conta as implicações da pergunta com os procedimentos de tabulação e análise dos dados;

e) devem ser evitadas perguntas que penetrem na intimidade das pessoas;

f) as perguntas devem ser formuladas de maneira clara, concreta e precisa;

g) deve-se levar em consideração o sistema de referência do entrevistado, bem como o seu nível de informação;

h) a pergunta deve possibilitar uma única interpretação;

i) a pergunta não deve sugerir respostas;

j) as perguntas devem referir-se a uma única ideia de cada vez;

I) o número de perguntas deve ser limitado;

m) o questionário deve ser iniciado com as perguntas mais simples e finalizado com as mais complexas;

n) as perguntas devem ser dispersadas sempre que houver possibilidade de "contágio";

o) convém evitar as perguntas que provoquem respostas defensivas, esteriotipadas ou socialmente indesejáveis, que acabam por encobrir sua real percepção acerca do fato;

p) na medida do possível, devem ser evitadas as perguntas personalizadas, diretas, que geralmente se iniciam por expressões do tipo "o que você pensa a respeito de...", "na sua opinião..." etc, as quais tendem a provocar respostas de fuga;

q) deve ser evitada a inclusão, nas perguntas, de palavras esteriotipadas, bem como a menção a personalidades de destaque, que podem influenciar nas respostas, tanto em sentido positivo quanto negativo;

r) cuidados especiais devem ser tomados em relação à apresentação gráfica do questionário, tendo em vista facilitar seu prenchimento;

s) o questionário deve conter uma introdução que informe acerca da entidade patrocinadora, das razões que determinaram a relização da pesquisa e da importância das respostas para atingir os seus objetivos;

t) o questionário deve conter instruções acerca do correto preenchimento das questões, preferencialmente com caracteres gráficos diferenciados. (GIL, 1991, p. 92)

Geralmente o uso de perguntas fechadas mostra mais respeito à opinião das pessoas, deixando-as classificar suas respostas como positivas, negativas ou neutras sem influência do pequisador (SOMMER; SOMMER, 1997, p. 130). Neste estudo adotou-se a escala Likert, pois "essa mensuração é a mais utilizada nas ciências sociais, especialmente em levantamentos de atitudes, opiniões e avaliações." (GÜNTHER, H., 2008, p. 134). Nesta escala pede-se ao respondente que avalie um 
fenômeno, geralmente, entre cinco alternativas (no caso deste estudo que envolve crianças este número foi reduzido, e utilizaram-se três alternativas ${ }^{299}$ ).

Como as crianças participantes desta pesquisa se encontravam em fase de alfabetização considerou-se apropriado ${ }^{300}$ que a aplicação do questionário ocorresse na presença do aplicador, bem como que as alternativas de resposta fossem ilustradas com fotos e/ou figuras de fácil entendimento. Segundo a Associação dos Designers Gráficos (ADG, 2000, p. 59), a ilustração é definida como uma "imagem cujo objetivo é corroborar ou exemplificar o conteúdo de um texto de livro, jornal, revista ou qualquer outro tipo de publicação." No dicionário (DICIONÁRIO HOUAISS DA LÍNGUA PORTUGUESA, 2001, p. 1572) o termo ilustração corresponde à "[...] adorno ou elucidação de texto por meio de estampa, figura [...] publicação que contém estampas, gravuras, desenhos [...] desenho, gravura, imagem que acompanha um texto $[\ldots] "$ Porém, suas atribuições podem ir muito além, podendo ser também considerada uma imagem que amplia um texto verbal, que adiciona a ele informações, que o questiona, que o substitui.

Segundo Lago (1997, p. 1), "[...] a linguagem verbal não é traduzível para o visual. São duas formas de pensar diferentes." Portanto, nem tudo o que é expresso por palavras pode ser traduzido em imagens, sendo que o oposto também é verdadeiro. "Assim como o texto verbal, o texto visual também exige uma espécie de alfabetização - ou [...] letramento visual" (CAMARGO, 2006, p. 13). Portanto, as

${ }^{299}$ Com uma exceção ver item 8.2.1. Segundo estudo de Matell e Jacoby (1971), o número de alternativas não influencia a fidedignidade nem a validade da escala, sendo necessário lembrar a capacidade discriminatória do respondente.

${ }^{300}$ Baseado em questionários desenvolvidos em estudo anterior (BARBOSA, 2009). 
ilustrações possuem um vocabulário próprio, que também necessita de um aprendizado para poder ser lido e compreendido. Em relação ao texto verbal e ao visual, "desenhar é uma forma de escrever. O desenho fala, chega mesmo a ser muito mais uma espécie de escritura, uma caligrafia [...]. Desenhos são para a gente folhear, são para serem lidos que nem poesias." (LAGO, 1991, p. 13). A leitura de uma ilustração baseia-se na decomposição da imagem e sua recomposição, passando pelas formas e significações mais amplas às mais específicas e complexas, fazendo por fim o que Oliveira (2005) chama de trânsito incansável entre os elementos e seus procedimentos relacionais, numa busca exaustiva dos efeitos de sentido gerados pelas relações entres as partes e na composição do todo. 0 observador é também agente, participando do processo de construção dos significados ${ }^{301}$.

\section{O uso da semiótica na elaboração da ilustração do questionário}

As ilustrações existentes nos questionários do presente estudo se basearam nos pressupostos da semiótica, que vem da raiz grega semeion e significa signo. A semiótica ${ }^{302}$ é a ciência dos signos que tem por objeto de investigação todos os tipos de linguagens e objetiva a "análise dos modos de constituição de todo e qualquer fenômeno de produção de significação e de sentido." (SANTAELLA, 1983, p. 13).

${ }^{301}$ Disponível em: <http://www.gpae.ceart.udesc.br/artigos/artigo_anelise_zimmermann.pdf>. Acesso em: 20 jul. 2010.

${ }^{302}$ A semiótica teve seu início com os filósofos John Locke (1632-1704) que, postulou uma doutrina dos signos em 1690 com o nome de Semeiotiké, e com Johann Heinrich Lambert (1728-1777) que, em 1764, foi um dos primeiros filósofos a escrever um tratado específico intitulado Semiotik (NÖTH, 1995). Charles Sanders Peirce (1839-1914), cientista, matemático, historiador, filósofo e lógico norteamericano é considerado o fundador da moderna semiótica. Uma das marcas do pensamento peirceano é a amplição da noção de signo e, consequentemente, da noção de linguagem. Peirce "foi o enunciador da tese anticartesiana de que todo pensamento se dá em signos, na continuidade dos signos; do diagrama das ciências; das categorias; do pragmatismo." (SANTAELLA, 2001, p. 32). 
Segundo Malanga (2004) as três formas de unidades de representação simbólica de acordo com a semiótica são:

a) Os índices, que apresentam uma relação causal com aquilo que representam, indicam ou significam. Por exemplo, o suor indica que a pessoa está sentindo calor, o trovão indica a iminência de chuva e assim por diante. Para que o receptor seja capaz de decodificar essa mensagem é preciso que ele conheça essa relação de causa e efeito.

b) Os ícones guardam uma relação de semelhança visual ou estrutural com a coisa representada. Por exemplo, o desenho ou a foto de uma casa, não representa a casa com exatidão, pois é bidimensional, mas, por reproduzir aspectos estruturais semelhantes, permite a identificação do objeto representado. c) Os signos têm uma relação arbitrária entre o que é representado (significado) e a forma de representar (significante). Eles formam códigos estabelecidos por um determinado grupo social para permitir a comunicação, como por exemplo, a linguagem verbal.

Segundo Peirce (1977) todo pensamento se dá em signos, não havendo pensamento sem os mesmos. O signo pode ser definido como "uma coisa que representa uma outra coisa: seu objeto. Ele só pode funcionar como signo se carregar esse poder de representar, substituir uma outra coisa diferente dele." (SANTAELLA, 1983, p. 58). O signo pode ser também definido como

qualquer coisa que, de um lado, é assim determinada por um objeto e, de outro, assim determina uma ideia na mente de uma pessoa, esta última determinação, que denomino o Interpretante do signo, é, desse modo, imediatamente determinada por aquele objeto. Um signo, assim, tem uma relação triádica com seu objeto e com seu interpretante." (SANTAELLA, 2000, p. 12) 


\section{2 $\quad 1^{\text {a }}$ etapa da pesquisa}

\subsubsection{Questionário ilustrado}

A técnica de coleta de dados por meio de questionário teve como objeto de estudo os alunos com deficiência visual (cegueira e baixa visão), auditiva e física aptos a participarem da pesquisa (ver Tabelas 4, 5 e 6) das pré-escolas das unidades-caso 1, 2 e 3 , respectivamente.

\section{a) Objetivo}

O objetivo do questionário foi o de identificar os aspectos relacionados ao conforto ambiental e à acessibilidade, a partir da opinião dos alunos com deficiência visual, auditiva e física.

\section{b) Procedimentos adotados}

$\mathrm{Na} 1^{\text {a }}$ etapa da pesquisa, os procedimentos de aplicação e elaboração do questionário destinado aos alunos com deficiência na foram discutidos com as respectivas docentes em entrevistas realizadas previamente e se encontram descritos no Quadro 55 a seguir. 


\begin{tabular}{|c|c|c|c|c|}
\hline \multicolumn{2}{|c|}{ Unidade-caso } & 1 & 2 & 3 \\
\hline \multicolumn{2}{|c|}{ Deficiência } & Visual & Auditiva & Física \\
\hline \multicolumn{2}{|c|}{$\begin{array}{l}\text { Ordenação em relação } \\
\text { à aplicação da } \\
\text { entrevista lúdica }\end{array}$} & Posterior & Posterior & Posterior \\
\hline \multicolumn{2}{|c|}{ Local da aplicação } & $\begin{array}{c}\text { Sala de brinquedos } \\
\text { e } \\
\text { sala de aula }\end{array}$ & Sala de aula & Sala de aula \\
\hline \multicolumn{2}{|c|}{ Forma de aplicação } & $\begin{array}{c}\text { Individual com ou } \\
\text { sem a presença dos } \\
\text { demais alunos }\end{array}$ & $\begin{array}{c}\text { Individual } \\
\text { (na presença dos } \\
\text { demais alunos aptos) }\end{array}$ & $\begin{array}{c}\text { Individual } \\
\text { (na presença dos demais } \\
\text { alunos aptos) }\end{array}$ \\
\hline \multicolumn{2}{|c|}{ Aplicador(es) } & $\begin{array}{l}\text { Pesquisadora e/ou } \\
\text { docente }\end{array}$ & $\begin{array}{c}\text { Docente com o apoio } \\
\text { de outra docente, na } \\
\text { presença da } \\
\text { pesquisadora }\end{array}$ & $\begin{array}{c}\text { Docente e pesquisadora } \\
\text { com o apoio de } 3 \text { a } 4 \\
\text { voluntários }\end{array}$ \\
\hline \multicolumn{2}{|c|}{$\begin{array}{l}\text { Forma de comunicação } \\
\text { para a aplicação }\end{array}$} & Verbal & LIBRAS $^{304}$ & Verbal \\
\hline \multicolumn{2}{|c|}{$\begin{array}{l}\text { Forma de comunicação } \\
\text { do aluno }\end{array}$} & Verbal & LIBRAS & $\begin{array}{l}\text { Verbal: alunos com fala e } \\
\text { CAA: alunos sem fala }\end{array}$ \\
\hline \multirow{7}{*}{ 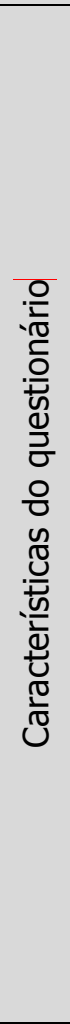 } & Temática & $\begin{array}{l}\text { Conforto térmico, } \\
\text { acústico e lumínico, } \\
\text { e acessibilidade } \\
\text { (baixa visão). } \\
\text { Conforto térmico e } \\
\text { acústico, e } \\
\text { acessibilidade } \\
\text { (cegueira) }\end{array}$ & $\begin{array}{l}\text { Conforto térmico e } \\
\text { lumínico, e } \\
\text { acessibilidade }\end{array}$ & $\begin{array}{l}\text { Conforto térmico, } \\
\text { acústico e lumínico, e } \\
\text { acessibilidade }\end{array}$ \\
\hline & $\begin{array}{l}\text { Número de } \\
\text { questões fechadas }\end{array}$ & $\begin{array}{c}4 \text { (baixa visão) } \\
3 \text { (cegueira) }\end{array}$ & 3 & 4 \\
\hline & $\begin{array}{l}\text { Número de } \\
\text { alternativas de } \\
\text { resposta }\end{array}$ & 3 & 3 & $\begin{array}{c}1^{\mathrm{a}} \text { aplicação: } 3 \\
2^{\mathrm{a}} \text { e } 3^{\mathrm{a}} \text { aplicações: } \\
\text { última questão com } 5^{*}\end{array}$ \\
\hline & $\begin{array}{l}\text { Número de } \\
\text { questões/folha A4 }\end{array}$ & 1 & 3 & 4 \\
\hline & Tamanho da fonte & 24 & 12 & 12 \\
\hline & $\begin{array}{l}\text { Gramatura do } \\
\text { papel }\end{array}$ & 180 gramas & 75 gramas & 75 gramas \\
\hline & Denominação & $\begin{array}{l}\text { Questionário } \\
\text { ilustrado ampliado } \\
\text { (baixa visão) e } \\
\text { questionário } \\
\text { ilustrado ampliado } \\
\text { tátil (cegueira) }\end{array}$ & Questionário ilustrado & $\begin{array}{l}\text { Questionário ilustrado e } \\
\text { questionário ilustrado em } \\
\text { PCS }\end{array}$ \\
\hline
\end{tabular}

Quadro 54 - Alguns dos procedimentos de elaboração e aplicação do questionário adotados na $1^{a}$ etapa da pesquisa (pré-teste), por deficiência.

* Após a $1^{\text {a }}$ aplicação do questionário ilustrado destinado aos alunos com deficiência física em uma das 3 classes existentes, verificou-se a dificuldade de execução do mesmo pelos alunos usuários de

${ }^{303}$ Somente em poucas aplicações destinadas aos alunos com baixa visão.

${ }^{304}$ A docente serviu como intérprete da LIBRAS dos alunos surdos. Nenhum outro intérprete, a não ser a própria docente destes alunos, poderia ser o aplicador em função da LIBRAS ainda não ser fluente entre estes alunos e da faixa etária em que se encontravam. 
$\mathrm{CAA}^{305}$. Portanto, durante a primeira etapa da pesquisa, esse questionário sofreu as seguintes alterações para a $2^{\mathrm{a}}$ e $3^{\mathrm{a}}$ aplicações: foi convertido para a linguagem dos Símbolos de Comunicação Pictórica (PCS) - ver item 2.2.1.1 - pela fonoaudióloga da unidade-caso 3, bem como a última questão relativa à acessibilidade passou a ter 5 alternativas.

A elaboração do questionário ilustrado (Quadros 56 a 59) considerou a utilização de recursos que facilitassem a compreensão das questões pelos alunos, o uso de vocabulário simples e direto no enunciado, a adoção de respostas de múltipla escolha - a partir da escala de 3 valores ${ }^{306}$ com o uso de ilustrações nas alternativas com seleção de fácil entendimento. Foram adotadas as seguintes ações na realização do questionário ilustrado: recompensar o respondente demonstrando consideração, oferecendo apreciação verbal usando uma abordagem consultiva, apoiando seus valores e tornando o instrumento interessante; reduzir o custo de responder fazendo com que a tarefa pareça breve, diminuindo o esforço físico e mental requerido e estabelecer confiança (GÜNTHER, H., 2008). Durante a elaboração do questionário, cada ilustração foi discutida com as respectivas docentes, sendo apresentadas várias opções de tipologias, sendo eleitas as mais adequadas às necessidades de cada deficiência. Ao mesmo tempo buscou-se elaborar um questionário que, dentro das limitações de cada deficiência, fosse universal, ou seja, usado por todos os alunos (inclusive os sem deficiência). Optou-se por ilustrações simples e com menos detalhes, principalmente ${ }^{307}$ em função dos alunos com baixa visão.

\footnotetext{
305 Sem fala funcional e sem movimentos nos membros superiores.

${ }^{306}$ Com exceção de uma das questões destinadas aos alunos com deficiência física.

307 A elaboração do questionário ilustrado também se baseou em estudo anterior (BARBOSA et al, 2009).
} 


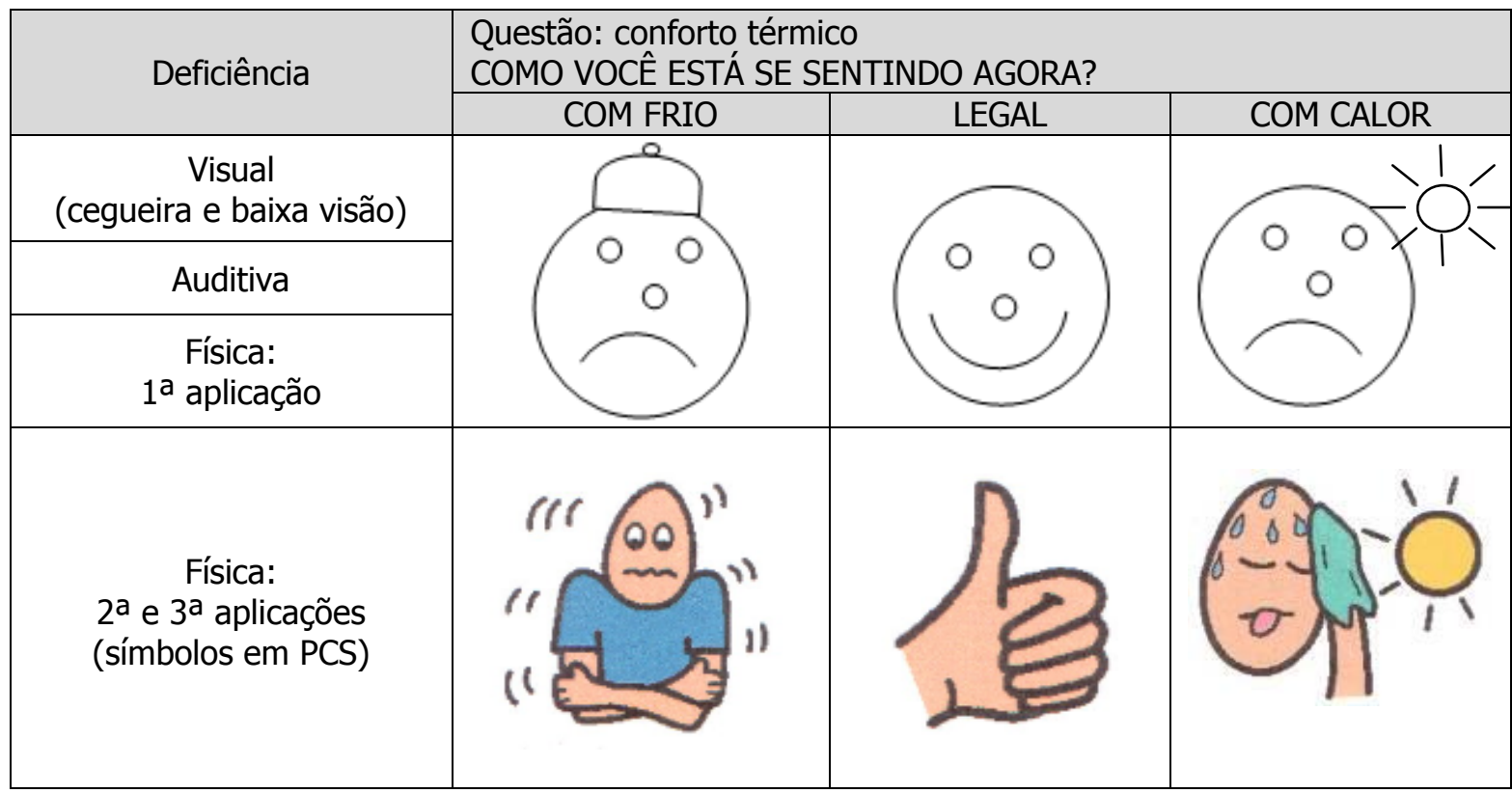

Quadro 55 - Ilustrações da questão de conforto térmico destinada aos alunos com deficiência visual (cegueira e baixa visão), auditiva e física na $1^{\text {a }}$ etapa da pesquisa.

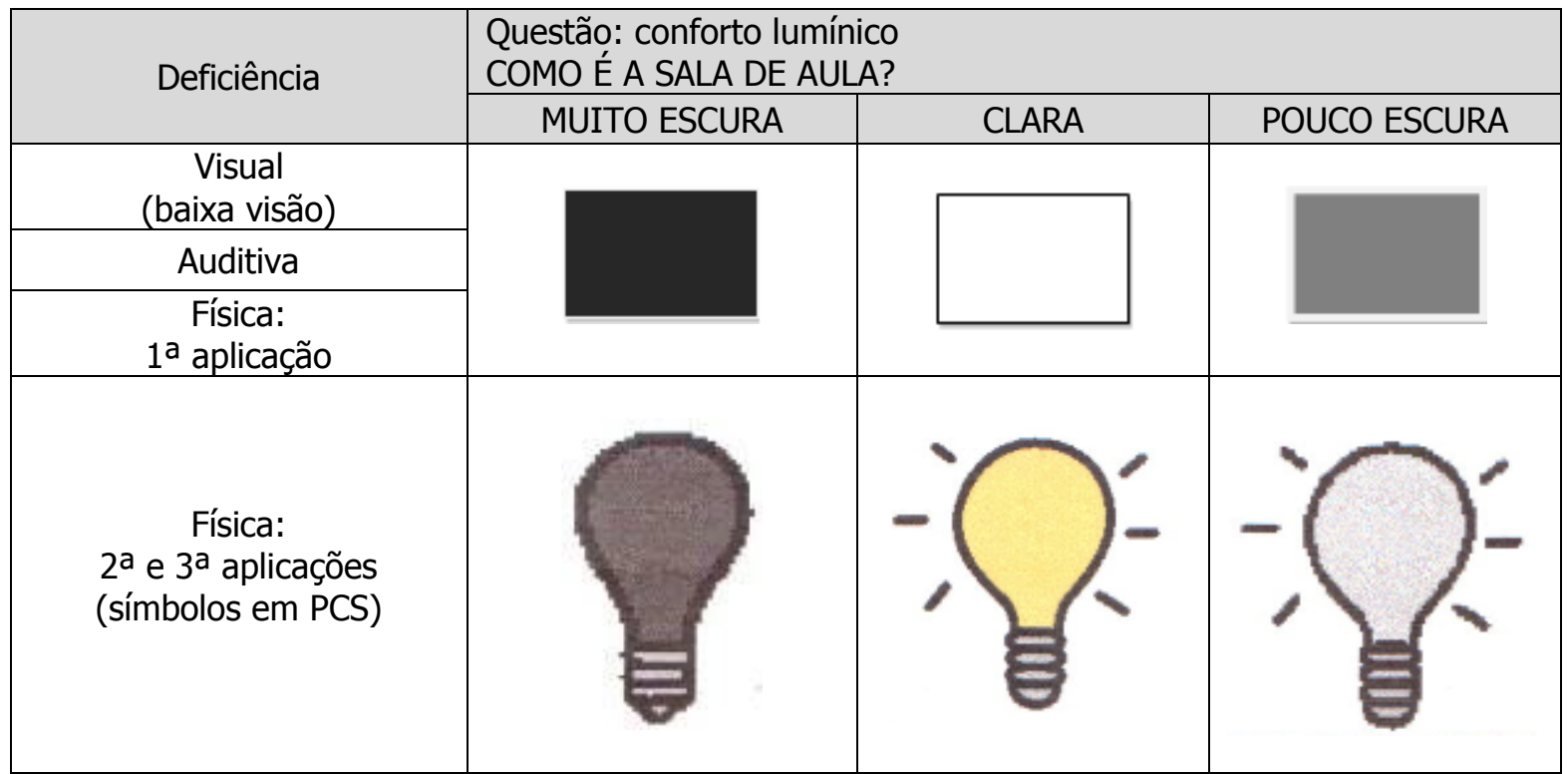

Quadro 56 - Ilustrações da questão de conforto lumínico destinada aos alunos com deficiência visual (baixa visão), auditiva e física na $1^{\text {a }}$ etapa da pesquisa. 


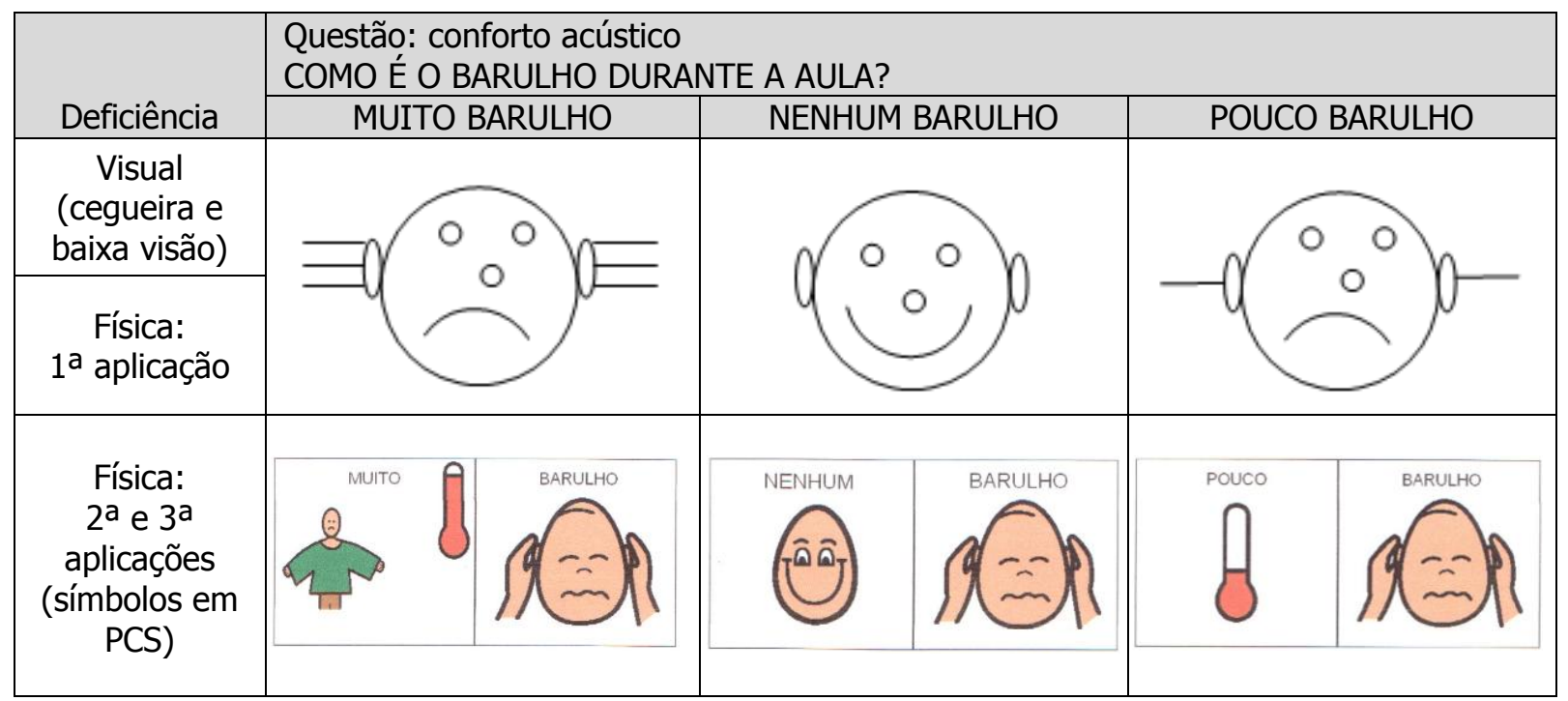

Quadro 57 - Ilustrações da questão de conforto acústico destinada aos alunos com deficiência visual (cegueira e baixa visão) e física na $1^{\text {a }}$ etapa da pesquisa.

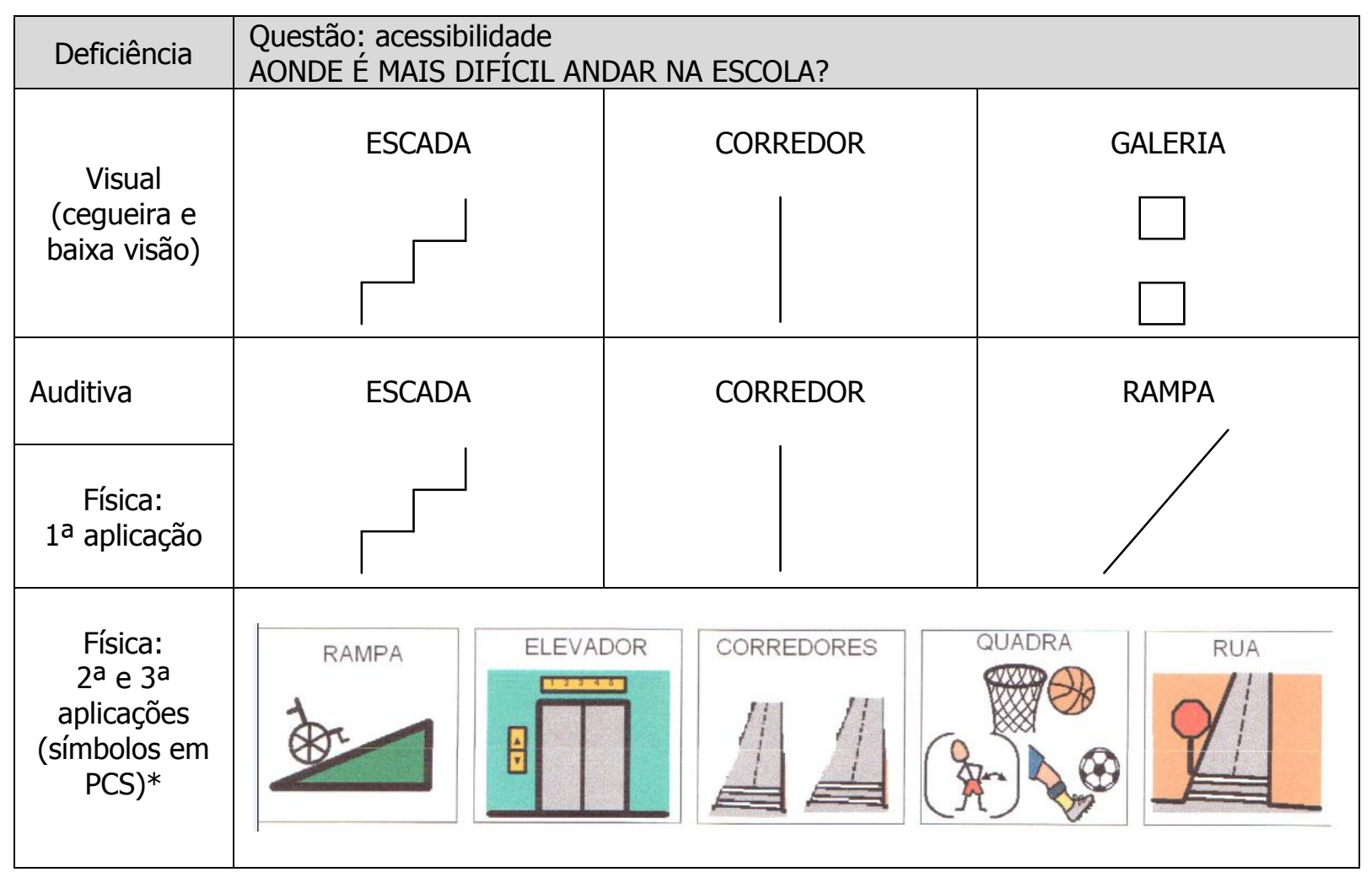

Quadro 58 - Ilustrações da questão de acessibilidade destinada aos alunos com deficiência visual (cegueira e baixa visão), auditiva e física na $1^{\text {a }}$ etapa da pesquisa.

*Observação: A rua descrita refere à interna ao lote da unidade-caso 3. 
No questionário ilustrato tátil (destinado aos alunos cegos) cada questão foi disposta em uma folha tamanho A4, pois o desenho em maior escala propiciaria um acabamento manual em tinta plástica para relevo (Figura 80a) visando o reconhecimento tátil de cada ilustração 308 pelos alunos cegos. A pesquisadora chegou a elaborar o acabamento do questionário em técnica mista - barbante e tinta plástica (Figura 80b), porém na entrevista realizada com a docente, indicou-se o uso somente da tinta plástica devido à facilidade de elaboração.

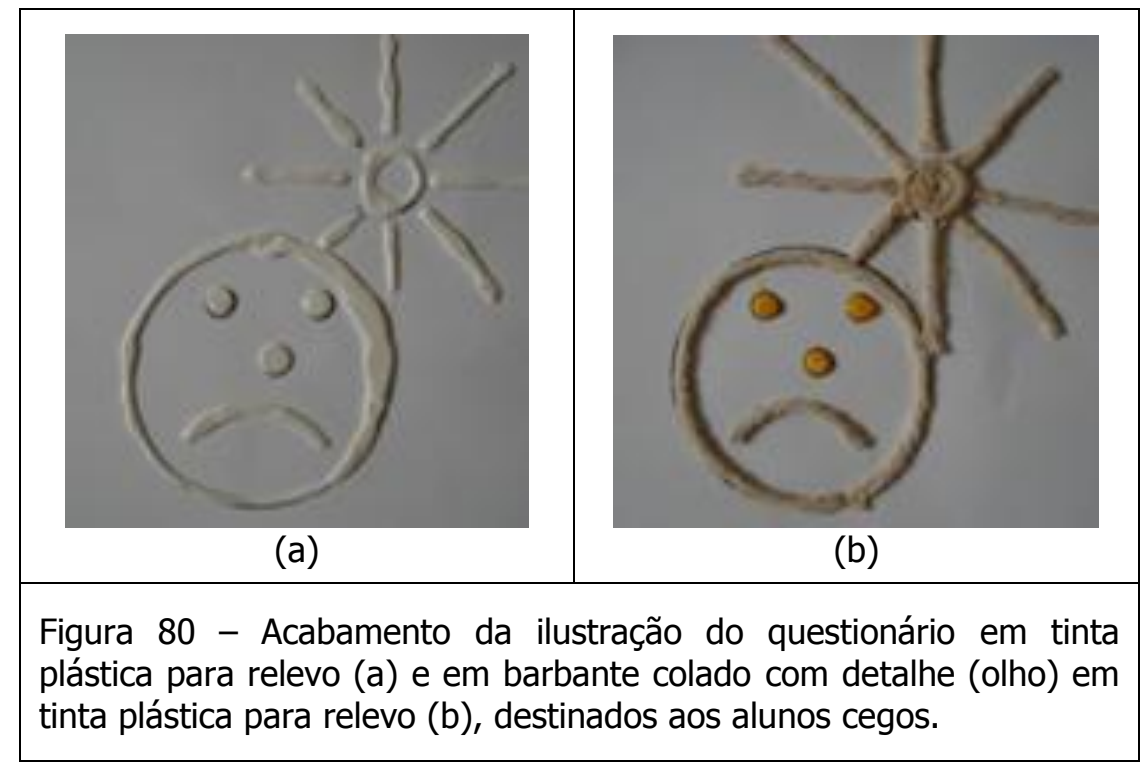

Datas: variadas, definidas em função da disponibilidade dos alunos.

Duração: variável, de 8 a 12 minutos por aluno cego, de 4 a 6 minutos por aluno com baixa visão, de 4 a 7 minutos por aluno surdo e de 3 a 6 minutos por aluno com PC.

A seguir serão apresentados os resultados do processo de aplicação do questionário ilustrado na primeira etapa da pesquisa.

${ }^{308}$ Em função da aplicação da tinta citada a gramatura do papel foi aumentada para 180 gramas. 


\subsubsection{Alunos cegos: resultados na unidade-caso 1}

Nesta primeira etapa, o questionário ilustrado tátil foi respondido por 7 alunos cegos aptos a participarem da pesquisa (ver Tabela 4) de forma individual, da única classe de pré-escola existente na unidade-caso 1, e ocorreu nos dias 08/10/2009 (4 alunos) e 10/10/2009 (3 alunos).

Apresenta-se o resultado do processo de aplicação do questionário realizado pelo aluno D. de 5 anos, cego, sendo que as demais aplicações ocorreram de forma similar. Inicialmente a pesquisadora convidou o aluno a brincar, o conduziu da sala de aula até a sala ao lado (de brinquedos), aplicou a entrevista lúdica com o brinquedo (descrita no item 7.2.1.1) e em seguida, acomodou o aluno em uma mesa existente para responder ao questionário. A folha com a primeira questão foi colocada em frente ao aluno para o reconhecimento inicial das formas das ilustrações em relevo (Figura 81). Porém, as suas mãos tateavam toda a folha e não cada ilustração tátil.

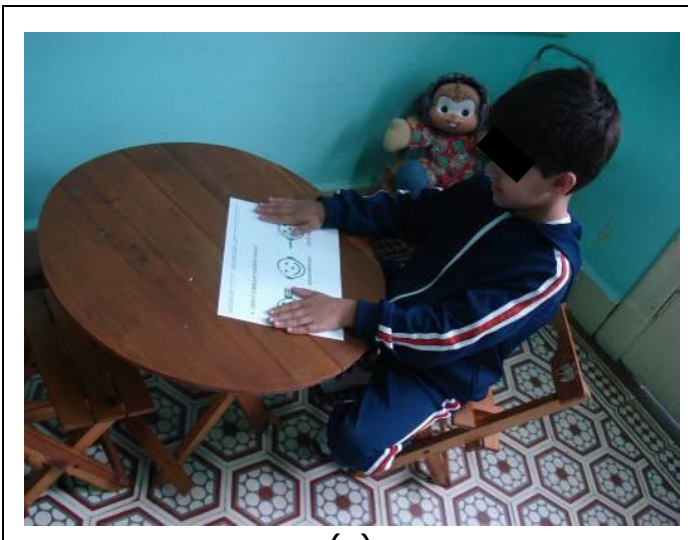

(a)

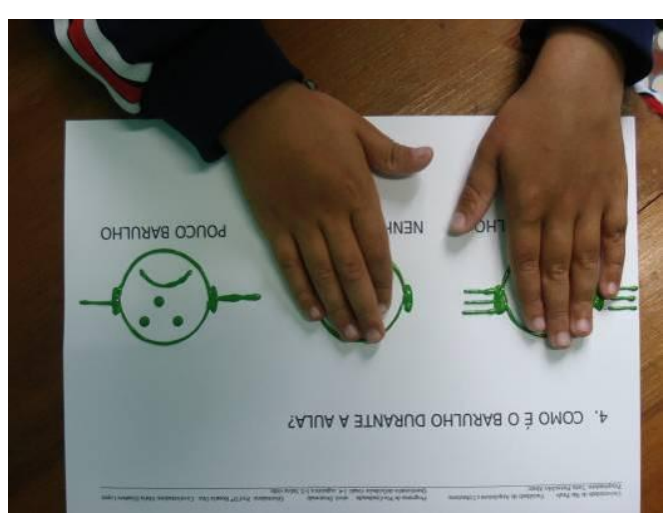

(b)

Figura 81 - Início da aplicação do questionário ilustrado tátil destinado ao aluno D., de 5 anos, cego. 


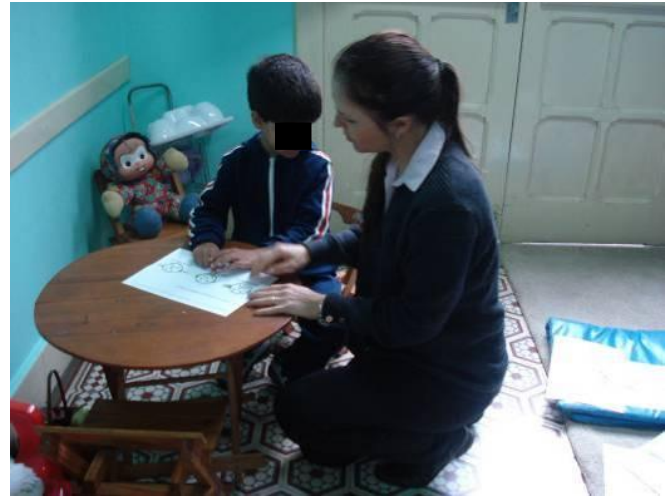

Figura 82 - Pesquisadora auxilia o aluno D., de 5 anos, cego, no posicionamento das mãos.
A pesquisadora posicionou os dedos do aluno na primeira ilustração a esquerda da folha descrevendo-a verbalmente, ao mesmo tempo (Figura 82).

O aluno conseguiu identificar os detalhes de cada ilustração, como olhos, nariz e a posição da boca (significando feliz ou triste) (Figura 83). As mãos do aluno, sem auxílio, não percorreram o restante da folha (através do tato) para buscar outras ilustrações presentes na folha. A pesquisadora então repetiu o processo de posicionamento dos dedos em cada uma das outras duas figuras existentes. Após o reconhecimento tátil de todas as ilustrações da folha a pesquisadora verbalizou 0 enunciado da questão. $\mathrm{O}$ aluno respondeu verbalmente, com facilidade, à primeira questão e indicou com as mãos a alternativa eleita. A pesquisadora assinalou a resposta na folha, sendo que as outras duas questões foram conduzidas pelo mesmo processo.

A docente participou de algumas das aplicações do questionário ilustrado tátil destinado aos alunos $\operatorname{cegos}^{309}$ (Figura 84), enquanto o restante da classe se encontrava nas aulas de educação física ou artes ${ }^{310}$.

${ }^{309} \mathrm{O}$ local foi a sala de aula.

${ }^{310}$ Ministradas por outros docentes. 


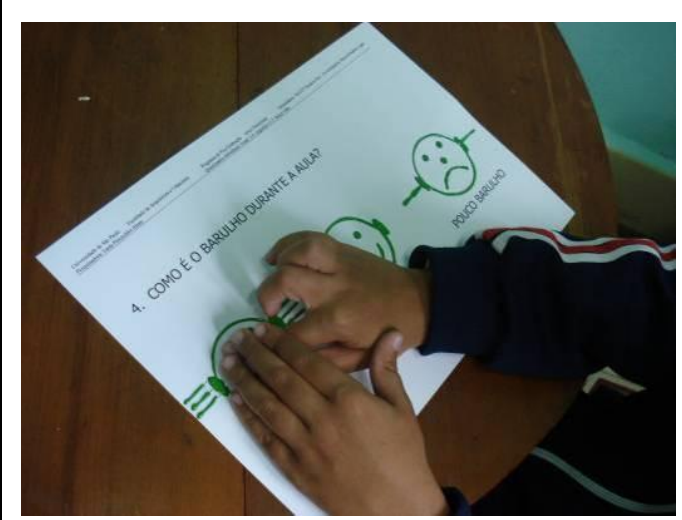

(a)

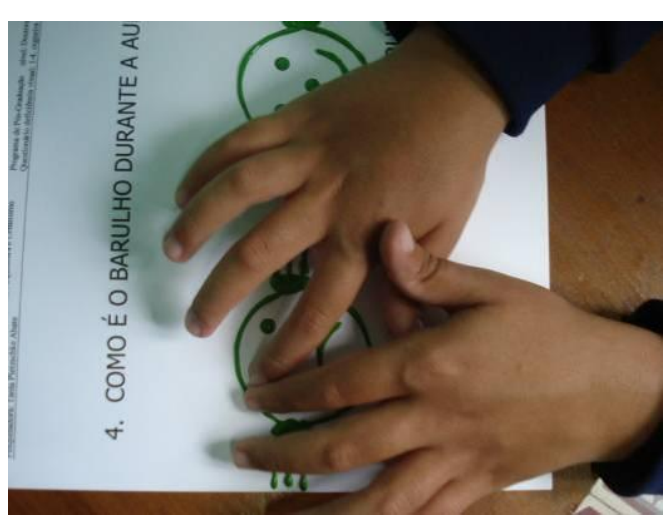

(b)

Figura 83 - Reconhecimento tátil da ilustração do questionário pelo aluno D., de 5 anos, cego.

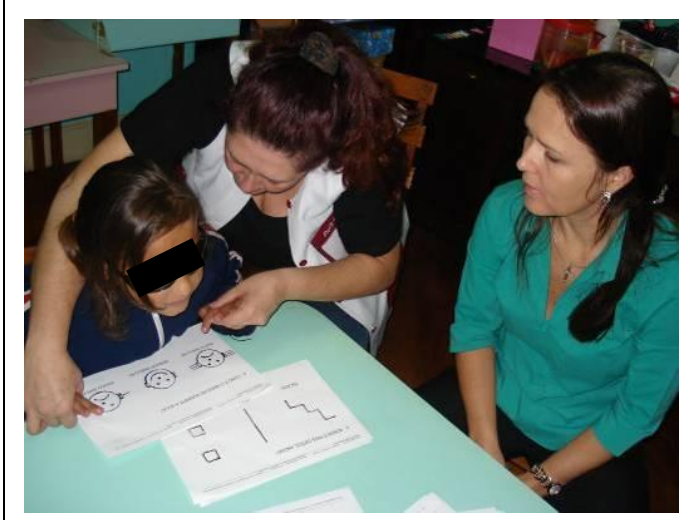

(a)

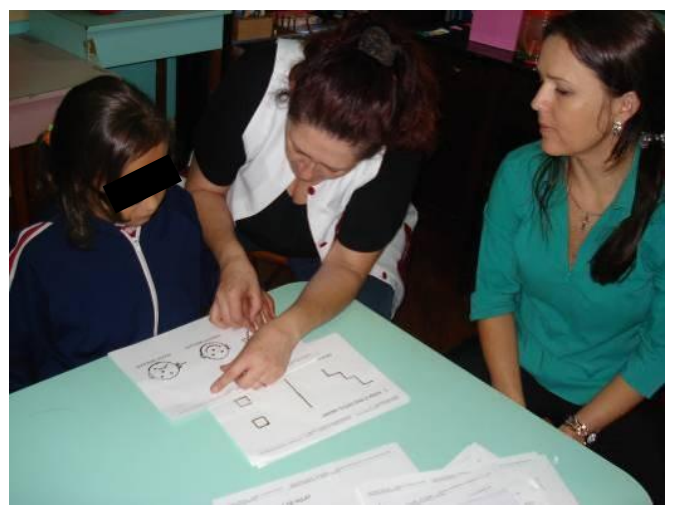

(c)

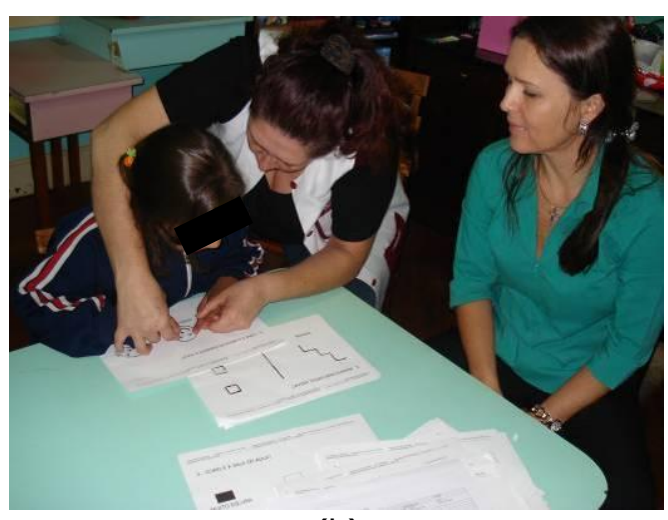

(b)

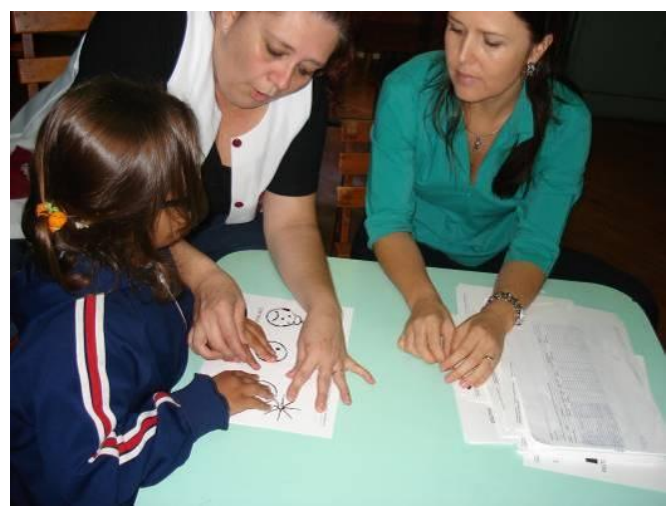

(d)

Figura 84 - Docente direcionou as duas mãos da aluna (a, b), alternou com o direcionamento de uma das mãos (c, d), durante a aplicação do questionário ilustrado tátil destinado a aluna cega. 
Os alunos cegos participantes conseguiram realizar o questionário, porém com dificuldade, mesmo com o auxílio durante toda a aplicação individual e apresentaram boas condições cognitivas e de fala, bem como movimentação dos membros superiores e inferiores. O acabamento das ilustrações em tinta em relevo foi percebida tatilmente com dificuldade, e a pesquisadora encontrou grande dificuldade no armazenamento dos questionários durante e após a aplicação, pois devido à tinta plástica, as folhas grudavam entre si.

\subsubsection{Alunos com baixa visão: resultados da unidade-caso 1}

Na primeira etapa da pesquisa, o questionário ilustrado ampliado foi respondido por 2 alunos com baixa visão presentes no dia da aplicação (do total de 3 alunos aptos a participarem da pesquisa, ver Tabela 4) da única classe de pré-escola existente na unidade-caso 1. A aplicação do questionário ocorreu no dia 08/10/2009.

Inicialmente, a pesquisadora conduziu os dois alunos, T. e V., ambos de 5 anos, da sala de aula até a sala ao lado, de brinquedos, aplicou a entrevista lúdica com desenho temático (descrita no item 7.2.2.1) e em seguida, sentou um aluno de cada vez, à mesa existente para a aplicação do questionário ${ }^{311}$. A folha contendo a primeira questão foi colocada em frente ao aluno V. de 5 anos, que aproximou seu rosto para a visualização das ilustrações ampliadas (Figura 85).

${ }^{311} \mathrm{O}$ outro aluno foi devolvido temporariamente à docente na sala de aula, ao lado. 


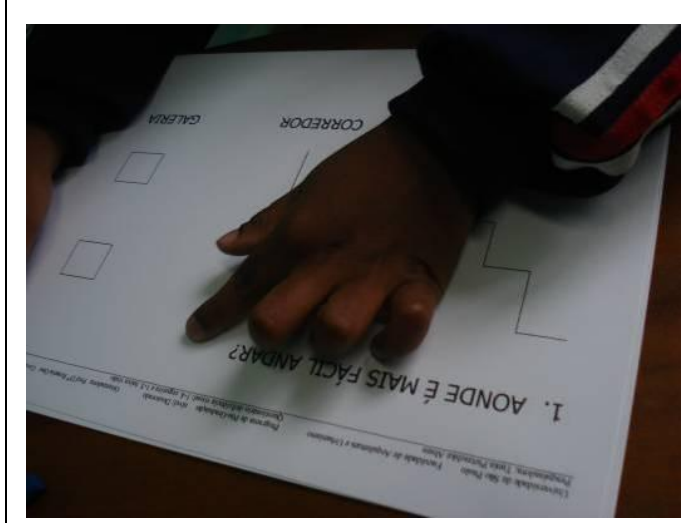

(a)

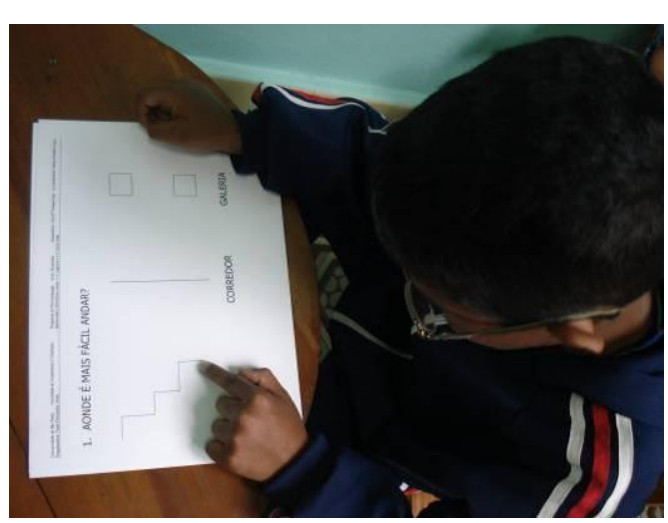

(b)

Figura 85 - Início da aplicação do questionário ilustrado ampliado destinado ao aluno V., de 5 anos, com baixa visão.

Cada questão e respectivas alternativas de resposta foram lidas pela pesquisadora, com tempo para a resposta pelo aluno que assinalou as alternativas eleitas; este processo ocorreu de forma similar no outro aluno. Não houve dificuldade dos alunos no entendimento do enunciado das questões, que apresentaram concentração durante a realização do questionário e assinalaram as alternativas eleitas.

\subsubsection{Alunos surdos: resultados da unidade-caso 2}

Na primeira etapa, o questionário ilustrado foi respondido por 4 alunos surdos presentes no dia da aplicação (do total de 7 alunos aptos a participarem da pesquisa, ver Tabela 5) da única classe de pré-escola apta a participar da pesquisa na unidadecaso 2. A aplicação do questionário ilustrado ocorreu no dia 04/11/2009. A aplicação desse instrumento foi realizada de forma coletiva e somente pela docente desses alunos (na presença da pesquisadora) em função da familiaridade e do nível de comunicação em LIBRAS de cada aluno, bem como a consequente necessidade de 
um intérprete. Inicialmente, a docente e a pesquisadora posicionaram um aluno por vez em uma mesa existente no fundo da sala e aplicaram a entrevista lúdica com desenho temático (descrita no item 7.2.2.2). Em seguida, o questionário foi aplicado de forma coletiva (Figura 86a), onde a docente explicou todas as questões do questionário em LIBRAS (Figura 86b).

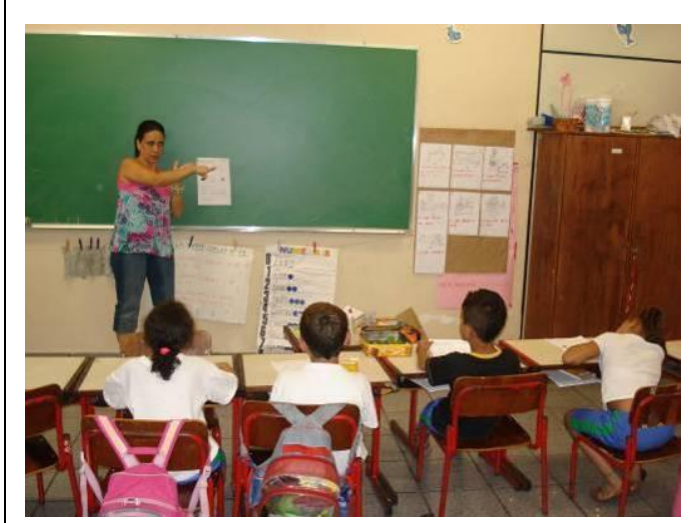

(a)

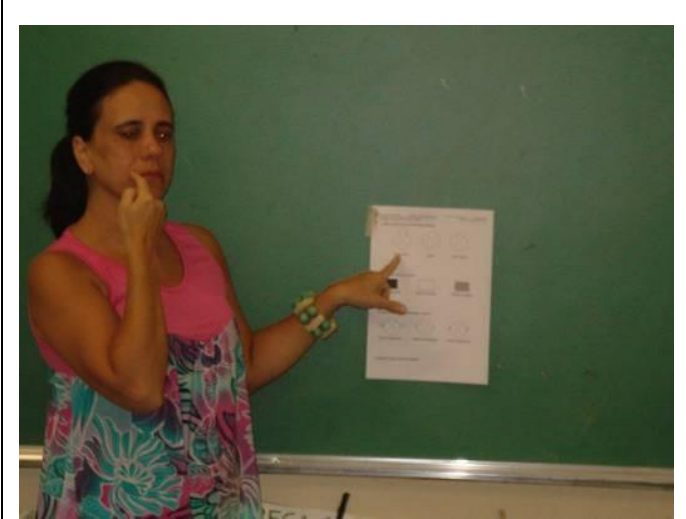

(b)

Figura 86 - Aplicação coletiva do questionário ilustrado em alunos surdos(a) e explicação do questionário em LIBRAS pela docente (b).

Em seguida, cada pergunta foi explicada novamente, havendo um período de tempo, entre cada questão, para a escolha da resposta pelos alunos (Figura 87).

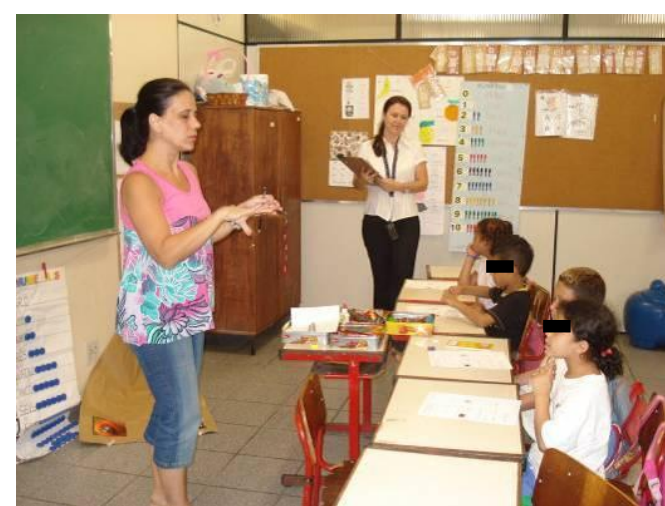

(a)

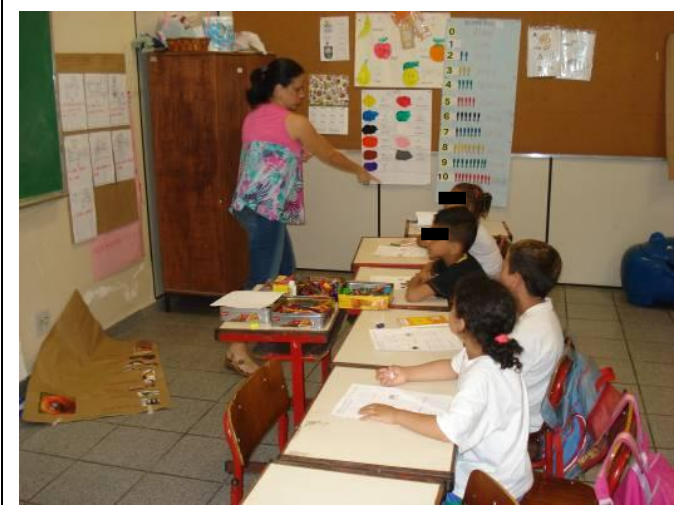

(b)

Figura 87 - Início da aplicação do questionário ilustrado destinado aos alunos surdos na $1^{\text {a }}$ etapa da pesquisa. 
O nível de dificuldade para responder ao questionário ilustrado se apresentou de forma variável entre os alunos em função do grau de abstração mental decorrente da surdez. Metade dos alunos apresentou dificuldade de compreensão dos enunciados das questões, que foram novamente explicados pela docente em LIBRAS. (Figuras 88a, b).

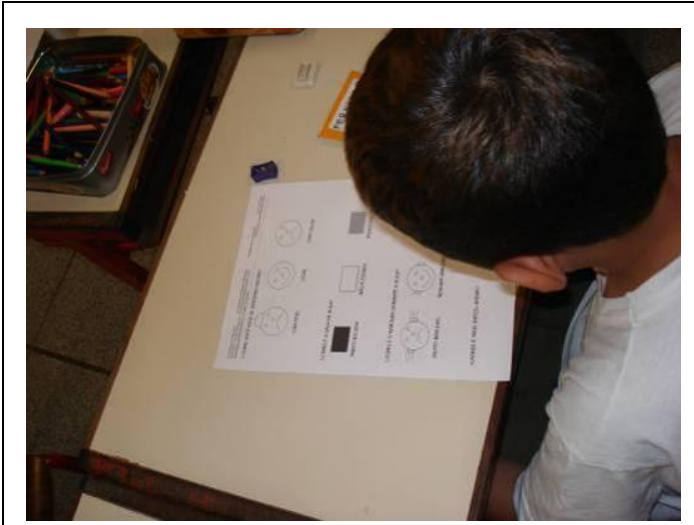

(a)

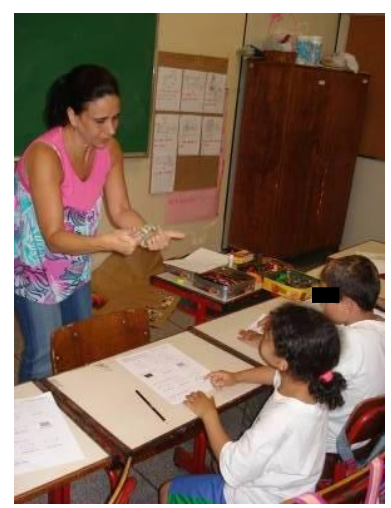

(b)

Figura 88 - 0 aluno F., de 7 anos, surdo, respondeu o questionário com facilidade (a) e a aluna T., de 7 anos, surda, não entendeu as questões (b).

\subsubsection{Alunos com PC: resultados da unidade-caso 3}

Na primeira etapa da pesquisa, o questionário ilustrado foi respondido por 19 alunos com deficiência física (18 com PC e 1 com distúrbio da medula espinhal) presentes nos dias das aplicações (do total de 25 alunos - ver Tabela 6) das três classes de pré-escola existentes unidade-caso 3. A aplicação do questionário ocorreu nos dias 12/11/2009 (duas salas, uma de cada vez, com 6 e 8 alunos, respectivamente) e 17/11/2009 (uma sala com 5 alunos). 
O processo de aplicação descrito a seguir ocorreu de forma similar nas três classes de pré-escola. A maioria dos alunos de uma das classes se encontrava sentada em suas respectivas cadeiras de rodas com as mesas acopladas. Inicialmente, a pesquisadora e a docente, com o apoio da equipe de voluntários, aplicaram a entrevista lúdica com desenho temático ${ }^{312}$. Em seguida, se iniciou a aplicação do questionário, de forma coletiva.

A pesquisadora explicou que os alunos não poderiam olhar a resposta dos colegas, e principalmente que não havia certo ou errado, pois o importante era a opinião de cada um. A pesquisadora solicitou à equipe de voluntários a não interferência nas respostas dos alunos. A presença desta equipe proporcionou um ambiente tranquilo, otimizou as três aplicações bem como uma grande produção de imagens, pois uma dos voluntários em cada aplicação era responsável por esta tarefa, sob a supervisão da pesquisadora ${ }^{313}$.

A pesquisadora entregou a cada aluno uma folha do questionário e solicitou que utilizassem o material disponível em seus estojos por serem adaptados (em alguns casos) para a marcação das alternativas. Os voluntários prenderam as folhas às mesas da maioria dos alunos com a fita adesiva. Cada pergunta foi lida pela pesquisadora em voz alta, de forma coletiva, havendo um período de tempo após o enunciado de cada questão para a execução da resposta pelos alunos. Durante este período a pesquisadora, a docente e os voluntários se dirigiram a cada aluno, de

\footnotetext{
312 Descrita no item 7.2.2.3).

${ }^{313}$ Com a orientação da pesquisadora de evitar as fotos dos rostos dos alunos, posicionando-se por trás do aluno.
} 
forma individual, para prestar auxílio, caso necessário, lendo novamente o enunciado da questão (Figura 89).

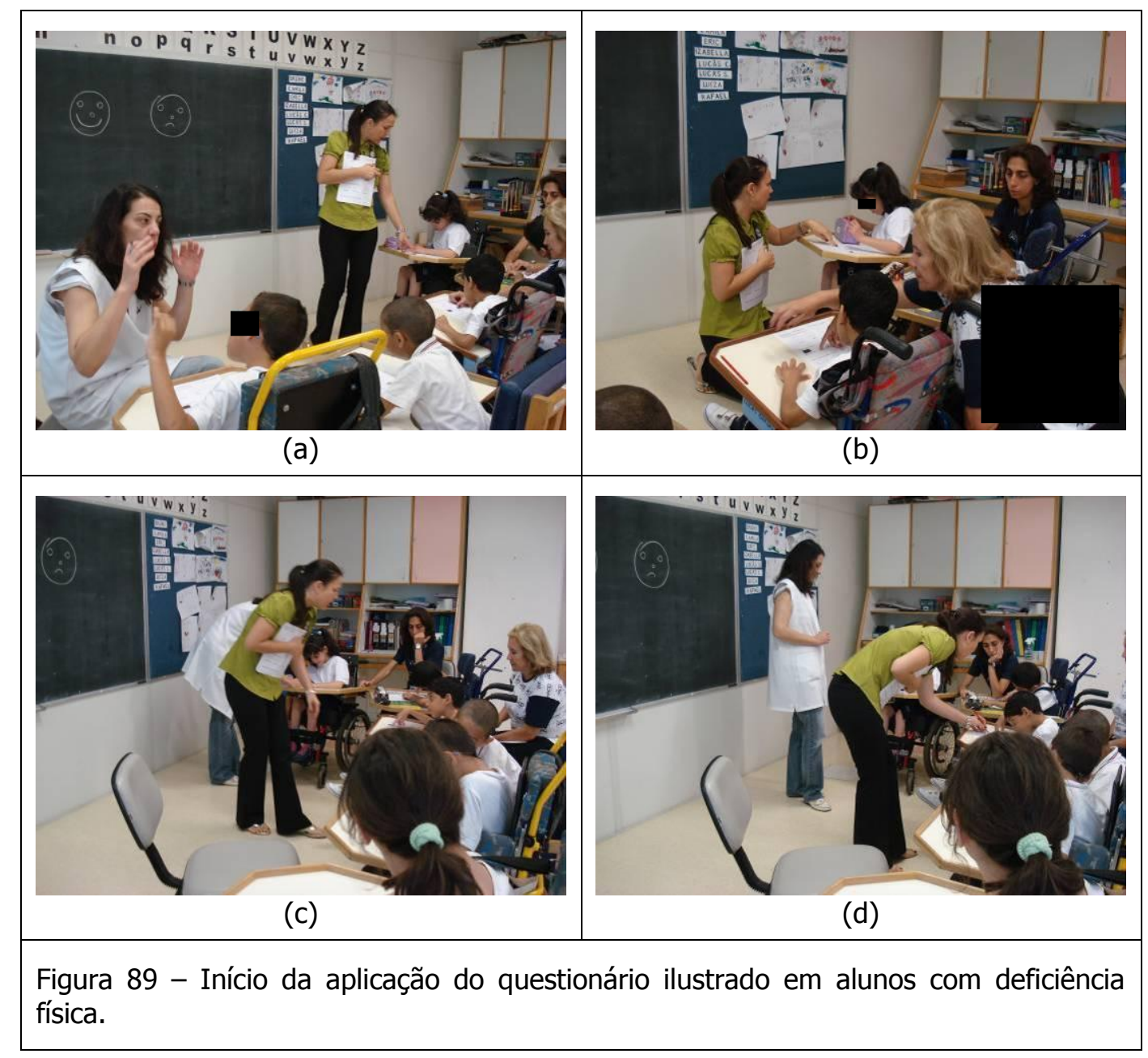

Todos os alunos apresentaram um ótimo desenvolvimento intelectual e conseguiram responder o questionário ilustrado de forma satisfatória. O nível de dificuldade física para a realização do questionário se apresentou de forma variável entre os alunos das três classes em função do grau de comprometimento decorrente da PC. Alguns alunos sem fala funcional (usuários de CAA) e com alguma coordenação motora nos membros superiores conseguiram apontar com o dedo (ou parte da mão) o símbolo referente à alternativa eleita do questionário (Figura 90a), através da técnica de 
seleção direta ${ }^{314}$, com o posterior auxílio da docente na marcação da alternativa eleita (Figura 90b).

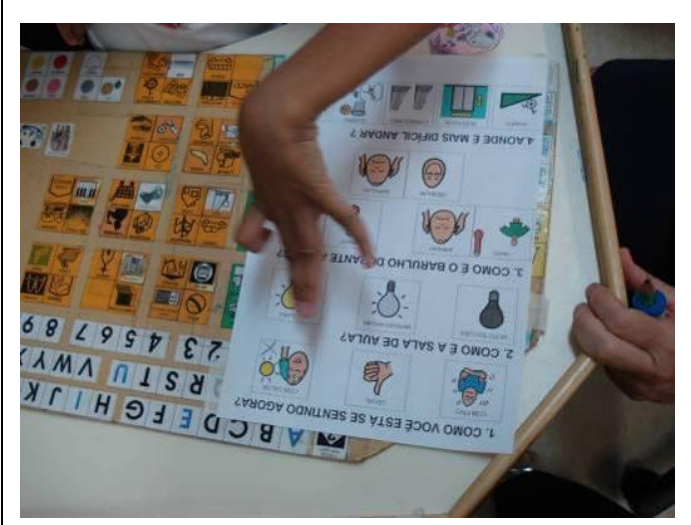

(a)

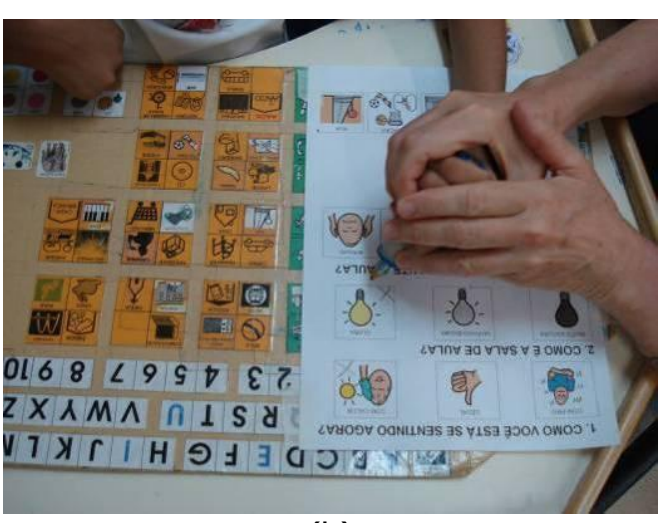

(b)

Figura 90 - Técnica de seleção direta (a) e auxílio na marcação da alternativa eleita (b) no questionário ilustrado destinado aos alunos com deficiência física.

Outros alunos com PC, sem fala funcional (usuários de CAA), e com maior comprometimento motor nos membros superiores não conseguiram apontar 0 símbolo referente à alternativa eleita do questionário, e utilizaram a técnica da varredura $^{315}$ através de outras respostas voluntárias consistentes, como sorrir ou emitir um som, para que possa sinalizar sua resposta para a posterior na marcação da alternativa pela docente (Figura 91).

${ }^{314}$ É o método preferível, quando possível. As técnicas mais comuns requerem que os indivíduos apontem ou toquem diretamente o símbolo. Pode-se apontar com o dedo ou com uma ponteira de cabeça ou luz fixada na cabeça. Diferentes partes do corpo, tais como o dedo do pé, punho ou cotovelo, também podem ser utilizados para a seleção direta. Disponível em: <www.proac.uff.br/.../comunicacao-alternativa->. Acesso em: 17 dez. 2009. Ver item 2.2.1.1 relativo a CAA.

${ }^{315}$ Esta técnica exige somente que a pessoa tenha uma resposta controlável consistente, como sacudir a cabeça, bater um pé ou piscar os olhos. Os recursos de baixa tecnologia necessitam de um facilitador para apontar para os símbolos de maneira sistemática, enquanto o usuário sinalizará quando o símbolo desejado for apontado. Alguns recursos de alta tecnologia apresentam varredura automática. Disponível em: <www.proac.uff.br/.../comunicacao-alternativa->. Acesso em: 17 dez. 2009. Ver item 2.2.1.1 relativo a CAA. 


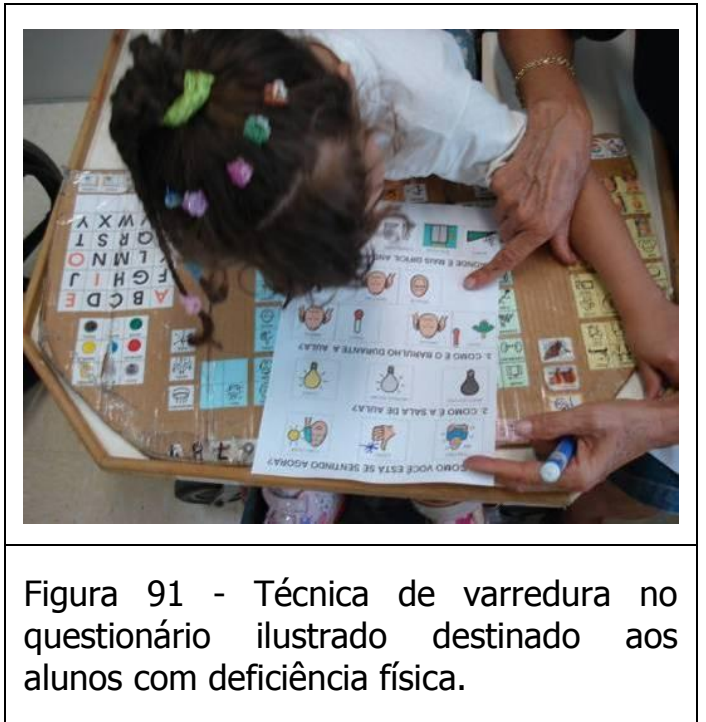

Alguns alunos com PC iniciaram a marcação das alternativas através da técnica da seleção direta (Figura 92a, b), porém não conseguiram terminar em função do cansaço. Utilizou-se, então, a técnica da varredura, através da qual a docente passava por todas as alternativas segurando o braço do aluno (Figura 92c, d), e o mesmo realizava um movimento voluntário indicando a alternativa eleita. 


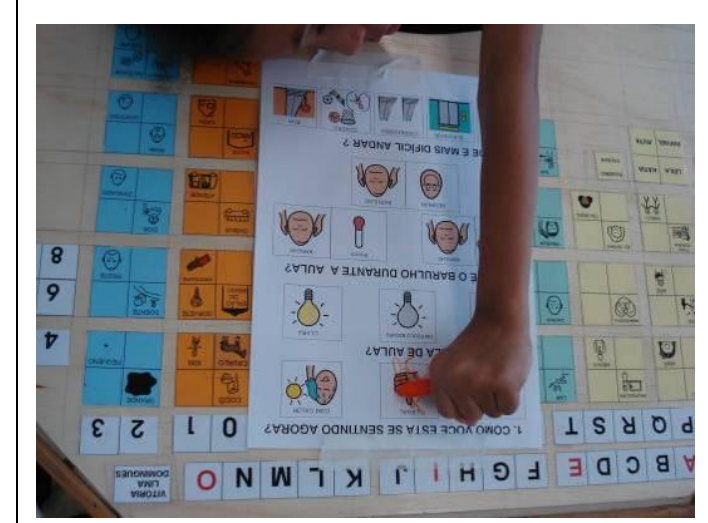

(a)

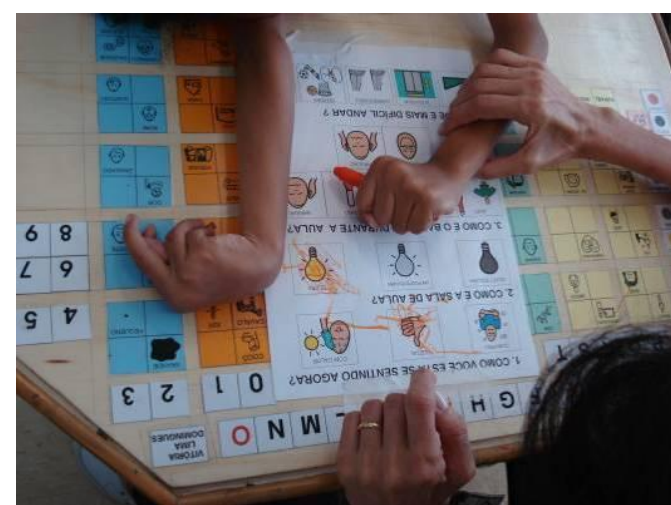

(c)

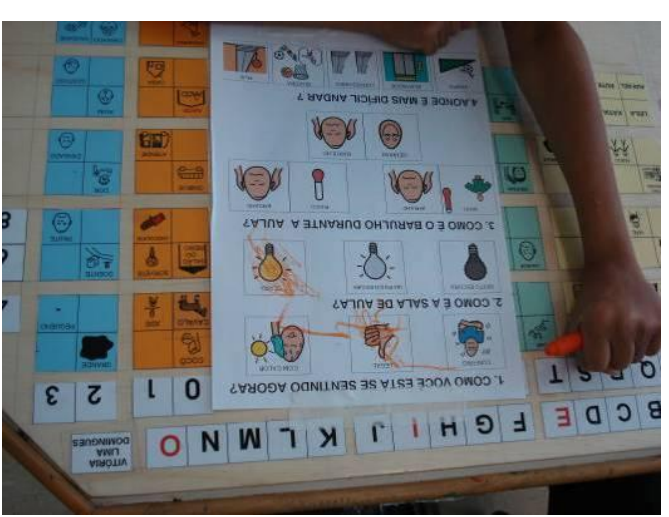

(b)

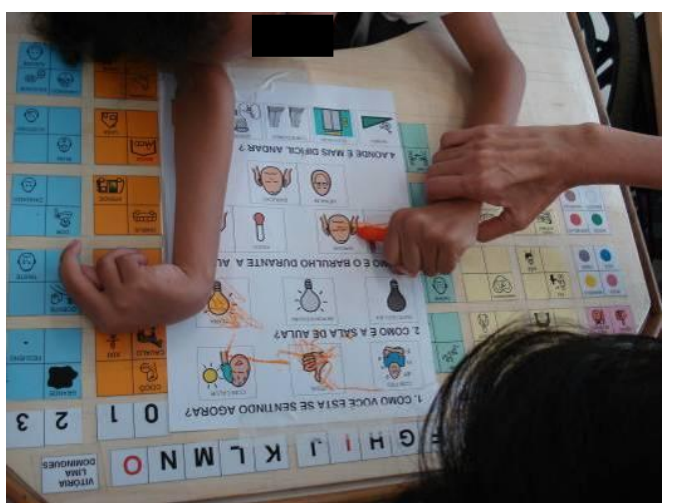

(d)

Figura 92 - Execução do questionário ilustrado em PCS pela aluna V., de 9 anos, com PC.

Alguns alunos com PC, com e sem fala funcional, e com menor comprometimento motor nos membros superiores conseguiram responder o questionário, com dificuldade (Figura 93a, c, d), com o auxílio da docente ou de uma voluntária em pequenas tarefas, como proteger o restante da folha em função do traço descordenado (Figura 93b) e axiliar na pega do giz ou da caneta. 


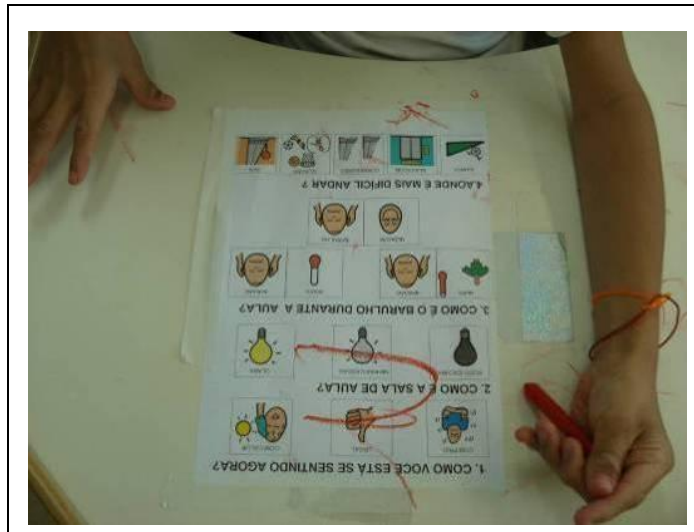

(a)

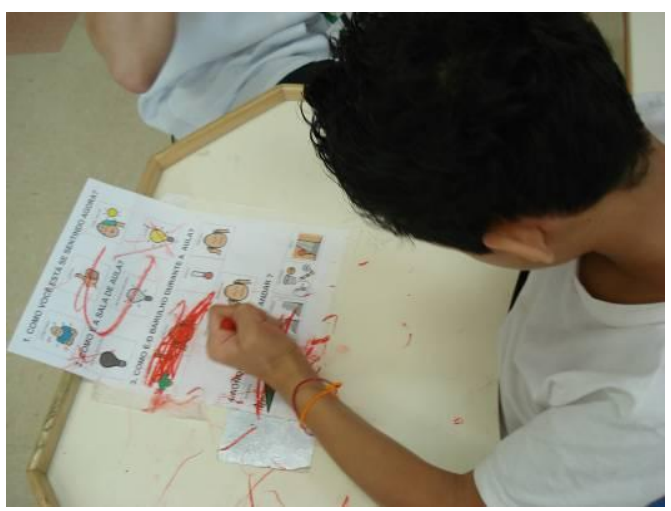

(c)

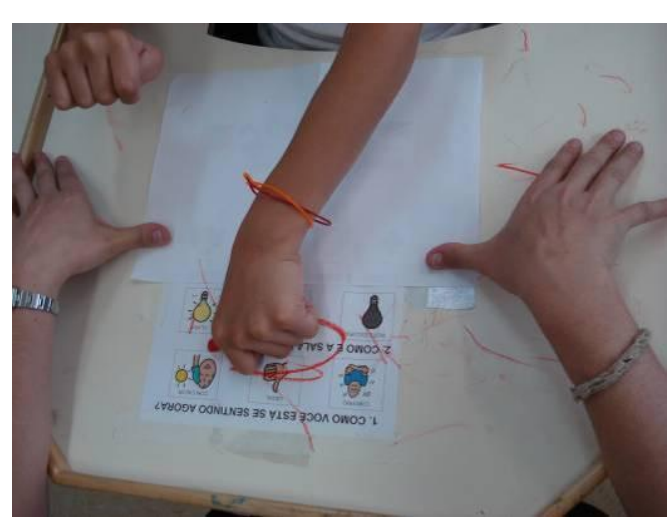

(b)

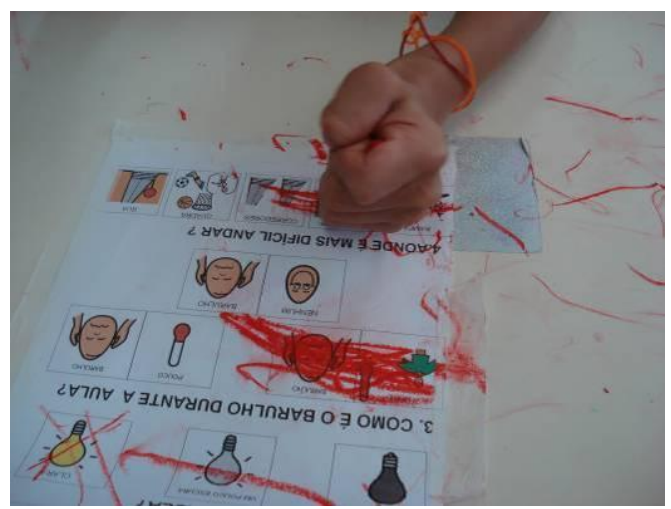

(d)

Figura 93 - Execução do questionário ilustrado em PCS pelo aluno M., de 8 anos, com PC.

Poucos alunos com deficiência física, sem (ou com leve) comprometimento na fala e motor nos membros superiores, responderam o questionário ilustrado com facilidade e conseguiram segurar o giz de cera ou a caneta para a marcação do símbolo referente à alternativa eleita do questionário sem nenhum auxílio da docente ou do voluntária, de forma autônoma (Figura 94). 


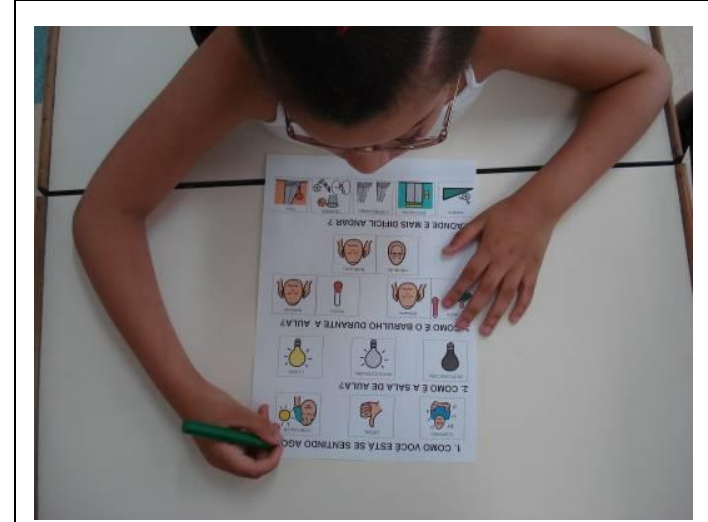

(a)

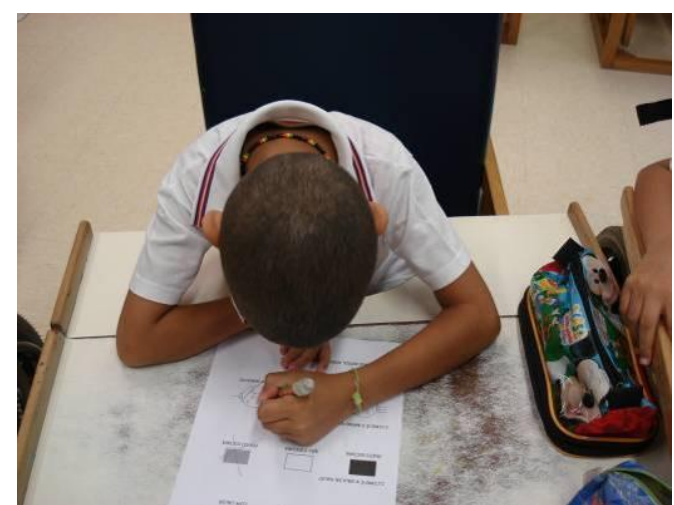

(c)

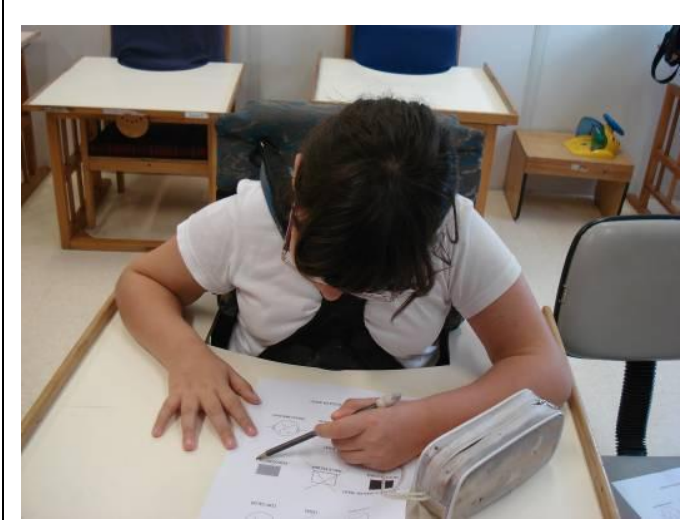

(b)

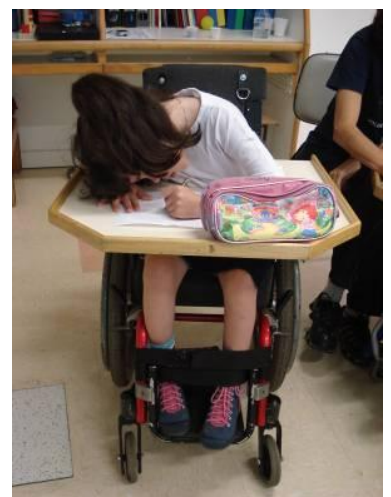

(d)

Figura 94 - Realização com independência do questionário ilustrado destinado aos alunos com deficiência física.

\subsubsection{Análise dos resultados e modificações para a próxima etapa}

\section{Apoio no processo de aplicação}

O processo de aplicação do questionário foi mais eficaz nos alunos com PC em função do apoio da docente e dos três a quatro voluntários, por classe, resultando em uma atmosfera tranquila e propícia a pesquisa. Ainda em função desse apoio, uma grande quantidade de imagens foi gerada ${ }^{316}$ ). $\mathrm{O}$ fato de os alunos com PC não se locomoverem sozinhos e de se encontrarem devidamente espaçados entre si em

316 Um dos voluntários era responsável por esta tarefa, sob a supervisão da pesquisadora. 
suas respectivas cadeiras de rodas não permitiu a influência entre os alunos na escolha das alternativas de resposta.

O processo de aplicação coletiva não foi satisfatório nos alunos surdos, pois falta a de espaçamento adequado entre os alunos permitiu a influência na escolha das alternativas de resposta entre os mesmos. O apoio da docente destes alunos foi muito importante devido à necessidade de uso da LIBRAS.

Esse processo também não foi satisfatório entre os alunos com baixa visão, pois a pesquisadora se encontrava sem apoio de outras pessoas, e, tinha que dar atenção concomitante ao aluno e ao processo de aplicação, não havendo oportunidade para registro fotográfico e maiores anotações do próprio processo.

\section{Entendimento e marcação das alternativas eleitas no questionário}

Os alunos com PC entenderam as questões, bem como as alternativas de resposta, e destacaram-se na pesquisa em função do alto nível de alfabetização (únicos na pesquisa) para o nível pedagógico relativo à pré-escola. Os alunos elegeram as respostas com o menor tempo em toda a pesquisa, porém levaram mais tempo para a marcação da alternativa eleita em função das limitações nos membros superiores (com algumas exceções). A marcação das alternativas foi uma tarefa difícil para 30\% dos alunos com PC (usuários da CAA) e com maior comprometimento dos membros superiores. Para esses alunos o ato de marcar a alternativa exigiu grande esforço físico mesmo com a ajuda da docente, o que reafirma a necessidade de um questionário breve. Todos os alunos com deficiência física conseguiram responder ao 
questionário (técnica da varredura e/ou seleção direta), com e/ou sem o auxílio do aplicador, porém com diferentes graus de dificuldade em função das limitações motoras individuais.

Os alunos com baixa visão entenderam as questões, que ainda eram lidas oralmente pelo aplicador; entretanto, levaram mais tempo do que os alunos com deficiência física para a escolha das alternativas de resposta. A marcação da alternativa pelos alunos com baixa visão, após sua eleição, foi rápida em função das boas condições motoras nos membros superiores dos respondentes.

Metade dos alunos surdos apresentou dificuldade em relação ao entendimento das questões em função de se encontrarem em estágio inicial de aprendizagem da LIBRAS e, portanto, com vocabulário restrito, bem como em função de as ilustrações do questionário estarem muito monótonas (formas muito simplificadas e acromáticas). A marcação da alternativa pelo aluno, após sua eleição, foi rápida devido às das boas condições motoras nos membros superiores. Após o término da aplicação, a docente, especialista em deficiência auditiva, relatou que achava mais produtivo se as perguntas realizadas fossem ilustradas através de fotos de ambientes da escola, pois as crianças surdas utilizam muito o sentido da visão. Percebeu-se que os alunos com PC e baixa visão também teriam melhores resultados na entrevista com a existência de alternativas de respostas ilustradas por fotos.

A forma de o aluno marcar a alternativa eleita no questionário não seguiu um padrão; ora os alunos riscavam a ilustração (em especial, os alunos com PC e sem 
coordenação dos membros superiores); ora a contornavam (em especial, os alunos surdos); ora faziam um $x$ em baixo, em cima ou sobre a ilustração (alunos com baixa visão). Somente no caso dos alunos cegos e de um aluno com PC sem coordenação motora nos membros superiores, a resposta foi marcada pelo aplicador após a indicação da alternativa eleita pelo aluno.

Após a análise do processo de aplicação do questionário ilustrado descrita anteriormente, foram elaboradas as seguintes alterações visando à nova aplicação na segunda etapa da pesquisa:

- o apoio à pesquisadora de pelo menos duas pessoas externas ${ }^{317}$ nas aplicações destinadas aos alunos cegos e com baixa visão (unidade-caso 1) e de pelo menos uma pessoa externa, no caso dos surdos (unidade-caso 2), em função da necessidade de auxílio na locomoção, no entretenimento dos demais alunos da classe, na geração de imagens e nas anotações das repostas verbais dos alunos;

- a ampliação dos dias de aplicação visando a incluir a totalidade dos alunos aptos a participarem da pesquisa ${ }^{318} \mathrm{e}$;

- a discussão sobre detalhes dos questionários e do seu processo de aplicação nas entrevistas com as respectivas docentes.

\section{Alunos cegos}

Na segunda etapa da pesquisa de campo, decidiu-se que o questionário destinado aos alunos cegos não seria em papel, $2 \mathrm{D}$, mas em maquetes táteis $3 \mathrm{D}^{319}$ visando à

${ }^{317}$ Trazida pela pesquisadora.

${ }^{318} \mathrm{Em}$ função dos alunos faltantes.

${ }^{319}$ Confeccionado pela pesquisadora - ver item 8.3.1. 
facilidade na aplicação pela pesquisadora (com formação em arquitetura), e principalmente, buscando melhores resultados por parte dos alunos.

Alunos com baixa visão, surdos e com PC

- a revisão da maioria das ilustrações das alternativas de resposta do questionário, adotando-se o uso combinado de símbolos em PCS e fotos, ambos coloridos ${ }^{320}$, com o intuito de evitar a abstração do questionário pelos alunos com surdez, de disponibilizar ao aluno com PC sem fala e sem movimentos nos membros superiores alternativas que fazem parte de sua rotina escolar que utiliza o PCS complementado por fotos. Buscou-se também, auxiliar os alunos com baixa visão no maior entendimento das questões;

- a utilização da caneta hidrográfica com bitola maior (modelo Jumbo) na marcação das alternativas do questionário em função da facilidade na pega dos alunos, em especial daqueles com falta de coordenação motora nos membros superiores (PC), evitando o uso de material do aluno;

- o aumento da gramatura do papel sulfite para 180 gramas em função da danificação do papel no caso de sua fixação à mesa.

As ilustrações em PCS do questionário foram revistas pela fonoaudióloga ${ }^{321}$ da unidade-caso 3 (Figura 95a) em conjunto com a pesquisadora. Foram pesquisadas e rastreadas as alternativas de resposta na biblioteca de dados do software

\footnotetext{
320 Menos monótonas em função do uso do sentido da visão.

${ }^{321}$ Que havia participado da elaboração do questionário na primeira etapa da pesquisa.
} 
Boardmaker (Figura 95b), bem como no Manual do Usuário (PEAKE, 2004) (Figuras $95 c, d)$.

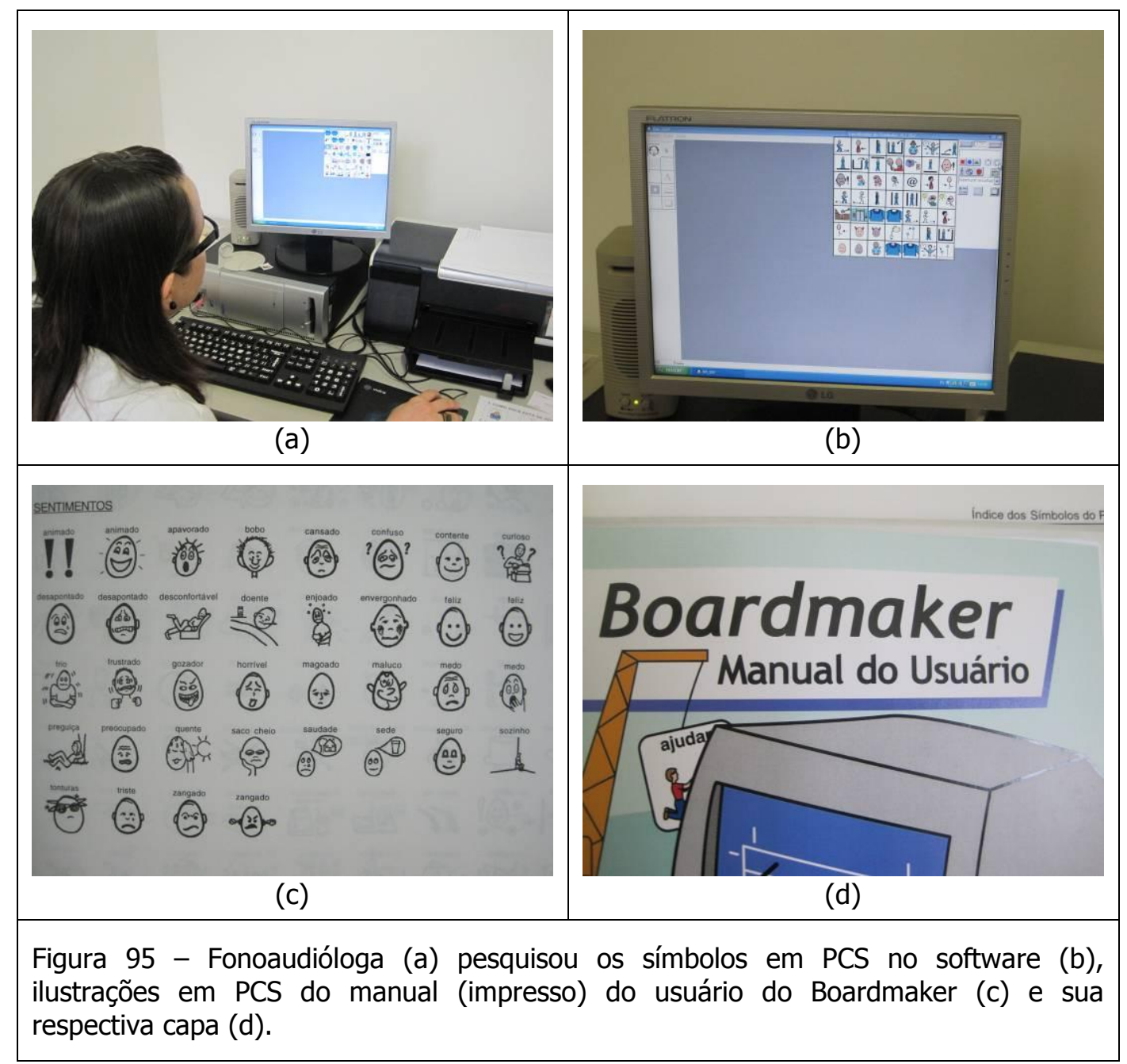

As ilustrações dos questionários destinados aos alunos com baixa visão, surdos e com PC na segunda etapa da pesquisa se encontram descritas e comentadas a seguir. 


\begin{tabular}{|c|c|c|}
\hline \multirow{2}{*}{ Deficiência } & \multicolumn{2}{|l|}{$\begin{array}{l}\text { Questão: conforto térmico } \\
\text { COMO VOCÊ ESTÁ SE SENTINDO AGORA? }\end{array}$} \\
\cline { 2 - 4 } $\begin{array}{c}\text { Visual } \\
\text { (baixa visão) }\end{array}$ & COM FRIO & COMAL CALOR \\
\hline $\begin{array}{c}\text { Auditiva } \\
\text { (surdez) }\end{array}$ &
\end{tabular}

Quadro 59 - Ilustrações em PCS da questão de conforto térmico destinada aos pré-escolares com deficiência visual (baixa visão), auditiva e física na $2^{\mathrm{a}}$ etapa da pesquisa.

\begin{tabular}{|c|c|c|c|}
\hline \multirow{2}{*}{ Deficiência } & \multicolumn{3}{|l|}{$\begin{array}{l}\text { Questão: conforto acústico } \\
\text { COMO É O BARULHO DURANTE A AULA? }\end{array}$} \\
\cline { 2 - 4 } $\begin{array}{c}\text { Visual } \\
\text { (baixa visão) }\end{array}$ & MUITO BARULHO & POUCO BARULHO & POUQUÍSSIMO BARULHO \\
\hline $\begin{array}{c}\text { Auditiva } \\
\text { (surdez) }\end{array}$ &
\end{tabular}

Quadro 60 - Ilustrações em PCS da questão de conforto acústico destinada aos pré-escolares com deficiência visual (baixa visão) e física na $2^{\mathrm{a}}$ etapa da pesquisa.

Na questão relativa ao conforto acústico, foram pesquisados vários símbolos em PCS (Figura 96), até que o do Quadro 61 fosse eleito.

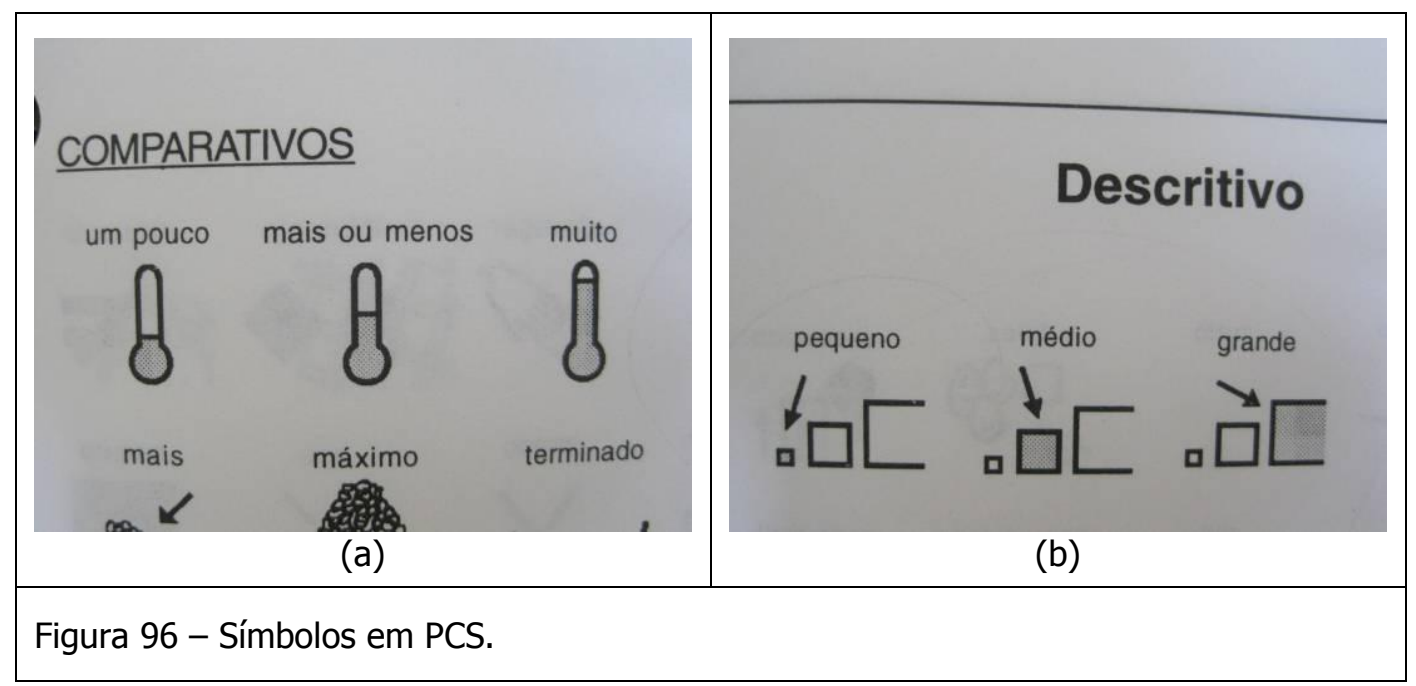




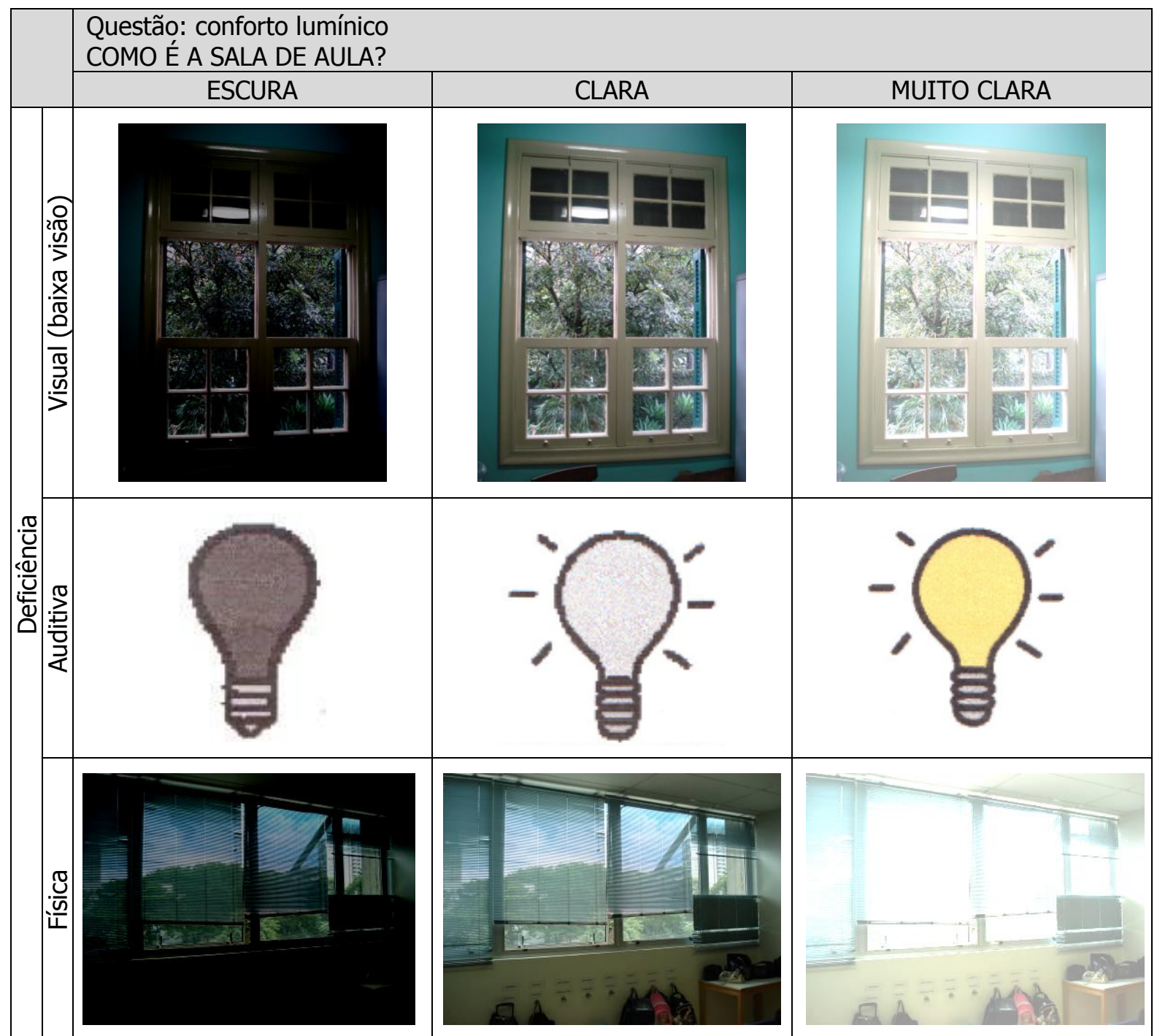

Quadro 61 - Ilustrações da questão de conforto lumínico destinada aos alunos com deficiência visual (baixa visão), auditiva e física na $2^{\mathrm{a}}$ etapa da pesquisa.

Em relação à questão de conforto lumínico, apresentou-se à docente, especializada nos alunos com surdez, a possibilidade de uso de outras ilustrações (como as constantes na Figura 97). Entretanto a docente optou pelas ilustrações em PCS do Quadro 62. 

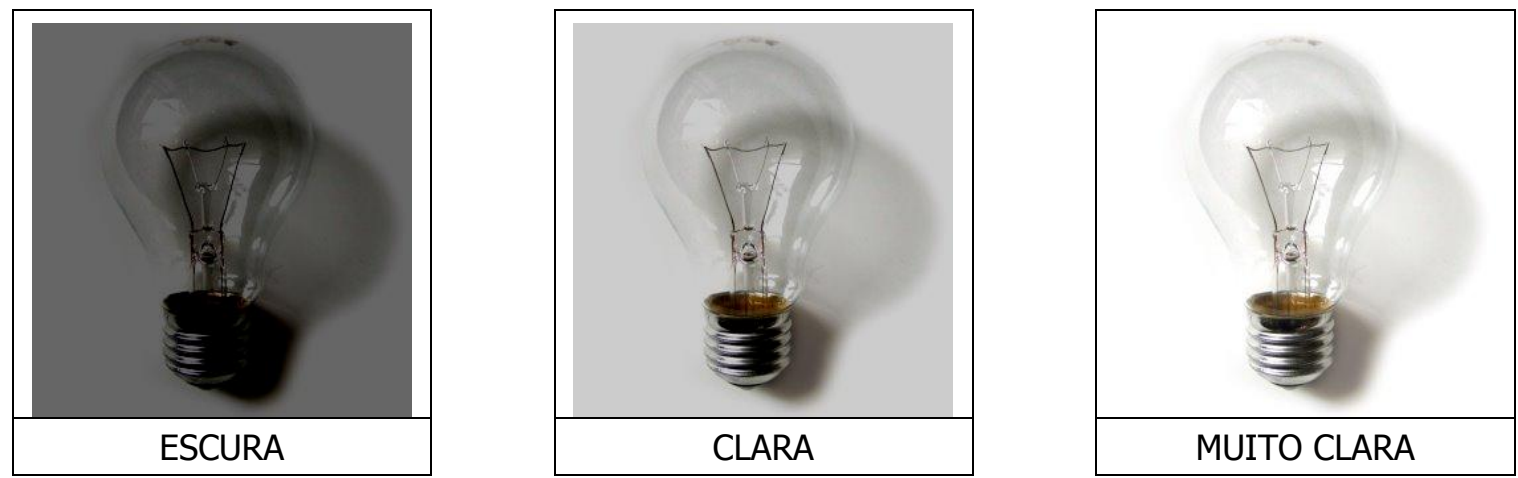

Figura 97 - Opções de ilustrações descartadas relativas à questão de conforto lumínico.

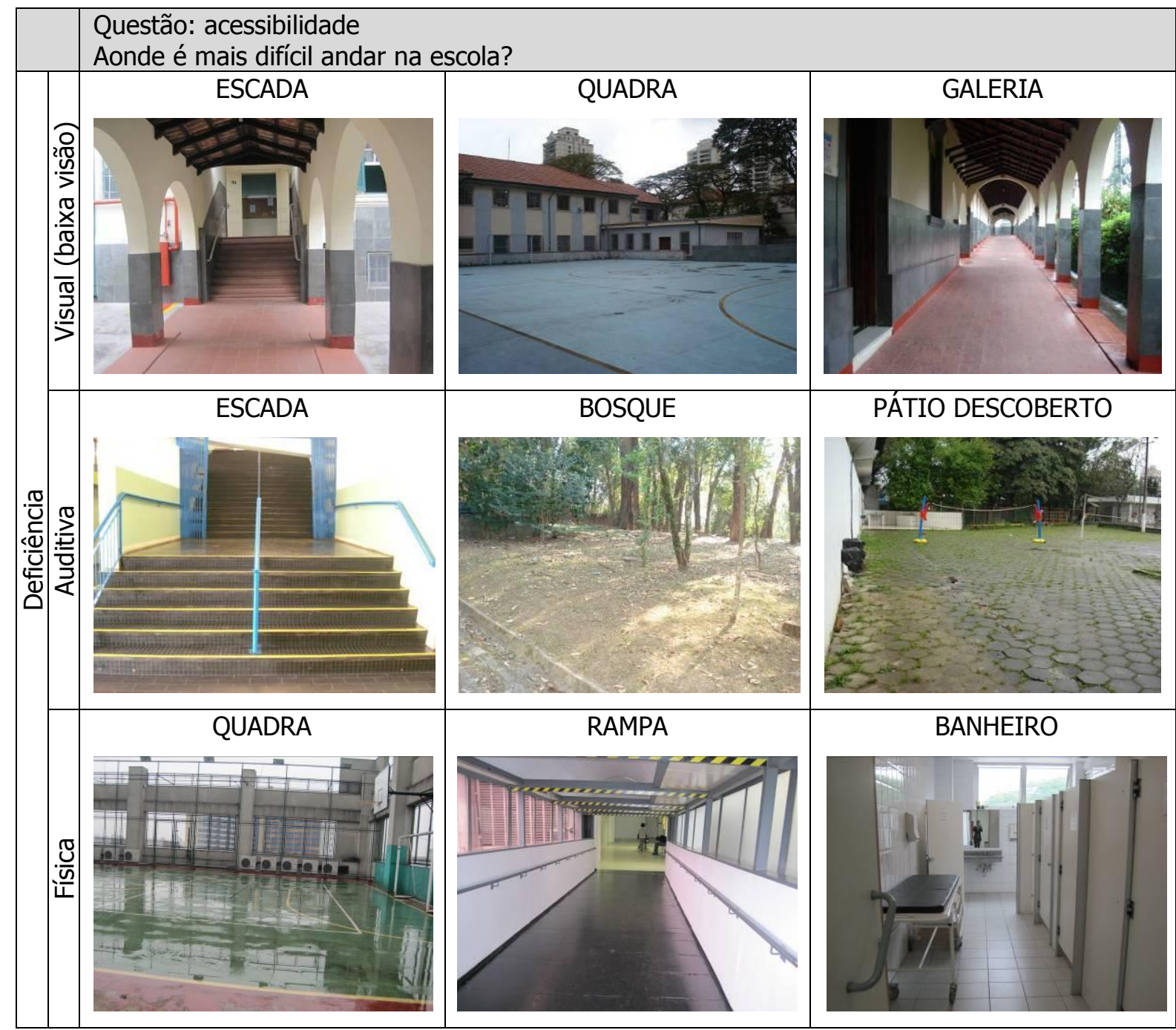

Quadro 62 - Ilustrações da questão de acessibilidade física destinada aos alunos com deficiência visual, auditiva e física na $2^{\mathrm{a}}$ etapa da pesquisa. 


\section{3 $\quad 2^{\mathrm{a}}$ etapa da pesquisa}

\subsubsection{Questionário 3D - com o uso de maquetes táteis}

Na segunda etapa, a modalidade do questionário 3D (3 dimensões) teve como objeto de estudo os alunos cegos aptos a participarem da pesquisa (ver Tabela 4) da préescola da unidade-caso 1.

O papel de uma maquete comum é o de "representar uma determinada área, ou um ambiente, em um formato menor, mas nas suas devidas proporções. 0 vidente consegue, quase que instantaneamente, obter a compreensão global e sintética do todo ao olhar para a maquete." (BASTOS et al, 2010). A maquete permite uma concreta manipulação e visualização, em terceira dimensão (3D), de diferentes dados e informações e possibilita percepção e compreensão dos mesmos. É construída a partir de uma base plana, em duas dimensões (2D). A pessoa com deficiência visual utiliza os sentidos remanescentes para obter a compreensão de uma maquete, como com o uso das percepções tátil, auditiva e cinestésica. ${ }^{1322} \mathrm{O}$ uso da maquete tátil é indicada nas escolas, pois permite potencializar o uso das habilidades sensoriais dos alunos videntes ou não. Segundo Bernardi, d' Abreu e Kowaltowski (2009, p. 1828), é importante diferenciar os termos mapa e maquete. A palavra mapa ${ }^{323}$ se refere a representação em 2D de algo descrito e/ou figurado com a clareza de um mapa geográfico convencional, e a maquete é a representação em 3D e escala reduzida,

\footnotetext{
${ }^{322}$ Disponível em: <http://www.bengalalegal.com/maquete.php>. Acesso em: 7 mai. 2011.

${ }^{323}$ Ver itens 2.2 .3 e 7.3.1.
} 
geralmente de uma obra de arquitetura ou engenharia à ser executada (HOUAISS, 2001).

\section{a) Objetivo}

O objetivo do questionário $3 \mathrm{D}$ foi o de identificar os aspectos relacionados ao conforto ambiental (térmico e acústico) e à acessibilidade, a partir da opinião dos alunos cegos.

\section{b) Procedimentos adotados}

A elaboração e os procedimentos de aplicação do questionário 3D destinado aos alunos cegos foram discutidos com as respectivas docentes nas entrevistas realizadas previamente. A pesquisadora elaborou três maquetes táteis ${ }^{324}$, adotando uma linguagem tátil e cuidados específicos, tais como o emprego de materiais de revestimento agradáveis ao tato, sem perigo de pontas ou rebarbas e de tamanho adequado $^{325}$. As dimensões adotadas nas maquetes levaram em consideração as medidas antropométricas da mão, do alcance frontal, da largura do cotovelo à cotovelo sentado, dentre outras, de uma criança de 6 anos (Figura 98).

\footnotetext{
${ }^{324}$ Algumas possibilidades de maquetes foram construídas.

${ }^{325} \mathrm{O}$ ideal é que as dimensões citadas sejam levantadas junto às crianças pertencentes ao universo da pesquisa, porém este estudo preocupou-se com o conceito do questionário 3D e não com questões mais aprofundadas relativas ao design do objeto.
} 


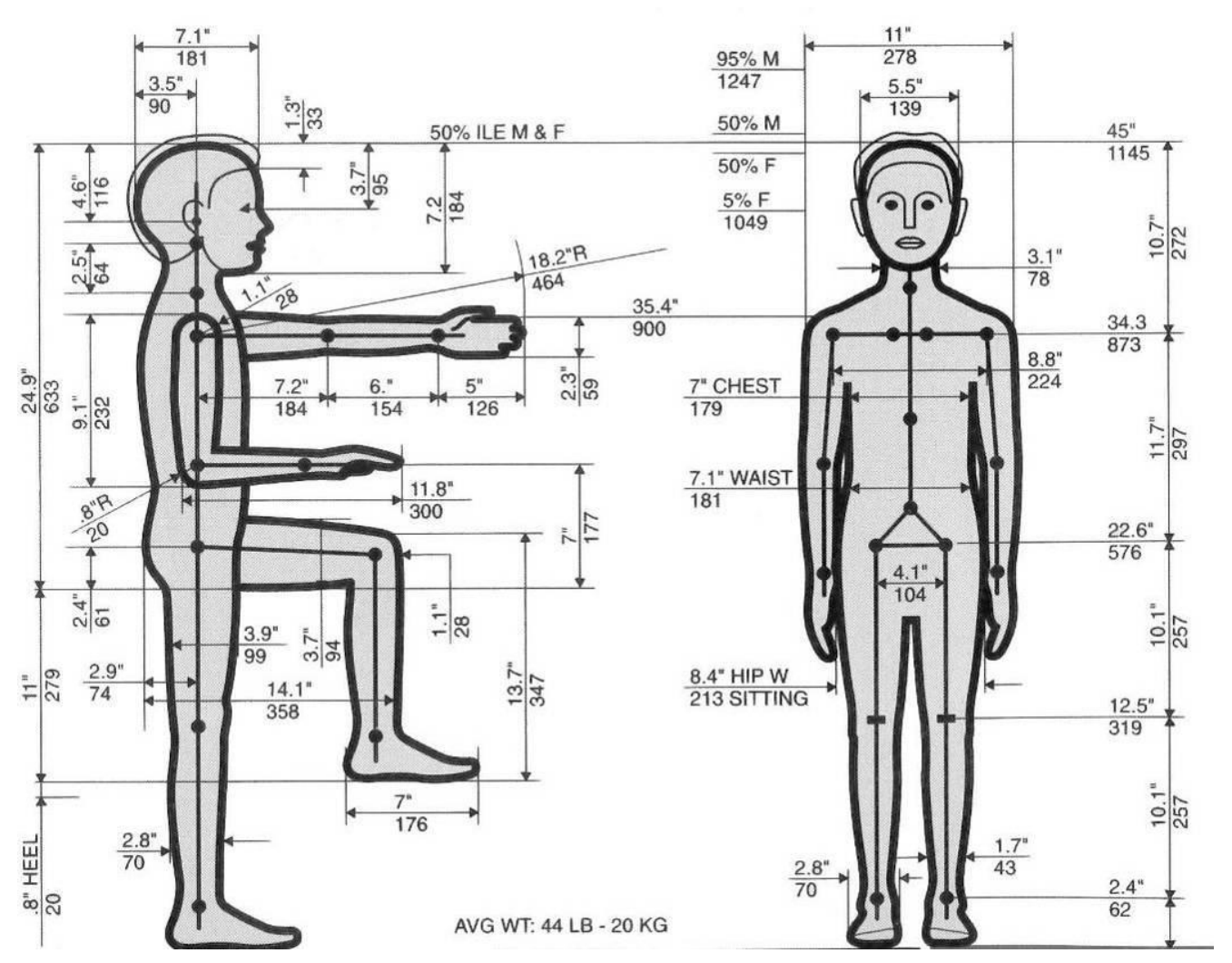

Figura 98 - Dados antropométricos da criança de 6 anos. Fonte: DREYFUSS, 1959.

A aplicação do questionário 3D destinado aos alunos cegos ocorreu de forma individual e contou com o apoio de duas pessoas trazidas pela pesquisadora. Cada aluno foi conduzido à sala de aula e trazido para a sala de orientação e mobilidade, onde foi aplicada a entrevista lúdica com mapa tátil ${ }^{326}$, e em seguida, o questionário 3D com as maquetes, que serão descritas a seguir.

\section{Maquete tátil sonora}

A seguir é descrita a maquete tátil sonora (Figuras 99 e 100), utilizada para a aplicação da questão de conforto acústico, bem como seus dados complementares (Quadro 63).

326 7.3.1. 


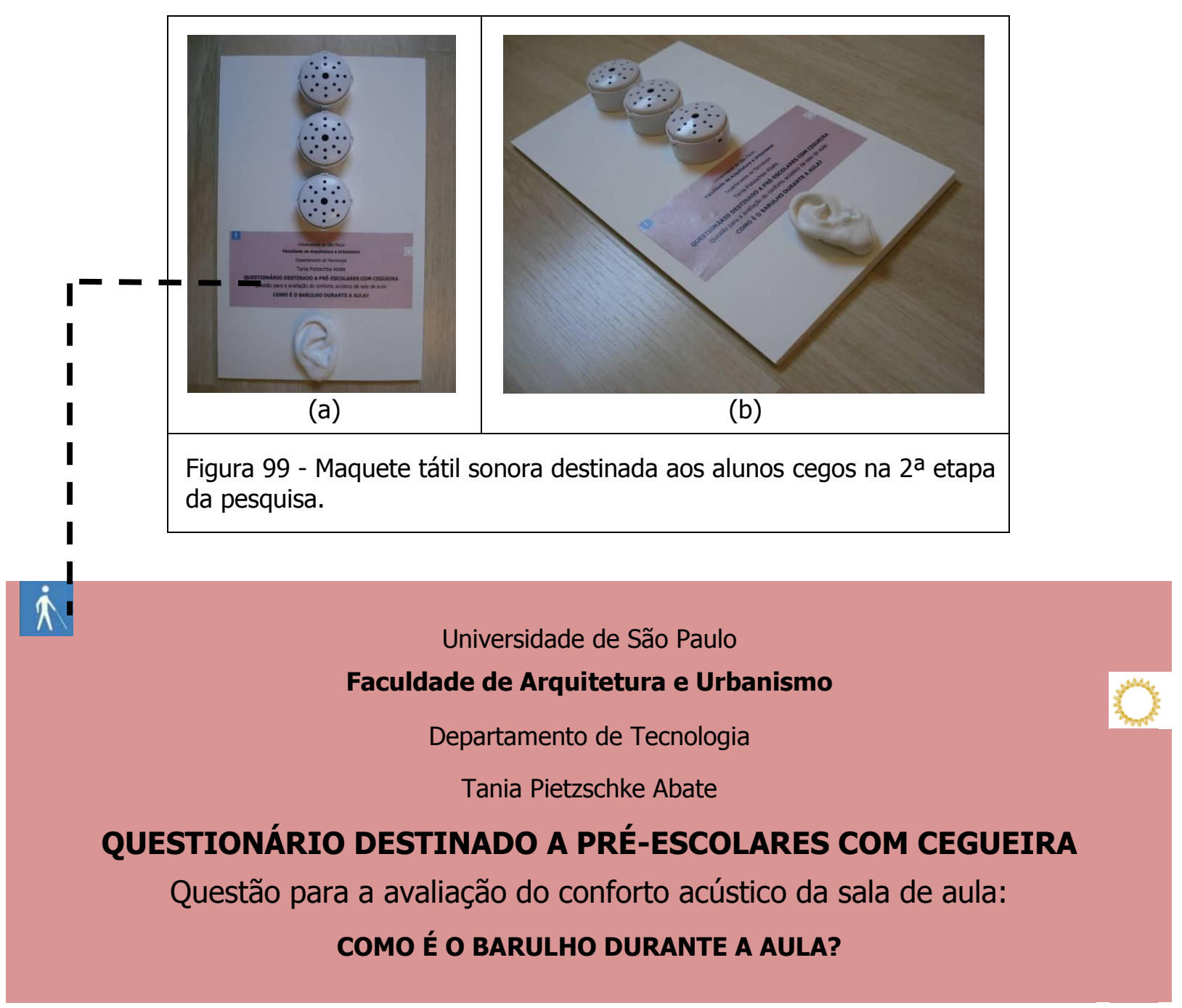

Figura 100 - Etiqueta afixada na maquete tátil sonora.

\begin{tabular}{|l|l|}
\hline Configuração & $\begin{array}{l}\text { Formada pela representação de } 3 \text { alternativas da questão relativa ao conforto } \\
\text { acústico. Na parte superior da maquete havia } 3 \text { botões (reprodutores de som) que ao } \\
\text { serem pressionados reproduziam gravações realizadas pela pesquisadora, } \\
\text { correspondentes, dentro do contexto das alternativas da questão, a } 3 \text { níveis de ruído. } \\
\text { Na parte inferior da base se localizava a prótese auricular infantil em gesso. }\end{array}$ \\
\hline Dimensões & L: $18 \mathrm{~cm} / \mathrm{C}: 29 \mathrm{~cm} / \mathrm{H}: 0,5 \mathrm{~cm}$ \\
\hline $\begin{array}{l}\text { Material } \\
\text { utilizado }\end{array}$ & $\begin{array}{l}\text { Placa de isopor revestida com papel sulfite, } 3 \text { reprodutores de som (chamados de } \\
\text { botões), uma prótese auricular infantil em gesso } \\
\text { papel contact, lixa fina. }\end{array}$ \\
\hline $\begin{array}{l}\text { Procedimento quente, fita dupla face, } \\
\text { para a } \\
\text { construção }\end{array}$ & $\begin{array}{l}\text { Medição, na base de isopor revestida com papel sulfite, do posicionamento vertical } \\
\text { dos gravadores. A colagem da prótese auricular com cola quente e dos gravadores } \\
\text { com fita adesiva dupla face. }\end{array}$ \\
\hline
\end{tabular}

Quadro 63 - Dados da maquete tátil sonora destinada aos alunos, cegos, na $2^{\mathrm{a}}$ etapa da pesquisa.

${ }^{327}$ Cedida pelo Dr. Pedro Cheque Bernardo. 
Em relação aos procedimentos para a aplicação, inicialmente, o aluno era posicionado em frente à maquete tátil sonora sendo convidado a tatear a parte inferior da mesma, onde se localizava a prótese auricular em gesso (suas mãos foram guiadas pela pesquisadora).

Enquanto o aluno tateava a prótese a pesquisadora explicava que este exercício era relacionado à audição (fase de aquecimento inicial). Então a pesquisadora conduzia as mãos do aluno para a parte superior da maquete, onde se localizavam os três botões (reprodutores de som gravado).

O aluno reconhecia tatilmente os elementos (formas) que eram descritos concomitantemente pela pesquisadora, que solicitava que o aluno apertasse um botão por vez para um reconhecimento dos níveis de ruído emitidos. Cada botão, ao ser acionado, reproduzia o som do ruído gravado de uma classe de alunos ${ }^{328}$. 0 botão localizado na parte superior emitia esse ruído em um nível mais alto, o na parte central em um nível médio e o na parte inferior em um nível baixo.

Após esta fase de reconhecimento tátil e sonoro pelo aluno, foi realizada verbalmente a pergunta relativa ao conforto acústico: Como é o barulho durante a aula? Solicitou-se que o aluno, sem condução de suas mãos pela pesquisadora, indicasse um dos três botões ou alternativas. A auxiliar da pesquisadora anotou a informação fornecida pelo aluno, e em sequência foi aplicada uma pergunta relativa ao conforto térmico, com a utilização da maquete térmica.

${ }^{328}$ Foram gravados previamente pela pesquisadora durante uma aula na unidade-caso em questão. 


\section{$>$ Maquete tátil térmica}

A seguir é descrita a maquete tátil térmica (Figuras 101 a 103) utilizada para a aplicação da questão relativa a conforto térmico, bem como seus dados complementares (Quadro 65). 


\section{COM FRIO}

LEGAL

Figura 101 - Alternativas impressas para visualização do aplicador.
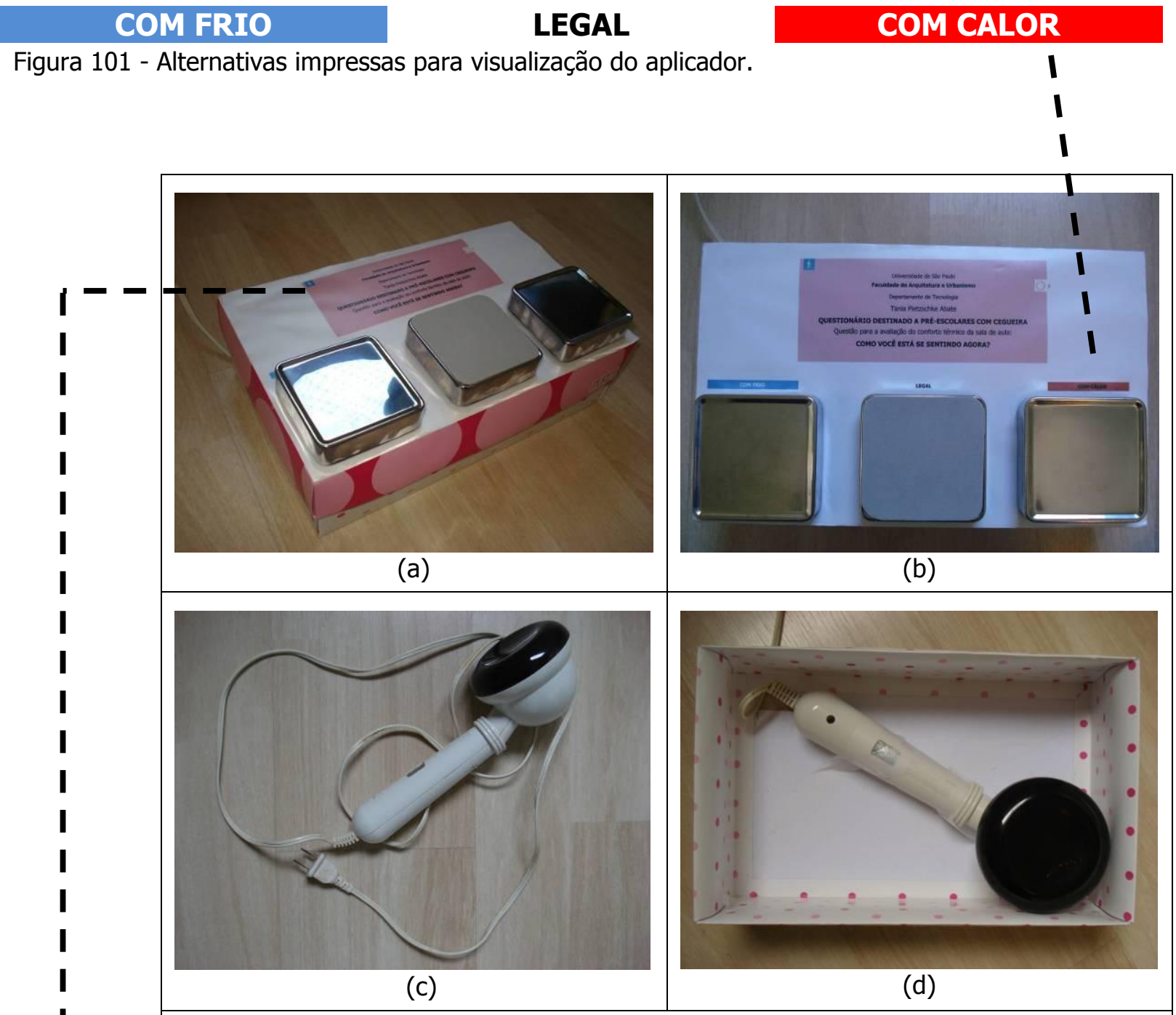

Figura 102 - Maquete tátil térmica destinada aos alunos cegos na $2^{\mathrm{a}}$ etapa da pesquisa $(a, b)$ aparelho de luz infravermelha (c) e o mesmo no interior da maquete citada (d).

Universidade de São Paulo

Faculdade de Arquitetura e Urbanismo

Departamento de Tecnologia

Tania Pietzschke Abate

\section{QUESTIONÁRIO DESTINADO A PRÉ-ESCOLARES COM CEGUEIRA}

Questão para a avaliação do conforto térmico da sala de aula:

\section{COMO VOCÊ ESTÁ SE SENTINDO AGORA?}

Figura 103 - Etiqueta de identificação afixada na maquete tátil térmica. 


\begin{tabular}{|l|l|}
\hline Configuração & $\begin{array}{l}\text { Formada pela representação de } 3 \text { alternativas de resposta da questão de conforto } \\
\text { térmico. Na parte inferior da maquete havia } 3 \text { placas metálicas (aço inox) sendo uma } \\
\text { delas revestidas com EVA (relativa à alternativa legal), outra aquecida pelo aparelho } \\
\text { (relativa à alternativa com calor) e outra em temperatura ambiente (relativa à } \\
\text { alternativa com frio). Portanto, as placas ao serem tateadas emitiam temperaturas } \\
\text { diferentes correspondentes, dentro do contexto das alternativas da questão, a } 3 \\
\text { níveis de temperatura. }\end{array}$ \\
\hline Dimensões & L: $18,5 \mathrm{~cm} / \mathrm{C}: 29,5 \mathrm{~cm} / \mathrm{H}: 8,5 \mathrm{~cm}$ \\
\hline $\begin{array}{l}\text { Material } \\
\text { utilizado }\end{array}$ & $\begin{array}{l}\text { Caixa de papelão, papel sulfite, } 3 \text { placas de aço inox, EVA, prótese auricular infantil } \\
\text { de gesso } 329, \text { cola quente, fita dupla face, papel contact, lixa fina, aparelho de luz } \\
\text { infravermelha portátil com lâmpada de } 110 \mathrm{~V} \text {. }\end{array}$ \\
\hline $\begin{array}{l}\text { Procedimento } \\
\text { para a } \\
\text { construção }\end{array}$ & $\begin{array}{l}\text { Medição, na sulfite impressa e colada na parte superior da maquete, do } \\
\text { posicionamento das placas de aço inox, bem como da distância entre elas. A colagem } \\
\text { do EVA com cola quente em uma das placas, e a furação da tampa da caixa na parte } \\
\text { relativa à placa metálica que seria aquecida pelo aparelho de luz infravermelha, } \\
\text { posicionado dentro da maquete. }\end{array}$ \\
\hline
\end{tabular}

Quadro 64 - Dados da maquete tátil térmica destinada aos alunos cegos na $2^{\mathrm{a}}$ etapa da pesquisa.

Em relação aos procedimentos para a aplicação da maquete tátil térmica, a mesma foi posicionada na frente do aluno cego, que se encontrava sentado ${ }^{330}$. O mesmo foi convidado a tateá-la e suas mãos foram guiadas pela pesquisadora, enquanto a mesma explicava que este exercício estava relacionado à temperatura (fase de aquecimento inicial).

A pesquisadora conduziu as mãos do aluno para que o mesmo reconhecesse tatilmente e termicamente os elementos, que eram descritos concomitantemente pela pesquisadora. $\mathrm{O}$ aluno sentiu a temperatura emitida por cada uma das três placas, uma por vez, para um reconhecimento comparativo dos níveis térmicos.

Após esta fase de reconhecimento tátil e térmico pelo aluno, foi realizada verbalmente a seguinte pergunta relativa ao conforto térmico: Como você está se sentindo agora? Solicitou-se que o aluno, sem condução de suas mãos pela

${ }^{329}$ Cedida pelo Dr. Pedro Cheque Bernardo.

330 Havia acabado de responder a questão anterior. 
pesquisadora, indicasse uma das três placas ou alternativas. A auxiliar da pesquisadora anotou a informação fornecida pelo aluno, e em sequência foi aplicada a questão relativa à acessibilidade, com a utilização da maquete tátil descrita a seguir.

\section{Maquete tátil}

A seguir é descrita a maquete tátil (Figuras 104 e 105) utilizada para a aplicação da questão relativa à acessibilidade, bem como seus dados complementares (Quadro 65).

\begin{tabular}{|l|l|}
\hline Configuração & $\begin{array}{l}\text { Formada pela representação de cada uma das } 3 \text { alternativas (montadas uma de cada } \\
\text { vez durante a aplicação) da questão relativa a acessibilidade. A forma básica da } \\
\text { maquete (placa vertical e horizontal) era a mesma para as } 3 \text { alternativas descritas na } \\
\text { Figura 105, sendo trocados os elementos escada e banheiro (não eram fixos na } \\
\text { base). }\end{array}$ \\
\hline Limensões & L: $33 \mathrm{~cm} / \mathrm{C}: 48 \mathrm{~cm} / \mathrm{H}: 33 \mathrm{~cm}$ \\
\hline $\begin{array}{l}\text { Material } \\
\text { utilizado }\end{array}$ & $\begin{array}{l}\text { Placas de isopor revestidas com papel sulfite, chapa de madeirite, blocos de madeira, } \\
\text { brinquedo plástico (miniaturas de peças sanitárias que emitiam som), cola quente, } \\
\text { fita dupla face, papel contact, lixa fina, tinta plástica branca. }\end{array}$ \\
\hline $\begin{array}{l}\text { Procedimento } \\
\text { para a }\end{array}$ & $\begin{array}{l}\text { Colagem das placas de isopor revestidas com papel sulfite à chapa de madeirite com } \\
\text { cola quente, de dimensões compatíveis ao posicionamento dos elementos móveis } \\
\text { relativos à escada e a miniatura do banheiro sonora. }\end{array}$ \\
\hline
\end{tabular}




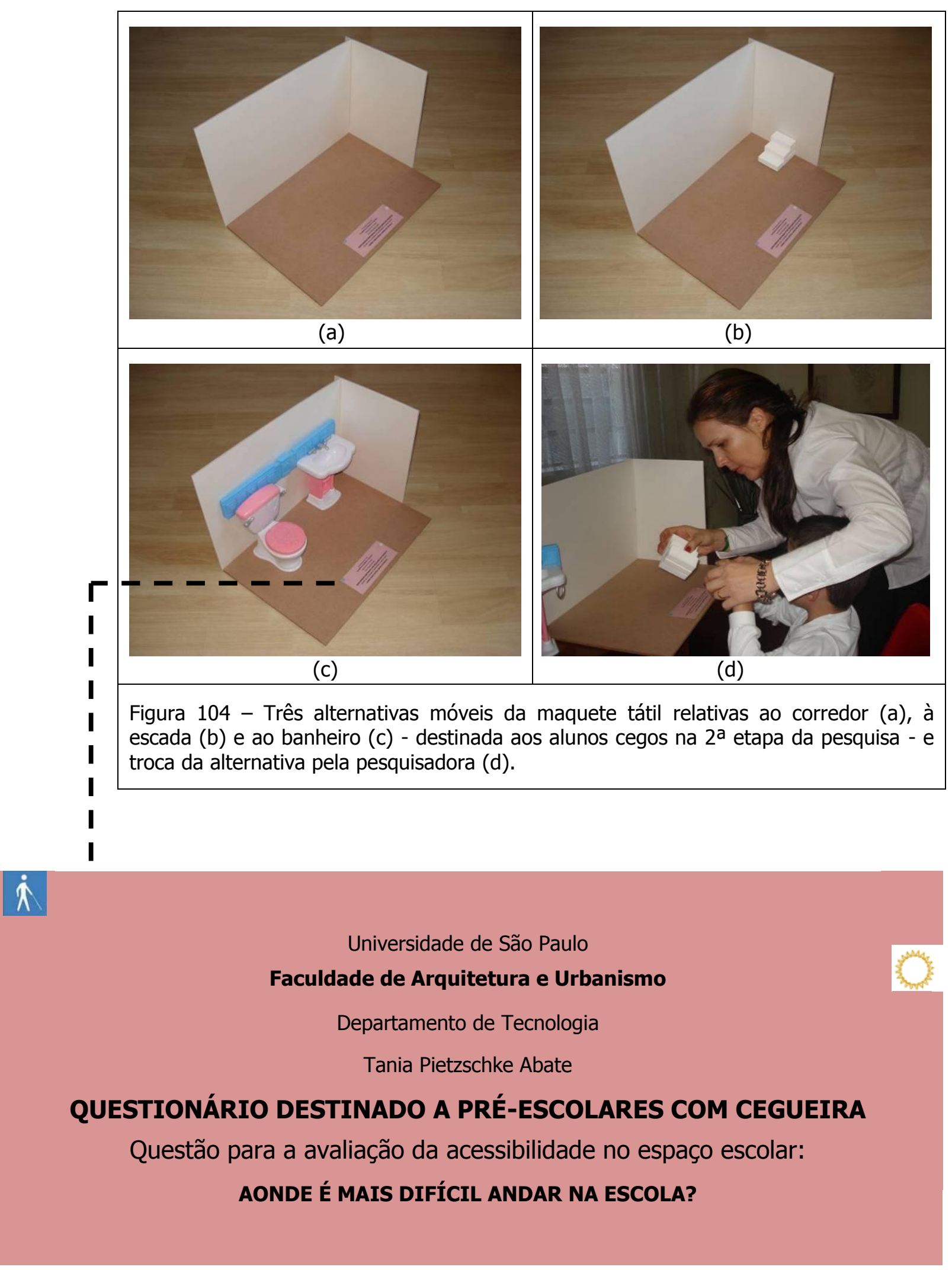

Figura 105 - Etiqueta de identificação afixada na maquete tátil. 
A maquete foi posicionada na frente do aluno cego, que se encontrava sentado ${ }^{331}$. 0 mesmo foi convidado a tateá-la, e suas mãos foram guiadas pela pesquisadora (fase de aquecimento inicial). A pesquisadora conduziu as mãos do aluno para que o mesmo reconhecesse tatilmente os elementos, que eram oralmente descritos pela pesquisadora.

Após esta fase de reconhecimento tátil pelo aluno, foi realizada verbalmente a seguinte pergunta: Onde é mais difícil andar na escola? Solicitou-se que o aluno indicasse verbalmente uma das três alternativas descritas na Figura 104. A auxiliar da pesquisadora anotou a informação fornecida pelo aluno.

A seguir, serão descritos procedimentos complementares do questionário 3D (maquete tátil sonora, maquete tátil térmica e maquete tátil).

> Condução: o questionário 3D foi aplicado pela pesquisadora com o apoio de duas pessoas externas com o prévio consentimento dos participantes, e suas aplicações não foram gravadas. ${ }^{332}$

Datas: variadas, definidas em função da disponibilidade dos alunos.

Duração: variável, de 7 a 12 minutos para a aplicação das três maquetes táteis, ou questões, por aluno.

\footnotetext{
${ }^{331}$ Havia acabado de responder a questão anterior.
}

${ }^{332}$ Voz ou imagem. 


\subsubsection{Alunos cegos: resultados da unidade-caso 1}

Nesta segunda etapa, o questionário 3D com o uso de maquetes táteis foi respondido por 6 alunos cegos aptos (apenas um aluno apto faltou nos dias das duas aplicações $^{333}$ ) a participarem da pesquisa (ver Tabela 4) de forma individual, das duas classes de pré-escola existentes na unidade-caso 1, e ocorreu nos dias 25/10/2010 (5 alunos) e 5/11/2010 (1 aluno).

Apresenta-se o resultado do processo de aplicação do questionário 3D realizado pelo aluno R., de 13 anos, cego, sendo que as demais aplicações ocorreram de forma similar. Inicialmente, a pesquisadora e a estudante de pedagogia conduziram o aluno R. da sala de aula até a sala de orientação espacial e mobilidade. Foi aplicada a entrevista lúdica com mapa tátil ${ }^{334}$ e em seguida, acomodaram-no em uma mesa, onde se encontrava a maquete tátil sonora (relativa a primeira questão de conforto acústico).

Inicialmente, o aluno R. foi convidado a tatear a parte inferior da maquete (Figura 106), onde se localizava a prótese auricular em gesso (suas mãos foram guiadas pela pesquisadora), sendo explicada a proposta da atividade (fase de aquecimento inicial).

333 A pesquisadora retornou em $1 / 12 / 2010$, mas o aluno também havia faltado nesta data.

${ }^{334}$ Ver item 7.3.1.1 


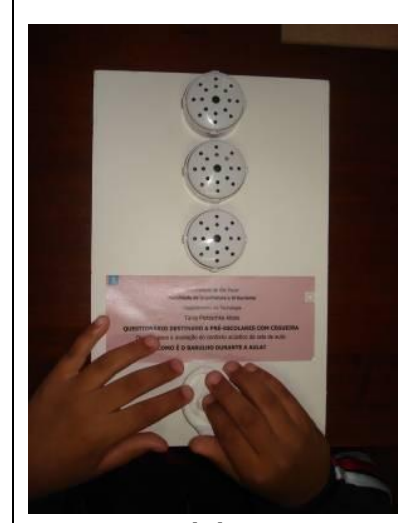

(a)

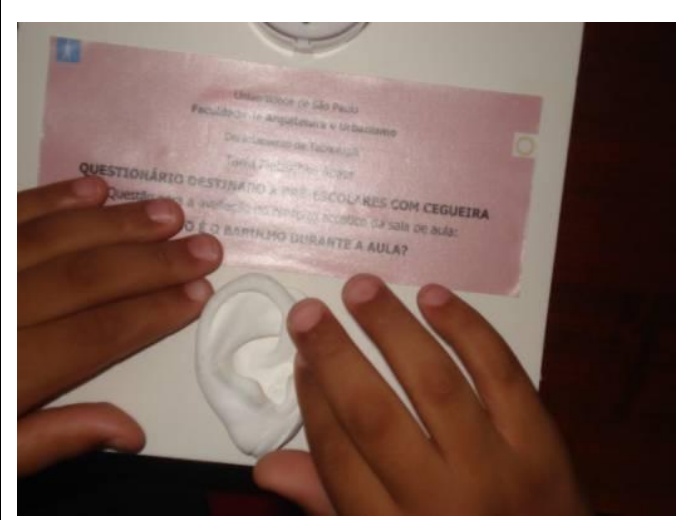

(b)

Figura 106 - Fase de aquecimento da questão relativa a conforto acústico pelo aluno R., de 13 anos, cego, na $2^{\mathrm{a}}$ etapa da pesquisa.

As mãos do aluno foram guiadas para a parte superior da maquete, onde se localizavam os três botões ${ }^{335}$ para o seu reconhecimento tátil e sonoro. (Figura 107).

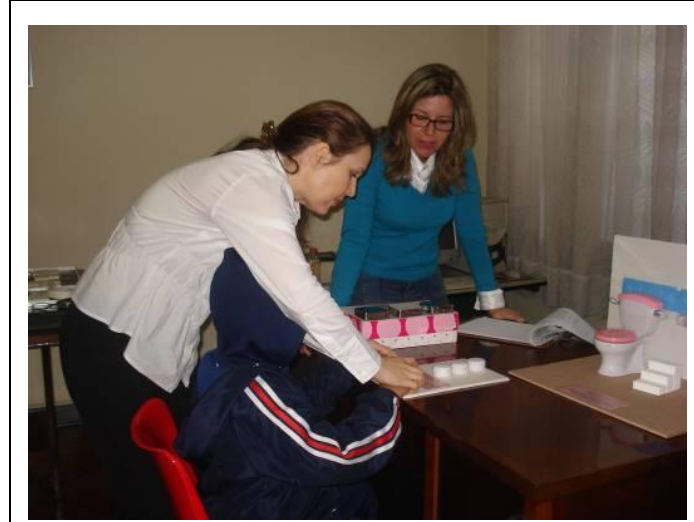

(a)

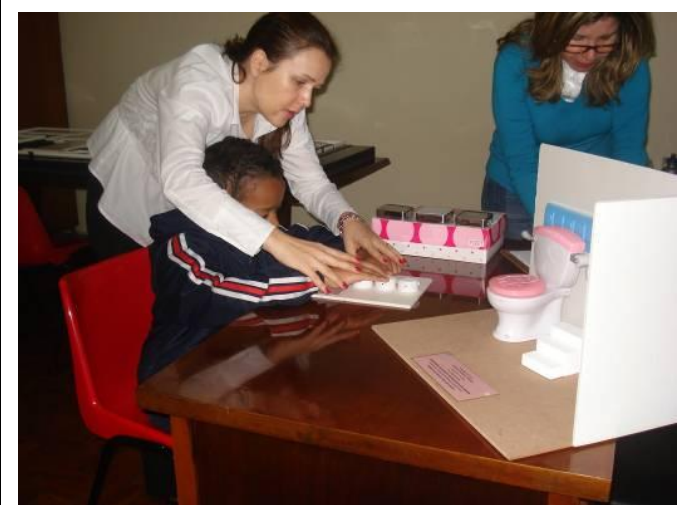

(c)

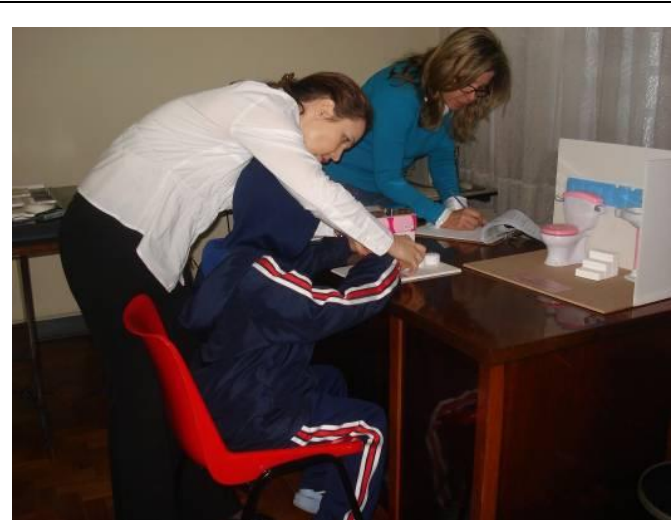

(b)

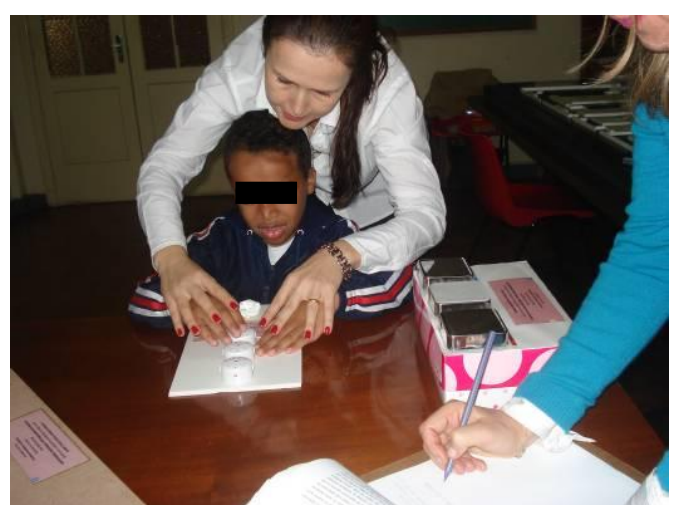

(d)

Figura 107 - Reconhecimento das alternativas da questão relativa a conforto acústico pelo aluno R., de 13 anos, cego, na $2^{\mathrm{a}}$ etapa da pesquisa.

${ }^{335}$ Que emitiam os níveis de ruído. 
Após a fase de reconhecimento tátil e sonoro, foi realizada a pergunta relativa ao nível de ruído na sala de aula e solicitado que o aluno indicasse um dos três botões (ou alternativas), dessa vez sem condução de suas mãos pela pesquisadora (Figura 108a). Usando as duas mãos, o aluno indicou com facilidade a alternativa escolhida (muito barulho) (Figura 108b).

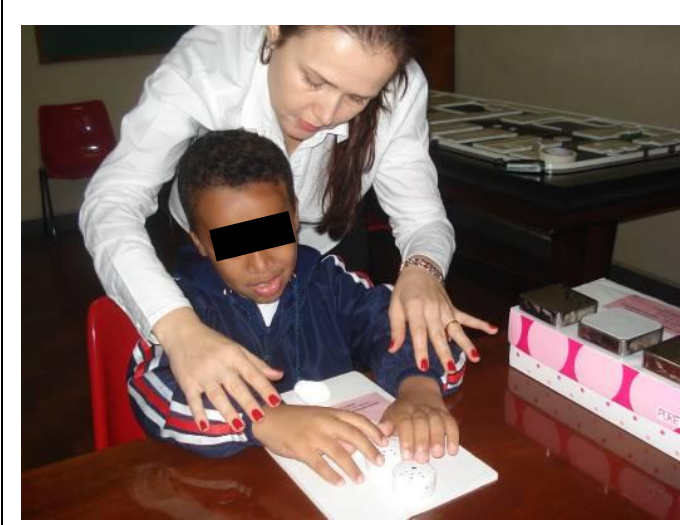

(a)

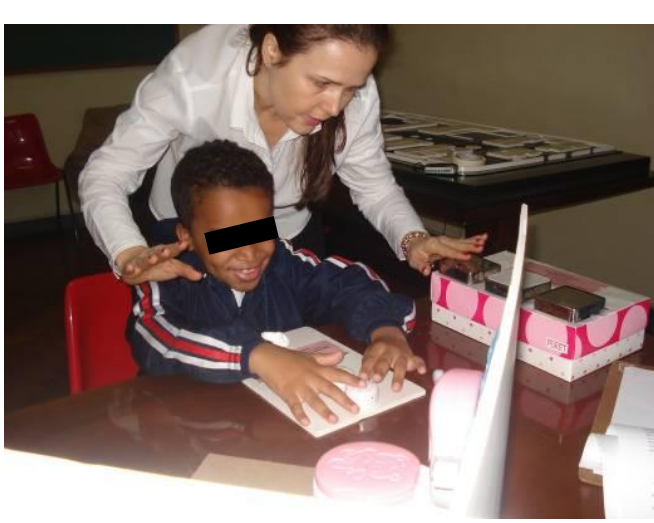

(b)

Figura 108 - Processo de escolha da alternativa referente a conforto acústico pelo aluno R., de 13 anos, cego, na $2^{\mathrm{a}}$ etapa da pesquisa.

A auxiliar da pesquisadora anotou a alternativa escolhida. Em seguida, a maquete tátil térmica, relativa à questão de conforto térmico, foi posicionada na frente do mesmo aluno, que iniciou reconhecimento tátil e térmico (Figura 109). As duas mãos do aluno foram guiadas sobre as três placas de aço inox ${ }^{336}$, uma a uma (figura 109a); depois, duas a duas, com uma mão em cada placa (Figura 109b), visando à comparação entre as temperaturas emitidas.

\footnotetext{
${ }^{336}$ Uma delas revestida em EVA.
} 


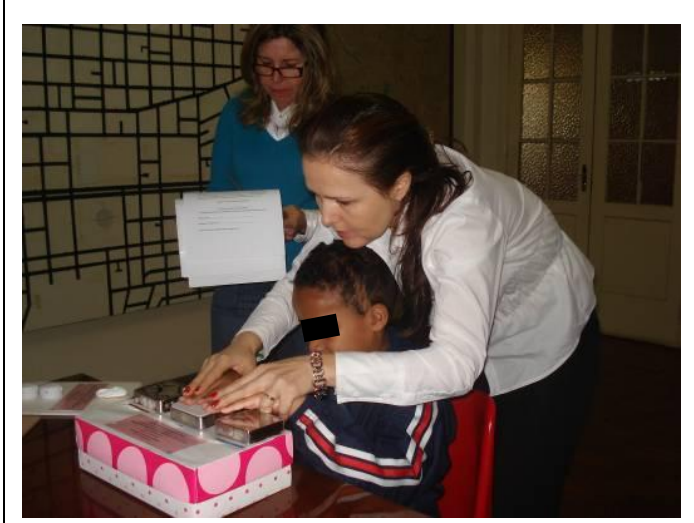

(a)

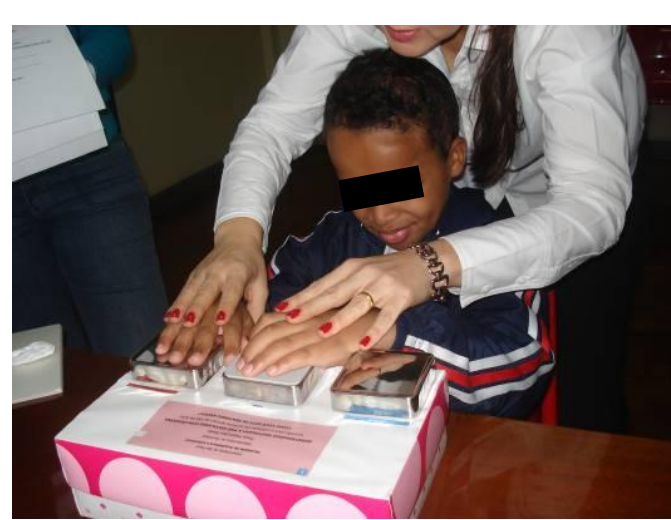

(b)

Figura 109 - Reconhecimento das alternativas da questão relativa a conforto térmico pelo aluno R., de 13 anos, cego, na $2^{\mathrm{a}}$ etapa da pesquisa.

Após esta fase de inicial, foi realizada a pergunta relativa ao conforto térmico na sala de aula, e solicitou-se que o aluno indicasse uma das três placas (ou alternativas), dessa vez sem a condução de suas mãos pela pesquisadora (Figura 110). Usando as duas mãos, o aluno indicou com facilidade a alternativa escolhida (muito frio).

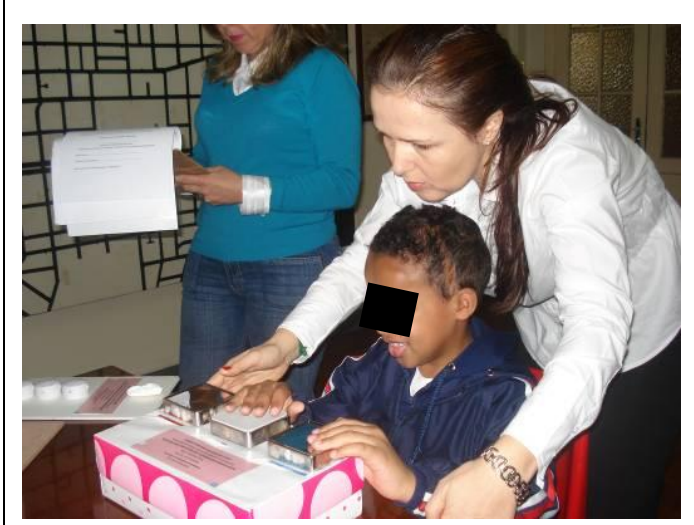

(a)

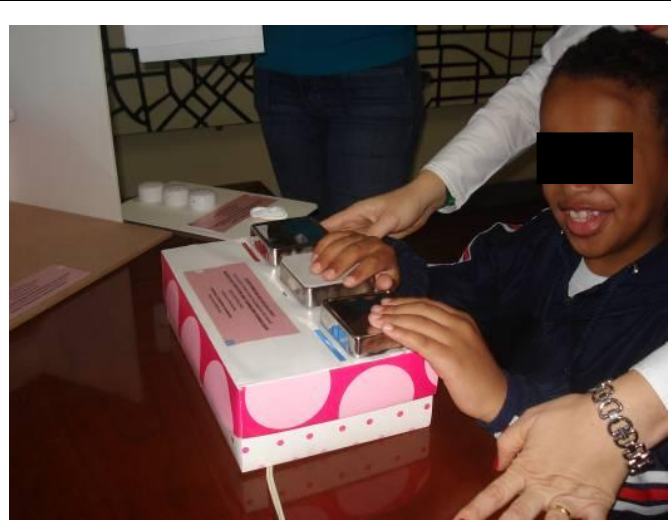

(b)

Figura 110 - Processo de eleição de uma das alternativas da questão relativa a conforto térmico pelo aluno R., de 13 anos, cego, na $2^{\mathrm{a}}$ etapa da pesquisa.

Em seguida, a terceira e última maquete tátil, com alternativas móveis, referente à questão de acessibilidade foi colocada na frente do aluno. A pesquisadora conduziu as mãos do aluno para que o mesmo reconhecesse tatilmente a primeira alternativa (configurada pelo corredor constituído pelos planos vertical e horizontal da maquete 
- Figura 111). Após o reconhecimento da primeira, apresentou-se ao aluno a segunda alternativa, que acrescentava o elemento escada à configuração anterior. Em seguida, apresentou-se a terceira alternativa do questionário através da montagem do banheiro com miniaturas das peças sanitárias - Figura 112) para reconhecimento tátil do aluno.

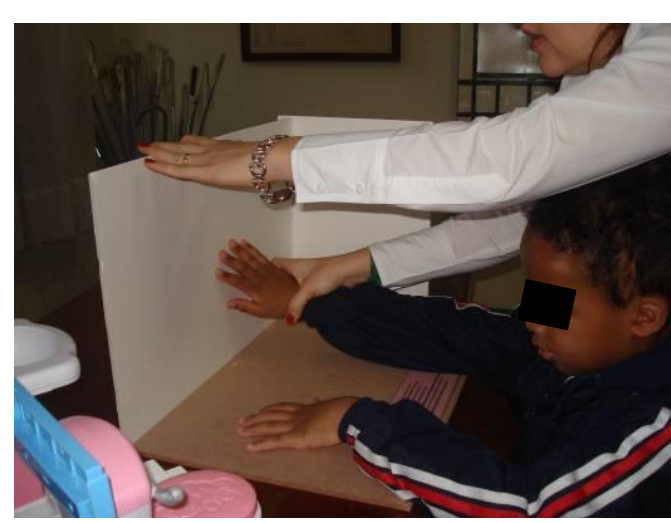

(a)

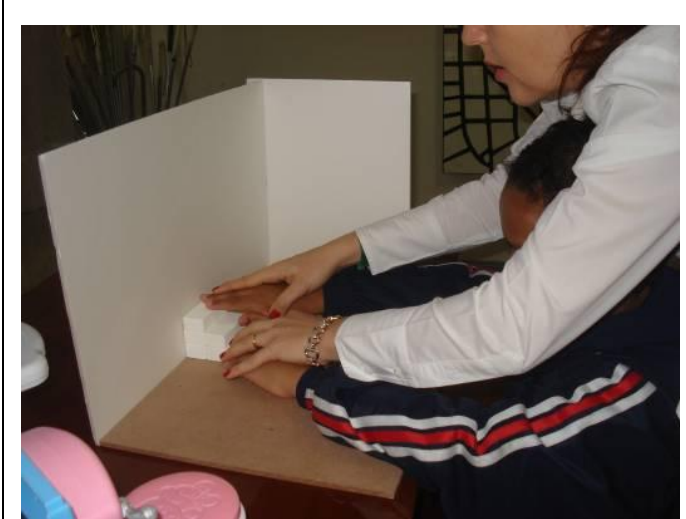

(b)

Figura 111 - As alternativas correspondentes ao corredor (a) e à escada (b) da questão de acessibilidade foram reconhecidas pelo aluno R., de 13 anos, cego, na $2^{a}$ etapa da pesquisa.

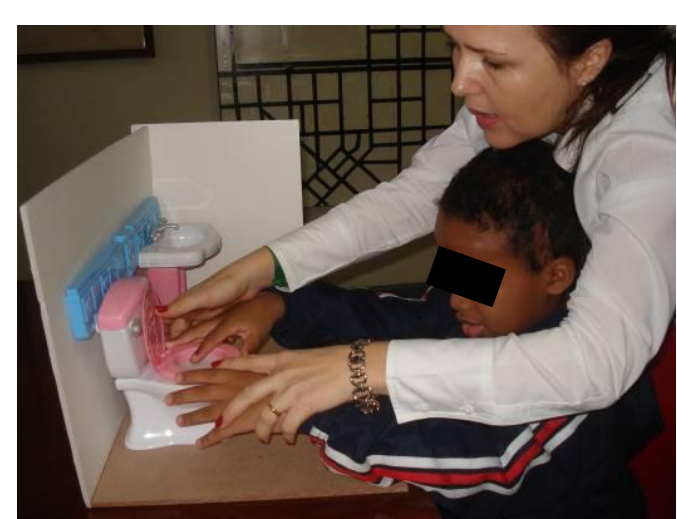

(a)

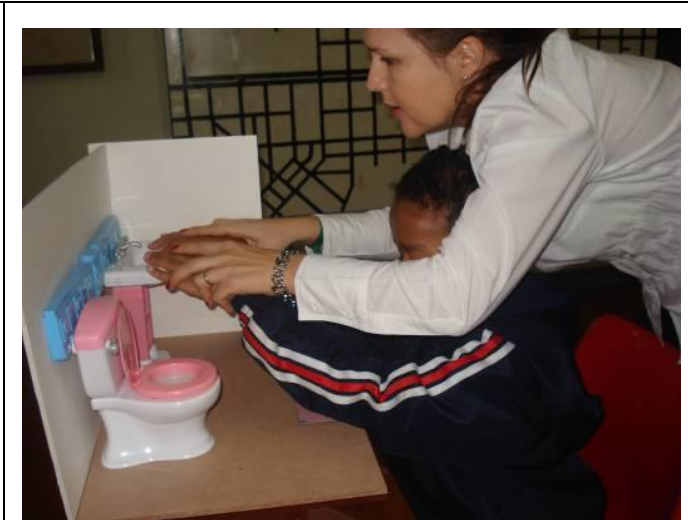

(b)

Figura 112 - A alternativa da questão de acessibilidade referente ao banheiro é tateada pelo aluno R., de 13 anos, cego, na $2^{\mathrm{a}}$ etapa da pesquisa.

Após essa fase de reconhecimento tátil pelo aluno, foi realizada a pergunta Onde é mais difícil andar na escola? , e todo o processo descrito de montagem das opções repetiu-se, com a reapresentação tátil das três alternativas. $O$ aluno elegeu 
verbalmente a alternativa relativa ao banheiro, e a auxiliar da pesquisadora anotou a informação fornecida pelo aluno, bem como o horário de término do questionário.

\subsubsection{Questionário ilustrado}

\subsubsection{Alunos com baixa visão: resultados da unidade-caso 1}

Na segunda etapa, o questionário ilustrado ampliado foi respondido por todos os alunos com baixa visão aptos a participarem da pesquisa (ver Tabela 4) de forma individual, na unidade-caso 1; sua aplicação ocorreu nos dias 25/10/2010 (2 alunos) $)^{337}$ e 5/11/2010 (2 alunos).

Sendo realizadas aplicações de maneira $\operatorname{similar}^{338}$, são apresentados nesta seção o resultado do processo de aplicação do questionário ilustrado ampliado realizado pela aluna $\mathrm{E}$., de 8 anos, com baixa visão, logo após a entrevista lúdica. Cada questão e respectivas alternativas de resposta foram lidas pela pesquisadora (Figura 113a, c), com tempo para a aluna assinalar as alternativas eleitas, tarefa esta realizada com facilidade (Figura 113b, d).

\footnotetext{
${ }^{337}$ Pois os demais aptos haviam faltado, e a pesquisadora retornou em 5/11/2010.
}

${ }^{338}$ Com uma exceção descrita ao final deste item. 


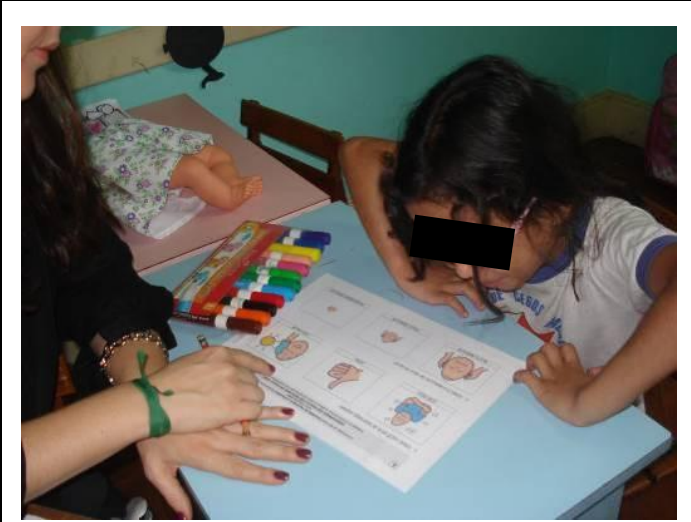

(a)

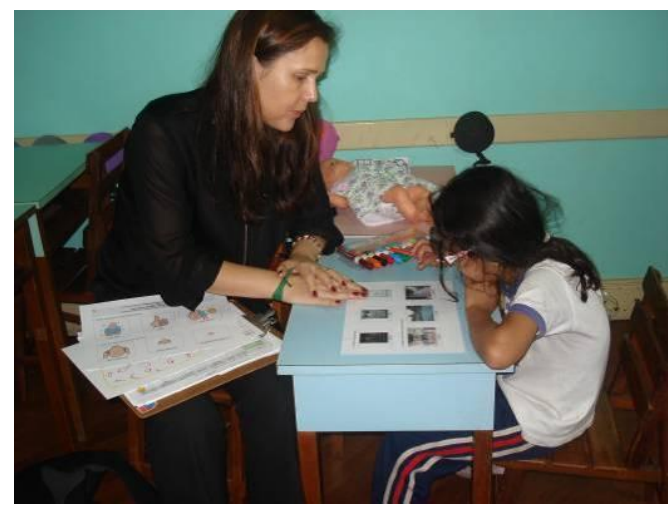

(c)

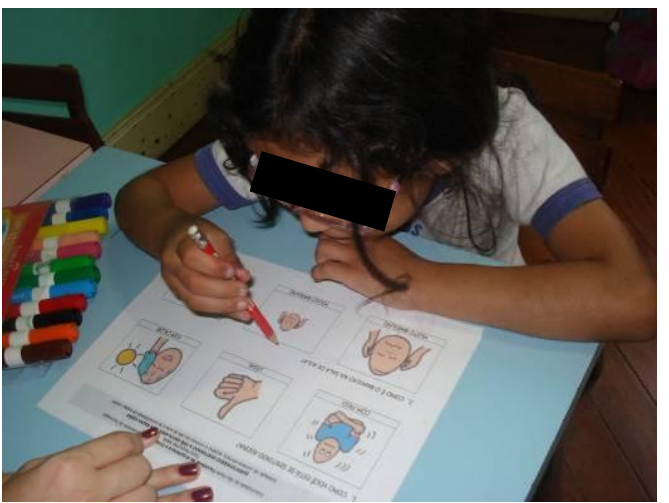

(b)

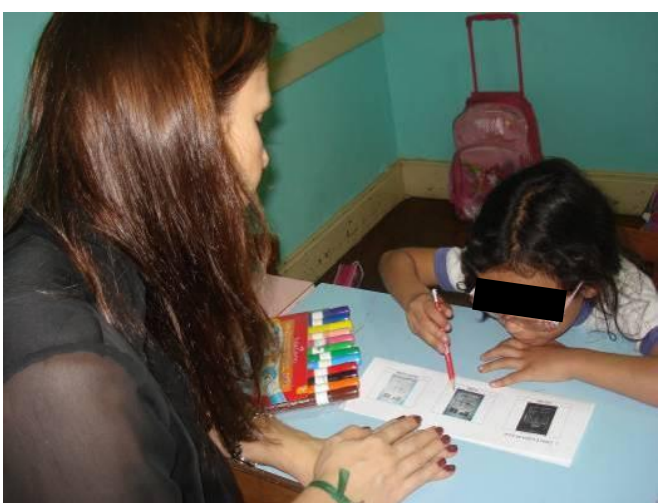

(d)

Figura 113 - Realização do questionário ampliado pela aluna E., de 8 anos, com baixa visão $(a, b$ c,d)

Sem dificuldade de compreensão do enunciado das questões, a aluna com baixa visão conseguiu visualizar todas as ilustrações e apresentou concentração durante a realização do questionário.

Apenas um dos alunos com baixa visão não conseguiu realizar o questionário de forma satisfatória, pois não foi capaz de visualizar as ilustrações ampliadas (Figura 114) e respondeu verbalmente as perguntas. 


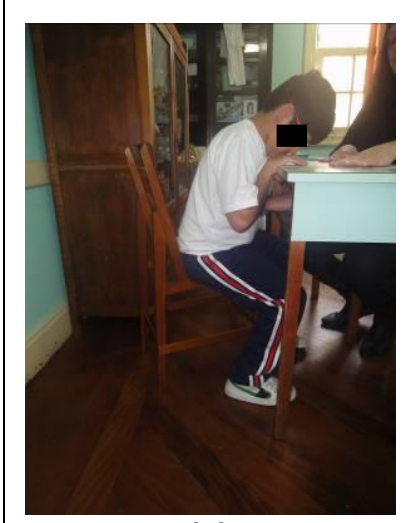

(a)

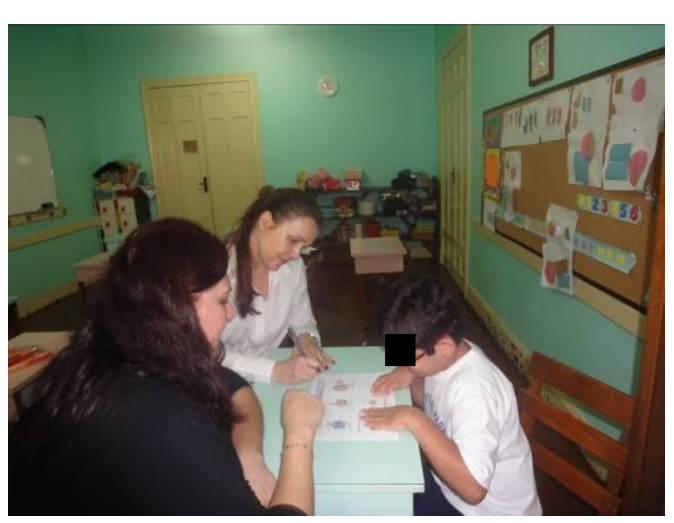

(b)

Figura 114 - Aluno N., de 9 anos, com baixa visão severa não conseguiu enxergar as alternativas do questionário ilustrado ampliado.

Percebeu-se que o questionário 3D com uso de maquetes táteis, destinado aos alunos $\operatorname{cegos}^{339}$, teria sido mais adequado a esse aluno.

\subsubsection{Alunos surdos: resultados da unidade-caso 2}

Na segunda etapa, o questionário ilustrado foi respondido por todos os alunos surdos aptos a participarem da pesquisa (ver Tabela 5). Os questionários foram aplicados de forma individual pela docente de uma das duas classes ${ }^{340}$ envolvidas em função da familiaridade e do nível de comunicação em LIBRAS de cada aluno ${ }^{341}$. Essa fase contou com apoio direto da pesquisadora e de seu auxiliar e apoio indireto da docente de outra sala de pré-escola ${ }^{342}$ da unidade-caso 2. O local de realização foi a sala de aula onde somente se encontravam os alunos aptos a participarem da

\footnotetext{
${ }^{339}$ Mais considerações serão apresentadas no item 8.3.3 - Análise dos resultados.

${ }^{340}$ Docente da sala de maior número de alunos aptos a participarem da pesquisa.

${ }^{341}$ Mesmo sendo a docente de apenas uma das classes, a mesma conhecia todos os alunos.

342 Que conduziu os alunos à aula de educação física em 09/09/2010 e permaneceu na sala de vídeo em 04/10/2010.
} 
pesquisa presentes nos dias das aplicações, 09/09/2010 (5 alunos) e 04/10/2010 (2 alunos) $)^{343}$

A docente e a pesquisadora posicionaram um aluno por vez nas mesas agrupadas na parte da frente da sala de aula e aplicaram a entrevista lúdica com desenho temático $^{344}$ (ver item 7.3.2.2), e em seguida, aplicaram o questionário ilustrado.

Tendo sido aplicados de maneira similar, nesta seção apresenta-se o resultado do processo de aplicação do questionário ilustrado realizado pela aluna M., de 6 anos, surda. Cada questão e respectivas alternativas de resposta foram lidas e repetidas pela docente em LIBRAS (Figura 115a, b); a aluna assinalou as alternativas escolhidas dentro do espaço de tempo destinado para resposta (Figura 115b, d).

${ }^{343}$ Os demais alunos da classe (não aptos) se encontravam-se na aula de educação física ou na sala de vídeo, respectivamente.

344 Os demais alunos permaneceram sentados em mesas agrupadas localizadas no fundo da sala, realizando atividades propostas pela auxiliar da pesquisadora. 


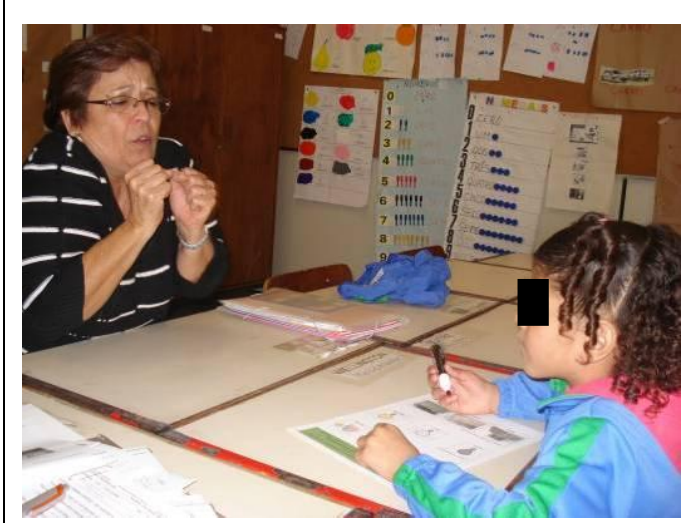

(a)

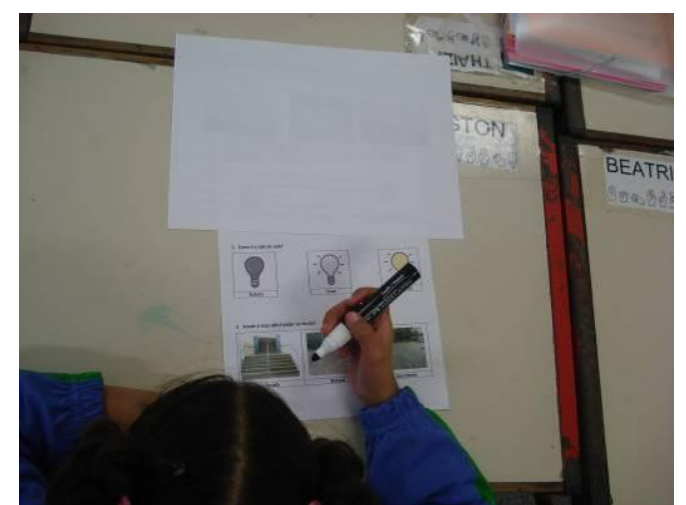

(c)

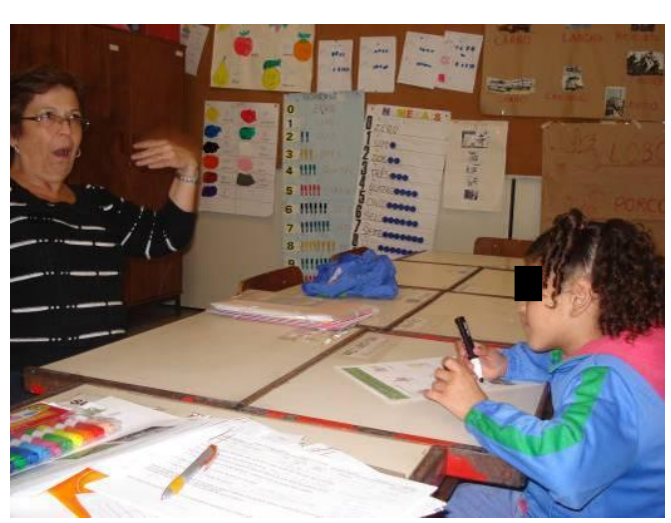

(b)

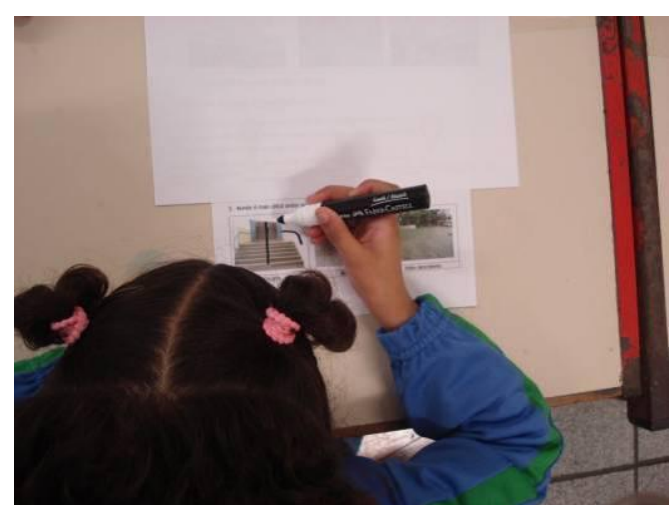

(d)

Figura 115 - As alternativas relativas à questão sobre conforto térmico $(a, b)$ são explicadas em LIBRAS à aluna M., de 6 anos, surda; a aluna responde o questionário ilustrado.

O nível de dificuldade para responder ao questionário ilustrado se apresentou de forma variável entre os alunos em função do grau de abstração mental decorrente da surdez. Embora os alunos não apresentassem sérias dificuldades na compreensão das questões, as mesmas foram-lhe lidas e repetidas pela docente. 


\subsubsection{Alunos com PC: resultados da unidade-caso 3}

Na segunda etapa da pesquisa, o questionário ilustrado foi respondido por todos os alunos com deficiência física ${ }^{345}$ (15 alunos - ver Tabela 6 ) de forma individual nas duas classes de pré-escola existentes na unidade-caso 3. A aplicação do questionário ocorreu nos dias 3/11/2010 (uma classe com 8 alunos), 8/11/2010 (outra classe com 4 alunos) e 9/11/2010 (3 alunos faltantes nas datas de aplicação anteriores de ambas as classes).

A maioria dos alunos se encontrava sentada em suas respectivas cadeiras de rodas com mesas acopladas. A pesquisadora e a docente, com o apoio da equipe de voluntários, aplicaram a entrevista lúdica com desenho temático ${ }^{346} \mathrm{de}$ forma individual e em sequência, o questionário ilustrado, também individualmente.

Todos os alunos apresentaram ótimo desenvolvimento intelectual para responder o questionário ilustrado. 0 nível de dificuldade física para a realização do questionário se apresentou de forma variável entre os alunos das duas classes em função do grau de comprometimento decorrente da PC. Os alunos com maior comprometimento dos membros superiores (não os movimentavam de forma ordenada), todos usuários de CAA e sem fala funcional, não conseguiram apontar o símbolo referente à alternativa eleita do questionário (cerca de $30 \%$ dos respondentes). Esses alunos utilizaram a técnica da varredura através de outras respostas voluntárias consistentes, como

\footnotetext{
${ }^{345}$ Todos os alunos matriculados participaram da pesquisa, pois todos foram considerados aptos.

${ }^{346}$ Descrita no item 7.2.2.3.
} 
sorrir ou emitir um som, para sinalizar sua resposta. A resposta dada foi registrada no questionário pela docente. Cerca de $20 \%$ dos alunos apresentaram menor comprometimento dos membros superiores e eram usuários de CAA (sem fala funcional). Esses alunos conseguiram apontar, com o dedo ou parte da mão, o símbolo referente à alternativa eleita do questionário. Para tanto, utilizaram a técnica de seleção direta, com o posterior auxílio da docente na marcação da alternativa eleita (Figura 116). Em alguns casos, os alunos conseguiam sustentar o próprio braço e marcar todas ou algumas das alternativas, com ou sem auxílio externo.

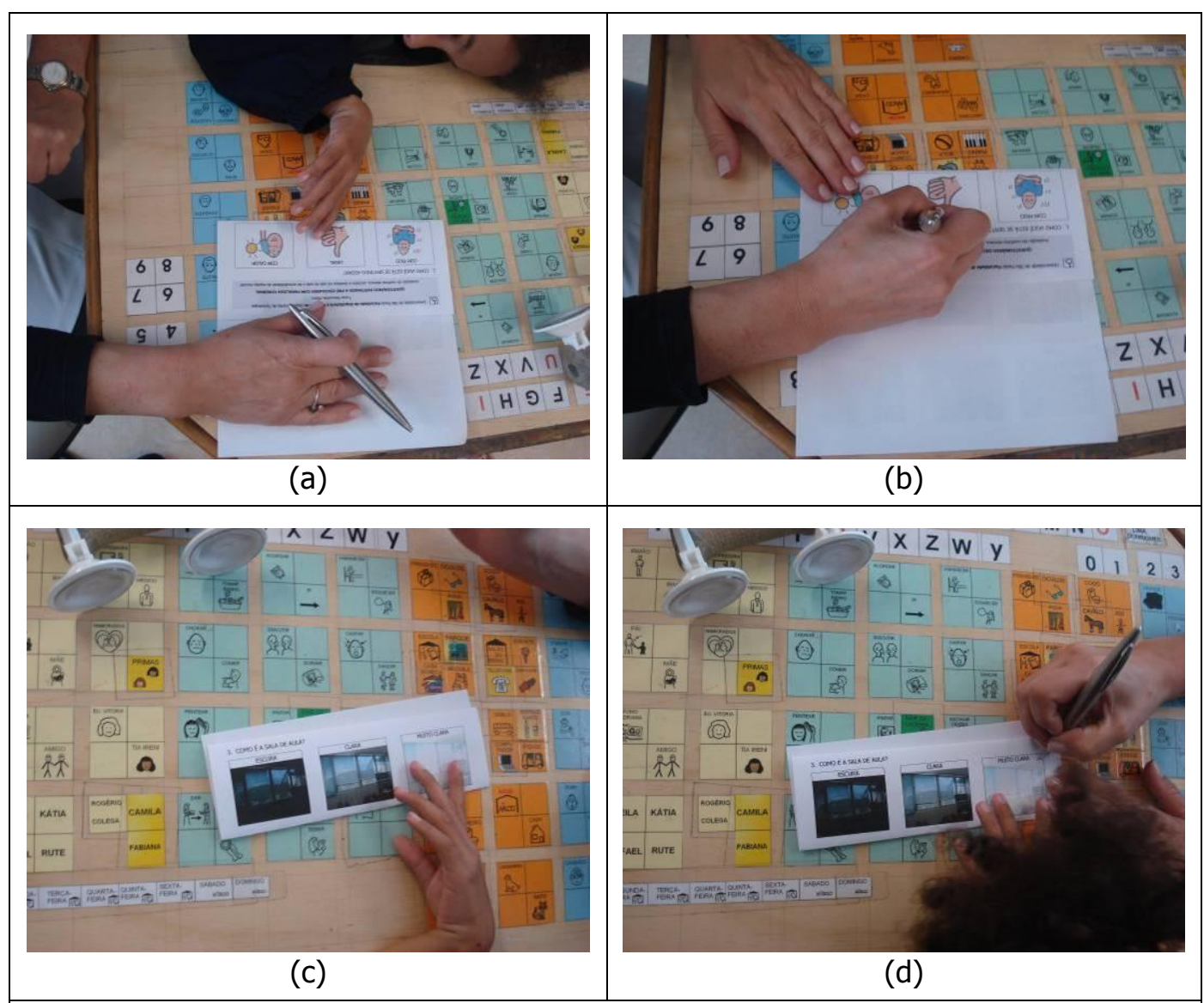

Figura 116 - A aluna V., de 10 anos, com PC indicou as alternativas $(\mathrm{a}, \mathrm{c})$ e a docente as assinalou (b, d).

Cerca de $50 \%$ dos alunos com PC responderam o questionário com independência apesar dos variados graus de dificuldade física, pois apresentavam menor 
comprometimento dos membros superiores (os movimentavam de forma coordenada $\left.{ }^{347}\right)$.

\subsubsection{Análise dos resultados}

Nesta segunda etapa, todos os alunos aptos a participarem da pesquisa e presentes nos dias das aplicações (Tabela 8) conseguiram responder ao questionário de forma satisfatória.

\section{a) Questionário 3D - com o uso de maquetes táteis}

Nesta segunda etapa, os alunos cegos aptos a participarem da pesquisa na préescola na unidade-caso 1 apresentaram boas condições de coordenação motora nos membros superiores e inferiores. Todos os alunos conseguiram responder de forma satisfatória ao questionário 3D e apresentaram bom nível de entendimento das questões e respectivas alternativas.

A aplicação individual do questionário 3D com o uso de maquetes táteis em ambiente tranquilo favoreceu a concentração do aluno durante o processo de aplicação. 0 apoio de duas pessoas externas trazidas pela pesquisadora proporcionou assistência ao aluno (locomoção) e à pesquisadora (anotações das respostas dos alunos e geração de imagens do processo de aplicação). As maquetes elaboradas pela pesquisadora não eram de conhecimento dos alunos, exigindo um maior período de aquecimento para a exploração tátil de reconhecimento inicial.

${ }^{347}$ Apresentavam fala funcional. 
As maquetes táteis foram instrumentos eficazes para a ampliação do conhecimento dos alunos sobre a acessibilidade e as condições de conforto acústico e térmico no ambiente da escola em que convivem e atuam, por tornarem os conceitos das alternativas de resposta mais concretos. Pode-se considerar que os objetivos e a aplicabilidade do questionário 3D com o uso das maquetes táteis foram plenamente atingidos, na medida em que propiciaram, aos alunos cegos, condições de acessibilidade ao instrumento de coleta de dados em si e consequente inclusão da opinião dos mesmos acerca do espaço físico escolar, onde circulam e permanecem por um longo período do dia.

Dentre todas as atividades realizadas nas unidades-caso pertencentes ao presente estudo, a unidade-caso 1 foi a única em que a pesquisadora precisou aplicar instrumentos de coletas de dados sem o acompanhamento de um docente da instituição. Isto ocorreu por que a instituição não dispunha de recursos humanos para atender os alunos não aptos a participarem da pesquisa durante sua aplicação. Apesar desta dificuldade, é possível afirmar que o objetivo proposto pelo instrumento, de identificar os aspectos relacionados ao conforto ambiental (térmico e acústico) e à acessibilidade a partir da opinião dos alunos cegos, foi alcançado.

\section{b) Questionário ilustrado}

Na segunda etapa da pesquisa, o processo de aplicação do questionário ilustrado foi eficaz em todos os alunos com deficiência física, auditiva e visual (baixa visão). Porém, é importante ressaltar que foi imprescindível o apoio de outras pessoas durante o processo de elaboração e aplicação para o seu sucesso. 
As entrevistas realizadas previamente com as docentes permitiram a elaboração do instrumento de forma satisfatória, bem como o planejamento do seu processo de aplicação. Entretanto, um dos alunos ${ }^{348}$ com baixa visão severa (quase não enxergava ${ }^{349}$ ) foi considerado apto, pelas docentes, a realizar o questionário ilustrado ampliado. No momento da sua aplicação, porém, foi constatada, pela pesquisadora, a sua inaptidão, conforme já relatado anteriormente. Esse aluno deveria ter realizado o questionário 3D destinado aos alunos cegos. Percebeu-se, então, que os critérios de seleção dos alunos com baixa visão aptos a realizarem um determinado instrumento de coleta de dados devem considerar o método de aprendizagem (sistema Braille e/ou material pedagógico ampliado) adotado pelo aluno, pois este pode servir como um indicador da severidade de sua deficiência visual (o método pedagógico adotado pela instituição para esse aluno era o Braille). É possível afirmar que o objetivo proposto pelo instrumento, de identificar os aspectos relacionados ao conforto ambiental e à acessibilidade a partir da opinião dos alunos com deficiência visual (baixa visão), deficiência auditiva e deficiência física foi alcançado.

\footnotetext{
${ }^{348} \mathrm{Na}$ entrevista realizada antes da pesquisa de campo, a pesquisadora apresentou os instrumentos à serem aplicados, para a verificação dos alunos aptos e não aptos a realizarem o mesmo, por deficiência (cegueira e baixa visão).

${ }^{349}$ Este aluno não participou da primeira etapa da pesquisa.
} 


\section{CONSIDERAÇÕES FINAIS}

\subsection{Considerações gerais}

Estamos assistindo nos últimos anos a uma série de mudanças educacionais que abrangem os parâmetros curriculares, com a ampliação da duração do ensino fundamental e consequente reestruturação da educação infantil, além do aumento da acessibilidade ao meio físico em função da proposta de uma escola inclusiva e uma sociedade mais aberta ao tema da inclusão social da pessoa com deficiência. A questão da inclusão social das minorias (negros, índios, pessoas com deficiência e outros) ganhou relevo recentemente nos documentos internacionais e nacionais. Especificamente, a inclusão da criança com deficiência nas classes comuns da rede regular de ensino no Brasil tem se estabelecido, a partir da década de 1990, um tema relevante para legisladores, gestores de políticas públicas, educadores, acadêmicos e para a sociedade como um todo, constituindo-se ainda em um desafio para as instituições educacionais e para as práticas pedagógicas. Esta inclusão educacional, que surgiu pela imposição da legislação, configura-se como um assunto polêmico entre diversos autores, ora pelas questões de direitos humanos e pela tão reclamada justiça social, ora pela falta de preparo das escolas para o recebimento das crianças com deficiência. No Brasil, a inclusão dos alunos com NEEs vem caminhando a passadas nem sempre uniformes e nem sempre dentro da velocidade desejada. Os estabelecimentos públicos de educação infantil no Brasil são obrigados por lei a oferecer a educação inclusiva e a atender todas as crianças. Porém, o fato de a criança estar matriculada e frequentar a classe comum da escola regular, por si 
só, não garante a sua inclusão - esta última pressupõe mudanças valorativas e atitudinais, envolvendo transformações dos padrões curriculares da escola, dos espaços e da sociedade como um todo.

As considerações levantadas ao longo desta tese não visam à transformação imediata e total em relação à inclusão da opinião da pessoa com deficiência na APO. Contudo, para que se possam visualizar os benefícios de uma arquitetura inclusiva, é necessário que um processo de mudança na avaliação do espaço construído ocorra de forma gradativa. Não se acredita que a APO que considere a opinião das crianças com deficiência tenha a força revolucionária na escola ao ponto de ser decisiva para a inclusão das mesmas. Entre elaborar instrumentos inclusivos de APO e efetuar a reestruturação destes espaços, transformando-os em espaços acessíveis, existe um grande caminho a ser percorrido.

Este estudo constitui-se como o início de um processo de mudança de posicionamento, onde a APO em escolas passa a considerar a opinião dos alunos com deficiência através dos instrumentos adaptados aos mesmos, onde a visão sistêmica transdisciplinar e multimétodos, característica da APO, contribuirá de forma efetiva para o futuro da inclusão escolar. O presente estudo busca colocar direcionamentos para um modelo inicial e não definitivo de instrumentos de APO, sendo a entrevista lúdica e o questionário eleitos em função da experiência e formação da pesquisadora, visando à avaliação da opinião dos alunos com deficiência em relação ao espaço escolar. Este trabalho caracteriza-se como multi, 
inter e transdisciplinar, nos quais se encontram informações de várias áreas relevantes no processo de inclusão escolar.

Este estudo, além de atender a política de pesquisa de cada entidade envolvida, contou com a colaboração de pesquisadores com experiência, sendo realizado com respaldo das equipes multidisciplinares existentes nas respectivas instituições onde se encontram as pré-escolas de educação especial conhecedoras das capacidades de cada aluno, compostas por educadores, voluntários, fisioterapeutas, fonoaudiólogos e psicólogos (em momentos-chave). Esse apoio colaborou para o resultado deste trabalho uma vez que a pesquisadora não tem essa formação.

O maior desafio foi o envolvimento com a questão da deficiência e, principalmente, o entendimento de suas reais limitações para o desenvolvimento dos instrumentos de coleta de dados. Vivenciar o cotidiano dessas crianças nas escolas envolvidas trouxe uma bagagem de conhecimento importante, porém também um sentimento de pesar, em especial pelas crianças que não puderam participar da pesquisa em função do nível de comprometimento cognitivo. Essas coabitaram o espaço da pesquisa de campo, fornecendo dados não verbais captados pelas observações não estruturadas realizadas pela pesquisadora. As condições de pobreza e severidade de deficiência recorrentes em algumas crianças deixaram lembranças inesquecíveis que não foram relatadas no texto do presente estudo, por ser de caráter científico. Entretanto, acredita-se que todas as dificuldades tenham sido superadas, conformadas em um ganho de conhecimento na área de instrumentos destinados à APO, bem como de ampla experiência por parte da pesquisadora. 


\subsection{Premissas de pesquisa}

A pesquisa levantou como premissa principal a afirmativa de que é possível aplicar os instrumentos de coleta de dados baseados na APO e no método de estudos centrados na pessoa, destinados aos alunos com deficiência física, auditiva e visual para a medição da satisfação desses usuários em relação ao ambiente escolar e consequente validação dos instrumentos aplicados. Tal premissa foi comprovada através dos resultados apresentados no decorrer desta tese, bem como as premissas secundárias, descritas a seguir:

- as limitações decorrentes de cada deficiência determinam as especificidades na adaptação e no processo de aplicação dos instrumentos de coleta de dados visando à medição da satisfação desses usuários em relação ao ambiente pré-escolar;

- independentemente do método pedagógico adotado pelas pré-escolas consideradas no presente estudo, seus ambientes devem oferecer condições de acessibilidade, de conforto ambiental, de segurança patrimonial e contra incêndio dentre outras, para a inclusão dos alunos com deficiência física, auditiva e visual.

Os objetivos do presente estudo foram alcançados por meio do levantamento de dados, ou seja, pelos referenciais teóricos e práticos desenvolvidos. O procedimento utilizado na elaboração desta tese de construção e reconstrução do conhecimento exigiu um amadurecimento. A ação fenomenológica solicitou o entendimento a fundo dos assuntos-fenômenos da tese para posterior libertação dos conceitos, preconceitos, crenças e valores vistos, em especial os adquiridos durante a pesquisa de campo. Por esse motivo, ao final deste estudo houve a necessidade de um 
processo de desligamento e distanciamento para uma retomada mais objetiva visando à elaboração da presente conclusão. Capítulos elaborados inicialmente foram excluídos, em função da extensão do trabalho final. Primeiramente, foi preciso compreender os pressupostos teóricos relativos à deficiência para então entender a complexidade de outro fenômeno pesquisado - a inclusão escolar. Ambos os assuntos foram estudados dentro do contexto pretendido de forma intensa, e a pesquisadora se viu mergulhada numa ampla pesquisa bibliográfica que se estendeu aos capítulos seguintes. Em seguida, dissecaram-se os fundamentos metodológicos norteadores da pesquisa de campo, minuciosamente pensados e justificados, para que a mesma ocorresse de uma forma acertada e os seus objetivos fossem alcançados com o máximo de rigor científico. Este processo pode ser visualizado na estrutura dos capítulos desta tese. Elaborar e aplicar os instrumentos destinados à direção e aos docentes foi uma tarefa trabalhosa, pois exigiu a transcrição das gravações e análise das entrevistas, que foram apresentadas para a avaliação dos entrevistados, e eventual correção pela pesquisadora. Outro desafio deste estudo foi a elaboração e a aplicação dos instrumentos junto aos alunos com deficiência. Vivenciar o processo de execução dos instrumentos de coleta de dados (entrevista lúdica e questionário) pelos alunos com deficiência nas três unidades-caso nas duas etapas da pesquisa (pré-teste e validação) foi testemunhar o processo de acertos e erros na elaboração desses instrumentos de forma conjunta com os respectivos docentes e diretores, a fim de adaptar cada instrumento de coleta de dados às capacidades de cada uma das três deficiências. 
A avaliação do processo de aplicação dos instrumentos de coleta de dados foi realizada através de observações estruturadas da realização da mesma, levando-se em consideração os níveis de complexidade das tarefas propostas e dos esforços físico e mental exigidos, além dos resultados efetivos apurados nos instrumentos, que embora não tenham sido tabulados na tese, foram analisados.

Do mesmo modo como existem vários processos de levantamentos de dados, existem vários modos de interpretação lógica destes dados. "Por isso, a ciência não pretende mais atingir uma verdade única e absoluta: suas conclusões não são consideradas como verdades dogmáticas, mas como formas de conhecimento $[. . .]^{\prime \prime}$ (SEVERINO, 2000, p. 150).

\subsection{Recomendações para trabalhos futuros}

O presente estudo envolveu inúmeros pontos de vista, buscando uma visão da realidade e do tema desta tese de forma não tendenciosa. Em função disto, apresenta-se uma série de possíveis encaminhamentos para pesquisas futuras a partir da análise do seu conteúdo. Listam-se algumas recomendações práticas para trabalhos futuros relacionados a instrumentos de APO destinados à criança com deficiência na escola:

Envolver pesquisadores com experiência, que suportem situações de estresse geradas na pesquisa de campo em decorrência de alunos com deficiência severa que, mesmo não sendo sujeitos diretos da pesquisa, coabitam o 
espaço foco de pesquisa. Em função dessas situações, bem como das necessidades específicas das crianças com deficiência, o respaldo de outros profissionais como psicólogos, fonoaudiólogos, fisioterapeutas e educadores é imprescindível;

Formar uma equipe de apoio durante a pesquisa de campo, de pessoas externas trazidas pelo pesquisador durante todo o processo de aplicação dos instrumentos ${ }^{350}$, em função da falta de recursos humanos, em geral, nas escolas públicas ou gratuitas;

Estudar a fundo as limitações e especificidades de cada deficiência, realizar entrevistas com direção e docentes da(s) unidade(s)-caso consideradas, bem como observações não estruturadas dos sujeitos da pesquisa visando à seleção dos instrumentos de coleta de dados;

Discutir de forma intensa o processo de escolha e desenvolvimento dos instrumentos de coleta de dados destinados aos alunos com os respectivos docentes através de entrevistas (mais de uma entrevista). Quanto maior o vínculo de confiança entre o pesquisador e o docente, mais fácil será o processo de elaboração e aplicação dos instrumentos de coleta de dados eleitos. Por este motivo, o pré-teste e as aplicações posteriores dos instrumentos deverão se concentrar na mesma unidade-caso;

Adotar o estudo de casos múltiplos e incorporados como estratégia de pesquisa, porém este tipo de estudo é caro e demanda tempo e dedicação

\footnotetext{
350 Para o registro de imagens, anotações e cuidados com os outros alunos, tanto em aplicações
} individuais como em grupo. 
integral do pesquisador, sendo indicado o apoio de instituições de fomento a pesquisa (YIN, 2005);

Ampliar as discussões sobre as questões éticas na APO (ELALI, 2010), em especial quando envolverem crianças com deficiência;

Adaptar outros instrumentos de coleta de dados às crianças com deficiência $^{351}$, em especial os listados no Quadro 10 (item 4.6).

Verificou-se neste estudo a importância dos instrumentos de APO destinados às crianças com deficiência para a avaliação do espaço escolar e constatou-se que as limitações das mesmas determinam as especificidades na adaptação e no processo de aplicação desses instrumentos para a coleta de dados. Os instrumentos de coleta de dados (entrevista lúdica e questionário) desenvolvidos no presente estudo são específicos para a avaliação do conforto ambiental e da acessibilidade física dos espaços, porém o processo de aplicação pode ser replicado em pesquisas que envolvam outras áreas, como a das ciências sociais. Constatou-se que futuros trabalhos na área da APO devem se apropriar dos instrumentos e processo de aplicação desenvolvidos no presente estudo com o intuito de aperfeiçoá-los e aplicálos nas escolas da rede regular, bem como adaptá-los a outras esferas de atividade humana que envolvam a APO, como a segurança contra incêndio.

A Avaliação Pós-Ocupação em edifícios em geral deve acompanhar a tendência mundial da inclusão da pessoa com deficiência em nossa sociedade, considerando a

\footnotetext{
${ }^{351}$ A possibilidade de elaboração e aplicação de instrumentos de coleta de dados para alunos com deficiência múltipla, em especial a surdocegueira, bem como para alunos com deficiência intelectual, deve ser aprofundada.
} 
opinião dos usuários com deficiência sobre o ambiente construído, pois são avaliadores relevantes da acessibilidade física, conforto ambiental e segurança contra incêndio, dentre outros fatores. Como ainda não existe no Brasil uma norma técnica destinada ao dimensionamento do ambiente escolar que contemple crianças com e sem deficiência, os arquitetos se baseiam na norma NBR 9050, destinada a adultos. Busca-se a elaboração de material referencial para os arquitetos dimensionarem o espaço escolar, dentre outros, específicos para o uso pelas crianças. Novos estudos são necessários para que essa norma se concretize, como a obtenção de dados antropométricos de crianças no Brasil ${ }^{352}$ e da opinião das crianças com deficiência física e sensorial em relação ao espaço escolar construído, bem como dos educadores envolvidos com as mesmas.

No Brasil, o futuro da inclusão escolar dependerá de um esforço coletivo que obrigará pesquisadores, políticos, prestadores de serviços, arquitetos, educadores, pedagogos e a sociedade como um todo a reverem seus papéis, para trabalhar em conjunto na garantia de uma educação inclusiva e de melhor qualidade para todos.

${ }^{352}$ Ver item 1.2. 
448

Instrumentos de Avaliação Pós-Ocupação (APO) adaptados a pré-escolares com deficiência física, auditiva e visual

ABATE, Tania Pietzschke 


\section{Referências}

ABATE, T. P. Aspectos ergonômicos da criança e o projeto da pré-escola no estado de São Paulo. 2004. Dissertação (Mestrado em Arquitetura e Urbanismo) Faculdade de Arquitetura e Urbanismo, Universidade de São Paulo, São Paulo, 2004.

; ONO, R.; LOPES, M. E. Reflexões sobre a elaboração e a aplicação dos instrumentos de APO destinados a pré-escolares com paralisia cerebral (PC). In: ENCONTRO NACIONAL DE TECNOLOGIA DO AMBIENTE CONSTRUÍDO I Entac 2010, Canela. Anais do XIII Encontro Nacional de Tecnologia do Ambiente Construído. Canela, RS, 2010a.

Reflexões sobre a elaboração e a aplicação dos instrumentos de APO destinados a pré-escolares com surdez. In: SEMINÁRIO INTERNACIONAL I Nutau 2010, São Paulo. Anais do $8^{\text {a }}$ Seminário Internacional NUTAU 2010 Design e Inovação. São Paulo: Núcleo de Pesquisa em Tecnologia da Arquitetura, 2010b.

. Reflexões sobre a ergonomia na inclusão escolar. In: CONGRESSO BRASILEIRO DE ERGONOMIA | Abergo 2010, Rio de Janeiro. Anais do XVI Congresso Brasileiro de Ergonomia: III Congresso Latino-Americano de Ergonomia da ULAERGO: IX Fórum de Certificação do Ergonomista Brasileiro: IV ABERGO Jovem: IV Congresso Brasileiro de Iniciação Científica em Ergonomia. Rio de Janeiro, RJ, 2010c.

ABERASTURY, A. Psicanálise da criança: teoria e técnica. Porto Alegre: Artes Médicas, 1992.

ABNT - ASSOCIAÇÃO BRASILEIRA DE NORMAS TÉCNICAS. NBR 9050:

Acessibilidade a edificações, mobiliário, espaços e equipamentos urbanos. Rio de Janeiro: ABNT, 2004.

NBR 14.350: Segurança de brinquedos de Playground, Rio de Janeiro: ABNT, 1999.

ADG - ASSOCIAÇÃO DOS DESIGNERS GRÁFICOS. ABC da ADG. Glossário de termos e verbetes utilizados em Design Gráfico. São Paulo: ADG, 2000.

AGÊNCIA EUROPEIA PARA O DESENVOLVIMENTO EM NECESSIDADES EDUCATIVAS ESPECIAIS. Educação Inclusiva e Práticas de Sala de Aula. Relatório Síntese, Março 2003. Disponível em: <http://www.european-

agency.org/publications/ereports/inclusive-education-and-classroom-practices/iecppt.pdf>. Acesso em: 4 jul. 2010.

AGUIAR, E. Desenho livre infantil - leituras fenomenológicas. Rio de Janeiro: EPapers, 2004. 
AHIMSA. Associação Educacional para Múltipla Deficiência. Definição de surdocegueira e lista de etiologias relacionadas. Panfleto. São Paulo, 2002. Disponível em: <http://saci.org.br/?modulo=akemi\&parametro=1954>. Acesso em:

AIELLO-VAISBERG, T. M. J. Encontro com a loucura: transicionalidade e ensino de psicopatologia. 1999. 185f. Tese (livre docência) - Instituto de Psicologia, Universidade de São Paulo, São Paulo, 1999.

. Investigação de representações sociais. In: TRINCA, W. (org.). Formas de investigação clinica em psicologia: procedimento de desenhos-estórias. São Paulo: Vetor, 1997. p. 255-288.

. O uso de procedimentos projetivos na pesquisa de representações sociais: projeção e transicionalidade. Psicologia USP, São Paulo, v. 6, n. 2, p. 103-127, 1995.

\section{Ser e fazer. Enquadres diferenciados na clínica winnicottiana.}

Aparecida, SP: Ideias e Letras, 2004.

ALMEIDA, L. R. de; SZYMANSKI, H. A dimensão afetiva na situação de entrevista de pesquisa em educação. In: SZYMANSKI, H. A entrevista na educação: a prática reflexiva. Brasília: Liber Livro, 2010. $3^{a}$ ed. rev. e ampl.

ALVES-MAZZOTTI, A. J. Usos e abusos dos estudos de caso. Cad. Pesqui., São Paulo, v. 36, n. 129, dez. 2006 . Disponível em:

<http://www.scielo.br/scielo.php?script=sci_arttext\&pid=S0100-

15742006000300007\&lng=en\&nrm=iso >. Acesso em: 14 jan. 2011.

AMARAL, I. A educação de estudantes portadores de surdocegueira. In: MASINI, E. F. S. (Org.). Do sentido... pelos sentidos... para o sentido. São Paulo: Vetor Editora, 2002. p. 121-144.

AMARAL, L. A. Conhecendo a deficiência (em Companhia de Hércules). São Paulo: Robe Editorial, 1995.

AMIRALIAN, M. L. T. M. Compreendendo o cego: uma visão psicanalíticada cegueira por meio de Desenhos-Estórias. São Paulo: Casa do Psicólogo, 1997.

ANDRADE, M. do V. B. Cem anos de pré-escola pública paulista: a história de sua expansão e descentralização: 1846-1996. 1996. Dissertação (Mestrado) Faculdade de Filosofia e Ciências, Universidade Estadual Paulista, Marília, 1996.

ANDRÉ, M. Pesquisa em educação: buscando rigor e qualidade. Cadernos de Pesquisa, São Paulo, n. 113, p. 7-38, jul. 2001.

ARANHA, M. L. de A. Filosofia da Educação. ed. 2a. São Paulo: Moderna, 1996. 
ARANHA, M. S. F. Overview of the Rehabilitation Movement in the United States and Proposals for a Rehabilitation Model in Brasil. 1979. Dissertação (Mestrado), Southern Illinois University at Carbondale, Illinois, USA, 1979.

ARAÚJO, R. M. E. de. Mobiliário Escolar Acessível e Tecnologia Apropriada. Uma Contribuição para o Ensino Inclusivo. Banco Mundial - Cnotinfor Portugal, 2004.

ARAÚJO, L. A. D. Em busca de um conceito de pessoa com deficiência. In: GUGEL, M. A. et al. Deficiência no Brasil: uma abordagem integral dos direitos das pessoas com deficiência. Florianópolis: Obra Jurídica, 2007.

ARFOUILLOUX, J. C. A entrevista com a criança: a abordagem da criança através do diálogo, do brinquedo e do desenho. Trad. de Analúcia T. Ribeiro. Rio de Janeiro: Zahar Editores, 1983.

\section{AZEVEDO, A. C. P. de. Brinquedoteca no diagnóstico e intervenção em} dificuldades escolares. São Paulo: Alínea, 2004.

BAIRD, G. et al. Building evaluation techniques. New York: McGraw-Hill, 1995.

BAKER, R. L.; MEDNICK, B. R. Protecting the high school environment as an island of safety: correlates of student fear of in-school victimization. Children's environments Quarterly, 7 (3), p. 37-39, 1990.

BANISTER, P. et al. Qualitative methods in psychology: a research guide. Buckingham: Open University Press, 1994.

BARBOSA, M. B.; BERNARDI, S. M.; ABATE, T. P.; MIYASATO, T.; ONO, R.; ORNSTEIN, S. W. Reflexão metodológica sobre instrumentos de APO aplicados em alunos de 6 a 10 anos: avaliação do conforto ambiental em escola da rede pública. In: X ENCONTRO NACIONAL E VI ENCONTRO LATINO AMERICANO DE CONFORTO NO AMBIENTE CONSTRUÍDO, 2009, Natal. Anais do ENCAC 2009 e ELACAC 2009. Natal: Associação Nacional de Tecnologia do Ambiente Construído e Universidade Federal do Rio Grande do Norte, 2009. v. 1. p. 1582-1591.

BARDIN, Laurence. Análise de Conteúdo. Lisboa: Edições 70 LDA, 1977.

BARROS, T. O Manifesto dos Pioneiros da Escola Nova de 1932: principais propostas. Revista eletrônica. Publicado em: 20 nov. 2007. Disponível em:

<http://pt.shvoong.com/social-sciences/education/1709158-manifesto-dos-pioneirosda-escola/>. Acesso em: 4 mar. 2009.

BASTOS, B. L. et al. Implementação de Maquete Tátil Sonora para Pessoas com Deficiência Visual. In: XXX Congresso da Sociedade Brasileira de Computação - SBC, 2010, Belo Horizonte. Anais do XXX Congresso da Sociedade Brasileira de Computação - SBC. Belo Horizonte, MG, 2010. p. 1079-1086. 
BATISTA, C. G. Formação de conceitos em crianças cegas: questões teóricas e implicações educacionais. Revista Psicologia: Teoria e Pesquisa, Brasília, v. 21, n. 1, jan./abr. 2005. Disponível em:

<http://www.scielo.br/scielo.php?script=sci_arttext\&pid=S0102-

37722005000100003\&nrm=iso\&tlng=pt >. Acesso em: 12 ab. 2009.

BATISTA, M. W.; ENUMO, S. R. F. Inclusão escolar e deficiência mental: análise da interação social entre companheiros. Estud. Psicol, Natal, [online], v. 9, n. 1, p. 101-111, 2004. Disponível em: <http://www.scielo.br/pdf/epsic/v9n1/22386.pdf>. Acesso em: 20 ab. 2009.

BECHTEL, R. B.; MARANS, R. W.; MICHELSON, W. Methods in environmental and behavioral research. New York: Van Nostrand Reinhold, 1987.

BEE, H. A criança em desenvolvimento. São Paulo: Artmed, 1996.

BERNARDI, N. Avaliação da interferência comportamental do usuário para a melhoria do conforto ambiental em espaços escolares: estudo de caso em Campinas, S. P. 2001. Dissertação (Mestrado em Arquitetura) - Faculdade de Engenharia Civil, Arquitetura e Urbanismo, Universidade Estadual de Campinas, Campinas, 2001.

; d'ABREU, J. V. V.; KOWALTOWSKI, D. C. C. K. Orientação espacial no campus da UNICAMP: desenvolvimento de um mapa de uso tátil e sonoro como ferramenta de auxílio ao percurso do usuário com deficiência visual. In: X Encontro Nacional e VI Encontro Latino Americano de Conforto no Ambiente Construído, 2009, Natal. Anais de X Encontro Nacional e VI Encontro Latino Americano de Conforto no Ambiente Construído. Natal, RN, 2009.

BERTONCELLO, I.; GOMES, L. V. N. Análise diacrônica e sincrônica da cadeira de rodas mecanomanual. Prod., São Paulo, v. 12, n. 1, 2002. Disponível em: $<$ http://www.scielo.br/scielo.php?script=sci_arttext\&pid=S010365132002000100007\&lng=en\&nrm=iso>. Acesso em: 12 jul. 2010.

BEUKELMAN, D.R.; MIRENDA, P. Augmentative and alternative communication: Management of severe communication disorders in children and adults. Baltimore: Paul Brookes, 1992.

BIREME - (Centro Latino-Americano e do Caribe de Informação em Ciências da Saúde). Terminologia em saúde. Disponível em:

<http://www.bireme.br/local/Site/bireme/P/objetivos.htm>. Acesso em: 23 mar. 2009.

BISHOP, J.; ADAMS, E.; KEAN, J. Children, environment and education: personal views of urban environmental education in Britain. Children's environments, 9 (1), p. 49-67, 1992. 
BLEICHER, J. Hermenêutica contemporânea. Tradução de M. G. Lisboa: Edições $70,1992$.

BLOWER, H. C. S. O lugar do ambiente da educação infantil: estudo de caso na Creche Doutor Paulo Niemeyer. 2008. 180 f. Dissertação (Mestrado em Arquitetura e Urbanismo) - Faculdade de Arquitetura e Urbanismo, Universidade Federal do Rio de Janeiro, Rio de Janeiro, 2008.

BOMENY, H. O Manifesto dos Pioneiros da Educação Nova (1932). Revista eletrônica. Publicado em: 20 nov. 2007. Disponível em:

<http://www.cpdoc.fgv.br/nav_jk/htm/o_brasil_de_jk/Manifesto_dos_pioneiros_da_e ducacao.asp>. Acesso em: 4 mar. 2009.

BOMFIM, Z. A. C. Afetividade e ambientes urbano. In: PINHEIRO, José de Queiroz; GÜNTHER, H. Métodos de pesquisa nos estudos pessoa-ambiente. São Paulo: Casa do Psicólogo, 2008.

BOOTHROYD, D.A. Hearing impariments in young children. In: Boothroyd DA. Development of the hearing-impaired children. Englewood: Prentice Hall; 1984. p. 57-71.

BOURDIEU, P. Futuro de classe a causalidade do provável. In: NOGUEIRA, M. A. e CATANI, A. (Org.). Escritos de Educação. $5^{\mathrm{a}}$ ed. Petrópolis: Vozes, 2003. p. 81126.

BRAGA, J. L. Para começar um projeto de pesquisa. Comun. educ., São Paulo, v. 10, n. 3, dez. 2005 . Disponível em:

<http://www.revistasusp.sibi.usp.br/scielo.php?script=sci_arttext\&pid=S010468292005000300005\&lng=pt\&nrm=iso >. Acesso em: 9 dez. 2010.

BRANDÃO, M. de M. et al. Acessibilidade Espacial no Colégio de Aplicação da Universidade Federal de Santa Catarina: em busca de uma escola livre de barreiras. In: CBEU - CONGRESSO BRASILEIRO DE EXTENSÃO UNIVERSITÁRIA, Florianópolis, 2006. Anais do Congresso. Florianópolis, 2006.

BRASIL. Convenção sobre os Direitos das Pessoas com Deficiência. Protocolo Facultativo à Convenção sobre os Direitos das Pessoas com Deficiência. Diário Oficial da União, Brasília, DF, 2007.

. A Convenção sobre Direitos das Pessoas com Deficiência comentada. Coordenação de Ana Paula Crosara de Resende e Flavia Maria de Paiva Vital. Brasília: Secretaria Especial dos Direitos Humanos, 2008a.

Constituição (1988). Constituição da República Federativa do Brasil. Diário Oficial da União, Brasília, DF, 1988. 
BRASIL. Declaração de Salamanca e linha de ação sobre necessidades educativas especiais. Diário Oficial da União, Brasília, DF, 1994.

Declaração Mundial sobre Educação para Todos: plano de ação para satisfazer as necessidades básicas de aprendizagem. UNESCO, Jomtiem/Tailândia, 1990. Disponível em:

<http://unesdoc.unesco.org/images/0008/000862/086291por.pdf > . Acesso em: 1 nov. 2008.

. Decreto Legislativo no 186, de 9 julho de 2008. Aprova o texto da Convenção sobre os Direitos das Pessoas com Deficiência e de seu Protocolo Facultativo, assinados em Nova Iorque, em 30 de março de 2007. Diário Oficial da União, Brasília, DF, 2008b.

. Decreto no 914, de 6 de setembro de 1993. Institui a Política Nacional para a Integração da Pessoa Portadora de Deficiência, e dá outras providências. Diário Oficial da União, Brasília, DF, 1993.

. Decreto no 3.298, de 20 de dezembro de 1999. Diário Oficial da União, Brasília, DF, 1999.

- Decreto no 3.956, de 8 de outubro de 2001. Promulga a Convenção Interamericana para a Eliminação de Todas as Formas de Discriminação contra as Pessoas Portadoras de Deficiência (Convenção da Guatemala de 1999). Diário Oficial da União, Brasília, DF, 2001.

. Decreto no 5.296 de 02 de dezembro de 2004. Regulamenta as Leis $\mathrm{n}^{\text {os }}$ 10.048 , de 8 de novembro de 2000 , que dá prioridade de atendimento às pessoas que especifica, e 10.098, de 19 de dezembro de 2000, que estabelece normas gerais e critérios básicos para a promoção da acessibilidade das pessoas portadoras de deficiência ou com mobilidade reduzida, e dá outras providências. Diário Oficial da União, Brasília, DF, 2004.

. Decreto n 6.253, de 13 de novembro de 2007. Dispõe sobre o Fundo de Manutenção e Desenvolvimento da Educação Básica e de Valorização dos Profissionais da Educação - FUNDEB, regulamenta a Lei no 11.494, de 20 de junho de 2007, e dá outras providências. Diário Oficial da União, Brasília, DF, 2007.

. Decreto no 6.571, de 17 de setembro de 2008. Dispõe sobre o atendimento educacional especializado, regulamenta o parágrafo único do art. 60 da Lei $n^{0} 9.394$, de 20 de dezembro de 1996, e acrescenta dispositivo ao Decreto $n^{\circ} 6.253$, de 13 de novembro de 2007. Diário Oficial da União, Brasília, DF, 2008c.

. Decreto $n^{0} 6.980$, de 13 de outubro de 2009. Aprova a estrutura regimental e o quadro demonstrativo dos Cargos em Comissão da Secretaria Especial dos Direitos Humanos da Presidência da República, e dá outras providências. Diário Oficial da União, Brasília, DF, 2009a. 
BRASIL. Decreto no 6.949, de 25 de agosto de 2009. Promulga a Convenção Internacional sobre os Direitos das Pessoas com Deficiência e seu Protocolo Facultativo, assinados em Nova York, em 30 de março de 2007. Diário Oficial da União, Brasília, DF, 2009b.

. Decreto no 10.890, de 16 de fevereiro de 2004. Autoriza, em caráter excepcional, a antecipação da transferência de recursos prevista no art. $1^{\circ}$-A da Lei no 10.336, de 19 de dezembro de 2001, nas condições que especifica. Diário Oficial da União, Brasília, DF, 2004.

. Estatuto da Criança e do Adolescente no Brasil. Lei no 8.069, de 13 de julho de 1990. Diário Oficial da União, Brasília, DF, 1990.

BRASIL. Lei no 7.853, de 24 de outubro de 1989. Diário Oficial da União, Brasília, DF, 1989.

Lei no 9.394 de 20 de dezembro de 1996. Lei de diretrizes e bases da educação nacional. Diário Oficial da União, Brasília, DF, 1996.

. Lei no 10.048, de 8 de novembro de 2000. Dá prioridade de atendimento às pessoas que especifica, e dá outras providências. Diário Oficial da União, Brasília, DF, 2000a.

Lei no 10.098, de 19 de dezembro de 2000. Estabelece normas gerais e critérios básicos para a promoção da acessibilidade das pessoas portadoras de deficiência ou com mobilidade reduzida, e dá outras providências. Diário Oficial da União, Brasília, DF, 2000b.

. Lei $\mathrm{n}^{0} 10.172$, de 9 de janeiro de 2001. Aprova o Plano Nacional de Educação e dá outras providências. Diário Oficial da União, Brasília, DF, 2001.

Lei $\mathrm{n}^{0} 10.845$, de 5 de março de 2004. Institui o Programa de Complementação ao Atendimento Educacional Especializado às Pessoas Portadoras de Deficiência. Diário Oficial da União, Brasília, DF, 2004.

. Lei $\mathrm{n}^{0} 11.114$ de 16 de maio de 2005 . Altera os arts. 6으 30, 32 e 87 da Lei $\mathrm{n}^{\mathrm{0}}$ 9.394, de 20 de dezembro de 1996, com o objetivo de tornar obrigatório o início do ensino fundamental aos seis anos de idade. Diário Oficial da União, Brasília, DF, 2005.

. Lei no 11.958, de 26 de junho de 2009. Altera as Leis nos 7.853, de 24 de outubro de 1989, e 10.683, de 28 de maio de 2003 e dá outras providências. Diário Oficial da União, Brasília, DF, 2009c.

. Ministério da Educação. Secretaria de Educação Especial. Diretrizes Nacionais para a Educação Especial na Educação Básica. Diário Oficial da União, Brasília, DF, 2001. 
BRASIL/CORDE - Coordenadoria Nacional para a Integração da Pessoa Portadora de Deficiência. Relatório sobre a prevalência de deficiências, incapacidades e desvantagens. Niterói: Ministério da Justiça/CORDE/AFR, 2004.

BRASIL/MINISTÉRIO DA SAÚDE. Secretaria de Atenção à Saúde. Política Nacional de Saúde da Pessoa Portadora de Deficiência / Ministério da Saúde, Secretaria de Atenção à Saúde - Brasília: Editora do Ministério da Saúde, 2008.

BRONFENBRENNER, U. A ecologia do desenvolvimento humano:

Experimentos naturais e planejados. Porto Alegre: Artes Médicas, 1996.

BROUGÈRE, G. A criança e a cultura lúdica. Rev. Fac. Educ., São Paulo, v. 24, n. 2, jul.1998. Disponível em:

<http://www.scielo.br/scielo.php?script=sci_arttext\&pid=S0102-

25551998000200007\&lng=en\&nrm=iso >. Acesso em: 21 jan. 2010.

BRUNO, M. M. G. O desenvolvimento integral do portador de deficiência

visual: da intervenção precoce a integração escolar. São Paulo: Newswork, 1993.

BRUSCATO, A. C. M. A regulamentação não-regulada das instituições de educação infantil no município de Porto Alegre. 2008. Dissertação (Mestrado em educação) - Faculdade de Educação, Universidade Federal do Rio Grande do Sul, Porto Alegre, 2008.

CAMARGO, L. A imagem. Material didático entregue no minicurso: O livro para crianças: onde o visual e o verbal se mesclam. Porto Alegre, 2006.

CARNEIRO, M. A. $\mathbf{O}$ acesso de alunos com deficiência às escolas e classes comuns: possibilidades e limitações. 2 ed. Petrópolis, RJ: Vozes, 2008.

CARVALHO, A. M. A. et al. O uso de entrevistas em estudos com crianças. Psicologia em Estudo, Maringá, v. 9, n. 2, p. 291-300, mai./ago. 2004.

CARVALHO, T. C. P. de. Arquitetura escolar inclusiva: construindo espaços para educação infantil. 2008. Tese (Doutorado em Arquitetura e Urbanismo) - Escola de Engenharia de São Carlos, Universidade de São Paulo, São Carlos, 2008.

CASAROTTO, R. A. Dados antropométricos de pré-escolares do município de São Paulo. 1993. Dissertação (Mestrado em Ciências Biomédicas) - Instituto de Ciências Biomédicas, Universidade de São Paulo, São Paulo, 1993.

CASTEL, R. As armadilhas da exclusão. In: BELFIORE-WANDERLEY, M. et al. (Orgs). Desigualdade e a questão social. São Paulo: EDUC, 1997. p. 15-48.

CAT - Comitê de Ajudas Técnicas. Ata da Reunião VII, de dezembro de 2007, Comitê de Ajudas Técnicas, Secretaria Especial dos Direitos Humanos da Presidência da República (CORDE/SEDH/PR). 2007. Disponível em: 
<http://www.mj.gov.br/corde/arquivos/doc/Ata_VII_Reunião_do_Comite_de_Ajudas _Técnicas.doc> Acesso em: 05 jan. 2008.

CHAGAS et al. Classificação da função motora e do desempenho funcional de crianças com paralisia cerebral. Revista Brasileira de Fisioterapia, São Carlos, v. 12, n. 5, set./out. 2008. Disponível em:

$<$ http://www.scielo.br/scielo.php?script=sci_arttext\&pid=S1413-

35552008000500011\&lng=pt\&nrm=iso >. Acesso em: 24 mar. 2009.

CIF - Classificação Internacional de Funcionalidade, Incapacidade e Saúde. Centro Colaborador da Organização Mundial da Saúde para a Família de Classificações Internacionais, org.; coordenação da tradução Cassia Maria Buchalla. São Paulo: Universidade de São Paulo, 2003.

COLL, C.; PALACIOS, J.; MARCHESI, A. (Orgs.). Desenvolvimento psicológico e educação: necessidades educativas especiais e aprendizagem escolar. Tradução: Marcos A. G. Domingues. Porto Alegre: Artes Médicas, vol. 3, 1995.

CONSELHO NACIONAL DE EDUCAÇÃO. Câmara de Educação Básica. Resolução CNE/CEB 2 de 14 de setembro de 2001. Institui Diretrizes Nacionais para a Educação Especial na Educação Básica. Brasília, Diário Oficial da União, Seção 1E.

COOK, A.; HUSSEY, S. Assistive technologies: Principles and practice. California: Mosby Year-Book, Inc, 1995.

COOPER, R. A. Wheelchair Selection and Configurationn. New York: Demos Medical Publishing, 1998.

CORRAZE, J. As comunicações não-verbais. Rio de Janeiro: Zahar, 1982.

CORREIA, L. M. Alunos com necessidades educativas especiais nas classes regulares. Porto: Porto Editora, 1999.

CORRER, R. Deficiência e inclusão social: construindo uma nova comunidade. Bauru, SP: EDUSC, 2003.

COSMOS Corporation. Case studies and organizational innovation: strengthening the connection. Bethesda, MD: Author, 1983.

COX, M. Desenho da criança. São Paulo: Martins Fontes, 2007.

CRESWELL, J. W. Research design: qualitative, quantitative, and mixed methods approaches. 2nd ed. Thousand Oaks: Sage Publications; 2003.

CUNHA, M. B. Metodologias para estudo de usuários de informação científica e tecnológica. Revista de Biblioteconomia de Brasília, Brasília, v. 10, n. 2, p. 5-19, jul./dez. 1982. Disponível em: 
<http://www.tempusactas.unb.br/index.php/RBB/article/viewFile/320/303>. Acesso em: 10 jan. 2011.

DEBUS, M. Manual para excelencia en la investigación mediante grupos focales. Washington(USA): Academy for Educational Development, 1997.

DI LEO, J. H. A interpretação do desenho infantil. Porto Alegre: Artes Médicas, 1985.

DI NUBILA, H. B. V.; BUCHALLA, C. M. O papel das Classificações da OMS - CID e CIF nas definições de deficiência e incapacidade. Rev. bras. epidemiol., São Paulo, v. 11, n. 2, jun. 2008. Disponível em: $<$ http://www.scielo.br/scielo.php?script=sci_arttext\&pid=S1415790X2008000200014\&lng=pt\&nrm=iso>. Acesso em: 13 fev. 2009.

DICIONÁRIO HOUAISS DA LÍNGUA PORTUGUESA. Rio de Janeiro: Objetiva, 2001.

DISCHINGER, M. et al. Desenho Universal em escolas: acessibilidade na rede escolar municipal de Florianópolis. Florianópolis: PRELO, 2004.

et al. A importância do desenvolvimento de métodos de avaliação de acessibilidade espacial - Estudo de Caso no Colégio de Aplicação - UFSC. IN: VI WORKSHOP BRASILEIRO DE GESTÃO DO PROCESSO DE PROJETO NA CONSTRUÇÃO DE EDIFÍCIOS, 2006, São Paulo. Anais do Seminário Internacional NUTAU 2006. São Paulo: Núcleo de Pesquisa em Tecnologia da Arquitetura, 2006.

DREYFUSS, $\mathrm{H}$. The measure of man and woman. New York: Whitney Library of Design, 1959.

DUARTE, M. L. B. O Desenho como Elemento de Cognição e Comunicação: ensinando crianças cegas. In: PORTO, T. M. E., (org.) Soc., democr. e educ.: qual universidade? ANPED, GT 16, Caxambu, p.109-127, 2004.

DUARTE, N. Concepções afirmativas e negativas sobre o ato de ensinar. Cad. CEDES, Campinas, v. 19, n. 44, abr. 1998. Disponível em <http://www.scielo.br/scielo.php?script=sci_arttext\&pid=S010132621998000100008\&lng=pt\&nrm=iso >. Acesso em: 05 jul. 2010.

DUARTE, R. Pesquisa qualitativa: reflexões sobre o trabalho de campo. Cad. Pesqui., São Paulo, n. 115, mar. 2002. Disponível em: <http://www.scielo.br/scielo.php?script=sci_arttext\&pid=S010015742002000100005\&lng=en\&nrm=iso>. Acesso em: 02 jan. 2011.

DUNN, J. The beginnings of social understanding. Oxford, UK: Basil Blackwell, 1988.

ECO, U. Como se faz uma tese. São Paulo: Perspectiva, 2008. 
ELALI, G. A. A APO como subsídio para a elaboração de normas para pré-escolas em Natal-RN. In: SEMINÁRIO INTERNACIONAL I Nutau 2002, São Paulo. Anais do Seminário Internacional NUTAU 2002. São Paulo: Núcleo de Pesquisa em Tecnologia da Arquitetura, 2002a.

Ambientes para educação infantil: um quebra cabeça? Contribuição metodológica na avaliação pós-ocupação de edificações e na elaboração de diretrizes para projetos arquitetônicos na área. 2002. Tese (Doutorado em Arquitetura e Urbanismo) - Faculdade de Arquitetura e Urbanismo, Universidade de São Paulo, São Paulo, 2002b.

Avaliação Pós-Ocupação e responsabilidade social: uma relação a ser sempre (re)discutida. Gestão \& tecnologia de projetos, v. 5, p. 3-17, 2010.

FACCIN, R. Melhorias de Conforto ao Ambiente Educacional por Meio da Avaliação do Edifício Escolar: Estudo de Caso em duas Escolas de Primeiro Grau em São Carlos. 1995. Dissertação (Mestrado em Engenharia) - Escola de Engenharia de São Carlos, Universidade de São Paulo, São Carlos, 1995.

Sistema informatizado de gerenciamento do ambiente escolar SIGAE - como instrumento de apoio a melhoria do conforto ambiental. 2001. Tese (Doutorado em Engenharia Civil) - Faculdade de Engenharia Civil, Universidade Estadual de Campinas, Campinas, 2001.

FÁVERO, E. A. G. Definição de discriminação. In: GUGEL, M. A. et al. Deficiência no Brasil: uma abordagem integral dos direitos das pessoas com deficiência.

Florianópolis: Obra Jurídica, 2007a. p. 67-87.

. O direito a uma educação inclusiva. In: GUGEL, M.A. et al. Deficiência no Brasil: uma abordagem integral dos direitos das pessoas com deficiência. Florianópolis: Obra Jurídica, 2007b. p. 89-109.

FERNANDES, P. V. Uso de órteses para crianças com mielomeningocele nível lombar baixo e sacral: abordagem literária. Artigo eletrônico. s/d. Disponível em: <http://www.interfisio.com.br/index.asp?fid=106\&ac=1\&id=2>. Acesso em: 25 abr. 2009.

FERRARI, M. J.H. Pestalozzi. O teórico que incorporou o afeto à pedagogia. Revista eletrônica Escola Abril, edição 171, abr. 2004. Disponível em:

<http://revistaescola.abril.com.br/edicoes/0171/aberto/mt_134371.shtml>. Acesso em: 5 fev. 2009.

FERREIRA, E. D. de S. Liberdade assistida no Estatuto da Criança e do

Adolescente: aspectos da luta pela implementação de direitos fundamentais. 2006. Tese (Doutorado). Pontifícia Universidade Católica de São Paulo, São Paulo, 2006. 
FERREIRA, M. C. A prática educativa e a concepção de desenvolvimento psicológico de alunos com deficiência mental. 1994. Tese (Doutorado em Educação) - Faculdade de Educação, Universidade Estadual de Campinas, Campinas, 1994.

FERREIRA, M. E. dos S. Construção de um mapa tátil do campus Seropédica da UFRRJ. Projeto final de curso apresentado como requisito parcial à conclusão do curso de Engenharia de Agrimensura, Departamento de Engenharia, Instituto de Tecnologia, Universidade Federal Rural do Rio de Janeiro, 2008. Disponível em: <http://www.ufrrj.br/institutos/it/deng/juliana/downloads/Orientacoes/Concluidos/M aria_Engracinda.pdf>. Acesso em: 20 mar. 2011.

FERREIRA, S. Imaginação e linguagem no desenho da criança. Campinas: Papirus, 2001.

FERREIRA, V. R. T.; MOUSQUER, D. N. Observação em psicologia clínica. Revista de Psicologia da UnC. Concórdia, SC, v. 2, n. 1, p. 54-61, dez. 2004.

Disponível em: <http://www.nead.uncnet.br/2009/revistas/psicologia/3/36.pdf>. Acesso em: 15 fev. 2011.

FRANÇA, C. Um novato na Psicopedagogia. In: SISTO, F. et al. Atuação psicopedagógica e aprendizagem escolar. Petrópolis, RJ: Vozes, 1996.

FRANCIOZI, C. E. da S. et al. Trauma na infância e adolescência: epidemiologia, tratamento e aspectos econômicos em um hospital público. Acta ortop. bras. [online], v. 16, n. 5, p. 261-265, 2008. Disponível em: <http://www.scielo.br/scielo.php?script=sci_arttext\&pid=S141378522008000500001\&lng=en\&nrm=iso >. Acesso em: 27 dez. 2010.

FRANCO, M. H. P.; MAZORRA, L. Criança e luto: vivências fantasmáticas diante da morte do genitor. Estud. psicol. (Campinas), Campinas, v. 24, n. 4, dez. 2007. Disponível em: <http://www.scielo.br/scielo.php?script=sci_arttext\&pid=S0103166X2007000400009\&lng=en\&nrm=iso >. Acesso em: 28 fev. 2011.

FUndAÇÃo GETÚlLIO VARGAS. SILVEIRA, E. Metodologia da Pesquisa. Rio de Janeiro: FGV, 2010.

GALVÃO FILHO, T. A. A. Tecnologia Assistiva: de que se trata? In: MACHADO, G. J. C.; SOBRAL, M. N. (Orgs.). Conexões: educação, comunicação, inclusão e interculturalidade. 1 ed. Porto Alegre: Redes Editora, 2009. p. 207-235.

GARRALDA, M. E. Chronic physical illness and emotional disorder in childhood. British Journal of Psychiatry, 1994, 164, p. 8-10.

GATTI, B. A produção da pesquisa em educação no Brasil e suas implicações sociopolítico-educacionais: uma perspectiva da contemporaneidade. In: CONFERÊNCIA DE PESQUISA SOCIOCULTURAL, 2000, Campinas. Anais. Campinas, 2000. 
GIL, A. C. Como elaborar projetos de pesquisa. São Paulo: Atlas, 1991.

GOFFMAN, E. Estigma: Notas sobre a Manipulação da Identidade Deteriorada. Rio de Janeiro: Editora Guanabara Koogan S.A., 1988.

GOLDBERG, L. G.; YUNES, M. A. M.; FREITAS, J. V. de. O desenho infantil na ótica da ecologia do desenvolvimento humano. Psicol. estud., Maringá, v. 10, n. 1, abr. 2005. Disponível em: <http://www.scielo.br/scielo.php?pid=S141373722005000100012\&script=sci_arttext>. Acesso em: 7 jan. 2010.

GOMES, W. B. A entrevista fenomenológica e o estudo da experiência consciente.

Psicol. USP, São Paulo, v. 8, n. 2,1997. Disponível em:

$<$ http://www.scielo.br/scielo.php?script=sci_arttext\&pid=S0103-

65641997000200015\&lng=en\&nrm=iso >. Acesso em: 10 jan. 2011.

GONÇALVES, M. de J. Editorial II - Comunicação alternativa na fonoaudiologia: uma área em expansão. Rev. CEFAC, São Paulo, v. 10, n. 3, 2008. Disponível em: $<$ http://www.scielo.br/pdf/rcefac/v10n3/v10n3a02.pdf>. Acesso em: $17 \mathrm{dez}$. 2009.

GONDRA, J. História, infância e escolarização. $1^{\text {a }}$ ed. Rio de Janeiro: 7 Letras, 2002.

GREENSPAN, S. I.; GREENSPAN, N. T. Entrevista clínica com crianças. (Tradução Daise Batista). Porto Alegre: Artes Médicas, 1993.

GRONING, G. An attempt to improve a school yard. Children's environments Quarterly, 3 (3), p. 12-19, 1986.

GROSSI, E.P.; BORDIN, J. (orgs.) Construtivismo pós-piagetiano. Rio de Janeiro, Vozes, 1993.

GUGEL, M. A. et al. Deficiência no Brasil: uma abordagem integral dos direitos das pessoas com deficiência. Florianópolis: Obra Jurídica, 2007.

GUIMARÃES, L. B. de M.; BIASOLLI, P. Levantamento antropométrico: o Brasil ainda precisa ter o seu? In: CONGRESSO INTERNACIONAL DE ERGONOMIA E USABILIDADE DE INTERFACES HUMANO-TECNOLOGIA. 2., 2002, Rio de Janeiro.

Anais do II Congresso Internacional de Ergonomia e Usabilidade de Interfaces Humano-Tecnologia: Produtos, Programas, Informação, Ambiente Construído Ergodesign. Rio de Janeiro: Departamento de Artes e Design PUC-Rio, 2002.

GÜNTHER, H. Como elaborar um questionário. In: PINHEIRO, J. de Q.; GÜNTHER, H. Métodos de pesquisa nos estudos pessoa-ambiente. São Paulo: Casa do Psicólogo, 2008. 
GÜNTHER, H.; ELALI, G. A.; PINHEIRO, J. de Q. A abordagem multimétodos em estudos pessoa-ambiente: características, definições e implicações. P.369-396. In: PINHEIRO, J. de Q.; GÜNTHER, $H$. Métodos de pesquisa nos estudos pessoaambiente. São Paulo: Casa do Psicólogo, 2008.

GÜNTHER, I. de A. O uso da entrevista na interação pessoa-ambiente. In: PINHEIRO, J. de Q.; GÜNTHER, $H$. Métodos de pesquisa nos estudos pessoaambiente. São Paulo: Casa do Psicólogo, 2008.

HIGUCHI, M. I. G. House, street, bairro and mata: ideas of place and space in an urban location in Brazil. 1999. Tese (doutorado), Inglaterra, Brunel University, 1999.

HÜBNER, M. M. Guia para elaboração de monografias e projetos de dissertação de mestrado e doutorado. São Paulo: Pioneira, 1998.

IBGE - INSTITUTO BRASILEIRO DE GEOGRAFIA E ESTATÍSTICA. Censo demográfico 2000. Disponível em:

<http://www.ibge.gov.br/home/estatistica/populacao/censo2000/default.shtm>. Acesso em: 17 nov. 2010.

ISSA, M. P.; POLTRONIERI, J. P.; ORNSTEIN, S. W. Procedimentos para Avaliação Pós-Ocupação (APO) de Edifícios Escolares: O Caso da E.E. Fernando Gasparian, na cidade de São Paulo. In: SEMINÁRIO INTERNACIONAL I Nutau 2008, São Paulo. Anais do Seminário Internacional NUTAU 2008. São Paulo: Núcleo de Pesquisa em Tecnologia da Arquitetura, 2008.

JANNUZZI, G. S. M. Oficina abrigada e a integração do deficiente mental. Revista Brasileira de Educação Especial, Piracicaba, vol. I, n. I, 1992.

JOHNSON, R. Guia dos Símbolos de Comunicação Pictórica. Porto Alegre: Clik, 1998.

KASSAR, M. de C. M. Deficiência múltipla e educação no Brasil: discurso e silêncio na história de sujeitos. Campinas: Autores Associados, 1999.

KELLER, H. A história de minha vida. Rio de Janeiro: José Olympio, 2008.

KIM, H.S.; STEINBOK, P.; WICKENHEISER, D. Predictors of poor outcome after selective dorsal rhizotomy in treatment of spastic cerebral palsy. Childs Nerv Syst., 22(1), p. 60-6, 2006.

KISHIMOTO, T. M. A pré-escola em São Paulo (1877 a 1940). São Paulo: Loyola, 1988.

. Jogo, brinquedo, brincadeira e a educação. São Paulo: CORTEZ, 1994. 
KISHIMOTO, T. M. Jogos infantis: o jogo, a criança e a educação. Rio de Janeiro: Petrópolis, 2007.

KITZINGER J., BARBOUR R. S. Introduction: the challenge and promise of focus groups. In: _. Organizadores. Developing focus group research: politics, theory and practice. London (UK): Sage, 1999. p. 1-20.

KOWALTOWSKI, D. C. C. K. Arquitetura escolar: o projeto do ambiente de ensino. São Paulo: Oficina de Texto, 2011.

; DELIBERADOR, M. S. 0 processo de projeto de arquitetura escolar no

Estado de São Paulo: caracterização e possibilidades de intervenção. In: $1^{0}$ Workshop GAE-PROLUGAR-SEL - O LUGAR DO PÁTIO ESCOLAR NO SISTEMA DE ESPAÇOS LIVRES, 2010, Rio de Janeiro, RJ, 2010.

; MOREIRA, D. de C. O Programa de Necessidades e a Importância de APO no Processo de Projeto. In: ENTAC 2008 - XII Encontro Nacional de Tecnologia do Ambiente Construído: geração de valor no ambiente construído: inovação e sustentabilidade, Fortaleza. Anais do congresso. Fortaleza, CE. 2008. p. 1-10

; PINA, S. A. M. G. A avaliação da funcionalidade de prédio escolar da rede pública: O caso de Campinas. In: VI ENCONTRO NACIONAL E III ENCONTRO LATINO AMERICANO SOBRE CONFORTO NO AMBIENTE CONSTRUÍDO, 11-14 nov. 2001, São Paulo. Anais do congresso. São Paulo: 2001. p. 8

et al. Ambiente Construído e Comportamento Humano: Necessidade de uma Metodologia. IN: VIII ENCONTRO NACIONAL DE TECNOLOGIA DO AMBIENTE CONSTRUÍDO - ENTAC2000, 26-28 abr. 2000, Salvador. Anais do ENTAC 2000 Modernidade e Sustentabilidade. Salvador: EDUFBA, 2000. p. 1-8.

Humanization in architecture: analysis of themes through high school building problems. University of California, PhD. Thesis, Berkeley, USA, 1980.

KUHLMANN JR., M.; BARBOSA, M.C. Pedagogia e rotinas no "Jardim-da-Infância". In: Infância e educação infantil: uma abordagem histórica. Porto Alegre: Mediação, 1998. p. 111-179.

LAGO, A. Anotações descosturadas sobre ilustrações e livros de imagens. In:

Revista Releitura. Biblioteca Pública Infantil e Juvenil de Belo Horizonte, p. 13 -17, 1991.

O computador e o livro. Belo Horizonte, jun./1997. Disponível em:

<http://www.angela-lago.com.br/aulaComput.html > Acesso em: 28 dez. 2010.

LAKATOS, A. M.; MARCONI, M. A. Fundamentos de metodologia científica. $3^{a}$ ed. São Paulo: Atlas, 1993. 
LAUFER, A. M. Recomendações para projeto de brinquedos de recreação e lazer existentes em playgrounds adaptados à criança com paralisia cerebral. 2001. Dissertação (Mestrado em Engenharia de Produção), Faculdade de Engenharia de Produção, Universidade Federal de Santa Catarina, Florianópolis, 2001.

LEIBOVICI, Z. Significações familiares e surdez. In: CONGRESSO DO INES INSTITUTO NACIONAL DE EDUCAÇÃO DE SURDOS (BRASIL), 2003. Anais do Congresso de surdez e escolaridade: desafios e reflexões. Rio de Janeiro: INSTITUTO NACIONAL DE EDUCAÇÃO DE SURDOS, 2003.

LIANZA, S. Reabilitação: a locomoção em pacientes com lesão medular. São Paulo: SARVIER/Associação Paulista de Medicina, 1994.

LIMA, C. L. A.; FONSECA, L. F. Paralisia cerebral - neurologiaortopedia-reabilitação. Rio de Janeiro: Medsi/Guanabara Koogan, 2004.

LOPES, M. E. Metodologia de análise e implantação de acessibilidade para pessoas com mobilidade reduzida e dificuldade de comunicação. 2005. 284p. Tese (Doutorado em Arquitetura e Urbanismo) - Faculdade de Arquitetura e Urbanismo, Universidade de São Paulo, São Paulo. 2005.

Ser acessível é ser legal. In: GUGEL, M. A. et al. Deficiência no Brasil: uma abordagem integral dos direitos das pessoas com deficiência. Florianópolis: Obra Jurídica, 2007.

LÚCIO, D. A. B. O Cued Speech ou o português falado complementado. In: CONGRESSO DO INES - INSTITUTO NACIONAL DE EDUCAÇÃO DE SURDOS (BRASIL), 2003. Anais do Congresso de surdez e escolaridade: desafios e reflexões. Rio de Janeiro: INSTITUTO NACIONAL DE EDUCAÇÃO DE SURDOS, 2003.

LUQUET, G. H. O desenho infantil. Porto: Ed. Minho, 1969.

LUZ, G. K. et al. Mesa para auxiliar a comunicação de aluno com paralisia cerebral. In: IX ENCONTRO NACIONAL E V LATINO AMERICANO DE CONFORTO NO AMBIENTE CONSTRUÍDO, 2007, Ouro Preto. Anais. Ouro Preto, 2007.

LYNCH, K. A imagem da cidade. São Paulo: Martins Fontes, 1980.

MACHADO, M. N. da M. Entrevista de pesquisa: a interação pesquisador /entrevistado. Belo Horizonte: C/ Arte, 2002.

MAIOR, I. M. M. de L. Apresentação. In: A Convenção sobre os Direitos das Pessoas com Deficiência Comentada. Coordenação de Ana Paula Crosara de Resende e Flavia Maria de Paiva Vital Brasília: Secretaria Especial dos Direitos Humanos. Coordenadoria Nacional para Integração da Pessoa Portadora de 
Deficiência - CORDE, 2008. Disponível em:

<http://www.bengalalegal.com/educacao.php>. Acesso em: 22 jul. 2010.

MALANGA, E. B. Linguagens e pensamento: introdução a uma abordagem interdisciplinar entre a psicopedagogia e a semiologia para a compreensão da construção do pensamento. Cad. Psicopedag, [online], v. 3, n. 6, p. 28-39, jun. 2004. Disponível em: <http://pepsic.bvspsi.org.br/scielo.php?script=sci_arttext\&pid=S1676$10492004000100004 \&$ Ing=pt\&nrm=iso >. Acesso em: 05 jul. 2010.

MANCINI, M. C. et al. Gravidade da paralisia cerebral e desempenho funcional. Rev Bras Fisioter, 8(3), p. 253-60, 2004.

MARCONDES, E. et al. Crescimento normal e deficiente. São Paulo: Sarvier, 1978.

MARTINS, G. A. Estudo de caso: uma reflexão sobre a aplicabilidade em pesquisas no Brasil. RCO - Revista de Contabilidade e Organizações, FEARP/USP, v. 2, n. 2, p. 8, 18 jan./abr. 2008. Disponível em: <http://www.revistasusp.sibi.usp.br/pdf/rco/v2n2/02.pdf>. Acesso em: 24 fev. 2010.

MARTINS, M. do R. et al. Protocolo de preparo da criança pré-escolar para punção venosa, com utilização do brinquedo terapêutico. Rev. Latino-Am. Enfermagem, Ribeirão Preto, v. 9, n. 2, abr. 2001. Disponível em:

<http://www.scielo.br/scielo.php?script=sci_arttext\&pid=S0104$11692001000200011 \& \mathrm{lng}=\mathrm{en} \& \mathrm{nrm}=\mathrm{iso}>$. Acesso em: 2 nov. 2009.

MARTINS, S. L. Práticas pedagógicas com aluna surdo-cega do $6 .^{\circ}$ ano do Ensino Fundamental. Revista Arqueiro, Rio de Janeiro, INES, v. 17, jan/jun. 2008.

Disponível em:

<http://www.ines.gov.br/paginas/publicacoes/Arqueiro/Arqueiro17.pdf >. Acesso em: 2 nov. 2009.

MATELL, M. S.; JACOBY, J. Is there an optimal number of alternatives for Likert scale items? Study in: Reliability and validity. Educational and Psychological Measurement, 31, 657-674.

MATTOS, E. A. de et al. Educação inclusiva: reflexões sobre a inclusão e inclusão total. Revista Inclusão, Braga, Portugal, Instituto de Estudos da Criança, Universidade do Minho, n. 5, p.49-61, 2004.

MATURANA, H.; VERDEN-ZÖLLER, G. Amor y juego. Santiago: Editorial Instituto de Terapia Cognitiva, 1993.

MAURÍCIO, J. T. Aprender brincando: o lúdico na aprendizagem. Artigo eletrônico. 2006. Disponível em: <http://www.profala.com/arteducesp140.htm>. Acesso em: 8 dez. 2009. 
MEC. SECRETARIA DE EDUCAÇÃO ESPECIAL. Saberes e práticas da inclusão: dificuldades de comunicação e sinalização: deficiência física. Coordenação geral - Francisca Roseneide Furtado do Monte, Idê Borges dos Santos - reimpressão Brasília: MEC, SEESP, 2004.

MEC/SEESP - Secretaria de Educação Especial do Estado de São Paulo. Orientação e mobilidade: conhecimentos básicos para a inclusão do deficiente visual. Elaboração Edileine Vieira Machado et al. Brasília, 2003. 167 p.

MENDES, E. G. A radicalização do debate sobre a inclusão escolar. Revista Brasileira de Educação, v.11, n. 33, p.387- 405, set./dez. 2006.

MÈREDIEU, F. de. O desenho infantil. São Paulo: Cultrix, 1974.

MINAYO, M. C. S. 0 desafio do conhecimento: pesquisa qualitativa em saúde. São Paulo: Hucitec-Abrasco, 1996.

; SOUZA E. R. de. Violência e saúde como um campo

interdisciplinar e de ação coletiva. História, Ciências, Saúde, Manguinhos, IV(3): 513-531, nov. 1997-fev. 1998.

MOOJEN, S. Dificuldades ou transtornos de aprendizagem? In: Rubinstein, E. (Org.). Psicopedagogia: uma prática, diferentes estilos. São Paulo: Casa do Psicólogo, 1999.

MOREIRA, N. S. Espaços educativos para a escola de ensino médio. 2005. Tese (doutorado em Arquitetura e Urbanismo) - Faculdade de Arquitetura e Urbanismo, Universidade de São Paulo, São Paulo, 2005.

; ORNSTEIN, S. W. Acessibilidade na Rede Física de Escolas Públicas do Estado de São Paulo: Condições Atuais e Desafios Futuros. In: PRADO, A. R. de A.; LOPES, M. E.; ORNSTEIN, S. W. (Org.). Desenho Universal. Caminhos da Acessibilidade no Brasil. 1 ed. São Paulo: Annablume, 2010, v. 1. p. 167-175.

NASCIMENTO, F. Ali A. A. Caderno Educação. Educação infantil; saberes e práticas da inclusão: dificuldades de comunicação e sinalização: surdocegueira/múltipla deficiência sensorial. [4. ed.] / elaboração profa ms. Fátima Ali Abdalah Abdel Cader Nascimento - Universidade Federal de São Carlos UFSC/SP, prof. Shirley Rodrigues Maia Associação Educacional para a Múltipla Deficiência - AHIMSA. Brasília: MEC, Secretaria de Educação Especial, 2006. Disponível em:<http://portal.mec.gov.br/seesp/arquivos/txt/surdosegueira.txt>. Acesso em: 17 jul. 2010.

NÖTH, W. Panorama da Semiótica: de Platão a Peirce. São Paulo: Annablume, 1995. 
NUTTI, J. Z. Distúrbios, transtornos, dificuldades e problemas de aprendizagem.

Revista de psicopedagogia, 2002. Disponível em:

<http://www.psicopedagogia.com.br/artigos/artigo.asp?entrID=339>. Acesso em: 23 ab. 2009.

OCAHITA, E.; ROSA, A. Percepção, ação e conhecimento em crianças cegas. In: COLL, C.; PALACIOS, J.; MARCHESI, A. Desenvolvimento Psicológico e educação: necessidades educativas especiais e aprendizagem escolar. v. 3. Tradução: Marcos A. G. Domingues. Porto Alegre: Artmed, 1995. p. 183-197.

OLIVEIRA, M. A. da C. Práticas de professores do ensino regular com alunos surdos inseridos: entre a democratização do acesso e permanência qualificada e a reiteração da incapacidade de aprender. In: Deficiência e escolarização: novas perspectivas de análise. BUENO, J. G. S. et al. Araraquara, SP: Junqueira \& Marin; Brasília, DF: CAPES, 2008. p. 163-204.

OLIVEIRA, R. C. S.; KARA-JOSÉ, N.; ARIETA, C. E. L. Manual da boa visão do escolar: solucionando dúvidas sobre o olho e a visão. $2^{a}$ ed. São Paulo: Conselho Regional de Oftalmologia, 2001.

OLIVEIRA, S. R. de. Imagem também se lê. São Paulo: Rosari, 2005.

OMS - ORGANIZAÇÃO MUNDIAL DA SAÚDE. Methods of assessment of avoidable blindness. Genebra, 1982. p. 42 (Scientific Publication, 54).

ONU. Convenção Internacional para Proteção e Promoção dos Direitos e Dignidade das Pessoas com Deficiência. Nova Iorque, 2006.

ORNSTEIN, S. W.; BRUNA, G.; ROMÉRO, M. Ambiente construído \& comportamento: a avaliação pós-ocupação e a qualidade ambiental. São Paulo: Studio Nobel, 1995.

et al. Healthcare architecture in São Paulo, Brazil: evaluation accessibility and fire safety in large hospitals. International Journal of Architectural Research, v. 1, p. 13-25, 2007.

; ONO, R. Post-occupancy evaluation and design quality in Brazil: concepts, approaches and an example of application. Journal of Architectural Engineering and Design Management, v. 6, p. 48-67, 2010.

; MOREIRA, N. S. Evaluating School Facilities in Brazil. PEB Exchange, v. 1, p. $1-6,2008$.

et al. Improving the quality of school facilities through building performance assessment: educational reform and school building quality in São Paulo, Brazil. Journal of Educational Administration, v. 47, p. 350-367, 2009. 
ORNSTEIN, S. W.; ROMÉRO, M. de A. Avaliação Pós-Ocupação do ambiente construído. 1. ed. São Paulo: Studio Nobel e Editora da Universidade de São Paulo, 1992. v. 1. 223 p.

PACHECO, R. V.; COSTAS, F. A. T. O processo de inclusão de acadêmicos com necessidades educacionais especiais na Universidade Federal de Santa Maria. Cadernos, n. 27, 2005. Disponível em: <http://coralx.ufsm.br/revce/ceesp/2006/01/a12.htm>. Acesso em: 17 ab. 2009.

PASCHOARELLI, L. C. O posto de trabalho carteira escolar como objeto de desenvolvimento da educação infantil: uma contribuição do design e da ergonomia. 1997. Dissertação (Mestrado em Arquitetura, Artes e Comunicação), Universidade Estadual Paulista Júlio de Mesquita Filho, Bauru, 1997.

PAULA, K. M. P. de; ENUMO, S. R. F. Avaliação assistida e comunicação alternativa: procedimentos para a educação inclusiva. Rev. bras. educ. espec., Marília, v. 13, n. 1, abr. 2007. Disponível em: <http://www.scielo.br/scielo.php?pid=S141365382007000100002\&script=sci_arttext>. Acesso em: 10 dez. 2009.

PEAKE, P. Manual do usuário do Boardmaker. U.S.A.: Mayer-Johnson, 2004.

PEIRCE, C. S. Semiótica. São Paulo, SP: Perspectiva, 1977.

PEREIRA, L. de T. K. $\mathbf{O}$ desenho infantil e a construção da significação: um estudo de caso. 2009. Texto. Disponível em:

<http://portal.unesco.org/culture/en/files/29712/11376608891lais-kruckenpereira.pdf/lais-krucken-pereira.pdf>. Acesso em: 20 nov. 2009.

PFEIFER, E. A. Formação profissional para surdos: resgatando uma história. Psicol. esc. educ., v. 3, n. 1, p. 87-96, 1999. Disponível em: <http://pepsic.bvspsi.org.br/scielo.php?script=sci_arttext\&pid=S141385571999000100011\&lng=en\&nrm=>. Acesso em: 19 dez. 2009.

PICCININI, C. A. et al. A doença crônica orgânica na infância e as práticas educativas maternas. Estud. psicol. (Natal), Natal, v. 8, n. 1, 2003. Disponível em: $<$ http://www.scielo.br/scielo.php?script=sci_arttext\&pid=S1413294X2003000100009\&lng=en\&nrm=iso >. Acesso em: 21 abr. 2009.

PINHEIRO, J. de Q.; GÜNTHER, H. Métodos de pesquisa nos estudos pessoaambiente. São Paulo: Casa do Psicólogo, 2008.

; ELALI, G. A.; FERNANDES, O. S. Observando a interação pessoa ambiente: vestígios ambientais e mapeamento comportamental. In: ; GÜNTHER, $\mathrm{H}$. Métodos de pesquisa nos estudos pessoa-ambiente. São Paulo: Casa do Psicólogo, 2008. 
PREISER, W. F. E.; OSTROFF, E. Universal design handbook. New York: Mc. Graw Hill, 2001.

; RABINOWITZ, H.; WHITE, E. Post-Occupancy Evaluation. New York: Van Nostrand Reinhold, 1988.

PROSHANSKY, H. M. et al. Environmental psychology: man and his physical setting. Nova York: Holt, Rinhart \& Winston, 1970.

QUARESMA, M. M. R. A aplicação de dados antropométricos em projetos de design: como projetar corretamente produtos ergonômicos. 2001. Dissertação (Mestrado em Desenho Industrial), Pontifícia Universidade Católica do Rio de Janeiro, Rio de Janeiro, 2001.

QUERY, J. M.; REICHELT, C.; CHRISTOFERSON, L. A. Living with chronic illness: a retrospective study of patients shunted for hydrocephalus and their families.

Developmental Medicine and Child Neurology, 32, p. 119-128, 1990.

QUINTANA, A. M. et al. A vivência hospitalar no olhar da criança internada. Cienc. Cuid. Saúde, 6(4), p. 414-423, out./dez. 2007 Disponível em: <http://periodicos.uem.br/ojs/index.php/CiencCuidSaude/article/view/3679/2678>. Acesso em: 27 jan. 2010.

REHABILITATION INTERNATIONAL. Carta para o Terceiro Milênio. Londres: Assembléia Governativa da REHABILITATION INTERNATIONAL, 1999.

RESENDE, A. P. C. de; VITAL, F. M. de P. Introdução. In: BRASIL. A Convenção sobre Direitos das Pessoas com Deficiência comentada. Coordenação de: . Brasília: Secretaria Especial dos Direitos Humanos, 2008.

REVAH, D. A (re)configuração do passado no discurso construtivista. Estilos clin., v. 13, n. 24, p. 190-209, jun. 2008. Disponível em: <http://pepsic.bvspsi.org.br/scielo.php?script=sci_arttext\&pid=S141571282008000100014\&lng=pt\&nrm=iso>. Acesso em: 05 jul 2010.

RHEINGANTZ, P. A. De Corpo Presente: Sobre o papel do observador e a circularidade de suas interações com o ambiente construído. In: SEMINÁRIO INTERNACIONAL I Nutau 2004, São Paulo. Anais do Seminário Internacional NUTAU 2004. São Paulo: Núcleo de Pesquisa em Tecnologia da Arquitetura, 2004.

et al. Observando a qualidade do lugar: procedimentos para a avaliação pós-ocupação. Rio de Janeiro: PROARQ/UFRJ, 2008.

RIBEIRO, D. P. de S. A. Transicionalidade e uso do Procedimento de Desenhos-estórias com Tema nas primeiras entrevistas clínicas. Campinas: PUC-Campinas, 2007. Disponível em: 
<http://biblioteca.universia.net/html_bura/ficha/params/id/33774085.html >. Acesso em: 2 jan. 2010.

ROCHA, E. F. Reabilitação de pessoas com deficiência. São Paulo: Roca, 2006.

RODRIGUES, M. R. C. Estimulação Precoce - a contribuição da psicomotricidade na intervenção fisioterápica como prevenção de atrasos motores na criança cega congênita nos dois primeiros anos de vida. Benjamin Constant, Rio de Janeiro, v. 8, n. 21, p. 6-22, 2002.

ROMAND, C. Alfabetização de surdos - técnicas e estratégias. In: CONGRESSO DO INES - INSTITUTO NACIONAL DE EDUCAÇÃO DE SURDOS (BRASIL), 2003. Anais do Congresso de surdez e escolaridade: desafios e reflexões. Rio de Janeiro: INSTITUTO NACIONAL DE EDUCAÇÃO DE SURDOS, 2003a.

. Acesso à linguagem oral e escrita numa abordagem bilíngue: uma visão pedagógica. In: CONGRESSO DO INES - INSTITUTO NACIONAL DE EDUCAÇÃO DE SURDOS (BRASIL), 2003. Anais do Congresso de surdez e escolaridade: desafios e reflexões. Rio de Janeiro: INSTITUTO NACIONAL DE EDUCAÇÃO DE SURDOS, 2003b.

ROMERO, E. O inquilino do imaginário: formas de alienação e psicopatologia. São Paulo: Lemos, 2001.

ROSENBAUM, P. et al. A report: the definition and classification of cerebral palsy.

Dev Med Child Neurol Suppl., 109, p. 8-14, Apr. 2006.

SAMPAIO, S. Discalculia. Psicopedagogia, 2004. Disponível em:

<http://www.psicopedagogiabrasil.com.br/disturbios.htm>. Acesso em: 21 ab. 2009.

SANOFF, $H$. Visual research methods in design. New York: Van Nostrand Reinhold, 1991.

Integrating programming, evaluation and participation in design: a theory Z approach. Hants: Ashgate, 1992.

et al. School building assessment methods. National Clearinghouse for Educational Facilities, Washington. 2001. Disponível em:

<http://www4.ncsu.edu/ sanoff/schooldesign/schoolclassses.pdf>. Acesso em: 15 set. 2010.

School Design. New York: John Wiley \& Sons, INC., 1994.

SANTAELLA, L. Matrizes da Linguagem e Pensamento. São Paulo: Iluminuras, 2001.

O que é Semiótica. São Paulo: Brasiliense, 1983. 
SANTAELLA, L. A teoria geral dos signos: Como as linguagens significam as coisas. $2^{\text {a }}$ ed. São Paulo: Pioneira, 2000.

SANTOS, G. M. dos. Espelho e cegueira: signos metafóricos do conhecimento. INCI, v. 29, n. 3, p.111-111, mar. 2004. Disponível em: $<$ http://www.scielo.org.ve/scielo.php?script=sci_arttext\&pid=S037818442004000300003\&lng=es\&nrm=iso >. Acesso em: 15 ab. 2009.

SANTOS, M. P. dos S. A formação dos professores no contexto da inclusão. In: CONGRESSO DO INES - INSTITUTO NACIONAL DE EDUCAÇÃO DE SURDOS (BRASIL), 2003. Anais do Congresso de surdez e escolaridade: desafios e reflexões. Rio de Janeiro: INSTITUTO NACIONAL DE EDUCAÇÃO DE SURDOS, 2003.

SANTOS, R. A. dos. Processos de escolarização e deficiência: trajetórias escolares singulares de ex-alunos de classe especial para deficientes mentais. In: BUENO, J. G. S. et al. Deficiência e escolarização: novas perspectivas de análise. Araraquara, SP: Junqueira \& Marin; Brasília, DF: CAPES, 2008.

SÃO PAULO (ESTADO). Conselho Estadual de Educação. Indicação CEE 52, de 09 de novembro de 2005. Amplia o Ensino Fundamental para nove anos. São Paulo:

Diário Oficial do Estado, 2005.

. Decreto estadual $n^{0} 48.060$, de 01 de setembro de 2003. Autoriza a Secretaria da Educação a, representando o Estado, celebrar convênios com instituições sem fins lucrativos, com atuação em educação especial, para promover o atendimento de educandos portadores de necessidades especiais e dá providências correlatas. São Paulo: Diário Oficial do Estado, 2003.

. Lei estadual $n^{\circ}$ 9.167, de 18 de maio de 1995. Cria o Programa Estadual de Educação Especial. São Paulo: Diário Oficial do Estado, 1995.

. Lei estadual $n^{\circ} 10.958$, de 27 de novembro de 2001. Torna oficial a Língua Brasileira de Sinais - LIBRAS e dá outras providências. São Paulo: Diário Oficial do Estado, 2001.

. Resolução SE-72, de 9 de outubro de 2009. Estabelece orientações e procedimentos para a celebração de convênios com instituições, sem fins lucrativos, atuantes em educação especial, e dá providências correlatas. São Paulo: Diário Oficial do Estado, 2009.

SÃO PAULO (MUNICÍPIO). Decreto $n^{\circ} 45.415$, de 18 de outubro de 2004. Estabelece diretrizes para a Política de Atendimento a Crianças, Adolescentes, Jovens e Adultos com Necessidades Educacionais Especiais no Sistema Municipal de Ensino. São Paulo: Diário Oficial do Município, 2004a. 
SÃO PAULO (MUNICÍPIO). Decreto no 45.652, de 23 de dezembro de 2004. Dá nova redação ao parágrafo único do artigo 70 do Decreto no 45.415, de 18 de outubro de 2004, que estabelece diretrizes para a Política de Atendimento a Crianças, Adolescentes, Jovens e Adultos com Necessidades Educacionais Especiais no Sistema Municipal de Ensino. São Paulo: Diário Oficial do Município, 2004b.

. Portaria Municipal n 5.718, de 18 de dezembro de 2004. São Paulo: Diário Oficial do Município, 2004c.

Secretaria Municipal de Educação. Diretoria de Orientação Técnica. Referencial sobre avaliação da aprendizagem de alunos com necessidades educacionais especiais / Secretaria Municipal de Educação - São Paulo: Diário Oficial do Município, 2007.

SASSAKI, R. K. Artigo 24-Educação. pág. 83. In: A Convenção sobre os Direitos das Pessoas com Deficiência Comentada. Coordenação de Ana Paula Crosara de Resende e Flavia Maria de Paiva Vital Brasília: Secretaria Especial dos Direitos Humanos. Coordenadoria Nacional para Integração da Pessoa Portadora de Deficiência - CORDE, 2008. Disponível em: <http://www.bengalalegal.com/educacao.php>. Acesso em: 18 jul. 2010.

Inclusão: construindo uma sociedade para todos. Rio de Janeiro: WVA, 1997.

Como chamar as pessoas que têm deficiência? Texto. 2005a.

Disponível em: <http://www.sineperj.org.br/view_artigos.asp?id=38>. Acesso em 15. abr. 2009.

. Atualizações semânticas na inclusão de pessoas: Deficiência mental ou intelectual? Doença ou transtorno mental? Revista Nacional de Reabilitação, ano IX, n. 43, p. 9-10, mar./abr. 2005b. Disponível em:

<portal.mj.gov.br/corde/.../deficiência\%20mental\%20ou\%20intelectual.doc>. Acesso em: 2 nov. 2010.

SAWAYA, S. M. Alfabetização e fracasso escolar: problematizando alguns pressupostos da concepção construtivista. Educ. Pesqui., São Paulo, v. 26, n. 1, jan. 2000. Disponível em:

$<$ http://www.scielo.br/scielo.php?script=sci_arttext\&pid=S1517-

97022000000100005\&lng=en\&nrm=iso >. Acesso em: 05 jul. 2010.

SBARRA, M. H. Observação incorporada e análise do discurso no contexto do pós-estruturalismo e da pós-modernidade: Revisão crítica da contribuição do grupo ProLugar para a avaliação pós-ocupação e para a pesquisa em arquitetura. 2007. Dissertação (Mestrado em Arquitetura), Faculdade de Arquitetura e Urbanismo, UFRJ, Rio de Janeiro, 2007. 
SEBBA, R.; CHURCHMAN, A. Schoolyard design as an expression of educational principles. Children's environments - Quarterly, 3 (3), p. 70-76, 1986.

SEESP/SEED/MEC. PEC formação universitária municípios. v. 2. São Paulo, 2004.

SCHIRMER, C. R. et al. Atendimento educacional especializado em

deficiência física. Formação Continuada a Distância de Professores para o Atendimento Educacional Especializado. Brasília/DF, 2007. Disponível em:

<http://portal.mec.gov.br/seesp/arquivos/pdf/aee_df.pdf>. Acesso em 17 dez. 2009.

SEKKEL, M. C. A inclusão de crianças com necessidades educacionais especiais na educação infantil. In: SEE-SP. PEC formação universitária municípios. v. 2. São Paulo, 2004.

SENA, C. C. R. G. Atlas histórico-geográfico da cidade de São Paulo: desenvolvimento e aplicação da cartografia tátil no ensino fundamental e médio. 2007. Tese (Doutorado). Faculdade de Filosofia, Letras e Ciências Humanas, Departamento de Geografia, Universidade de São Paulo, 2007.

SEVERINO, A. J. Metodologia do trabalho científico. São Paulo: Cortez, 2000.

SHEAT, L. G.; BEER, A. R. User participation - a design methodology for school grounds design and environmental learning. Children's environments - Quarterly, 6 (2/3), p. 15-30, 1989.

SILVA, E. L. da; MENEZES, E. M. Metodologia da pesquisa e elaboração de dissertação. $3^{a}$ ed. rev. e atual. Florianópolis: Laboratório de Ensino a Distância da UFSC, 2001. Disponível em:

<http://projetos.inf.ufsc.br/arquivos/Metodologia\%20da\%20Pesquisa\%203a\%20edic ao.pdf>. Acesso em: 21 dez. 2009.

SILVA, M. O. E. da. Da Exclusão à Inclusão: Concepções e Práticas. Rev. Lusófona de Educação, [online], n. 13, p. 135-153, 2009. Disponível em:

<http://www.scielo.oces.mctes.pt/scielo.php?script=sci_arttext\&pid=S1645-

72502009000100009\&lng=pt\&nrm=iso >. Acesso em: 05 jul. 2010.

SILVA FILHO, L. F. da; FOGLI, B. F. C. dos S. Educação inclusiva: uma possibilidade em um cenário de contradições? Revista Democratizar, Instituto Superior de Educação da Zona Oeste/Uezo/Faetec, v. I, n. 1, set./dez. 2007. Disponível em: <http://www.faetec.rj.gov.br/isezonaoeste/publicacoes/democratizar/ed1/artigo_luci ndo_bianca.pdf>. Acesso em: 26 fev. 2009.

SILVA NETO, M. J. Constituição e pessoa com deficiência. In: GUGEL, M. A. et al. Deficiência no Brasil: uma abordagem integral dos direitos das pessoas com deficiência. Florianópolis: Obra Jurídica, 2007. 
SINDER, M. Vygotsky e Bakhtin - Psicologia e educação: Um intertexto. Educação \& Sociedade, ano XVIII, n. 60, dez. 1997. Disponível em:

<http://www.scielo.br/pdf/es/v18n60/v18n60a11.pdf>. Acesso em: 17 jul. 2010.

SIQUEIRA, B. A. Inclusão de crianças deficientes mentais no ensino regular: limites e possibilidades de participação em sala de aula. In: BUENO, J. G. S. et al.

Deficiência e escolarização: novas perspectivas de análise. Araraquara, SP:

Junqueira \& Marin; Brasília, DF: CAPES, 2008.

SKLIAR, C. A inclusão que é "nossa" e a diferença que é do "outro". In:

RODRIGUES, D.(org.). Inclusão e educação: doze olhares sobre a educação

inclusiva. São Paulo: Summus Editorial, 2006.

SMITH, D. D. Introdução à educação especial. (Tradução de Sandra Moreira de Carvalho). Porto Alegre: Artmed, 2008.

SOMMER, R. Espaço pessoal. São Paulo: EPU, 1973.

; SOMMER, R. A pratical guide to behavioral research: tools and techniques. NY: Oxford U Press, 1997.

SOUSA, F. dos S. Premissas projetuais para ambientes da educação infantil: recomendações com base na observação de três UMEIs de Belo Horizonte, MG. 2009. $404 \mathrm{f}$. Tese (doutorado em Arquitetura e Urbanismo) - Faculdade de Arquitetura e Urbanismo, Universidade Federal do Rio de Janeiro, Rio de Janeiro, 2009.

; RHEINGANTZ, P. A. Contribuições para o uso de instrumentos destinados a crianças em APO de pré-escola. Cadernos do Proarq, 2001. Disponível em: <www.proarq.fau.ufrj.br/cadernos_proarq/cadernosproarq09.pdf>. Acesso em: 21 set. 2009.

\section{SOUZA, V. L. V. de. Caracterização da comunicação alternativa:}

Um estudo entre alunos com deficiência física em escolas de uma região do município do Rio de janeiro. 2000. Dissertação (Mestrado em Educação) - Faculdade de Educação, Universidade do estado do Rio de Janeiro, Rio de Janeiro, 2000. Disponível em:

<http://www.proped.pro.br/teses/teses_pdf/Dissertao\%20VERA\%20LCIA\%20VIEIRA \%20DE\%20SOUZA.pdf>. Acesso em: 12 dez. 2009.

\section{SOUZA FREITAS, J. A. Estudo antropométrico, dentário e ósseo de brasileiros} de 3 a 18 anos de idade na região de Bauru. Bauru:FOB/USP, 1975.

STAINBACK, S.; STAINBACK, W. Inclusão: um guia para educadores. Tradução Magda França Lopes. Porto Alegre: Artes Médicas Sul, 1999. 
STAKE, R. E. Case studies. In: DENZIN, N. K.; LINCOLN, Y. S. (ed.)

Handbook of qualitative research. London: Sage, 2000. p. 435-454.

STEFANELLI, M. C. Comunicação com o paciente: teoria e ensino. $2^{a}$ ed. São Paulo: Robe, 1993.

Um sistema de escrita para línguas de sinais. DAC - Deaf Action

Committee For SignWriting. Tradução Marianne Rossi Stumpf. Colaboração Antônio Carlos da Rocha Costa e Ronice Muller de Quadros. 2000. Manuscrito não publicado. Disponível em: <http://www.signwriting.org/archive/docs5/sw0472-BRLicoes-SignWriting.pdf>. Acesso em: 10 dez. 2009.

SZYMANSKI, H. A entrevista na educação: a prática reflexiva. Brasília: Liber Livro, 2010. $3^{a}$ ed. rev. e ampl.

TACHIBANA, M.; AIELLO-VAISBERG, T. M. J. Desenhos estórias em encontros terapêuticos na clínica da maternidade. Mudanças - Psicologia da Saúde, 15 (1), p. 23-31, jan./jun. 2007. Disponível em:

<https://www.metodista.br/revistas/revistasims/index.php/MUD/article/viewFile/661/ 662>. Acesso em: Acesso em: 15 dez. 2009.

TETZCHNER, E. V.; MARTINSEN, H. Augmentative and Alternative Communication. In: Sign teaching \& the use of communication aids. London: Whurr Publishers, 1992.

TRINCA, W. Investigação clínica da personalidade: o desenho livre como estímulo de apercepção temática. São Paulo: Editora Pedagógica e Universitária, 1976.

Vozes, 1983.

O pensamento clínico em diagnóstico da personalidade. Petrópolis:

TRUJILLO-FERRARI, A. Metodologia e técnicas de pesquisa social. Campinas: Ippacc, 1971.

UNIVERSIDADE DE SÃO PAULO. Sistema Integrado de Bibliotecas. Vocabulário controlado do SIBi/USP. São Paulo, 2006. Disponível em:

<http://143.107.73.99/vocab/sibix652.dll>. Acesso em: 2 dez. 2010.

VASCONCELOS, C.; PRAIA, J. F.; ALMEIDA, L. S. Teorias de aprendizagem e o ensino/aprendizagem das ciências: da instrução à aprendizagem. Psicol. esc. educ. [online], v.7, n.1, p. 11-19, jun. 2003. Disponível em:

<http://pepsic.bvspsi.org.br/scielo.php?script=sci_arttext\&pid=S1413855720030001 00002\&lng=pt\&nrm=iso $>$. Acesso em: 05 jul. 2010.

VYGOTSKY, L. S et al. Linguagem, desenvolvimento e aprendizagem. São Paulo: Icone, 1988. 
VIROLE, B. A influência dos implantes cocleares no desenvolvimento sócio-afetivo da criança surda. In: CONGRESSO DO INES - INSTITUTO NACIONAL DE EDUCAÇÃO DE SURDOS (BRASIL), 2003. Anais do Congresso de surdez e escolaridade: desafios e reflexões. Rio de Janeiro: INSTITUTO NACIONAL DE EDUCAÇÃO DE SURDOS, 2003.

VITAL, F. M. de P. Artigo 32 - Cooperação Internacional. In: A Convenção sobre os Direitos das Pessoas com Deficiência Comentada. Coordenação de Ana Paula Crosara de Resende e Flavia Maria de Paiva Vital Brasília: Secretaria Especial dos Direitos Humanos. Coordenadoria Nacional para Integração da Pessoa Portadora de Deficiência - CORDE, 2008. Disponível em:

<http://www.bengalalegal.com/educacao.php>. Acesso em: 18 jul. 2010.

WASSERMAN, M. D. A. Princípios de tratamento psiquiátrico de crianças e adolescentes com doenças físicas. In: GARFINKEL, B.; CARLSON, G.; WELLER, E. (Orgs.), Transtornos psiquiátricos da infância e adolescência. Porto Alegre: Artes Médicas, 1992.

WINNICOTT, D. W.O brincar e a realidade. Rio de Janeiro: Imago Editora, 1975.

WORLD HEALTH ORGANIZATION. Programme for the Prevention of Blindness. Management of low vision in children - Report of a WHO Consultation. Bangkok: WHO/PBL/93-27, 1992.

YATES, C.; SMITH, P. K. Bullying in two english comprehensive schools. In: E. Munthe \& E. Roland (Eds.), Bullying: an international perspective (pp. 22-34). Londres: David Fulton, 1989

YIN, R. K. Estudo de caso: planejamento e métodos. $3^{\mathrm{a}}$ ed. Porto Alegre: Bookman, 2005.

ZEISEL, J. Inquiry by design. New York: Norton, 2005.

. Inquiry by design: Tools for environment-behavior research. Cambridge: University Press, 1981. 


\section{BIBLIOGRAFIA}

ABI-SÁBER, N. F. O que é o Jardim de Infância. Rio de Janeiro: Editora Nacional de Direito, 1965.

ABNT - ASSOCIAÇÃO BRASILEIRA DE NORMAS TÉCNICAS. NBR 6023: Informação e documentação - Referências - elaboração. Rio de Janeiro: ABNT, 2002.

ABRAMOVAY, M.; KRAMER, S. O rei está nu: um debate sobre as funções da préescola. Cadernos CEDES, v. 9, p. 27-38, 1985.

ALENCAR, G. A. R. de. O direito de comunicar, por que não? Comunicação Alternativa aplicada a portadores de necessidades educativas especiais no contexto de sala de aula. Texto s/d. Disponível em:

$<w w w . a n p e d . o r g . b r / r e u n i o e s / 25 / g i z e l i r i b e i r o a l e n c a r t 15 . r t f>$. Acesso em: 17 dez. 2009.

ALVES, J. M. et al. Concepções subjacentes à prática pedagógica em uma pré-escola. Psicologia em Estudo, Maringá, v.6, n.2, jul./dez. 2001. Disponível em: <http://www.scielo.br/scielo>. Acesso em: 23 mar. 2009.

ALVES, S. A.; TEIXEIRA, C. F.; KOWALTOWSKI, D. C. C. K.; PINA, S. M. A. G.; BARROS, R.; FUNARI, T. Avaliação do ambiente construído através da percepção ambiental: metodologia aplicada à escola PRODECAD - Unicamp In: VIII ENCONTRO NACIONAL E IV ENCONTRO LATINO-AMERICANO SOBRE CONFORTO NO AMBIENTE CONTRUÍDO, 5-7 out. 2005, Maceió. Anais do VIII ENCAC e IV ELACAC. ANTAC Associação Nacional de Tecnologia do Ambiente Construído, 2005. p. 27-36.

ANDRADE, S. A. et al. Ambiente familiar e desenvolvimento cognitivo infantil: uma abordagem epidemiológica. Rev. Saúde Pública, São Paulo, v. 39, n. 4, 2005. Disponível em: <http://www.scielosp.org/scielo.php?script=sci_arttext\&pid=S003489102005000400014\&lng=en\&nrm=iso>. Acesso em: 29 abr. 2009.

ANELLI, R. Centros Educacionais Unificados: arquitetura e educação em São Paulo. Arquitextos, São Paulo, n. 55.02, Portal Vitruvius, dez. 2004. Disponível em: <http://www.vitruvius.com.br/arquitextos/arq055/arq055_02.asp> Acesso em: 21 dez. 2008.

ANTUNES, C. É bom começar cedo. Revista eletrônica Veja. Edição 2004. Disponível em: <http://veja.abril.com.br/180407/p_088.shtml>. Acesso em: 23 mar. 2009.

\section{ARCE, A. As pesquisas na área da educação infantil e a história da}

Educação: reconstruindo a história do atendimento às Crianças pequenas no Brasil. FFCLRP/USP. GT: História da Educação / n.02. 2001. Disponível em:

<http://www.anped.org.br/reunioes/27/gt02/t021.pdf>. Acesso em: 3 mar. 2009. 
ARELARO, L. R. G. Resistência e submissão: a reforma educacional na década de 1990. In: KRAWCZYK, N.; CAMPOS, M. M.; HADDAD, S. (orgs.). 0 cenário educacional latino-americano no limiar do século XXI. Campinas, SP: Autores Associados, 2000.

BARBA, P. C. de S. D.; MARTINEZ, C. M. S.; CARRASCO, B. G. Promoção da saúde e educação infantil: caminhos para o desenvolvimento. Paidéia (Ribeirão Preto), Ribeirão Preto, v.13, n.26, jul./dez. 2003. Disponível em:

<http://www.scielo.br/scielo.php?script=sci_arttext\&pid=S0103863X2003000300002\&lng=pt\&nrm=iso>. Acesso em 11 dez. 2008.

BARROS, M. E. C. A LIBRAS por escrito. Revista Estudos, Goiânia, v. 33, n. 5/6, p. 385-396, mai./jun. 2006. Disponível em:

<http://seer.ucg.br/index.php/estudos/article/view/293/237>. Acesso em: 10 dez. 2009.

BELSKY, J.; EARLY CHILD CARE RESEARCH NETWORK et al. Are there long-term effects of early child care? Journal Compilation (C) 2009, Society for Research in Child Development, Inc. Volume 78 Issue 2, Pages 681 - 701. Published Online: 2007. Disponível em: <http://www3.interscience.wiley.com>. Acesso em: 23 mar. 2009.

BERTENTHAL, B. I.; CAMPOS, J. J. New directions in the study of early experience. Child Development, n. 58, 1987.

BORDONI, T. Descoberta de um universo: a evolução do desenho infantil. Artigo s/d. Disponível em: <http://www.profala.com/arteducesp62.htm>. Acesso em: 10 dez. 2009.

BRASIL. Ministério da Educação. Secretaria de Educação Básica. Padrões de infraestrutura para as instituições de educação infantil e parâmetros de qualidade para a educação infantil. Documento preliminar. Brasília, DF, 2004.

. Ministério da Educação. Secretaria de Educação Especial. Política Nacional de Educação Especial. Brasília: MEC/SEESP, 1994. Disponível em: <http://portal.mec.gov.br>. Acesso em: 24 out. 2008.

- Ministério da Educação. Secretaria de Educação Básica. Política Nacional de Educação Infantil: pelo direito das crianças de zero a seis anos à educação. Brasília: MEC, SEB, 2006. 32 p.

. Ministério Público Federal. 0 acesso de alunos com deficiência às escolas e classes comuns da rede regular de ensino. Fundação Procurador Pedro Jorge de Melo e Silva( Orgs). $2^{a}$ ed. ver. e atualiz. Brasília: Procuradoria Federal dos Direitos do Cidadão, 2004. Disponível em: <http://www.pgr.mpf.gov.br/o_mpf/sobre_o_mpf>. Acesso em: 24 out. 2008. 
BRASIL. Parecer CEB n. 022/98: Resolução CEB n. 1, 7 abr. 1999. Diretrizes Curriculares Nacionais para a Educação Infantil. Brasília, DF: Conselho Nacional de Educação/Câmara da Educação Básica, 1990.

. Parecer CEB n.4/2000, 16 fev. 2000. Diretrizes Operacionais para a Educação Infantil. Brasília, DF: Conselho Nacional de Educação/Câmara da Educação Básica, 2000.

BUENO, J. G. S. Práticas institucionais e exclusão social da pessoa deficiente. In: Conselho Regional de Psicologia de São Paulo (Org.). Educação especial em debate (pp. 37 - 54). São Paulo: Casa do Psicólogo, 1997.

BUJES, M. I. E. A invenção do eu infantil: dispositivos pedagógicos em ação. Revista Brasileira de Educação, Rio de Janeiro, n. 21, set./dez. 2002. Disponível em: <http://www.scielo.br/scielo.php?script=sci_arttext\&pid=S141324782002000300003\&lng=pt\&nrm=iso>. Acesso em: 12 dez. 2008.

CAMPOS, M. M. Educação infantil no primeiro mundo: uma visão daqui debaixo do Equador. In: ROSEMBERG, F.; CAMPOS, M. M. (Orgs.). Creches e pré-escolas no hemisfério norte. São Paulo: Cortez/Fund. Carlos Chagas, 1994. p. 323-353.

- Pré-escola: entre a educação e o assistencialismo. Cadernos de Pesquisa da Fundação Carlos Chagas, São Paulo, n. 53, p. 21-24, 1985.

; ROSEMBERG, F.; FERREIRA, I. M. Creches e pré-escolas no Brasil. 3 ed. São Paulo: Cortez, Fundação Carlos Chagas, 2001.

Critérios para um atendimento em creches que respeite os direitos fundamentais das crianças. Brasília: MEC/SEF/COEDI, 1995. ; FÜLLGRAF, J.; WIGGERS, V. A qualidade da educação infantil brasileira: alguns resultados de pesquisa. Cadernos de Pesquisa, São Paulo, v. 36, n. 127, jan./abr. 2006. Disponível em:

<http://www.scielo.br/scielo.php?script=sci_arttext\&pid=S010015742006000100005\&lng=pt\&nrm=iso >. Acesso em: 2 dez. 2008.

CASTRO, C.C. et al. Correlação da função motora e o desempenho funcional nas atividades de auto-cuidado em grupo de crianças portadoras de paralisia cerebral. Med. Reabil., 25(1), p. 7-11, 2006.

CERIS. Direitos Humanos no Brasil: diagnóstico e perspectivas, olhar dos parceiros de Misereor. Organizado por Cláudio Moser e Daniel Rech. Coletânea CERIS (Centro de estatística Religiosa e Investigações Sociais). Ano 1, n.1 (2003). Rio de Janeiro: CERIS/MAUAD, 2003.

CERISARA, A. B. A pré-escola e as implicações pedagógicas do modelo históricocultural. Cadernos CEDES, n. 35, Campinas: Papirus/CEDES, 1995. 
CERISARA, A. B. A produção acadêmica na área da educação infantil com base na análise de pareceres sobre o referencial curricular nacional da educação infantil. In: FARIA, A. L. G. de; PALHARES, M. S. Educação Infantil Pós - LDB: rumos e desafios. Campinas, São Paulo: Autores Associados, 6 a ed., 2007.

. O Referencial Curricular Nacional para a Educação Infantil no contexto das reformas. Revista Educação \& Sociedade, Campinas, v. 23, n. 80, set. 2002. Disponível em: <http://www.scielo.br/scielo.php?pid=S010173302002008000016\&script=sci_arttext>. Acesso em: 4 mar. 2009.

\section{CIEGLINSKI, A. Agência Brasil. MEC quer tornar pré-escola e ensino médio} obrigatórios. Brasília: 30 de Outubro de 2008. Disponível em: <http://www.agenciabrasil.gov.br/noticias/2008/10/30/materia.2008-1030.7723290806/view>. Acesso em: 26 fev. 2009.

CIVILETTI, M. V. P. O cuidado às crianças pequenas no Brasil escravista. Faculdade de Educação da Universidade Federal Fluminense (FEUFF), Cadernos de Pesquisa, n. 76, 1991. Disponível em:

<http://www.uff.br/feuff/departamentos/docs_edu_infantil_mural/muinfa21.doc.>. Acesso em: 2 mar. 2009.

\section{COIMBRA, I. D. A inclusão do portador de deficiência visual na escola} regular. Salvador: EDUFBA, 2003.

CORRÊA, B. C. Considerações sobre qualidade na educação infantil. Cadernos de Pesquisa, São Paulo, n. 119, 2003. Disponível em:

$<$ http://www.scielo.br/scielo.php?script=sci_arttext\&pid=S0100-

$15742003000200005 \&$ Ing=pt\&nrm=iso >. Acesso em: 2 dez. 2008.

CORREA, P. M. Acessibilidade: conceitos e formas de garantia. Rev. bras. educ. espec., Marília, v. 15, n. 1, abr. 2009. Disponível em:

$<$ http://www.scielo.br/scielo.php?script=sci_arttext\&pid=S1413-

65382009000100012\&lng=en\&nrm=iso>. Acesso em: 17 nov. 2010.

CORSINO, P. (org). Educação infantil: cotidiano e políticas. Campinas: Autores Associados, 2009.

CRÉPON, Pierre. O ritmo biológico da criança. São Paulo: Verbo, 1985.

CRUZ, S. H. V (org). A criança fala: a escuta de crianças em pesquisas. São Paulo: Cortez, 2008.

CURY, C. R. J. Os fora de série na escola. Campinas, São Paulo: Armazém do Ipê (Autores Associados), 2005. 
DALLABRIDA, A. M. Escolarização e deficiência: a escolha da escola. In: BUENO, J. G. S. et al. Deficiência e escolarização: novas perspectivas de análise. Araraquara, SP: Junqueira \& Marin; Brasília, DF: CAPES, 2008.

DEL PRIORE, M. História das crianças no Brasil. São Paulo: Contexto, 1999.

DERDYK, E. Formas de pensar o desenho. São Paulo: Scipione, 1989.

ELALI, G. A. O ambiente da escola - o ambiente na escola: uma discussão sobre a relação escola-natureza em educação infantil. Estudos de Psicologia, n. 8(2), p. 309-319, 2003.

ELISEI, M. G. M. Diagnóstico da percepção ambiental através de desenho infantil. Taubaté-SP: Cabral, 2008.

\section{EVANS, J. L. Early childhood care and development in the twenty-first} century: the challenge we face. Bernard van Leer Foundation, 2000.

FARIA, A. L. G. de. O espaço físico como um dos elementos fundamentais para uma pedagogia da educação infantil. In: ; PALHARES, M. S. Educação Infantil Pós - LDB: rumos e desafios. Campinas, São Paulo: Autores Associados, $6^{\text {a ed., }}$ 2007.

. Pequena infância, educação e gênero: subsídios para um estado da arte.

Cadernos Pagu, Campinas, n. 26, jan./jun. 2006. Disponível em:

$<$ http://www.scielo.br/scielo.php?script=sci_arttext\&pid=S0104-

$83332006000100012 \&$ lng=pt\&nrm=iso >. Acesso em: 20 dez. 2008.

. Políticas de regulação, pesquisa e pedagogia na educação infantil, primeira etapa da educação básica. Revista Educação \& Sociedade, Campinas, v. 26, n. 92, out. 2005. Disponível em:

<http://www.scielo.br/scielo.php?script=sci_arttext\&pid=S010173302005000300014 \&lng=pt\&nrm=iso > . Acesso em: 14 dez. 2008.

; PALHARES, M. S. Educação Infantil Pós - LDB: rumos e desafios.

Campinas, São Paulo: Autores Associados, $6^{\text {a }}$ ed., 2007. (inclui posfácio: Como ficam as crianças de 6 anos?)

FARIAS, N.; BUCHALLA, C. M. A classificação internacional de funcionalidade, incapacidade e saúde da organização mundial da saúde: conceitos, usos e perspectivas. Rev. bras. epidemiol., São Paulo, v. 8, 2005. Disponível em: <http://www.scielo.br/scielo.php?script=sci_arttext\&pid=S1415-

790X2005000200011\&lng=en\&nrm=iso>. Acesso em: 25 ab. 2009.

FELIPE, T. A. A função do intérprete na escolarização do surdo. In: CONGRESSO DO INES - INSTITUTO NACIONAL DE EDUCAÇÃO DE SURDOS (BRASIL), 2003. Anais 
do Congresso de surdez e escolaridade: desafios e reflexões. Rio de Janeiro: INSTITUTO NACIONAL DE EDUCAÇÃO DE SURDOS, 2003.

FERREIRA, J. R. Educação especial, inclusão e política educacional: notas brasileiras. In: RODRIGUES D. (org.). Inclusão e educação: doze olhares sobre a educação inclusiva. São Paulo: Summus Editorial, 2006. p. 85-114.

FERREIRA, L. P.; BENEDETTI, P. H. Condições de produção vocal de professores de deficientes auditivos. Rev. CEFAC, São Paulo, v. 9, n. 1, mar. 2007. Disponível em: $<$ http://www.scielo.br/scielo.php?pid=S1516-

18462007000100011\&script=sci_arttext>. Acesso em: 7 jan. 2009.

FREITAS, L. B. de L.; SHELTON, T. L. Atenção à primeira infância nos EUA e no Brasil. Psicologia: Teoria e Pesquisa, Brasília, v. 21, n. 2, mai./ag. 2005. Universidade Federal do Rio Grande do Sul e University of North Carolina at Greensboro. Disponível em:

<http://www.scielo.br/scielo.php?pid=S010237722005000200010\&script=sci_arttext \&tlng=es $>$. Acesso em: 2 mar. 2009.

FUNDAÇÃO PARA O DESENVOLVIMENTO DA EDUCAÇÃO. Catálogos Técnicos. Normas, leis e decretos. Disponível em:

<http://catalogotecnico.fde.sp.gov.br/Setembro_08/biblio\%20normas\%20leis\%20m ob.htm>. Acesso em: 25 jan. 2009.

. O cotidiano da pré-escola. Séries Ideias, São Paulo, FDE, n. 7, 1988.

. O jogo e a construção do conhecimento na pré- escola. Séries Ideias, São Paulo, FDE, n. 10, 1992.

FUNDAÇÃO PREFEITO FARIA LIMA - CEPAM. Coordenadoria de Gestão de Políticas Públicas - Cogepp. Acessibilidade nos municípios: como aplicar o decreto 5.296/04. São Paulo, 2008. 208 p.

\section{GALVÃO, C. R. C. Análise crítica dos produtos de mobilidade sentada -} cadeiras de rodas - utilizados por crianças e adolescentes com paralisia cerebral em Natal/RN e outros municípios do Rio Grande do Norte. 2006. Dissertação (Mestrado em Engenharia de Produção) - Universidade Federal do Rio Grande do Norte, Natal, RN, 2006. Disponível em:

$<$ http://bdtd.bczm.ufrn.br/tedesimplificado//tde_busca/arquivo.php?codArquivo=482 >. Acesso em: dez. 2009.

GANDRA, Y. R. O pré-escolar de dois a seis anos de idade e o seu atendimento. Rev. Saúde Pública [online], vol.15, suppl. pp. 3-8, 1981. Disponível em:

$<$ http://www.scielo.br/scielo.php?script=sci_arttext\&pid=S003489101981000700002\&lng=pt\&nrm=iso >. Acesso em: 15 ab. 2009. 
GOMES, I. R. de L. Escola como espaço e tempo de prazer: uma análise proxêmica. 1992. Tese (Doutorado em Educação) - Faculdade de Educação da USP, São Paulo, 1992.

GRIFFIN, J. et al. Teachers' Education, Classroom Quality, and Young Children's Academic Skills: Results From Seven Studies of Preschool Programs. Journal Compilation, Society for Research in Child Development, Inc. v. 78, 2007. Disponível em: $<$ http://www3.interscience. wiley.com/journal/117957232/abstract?CRETRY=1\&SRET $\mathrm{RY}=0$ > . Acesso em: 23 mar. 2009.

HADDAD, L. Políticas integradas de educação e cuidado infantil: desafios, armadilhas e possibilidades. Cadernos de Pesquisa, São Paulo, v. 36, n. 129, set./dez. 2006. Disponível em: <http://www.scielo.br/scielo.php?script=sci_arttext\&pid=S0100$15742006000300002 \&$ Ing=pt\&nrm=iso >. Acesso em: 2 dez. 2008.

HADDAD, S. (orgs.). 0 cenário educacional latino-americano no limiar do século XXI. Campinas, SP: Autores Associados, 2000.

HAITH, M. M. Perceptual and sensory processes in early infancy. Merrill-Palmer Quarterly, 36, p. 1-26, 1990. Disponível em:

<http://www.du.edu/psychology/research/developmental.htm>. Acesso em: $20 \mathrm{dez}$. 2008.

HALPERN, R.; FIGUEIRAS, A. C. M. Influências ambientais na saúde mental da criança. Jornal de Pediatria, Sociedade Brasileira de Pediatria, 2004. Disponível em: <http://www.scielo.br/pdf/jped/v80n2s0/v80n2Sa12.pdf>. Acesso em: 17 fev. 2009.

HEYDEBRAND, C. V. A natureza anímica da criança. (Trad. Rudolf Lanz). São Paulo: Antroposófica, 1991.

HOLTZAPFEL, W. Distúrbios do desenvolvimento infantil: uma abordagem pedagógico-terapêutica. (Trad. Rudolf Lanz e Sonia Setzer). São Paulo:

Antroposófica, 2006.

HORN, Maria da Graça Souza. Sabores, cores, sons, aromas: a organização dos espaços na educação infantil. Porto Alegre: ARTMED, 2004.

IBGE/INEP. Censo Escolar, 2006. Disponível em: < http:// http://www.inep.gov. br/basica/censo/default.asp >. Acesso em: 20 set. 2008.

IIDA, I. Ergonomia: projeto e produção. São Paulo: Edgard Blücher Ltda, 2005.

JANNUZZI, G. de M. A educação do deficiente no Brasil: dos primórdios ao início do século XXI. Campinas, SP: Autores Associados, 2006. 
KAWAUCHI, P. Linguagem dos ambientes escolares. 1995. Tese (Doutorado em Arquitetura e Urbanismo) - Faculdade de Arquitetura e Urbanismo, Universidade de São Paulo, São Paulo, 1995.

KISHIMOTO, T. M. Brinquedos e materiais pedagógicos nas escolas infantis. Educ. Pesqui., São Paulo, v. 27, n. 2, jul. 2001. Disponível em: <http://www.scielo.br/scielo.php?script=sci_arttext\&pid=S151797022001000200003\&lng=en\&nrm=iso>. Acesso em: 21 jan. 2010.

KRAMER, S. A política do pré-escolar no Brasil: a arte do disfarce. $7^{a}$ ed. São Paulo: Cortez, 2003.

As crianças de 0 a 6 anos nas políticas educacionais no Brasil: educação infantil e/é fundamental. Revista Educação \& Sociedade, Campinas, v. 27, n. 96, out. 2006. Disponível em:

<http://www.scielo.br/scielo.php?script=sci_arttext\&pid=S010173302006000300009 \&lng=pt\&nrm=iso $>$. Acesso em: $12 \mathrm{dez} .2008$.

; NUNES, M. F. Gestão pública, formação e identidade de profissionais de educação infantil. Cadernos de Pesquisa, São Paulo, v. 37, n. 131, mai./ago. 2007. Disponível em:

<http://ww.scielo.br/scielo.php?script=sci_arttext\&pid=S010015742007000200010\&l $\mathrm{ng}=\mathrm{pt \& nrm}=\mathrm{iso}>$. Acesso em: 2 dez. 2008.

KRAWCZYK, N.; CAMPOS, M. M.; HADDAD, S. (orgs.). 0 cenário educacional latino-americano no limiar do século XXI. Campinas, SP: Autores Associados, 2000.

KUHLMANN JR., M. Educação infantil. In: FARIA, A. L. G. de; PALHARES, M. S. Educação Infantil Pós - LDB: rumos e desafios. Campinas, São Paulo: Autores Associados, $6^{\text {a }}$ ed., 2007.

Educando a infância brasileira. In: LOPES, E.M.T.; FARIA FILHO, L.M.; VEIGA, C.G. (orgs.). 500 anos de educação no Brasil. Belo Horizonte: Autêntica, 2000, p. 469-496.

. Entrevista concedida à FOLHA DIRIGIDA. Fundação Carlos Chagas.

Difusão de Ideias, out. 2007. Disponível em:

<http://www.fcc.org.br/pesquisa/publicacoes/difusao_ideias/pdf/entrevista_educaca o_infantil.pdf>. Acesso em: 23 fev. 2009.

Histórias da educação infantil brasileira. Revista Brasileira de Educação, Fundação Carlos Chagas, São Paulo, 2000. Disponível em:

<http://www.anped.org.br/rbe/rbedigital/RBDE14/RBDE14_03_MOYSES_KUHLMANN _JR.pdf>. Acesso em: dez. 2008. 
KUHLMANN JR., M. Infância e educação infantil: uma abordagem histórica. Porto Alegre: Mediação, 1998.

. O Jardim de Infância Caetano de Campos. In: REIS, M. C. D. Caetano de Campos: fragmentos da história da instrução pública em São Paulo. São Paulo, 1994. p. 61-72.

; ROCHA, J. F. T. da. Educação no asilo dos expostos da Santa Casa em São Paulo: 1896-1950. Cadernos de Pesquisa, São Paulo, v. 36, n. 129, set./dez. 2006. Disponível em:

<http://www.scielo.br/scielo.php?script=sci_arttext\&pid=S010015742006000300005 \&lng=pt\&nrm=iso $>$. Acesso em: 2 dez. 2008.

LAMPARELLI, C. M. Metodologia aplicada à arquitetura e urbanismo. Cadernos de Pesquisa do LAP, São Paulo, USP, n. 15, 2000.

LAPLANE, A. L. F.; BATISTA, C. G. Um estudo das concepções de professores de ensino fundamental e médio sobre a aquisição de conceitos, aprendizagem e deficiência visual [Resumo]. 2003. In: Associação Brasileira de Pesquisadores em Educação Especial (Org.), Anais do I Congresso Brasileiro de Educação Especial, IX Ciclo de Estudos sobre Deficiência Mental, (p. 14-15). São Carlos: UFSCar.

LEITE, M. K. O espaço e o mobiliário escolar: análise das atividades e tarefas realizadas em escolas estaduais do município de Bauru. A importância do design ergonômico em ações na educação. 2008. Dissertação (Mestrado) - Faculdade de Arquitetura, Artes e Comunicação, Universidade Estadual Paulista, Bauru, 2008.

LEMES, V. P. Implante Coclear. In: CONGRESSO DO INES - INSTITUTO NACIONAL DE EDUCAÇÃO DE SURDOS (BRASIL), 2003. Anais do Congresso de surdez e escolaridade: desafios e reflexões. Rio de Janeiro: INSTITUTO NACIONAL DE EDUCAÇÃO DE SURDOS, 2003.

LIMA, M. W. de S. A cidade e a criança. São Paulo: Studio Nobel, 1989.

. Arquitetura e educação. São Paulo: Studio Nobel, 1995.

LOPES, L. V. C. de F. Convenção sobre os direitos das pessoas com deficiência da ONU. In: GUGEL, M. A. et al. Deficiência no Brasil: uma abordagem integral dos direitos das pessoas com deficiência. Florianópolis: Obra Jurídica, 2007.

LOUREIRO, C. Classe, controle, encontro. 1999. Tese (Doutorado em Arquitetura e Urbanismo) - Faculdade de Arquitetura e Urbanismo, Universidade de São Paulo, São Paulo, 1999.

MEC/INEP (Instituto Nacional de Estudos e Pesquisas Educacionais Anísio Teixeira). Sinopses Estatísticas da Educação Básica. Disponível em: 
<http://www.inep.gov.br/basica/censo/Escolar/Sinopse/sinopse.asp>. Acesso em: 20 dez. 2008.

MEC/SEESP - Secretaria de Educação Especial. Inclusão: um desafio para os sistemas de ensino. Disponível em:

$<$ http://portal.mec.gov.br/seesp/index.php?option=content\&task=view\&id=10>. Acesso em: 21 fev. 2009.

. Legislação Específica e os Documentos Internacionais. Disponível em: $<$ http://portal.mec.gov.br/seesp/index.php?option=content\&task=view\&id=159\& Itemid=311>. Acesso em: 21 fev. 2009.

MINISTÉRIO PÚBLICO FEDERAL. $\mathbf{O}$ acesso de alunos com deficiência às escolas e classes comuns da rede regular. Fundação Procurador Pedro Jorge de Melo e Silva (organizadores) / $2^{\mathrm{a}}$ ed. rev. e atualiz. . Brasília: Procuradoria Federal dos Direitos do Cidadão, 2004. Disponível em:

<http://www.prgo.mpf.gov.br/cartilha_acesso_deficientes.pdf>. Acesso em: 13 ab. 2009.

MÜLLER, F.; CARVALHO; A. M. A. (Orgs.). Teoria e prática na pesquisa com crianças. Diálogos com Willian Corsaro. São Paulo: Cortez, 2009.

MYERS, R. G. Early childhood care and development. Unesco, 2000.

NASCIMENTO, M. E. P. do. Os profissionais da educação infantil e a nova Lei de Diretrizes e Bases da Educação Nacional. In: FARIA, A. L. G. de; PALHARES, M. S. Educação Infantil Pós - LDB: rumos e desafios. Campinas, São Paulo: Autores Associados, $6^{\text {a }}$ ed., 2007.

NASCIMENTO, M. L. Creche e família na constituição do "eu": um estudo sobre crianças no terceiro ano de vida na cidade de São Paulo. 2003. Tese (Doutorado em Educação) - Faculdade de Educação, Universidade de São Paulo, São Paulo, 2003.

NICOLAU, M. L. M. A educação pré-escolar: fundamentos e didática. São Paulo: Ática, 1985.

NOGUEIRA, M. E. de A. C. A pré-escola na rede estadual de ensino de São Paulo. 1996. Dissertação (Mestrado em Educação) - Faculdade de Educação, Universidade de São Paulo, São Paulo, 1996.

NUNES, I. M. A aquisição de conhecimentos sobre diferentes conceitos em crianças cegas totais com diferentes histórias de vida: uma investigação. 2002. Dissertação (Mestrado) - Universidade Federal de São Carlos, São Carlos, 2002. 
NUNES, L. R. O. P. (Org.). Favorecendo o desenvolvimento da comunicação em crianças e jovens com necessidades educacionais especiais. Rio de Janeiro: Dunya, 2003.

NUNES, M. F. R. Educação infantil no estado do Rio de Janeiro: um estudo das estratégias municipais de atendimento. 2005. Tese (Doutorado) - Universidade Federal do Rio de Janeiro, Rio de Janeiro, 2005.

OLIVEIRA, C. M. A. S. de. 0 ambiente urbano e a formação da criança. 2003. Tese (Doutorado em Arquitetura e Urbanismo) - Faculdade de Arquitetura e Urbanismo, Universidade de São Paulo, São Paulo, 2003.

OLIVEIRA, J. V. G. Arte e visualidade: a questão da cegueira. Revista Benjamin Constant, n. 4(10), p. 7-10, 1998.

ONO, R.; TATEBE, K. A study on school children's attitude towards fire safety and evacuation behavior in Brazil and the comparsion with data from Japanese children. In: Proceedings of the $3^{\text {rd }}$. Human Behavior in Fire Symposium, Belfast, 2004.

PAGLIUCA, L. M. F. A arte da comunicação na ponta dos dedos - a pessoa cega. Revista Latino-Americana de Enfermagem, Ribeirão Preto, v. 4, abr. 1996. Disponível em: <http://www.scielo.br/scielo.php?script=sci_arttext\&pid=S010411691996000700013\&nrm=iso\&tlng=pt>. Acesso em: 15 ab. 2009.

PALHARES, M. S.; MARTINEZ, C. M. S. A educação infantil. Uma questão para o debate. In: FARIA, A. L. G. de; PALHARES, M. S. Educação Infantil Pós - LDB: rumos e desafios. Campinas, São Paulo: Autores Associados, $6^{\text {a }}$ ed., 2007.

PEB (Programme on Educational Building) Compendium of Exemplary Educational Facilities: 3rd ed. 2006. OECD. Organisation for economic cooperation and development.

PELOSI, M. Comunicação alternativa - uma necessidade de educação para todos. Conversando com os professores sobre a comunicação alternativa. Texto s/d. Disponível em: <www.proac.uff.br/.../comunicacao-alternativa->. Acesso em: 17 dez. 2009.

PIAGET, J. A psicologia da criança. Rio de Janeiro: Bertrand, 1999. Livro, 1973.

INHELDER, B. A psicologia da criança. São Paulo: Difusão Européia do

PINHEIRO, J. de Q. et al. Diário pessoal como técnica de coleta de dados em estudos sobre as reações pessoa-ambiente. In: ; GÜNTHER, H. Métodos de pesquisa nos estudos pessoa-ambiente. São Paulo: Casa do Psicólogo, 2008. 
PIRES, C. L. O intérprete de LIBRAS - Um olhar sobre a prática profissional. In: Anais do seminário desafios para o próximo milênio. 2000. Rio de Janeiro: INES, Divisão de Estudos e Pesquisas.

PRADO, A. R. de A.; LOPES, M. E.; ORNSTEIN, S. W. (Org.). Desenho Universal. Caminhos da Acessibilidade no Brasil. $1^{\text {a }}$ ed. São Paulo: Annablume, 2010, v. 1, p. 167-175.

PRIETO, R. G.; SOUSA, S. Z. L. Educação especial no município de São Paulo: acompanhamento da trajetória escolar de alunos no ensino regular. Rev. bras. educ. espec, Marília, v. 12, n. 2, 2006. Disponível em:<http://www.scielo.br/scielo.php?script=sci_arttext\&pid=S141365382006000200 004\&lng=en\&nrm=iso>. Acesso em: 22 ab. 2009.

QUADROS, R. M. 0 tradutor e intérprete de língua brasileira de sinais e língua portuguesa. Secretaria de Educação Especial; Programa Nacional de Apoio à Educação de Surdos - Brasília: MEC; SEESP, 2002.

RABELLO, S.; MOTTI, T. F. G.; GASPARETTO, M. E. R. F. Avaliação educacional por meio do teste iar em escolares com cegueira. Rev. bras. educ. espec., Marília, v. 13, n. 2, ag. 2007. Disponível em:

<http://www.scielo.br/scielo.php?script=sci_arttext\&pid=S1413-

65382007000200009\&lng=en\&nrm=iso>. Disponível em: 18 ab. 2009.

ROCHA, H.; RIBEIRO-GONÇALVES, E. (Coord.). Ensaio sobre a problemática da cegueira: prevenção, recuperação, reabilitação. Belo Horizonte: Fundação Hilton Rocha, 1987.

RODRIGUES, D. (Org.). Inclusão e educação: Doze olhares sobre a educação inclusiva. São Paulo: Summus, 2006.

ROSA, M. V. de F. P. do C.; ARNOLDI, M. A. G. C. A entrevista na pesquisa qualitativa: mecanismos para validação dos resultados. Belo Horizonte: Autêntica, 2008.

ROSEMBERG, F. Organizações multilaterais, estado e políticas de educação infantil. Cadernos de Pesquisa, São Paulo, n. 115, mar. 2002. Disponível em:

<http://www.scielo.br/scielo.php?script=sci_arttext\&pid=S0100 15742002000100002\&lng=pt\&nrm=iso>. Acesso em: 2 dez. 2008.

. Uma introdução ao estudo das organizações multilaterais no campo educacional. In: KRAWCZYK, N.; CAMPOS, M. M.; HADDAD, S. (orgs.). 0 cenário educacional latino-americano no limiar do século XXI. Campinas, SP: Autores Associados, 2000.

ROSSETTI-FERREIRA, M. C. Os afazeres na educação infantil. São Paulo: Cortez, 2005. 
ROSSETTI-FERREIRA, M. C.; RAMON, F.; SILVA, A. P. S. Políticas de atendimento à criança pequena nos países em desenvolvimento. Cadernos de Pesquisa, São Paulo, n. 115, mar. 2002. Disponível em:

$<$ http://www.scielo.br/scielo.php?script=sci_arttext\&pid=S0100$15742002000100003 \&$ Ing=pt\&nrm=iso >. Acesso em: 2 dez. 2008.

RUTH, D. Study is the first to show school programs have enduring impact. University of Minnesota. Public release date: 6 Aug. 2007. Disponível em:

$<$ http://news.bio-medicine.org/medicine-news-3/U-of-M-report-says-early-childhoodintervention-improves-well-being-through-young-adulthood-131-2/>. Acesso em: mar. 2009.

SÁ, E. D. de. Educação especial: construindo espaços de formação. Texto eletrônico. (s/d). Disponível em: <http://www.defnet.org.br/elizabet.htm>. Acesso em: 28 mar. 2009.

SAMPAIO, R. F.; MANCINI, M. C. Tecendo uma rede de usuários da CIF. Rev. bras. fisioter., São Carlos, v. 11, n. 4, ag. 2007. Disponível em: $<$ http://www.scielo.br/scielo.php?script=sci_arttext\&pid=S141335552007000400001\&lng=en\&nrm=iso>. Acesso em: 04 mai. 2009.

SANCHEZ, C. A. M.; COSTA, G. R. V. Ajudas técnicas: independência e autonomia como estratégia de inclusão. In: GUGEL, M. A. et al. Deficiência no Brasil: uma abordagem integral dos direitos das pessoas com deficiência. Florianópolis: Obra Jurídica, 2007.

SANDER, R. Registro dos intérpretes para surdos. Trad. do original Interpreting for Deaf People, Stephen (Ed.), USA, 1992.

SANOFF, H. Creating Environments for Young Children. Mansfield: BookMasters, Inc., 1995. ; SANOFF, J. Learning environments for children: a developmental approach to shaping activity areas. Washington, DC: Humanics, 1981.

SÃO PAULO (MUNICÍPIO). Legislação Municipal. São Paulo: Câmara Municipal de São Paulo. Disponível em: <www. prefeitura.sp.gov.br>. Acesso em: 20 dez. 2008.

SÃo PAULO (ESTADO). Assembléia Legislativa. Pessoas Portadoras de (d)Eficiência: legislação federal, estadual e municipal. São Paulo: IMESP, 2004.

SICORDE. Sistema de Informações da Coordenadoria Nacional para Integração da Pessoa Portadora de Deficiência (CORDE). Documentos internacionais. Disponível em: <http://www.mj.gov.br/sedh/ct/corde/dpdh/sicorde/document_int.asp\#conteudo>. Acesso em: 26 fev. 2009. 
SILVA, F. G. da; DAVIS, C. Conceitos de Vigotski no Brasil: produção divulgada nos Cadernos de Pesquisa. Cadernos de Pesquisa, São Paulo, v. 34, n. 123, set./dez. 2004. Disponível em: <http://www.scielo.br/scielo.php>. Acesso em: 23 mar. 2009.

SILVA, N. L. P., DESSEN, M. A. Deficiência mental e família: implicações para o desenvolvimento da criança. Revista Psicologia: Teoria e Pesquisa, Brasília, v. 17, n. 2, mai/ago. 2001. Disponível em:

$<$ http://www.scielo.br/scielo.php?script=sci_arttext\&pid=S0102-

37722001000200005\&lng=pt\&nrm=iso>. Acesso em: 24 mar. 2009.

SMITH, P. K.; HUNTER, T.; CARVALHO, A. M. A.; COSTABILE, A. Children's perceptions of playfighting, playchasing and real fighting: A cross-cultural interview study. Social Development, 1(3), p. 211-229, 1992.

SIPERSTEIN, G. N.; LEFFERT, J. S.; WIDAMAN, K. Social behavior and the social acceptance and rejection of children with mental retardation. Education and Training in Mental Retardation and Developmental Disabilities, 31 (4), p. 271-281, 1996.

SOCIEDADE BRASILEIRA DE PEDIATRIA. Instituto de Proteção e Assistência à Infância do Rio de Janeiro. Academia Brasileira de Pediatria. Disponível em: <http://www.sbp.com.br/>. Acesso em: 2 mar. 2009.

SOUZA, G. de. Educação da infância - estar junto sem ser igual. Conflitos e alternativas da relação da educação infantil com o ensino fundamental! Dossiê: Estado e Educação no Brasil. Educar em Revista, Curitiba, n. 31, 2008. Disponível em: <http://www.scielo.br/scielo.php?script=sci_arttext\&pid=S0104$40602008000100003 \&$ Ing=pt\&nrm=iso >. Acesso em: 2 dez. 2008.

STEINER, R. Curso de pedagogia curativa: doze palestras proferidas em Dornach, 1924. (Trad. Nico Brodnitz). São Paulo: Federação das Escolas Waldorf no Brasil, 2005.

SUTTON, V. Lessons in sign writing. La Jolla: Deaf Action Comitee for SignWriting, 1981

SZYMANSKI, H. (org); ALMEIDA, L. R. de; PRANDINI, R. C. A. R. A entrevista na pesquisa em educação: a prática reflexiva. Brasília: Liber Livro Editora, 2010. $3^{a}$ ed. ver. e ampl.

TANNER, J. M. Fetus into man: Physical growth from conception to maturity. Cambridge, MA: Harvard University Press, 1978.

TUAN, Y. F. Espaço e lugar. São Paulo: Difel, 1983.

VARGAS, M. Metodologia da pesquisa tecnológica. Rio de Janeiro: Globo, 1985. 
VIEIRA, S. A. B. Os Parques Infantis da cidade de São Paulo (1935-1938): análise do modelo didático-pedagógico. Revista de Iniciação Científica da FFC, v. 4, n. 1, 2004. Disponível em:

$<$ www.portalppgci.marilia.unesp.br/ric/include/getdoc.php?id=44\&article=13\&mode =pdf $->$. Acesso em: 2 mar. 2009.

VYGOSTSKY, L. A formação social da mente: o desenvolvimento dos processos superiores. São Paulo: Martins Fontes, 1988.

WANDERLEY, L. E. Espaço público e educação. In: KRAWCZYK, N.; CAMPOS, M. M.; HADDAD, $S$. (orgs.). $O$ cenário educacional latino-americano no limiar do século XXI. Campinas, SP: Autores Associados, 2000.

WEBB, E. J.; CAMPBELL, D. T.; SCHWARTZ, R. D.; SECHREST, L. Unobtrusive measure: non reactive research in the social sciences. Chicago: Rand MccNally, 1966.

; CAMPBELL, D. T.; SCHWARTZ, R. D.; SECHREST, L; GROVE, J. B. Nonreactive measures in the social sciences. Boston: Houghton Mifflin, 1981.

WILLRICH, A.; AZEVEDO, C. C. F. de, FERNANDE, J. O. Desenvolvimento motor na infância: influência dos fatores de risco e programas de intervenção. Revista Neurocienc, 2008. Disponível em:

<http://www.unifesp.br/dneuro/neurociencias/226_revisao.pdf >. Acesso em: 20 ab. 2009. 